\title{
Italian Translations of the Works of P.G.Wodehouse: an Epistemic Approach
}

\author{
Valentino, Gabriella
}

How to cite:

Valentino, Gabriella (2017) Italian Translations of the Works of P.G.Wodehouse: an Epistemic Approach. Doctoral thesis, Swansea University.

http://cronfa.swan.ac.uk/Record/cronfa40909

Use policy:

This item is brought to you by Swansea University. Any person downloading material is agreeing to abide by the terms of the repository licence: copies of full text items may be used or reproduced in any format or medium, without prior permission for personal research or study, educational or non-commercial purposes only. The copyright for any work remains with the original author unless otherwise specified. The full-text must not be sold in any format or medium without the formal permission of the copyright holder. Permission for multiple reproductions should be obtained from the original author.

Authors are personally responsible for adhering to copyright and publisher restrictions when uploading content to the repository.

Please link to the metadata record in the Swansea University repository, Cronfa (link given in the citation reference above.)

http://www.swansea.ac.uk/library/researchsupport/ris-support/ 


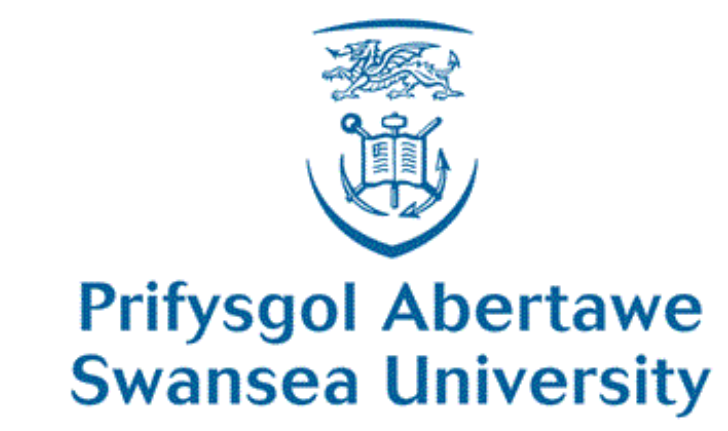

College of Arts and Humanities

Italian Translations of the Works of P.G. Wodehouse:

an Epistemic Approach

Gabriella Valentino

$\mathrm{PhD}$

Swansea University

2017 


\section{DECLARATION}

This work has not previously been accepted in substance for any degree and is not being concurrently submitted in candidature for any degree.

Signed

Date $29^{\text {th }}$ September 2017

\section{STATEMENT 1}

This thesis is the result of my own investigations, except where otherwise stated.

Other sources are acknowledged by footnotes giving explicit references. A bibliography is appended.

\section{Signed}

Date $29^{\text {th }}$ September 2017

\section{STATEMENT 2}

I hereby give consent for my thesis, if accepted, to be available for photocopying and for inter-library loan, and for the title and summary to be made available to outside organisations.

\section{Signed}

Date $29^{\text {th }}$ September 2017 


\begin{abstract}
This dissertation addresses the area of Translation and Humour Studies where the two disciplines overlap. My main original contribution is an Epistemic Approach to the translation process that focuses on the role that knowledge plays in the process of producing, reading and translating a written fictional text. Moreover, I propose a model for the description of the process of translation, tools to identify and evaluate items of verbally expressed humour, and a methodology to classify their renderings in translation.
\end{abstract}

The study investigates the Italian translations of the works by the English humorist P. G. Wodehouse. It is based on a vast primary literature ( 87 books) translated into Italian ( 176 translations and 579 editions) for which I collected metadata, available for research in the form of an Excel spreadsheet. In the light of the Epistemic Approach, this work analyses and describes texts from the translations commissioned by 16 Italian publishers to 63 translators from 1928 to 2017.

After an introductory chapter where I present my model of text activation and the Epistemic Approach to translation, the project begins with a presentation of the data I collected and an exposition of the complex publishing history of Wodehouse's works in Italy. In the second chapter, I identify a definition of style suitable for both quantitative and qualitative interdisciplinary empirical research and apply it to systematically describe Wodehouse's style. The third chapter presents the main theories developed in Humour Studies, the key concepts I identified to describe Wodehouse's humour and the tools I developed to assess it. Chapter 4 and Chapter 5 show the results of the analyses I performed on numerous Italian translations and retranslations. I conclude by presenting the contributions that my approach and my findings offer to the disciplines of Translation and Humour Studies and possible future developments. 


\section{TABLE OF CONTENTS}

$\begin{array}{ll}\text { AbSTRACT } & \text { ii }\end{array}$

TABLE OF CONTENTS iii

TABLE OF FIGURES Viii

TABLE OF TABLES Viii

LIST OF ABBREVIATIONS

ACKNOWLEDGEMENTS _ Xii

\section{INTRODUCTION}

Aim and scope $\quad 1$

Text activation: the role of the reader

Text activation: the role of knowledge 4

$\begin{array}{ll}\text { The Epistemic Approach to translating } & 7\end{array}$

$\begin{array}{ll}\text { Dissertation overview } & 10\end{array}$

\section{CHAPTER 1}

WODEHOUSE AND ITALY 13

Wodehouse in Italy: reception $\quad 14$

$\begin{array}{ll}\text { Italian editions: books } & 15\end{array}$

$\begin{array}{ll}\text { Data collection: } \text { procedure } & 16\end{array}$

Analyses of data 19

Different titles for the same original work $\quad 21$

Different publishers $\quad 22$

Different translators $\quad 23$

Historical exposition $\quad 24$

1928-1945: Wodehouse published in the fascist era $\quad 24$

1946-1951: Wodehouse published in the aftermath of Second World War 33

1951-1969: Wodehouse published in the economic boom 40 
1970-1980: Wodehouse published during the "years of lead"

1981-1991: Wodehouse published during "edonism"

1992-1997: Wodehouse published during "tangentopoli"

1998-2017: Wodehouse published now

Italian editions: paratexts and cover art

\section{CHAPTER 2}

\section{WODEHOUSE AND STYLE}

Wodehouse's style

The roots of Wodehouse's style

Comic mood

Plots, characters and language

Potty plots

Characteristic characters

Wodehouse's stylistic devices

Stylistic devices on discourse level 82

Imagery

Personification

Similes

Intertextuality

Leitmotifs

Stylistic rhythm 98

Stylistic devices on word level

Morphological devices

Inventive word formation

Invented words

Use of synonyms

Varieties of language

Characters' names 
$\begin{array}{ll}\text { Lexical devices } & 105\end{array}$

$\begin{array}{ll}\text { Lexical ambiguities } & 105\end{array}$

$\begin{array}{ll}\text { Syntactic devices } & 105\end{array}$

$\begin{array}{ll}\text { Syntactic ambiguities } & 105\end{array}$

$\begin{array}{ll}\text { Transferred epithets } & 106\end{array}$

$\begin{array}{ll}\text { Bathos } & 107\end{array}$

$\begin{array}{lr}\text { Conclusions } & 108\end{array}$

\section{CHAPTER 3}

WODEHOUSE AND HUMOUR 110

Humour: an overview $\quad 113$

$\begin{array}{ll}\text { Humour research: contributions and perspectives } & 118\end{array}$

Humour research: theories $\quad 120$

Superiority 121

Relief 123

$\begin{array}{ll}\text { Incongruity } & 125\end{array}$

Humour research and language $\quad 131$

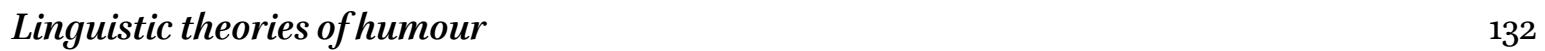

$\begin{array}{ll}\text { Wodehouse's humour } & 137\end{array}$

Humorous mechanisms in Wodehouse's stylistic devices 139

Key concepts in analysing Wodehouse's humour 141

$\begin{array}{ll}\text { Script-clash and hyperwording } & 145\end{array}$

$\begin{array}{ll}\text { Incongruity index and incongruity value } & 148\end{array}$

$\begin{array}{ll}\text { Conclusions } & 157\end{array}$

CHAPTER 4

WODEHOUSE AND TRANSLATION

Translating Wodehouse into Italian $\quad 160$

Knowledge of Linguistic Codes: English/Italian contrastive annotations $\quad 163$

$\begin{array}{ll}\text { Affixation } & 163\end{array}$ 
False friends

Adjectives and pronouns

Knowledge about the author's culture and style

Culturally-Specific Terms in Wodehouse and their translation 171

Humour Devices in Wodehouse and their translation

Case studies

The first book translated into Italian

The worst translation

The most anomalous editions

The most modified books

The most prolific translator 195

Conclusions

196

\section{CHAPTER 5}

$\begin{array}{ll}\text { WODEHOUSE AND RETRANSLATION } & 198\end{array}$

$\begin{array}{lr}\text { Retranslation and Translation Studies } & 198\end{array}$

$\begin{array}{ll}\text { Motives for retranslation } & 199\end{array}$

$\begin{array}{ll}\text { Wodehouse retranslated into Italian } & 201\end{array}$

Two translations 8o years apart: The Inimitable Jeeves $\quad 204$

$\begin{array}{ll}\text { Culturally-Specific Terms in The Inimitable Jeeves } & 207\end{array}$

Humour Devices in The Inimitable Jeeves $\quad 217$

Five (re)translations and a manuscript: A Damsel in Distress 223

$\begin{array}{ll}\text { Intertextuality in A Damsel in Distress } & 223\end{array}$

Similes in A Damsel in Distress $\quad 228$

$\begin{array}{ll}\text { The (re)translation of titles } & 232\end{array}$

$\begin{array}{ll}\text { Conclusions } & 236\end{array}$

$\begin{array}{ll}\text { CONCLUSIONS } & 238\end{array}$

The model, the approach and the tools $\quad 239$

$\begin{array}{ll}\text { A synthesis of findings and further developments } & 239\end{array}$ 


\section{APPENDIXES}

Appendix $1 \quad$ P.G. Wodehouse: works considered in this study (with GV codes) 246

$\begin{array}{lll}\text { Appendix } 2 & \text { P.G. Wodehouse: works and cycles } & 249\end{array}$

$\begin{array}{lll}\text { Appendix } 3 \quad \text { Wodehouse studies: key sources } & 255\end{array}$

Appendix $4 \quad$ First editions of Italian translations with translators $\quad 256$

Appendix $5 \quad$ Database of all Italian editions $\quad 260$

$\begin{array}{lll}\text { Appendix } 6 & \text { Italian translators and titles translated } & 272\end{array}$

Appendix $7 \quad$ Selected instances of intertextuality in A Damsel in Distress 290

Appendix $8 \quad$ Covers 283

\section{BIBLIOGRAPHY}

Primary literature: source texts $\quad 284$

$\begin{array}{ll}\text { Primary literature: target texts } & 287\end{array}$

Secondary sources $\quad 293$ 


\section{TABLE OF FIGURES}

Figure 1: Graph of Italian editions 1928-2017 (total no: 579) 21

Figure 2: Suls's Humor-appreciation model (1972, p. 85) 129

Figure 3: The three families of theories of humour (Attardo, 1994 p.47) 131

\section{TABLE OF TABLES}

Table 1.1: Italian publishers of Wodehouse with publishing period 22

Table 1.2: Wodehouse's Italian translators listed according to years of activity 24

Tab 1.3: First editions of Wodehouse titles published by Monanni (1928-1934) 28

Table 1.4: Comparison between Monanni and Bietti in publishing Wodehouse during

Monanni's years of activity (1928-1934) 29

Table 1.5: Total publications of Wodehouse's books by Bietti $(1930 \div 1940)$

Table 1.6: Wodehouse books published by Elmo (1948-1970) 35

Table 1.7: Wodehouse books translated by Motti for Elmo 38

Table 1.8: Number of titles and editions issued in Italy by each publisher during the economic boom (1951-1969) 41

Table 1.9: Wodehouse books published by Mondadori (1970-1980) 44

Table 1.10: Wodehouse books published by Mursia (1981-1991) $\quad 46$

Table 1.11: Wodehouse books published by TEA (1993-1997) 50

Table 1.12: Polillo editore series "IJeeves" (2005-2017) 52

Table 2.1: Examples of Wodehouse's similes according to semantic sources 86

Table 3.1: Wodehouse's Humour Devices according to key-term $\quad 142$

Table 3.2: Contrasting pairs (formal vs informal) in Much Obliged, Jeeves (p. 13) 146

Table 3.3: Tenor, ground, comparator and vehicle in simple similes $\quad 149$

Table 3.4: Examples of Wodehouse's similes, according to semantic fields belongingto the four different worlds (the human, the animal, the vegetal, the inanimate) 150

Table 3.5: Examples of pairs in Wodehouse's similes belonging to the four differentworlds (the human, the animal, the vegetal, the inanimate) $\quad 15^{1}$

Table 3.6: Comparison of similes belonging to the human world 152

Table 3.7: Comparison of similes belonging to the animal world $\quad 15^{2}$

Table 3.8: Comparison of similes belonging to the vegetal world $15^{2}$ 
Table 3.9: Comparison of similes belonging to the inanimate world

Table 3.10: Comparison between Dickens's and Wodehouse's similes belonging to the animal world

Table 3.11: Comparison of Wodehouse's similes comparing a man to a snail

Table 3.12: Examples of Wodehouse's similes listed according to decades (1906 - 1970)

Table 4.1: Treatment of "including out" by Elena Spagnol

Table 4.2: Treatment of English/Italian false friend “ape" in Right Ho, Jeeves

Table 4.3: Treatment of adjective "short" by Monicelli

Table 4.4: Treatment of insulting words by Tedeschi

Table 4.5: Translation of "you" by Wodehouse's Italian translators ordered according to years of activity

Table 4.6: Examples of Culturally-Specific Terms (realia) in Wodehouse classified in four categories

Table 4.7: Proposed Translation Procedures for Culturally Specific Terms

Table 4.8: Classification of the treatment of "Drake's Drum" by Motti and Bernardinis

Table 4.9: Classification of the treatment of "Brigham Young" by Motti and Bernardinis

Table 4.10: Classification of the treatment of "O.B.E.s” by Brioschi

Table 4.11: Classification of the treatment of "pip-pip" by Monicelli, Campagna Ponzetto and Lord

Table 4.12: Classification of the treatment of "It's in the bag" by Agnati and Morzenti

Table 4.13: Classification of the treatment of "To get spliced” by Tedeschi

Table 4.14: Proposed Translation Procedures for Humour Devices

Table 4.15: Classification of the treatment of "loaded names" by Elena Spagnol

Table 4.16: Classification of the treatment of pun played on "Pinafore" by Lampronti

Table 4.17: Classification of the treatment of pun on "Pinafore" by Pitta and Casale-Rossi

Table 4.18: Classification of the treatment of a simile with large semantic distance and hyperwording by Sacchi-Perego and Buitoni Duca

Table 4.19: Classification of the treatment of hyper-wording in description by Brioschi

Table 4.20: Comparison of the backtranslation (GoogleTranslate) of Brioschi's rendering of hyper-worded description to Wodehouse's original text.

Table 4.21: Classification of the treatment of foreign languages (French) by Spaventa Filippi

Table 4.22: Classification of the treatment of hyper-wording by Tedeschi

Table 5.1: Original titles and their codes, grouped according to the number of (re)translations 
Table 5.2: Italian translations of the chapters of The Inimitable Jeeves

(GV.26) by Traverso and Lord

Table 5.3: Italian renderings of Culturally-Specific Terms from the worlds of betting and horse-racing by Traverso, Ragusa and Lord

Table 5.4: Italian renderings of "Smalls" by Traverso, Ragusa and Lord

211

Table 5.5: Italian renderings of "Smile's Self Help" by Traverso, Ragusa and Lord 212

Table 5.6: Italian renderings of "Welsh rarebit" by Traverso and Lord 212

Table 5.7: Italian renderings of "Hallo, old scream" by Traverso, Ragusa and Lord 213

Table 5.8: Italian renderings of "Pip-pip" by Traverso and Lord $\quad 213$

Table 5.9: Italian renderings of "What-ho" by Spaventa Filippi 214

Table 5.10: Italian renderings of "What ho!" by Traverso and Lord 215

Table 5.11: Italian renderings of "give the bird" by Traverso, Ragusa and Lord 215

Table 5.12: Italian renderings of "give the raspberry" by Traverso, Ragusa and Lord $\quad 216$

Table 5.13: Italian renderings of "old" by Traverso and Lord $\quad 216$

Table 5.14: Italian renderings of script-clash between "wind up" and "somehow vertically" by Traverso, Ragusa and Lord $\quad 218$

Table 5.15: Italian renderings of script-clash between "SP job" and "technical term" by Traverso, Ragusa and Lord $\quad 219$

Table 5.16: Italian renderings of "to snooter" by Traverso and Lord 220

Table 5.17: Italian renderings of "the f. of the s. being more d. than the m."

by Sacchi-Perego and Buitoni Duca $\quad 221$

Table 5.18: Italian renderings of 50 instances of intertextuality from A Damsel in Distress (1919, GV.19) by Palumbo (1931), Mozzati (1931), Bianchini (1935), Dàuli (1935) and Palazzi (1994) 225

Table 5.19: Number and percentages of Translation Procedures employed the $\begin{array}{ll}\text { five Italian translators } & 226\end{array}$

Table 5.20: Selected similes in A Damsel in Distress (GV.19) 229

Table 5.21: Translator A: Francesco Palumbo, 1931

Table 5.22: Translator B: Ariberto Mozzati, 1931

Table 5.23: Translator C: Alfredo Bianchini, 1935

Table 5.24: Translator D: Gian Dàuli, 1939

Table 5.25: Translator E: Rosetta Palazzi, 1994 


\section{LIST OF ABBREVIATIONS}

*LC Lack of knowledge of Linguistic Code

AD Addition

AM Amendment

$\mathrm{C}_{\mathrm{n}} \quad$ Number of Collocates

CST Culturally-Specific Term

CSTTP Translation Procedure for Culturally-Specific Terms

EA Epistemic Approach

FE Functional Equivalence

GN Generalisation

GTVH General Theory of Verbal Humor

HD Humour Device

HDTP Humour Device Translation Procedure

HW Hyper-Wording

II Incongruity Index

IV Incongruity Value

KnoLC Knowledge of the Linguistic Code

KnoW Knowledge of the World

LC Linguistic Code

MS Manuscript

OED Oxford English Dictionary

RH Retranslation Hypothesis

SC Script-Clash

SD Stylistic Device

SL Source Language

SM Simplification

ST Source Text

TL Target Language

TP Translation Procedure

Trans Translator

TT Target Text

$\overline{\mathrm{TV}} \quad$ Cartesian distance between Tenor and Vehicle in a simile

WW Word-for-Word 


\section{ACKNOWLEDGEMENTS}

First and foremost I wish to express my deepest gratitude to my supervisor, Prof. Tom Cheesman, for his help, advice, for the many insights and stimuli he has offered to this work for three intense years and for having taught me so much. My thanks go to him and to Swansea University and its College of Arts and Humanities for having granted the scholarship that has allowed me to conduct this research. Particularly, I want to thank the Head of the College, Prof. John Spurr, the present Director of the Graduate Centre of the College, Prof. Jonathan Dunnage and my second supervisor, Dr Roberta Magnani for their support. Moreover, I wish to express my gratefulness to Prof. Julian Preece, Dr Brigit Haines, Dr Patricia Rodriquez-Martinez, to Mrs Gabriella Wasiniak and, of course, to all my colleagues in the Talbot Research Suite at the Singleton Park campus of Swansea University.

My appreciation goes to the International Society of Humour Studies to which I have the honour to belong. I also owe a huge debt of gratitude to the members of the P.G. Wodehouse Society UK and particularly to Hilary Bruce, Christine Hewitt, Elin Murphy, Paul Kent, Tony Ring, and Christopher Makey. I wish also to thank the agents of the Wodehouse Estate, Rogers, Coleridge \& White in London.

I wish to express my gratitude to Marco Polillo and his publishing company in Milan for always having been so prompt, collaborative and ready to offer treasured information and material for this research. Moreover, my unreserved appreciation goes to all the Italian librarians and archivists who have helped me in my field work. Particularly, I wish to thank Lavinia Iazzetti, Giorgio Bassi, Roberto Monaco, Stefano Sella, Andrea Zonato and the invaluable archivists at Centro Apice, Milan, Raffaella Gobbo and Valentina Zanchin. Especially, my gratefulness goes to Silvia Ciliberti who, I have just learnt, is leaving the Biblioteca Provinciale Cappuccini, Turin, where she has been such a valuable source of information for this study.

I could not have collected all the information on Wodehouse's Italian translations presented here without the support, the help and the books offered as gifts by so many friends, among whom I particularly wish to thank my mother for having offered my father's collection, Alessandra Benalli, Alice Gillio, Maurizio and Maria Cristina Godio, Santina Rugolo and Dott. Giancarlo Bortolami. I am extremely grateful for all the help and support received in these three years from my family and friends, especially from Winkie Williamson. However, my deepest thanks go to Master, P.G. Wodehouse, to my father for having introduced me to him and to my companion in this extraordinary adventure and in my new life, Adelmo. 


\section{INTRODUCTION}

\section{Aim and scope}

This study was inspired by the need to understand what extant translations and retranslations of written fictional texts can tell us about the process of translating. It investigates and describes the Italian translations of works by the English humourist P.G. Wodehouse in the light of a new approach to translating, which I term "epistemic". This approach focuses on the role that knowledge plays in the process of producing, reading, and translating a written fictional text.

My research, developed in the remit of both the disciplines of Translation and Humour Studies, deals with what Jeroen Vandaele names their "combined objects" (2002, p. 149) and tackles key issues, such as untranslatability, the relationship between language and culture, incommensurability of language structures, modernisation, domestication versus foreignization, compensation and visibility (for a review, see Bassnett, 2013, pp. 24-46). Like any study on translation, it is also meant as a contribution to the debate about equivalence, definable, with Jeremy Munday (2009, p. 185), as "the translational relationship between either an entire ST and a TT or between an ST unit and a TT unit in terms of the degree of correspondence between the texts or the text units".

Equivalence is a concept that has evolved since Roman Jakobson's seminal work in 1959 (Jakobson in Venuti, 2012, p. 127) and is still open to debate (for a review, see Kenny in Baker \& Saldanha, 2009, pp. 9699). Notwithstanding its complexity, equivalence is a common assumption when we open a translated book: absorbed in our reading, we become oblivious of the fact that what is before our eyes are not the words originally produced by the author. This assumption is at the basis of what could be renamed "alief in equivalence". Alief is a term coined by the philosopher Tamar Gendler (2007, p. 9; 2008, p. 557), defined as "a more primitive state than either belief or imagination" and "a mental state with associatively-linked content that is representational, affective and behavioral, and that is activated consciously or unconsciously - by features of the subject's internal or ambient environment". It is used to describe "the response to how things seem, in contrast to belief that describes the attitudes we have in response to how things are" (Bloom, 2010, p. 169, italics in original). A possible explanation of a translation reader's "alief in equivalence" lies in the notion of the reader's mind as a "cognitive miser", as defined by social psychology (Fiske \& Taylor, 1991; Stanovich, 2009).

Assumed equivalence in translation might, in fact, be regarded as one of the "heuristics", i.e. the cognitive shortcuts, that the human mind employs when challenged by complexity (see Tobergte \& 
Curtis, 2013 for a critical review). Such alief may have disastrous consequences, particularly on the reputation of an author, if a victim of a poor translation. As a researcher, I deal with this alief by examining the Italian translations of Wodehouse in the light of a model of text "activation" that focuses on the role of the reader and on the role played by knowledge. The main purpose of this model is to describe the system of cognitive operations that underlie the processes occurring in text production and reception and in text translation (Risku, 2012). It is based on two postulations: a text (1) does not exist per se (Iser, Suleiman, \& Crosman, 1980) and (2) does not tell everything (Gracia, 1996).

\section{Text activation: the role of the reader}

A written text can be defined, with Ricoeur (Ricœur \& Thompson, 1981, p. 135), as "every utterance or set of utterances fixed by writing". It is not a fixed entity in the least and requires an audience: the reader. As Nord (1997, p. 31) remarks, "[w]e might even say that a 'text' is as many texts as there are receivers", since a text is made meaningful by and for its reader. Ricoeur compares reading a text to the "performance of a musical score" (Ricœur \& Thompson, 1981, p. 145) and calls this process "appropriation". To underline the active role played by the reader, I term it "activation" and suggest that it starts when the reader engages a process of interaction with the text. This is a position already held in the 197os by Reader-Response Theory (see, for example, Iser, 1974 and 1978), among whose tenets is the prominent role of the reader in literary interpretation (for a theoretical review, see Davis \& Womack, 2002). The process of activation is what brings a text to life. It starts when a process of interaction is engaged, when the reader relates "textual elements to his/her background knowledge and experiences" (Colina, 2015, p. 162).

The cognitive activity that readers perform is of three different kinds:

1. syntactic, when readers re-construct the possible structures of a section of a text, e.g. a sentence;

2. semantic, when readers select a pertinent meaning of each single word within the possible semantic areas to which it belongs;

3. pragmatic, when readers focus on the logical connections of possible meanings to the surrounding text and to their experiences and knowledge.

My model of text activation considers the complex network of relations that occur among the actors involved in the process of text production, reading, and translating: in the first place, the author, the reader, and the translator. It also includes other, less obvious, actors involved in the process, directly (e.g. 
publishers, editors, agents, booksellers etc) and indirectly (censors, critics, fans, and the author's and the translator's "significant others", family, friends, colleagues). ${ }^{1}$ All actors share the capacity of being readers, hence they are potentially accountable for the activation of the text, since they all may influence its production and its translation. Central to my model is, therefore, the "Reader": not a physical entity but, rather, a role.

This model also partly draws from social theory that regards translation as a social phenomenon and highlights the central position of the translator in the process, for example considering Bourdieu's notion of habitus $^{2}$ (Bourdieu \& Thompson, 1991, p. 53) integrated in the field of Translation Studies. Particularly relevant for my model is the way Latour $(1987,2005$; Latour \& Woolgar, 1986) emphasises the relevance of the understanding of actor-networks, although, as Moira Inghilleri (in Baker \& Saldanha, 20o9, pp. $28 \mathrm{o}-281)$ remarks, "[h]e is content to leave unanswered $[\ldots]$ the question of who or what is influencing their actions". In Translation Studies, the potential of Latour's Actor Network Theory has been explored, for example, by Hélène Buzelin (2005) who highlights the roles of the various actors who contribute to the production and circulation of translations, such as publishers, editors, literary agents, promotion and marketing managers. The role of these actors is taken into account, as Lawrence Venuti (2012) reminds us, to reconceptualise the notion of agency in Translation Studies in the light of the "embodied cultural and social conventions that motivate the translator's choices" (ibid. p. 393).

The model I propose acknowledges the contribution to the activation of a text by the various actors involved in the process and how each actor influences the others. Moreover, my model includes "mental" actors, such as the "implied (or assumed or model) reader", i.e., a reader supposed by the writer to share the knowledge necessary to fully understand the text (Booth, 1983; Eco, 1994; Iser, 1974) and the "inner reader", i.e. an interiorised reader with whom the writer consciously or unconsciously interacts. ${ }^{3}$

\footnotetext{
${ }^{1}$ For Wodehouse, we have evidence of how his "significant others" influenced his work, for example in the letters exchanged with his friend, the writer William Townend, collected in Performing Flea (1953), in the testimony of acquaintances who described the role his wife, Ethel, had in supporting his career (McCrum, 2004, p. 186) and their economic interests (Sproat, 1981, p. 99) and in entertaining guests, friends and journalists so that Wodehouse, a shy and quiet man and a workaholic, could keep on writing (ibid.). Moreover, we have the witty and renowned dedication in The Heart of a Goof (1926): "To my daughter Leonora without whose never-failing sympathy and encouragement this book would have been finished in half the time" (cited in McCrum, 2004, p.168). We also know that Leonora, Ethel's daughter that Wodehouse had adopted, is the reason behind the production of another book by Wodehouse, Leave It to Psmith (1923), since "[s] he wanted Wodehouse to write another Psmith story" (Phelps, 1992, p. 142).

${ }^{2}$ Habitus is defined by Bourdieu as "a subject's internalised system of social structures in the form of dispositions (Bourdieu \& Wacquant, 1992, p. 97).

${ }^{3}$ For example, Wodehouse was said to take solitary walks, during which, he "would frequently break out into loud
} 
The model of text activation requires historical, sociological, and psychological contextual information gathered through research on the writer's life and experiences. Regarding the translators' work, similar research should be conducted on their careers and contexts too.

\section{Text activation: the role of knowledge}

The model of text activation that I propose can be applied to any kind of text and, as said, focuses on the Reader, a role assumed by various actors within the activation process. However, the central relationship is the one between the "actual reader" and the author of the text, here, the "writer" (Munday, 2012, p. 113). The relationship between writer and actual reader is informed by the linguistic code and common knowledge, i.e. what semioticians call the "encyclopedia" (Eco in Nergaard \& Jakobson, 1995) which writer and reader possess to a certain, but not necessarily equal extent: a certain degree of commonality in knowledge between writer and reader may be assumed but cannot be quantified by the writer, who may - or may not ${ }^{4}$ - decide to act according to this guess. The relation between writer and reader possesses specific properties: it is dialogic, since "in interpretation reading becomes like speech" (Ricoeur, 1970, p. 146) and dyadic, i.e. pertaining to a couple, although of a unique kind, since, even if the writer has a general readership in mind, i.e. the "implied reader", the message is in fact meant to be interpreted by one reader at a time. Other properties of the relation are its asynchronicity, and its asymmetry. In other words, the text is "fixed by writing" (Ricoeur, 1970, p. 135) and the writer knows more than the reader does.

An implicit pact links the writer and the reader: the reader is willing to allocate a certain degree of reliability to the writer, provided some conditions are met. In academic writing, for example, reliability is granted by the process that leads to publishing: peer-reviewed journals and books edited under the supervision of experts (Valentino, 2010, p. 76). When the text is fictional, the reader accepts the writer as a "licenced liar", as Cesare Segre calls the author of fictional texts (my translation). Segre (1999, pp. 215217) argues that the writer is granted three rights: (1) to establish possible worlds, (2) to be omniscient in such worlds, and (3) to be functionally selective, i.e. the writer can choose which "facts" from the continuum of (imagined) "empirical reality" to communicate. Therefore, a text does not tell everything; writers often just hint: information comes in discrete pieces and the gaps must be filled by the reader. 
When the information necessary to fill the gaps is not present in the text, the reader will actively question it and make deductions from the "given", both internal and external to the text (Singer, Graesser, \& Trabasso, 1994). However, the pact holds only if the text is interpretable. Of the seven standards outlined in Beaugrande and Dressler's seminal work (1981) for a text to be communicative, ${ }^{5}$ hence acceptable and interpretable, two pertain to how the text is organized. The first, cohesion, concerns its texture, in other words in what ways the surface components, i.e. the words we hear or read, are interconnected. The second one, coherence, represents the network of conceptual relations underlying the surface text. The reader, by interacting with the text, is continuously verifying that these criteria are met, in order to make predictions about the parts of the text yet to be encountered. Coherence is achieved in writing and, hence, perceived by the reader, by means of a number of devices, such as the six identified in 1976 by Halliday and Hasan for the English language, namely Reference, Substitution, Ellipsis, Lexical Chains, Cohesive Nouns and Conjunction. As Baker observes, such devices are "probably common to a number of languages" (Baker, 2011, p. 222), but languages differ in how they employ them. This aspect is treated in Chapter 4, with reference to the language pair English/Italian.

Interaction is what brings a text to life. Relating to the text and questioning it is necessary not only in order to get the meaning of what we are reading; it is also a psychological need: as humans, we have "an inborn propensity to look for regularities, or with a need to find regularities" (Popper, 1963, pp. 47-48). Therefore, we tend to organize in a coherent way the stimuli we are exposed to. Coherence is a "mental entity" (Gernsbacher \& Givón, 1995, p. vii), since the involvement of the reader's cognition is crucial. When incoherence is perceived in a text or some information is missing, the reader will spontaneously make inferences, educated guesses that are actively performed by trying to draw conclusions from what is not explicit in the text. As Baker (2011, p. 96) suggests, inferences are reasonably inferred from the text; however, as Grice remarks, "the inference-making process is based on more or less conventional background knowledge" (cited in Houdé, 2004, p. 114). Therefore, inferences are drawn from what is already known and available and from other sources of information that are deeply interiorised, such as schemata.

The term "schema" has been used in psychology since the 193os, to refer to mental representations of objects, settings and situations used as a scaffold to fill the gaps perceived in a situation or in communication (Emmott \& Alexander in Hühn, 2014). It has often been employed as a synonym of "frame". However, as Fillmore points out (in Geeraerts, 2006), a frame is an umbrella term for a whole set

\footnotetext{
${ }^{5}$ Namely, cohesion, coherence, intentionality, acceptability, informativity, situationality, and intertextuality.
} 
of constructs, such as script, scenario, schema, and cognitive model, i.e. "any system of concepts related in such a way that to understand any one of them you have to understand the whole structure in which it fits" (p. 373). Eco (1994) uses "frame" where cognitive psychology would employ the term "script", distinguishing between intertextual frames that are narrative schemes and common frames that "come to the reader from his storage of encyclopaedic knowledge" (ibid. p. 21). Therefore, a less confusing and a better definition of schemata is "cognitive structures representing generic knowledge, i.e. structures that do not contain information about particular entities, instance or events, but rather about their general form" (Emmott \& Alexander in Hühn, 2014, p. 765). Schemata are often shared in the same community and are temporally specific. When activated in reading, schemata are "organizational structures known to the reader and related to a particular situation" (Colina, 2015, p. 159) that provide the background information necessary to understand a situation. While reading, two main types of schemata are activated: formal and content schemata (P. L. Carrell, 1987). The first type pertains to knowledge of discourse (conventions and structures), while the second type represents prior knowledge of situations and objects. For my argument, I will term the first "knowledge of the linguistic code" (KnoLC) and the second "knowledge of the world" (KnoW), defined as knowledge achieved through experience (Valentino 2010, p. 9). Both are necessary to establish coherence in a text. Schemata are both culturally and epistemically loaded, in that they differ in terms of salience, i.e. they are more or less relevant in a given culture at a given time, and according to individual differences related to one's KnoW.

The same applies to implicatures, i.e. what the text suggests, neither expressing nor openly entailing it, so that the reader can retrieve unstated meaning provided they are correctly interpreted. Figures of speech, such as metaphors, or over- and under-statements are forms of implicature that require some effort to be interpreted. They become "given" only once they are decoded on the basis of what is known about communicative conventions (KnoLC). The notion of implicature was introduced into Pragmatics by H. P. Grice who defined it as: (i) the act of meaning or implying one thing by saying something else, or (ii) the object of that act (Grice, 1975, p. 87). Grice suggested that discourse is connected, has a purpose and is a co-operative effort. Even if Grice was more concerned with speech, his views can be applied to written texts as well and have important applications in translating (Baker, 2011, p. 236).

Therefore, in the process of reading, some inferences are made on the basis of what is known about the conventions of the linguistic code employed (KnoLC) and some others from individual experiences and assumptions (KnoW). Inferences can be accurate or inaccurate. They are accurate if they are based on sound assumptions, i.e. if they are grounded on what we know, for example because we have learnt 
and do not question IT (Craighead \& Nemeroff, 2004). While activating a text, the cognitive actions in which a reader is engaged yield:

1. a micro-analysis aimed at verifying the cohesion of a text and its internal coherence;

2. a macro-analysis aimed at verifying the coherence of a text with the kind of text to which it is assumed to belong, i.e. its genre.

These considerations assume specific relevance when the text processed is comic or humorous, as we will see in Chapter 3, since the reader must engage in a process of text disambiguation in order to solve the incongruities produced by the author to achieve humour.

When the focus of the investigation is the process of translating, the research should highlight the cognitive mechanisms employed by the Reader/translator to activate the text in the target language. Working on the translations of Wodehouse published in Italy, I analyse and classify the Italian renderings of "problematic textual items" (Laviosa, Pagano, Kemppanen, \& Ji, 2016, p. 66). I first identify them and describe their renderings, using the Epistemic Approach, detailed in the next section, as a way of investigating the process of activation of a text through its translation, which coincides with the process of its "re-activation" in a language different from the original (Lefevere, 1992, p. xi).

\section{The Epistemic Approach to Translating}

The Epistemic Approach to translating borrows its terminology from Translation Studies, linguistics and stylistics, and addresses crucial issues in Translation Studies. It possesses its own methodology that will be presented in detail in Chapter 4. It aims to shed light on the complex interplay among the actors involved in the process of text activation, namely the writer, the reader, the translator, and all the other actors and how their respective KnoWs interact.

I have termed my approach "epistemic", since it focuses on the way "what is known" informs the choices that a translator makes. The role of KnoW in text activation through translation is crucial, firstly because it is the recursive generator of the predictions necessary to interpret the text and, secondly, because it influences the translating process by informing the choices translators make. Epistemic approaches, for example to abductive reasoning (Nepomuceno-Fernandez, Soler-Toscano, \& VelazquezQuesada, 2013), to cognitive therapy (Kruglanski, 1981) or to writing instruction (Donovan \& McClelland, 1980) acknowledge the socially constructed nature of knowledge (Latour \& Woolgar, 1986) and are 
centred on the assumption that perceptions ${ }^{6}$ are changed into coherent experiences that are eventually transmuted into more abstract sorts of knowledge (Dowst in Donovan \& McClelland, 198o, p. 69). The pattern of this process is understandably circular: once a new piece is added to abstract knowledge, it will be ready to be used for the evaluation of new perceptions to be analysed, organised, and added to what is known about the world $(\mathrm{KnoW})$. KnoW is the result of individual interventions in and on the world and of active relations with signs; it engages a continuous dialogue with external stimuli; it is dynamic and open, and, like any form of knowledge, it is conjectural, uncertain, and critical (Popper, 1972).

The Epistemic Approach to translation, underpinned by the model of text-activation presented above, is based on the following assumptions:

1. a text must be actualised; ${ }^{7}$

2. reading is an experience and an active process that implies interaction;

3. a relation or "pact" exists between the author of the text (the writer) and the reader; a similar relation also holds between the writer and the translator, since the latter is in the first instance a reader him/herself;

4. activation through translation is the outcome of the interactions between the reader (here: the translator) and the text;

5. translation is a process of making choices; a translation as text is a product resulting from choice-making processes;

6. choices are informed by inferences, drawn on the basis of previous knowledge;

7. the translator's choices have an impact on the reader's KnoW and, ultimately, on the target culture.

Therefore, in Translation Studies, the epistemic approach focuses interest on evaluating (1) in what way the readers' KnoW is taken into account by translators when they choose a translation procedure and (2) to what extent the translators' choices influence the readers' KnoW, for example by enhancing it.

\footnotetext{
${ }^{6}$ Identifying the exact nature of perceptions falls outside the scope of this work, which is limited to investigating exposure to a written fictional text. Nevertheless, in the light of the most recent achievements of cognitive science, the notion that text understanding is embodied, that is to say that the processing of speech and word meaning is partly achieved by means of channels other than the visual/aural (as traditionally assumed), and that subjective experiences in one's body in action "provide part of the grounding for knowledge and language" (Gibbs quoted in Lindblom, 2015, p. 85) are here implied, although not specifically addressed.

${ }^{7}$ I mean by "text" any purposely constructed stretch of language, either in writing or speech: given the scope of this dissertation, it will here be meant as an instance of fictional narrative.
} 
The Epistemic Approach to translation is cognitive in nature. Since it strongly connects "actually doing" to knowledge, it can be defined as a "situated" cognitive approach (Gee, 2001). This approach also underlines the fact that declarative knowledge ("knowing that") informs procedural knowledge ("knowing how") (for a definition, see Fantl, 2008, p. 451). In other words, the application of what we know about an author (career, style, reception etc) to the translation process guides us towards knowing how to translate a text. Such a stance might be deemed strongly intellectualist. However, since my approach also takes into account Ryle's remark (1971) that knowledge entails "establishing", an intelligent operation "requiring rules of method, checks, tests, criteria, etc" (p. 224), declarative knowledge also presupposes some procedural knowledge.

According to the Epistemic Approach, the steps in text re-activation through translating are:

1. identifying the "problematic textual items" on the basis of one's procedural knowledge, including KnoLC;

2. drawing inferences relying on one's KnoW and KnoLC, both about the linguistic codes and about the text as a whole (e.g. genre, author's style, career, reception) and as an item (e.g. stylistic device, extant translations);

3. whenever deemed necessary, enhancing KnoW and KnoLC by researching, i.e. through dictionaries, encyclopedias, personal exchanges with others, e.g. experts, or the Internet;

4. choosing among possible alternatives, relying on one's procedural knowledge, taking into account intent (including the translator's visibility), consistency, editorial policies, clients' requirements and instructions, constraints, impact on the readership's KnoW and culture, and taking a stance regarding strategic options, e.g. foreignisation vs domestication.

Therefore, when applied to research to describe translations, the Epistemic Approach takes into consideration:

1. knowledge of the two linguistic codes (LCs) necessary;

2. knowledge about the writer's culture, literary career, specificities, and idiosyncrasies (e.g. genre and style);

3. knowledge about the translators (e.g. period of activity) and about their relations with the other actors implied in the process (e.g. publishers). 
In this dissertation, I test the Epistemic Approach to the translation of humour, a field of research that entails issues that, according to Zabalbeascoa (2005, p. 186) "need to be addressed from both sides of the area where humour and translation overlap".

\section{Dissertation overview}

I first present information about the texts analysed. Chapter 1 shows how Wodehouse's work was received, both in the English-speaking world and in Italy, and presents the corpus of texts on which my analyses are based. Chapter 2 investigates Wodehouse's style with the aim of highlighting the distinctive traits that translators must first recognise and then render to the best of their ability. Chapter 3 identifies specific features that should be precisely rendered in the translation of Wodehouse's works in order to do them justice. The two subsequent chapters offer examples taken from published Italian translations of the 87 works by Wodehouse considered in this study. Chapter 4 employs the tenets of the Epistemic Approach to identify, classify, and describe the translation procedures employed by Italian translators in rendering Culturally-Specific Terms and the "Humour Devices" which Wodehouse employed, with regard to impacts on the target readership's KnoW. Chapter 5 deals with the phenomenon of re-translations: I classify and compare renderings of Culturally-Specific Terms and Humour Devices in several sets of retranslations of the same work, over periods of up to 8 o years.

Chapter 1 discusses:

1. Wodehouse's career and reception, and the methodology I employed to collect the primary texts;

2. the potential of the corpus as material for a study on the translating process;

3. the complex publishing history of Wodehouse's works in Italy, from 1928 to 2017.

This chapter mainly draws on the scant scholarly literature on Wodehouse, biographies and bibliographies on him (see Appendix 3), book reviews and the paratexts of both original and Italian editions, including texts found through archival work.

Chapter 2 discusses:

1. a definition of style that allows for both quantitative and qualitative investigations within Translation Studies, since it identifies the properties of a text that should be transferred in translation if possible; 
2. Wodehouse's "Stylistic Devices" (Hall, 1974), treated systematically in relation to their origins in Wodehouse's career, life, and experiences.

This chapter mainly draws on cognitive stylistics in Translation Studies, such as Jean Boase-Beier's Stylistic Approaches to Translation (2006) and on the only scholarly book about Wodehouse's style, namely Robert Hall's The Comic Style of P.G. Wodehouse (1974). Evidence supplied by "informants" (as termed by Riffaterre, 1959) such as critics, reviewers, biographers, fans, and readers help to identify Wodehouse's most characteristic and admired Stylistic Devices. Wodehouse's style is also framed in terms of what Eli Rozik (2011) names "comic mood". The discussion presents information supplied by Wodehouse himself and by his biographers and from the literature on the tradition of comedy.

Chapter 3 identifies the Humour Devices that must be rendered in translation of Wodehouse's work. The phenomenon of humour is composite. This chapter discusses:

1. the multidisciplinarity of Humour Studies, by surveying and evaluating approaches in philosophy, psychology, anthropology and sociology;

2. a conceptual framework for all Wodehouse's Humour Devices;

3. the concept of "script-clash", derived from "script-opposition" in the General Theory of Verbal Humour developed by Salvatore Attardo and Victor Raskin (1991);

4. "hyper-wording", a term which I have coined to describe one of the most striking characteristics of Wodehouse's prose;

5. a tool that I have developed to assess instances of humour, namely a measure of "Incongruity Value";

6. applications of the Epistemic Approach and the afore-mentioned constructs and tools in analysing instances of Wodehouse's wordplay;

7. a formula to describe Wodehouse's humour.

Chapter 4 turns to the Italian renderings of Wodehouse's Humour Devices. In light of the description of them developed in Chapter 3 , and the model of text activation, this chapter discusses:

1. the "untranslatability" of humour;

2. connected issues in Translation Studies: visibility, foreignization, domestication, modernisation, loss and gain, and compensation;

3. the procedures that translators have at their disposal, hence a classification of renderings of both Culturally-Specific Terms and Humour Devices; 
4. how comparing translators' procedures sheds light on the translation process, the role of the translator as an actor in this process, and the impact that translators' choices may have on their readers and on the target culture.

This chapter demonstrates the critical importance of knowledge of linguistic codes (KnoLC) and of the world (KnoW) in the translation process. The classification of the renderings of Culturally-Specific Terms follows on the work of Nida (1964), Newmark (1988), Venuti (1998), Graendler (200o), Vlakhov and Florin (2011), Baker (2011). The classification of the renderings of Humour Devices elaborates on Delabastita's (1993; 1996) scheme of translation techniques.

Chapter 5, on retranslation, discusses the literature on this topic, starting from Paul Bensimon and Antoine Berman's historical contribution in Palimpsestes (1990). The model of text activation, the Epistemic Approach and the methodology and tools developed in earlier chapters are employed in a descriptive study of renderings of the same Culturally-Specific Terms and Humour Devices in translations issued at different times in the same target language.

The Conclusion sums up the contributions offered by my approach and findings to the disciplines of Translation and Humour Studies, and discusses possible avenues of future research. 


\section{CHAPTER 1}

\section{WODEHOUSE AND ITALY}

The purpose of this first chapter is to establish the value of the extant Italian translations of P.G. Wodehouse's works for a study aimed at describing the translation process. To achieve this, it is first necessary to establish the important status of the author, the unique characteristics of his particular brand of humour, the spread of his popularity globally, before examining the importance of the translated versions of his works, and in particular, the publication of translations of his works into Italian.

Pelham Grenville Wodehouse (1881-1975), referred to generally as P.G. Wodehouse, enjoyed an exceptionally long career, from his first publication in 1902 to his last in 1975 . Perhaps best known as the creator of half-witted Bertie Wooster and his brainy valet Jeeves, Wodehouse's characters and plots are rooted in an Edwardian England crowded with earls, dukes, aunts, and butlers, a unique world that appealed to audiences of the time. Such was his popularity and success that fellow author, and near contemporary, Hilaire Belloc described him as "the best writer of our time" and "the head of my profession". ${ }^{8}$

For a dissertation in Translation Studies, P.G. Wodehouse's exceptionally long and prolific career opens up indubitable opportunities. Much of his rich and heterogeneous production (novels, short stories, poems, song lyrics, theatre, and cinema scripts) has been translated all over the world. One of his short stories was the subject of a translation experiment. "The Great Sermon Handicap", a story that originally appeared in 1923 both in the UK and in the USA, was published in a 6-volume edition in 59 languages, commissioned by the Heinemann Publishing Company (Wodehouse, 1989-94).

Wodehouse's work has lasting appeal, and reaches audiences all over the world. This is attested by the plays performed on stage and on TV, by the steady sales of his books, by the praise found in books devoted to him, in magazines and newspapers, and on the web, ${ }^{9}$ and not least by the translations issued in many languages. Most praise refers to his superb command of the English language. For example, already back in 1929, Gerald Gould on The Observer was remarking that "[i]n the most serious and exact sense of the word, [Wodehouse] is a great artist. He has founded a school, a tradition. He has made a

\footnotetext{
${ }^{8}$ Reprinted in the Introduction to the Arrow Books edition of Weekend Wodehouse, 2012.

${ }^{9}$ See, for example, a discussion among a group of Indian students at: https://www.quora.com/P-G-Wodehouseauthor-What-are-the-great-aspects-of-Wodehousian-humor-and-how-to-enjoy-it.
} 
language" (quoted in Jordison, 2014). Many years later, in 2013, Charlotte Jones wrote in The Guardian: "What makes Wodehouse wonderful, though, isn't the preposterous lunacy of the plots, or even the easy nostalgia of the setting; it is his prose" (Jones, 2013). He invented new words and skilfully played with English syntax and varieties, such as slang and different registers.

Given the fundamental importance of his prose, and since language is the medium through which translators must render the source text in another one, Wodehouse's works surely present a challenge to any translator. How, for example, would a translator treat this exchange from The Code of The Woosters (1938, p. 232): "Oh, Bertie, you know your Shelley." "Am I?", or, the five different ways of saying "goodbye” that Lord Tidmouth uses in Doctor Sally (1932): "Bung-ho", "Poo-boop-a-doop", "Teuf-teuf", "Honk-honk", and "Tinkerty-tonk"?

Yet, in spite of these challenges, translations were and are still made. In an interview given in 1961, Wodehouse expressed his surprise at receiving "books in Burmese and Korean and Japanese" which he could not read. "It's most amazing" he told Alistair Cooke, reporting for The Manchester Guardian (quoted in McCrum, 2004, p. 403). Translations also had an important economic value. In fact, as he admitted in an interview with Gerald Clark published in The Paris Review in 1975, he admitted that he got his money, not so much from the United States where he was living at that time, but from "England, Sweden, Italy, France, and Germany" (Clark, 1975).

The P.G. Wodehouse Society UK (2008, IS6) states that his works are translated into 28 languages, without taking into account the Heinemann edition of the "Great Sermon Handicap" in 59 languages mentioned above. Tony Ring, author, former president of the Society, and Wodehousian enthusiast and expert, has collected 934 hard-copy books translated into 25 languages, mostly European, including what was probably the earliest translation of a Wodehouse book, a German edition of A Gentleman of Leisure (1910), published in $1917^{10}$ (personal communication, $29^{\text {th }}$ November 2016). By far the best represented language in his collection is Italian, with 179 books, including several retranslations.

\section{Wodehouse in Italy: reception}

Italians favour Wodehouse's fiction much more than his other work. Only a few traces are left of Wodehouse's plays performed in Italian theatres in the 1930s and $1940 \mathrm{~s}^{\mathrm{I1}}$ and none of the British TV

\footnotetext{
${ }^{10}$ Jimmy, der Eindringling, translated by Gertrud Bauer and published by Engelhorns Verlag.

${ }^{11}$ For example, on the Italian newspaper La Stampa on $29^{\text {th }}$ December 1934, advertising Teatro Alfieri.
} 
productions based on his stories has ever been broadcast in Italy. Moreover, to my knowledge, only one of the many films taken from his works was dubbed for the Italian public, Una magnifica avventura ${ }^{12}$, based on Wodehouse's novel, A Damsel in Distress (1909). However, nearly all his novels and short stories have been translated and published in Italy, some being republished several times and most of them have been retranslated. For this reason, while acknowledging the existence of some other forms of translated works, this study limits its investigation to the 176 Italian translations of written works published in book form.

\section{Italian editions: books}

Having identified the appropriate focus for this study, it is necessary to revisit Wodehouse's works in English in order to be able to investigate their Italian translations. This, in itself, causes a potential difficulty. For a series of reasons, there is no agreement about the number of titles written by Wodehouse (McCrum, 2004, p. 511; Donaldson, 2014). Some of these reasons are merely technical, i.e. "several books, particularly collections of short stories, which were published in the United States differed from the nearest equivalent collection in the United Kingdom" (The P.G. Wodehouse Society UK, 2008, IS1) and others, specifically Mike, The Prince and Betty and Psmith, Journalist were published in different versions during Wodehouse's lifetime. Some other reasons imply a decision to be made on whether or not to include some books, namely those jointly authored, e.g. Bring on the Girls (with Guy Bolton, 1953), collections of essays, journalism or poetry, autobiographical and children's books, e.g. Over Seventy (1957) and William Tell Told Again (1904). Also, there exist collections of short stories published in book form for individual or promotional reasons. This is the case, for example, of a collection of stories, arbitrarily selected for a 2004 US edition, Death at the Excelsior and Other Stories by Wildside Press, which was published in Italy in 2007 by Excelsior 1881, under the title Delitto all'Excelsior e altri racconti. Some other collections of stories were first published in book form after Wodehouse's death and lack his authority. Lastly, in compiling the bibliography to be examined, a researcher must make a decision regarding Wodehouse's last and unfinished novel Sunset at Blandings. ${ }^{13}$

For my research, I decided to focus on the novels and the collections of stories originally published in book form in Wodehouse's lifetime, assuming that their editions had been authorized by the author. I

\footnotetext{
${ }^{12}$ Original 1937 RKO Radio Picture Inc. film A Damsel in Distress, starring Fred Astaire.

${ }^{13}$ Published posthumously with annotations by Richard Usborne in 1977; not yet published in Italy.
} 
based my list on those published by the P.G. Wodehouse Society UK, where titles are recorded under the headings "Novel published during Wodehouse's lifetime" and "Short story collection published during Wodehouse's lifetime" (2008 IS1). I then collated the two lists and ordered the titles chronologically, according to the year in which they were published in the UK. I identified each book by means of a numerical code, preceded by the initials GV. This procedure yielded a list of 87 works, here found in Appendix 1.

\section{Data collection: procedure}

The first phase of this research aimed at the compilation of a complete bibliography of P.G. Wodehouse's books in Italian. Such an inventory did not exist when this research started. Several lists can be retrieved on the Internet, e.g. at the Index Translationum ${ }^{14}$ or WorldCat, ${ }^{15}$ or published by Italian publishers, ${ }^{16}$ bookshops and even P.G. Wodehouse's Italian admirers, ${ }^{17}$ but they are all partial and do not take into account aspects such as the British or American original titles, or the fact that the same work might have been published in Italian under a different title. Recently, in 2015, Rino Pensato, a librarian and curator of an Italian website devoted to Wodehouse, ${ }^{18}$ published Ben detto, Jeeves, P.G. Wodehouse: gli aforismi e $i$ motti di spirito, la fortuna editoriale in Italia (1928-2015), that includes a catalogue of the translations of Wodehouse's works published in Italy between 1928 and 2015. Pensato refers to his work as a "divertissement" and admits that more comprehensive research is needed. ${ }^{19}$ Unfortunately, this text was not available when I started my research, in 2014. Notwithstanding the different nature of his work compared to mine, I was eventually able to compare my findings with Pensato's, whose aim was to present the works by Wodehouse published in Italy, irrespectively of translations. In fact, his list also contains works published in Italy in English, mainly short stories originally published in The Strand and, as expected, his inventory of Italian translations is not as complete and accurate as the one I compiled following the procedure detailed below.

\footnotetext{
${ }^{14}$ http://www.unesco.org/xtrans/.

${ }^{15} \mathrm{http}: / /$ www.worldcat.org/.

${ }^{16}$ See, for example: the publishers Mursia (http://www.mursia.com/index.php/it/letteratura/i-libri-di-wodehouse), Guanda (http://www.guanda.it/?s=wodehouse), and Polillo (http://www.polilloeditore.it).

${ }^{17}$ See, for example, at the crowd-sourced site Girodivite at www.girodivite.it/antenati/xx2sec/wodehouse.htm.

${ }^{18}$ Unfortunately, now dormant but still available at http://www. amiciwodehouse.net/.

${ }^{19}$ Rino Pensato, personal communication (13 ${ }^{\text {th }}$ September 2016).
} 
Starting from the complete list of works supplied by the P.G. Wodehouse Society, organised as explained above, I conducted a survey aimed at listing all works translated into Italian, to match each original work with its Italian title/s, to find out how many Italian editions of each title had been issued to date and if new translations had been released over time or if the same version had always been employed for each edition. My intention was to establish a comprehensive database containing information on all editions published in Italy, in the form of an Excel spreadsheet. For each edition, metadata would include: original title, year of publication, name of the translator, publishing company, cover price, ISBN code (introduced in Italy in 1977) and any other additional information, such as the series the title belonged to, the editor's name etc. The design of the database also includes a column where I recorded where each title could be found, e.g. public libraries or private collections. The spreadsheet was designed to be updated any time new information was found. The intention was that the database could be expanded through a crowd-sourcing strategy, similarly to Cheesman's Multilingual crowd-sourcing of Shakespeare's Othello. ${ }^{20}$ Contributors would fill in a form to supply information about the titles they have access to and give evidence by means of photos attached. In this way, the database would be available also to a range of researchers in the future.

In theory, the task of data collection would be made easier because, since $1939^{21}$ a copy of every book published in Italy must be deposited in each of the following national libraries: Biblioteca Nazionale Centrale in Rome, Biblioteca Nazionale Centrale in Florence and Biblioteca Nazionale Universitaria in Turin, the so-called "deposito legale"/"legal deposit", and the complete Italian bibliographical catalogue is now available as an OPAC. ${ }^{22}$ Unfortunately, the three Italian national OPACs turned out not to be a reliable source since they are not integrated and records do not always supply all information needed for this research, such as, for example, the translator's name.

A second kind of investigation was therefore necessary. In order to find the missing information and to be sure that no title had been omitted, I asked Italian publishers still in activity to supply lists of the titles in their catalogues. Unfortunately, they did not prove very collaborative, at least in this first phase of my research: only one, Polillo Editore, was so kind as to send me their list.

I also wished to physically check the books, to ascertain which source text had been translated and whether a translation was a re-edition or new, and also to take a record of meta-texts, i.e. the paratexts

\footnotetext{
${ }^{20} \mathrm{https}$ //sites.google.com/site/delightedbeautyws/ (last accessed 30-05-2015).

${ }^{21} 1939$ Statute (Legge 2 febbraio 1939, n. 374).

${ }^{22}$ http://opac.sbn.it.
} 
printed on cover and endpapers, in addition to prefaces, introductions, tables of contents, and any additional material the publisher had included, such as advertising pages, or lists of other works published in the same series. I also paid attention to cover prices, as a parameter for the potential diffusion of books, and compared them to the cost of one kilogram of bread in the same year, one of the parameters used in Italy to calculate the cost of living. The information I collected is presented in the following sections of this chapter.

Throughout the three-year period of research, I was able to access printed copies of Italian translations from a range of sources. At the outset, I could inspect 33 printed books available from my father's collection; the number has eventually increased to 67 as more books were acquired. My field work involved visits to Italian libraries, where I could consult and photograph the books. Contrary to expectations, the richest source has proven not to be one of the National Libraries, but Biblioteca Braidense in Milan, which holds 243 different editions of Wodehouse's books in Italian. This hands-on inspection of printed books was supplemented by internet searches, in particular sites managed by sellers of second-hand and rare books, where pictures of the covers and the frontispieces of old editions were also available, and from which it was sometimes possible to obtain useful information.

Given the focus of this research, it was important to know the identity of the translator for each work. As already indicated, this information was not always shown on the book. In such cases, I compared selected pages of the book to the corresponding pages of another edition whose translator is known, in order to ascertain if the translation was the same. If not, I left the corresponding field in the spreadsheet blank, in the hope that some other source would eventually enable me to insert the missing name. Moreover, conscious of some specific issues that translators inevitably had to face, by reason of different usages in English and Italian, e.g. courtesy forms, and of the editorial customs favoured in Italy at different times, such as the treatment of foreign words, I was also keen to scan the pages of each book and take notes of these. I used this material in my investigations and comparisons of Italian translations that will be presented in Chapters 4 and 5 .

No information could unfortunately be retrieved from the now Milan-based Agenzia Letteraria Internazionale, the literary agents who used to represent Wodehouse in Italy. They informed me that it was several years since they managed the Italian rights to Wodehouse's works for years ${ }^{23}$ and suggested I should direct my requests to the UK-based literary agency Rodgers, Coleridge, and White. They, in turn, confirmed my findings concerning three books, William Tell Told Again (1904), The Swoop! (1909), and

\footnotetext{
${ }^{23}$ Stefania Fietta, Agenzia Letteraria Internazionale, personal communication $\left(17^{\text {th }}\right.$ February 2015$)$.
} 
Sunset at Blandings (1977) for which the rights have never been acquired by any Italian publisher. ${ }^{24}$ These titles were therefore not included in my database.

Through these various strategies, I was able to collect information regarding 87 original works by Wodehouse, published in the UK between 1902 and 1974. These are listed in the Bibliography, under the heading "Primary Literature: Source texts", where the editions I consulted are listed alphabetically by title and "GV code". Additional information about these books, grouped according to the "cycle" to which they belong, is found in Appendix 1. When citing from a published book, I will refer to the "GV code" and page of the edition I consulted. For those texts available from Project Gutenberg (being texts which are not protected by U.S. copyright law, as the rights have expired) which are not paginated, I will refer to the chapter containing the text quoted.

As of September 2017, the database, whose most relevant columns ${ }^{25}$ are reproduced in Appendix 5: "Database of Italian editions", contains records of 579 Italian editions. Since several books were translated into Italian more than once, 177 of them are "first editions", i.e. translations of one of the 87 original works considered in this study commissioned by an Italian publisher from an Italian translator. Appendix 4: "First editions of Italian translations with translators" reports data relative to 87 "first translations", i.e. each initial Italian translation of the 87 works , and 90 re-translations. In it, "first translations" are highlighted in bold. The "first editions" from which I quote are listed alphabetically by Italian title in "Primary literature: target texts". Appendix 6 lists Italian works by translator. When referring to Italian editions, I identify them by title, year and "GV code"; while in reporting my analyses, I cite them by translator and page number. It is relevant to point out here, in the light of the model of text activation, that even if I attribute the Italian text to its translator, I hold the publisher responsible for it.

\section{Analyses of data}

The analysis of the data enables me to highlight some key points:

1. 1928 is the date of the earliest first translation of a work by Wodehouse in book form in Italy: Carry On, Jeeves (GV.30), first published in the UK in 1925.

2. Earlier works, except the "Schools Stories", were all published in Italy before $193^{2}$.

\footnotetext{
${ }^{24}$ Stephen Edwards, Director Foreign Rights at Rogers, Coleridge \& White Ltd, personal communication $\left(23^{\text {rd }}\right.$ November 2016).

${ }^{25}$ Namely, Code, Original title, Publication year of original title, Italian title, Publication year of Italian title, Publisher.
} 
3. The "School Stories", originally published between 1902 and 1905, were all published in Italy by Bietti in 1932.

4. "Contemporaneous" editions, i.e. Italian editions that were published in the same or the following year of their first edition in the UK, started to appear in 1933 and the trend continued until Wodehouse's death in 1975, with some rare exceptions. ${ }^{26}$ That is to say, from 1933 to the end of Wodehouse's life, the Italian public was supplied with his work contemporaneously with the UK (and, usually, US) public.

5. The last Italian "first translation", i.e. the last book translated into Italian for the first time, was Jeeves e la cavalleria, the translation of Jeeves and the Feudal Spirit (1954; GV.69) by Mary Buckwell Gilson, published by Mursia in 1988.

6. The complete Jeeves and Bertie cycle started to be systematically published in 2005 by Polillo who commissioned new translations for most of the books.

7. The last Italian "first edition", i.e. the last translation of one of the 87 original works considered in this study commissioned by an Italian publisher from an Italian translator appeared in $2013 \cdot{ }^{27}$

The graph below (Figure 1), based on data relating to the overall number of Italian editions (i.e. including re-issues), issued between 1928 and 2017 , with a total of 579 editions, shows a first peak of editions in 1932. As we will see later in detail, only one company, Monanni, published Wodehouse before $193^{\circ}$. However, a competition soon started between Monanni and Bietti, yielding a considerable number of editions between 1932 and 1938, so that also retranslations started to appear on the Italian market. During the Second World War, not unsurprisingly, not many Wodehouses were published; however, the only year in which no editions appeared was 1944. The graph also shows a steady growth from 1962 to 1966, with a peak (42 editions) in 1966, and that no Wodehouses were published between 1967 and 1969. The same applies to the years 1986 and 1987 , while the production started to increase again in 1991. The reasons that explain these data, particularly the steady growth between 1962 and 1966, the sudden drop in the late 196os and the increased volume of editions published in the 1990s will be outlined in the

\footnotetext{
${ }^{26}$ Besides Sunset at Blandings, never translated into Italian, works published with delay are:Jeeves and the Feudal Spirit (GV.69; English date: 1954, Italian date: 1988), Service with a Smile (GV.76; English date: 1962, Italian date: 1970), and Company for Henry (GV.80; English date: 1967, Italian date: 1977).

${ }^{27}$ Young Men in Spats (1936, GV.50), translated by Silvia Pieraccini and published by Guanda.
} 
sections below, which discuss some of the difficulties in disentangling the complicated publishing history of Wodehouse's books in Italy.

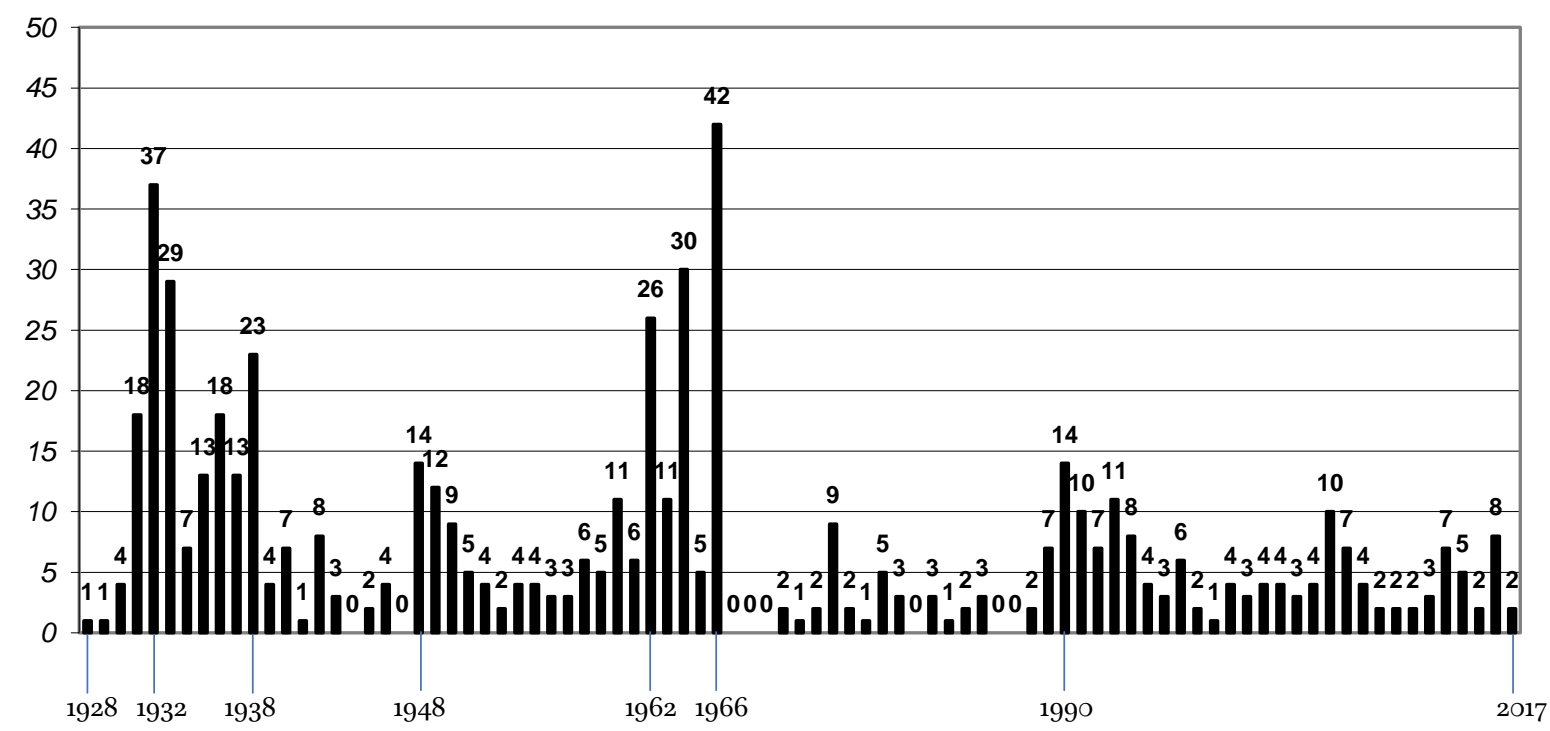

Figure 1: Graph of Italian editions 1928-2017 (total no.: 579)

Different titles for the same original work

As noted above, the metadata collected reveal that in most cases the same original work has been published several times in Italy. This includes reprintings, re-issues and re-editions of the same text by the same or different publishers, as well as new translation texts (also issued by the same or different publishers). There are no cases of a translator producing more than one translation of the same work. However, the publishing history of Wodehouse in Italian is complex in many other ways. Titles are not a sure guide to whether a translation is the same. In some cases, the title was changed while the translated text is the same; in other cases, both title and translator (hence translation) are different; some retranslations reproduce a previous title. This can make it difficult to ascertain which English text has been translated in an Italian one, or whether a translation is a retranslation, without close inspection. Examples include: The Little Nugget (1913; GV.12), once published as Pepita d'oro ("golden nugget"), nine times by two different publishers under the literal title of La piccola pepita and by another one as Il filone d'oro ("the gold vein"). The title Danaro incomodo (Uneasy Money; 1917; GV.17) was changed after 6o years into the more contemporary Denaro difficile. The name of the protagonist of Jill, the Reckless (1921; GV.21) was once translated as "Giulia", while it was kept as "Jill" in eight other editions. Eggs, Beans and Crumpets (GV.57), a collection of nine short stories, published in the UK in 1940, was once published as Il 
club dei nati stanchi, which roughly translates "the Drones club", since "nato stanco" is an Italian humorous expression meaning "born idle". Mursia's title is Tizio, Caio e Sempronio, three names used in Italy to refer to hypothetical people, on a par with the English expression "Tom, Dick and Harry". The title chosen by Guanda, Colpo di fulmine alle terme, literally "thunderbolt at the spa", plays on the Italian idiom "colpo di fulmine", meaning "love at first sight" and refers to a story in the book set at Droitgate Spa. One of the most striking examples of an inventive title is The Heart of a Goof (1926; GV.32), usually translated as Il cuore di un coniglio ("the heart of a rabbit") and once - frankly inexplicably - as Il cuore di un paranoico. Data and more remarks in this respect are contained in Appendix 5: Italian translators and titles translated and in the section of Chapter 5 : "The (re)translation of titles".

Different publishers

Dates of publication in Italy range from 1928 to the present, showing that Wodehouse raised interest in Italy quite soon and that he is still appreciated in our times. Over the years, 16 companies have published his books, all based in Milan. At present, only one publisher, Polillo, is constantly reprinting and, from time to time, also issuing new translations. The features and contributions of these companies to Italian publishing history will be reported later in this chapter, with a focus on the socio-historical period in which they started to publish Wodehouse, in line with the tenets of the Epistemic Approach I applied.

\begin{tabular}{|l|c|c|}
\hline \multicolumn{1}{|c|}{ PUBLISHERS } & YEARS OF ACTIVITY & NO. EDITIONS \\
\hline Monanni & $1928-1934$ & 42 \\
\hline Bietti & $1930-1977$ & 302 \\
\hline Novissima & 1931 & 1 \\
\hline S.A.C.S.E. & $1935-1938$ & 5 \\
\hline Aurora & $1937-1938$ & 2 \\
\hline Lucchi & $1939-1940$ & 3 \\
\hline Mondadori & $1939-1979$ & 34 \\
\hline Elmo & $1948-1970$ & 8 \\
\hline Rizzoli & $1961-1994$ & 61 \\
\hline Mursia & $1988-2015$ & 1 \\
\hline Lucarini & 1989 & 28 \\
\hline Guanda & $1989-2016$ & 24 \\
\hline Tea & $1993-2008$ & 1 \\
\hline Fabbri & 1994 & 1 \\
\hline Euromeeting & 2003 & 32 \\
\hline Polillo & $2005-2017$ & \\
\hline
\end{tabular}

Table 1.1: Italian publishers of Wodehouse with publishing period 
Different translators

The database shows that Italian publishing companies have not always invested in a new translation once they had acquired rights to one of Wodehouse's works for the Italian language market. Very often, the same translation was reprinted by the new company. Moreover, as we have just seen, sometimes the same translation, for sure to the great disappointment of habitual readers, was published under a different title, as if it were a new Wodehouse work in Italian. This issue is particularly relevant to this study, since my model of text activation takes into account the roles played by all the actors engaged in the process of producing a text and it is therefore worth investigating if this choice was purely economic or if the editorial board or the editorial director believed that the already extant translation was still satisfactory to the current reader. Such investigation might disclose stylistic, sociological, and even political reasons. My efforts to explore the issue further have not been successful since most publishers have not shown any interest in this research.

\begin{tabular}{|l|l|l|l|}
\hline \multicolumn{1}{|c|}{ TRANSLATOR } & \multicolumn{1}{|c|}{ ACTIVITY } & \multicolumn{1}{c|}{ TRANSLATOR } & \multicolumn{1}{c|}{ ACTIVITY } \\
\hline Spaventa, Filippi Silvio & $1928-1929$ & Comucci, Vittoria & 1954 \\
\hline Traverso, Aldo & 1930 & Buckwell Gilson, Mary & $1955-1997$ \\
\hline Tedeschi, Alberto & $1930-1940$ & Previtali, Oriana & 1961 \\
\hline Martone, Maria & 1931 & Ferri, Corrado & 1966 \\
\hline Mozzati, Ariberto & 1931 & Brioschi, Luigi & $1966-2001$ \\
\hline Malatesta, Mario & $1931 \div 1937$ & Longanesi, Caterina & 1970 \\
\hline Palumbo, Francesco & $1931 \div 1937$ & Spagnol, Elena & $1972-1976$ \\
\hline Lori, Ida & $1931-193^{2}$ & Janin, Pia & 1984 \\
\hline Pitta, Alfredo & $1931-193^{2}$ & Buitoni Duca, Maria & 1985 \\
\hline Baraldi, Lina & 1932 & Brera, Carlo & 1989 \\
\hline Benzi(g), Mario & 1932 & Serragli, Nadia & 1989 \\
\hline Bernardini, L. & 1932 & Zuffada Locuratolo, Angela & 1990 \\
\hline Carlesimo, Maria & 1932 & Campagna Ponzetto, Sandra & $1990-1992$ \\
\hline Casale Rossi, Teresita & 1932 & Castelli, Giulia & $1990-1992$ \\
\hline Fratta, Lepido & 1932 & Spagnol, Luigi & $1990-1993$ \\
\hline Pisano, G. V. & 1932 & Trimarchi, Anna Chiara & $1990-1993$ \\
\hline Rafanelli, Metello Brunone & $1932-1933$ & Bodoman, Mario & $1990-2011$ \\
\hline Zanini, A. & $1932-1933$ & Bertola, Stefania & $1990-1991$ \\
\hline Gilli, Mario & 1933 & Salvatorelli, Franco & 1991 \\
\hline Roberti, Roberto & 1933 & del Tanaro, Teobaldo & $1991-1992$ \\
\hline Shepley, F. Leon & 1933 & Morzenti, Monica & $1992-1997$ \\
\hline Lampronti, Zoe & $1933 \div 1936$ & Palazzi, Rosetta & $1992-1997$ \\
\hline Brugiotti, Giulia & $1934 \div 1940$ & Melani, Sandro & 1993 \\
\hline Bianchini, Alfredo & 1935 & Salmaggi, Cesare & 1995 \\
\hline Sacchi-Perego, Cina & 1935 & Mainardi, Riccardo & 1997 \\
\hline & & & \\
\hline
\end{tabular}




\begin{tabular}{|l|l|l|l|}
\hline Carter, Dienne & 1938 & Bernardinis, Fulvio & 1998 \\
\hline Dauli, Gian & $1939-1940$ & Mazzarelli, Paola & 2005 \\
\hline Monicelli, Giorgio & 1948 & Lord, Tracy/Calise, Leslie & $2005-2017$ \\
\hline Agnati, Sirio/Sario & $1949 \div 1966$ & Latronico, Vincenzo & 2007 \\
\hline Motti, Adriana & $1949 \div 1977$ & Musso, Dolores & 2007 \\
\hline Lattanzi, Luciano & 1952 & Pieraccini, Silvia & $2010-2013$ \\
\hline
\end{tabular}

Table 1.2: Wodehouse's Italian translators listed according to years of activity

Historical exposition

1928-1945: Wodehouse published in the fascist era

P.G. Wodehouse started to be translated and published in Italy in 1928, just before the beginning of the decade that has been described by Cesare Pavese as the "decade of translations" (1990, p. 223). As said, Wodehouse's first novel published in Italy in book form was Carry On, Jeeves (1925; GV.30; Italian title Avanti, Jeeves!: romanzo umoristico inglese) translated by Silvio Spaventa Filippi and published by the Casa Editrice Monanni. He was soon being published on a regular basis, with 55 novels from 1928 to 1934, several of them reprinted. This period witnessed a wider diffusion of popular novels ("romanzo d'appendice") and light literature, in contrast with the more elitist production of erudite books that had monopolized the literary publishing domain in preceding eras in Italy.

In these years the sectors in which Italian publishing companies operated were four: scholarly (the owners of the companies were for the most part intellectuals themselves), educational (mainly in Tuscany and in Turin), low-level production (scandalous books and the already mentioned "romanzi d'appendice"), and books targeted at a middle-class readership. Demography played in favour of entertaining but respectable literature, since the Northern urban middle-class population was increasing as was the number of people employed in clerical work: these would represent interesting addressees for publishing companies, as they accounted for $5 \%$ of the whole population (Ragone, 1999). The core area of activity moved from Tuscany to the more industrialised Northern Italy, mainly in Milan.

Why Wodehouse came to be chosen among foreign novelists to entertain this new potential audience can only be hypothesized. The reasons will become clearer in the light of the political and cultural climate of the approximately twenty years of the fascist era, i.e "il Ventennio", from 1922 to 1943, that will be described in the following paragraphs, coupled with the characteristics of his style and narratives that 
will be highlighted later in this dissertation. It is relevant to point out here that, far from being alien to the general public, England and its novelists, both literary and entertaining, were already familiar to Italian readers, thanks to the numerous English titles already translated before Wodehouse made his first appearance on the Italian market. This was the period of A. Mondadori's "Libri gialli”, ("yellow books"), a long-lasting series of thrillers with bright yellow covers, mainly works by English and American authors. ${ }^{28}$

English-language authors already well-known to the Italian public by 1928 included George Bernard Shaw, Arthur Conan Doyle, Gilles Litton Strachey, and Virginia Woolf, all published by A. Mondadori, in addition to works made known by the Libri gialli, such as novels by Edgar Wallace and Agatha Christie and Robert Louis Stevenson's The Strange Case of Dr Jekyll and Mr Hyde. Such familiarity has had a long life, too. In their introduction to Lampi d'estate, the 1993 Italian reprint by TEA of Wodehouse's Summer Lightning (1929; GV.37), two well-known writers and literary critics, Franco Fruttero and Carlo Lucentini, placed Wodehouse's depictions of English life in the company of Laurence Sterne, Lewis Carroll, Charles Dickens, and Oscar Wilde, stating that a mere hint is sufficient for an Italian reader to complete the picture with blazing fireplaces, glasses of port, private libraries and sitting rooms, horse carriages and steam locomotives. They also assert that English humour is acknowledged by the Italian collective imagination, not as a cliché such as French esprit or German precision but as something "deeply interiorized and greatly appreciated" (Fruttero and Lucentini, preface to Lampi d'estate (1993; GV.37), p. iv, my translation).

Wodehouse's first translator, Silvio Spaventa Filippi, is presented in the preface to the first edition of Avanti, Jeeves! (1928; GV.30) as "a fine man of letters" ("un fine letterato"). He was a journalist who, back in 1908, had founded the illustrated humorous children's magazine "Il Corriere dei Piccoli", at first as a supplement of the Corriere della Sera, the leading Italian newspaper, but later sold separately at a low price. Spaventa Filippi was also the author of L'umorismo e gli umoristi, a collection of essays on humour, published in $193^{2}$.

\footnotetext{
${ }^{28}$ A. Mondadori's series rapidly became so popular that, even today, in Italy thrillers are referred to as "gialli". Evidence is found in Wodehouse's translations too. For example, when Adriana Motti translated The Old Reliable (1951; GV.65), she rendered "whodunits" (p. 48) with "gialli" (p. 58). Mondadori's successful initiative is a subject of great interest in a study on translation (Rundle, 2010; Sfondrini, 1997), especially in relation to the connections between the fascist regime and Arnoldo Mondadori, who managed to only apparently comply with the regime's requests and at the same to achieve prominence as most successful publisher of the time and the first industrial publisher ever in Italy. But that falls beyond the scope of this research.
} 
In Italy, during the first period of the fascist era, before the enacting of the racial laws (1938), humour and satire were highly valued. Several illustrated magazines of humour circulated in those days, such as Marc'Aurelio (1933-1958) and Bertoldo (1936-1943) that hosted some Wodehouse's stories. Political satire was limited but well represented by Il travaso delle idee (1900-1966) and Becco Giallo (1924-1926). Italian humorists of the time include Vittorio Metz, Giovanni Mosca, Carlo Manzoni, Giovanni Guareschi, and Federico Fellini, some of them also published in book form. In this context, it is no surprise that Wodehouse's novels were well received in Italy and sold so well that several reprints were issued in a few years (see Figure 1).

Wodehouse's first publisher was Giuseppe Monanni, born Monnanni, a unique figure in the Italian publishing world of the time. He was an individualistic anarchist who began his career in publishing by founding anarchist journals in Florence and in Milan. He started a relation with Leda Rafanelli, a freethinker and an anarchist who worked as a publicist and was later to have a relationship with the then young and socialist Benito Mussolini. In 1909 Monanni and Rafanelli founded the Società Editoriale Milanese, the following year renamed Libreria Editrice Sociale. In 1919 the company changed its name into Casa Editrice Sociale. This was to last until 1926 when Monanni opened his Casa Editrice Monanni. These continual changes were due to the persistent interest the political police were showing in Monanni's publishing activities. Both he and Rafanelli had files in the records of the "Casellario Politico Centrale", ${ }^{29}$ where antifascists were classified according to their profession and their "political colour" ("colore politico"), e.g. communist, republican, socialist, anarchist. Monanni was well known by the police as a publisher of subversive books, as documented by a letter written on $30^{\text {th }}$ September 1929 by the prefect of Ferrara, cited by Guido Bonsaver (2007, p. 35). He mostly published pamphlets and foreign titles translated into Italian. One of his titles, a translation of Jack London's The Iron Heel (Italian title: Il tallone di ferro), that predicted "the rise of fascism emerging from a rotting capitalism, and the terrible implications of that for the working class and its leadership" (Hood, 2012), was regularly found during searches of anti-fascists' homes, according to a police memo ("pro-memoria"), annotated in pencil by Mussolini and kept in the "Archivio Centrale dello Stato in Rome" (Bonsaver, 2007, p. 38). In 1931, 790 copies of the book were sequestrated in Monanni's office. ${ }^{30}$ He was not new to this kind of harassment:

\footnotetext{
${ }^{29}$ Archivio centrale dello Stato: http://dati.acs.beniculturali.it/CPC: Monnanni Giuseppe, anarchist, envelope no 3355; Rafanelli Leda Bruna, anarchist, envelope no 4193.

${ }^{30}$ The fact that Monanni considered Wodehouse a "safe" author to be published during the regime is proved by one of the books which I inspected in his archives (APICE Archivi della Parola, dell'Immagine e della Comunicazione Editoriale, Milan) in December 2014. Monanni kept his copy of Jack London's Il Tallone di ferro
} 
his offices were frequently searched by the fascist secret police and his books were also confiscated in bookshops. He complained directly to Mussolini. Two letters from Monanni were found in Mussolini's archives. In the first, written in 1931, Monanni reported the seizure in bookshops of some translations of Maxim Gorky's works and protested because the same author had been printed by other publishers without any consequences. In the second, two years later, he complained about the withdrawal of three of his titles in a bookshop in Rome. Both letters must have been passed on to the police who replied to Monanni that the seizures had only been provisional in order that the books could be inspected and that they had been released once it had been established that they were not on any "black list" (Bonsaver, 2007).

In 1934 Monanni ceased his activity as a publisher. Some years later, in 1939, he was arrested under the allegation of anti-fascism on evidence that he had maintained relationships with anarchists abroad. After the Second World War he became editorial director of the Milanese publishing company Rizzoli, ${ }^{31}$ where he helped to conceive and launch the new series of low-price classics, "Biblioteca Universale Rizzoli (BUR)", ${ }^{22}$ that would also contain two Wodehouses (Right Ho, Jeeves, 1934; GV.47 and Love Among the Chickens, 1906; GV.o6) previously published in 1928 and 1929 by his company, but now with different translations, by Maria Buitoni Duca (1985) and Oriana Previtali (1961) respectively, while both Monanni's translations were by Luigi Spaventa Filippi.

For his Casa Editrice Monanni, he chose 28 titles from Wodehouse's huge production from 1906 to 1933, and kept on publishing them until he ceased his activity. A significant number (14) of translators worked on his Wodehouses: ${ }^{33}$ altogether he published 45 editions, from 1928 to 1933 . The most reprinted title was his first one, Avanti, Jeeves! (GV.30) with 5 editions in 1928, 1930, 1931, 1932 and 1933.

hidden under the cover of one of his Wodehouses, Benissimo, Jeeves (1930; GV.38), cunningly gluing one corner of the frontispiece to the first page of the book so that the title and the name of the author were concealed. See: http://xdams.lib.unimi.it/xdams-public/search/apiceSto32/title.html.

${ }^{31}$ Interestingly, in 1946 Rizzoli published Leda Rafanelli's Una donna e Mussolini, containing the 40 letters that Mussolini had sent her from 19th March 1913 to 7 th October 1914.

${ }^{32}$ Started in 1949, it was meant to bring "both ancient and modern fundamental works of literature" within everyone's means, with the "lowest cover prices on the Italian market, about 70 Lire per 100 pages" (presentation page of BUR's Amore tra i polli, GV.o6, nos 1693-1994,1961, my translation).

${ }^{33}$ The already mentioned Silvio Spaventa Filippi, A. Zanini, Alberto Tedeschi, Alfredo Pitta, F. Leon Shepley, Francesco Palumbo, Lepido Bernardini, Metello Brunone Rafanelli (Leda's brother), M. Carlesimo, Maria Martone, Mario Benzi, Mario Gilli, Mario Malatesta, and Roberto Roberti. 


\begin{tabular}{|c|c|c|c|c|}
\hline CODE & ORIGINAL TITLE UK & $\begin{array}{c}\text { UK } \\
\text { YEAR } \\
\end{array}$ & ITALIAN TITLE & $\begin{array}{c}\text { IT } \\
\text { YEAR }\end{array}$ \\
\hline GV.05 & The Head of Kay's & 1905 & Il capo del Kay: romanzo sportivo inglese & 1933 \\
\hline GV.o6 & Love Among the Chickens & 1906 & L'amore tra i polli & 1929 \\
\hline GV.o9 & A Gentleman of Leisure & 1910 & $\begin{array}{l}\text { Un gentiluomo in ozio: romanzo umoristico } \\
\text { inglese }\end{array}$ & 1932 \\
\hline GV.11 & The Prince and Betty & 1912 & $\begin{array}{l}\text { Il principe e Betty: romanzo umoristico } \\
\text { inglese }\end{array}$ & 1932 \\
\hline GV.12 & The Little Nugget & 1913 & Pepita d'oro: romanzo umoristico inglese & 1932 \\
\hline GV.13 & $\begin{array}{l}\text { The Man Upstairs and } \\
\text { Other Stories }\end{array}$ & 1914 & $\begin{array}{l}\text { L'uomo del piano di sopra: racconti } \\
\text { umoristici inglesi }\end{array}$ & 1933 \\
\hline GV.15 & Something Fresh & 1915 & $\begin{array}{l}\text { Qualche cosa di nuovo: romanzo umoristico } \\
\text { inglese }\end{array}$ & 1932 \\
\hline GV.17 & Uneasy Money & 1917 & Denaro difficile: romanzo umoristico inglese & 1932 \\
\hline GV.18 & Piccadilly Jim & 1918 & Jim di Piccadilly: romanzo umoristico inglese & 1931 \\
\hline GV.19 & A Damsel in Distress & 1919 & $\begin{array}{l}\text { Una donzella in imbarazzo: romanzo } \\
\text { umoristico inglese }\end{array}$ & 1931 \\
\hline GV.20 & The Coming of Bill & 1920 & La venuta di Bill: romanzo umoristico inglese & 1932 \\
\hline GV.21 & Jill, the Reckless & 1921 & $\begin{array}{l}\text { Giulia la bizzarra: romanzo umoristico } \\
\text { inglese }\end{array}$ & 1932 \\
\hline GV.22 & Indiscretions of Archie & 1921 & Indiscrezioni di Arcibaldo & 1931 \\
\hline GV.23 & The Girl on the Boat & 1922 & $\begin{array}{l}\text { La ragazza del transatlantico: romanzo } \\
\text { umoristico inglese }\end{array}$ & 1932 \\
\hline GV.25 & The Adventures of Sally & 1922 & $\begin{array}{l}\text { Le avventure di Sally: romanzo umoristico } \\
\text { inglese }\end{array}$ & 1931 \\
\hline GV.26 & The Inimitable Jeeves & 1923 & L'inimitabile Jeeves & 1930 \\
\hline GV.27 & Leave it to Psmith & 1923 & $\begin{array}{l}\text { Lasciate fare a Psmith: romanzo umoristico } \\
\text { inglese }\end{array}$ & 1933 \\
\hline GV.28 & Ukridge & 1924 & Ukridge Romanzo umoristico inglese & 1931 \\
\hline GV.3o & Carry On, Jeeves & 1925 & Avanti, Jeeves!: romanzo umoristico inglese & 1928 \\
\hline GV.32 & The Heart of a Goof & 1926 & Il cuore di un coniglio & 1931 \\
\hline GV.33 & Meet Mr Mulliner & 1927 & Mr Mulliner: romanzo umoristico inglese & 1931 \\
\hline GV.34 & The Small Bachelor & 1927 & $\begin{array}{l}\text { Il piccolo scapolo: romanzo umoristico } \\
\text { inglese }\end{array}$ & 1932 \\
\hline GV.35 & Money for Nothing & 1928 & Denaro trovato: romanzo umoristico inglese & 1932 \\
\hline GV.36 & Mr Mulliner Speaking & 1929 & $\begin{array}{l}\text { Parla Mr Mulliner: romanzo umoristico } \\
\text { inglese }\end{array}$ & 1931 \\
\hline GV.37 & Summer Lightning & 1929 & Lampi d'estate: romanzo umoristico inglese & 1933 \\
\hline GV.38 & Very Good, Jeeves & 1930 & Benissimo, Jeeves & 1930 \\
\hline GV.4O & Big Money & 1931 & $\begin{array}{l}\text { Quattrini a palate: romanzo umoristico } \\
\text { inglese }\end{array}$ & 1932 \\
\hline GV.41 & Doctor Sally & 1932 & Dottor Sally: romanzo umoristico inglese & 1933 \\
\hline
\end{tabular}

Tab 1.3: First editions of Wodehouse titles published by Monanni (1928-1934) 
Spaventa Filippi translated a number of books for Monanni, including four Wodehouses. When Filippi fell ill, Monanni commissioned translations by Alberto Tedeschi who translated three Wodehouses $\left(\mathrm{GV}_{33}, \mathrm{GV}_{3} 6\right.$ and $\left.\mathrm{GV}_{3} 8\right)$ that were later reprinted several times by other publishers. Tedeschi was very gifted at languages; he studied French at school and English privately with a teacher who introduced him to the British literature of the $20^{\text {th }}$ century. ${ }^{34}$ In 1930 , he founded a small and short-lived publishing company, Alberto Tedeschi Editore. However, he did not publish any Wodehouse, since he was more attracted by thrillers, particularly by American authors. He later became an editorial director of A. Mondadori’s series “I Gialli”.

Another of Monanni's translators, Mario Benzi, deserves attention. Born in 1896, he studied in Lausanne and in London (Benzing, 2008). During the fascist period, bearers of family names ending with a consonant, hence sounding foreigners, were "advised" to change their names into others sounding "more Italian". Benzi was in fact of German origins and born Benzing, so he authored his works with the new "Italian" name. He settled in Milan and mainly worked as a professional translator. Between 1928 and 1947 he translated 121 books, among these works by Jack London, Edgar Allan Poe and Joseph Conrad. Wounded, during the First World War, he was treated at the same hospital as Ernest Hemingway and they became acquaintances. Benzi lost all his belongings and, above all, his valuable books in an airraid on Milan by the the Royal Air Force in the night of $7^{\text {th }}$ August 1943 (ibid. p. 42). In the aftermath of the war, he did not author any other literary translation but worked as a translator of technical texts. He translated all his Wodehouses for Monanni in 1932.

In publishing Wodehouse, Monanni was competing with the Casa Editrice Bietti, in Milan, who continued to publish Wodehouse well into the 196os. Bietti's first Wodehouse was The Inimitable Jeeves (1923; GV.26), published in 1930 and - not very imaginatively - entitled L'inimitabile Jeeves.

\begin{tabular}{|l|c|c|c|c|}
\hline \multicolumn{1}{|c|}{ PUBLISHER } & ORIGINAL TITLES UK & ITALIAN TITLES & TRANSLATORS & EDITIONS \\
\hline Monanni & 28 & 28 & 15 & 42 \\
\hline Bietti & 41 & 44 & 18 & 55 \\
\hline
\end{tabular}

Table 1.4: Comparison between Monanni and Bietti in publishing Wodehouse during Monanni's years of activity (1928-1934)

\footnotetext{
${ }^{34}$ Significantly, and as a consequence, the first title he issued as a young publisher was the translation of Edgar Wallace's The Man Who Knew (1918), under the title of L'uomo che sapeva (1930), translated by Antonio Radames Ferrarin. (http://www.fondazionemondadori.it/qb/index.php?issue_id=41).
} 
As said, Bietti started to publish Wodehouse in 1930, while Monanni's first was issued in 1928. However, Bietti published many more titles. Moreover, anticipating a trend that he was later to develop in full, Bietti issued some translations under different titles, hence he published 44 titles from 41 original books. This habit was not followed by Monanni, whose translations were always reprinted with the same title.

From 1934 until 1948, Bietti maintained a near-monopoly on new works by Wodehouse in Italy, with some rare incursions by A. Mondadori, ${ }^{35}$ S.A.C.S.E and Lucchi. Angelo Bietti had started his publishing company, Casa Editrice Angelo Bietti e C., in 1864 based on his family's printing firm (Caccia, 2013). At first, he only distributed other publishers' books. When he started to publish, he chose to bet on works aimed at a large audience sold at low prices. With the intention of finding new markets and of improving his business, Angelo moved to Argentina and his son Antonio started to work in the Italian headquarters, continuing his father's mission. Among others, they published works by Victor Hugo, Emile Zola, and Alexandre Dumas. They also issued grammars of foreign languages, specifically aimed at Italian emigrants. In 1902 the company changed its name into Angelo Bietti e C. and in 1907 it was renamed Società Anonima Casa Editrice Bietti (henceforth Bietti), that was taken over by Gianbattista Pirolini around 1907-1909 (Caccia, 2013). The company bought out the assets of Istituto editoriale italiano in the 1920's and was once more, in 1924, sold to Luigi della Torre, a senator, a banker, and the president of the Società editoriale Italiana and the company was extremely successful (Caccia, 2013). Its greatest success was the first edition of the Vocabolario della lingua italiana by Nicola Zingarelli in $1922 .{ }^{36}$ In 1936 its General Director was Paolo Maranini who managed to obtain a substantial contribution ${ }^{37}$ from "Istituto per la Ricostruzione Industriale" (IRI, the State holding company) $)^{38}$ thanks to the intercession of Mussolini, even though he was not enrolled in the Fascist Party (Caccia, 2013).

In 1934, Bietti took over Monanni's company and, in 1938, also tried to distribute the stock left by a Jewish publisher, Angelo Fortunato Formìggini who had committed suicide after the Italian racial laws had been enforced. This initiative was, however, immediately blocked by the authorities (Caccia, 2013). During the "decade of translations", Bietti also published, among others, Edgar Wallace, Joseph Conrad, Aldous Huxley, Gilbert Keith Chesterton, and Edmund Dulac.

\footnotetext{
${ }^{35}$ A. Mondadori published the first edition of Summer Moonshine (GV.53) in 1939 in its Romanzi della Palma, an extremely successful periodical series with 3,442,221 copies printed between 1932 and 1943, specifically addressed to a female audience. (www.fondazionemondadori.it/qb/article.php?issue_id=45\&article_id=185).

${ }^{36}$ Still annually published today by Casa Editrice Zanichelli.

${ }^{37}$ Archivi storici IRI http://www.maas.ccr.it/asirihap3/ (accessed 13-03-2015).

${ }^{38}$ Formed in January 1933 to bail out Italy's largest banks (Holland, 1992) and starting the era of government-linked companies in Italy.
} 
Wodehouse's popularity probably grew as a result of Bietti's policy: regularity in publishing, updated titles, in addition to conspicuous and "modern" covers. Books were inexpensive, i.e. 2 Lire in 1935, corresponding to some cents less than a kilo of bread, ${ }^{39}$ but eye-catching. ${ }^{40}$ New titles appeared regularly so that Wodehouse could become a trustworthy bedside companion. From 1930 to 1940 Bietti issued $5^{1}$ Wodehouse translations, more than 4 titles per year, on average. Bietti's Wodehouses sold very well and were often reprinted (a total of 130 editions from 1930 to 1940). ${ }^{41}$

\begin{tabular}{|l|c|c|c|c|}
\hline PUBLISHER & ORIGINAL TITLES UK & ITALIAN TITLES & TRANSLATORS & EDITIONS \\
\hline Bietti & 51 & 53 & 21 & 130 \\
\hline
\end{tabular}

Table 1.5: Total publications of Wodehouse's books by Bietti (1930 - 1940)

All this was happening in an era in which cultural production was strongly controlled by the regime that used two means to exercise control on publishing companies: economic support, in the forms of direct financial subsidy help (see: Enciclopedia Treccani, 2009) (2) $^{2}$ in addition to public book purchases (especially after the introduction of the state course textbooks in 1929-30 school year), and censorship. Publishers were forced to become aligned to fascism. Unlike newspapers, books were not preventively censored. The "prefetti" (the State's representatives in each province) might nevertheless judge a book contrary to morals or containing undesirable notions and order all copies to be seized. The regime wished to convey the idea of Italy as a healthy, prosperous, and happy country. Any reference to crime, mental disorders, or suicide was to be avoided, not only in the news but in novels as well. ${ }^{43}$ Morally

\footnotetext{
${ }^{39}$ Cover price corresponding to 1.81 Euros, while a kilo of bread in 1935 corresponded to 1.89 Euros, actualized prices (2010): http://www3.istat.it/dati/catalogo/20120118_oo/cap_21.pdf.

${ }^{40}$ Bietti maintained this editorial policy. In the 196os Wodehouse's titles were still inexpensive and their covers were characterized by a red and white banner on the cover, reading "Se sei saggio ridi!" (If you are wise, laugh!). They were part of the series of humour "Il Picchio", including Mark Twain, Oscar Wilde, Jerome Klapka Jerome. Some covers are reproduced in the Appendix,.

${ }^{41}$ Bietti continued to reprint the same translations until 1977, with a total of 302 editions.

${ }^{42} \mathrm{http}: / /$ www.treccani.it/enciclopedia/.

${ }^{43}$ In translating a Georges Simenon story, Giorgio Monicelli was faced with a serious issue. The protagonist, broke and desperate, had successfully planned to commit suicide in an ingenious way in order to let his daughter cash in his life insurance. In the original story, the detective discovered the deceit. Monicelli had the ingenious idea of having the detective explain that, in an act of courage, the protagonist had decided to give up his insane plan and had thrown his handgun away. Unfortunately, it had hit the mechanism he had so skillfully devised and had killed him (Petrillo, 2014).
} 
offending circumstances and offences to national pride were banned. ${ }^{44}$ Stories involving prostitution, incest, abortions, hints of sexual "deviance", supposed to damage the moral fibre of the people, would never pass the censor's block and a suppressed publication would result in an economic loss that publishers obviously tried to avoid. In choosing what to issue - select, commission, or have translated publishers had to take into account not only economic but also political aspects, since the two factors were strictly interwoven.

On the other hand, the regime was deeply concerned in the economic success of industrial publishing and was watching closely its steps in becoming a prestigious feature of Italy's growing reputation in the world. Some publishers adopted a policy of collaboration with well-disposed officers who sometimes agreed to examine the proofs before the book was actually printed (Rundle, 2010). The most willing to show signals of cooperation were the rising industrials: Mondadori, Rizzoli, Bietti. Some others were openly lined up with the regime, among them Vallecchi, Cappelli, Bemporad (mainly engaged in publishing school books and later overwhelmed by the so-called racial laws), and Modernissima (owned by Gian Dàuli, who also translated P.G. Wodehouse). Others (Gobetti, Laterza, Corbaccio and the already mentioned Formiggini) refused to compromise with the regime and were to suffer serious consequences.

Another policy adopted by publishers was self-censorship: texts were edited, bowdlerized and adapted to meet the criteria set by the censor, who, in many cases, happened to be Mussolini himself, having been an editor in his young years (Bonsaver, 2007). Such a procedure was more easily applied to translated texts since "what was important was respecting the integrity of content rather than the linguistic correctness of translation" (Mancini, 2006, p. 147, my translation).$^{45}$ Commissioning editors had a role, too. They were hired to read and evaluate texts worth being translated and the caveats were evident to them (Rundle, 2010). Nevertheless, sometimes their evaluation of the work was so favourable that they were ready to suggest a way to change or cut some parts of the story.

When the infamous Italian "racial laws" - even harsher than the German ones (Di Porto, 200o) - were passed, between September and November 1938, industry, public administration, school and university were involved in the expurgation requested by the regime: Jewish workers were expelled from their

\footnotetext{
${ }^{44}$ For example, in Alfredo Pitta's translation of Agatha Christie's Murder on the Orient Express (1934), issued by A. Mondadori in 1935, a reference to a suicide was omitted. Morever, the name of a notorious fugitive from the United States, Cassetti, of obvious Italian origins, was changed into O'Hara. Conversely, anti-semitic remarks were added in A. Mondadori Italian edition of Christie's Lord Edgware Dies (1933), published in 1935 as Se morisse mio marito, translated by Tito Sarego (Gianni, 2001).

${ }^{45}$ Some of the Italian translations of Wodehouse's book issued in these years, particularly those of The Man with Two Left feet (GV.16) and The Coming of Bill (GV.20) reveal Bietti's adherence to these directives.
} 
workplace. Publishing was as much affected as other sectors. Workers were dismissed and publishing companies owned by Jews were forced to close down. A most dramatic and exemplary story is that of the Jewish Modenese publisher Angelo Fortunato Formìggini. A lover of humour, Formìggini got his degree in Bologna in 1907 with a dissertation entitled Filosofia del ridere (Philosophy of Laughter). A "fascist of the first hour" ${ }^{46}$ he held prestigious positions in cultural institutions. In publishing, he made some foreign writers well known in Italy, for example with his series I Classici del ridere, in which he published translations of humorous works of Alphonse Daudet, Oscar Wilde, Edgar Allan Poe and Jerome K. Jerome. After the racial laws were published, he fell into disgrace and threw himself from the Ghirlandina tower in his hometown.

1946-1951: Wodehouse published in the aftermath of the Second World War

After the Second World War, publishing was as badly damaged as any other sectors of industry and trade in Italy. The whole of war-ravaged Europe was facing food shortages and depended on foreign aid for raw materials. The USA was the only country involved in the Second World War that still had a strong economy and it needed markets for the goods it produced. With some resistance, Italy joined other European countries in accepting the financial support offered by the European Recovery Program, proposed by the US administration, known as the Marshall Plan. Aid was given to European countries in the form of "grants", i.e. free food, fuel, medicine and raw materials and "loans", i.e. money given to companies to be paid back to their government that could spend it in accordance with the Marshall planners. In total, Italy received 1,171 million dollars in the so-called Post-War Relief Period and 1,516 million dollars from the Marshall Plan. Of these, some were also received by publishing companies, mainly the largest ones based in Northern Italy, i.e. A. Mondadori and Rizzoli. Italy witnessed an industrial "second generation" in publishing. Starting in 1946, A. Mondadori launched a number of popular series. Being a printing company as well, it also took advantage of job orders commissioned by American and British companies. Rizzoli, in Milan, started to grow again. Books were issued together with new popular weekly magazines and in 1949 Rizzoli launched the first successful pocketbook series in Italy, the "Biblioteca Universale Rizzoli" (BUR) that, as previously stated, was some years later to

\footnotetext{
${ }^{46}$ A term employed to describe to those who had joined Mussolini's movement at its onset, in 1919 (Whittam, 1995, p. 6).
} 
publish a new translation of Wodehouse's Love Among the Chickens (1906; GV.o6) retranslated by Oriana Previtali and published in 1961, with the same title, Amore tra i polli.

None of these large companies published any Wodehouse in the post war years, but in 1948 a new small publisher, Elmo Editore, appeared to compete with Bietti. Of the 39 titles issued in this period, 34 were published by Bietti - all reprints - and 4 by Elmo - all new editions. Elmo Editore had been founded by Federico Elmo in 1944 and continued to publish Wodehouse until 197o. Federico's first post in publishing was with Baldini \& Castoldi, a reputable company founded in Milan in 1879. One of their bestselling authors, novelist Salvador Gotta, followed Federico Elmo when he decided to set up his own business. ${ }^{47}$ Elmo released a series of books, named "Moderna Libreria Straniera" ("Modern Foreign Books") and commissioned translations for four Wodehouses. Joy in the Morning (1947; GV.59) was translated by Giorgio Monicelli and published in 1948 as La gioia è col mattino. Money in the Bank (1946; GV.58) was issued in 1949 under the title of Quattrini in banca, translated by Sirio Agnati, a translator to become one of Bietti's most regular collaborators in the years that followed. Uncle Dynamite (1948; GV.62) and The Mating Season (1949; GV.63) followed in 1949 and 1950, respectively entitled Lo zio Dinamite and Sotto le fresche frasche, both translated by Adriana Motti. The table, in which first editions are highlighted in bold, lists all Elmo's editions of Wodehouse's books, from 1948 to 1970, a total of 92 editions.

\begin{tabular}{|l|l|c|l|c|}
\hline CODE & \multicolumn{1}{|c|}{ ORIGINAL TITLE UK } & $\begin{array}{c}\text { UK } \\
\text { YEAR }\end{array}$ & \multicolumn{1}{c|}{ ITALIAN TITLE } & $\begin{array}{c}\text { IT } \\
\text { YEAR }\end{array}$ \\
\hline GV.56 & Quick Service & $\mathbf{1 9 4 0}$ & Servizio espresso & $\mathbf{1 9 5 1}$ \\
\hline GV.56 & Quick Service & 1940 & Servizio espresso & 1962 \\
\hline GV.57 & Eggs, Beans and Crumpets & $\mathbf{1 9 4 0}$ & Il club dei nati stanchi & 1962 \\
\hline GV.58 & Money in the Bank & $\mathbf{1 9 4 6}$ & Quattrini in banca: romanzo & 1949 \\
\hline GV.59 & Joy in the Morning & 1947 & La gioia è' col mattino & 1948 \\
\hline GV.59 & Joy in the Morning & 1947 & La gioia è col mattino & 1949 \\
\hline GV.59 & Joy in the Morning & 1947 & La gioia è col mattino & 1961 \\
\hline GV.61 & Spring Fever & 1948 & Febbre di primavera & 1952 \\
\hline GV.61 & Spring Fever & 1948 & Febbre di primavera & 1965 \\
\hline GV.62 & Uncle Dynamite & $\mathbf{1 9 4 8}$ & Lo zio dinamite & 1949 \\
\hline GV.62 & Uncle Dynamite & 1948 & Lo zio dinamite & 1955 \\
\hline GV.62 & Uncle Dynamite & 1948 & Lo zio dinamite & 1962 \\
\hline GV.63 & The Mating Season & $\mathbf{1 9 4 9}$ & Sotto le fresche frasche & 1950 \\
\hline
\end{tabular}

\footnotetext{
${ }^{47}$ Between 1947 and 1951 Elmo Editore also published works by Giuseppe Marotta, John Dos Passos, Gore Vidal, William Somerset Maugham. Later on, it specialized in humour (see following sections).
} 


\begin{tabular}{|l|l|c|l|c|}
\hline GV.64 & Nothing Serious & 1950 & Non c'è da preoccuparsi & 1965 \\
\hline GV.65 & The Old Reliable & 1951 & Diario segreto & 1952 \\
\hline GV.66 & Barmy in Wonderland & $195^{2}$ & Grullo nel paese delle meraviglie & 1953 \\
\hline GV.66 & Barmy in Wonderland & $195^{2}$ & Grullo nel paese delle meraviglie & 1963 \\
\hline GV.67 & Pigs Have Wings & $195^{2}$ & I porci hanno le ali & 1953 \\
\hline GV.67 & Pigs Have Wings & 1952 & I porci hanno le ali: romanzo & 1962 \\
\hline GV.68 & Ring for Jeeves & 1953 & Chiamate Jeeves: romanzo & 1954 \\
\hline GV.68 & Ring for Jeeves & 1953 & Tanto di cappello a Jeeves & 1955 \\
\hline GV.70 & French Leave & 1956 & E chi s'è visto s'è visto & 1956 \\
\hline GV.70 & French Leave & 1956 & E chi s'è visto s'è visto & 1966 \\
\hline GV.71 & Something Fishy & 1957 & Qualcosa di losco & 1958 \\
\hline GV.72 & Cocktail Time & 1958 & Mister I ci sa fare & 1960 \\
\hline GV.72 & Cocktail Time & 1958 & Mister I ci sa fare & 1961 \\
\hline GV.72 & Cocktail Time & 1958 & Mister I ci sa fare & 1964 \\
\hline GV.73 & A Few Quick Ones & 1959 & Storie spicciole & 1961 \\
\hline GV.74 & Jeeves in the Offing & 1960 & Jeeves taglia la corda & 1962 \\
\hline GV.75 & Ice in the Bedroom & 1961 & Ghiaccio in una stanza da letto & 1962 \\
\hline GV.76 & Service with a Smile & 1962 & I signori sono serviti & 1970 \\
\hline GV.77 & Stiff Upper Lip, Jeeves & 1963 & Lei e' unico, Jeeves & 1964 \\
\hline GV.78 & Frozen Assets & 1964 & L'eredita' sotto chiave & 1965 \\
\hline GV.79 & Galahad at Blandings & 1965 & Genero al verde & 1966 \\
\hline
\end{tabular}

Table 1.6: Wodehouse books published by Elmo (1948-1970)

Of the above titles, one, Joy in the Morning (GV.59, La gioia è col mattino) was translated in 1948 by Giorgio Monicelli, whose life was inextricably tied to the Italian publishing industry. Born in 1910 in a small town near Mantova to a journalist and playwright, Tomaso Monicelli, Giorgio was brought up by his aunt Andreina and her husband, the publisher Arnoldo Mondadori. Even when Monicelli moved back to live with his father, he still spent summers with the Mondadoris. At school, he studied French but he was so fascinated by Anglo-Saxon culture that he learnt English by himself (Cozzi, 20o6). He had a difficult character and was intolerant of discipline. He wanted to work immediately after compulsory school and got a job in A. Mondadori's printing plant in Verona, soon to be moved, in 1929, to the headquarters of the publishing company in Milan. Here, again, he showed his intolerance of discipline and office hours and was advised to start translation as a freelance. His career as a translator was long and chequered. He translated more than 200 works, both from French and from English, including Eduard Estaunié and Guy de Maupassant, Roland Dorgelès's Le château des brouillards (unfortunately 
seized by the fascist censors) and his masterpiece, the translation of Malcom Lowry's Under the Volcano, published in 1961 by Feltrinelli. ${ }^{48}$ His half-brother, Mario Monicelli, the film director, in an interview published on $30^{\text {th }}$ September 2012 in La Repubblica, stated that Giorgio could read and translate English, but could not speak nor understand the "live language". Having learnt English on paper, he read "those signs as if they were Sanskrit" (ibid., my translation). His translations reflect his restless personality and his style was perfectly suitable for the time: the aim was the quick fabrication of pleasant and light texts, produced with little or no consideration for philological accuracy. The most important virtue for a translator was an excellent command of the Italian language and the ability to attain the right register for Italian readers, even if the resulting text was not faithful to the original. His knowledge of English was, as already stated, partial. He very often used the French translation instead of the original English text. Evidence was found by Claudio Gorlier, the Italian scholar of American literature who pointed out Monicelli's mistake in Sotto il vulcano (La Stampa, $27^{\text {th }}$ February 1998, p. 27). Here, Monicelli rendered "Ferris Wheel" with "Via Ferris" (backtranslation: "Ferris Road"). Gorlier asserts that such a mistake can only be explained by Monicelli's reading "rue" ("road") instead of "roue" ("wheel"). The only Wodehouse he translated, Joy in the Morning (GV.59), was reprinted twice by Elmo (in 1949 and 1961) and was later retranslated by Sandra Campagna Ponzetto for Mursia in 1990 and by Tracy Lord for Polillo in 2013 . Comparisons reveal that Monicelli's version is freer than the other two. It is also apparent that he was rarely puzzled by any problematic item, since his prose is fluid, albeit frequently unfaithful.

This is a characteristic that Monicelli shared with Adriana Motti, the translator Elmo employed most often. She, too, had studied French. However, she started her long career in translation in 1949 with an English novel: Wodehouse's Uncle Dynamite (1948; GV.62). As a young journalist at l'Avanti!', the socialist newspaper, she asked her cousin, Federico Elmo, to commission from her a translation from French for his publishing company. He commissioned instead a translation from English, a language she did not know at all. Patiently, with a dictionary, she "built up sentence after sentence" (from an interview to her nephew, Tommaso Baldovino, $29^{\text {th }}$ April 2015, my translation). This was her first Wodehouse. She would later translate others, that were reprinted several times, as the table below shows. She also translated works by other writers, including Karen Blixen, E. F. Morgan, Katherine Anne Porter, Gerald Durrell, a total of more than 40 books. The reason why she became famous was her translation of J. D. Salinger's The Catcher in the Rye, published by Einaudi in 1961. Her style in translation was very free and she had an excellent command of Italian. In translating Salinger, for example, she invented a lot of different phrases

\footnotetext{
${ }^{48}$ Lowry, Malcom, 1961, Sotto il vulcano, translated by Giorgio Monicelli, Feltrinelli Editore.
} 
to render Holden's repeated "and all" throughout the novel. She aimed to achieve the language register she thought right for the author she was translating. She said: "Salinger used expressions I could not translate and that I tried to compensate for, in order to render his style" (quoted in an interview with Adriana Motti published in the magazine Wittgenstein, ${ }^{\text {st }}$ September, 1999, my translation). In the same interview she recalls having been scolded ("mi hanno fatto una rimenata") by the Catholic Digest for having used "cacchio" (a euphemistic variant of cazzo [prick]) in her rendering of the coarse American slang of one of Wodehouse's characters in Quick Service (1940; GV.56), published by Elmo as Sotto le fresche frasche (1950). She later used the same word to render "goddam" in Salinger. She worked with pen and ink and a school notebook: the translation on the right page, the amendments on the left. She did not like travelling, and never met any of the authors she had translated. Of her job, she said that it is awfully underpaid, whereas she admitted she was paid extremely well. She said that she understood why translators worked badly and added that thrillers are the best choice: it "takes you less time" (ibid. my translation). She was slow ("In the end, I am always late") and reported that Italo Calvino, editor-in-chief at Einaudi once wrote to her: "If you do not give us the book in May, you will in June, if not in June, then in July we'll send a killer, but you should work with a quiet mind, like in a bed of roses": she was in fact translating Salinger lying in bed and scribbling in her notebooks (ibid.). More about Motti will be said in Chapter 4. In one of the case studies I present, namely in "The most prolific translator", her translation style will be analysed in the light of the Epistemic Approach.

\begin{tabular}{|l|l|c|l|c|}
\hline CODE & \multicolumn{1}{|c|}{ ORIGINAL TITLE UK } & $\begin{array}{c}\text { UK } \\
\text { YEAR }\end{array}$ & \multicolumn{1}{c|}{ ITALIAN TITLE } & $\begin{array}{c}\text { IT } \\
\text { YEAR }\end{array}$ \\
\hline GV.56 & Quick Service & 1940 & Servizio espresso & 1962 \\
\hline GV.62 & Uncle Dynamite & 1948 & Lo zio dinamite & 1949 \\
\hline GV.62 & Uncle Dynamite & 1948 & Lo zio dinamite & 1955 \\
\hline GV.62 & Uncle Dynamite & 1948 & Lo zio dinamite & 1962 \\
\hline GV.63 & The Mating Season & 1949 & Sotto le fresche frasche & 1950 \\
\hline GV.65 & The Old Reliable & 1951 & Diario segreto & 1952 \\
\hline GV.66 & Barmy in Wonderland & $195^{2}$ & Grullo nel paese delle meraviglie & 1953 \\
\hline GV.66 & Barmy in Wonderland & 1952 & Grullo nel paese delle meraviglie & 1963 \\
\hline GV.67 & Pigs Have Wings & 1952 & I porci hanno le ali & 1953 \\
\hline GV.67 & Pigs Have Wings & $195^{2}$ & I porci hanno le ali: romanzo & 1962 \\
\hline GV.68 & Ring for Jeeves & 1953 & Chiamate Jeeves: romanzo & 1954 \\
\hline GV.68 & Ring for Jeeves & 1953 & Tanto di cappello a Jeeves & 1955 \\
\hline GV.70 & French Leave & 1956 & E chi s'è visto s'è visto & 1956 \\
\hline GV.70 & French Leave & 1956 & E chi s'è visto s'è visto & 1966 \\
\hline
\end{tabular}




\begin{tabular}{|l|l|c|l|c|}
\hline GV.71 & Something Fishy & 1957 & Qualcosa di losco & 1958 \\
\hline GV.72 & Cocktail Time & $195^{8}$ & Mister I ci sa fare & 1960 \\
\hline GV.72 & Cocktail Time & $195^{8}$ & Mister I ci sa fare & 1961 \\
\hline GV.72 & Cocktail Time & $195^{8}$ & Mister I ci sa fare & 1964 \\
\hline GV.74 & Jeeves in the Offing & 1960 & Jeeves taglia la corda & 1962 \\
\hline GV.76 & Service with a Smile & 1962 & I signori sono serviti & 1970 \\
\hline
\end{tabular}

Table 1.7: Wodehouse books translated by Motti for Elmo

Adriana Motti translated her first Wodehouse in 1949 when he was already well-known in Italy. Consulting the historical archives of one of the leading Italian newspapers, La Stampa, the familiarity with Wodehouse of the Italian audience in these years is apparent. On $1^{\text {st }}$ January 1949 , commenting about the release of the first volume of the new appendix to the Enciclopedia italiana, the journalist (signed as p.m.) refers to a short story, "The Man with Two Left Feet", where one of Wodehouse's characters buys the first volumes of the Encyclopaedia Britannica. Moreover, in the opening paragraph of an article that appeared on La Stampa in 1949, "Milord apre bottega" ("Milord sets up shop"), about the fiscal grip imposed by Stafford Cripps in the United Kingdom that was impoverishing the aristocracy, Wodehouse's noble characters are quoted: "Noblemen don't work". But things are changing. Consequently, the Earl of Shrewsbury and Waterford now personally sells fruit and vegetables produced on his farmland (photo) and Sir Campbell Mitchell-Cotts has recently found a job with the movie industry in the role of a butler (photo). Some months later, reporting about the "Labour's silent revolution of labour", under the headline "Cinque anni di governo laburista. E' scomparso il maggiordomo" ("Five years of Labour government. The butler has disappeared"), the journalist even states that "Jeeves is dead", to represent the current impoverishment of the British upper classes who cannot afford to keep servants in their households any more. In 1951, commenting on the new trend of casual clothing in men, Paolo Novelli, in La Stampa, reports having recently re-read one of Wodehouse's stories (the opening chapter of The Man Upstairs, 1914; GV.13) in an old edition: his stance is dismissive and patronizing but he concedes that "so many good things" can be found in Wodehouse's old "romanzetti" (i.e. "novelettes"). Moreover, one of Wodehouse's novels (Doctor Sally, 1932; GV.41) was published in instalments, under the title Amore e termometro ("Love and thermometer") in La Stampa, in December 1950, and a drastically cut anonymous version of Tempo pesante (Heary Weather, 1933; GV.45) was broadcast on the radio in $1951\left(26^{\text {th }}\right.$ June - Radio Monteceneri). 
Humour and satire was well represented in these years in Italy. Given the unstable political situation and dramatic social changes, satirists directed their darts particularly towards the "chameleons", politicians or intellectuals who recycled themselves after serving and backing Fascism. Il Travaso delle Idee started to be issued again in 1946. The same happened to Il Bertoldo, that had hosted some of Wodehouse's short stories in 1937 (Dossena, 1991). New magazines also appeared. Some were more leftwing, such as Cantachiaro, antigiornale satirico-politico ("satirical-political anti-paper"), and Don Basilio, a magazine so anticlerical that it was excommunicated by the Vatican (Chiesa, 1972). ${ }^{49}$ The paper that was going to play a major role in the Italian political scene, L'Uomo Qualunque ("the ordinary man") first appeared in December 1944 and soon became a major political phenomenon, referred to as "qualunquismo" (a term drawn from "qualunque", meaning "ordinary" or "common", one of the many untranslatable Italian "isms"). It diffused ideas of scepticism about political parties and emphasised the need for a moral reconstruction of Italy, attacking parties and addressing issues regarding the "ordinary" man's rights. However, its success did not last because of the lack of strong political roots and serious political proposals (Lomartire, 2008). A comparable role in terms of following was to be played by a new satirical magazine. In 1945 Giovannino Guareschi, after having coedited Il Bertoldo from 1936 to 1943, founded Candido, a new satirical weekly paper (Domenico \& Hanley, 2006). It was a right-wing magazine where Guareschi openly attacked Communist rhetoric (Perry \& Gibson, 2010) but also revealed the well concealed secrets of the new Christian Democratic political generation. The Italian political climate in those days was one of harsh ideological confrontation: Guareschi's recipe for Italians to defeat hate and discord was humour. Guareschi also wrote several novels, among them the famous books belonging to the saga of Don Camillo and Peppone, comically depicting the rivalry between Catholicism and Communism in a sleepy village in the Po river valley, sometime after the Second World War.

It might be asserted that Guareschi shares some traits with P.G. Wodehouse: both were popular humourists, both wrote more than 9o books that were translated worldwide, both were loved by their readers but ignored by the critics, both were confined in German prison camps during the war and later persecuted in their homelands because of the way they had made use of their wit. However, their styles differ greatly and none of the humorous devices employed by Wodehouse that I will present in Chapter 3 belong to Guareschi. To him, humour must be "ruthlessly simple, incisive, quick, and potent" (Perry \&

\footnotetext{
${ }^{49}$ Decree of the Holy Office against Communism, 1946.
} 
Gibson, 2010, p. 38), whereas, as we will later see in great detail, Wodehouse's humour is found in his admirable use of language that "has a jungle-exotic quality as it tangles like vines around the plots" (Carlson, 1975, p. 58).

1951-1969: Wodehouse published in the economic boom

Having restored its productive sectors, Italy grew both economically and socially - a period often referred to as the Economic Miracle. Governments enacted wise policies and management had become efficient. Large companies such as FIAT, the leading automobile manufacturer, could count on a large stock of labour force, so that "industrial production averaged a yearly increase of about 8.5\%" (Coppa, 1985, p. 131). Fiat rode the economic boom and its small model, Fiat 50o, launched in 1957, rapidly became the symbol of Italy's rejuvenated economic wellbeing. Publishing was a sector that took great advantage of the changed circumstances: unemployment had been defeated, people felt more optimistic about their future and had money to spend on books too. The levels of literacy also dramatically increased, reaching 90\% of Italians in $195^{8}$ (Panetta, 2012). By the end of the 1950 os many small companies had been absorbed by larger ones: a process of concentration had started. Large companies, such as A. Mondadori and Rizzoli, split their investments between books and illustrated magazines and other media. New titles were reviewed and launched by articles and advertisements on weekly magazines and in radio and television programmes. Books, mainly cheap weekly or monthly series, such as A. Mondadori's Oscar, could be bought also from newsstands, while "quality" literature was still only to be found in bookshops (Cadioli \& Vigini, 2012).

In these years Wodehouse was widely published in Italy: 167 editions appeared between 1951 and 1966: on average, more than 10 per year, a figure never to be reached again. Bietti and Elmo were still the main contributors, but other companies also started to draw from his huge output: A. Mondadori (hereinafter referred to as "Mondadori") issued 6 titles between 1951 and 1966, mostly in its Oscar series; while Rizzoli published Love Among the Chickens (1906; GV.o6) in a new translation by Oriana Previtali. However, given the uncertain political situation in the late 196os, no books by Wodehouse appeared on the Italian market, already stagnant, between 1967 and 1969 .

\begin{tabular}{|l|c|c|}
\hline \multicolumn{1}{|c|}{ PUBLISHERS } & NO OF ORIGINAL TITLES & NO OF EDITIONS \\
\hline Bietti & 39 & 130 \\
\hline Elmo & 19 & 28 \\
\hline
\end{tabular}




\begin{tabular}{|l|l|c|}
\hline Mondadori & 6 & 8 \\
\hline Rizzoli & 1 & 1 \\
\hline
\end{tabular}

Table 1.8: Number of titles and editions issued in Italy by each publisher during the economic boom (1951-1969)

Of Mondadori's publications, only two, Luna piena and Gas esilarante were first translations, by Vittoria Comucci and by Alberto Tedeschi respectively, while Poi, tutto s'accomoda, Jeeves non si smentisce and Zio Fred in primavera had already been published by Mondadori in late 193os, with the same translation by Alberto Tedeschi. Quattrini in banca was released in the same translation Elmo had previously commissioned from Sirio Agnati. In the early 1950s Mondadori started a paperback series, "Biblioteca Economica Mondadori", a collection offering "readings for every taste" according to the blurb of the Italian first edition of Summer Moonshine (1938; GV.53). These books ("everybody's and for everybody", ibid.) were low-priced (200 Lire $)^{50}$ yet "well printed and elegantly presented with a colour photographic cover" (ibid.). The collection was "conceived under the sign of pastime" (ibid.) and consisted of three series: blue, yellow and pink. Wodehouse's novels printed or reprinted in the 195os appeared in the pink one ("good humour", adventure, imagination and love books), while later series, "Il girasole" ("The sunflower") and "I libri del pavone" ("The Peacock books"), priced: 300 lire, ${ }^{51}$ housed the reprints in the $1960 s$.

Love Among the Chickens (1906; GV.o6), Wodehouse's first great success as a novelist (Wodehouse \& Ratcliffe, 2012), originally published in the UK in 1906, was republished in Italy by Rizzoli in 1961. It had already been translated by Silvio Spaventa Filippi and had been issued by Monanni (3 editions in translation), Bietti (8 editions, up to 7 of Filippi's translation and at least one in a different translation by Francesco Palumbo) and Aurora (with a translation by Dienne Carter, in 1938). Rizzoli commissioned a new translation from Oriana Previtali and the book appeared in the series Biblioteca Economica Rizzoli (BUR), defined in the back endpaper of the book as "the most authoritative Italian literary corpus of the post-war period". The (anonymous) preface to this edition offers a brief (and not completely accurate $)^{5^{2}}$

\footnotetext{
${ }^{5}$ Corresponding to just under 1.5 kilo of bread. Actualized prices (2010): http://www3.istat.it/dati/catalogo/20120118_oo/cap_21.pdf.

${ }^{51}$ Corresponding to about 2 kilos of bread. Actualized prices (2010): http://www3.istat.it/dati/catalogo/20120118_oo/cap_21.pdf.

${ }^{52}$ For example, Ethel, Wodehouse's wife, is said to "have born him a child", (...) heiress of his father's "inspiration" (p. 5): Leonora was in fact Ethel's daughter from her previous marriage. Wodehouse had formally adopted her (McCrum, 2004, p. 113).
} 
biography of P.G. Wodehouse, states that his books had been often published by various companies (none of which is mentioned) and lists his "most renowned" titles: a total of 3 o books. The preface asserts that, although already known in Italy, the book rightly deserves to be presented to the readers of BUR in a new translation, "fresh, cheerful and amusing" (Preface to Amore tra i polli, 1961, p. 7, my translation). The preface also explains that the novel belongs to the "Ukridge series" and gives a short account of the story. Some other recurring characters of Wodehouse's (Psmith, Bertie Wooster, Jeeves, Mr Mulliner, and Lord Emsworth) are also described in few, well-chosen words.

In these years, Wodehouse was very well received in Italy and his books were bought by public and private libraries. Illustrato FIAT, the company's in-house magazine listed the books recently acquired by the in-house library, the "Biblioteca circolante Fiat". For example, Poi, tutto s'accomoda was listed in the October 1955 issue, Cocktail Time (1958; GV.72) in the June/July issue, Storie spicciole (A Few Quick Ones 1959; GV.73) in February 1961.

1970-1980: Wodehouse published during the "years of lead"

After the economic and social achievements reached in the 196os, the 197os witnessed social conflicts in Italy. General unrest was triggered by recession and inflation. Plans for the economic development of Southern Italy and major reforms were continuously postponed (Mack Smith, 1997). Earthquakes in Sicily and Campania and floods throughout Italy devastated the country and aggravated its economic conditions, further exacerbated by the 1973 oil crisis. (Lanaro, 1994). The eleven governments that followed one another did not succeed in solving the conflicts or in forging new coalitions able to tackle the stagnant domestic situation and crucial issues, the chaotic urban development in large cities, corruption in public administration and the elevated concentration of arbitrary power in key institutions such as universities (Santarelli, 1996).

In 1967 the media revealed that a coup d'état had been attempted three years before. Journalistic investigations (the official one was to remain classified until 1992) showed that the national military police, the "carabinieri", backed by the secret services, had planned to occupy strategic institutions and to deport Communist leaders and political opponents, if the Communist party had become part of the coalition backing the new government (Flamini, 2007).

The results of the 1968 elections expressed public alarm (Mack Smith, 1997). Centrist leaders, especially Aldo Moro, secretary of the Christian Democrats since 1957, who led 5 governments, tried to 
pass an accommodation in which the Communist party would support the government. Such a so-called "historic compromise" was strongly opposed by most of the centrists and was never reached. Factories, schools, and universities were in turmoil. Students were fighting the government, asking for a radical reform of education and also marched to support the "national liberation in Vietnam" (Meade, 1990, p. 2). A terrorist war against the state culminated in the kidnapping and murder of Aldo Moro in 1978. This period has become known as the "Years of Lead", after Margarete Von Trotta's 1981 film, Die bleierne Zeit (in the English version: The German Sisters). Allegations were made that the Italian government had backed what was later called a "strategy of tension", orchestrated behind the scenes by the army and supported by the USA (Silj, 1994). The consequences were high social tension and a general feeling of mistrust and uncertainty. Life in big cities, such as Rome, Milan and Turin had become dangerous: there were fights in the streets, magistrates, journalists, and politicians were shot on their doorsteps, ordinary people felt insecure and threatened. The air Italians were breathing was motionless.

Publishing was stagnant, too. The trend had already been started in the late 196os and production slowed down significantly at the beginning on the 1970s (Panetta, 2012). Initiatives such as new book series were prerogatives of large companies, namely Mondadori and Rizzoli, who were also steadily absorbing smaller ones. Not many Wodehouses were published in these years, a trend that had already started in the late 196os, as Figure 1 shows. Bietti was still in activity but did not issue any new edition, simply reprinting their old translations several times. Nine were on the contrary translated and published by Mondadori. They were: A Pelican at Blandings (1969; GV.82), Much Obliged, Jeeves (1971; GV.84), The Girl in Blue (1970; GV.83), Pearls, Girls and Monty Bodkin (1972; GV.85), Bachelor Anonymous (1973; GV.86), Aunts Aren't Gentlemen (1974; GV.87) and Company for Henry (1967; GV.80). The translation of the last one was commissioned from Adriana Motti, while one of the others was translated by Caterina Longanesi and the remaining ones by Elena Spagnol. In 1980 Rizzoli republished Love Among the Chickens (1906; GV.o6) in the extant 1961 translation by Oriana Previtali.

\begin{tabular}{|l|l|c|l|c|l|}
\hline CODE & \multicolumn{1}{|c|}{ ORIGINAL TITLE UK } & $\begin{array}{c}\text { UK } \\
\text { YEAR }\end{array}$ & \multicolumn{1}{|c|}{ ITALIAN TITLE } & $\begin{array}{c}\text { IT } \\
\text { YEAR }\end{array}$ & TRANSLATOR \\
\hline GV.51 & Laughing Gas & 1936 & Gas esilarante & 1971 & Tedeschi Alberto \\
\hline GV.54 & $\begin{array}{l}\text { The Code of the } \\
\text { Woosters }\end{array}$ & 1938 & $\begin{array}{l}\text { Jeeves non si smentisce mai: } \\
\text { romanzo }\end{array}$ & 1973 & Tedeschi Alberto \\
\hline GV.55 & $\begin{array}{l}\text { Uncle Fred in the } \\
\text { Springtime }\end{array}$ & 1939 & Zio Fred in primavera & 1972 & Tedeschi Alberto \\
\hline GV.58 & Money in the Bank & 1946 & Quattrini in banca & 1974 & Agnati Sirio \\
\hline
\end{tabular}




\begin{tabular}{|l|l|c|l|c|l|}
\hline GV.68 & Ring for Jeeves & 1953 & Tanto di cappello a Jeeves & 1979 & Motti Adriana \\
\hline GV.74 & Jeeves in the Offing & 196 o & Jeeves taglia la corda & 1979 & Motti Adriana \\
\hline GV.8o & Company for Henry & 1967 & In compagnia di Henry & 1977 & Motti Adriana \\
\hline GV.81 & Do Butlers Burgle Banks? & 1968 & $\begin{array}{l}\text { I maggiordomi rapinano le } \\
\text { banche? }\end{array}$ & 1977 & Motti Adriana \\
\hline GV.82 & A Pelican at Blandings & 1969 & Il pellicano a Blandings & 1970 & $\begin{array}{l}\text { Longanesi } \\
\text { Caterina }\end{array}$ \\
\hline GV.83 & The Girl in Blue & 1970 & La ragazza in blu & 1973 & Spagnol Elena \\
\hline GV.84 & Much Obliged, Jeeves & 1971 & Molto obbligato, Jeeves & 1972 & Spagnol Elena \\
\hline GV.85 & $\begin{array}{l}\text { Pearls, Girls and Monty } \\
\text { Bodkin }\end{array}$ & 1972 & $\begin{array}{l}\text { I <<gioielli >> di Monty } \\
\text { Bodkin }\end{array}$ & 1974 & Spagnol Elena \\
\hline GV.86 & Bachelors Anonymous & 1973 & Anonima scapoli & 1975 & Spagnol Elena \\
\hline GV.87 & Aunts Aren't Gentlemen & 1974 & Le zie non sono gentiluomini & 1976 & Spagnol Elena \\
\hline
\end{tabular}

Table 1.9: Wodehouse books published by Mondadori (1970-1980)

1981-1991: Wodehouse published during "edonism"

The previous decade had seen the defeat of the trade unions in Italy that might be regarded as the end of the industrial era (Ginsborg, 2001). The focus of the economy shifted from industry to services and Milan became the symbol of this change, having become the centre for fashion, architecture and design. As in many other countries of the Western world, Italy witnessed an era of fun and luxury, labelled as "edonism". As for Milan, it was nicknamed "Milano da bere" ("Milan you can drink"), recalling the aperitif ritual, as a symbol of leisure, lazy time after a frantic and fruitful but short working day (Pivato \& Tonelli, 2004, p. 168). The family, a key element in Italian society, changed significantly, with an increase in women's political and social commitment and visibility at the expense of male-centred tradition. Middleclass citizens gained a prominent role in influencing policies, being more sensitive to issue-oriented politics than the previous generations. Both the Christian Democrats and the Communist party had lost consensus and coalition governments were led by the secretary of the Socialist party, Bettino Craxi, starting from 1980. He was praised for cutting inflation and for his foreign politics. He was born in Milan and had tight links with it. He was a close friend of Silvio Berlusconi, then a Milanese entrepreneur on his way up. Craxi manipulated parliament to pass a bill that allowed Berlusconi's private TV channels to broadcast in spite of breaching the law forbidding national private networks (Flores D'Arcais, 2006). This was the starting point of Berlusconi's march toward control of most of the Italian media. From 1984 he 
started to acquire shares in Mondadori and managed to control it as soon as 199o. In the meantime, Mondadori had significantly grown, making its way into the press with monthly magazines and daily newspapers, and in the television business, with the private channel Retequattro sold to Berlusconi in 1984 (Gomez \& Travaglio, 2005). At the same time, the company had lost interest in books, a sector in which it did not invest much. One must not be surprised, therefore, to learn that no Wodehouses were published by Mondadori or any other big company (Rizzoli had to face a major crisis in these years).

The figure of the "publisher protagonist" had almost disappeared from the Italian scene, replaced by managers and CEOs. Most of the sales proceeds derived from bestsellers and instant books (Panetta, 2012). However, two companies, Mursia and Guanda, founded by book enthusiasts started to publish Wodehouse in this period.

Ugo Mursia was born in Sicily but grew up in Rome and Padua. After a degree in Political Sciences and Law Studies, he began to move "on the tips of his toes" into the world of publishing as "a provincial intellectual" (see www.mursia.com), ${ }^{53}$ first as a publicist, later as an agent, then taking over A.P.E. (Azienda Padana Editrice), a small company specializing in school books. In 1951, he bought Alberto Corticelli, a long-established historical brand of children's books. In 1955 the two companies merged and unabridged translations of foreign classics, including Kipling, London, Twain, Swift, Scott and Melville appeared in Mursia's children's series “Collana Corticelli” (Tranfaglia \& Vittoria, 2007). Ugo Mursia’s two passions, books and the sea, happily blended into his editing and publishing of Joseph Conrad's complete works, most of which he personally translated into Italian (Milani, Corriere della Sera, 20-01-2012). ${ }^{54}$ Mursia's first two Wodehouses (GV.68 and GV.69) were published in 1988. After Ugo Mursia's death, the company was managed first by his wife, Giancarla Re, and later, in 1990, by his daughter, Fiorenza. Altogether Mursia published 25 titles in this period, as the table below shows.

\begin{tabular}{|l|l|c|l|c|l|}
\hline CODE & ORIGINAL TITLE UK & $\begin{array}{c}\text { UK } \\
\text { YEAR }\end{array}$ & \multicolumn{1}{|c|}{ ITALIAN TITLE } & $\begin{array}{c}\text { IT } \\
\text { YEAR }\end{array}$ & \multicolumn{1}{|c|}{ TRANSLATOR } \\
\hline GV.o6 & $\begin{array}{l}\text { Love Among the } \\
\text { Chickens }\end{array}$ & 1906 & L'amore fra i polli & 1990 & Bodoman Mario \\
\hline GV.10 & Psmith in the City & 1910 & Psmith in banca & 1990 & $\begin{array}{l}\text { Trimarchi Anna } \\
\text { Chiara }\end{array}$ \\
\hline GV.11 & The Prince and Betty & 1912 & Il principe e Betty & 1990 & Castelli Giulia \\
\hline GV.12 & The Little Nugget & 1913 & La piccola pepita & 1991 & [Not Given] \\
\hline
\end{tabular}

${ }^{53}$ Mursia: 'Chi siamo': http://www.mursia.com/index.php?option=com_content\&view=category\&id=81\&Itemid=57 (visited 24-05-2015).

${ }^{54} \mathrm{http} / /$ www.mursia.com/images/generali/corriere_sera_2o-o1-2012.pdf. 


\begin{tabular}{|c|c|c|c|c|c|}
\hline GV.14 & Psmith, Journalist & 1915 & Psmith giornalista & 1991 & $\begin{array}{l}\text { Trimarchi Anna } \\
\text { Chiara }\end{array}$ \\
\hline GV.15 & Something Fresh & 1915 & Qualcosa di nuovo & 1991 & Bodoman Mario \\
\hline GV.16 & $\begin{array}{l}\text { The Man With Two Left } \\
\text { Feet }\end{array}$ & 1917 & $\begin{array}{l}\text { L'uomo con due piedi } \\
\text { sinistri }\end{array}$ & 1991 & del Tanaro Teobaldo \\
\hline GV.18 & Piccadilly Jim & 1918 & Piccadilly Jim & 1991 & Salvatorelli Franco \\
\hline GV.21 & Jill, the Reckless & 1921 & Jill ragazza bizzarra & 1991 & Bodoman Mario \\
\hline GV.24 & $\begin{array}{l}\text { The Clicking of } \\
\text { Cuthbert }\end{array}$ & 1922 & $\begin{array}{l}\text { Il colpo di Cuthbert e altri } \\
\text { racconti }\end{array}$ & 1990 & Buckwell Gilson Mary \\
\hline GV.30 & Carry On, Jeeves & 1925 & Avanti, Jeeves & 1991 & Salvatorelli Franco \\
\hline $\mathrm{GV} \cdot 38$ & Very Good, Jeeves & 1930 & Benissimo, Jeeves & 1990 & $\begin{array}{l}\text { Zuffada Locuratolo } \\
\text { Angela }\end{array}$ \\
\hline GV.41 & Doctor Sally & $193^{2}$ & La dottoressa Sally & 1990 & Bodoman Mario \\
\hline GV.54 & $\begin{array}{l}\text { The Code of the } \\
\text { Woosters }\end{array}$ & 1938 & Il codice dei Wooster & 1989 & Buckwell Gilson Mary \\
\hline GV.59 & Joy in the Morning & 1947 & Un mattino di gioia & 1990 & $\begin{array}{l}\text { Campagna Ponzetto } \\
\text { Sandra }\end{array}$ \\
\hline GV.63 & The Mating Season & 1949 & La stagione degli amori & 1990 & $\begin{array}{l}\text { Campagna Ponzetto } \\
\text { Sandra }\end{array}$ \\
\hline GV.68 & Ring for Jeeves & 1953 & Chiamate Jeeves & 1988 & Palazzi Rosetta \\
\hline GV.69 & $\begin{array}{l}\text { Jeeves and the Feudal } \\
\text { Spirit }\end{array}$ & 1954 & Jeeves e la cavalleria & 1988 & Buckwell Gislon Mary \\
\hline GV.74 & Jeeves in the Offing & 1960 & Jeeves sta alla larga & 1989 & Palazzi Rosetta \\
\hline GV.77 & Stiff Upper Lip, Jeeves & 1963 & Teniamo duro, Jeeves & 1990 & Palazzi Rosetta \\
\hline GV.83 & The Girl in Blue & 1970 & La ragazza in blu & 1990 & Spagnol Elena \\
\hline GV.84 & Much Obliged, Jeeves & 1971 & Molto obbligato, Jeeves & 1989 & Buckwell Gilson Mary \\
\hline GV.85 & $\begin{array}{l}\text { Pearls, Girls and Monty } \\
\text { Bodkin }\end{array}$ & 1972 & I gioielli di Monty Bodkin & 1990 & Spagnol Elena \\
\hline GV.86 & Bachelors Anonymous & 1973 & Anonima scapoli & 1990 & Spagnol Elena \\
\hline GV.87 & $\begin{array}{l}\text { Aunts Aren't } \\
\text { Gentlemen }\end{array}$ & 1974 & $\begin{array}{l}\text { Le zie non sono } \\
\text { gentiluomini }\end{array}$ & 1989 & Spagnol Elena \\
\hline
\end{tabular}

Table 1.10: Wodehouse books published by Mursia (1981-1991)

The other new Italian publisher of Wodehouses, Guanda, had been founded in Parma by Ugo Guandalini in $1932 .{ }^{55}$ In 1986, it was bought by Luciano Mauri and Mario Spagnol and in 1989 it started to be managed by Luigi Brioschi, one of Wodehouse's translators for Rizzoli. Between 1989 and 1990 Guanda published 5 titles by Wodehouse: some in a new translation by Stefania Bertola (Psmith, Journalist 1915; GV.14 and Full Moon 1947; GV.6o) or Carlo Brera (Summer Lightning 1929; GV.37). Some others (Heavy Weather 1933;

\footnotetext{
${ }^{55} \mathrm{http}: / /$ www.treccani.it/enciclopedia/guanda/.
} 
GV.45 and Uncle Fred in the Springtime 1939; GV.55) were issued in earlier translations, respectively by Luigi Spagnol and Alberto Tedeschi.

According to Pensato (2015), the year 1989 marks an important date in the history of Wodehouse in Italy for two reasons. First, on $10^{\text {th }}$ May, a group of Italian Wodehousian enthusiasts,$^{56}$ some already mentioned here as they authored prefaces to Italian editions, founded in Milan the "Società degli (illustrissimi) amici di Wodehouse, meaning "Society of Wodehouse's (very distinguished) friends Wodehouse". Secondly, and, according to Pensato, consequently, a deal was made between Mursia and Guanda to publish Wodehouse's complete works in new, more accurate editions (ibid., p. 20). The data I collected reveal that this plan was only partly fulfilled. No early stories, namely the School Stories, originally published between 1902 and 1905, were published in Italy in this period. The oldest Wodehouse published by Mursia was GV.o6 (Love Among the Chickens, 19o6), while Guanda's oldest one was GV.13 (The Man Upstairs and Other Stories, 1914). It is however apparent that the two publishers made a deal to share out Wodehouse's production, with Guanda mainly publishing the Blandings cycle and Mursia the rest of Wodehouse works, particularly the whole of the Jeeves and Bertie cycle, with the notable exception of The Inimitable Jeeves (GV.26), mostly in new translations. ${ }^{57}$

Wodehouse was noticed in more "high-brow" venues in Italy at this time. L'indice dei libri del mese, a monthly magazine inspired by The Times Literary Supplement, was founded in $1984.5^{8}$ Wodehouse was often listed on the occasion of a new edition, e.g. in the October 1988 issue, listing Mursia's re-edition of Ring for Jeeves (1953; GV.68), or in June 1989, again for a Mursia book (Jeeves in the Offing 196o; GV.74). In the April 1987 issue, Franco Marenco, an Italian anglicist, reviewed Guido Almansi's La ragion comica ('Comic reason', 1986), published by Feltrinelli a few months before. Marenco approves of Almansi's definition of Wodehouse as "a giant of modern literature, not so much for the quality of his pages, but for the gigantic distance between him and Shakespeare: in one of his sonnets, Shakespeare had explored the stereotypy of originality, while Wodehouse explored the originality of stereotype" (Marenco, 1987, p. 6, my translation). Another example is the review of the Italian translation of Barbara Pym's An Unsuitable

\footnotetext{
${ }^{56}$ Among them, Franco Cavallone, Gianpaolo Dossena, Giorgio Bocca, Silvia Giacomoni, Guido Besana, Giorgio Manganelli, Claudio Magris, Carlo Fruttero, Franco Lucentini, Luciano Foà, Indro Montanelli, Tullio Pericoli, Giovanni Gandini, Lucio Villari, Guglielmo Zucconi, Guido Almansi and Attilio Bertolucci (Pensato, 2015, p. 19). ${ }^{57}$ Translators working for Mursia from 1989 include Mary Buckwell Gilson, Rosetta Palazzi, Elena Spagnol, Sandra Campagna Ponzetto, Franco Salvatorelli, and Angela Zuffada Loruratolo.

${ }^{58} \mathrm{http}$ ///www.lindiceonline.com/index.php/storia (accessed 30-05-2015).
} 
Attachment: ${ }^{59}$ Masolino d'Amico, university professor of English literature in Rome, cited Wodehouse twice (L'Indice dei Libri del Mese, n. 5, May 1987), implying that his works were sufficiently well known to be used in a comparison.

Guido Almasi also wrote an article in the newspaper la Repubblica on $5^{\text {th }}$ July 1989 , entitled "Porco bello", playing with the assonance between "porco" ("swine") and "porto" in referring to both Portobello Road and to Wodehouse's heroine, the Empress of Blanding's, the multi-prize-winning swine Lord Emsworth proudly breeds. Moreover, as "bello" means "beautiful", a second joke is subtly suggested. In his article, Almansi praises Wodehouse: "a wizard who pulls together a sequence of words so as to get the strongest effect" (my translation). He also complains about the lack of critical bibliographies on Wodehouse and relates that, when he once suggested Wodehouse as a subject in one of his courses at an English university (not mentioned), colleagues had made fun of him. On $24^{\text {th }} \mathrm{June} 1989$, Antonio Gnoli, a journalist at la Repubblica, in presenting Guanda's edition of Summer Lightning (1929; GV.37), stated that Italian publishers did not love Wodehouse, feeling "literary uncertainty, trade fears, perhaps metaphysical [sic] annoyance" (my translation). It is worth underlining that reviews and prefaces never explicitly mention the original works in English. They often quote phrases and comment on passages taken from extant translations, hence contributing to the creation and the persistence of what I term "the alief in equivalence"(see Introduction, p. 1).

1992-1997: Wodehouse published during "tangentopoli"

Tangentopoli, sometimes translated into English as Bribesville, (Emmott, 2012, p. 16) is the name the media gave to a major scandal unearthed by judicial investigations started in Milan and eventually involving all major parties. Political corruption was found to be closely linked to organized criminal organizations, i.e. and e.g. mafia, camorra and 'ndrangheta. The operation, referred to by journalists as "mani pulite", meaning "clean hands" (Emmott, 2012, p. 35,) began when a marginal socialist politician was caught while cashing a bribe in Milan. The investigation rapidly grew and most political leaders, including previous Prime Minister Bettino Craxi, were committed for trial. Citizens felt outraged and indignant. The Christian Democrats and the Socialist party, marred by scandal, split into subgroups and

\footnotetext{
${ }^{59}$ Pym, Barbara (1987), Una relazione sconveniente, translated by Neri Carano, published by La tartaruga, a publishing company founded in 1975, now belonging to the Baldini \& Castoldi group, publishing exclusively books authored by women.
} 
eventually disappeared. The whole political system was discredited and the effects on society were devastating. The only power to maintain its credibility was the judiciary and the "mani pulite" ("clean hands") pool of magistrates became the heroes of the day (Mammone \& Veltri, 2010, p. 102). Television was the most efficient medium to get updated information. Newspapers - owned by corporations that had been long been backed by political parties - were seen as no longer reliable. Surveys conducted in this period showed that Italians' reading habits were steadily decreasing, due to "lack of time and to disaffected readers" (Panetta, 2012, p. 25, my translation).

Publishing companies reacted by launching extremely inexpensive series. However, no Wodehouses were published in them. From 1992 to 1995, 40 titles were reprinted, mostly by Mursia ( 8 titles, all of them in extant translations). Rizzoli twice (1993 and 1994) republished Love Among the Chickens (1906; GV.o6), in the translation commissioned from Oriana Previtali in 1961. Guanda's only title was Blanding Castle and Elsewhere (1935; GV.48). Mursia and Rizzoli published cheap paperback editions, ${ }^{60}$ while Guanda's hardback books were more expensive ${ }^{61}$ Two new translators worked on Wodehouse for Mursia, Monica Morzenti and Sandro Melani. For the first, the translation of three Wodehouses (GV.34, GV.56 and GV.78) between 1992 and 1997 was just the beginning of a career in translation, mainly from Chinese; while Sandro Melani specialised in English literature. Now retired, he worked as a professor at Università della Tuscia and Università di Firenze.

The only new company to publish Wodehouse was TEA (Tascabili degli Editori Associati). A joint venture between Mario Spagnol (Longanesi), Gianni Merlini (UTET, a long-established Turinese publishing company), and Luciano Mauri (Messaggerie italiane, a book-distributor since 1914), it was born in $1987 .{ }^{62}$ As shown in the table below, between 1993 and 1997, TEA published 6 Wodehouses, and 7 editions, all in previous translations and all belonging to the Blandings cycle.

\begin{tabular}{|l|l|c|l|c|l|}
\hline CODE & \multicolumn{1}{|c|}{ ORIGINAL TITLE UK } & $\begin{array}{c}\text { UK } \\
\text { YEAR }\end{array}$ & \multicolumn{1}{|c|}{ ITALIAN TITLE } & $\begin{array}{c}\text { IT } \\
\text { YEAR }\end{array}$ & \multicolumn{1}{|c|}{ TRANSLATOR } \\
\hline GV.37 & Summer Lightning & 1929 & Lampi d'estate & 1993 & Brera Carlo \\
\hline GV.45 & Heavy weather & 1933 & Aria di tempesta & 1994 & Spagnol Luigi \\
\hline GV.48 & Blandings Castle and Elsewhere & 1935 & Il castello di Blandings & 1995 & Brioschi Luigi \\
\hline
\end{tabular}

\footnotetext{
${ }^{60}$ Mursia books were sold at 14,0oo lire, corresponding to less than 4 kilos of bread; while Rizzoli BUR books sold at 8,ooo lire, corresponding to 2 kilos of bread, hence in line with Mondadori's prices in the 196os. Actualized prices (2010): http://www3.istat.it/dati/catalogo/20120118_oo/cap_21.pdf.

${ }^{61}$ Guanda sold at 27,0oo lire, corresponding to about 6.5 kilos of bread. Actualized prices (2010): http://www3.istat.it/dati/catalogo/20120118_oo/cap_21.pdf.

${ }^{62}$ See http://www.messaggerie.it/editoria/tea-tascabili-editori-associati.
} 


\begin{tabular}{|l|l|c|l|c|l|}
\hline GV.52 & Lord Emsworth and Others & 1937 & $\begin{array}{l}\text { Ondata di crimini a } \\
\text { Blandings }\end{array}$ & 1997 & Spagnol Luigi \\
\hline GV.55 & Uncle Fred in the Springtime & 1939 & Zio Fred in primavera & 1994 & Tedeschi Alberto \\
\hline GV.55 & Uncle Fred in the Springtime & 1939 & Zio Fred in primavera & 1997 & Tedeschi Alberto \\
\hline GV.6o & Full Moon & 1947 & Luna piena & 1996 & Bertola Stefania \\
\hline
\end{tabular}

Table 1.11: Wodehouse books published by TEA (1993-1997)

The editors at TEA did their best to introduce the saga: the front endpapers contained an accurate description of the castle, its denizens and its location- even naming Sir Lancelot "Capability" Brown as the likely designer for its park. The main characters of the saga were listed at the back of the book, each with a conscientious and well-designed description. The books even contained a drawing of the castle and its surroundings, not credited, but very similar to the one by Ionicus, ${ }^{63}$ reproduced in the Penguin edition of Wodehouse's posthumous Sunset at Blandings (1977), and on the back cover, a brief summary of the story and an even briefer biography of Wodehouse. This is in fact the period in which Wodehouse's books started to appear with prefaces, introductions, and, sometimes, afterwords. This matter is more systematically treated later in this chapter, in the section on paratexts.

1998-2017: Wodehouse published now

The year 1997 opened up a new period in Italian history. The so-called "first republic" was substituted by a second one, at least in the collective imagination. Citizens asked for reforms and as voters they expressed their opinion through a number of referendums held in 1993. Old parties had been swept away and time was ready for new movements to take the stage (Koff \& Koff, 200o). Silvio Berlusconi was the first to take advantage of the changed scenario and in 1994 had founded his own party "Forza Italia" ("Go, Italy") gathering former socialists, conservative forces and new actors, eager to follow his steps to success. The new party won the 1994 general elections and Berlusconi, appointed Prime Minister, led a right-wing government (Frei, 1996). He was already a media tycoon. By employing faithful companions in statecontrolled institutions and companies, such as RAI, the Italian national broadcast company, he practically controlled the Italian mass media (Gomez \& Travaglio, 2005). His empire extended from TV,

\footnotetext{
${ }^{63}$ Ionicus, a pseudonym of Joshua Charles Armitage (1913-1998) illustrated the covers of Wodehouse's Penguin paperback editions. His bird's-eye view of Blanding castle was drawn in 1977 .
} 
radio, newspapers and magazines to books, being now the sole owner of Mondadori and of the many publishing companies Mondadori had eventually taken over, such as Einaudi, Piemme, Sperling \& Kupfner, and Electa (Panetta, 2012).

In this period, Mondadori did not republish any Wodehouse, while Mursia, Guanda and TEA did, with 8,15 , and 17 titles each. A few new translators appeared, ${ }^{64}$ together with a new publisher, Marco Polillo Editore (or Polillo Editore), who is gradually publishing all books in the Jeeves and Wooster cycle, mostly with new translations, starting from 2005. Marco Polillo founded his company in 1995 after having worked for Mondadori and Rizzoli. He launched a number of series, mostly thrillers. The most successful of them is "Bassotti", a series of books characterized by blood-red covers. His Wodehouses belong to the series named "I Jeeves" (the Jeeves) and have a captivating logo, a black silhouette of an archetypical decent valet. ${ }^{65}$ The collection contains today 14 titles. All of them, except two, were translated by Tracy Lord. $^{66}$

\begin{tabular}{|l|l|c|l|c|l|}
\hline CODE & \multicolumn{1}{|c|}{ ORIGINAL TITLE UK } & $\begin{array}{c}\text { UK } \\
\text { YEAR }\end{array}$ & \multicolumn{1}{|c|}{ ITALIAN TITLE } & $\begin{array}{c}\text { IT } \\
\text { YEAR }\end{array}$ & \multicolumn{1}{|c|}{ TRANSLATOR } \\
\hline GV.26 & The Inimitable Jeeves & 1923 & L'inimitabile Jeeves & 2010 & Lord Tracy \\
\hline GV.26 & The Inimitable Jeeves & 1924 & L'inimitabile Jeeves & 2013 & Lord Tracy \\
\hline GV.26 & The Inimitable Jeeves & 1925 & L'inimitabile Jeeves & 2014 & Lord Tracy \\
\hline GV.26 & The Inimitable Jeeves & 1926 & L'inimitabile Jeeves & 2016 & Calise Leslie \\
\hline GV.30 & Carry On, Jeeves & 1925 & Avanti, Jeeves & 2011 & Lord Tracy \\
\hline GV.38 & Very Good, Jeeves & 1930 & Molto bene, Jeeves & 2012 & Lord Tracy \\
\hline GV.38 & Very Good, Jeeves & 1930 & La vita e' strana, Jeeves & 2013 & Lord Tracy \\
\hline GV.38 & Very Good, Jeeves & 1930 & La vita e' strana, Jeeves & 2014 & Lord Tracy \\
\hline GV.38 & Very Good, Jeeves & 1930 & La vita e' strana, Jeeves & 2016 & Calise Leslie \\
\hline GV.46 & Thank You, Jeeves & 1934 & Grazie, Jeeves & 2005 & Lord Tracy \\
\hline GV.46 & Thank You, Jeeves & 1934 & Grazie, Jeeves & 2013 & Lord Tracy \\
\hline GV.46 & Thank You, Jeeves & 1934 & Grazie, Jeeves & 2014 & Lord Tracy \\
\hline GV.46 & Thank You, Jeeves & 1934 & Grazie, Jeeves & 2016 & Calise Leslie \\
\hline GV.47 & Right Ho, Jeeves & 1934 & Perfetto, Jeeves & 2005 & Buitoni Duca Maria \\
\hline GV.54 & The Code of the Woosters & 1938 & Il codice dei Wooster & 2005 & Vigano' Giovanni \\
\hline GV.59 & Joy in the Morning & 1947 & Un mattino di gioia & 2006 & Lord Tracy \\
\hline GV.59 & Joy in the Morning & 1947 & Un mattino di gioia & 2013 & Lord Tracy \\
\hline GV.59 & Joy in the Morning & 1947 & Un mattino di gioia & 2017 & Calise Leslie \\
\hline GV.63 & The Mating Season & 1949 & La stagione degli amori & 2006 & Lord Tracy \\
\hline GV.63 & The Mating Season & 1949 & La stagione degli amori & 2016 & Calise Leslie \\
\hline
\end{tabular}

\footnotetext{
${ }^{64}$ Namely, Fulvio Bernardis, Tracy Lord, Paola Mazzarelli, Dolores Musso, Silvia Pieraccini, and Giovanni Vigano.

${ }^{65}$ See http://www.polilloeditore.it/.

${ }^{66}$ A pseudonym for Leslie Calise. Since 2015, she has been publishing under her true name.
} 


\begin{tabular}{|l|l|c|l|c|l|}
\hline GV.68 & Ring for Jeeves & 1953 & Chiamate Jeeves & 2007 & Lord Tracy \\
\hline GV.69 & Jeeves and the Feudal Spirit & 1954 & Tanto di cappello a Jeeves & 2006 & Lord Tracy \\
\hline GV.74 & Jeeves in the Offing & 1960 & Jeeves taglia la corda & 2007 & Lord Tracy \\
\hline GV.74 & Jeeves in the Offing & 1960 & Jeeves taglia la corda & 2014 & Lord Tracy \\
\hline GV.74 & Jeeves in the Offing & 1960 & Jeeves taglia la corda & 2017 & Calise Leslie \\
\hline GV.77 & Stiff Upper Lip, Jeeves & 1963 & Teniamo duro, Jeeves & 2007 & Lord Tracy \\
\hline GV.77 & Stiff Upper Lip, Jeeves & 1963 & Teniamo duro, Jeeves & 2013 & Lord Tracy \\
\hline GV.77 & Stiff Upper Lip, Jeeves & 1963 & Teniamo duro, Jeeves & 2016 & Calise Leslie \\
\hline GV.84 & Much Obliged, Jeeves & 1971 & Molto obbligato, Jeeves & 2008 & Lord Tracy \\
\hline GV.87 & Aunts Aren't Gentlemen & 1974 & $\begin{array}{l}\text { Le zie non sono } \\
\text { gentiluomini }\end{array}$ & 2009 & Lord Tracy \\
\hline GV.87 & Aunts Aren't Gentlemen & 1974 & $\begin{array}{l}\text { Le zie non sono } \\
\text { gentiluomini }\end{array}$ & 2013 & Lord Tracy \\
\hline GV.87 & Aunts Aren't Gentlemen & 1974 & $\begin{array}{l}\text { Le zie non sono } \\
\text { gentiluomini }\end{array}$ & 2016 & Calise Leslie \\
\hline
\end{tabular}

Table 1.12: Polillo editore series "I Jeeves" (2005-2017)

\section{Italian editions: paratexts and cover art}

A paratext of a published work was defined in 1987 by Gerard Genette ${ }^{67}$ as the material that accompanies the book and directs the reader. By physically checking books during the research I could highlight some features that characterize the different editions, in terms of covers, spines, layout and the presence of prefaces, introductions, pre- and after-words, and, most importantly, to note if the translator was named.

A chronological survey shows that at first, from 1928 to the 196os, paratexts were scant, normally consisting of the front cover, a frontispiece and, if present in the original book, the table of contents. This was usually printed, according to the Italian usage, at the back of the book. Gradually, after publishers had started to launch their series, both front and back covers acquired a character of their own, designed to enable readers to spot promptly a new title and to support collectors.

Elmo and Bietti were the first to devise a very personal cover layout for their Wodehouses. Bietti, in particular, experimented with photographs, with covers that today look incongruous, if not frankly hideous (two examples are reproduced in Appendix 8). Not much room was allowed to the author, apart from a list of other titles published in the same series. Much more was introduced in the 1970s: in most series, the front and back endpapers or the flap, in more expensive editions, contained, respectively, a summary of the book and a biography of Wodehouse. Prefaces also started to be published, some

\footnotetext{
${ }^{67}$ Genette, G. (1987, p. 1) Seuils, Paris: Éditions du Seuil.
} 


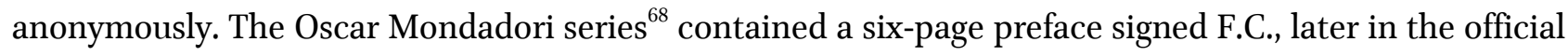
catalogue, disclosed as Franco Cavallone. ${ }^{69}$ It sketches Wodehouse's early career and traces the origins of Wodehouse's "distinctive language" back to 1910, with the introduction of Psmith. This language, Cavallone asserts, "scorns any direct expression, while it takes pleasure in abstractions, in amusing generalizations, in involved metaphors, in audacious transpositions, in manifestly excessive judgements, in learned reminiscences and exoteric references" (second page, my translation). Cavallone also relates some events in Wodehouse's life and connects them to the evolution (or rather, involution) of his style and characters. Recalling that Wodehouse had not been living in England after the 1920's, for example, Cavallone explains his uprooting from contemporary England and his sticking with English upper-class customs.

For its GUM series, Mursia made up a standard preface summarizing Wodehouse's life and works ${ }^{70}$ to be printed in every book of the series. It opens with a brief remark, stating that Wodehouse is commonly considered one of the few great humourists of our century. It then gives the reader a potted yet engaging outline of Wodehouse's life and works, presented by characters and cycles. The most remarkable passage is the one in which the anonymous reviewer states that Wodehouse's production is repetitive and full of "familiar platitudes" but it is meant as such to "capture legions of readers, induce addiction and initiate a cult" (my translation). The author then cites Wodehouse's renowned words on writing a novel, from a letter to Townend, contained in Performing Flea (1953): "I believe there are two ways of writing novels. One is making a sort of musical comedy without music and ignoring real life altogether; the other is going deep down into life and not caring a damn..." but objects to these words: Wodehouse's stories, on the contrary, help to understand "how British society was changing after WWı" since Wodehouse "has eyes open wide on the present" (my translation). Mursia's writer also reports favourable remarks on Wodehouse's works by Lord David Cecil ${ }^{71}$ and Evelyn Waugh. Four long paragraphs are devoted to Jeeves, erroneously described as a butler ("maggiordomo"). The final paragraph comments on the "futility" of Wodehouse's stories, while highlighting their strengths: on the one side, a set environment where jokes

\footnotetext{
${ }^{68}$ Including GV.51, GV.54, GV.55, GV.58, GV.68, GV.74, GV.8o, GV.81, GV.82, GV.83, GV.85, GV.86 and GV.87.

${ }^{69} \mathrm{http}: / /$ catalogostorico.fondazionemondadori.it/opac. Franco Cavallone, Italian, an intellectual and bibliophile, was the translator of the Peanuts cartoons into Italian between 1962 and 1972 (Gandini, 2011, p. 12).

${ }^{70}$ Contained in Mursia's editions of GV.o8, GV.10, GV.14, GV.22, GV.25, GV.32, GV.57, GV.63, and GV.78, from 1990 to 1997 .

${ }^{71}$ English literary critic and biographer (1902-1986) and father to Jonathan Cecil (1939-2011), actor and reader of more than 40 Wodehouse audiobooks.
} 
spring out of misunderstandings or a "variation of a detail", on the other, a style "characterized by a great linguistic and expressive skill" (ibid., my translation).

Jeeves e la cavalleria (GV.69) in the 1988 edition by Mursia, although issued in the GUM series, is introduced by a different preface, signed by Guglielmo Zucconi. ${ }^{72}$ He starts by commenting on Wodehouse's quotation on the two ways of writing novels and affirms that he was "unjust to himself" since his works do not at all ignore life. Zucconi draws a lot from the GUM standard preface, raising a suspicion of having been its anonymous writer. He also shows erudite knowledge of English classics of humour and places Wodehouse in the school of the humoristic, satirical, and libellous works that offered English generations a "deforming mirror" in which they could recognize themselves. Differently from Swift and Shaw, Wodehouse - Zucconi writes - "did not have it in for anyone": he was "a quiet man", ${ }^{73}$ a "diligent hard worker and a creature of habit" (my translation). The following very long paragraphs start introducing Jeeves, described as "the incomparable butler [again!] of an idiotic master". Zucconi asserts that in creating Jeeves, Wodehouse was catching the first signs of the drastic social change that would bring Labour to power. He then directly refers to the novel he is introducing, underlining Jeeves's extraordinary skills and vast knowledge. Particularly salient is the comparison between Wodehouse and Carlo Goldoni, the $18^{\text {th }}$ century Italian playwright, defined as the "smiling witness of the decline of Venice" in Zucconi's words (my translation). Again, there is a mention of Wodehouse's linguistic skills, and how he, similarly to Goldoni ${ }^{74}$ takes advantage of the lexical and stylistic switching of register between his characters, namely Bertie and Jeeves. Zucconi asserts that Bertie, the master educated at Eton and Oxford, uses "indecorous" and "rude" expressions, whereas his valet is widely read and employs understatement extensively, the "linguistic mitigation typical of the British upper class".

Starting from the mid-8os, prefaces were written by the editors or by the directors of the series. Some books, namely those belonging to the golf cycle, are rich in explanations of terms, either in their prefaces or in the form of translator's notes. The use of footnotes, one of the translation techniques translators can employ, will be treated in greater detail in Chapter 4. It is, however, already worth noting here that, for example, one of Mursia's translators, Sandra Campagna Ponzetto, was particularly generous in her footnotes. Sandro Melani, too, in translating Eggs, Beans and Crumpets (1940; GV.57) added some translator's footnotes. For example, he kept "Yard" in the Italian text where Wodehouse made a pun

\footnotetext{
${ }^{72}$ (1919-1998) Journalist, writer and TV author and anchorman. From 1961 to 1963 he was director of $I l$ Corriere dei Piccoli, founded by Luigi Spaventa Filippi.

${ }^{73}$ English in the original.

${ }^{74}$ Goldoni's characters speak either Italian or the Venetian dialect, in accordance to their social status.
} 
between Scotland Yard and a back-garden and explains in a note that "yard" has several meanings in English. Alberto Tedeschi used a footnote to explain that Eggy is a nickname for Egremont (Laughing Gas, 1936; GV.51): the meaning of the surrounding text would otherwise be puzzling to an uninformed reader.

On the whole, paratexts in the Italian translations of Wodehouse's works supply the reader with biographical information and relevant contextual material. This allowed me to evaluate how Wodehouse and his works were presented and received in Italy. However, in the light of the model of text activation that I propose, it is significant to note that Wodehouse speaks only from the fictional text, since his own prefaces were rarely reproduced. An exception is Mursia's 1990 translation of Joy in the Morning (1947; GV.59). In his preface (pp. 213-216), Wodehouse describes the Edwardian world around the Drones club and its "knuts". He states that this world had disappeared at the time of his writing Joy in the Morning and objects to his critics who accuse him of being old-fashioned by asserting: "Mine, I protest, are historical novels" (p. 213). In Mursia's edition the preface is translated by Sandra Campagna Ponzetto with brilliant verbal choices. For example, she rendered "knuttery" by a neologism, "rampolleria", coined after "rampollo", meaning "scion". The previous translation of Joy in the Morning, by Giorgio Monicelli published by Elmo in 1948, on the contrary, did not contain any preface.

As for titles, as said, they tend to translate the UK title almost literally, with some notable exceptions, typically in Guanda's editions: the same extant translation issued previoulsly by another publisher has sometimes been republished with a different title. Moreover, Guanda's editions, more expensive than Mursia's and Polillo's, show attention to cover art. This aspect seems to appeal to readers, as a comment by an Italian reader of Guanda's edition of Bill the Conqueror (1924, GV.29) published in 2010 on the website of an internet bookshop demonstrates. ${ }^{75}$ The contributor, a Roberta, states: "I had read Grazie, Jeeves and did not like it. Then, I saw this nice cover and, out of curiosity, I decided to give Wodehouse another chance. What a pleasant surprise! [...]. I will definely read some more of his books". The same translation of Bill the Conqueror by Brioschi had been published in a soberer edition by Mursia in 1993 and had never been reprinted. Indeed, cover art is an element that can contribute to the sales of a book and that, as Jerome McGann (1991, p. 13) argues, enables a translation to compete strongly on the book market.

\footnotetext{
${ }^{75}$ https://www.ibs.it/conquista-di-londra-libro-pelham-g-wodehouse/e/9788882464714.
} 


\section{Conclusions}

The collection I gathered has verified the worth and the potential of Wodehouse's works translated into Italian as material for a study aimed at describing the translation process, according to the model of text activation (see page 2) and in the light of the Epistemic Approach (see page 7) presented in the Introduction.

From 87 source tests, the collection yielded 177 translations issued from 1928 to 2013 , with 62 translators working on them. In total, 579 editions were on the Italian market from 1928 to the present day (2017), published by a total of 16 publishers. These figures and this span of time allow for analyses aimed at addressing key issues in Translation Studies, such as the relationship between languages and culture. Besides, since most of the 87 works considered in this study were translated more than once, the material permits research in the remit of retranslation, hence, to address issues such as modernisation and, possibly, domestication versus foreignization. In addition, as we will see in detail later, being instances of translation of humour, an investigation performed on these editions can shed light on the various translation strategies employed, for example, to compensate for the loss of humour in a translated text. Moreover, the paratexts and the information that can be collected about Wodehouse's reception both in the English-speaking world and in Italy, allow for the identification of the characteristic of his writings that were, and still are, appreciated by his readers. They do, hence, supply information as to what features translators should render.

In line with the approach taken by Sharon Deane-Cox (2014, p. 22), this research "starts from the context and moves towards the text". Chapter 2 and 3 illustrate, respectively, Wodehouse's most appreciated stylistic devices and the way in which he achieved his humorous intent, with the aim of identifying the "problematic textual items" on which my analyses on Italian translations focus. 


\section{CHAPTER 2}

\section{WODEHOUSE AND STYLE}

I suppose the fundamental distinction between Shakespeare and myself is one of treatment. We get our effects differently. Take the familiar farcical situation of the man who suddenly discovers that something unpleasant is standing behind him. Here is how Shakespeare handles it. (The Winter's Tale, Act Three, Scene three)

\section{... Farewell!}

The day frowns more and more: thou art like to have

A lullaby too rough. I never saw

The heavens so dim by day. A savage clamour!

Well may I get aboard! This is the chase:

I am gone for ever.

Exit pursued by a bear.

I should have adopted a somewhat different approach.

I gave my man one of my looks.

"Touch of indigestion, Jeeves?"

"No, sir."

"Then why is your tummy rumbling?"

"Pardon me, Sir, the noise to which you allude does not emanate from my interior but from that of that animal that has just joined us."

"Animal? What animal?"

"A bear, sir. If you will turn your head, you will observe that a bear is standing in your immediate rear inspecting you in a somewhat menacing manner."

I pivoted the loaf. The honest fellow was perfectly correct. It was a bear. And not a small bear, either. One of the large economy size. Its eye was bleak and it gnashed a tooth or two, and I could see at a g. that it was going to be difficult for me to find a formula.

"Advise me, Jeeves," I yipped. "What do I do for the best?"

"I fancy it might be judicious if you were to make an exit, sir."

No sooner s. than d. I streaked for the horizon, closely followed across country by the dumb chum. And that, boys and girls, is how your grandfather clipped six seconds off Roger Bannister's mile.

Who can say which method is the superior?

P.G. Wodehouse, Over Seventy, 1957, pp. 73-74.

This chapter is devoted to what makes Wodehouse's prose so distinctive and enjoyable for his readers: his style. Such an investigation is worthwhile in a study on translation, since style is an author's hallmark, the distinctive trait that must be recognized and rendered by translators to the best of their knowledge 
and ability. Besides, I hold that, in order to examine and compare the translators' renderings of a work, a researcher must, first of all, rely on a definition of style that allows for the analysis of all the elements that constitute it and, secondly, on a methodology that enables us to appreciate whether these elements have been given justice in translation. The first section of this chapter is therefore an overview of some of the definitions of style that have been proposed, aimed at finding the one most suitable to the objective declared above. The subsequent sections first suggest a reading of the origins of Wodehouse's style, and, secondly, drawing from the theory of comedy, analyse the influences this genre had on his work and in shaping his particular kind of "comic mood" (Rozik, 2011). The final sections of the chapter systematically highlight Wodehouse's stylistic features that translators must render, since they are acknowledged as the tools Wodehouse employed to achieve his humorous intent.

\section{A Definition of Style}

There is no single definition of literary style which could satisfy all scholars in the fields of stylistics and linguistics. Positions range from the ones that can be epitomized in Buffon's motto "The style is the Man" (Le style, c'est l'homme même, from his discourse delivered at the Académie française on 25th August 1735) to those advocating the abolition of the term tout court (see, for example, Gray, 1969). Since language is the instrument of style, some authors, for example Murray (1982) and Ohman (in Martin, 2007), maintain that style is "the result of an author's success in compelling language to conform to his mode of experience" (Murray, 1922, p. 23) and is therefore deeply rooted in the author's modes of thought and experience. Some others hold a quite opposite view and consider style as disembodied, detached and impersonal, for example Miller (2003) who, in his book on Jane Austen, defines Style (with a capital S) as a "refusal to realize its author personally" (p. 56) and praises Austen for typifying "absolute impersonality" (p. 96). Reviews of this debate can be found, for example, in Uitti (1969), who examines the concept style from Plato to Jakobson, and in Simpson (2004) and Crystal (2004), mostly treating in detail Anglo-American traditions, while Herrmann et al. (2015) analyse studies on style in the French, German and Dutch traditions.

Most definitions of style revolve around the idea of "a way of using language" (e.g. Crystal \& Davy, 1969; Enkwist, 1973). They are numerous and varied but can be classified according to a finite number of approaches: style as a text-constituting element, or as a work of art that implies a choice amongst possible alternatives (Halliday, 1994), but also as "an emphasis added to the information conveyed by [a] 
linguistic structure" (Riffaterre, 1959, p. 155) or as a linguistic feature that can be assessed by means of an aesthetic evaluation (Wales, 2001; Crystal, 2010) or measured computationally (Ramsay, 2011). A different and captivating direction, although with a focus more on the reader than on the writer, was taken by Steven Pinker who has recently defined style as "the effective use of words to engage the human mind" (Pinker, 2014, p.2).

Since their beginnings as separate disciplines in the 196os, Stylistics and Translation Studies have engaged in a mutually beneficial relationship. Stylistician Riffaterre, as an example, was also concerned with translation, as shown by his writings in the 1960s and 1970s (Boase-Beier, 2006) and later overtly researched the translation of style (Riffaterre, 1992). By the same token, the father of modern Translation Studies, Roman Jakobson, showed his interest in stylistics (see, for example, Jakobson, 1966).

In Translation Studies, style is one of an author's features that cannot be ignored. It is true that not much expertise in stylistics is required of translators, as not much creativity nor interpretation is assumed of them (Boarse-Beier, 2011); nevertheless, Translation Studies take for granted that translation is in itself "an act of creative writing" (ibid., p. 401) which implies choices to be made. In line with Ernst August Gutt's (2000) application of Relevance Theory (Sperber \& Wilson, 1995) to Translation Studies, I consider the translator's choices as being, ideally, a result of the attempt to "reproduce exactly not only what is said, but also how it is said, not only the content but also the style" (Hatim \& Manson, 199o, p. 208, my emphasis). This aspect is relevant in applying the Epistemic Approach to the translation process. Translators may sometimes be puzzled at some conundrum: knowing in what area of the author's style such a conundrum lies, what mechanism (stylistic device or feature) the author has applied, can significantly help them in making their choice.

A tool that has been employed to prove or disprove authorship, even in legal proceedings (Olohan, 2004,) is stylometry (or stylometrics). It can be defined as "the study of measurable features of (literary) style, such as sentence length, vocabulary richness and various frequencies" (Rybicki in Oakes \& Ji, 2012, p. 231). It is based on the assumption that "authors have an unconscious aspect to their style, an aspect which cannot consciously be manipulated but which possesses features which are quantifiable and which may be distinctive" (Holmes, 1998, p. 111) and that are therefore stable throughout an author's career (Wales, 2001). Stylometry, hence, is concerned with style as an idiolect (Wales, 2001, p. 439), i.e. the "system of [an author's] individualistic features" (Wales, 2001, p. 230). Attempts have been made to apply stylometry to Translation Studies, for example to differentiate between individual translators' styles. However, its most widely adopted method, Burrow's Delta, based on most-frequent-word 
frequencies, "usually fails to identify the translator" (Rybicki in Oakes \& Ji, 2012, p. 232) "possibly for the simple reason that word usage [...] is not style, or not solely style" (Rybicki, in Oakes \& Ji, 2012, p. 246, italics in original).

An interesting proposal for a definition of style in the era of Digital Humanities has recently been brought forward by Herrmann, van Dalen-Oskam and Schöch (2015), whose aim is to offer "an operational definition of style that incorporates a minimal common ground for interdisciplinary empirical research and the application of new, digital methods" (p. 3). The focus of their definition is on empirical research and the novelty of their proposal lies in its applicability to both literary studies and computational stylistics and linguistics. I think that this definition is the most appropriate to be applied also within the field of Translation Studies and its relevance within the scope of this dissertation will become apparent when it will be applied in Chapter 4:

Style is a property of texts constituted by an ensemble of formal features which can be observed quantitatively or qualitatively (Herrmann et al., 2015, p. 14).

"Text" here means any complete text or a fragment, but also single texts or collections (for example, by the same author) and can be literary or non-literary. By "formal features" the authors refer to linguistic features both on sentence level (for example, lexicon, syntax or semantics) and beyond the sentence (e.g., narrative perspective). These features are those that Hall (1974), drawing from Riffaterre (1959), termed Stylistic Devices (SDs). Riffaterre's notion of Stylistic Device implies its function to convey a definite effect (e.g. irony) and its nature of "stylistic stimulus" (1959, p. 171), i.e. the contrast perceived by the receiver when "a linguistic pattern is broken by an element which was unpredictable" (ibid.). Examples of Stylistic Devices in Riffaterre are: metaphor, expressive word-order unit, rhythm etc. (ibid., p. 165 , fn 17).

\section{Wodehouse's style}

In his book on Wodehouse, Hall (1974) identifies the Stylistic Devices used by Wodehouse at word level (phonological, lexical and morpho-syntactic) and others at the discourse level (incongruity, imagery, citations and what he calls "stylistic rhythm"). In my own analysis, I have identified a number of features of Wodehouse's style, in addition to those identified by Hall, that I treat in the following sections 
together with his. After an overview about the origins of Wodehouse's style, relevant in the light of both the model of text activation and the Epistemic Approach that I propose, I analyse textual macrostructures in his novels and short stories and move then on to his comic Stylistic Devices at word and discourse levels.

In the light of Herrmann, van Dalen-Oskam and Schöch's broad definition of style, I therefore describe each Stylistic Device employed by Wodehouse and draw attention to those that can be more problematic in translation by choosing examples with an emphasis on the conundra that are likely to puzzle translators and potentially jeopardize their efforts. Similar examples will be treated in greater detail in the chapters specifically devoted to translations and their comparisons, i.e. Chapters 4 and 5 .

\section{The roots of Wodehouse's style}

The origins of Wodehouse's style are found in his education and his reading during his school days, in his first job as a contributor to the Globe and in his early work in musical comedy. As I will highlight throughout this study, there is evidence that the input he received during these years was to influence his whole work, starting from the first novels he wrote, the "school stories". In the light of the Epistemic Approach, it is appropriate to note how distant this input was from the one his foreign readers, particularly Italian ones, received in their formative years. In other words, it is worth noting the probable discrepancies between Wodehouse's and his Italian readers' knowledge of the world (KnoW), since this might be key to speculating as to why his works were - and still are - so popular in Italy. In other words, Italian readers may have perceived some degree of exoticism in Wodehouse's works, making them curious about the world he was offering.

From his school days onwards, Wodehouse was always a voracious reader (Donaldson, 2014; McCrum, 2004; Usborne, 1978; Wodehouse \& Townend, 1953). He "was the kind of boy who was rarely without a book" (McCrum, 2004, p. 30): his friend Townend recalls him reading works by "Barry Pain and James Payn, Kipling and W.S. Gilbert" (Donaldson, 2014, p. 52). At Dulwich, the public school for middle-class children he attended from 1894 to 1900, his parents made him take the Classical side (Green, 1983) so he studied Latin and Greek, together with English literature and French. He read poetry (Tennyson and Browning for sure) at school, where poems were "memory passages" to be learnt by rote (Olney, 1962, p. 393). There are numberless instances of these reminiscences in his later work, treated in a variety of different ways, from the literal to the garbled. For example, in The Code of the Wooster (1938; GV.54), 
Bertie asks Jeeves to remind him about "that thing [...] about larks" and "I rather think, snails", a reference to Browning's "Pippa Passes" ${ }^{m 6}$ and, possibly, a wink to his readers who may have been through the same experience of having to learn long passages by heart. However, this is an experience far from his Italian readers'. Wodehouse was surely familiar with English classics, Charles Dickens's and Jerome K. Jerome's works, for example (McCrum, 2004). However, references to Dickens are scant throughout his oeuvre, possibly because he was not his favourite; in a letter to Denis Mackail, in 1954, Wodehouse wrote: “[...] do you hate Dicken's stuff? I can't read it” (Wodehouse \& Ratcliffe, 2012, p. 468). In fact, he must have read it, since Dickens's Great Expectations (1861) is referred to in an exchange between two characters in Wodehouse's first school-story, The Pothunters (1902; GV.o1, chapter 5):

"[...] Half the staff have gone. Good opportunity for a chap to go for a stroll if he wanted to. Shall we, by the way?"

"Not for me, thanks. I'm in the middle of a rather special book. Ever read 'Great Expectations?? Dickens, you know”.

"I know. Haven't read it, though. Always rather funk starting on a classic, somehow. Good?"

"My dear chap! Good's not the word".

"Well, after you. Exit Livy, then. And a good job, too. You might pass us the great Sherlock. Thanks".

He plunged with the great detective into the mystery of the speckled band, while Vaughan opened 'Great Expectations' at the place where he had left off the night before.

In this passage, it is easy to recognize the special relationship between Wodehouse's young characters and reading: given the opportunity, they "plunge" into reading a favourite author. This scene happens in the boys' study. One of them is "in the middle of a special book" and the other struggling with Titus Livius. Taking advantage of the lack of staff on the premises, textbooks are dropped (exit Livy) and, instead of going for a stroll, the boys prefer reading their novels. Dickens is acknowledged as "a classic"

\footnotetext{
${ }^{76}$ Pippa's Song (1841): The year's at the spring,/And day's at the morn;/Morning's at seven;/The hill-side's dewpearled;/The lark's on the wing;/The snail's on the thorn;/God's in His heaven—/All's right with the world!
} 
(associated with 'funk' or dread by the narrator) but one that is read night after night by other boys, while Sherlock Holmes is somebody the reader will almost physically follow in his adventures.

Similarly, The Pickwick Papers (1836) are mentioned in the 1903 school story, Tales of St. Austin's (GV.o3, Chapter 6). On the night before the exams, the narrator is revising Thucydides Book II, their teacher's (Mr Mellish) choice for that term, and his friend Bradshaw should be doing so too:

"Bradshaw, I said, as I reached page 103 without having read a line, do you know any likely bits?"

Bradshaw looked up from his book. He was attempting to get a general idea of Thucydides' style by reading Pickwick.

"What? he said."

I obliged with a repetition of my remark.

“Likely bits? Oh, you mean for the Thucydides. I don't know. Mellish never sets the bits any decent ordinary individual would set. I should take my chance if I were you".

"What are you going to do?"

"I'm going to read Pickwick. Thicksides [sic] doesn't come within a mile of it". I thought so too.

Again, the scene is set in the boys' study and, again, there is a conflict between textbooks and leisure reading, even if the latter is ironically masked as studying ("He was attempting to get a general idea of Thucydides' style by reading Pickwick"). At least with Bradshaw, Dickens wins the contest. Given the popularity of the book, here the reference to Dickens as the author of "Pickwick" is implicit, like the reference to Conan Doyle in the previous passage from The Pothunters. Luckily for the Italian translator of The Tales of St. Austin's, Ida Lori, Dickens' book enjoyed considerable popularity also in Italy, so this passage did not pose any difficulty for her. In the passage above, both boys show their high opinion of Dickens. The following passage (ibid., p. 66) shows how his humour, in particular, is appreciated:

Bradshaw, having picked up the thread of his story again, emitted hoarse chuckles like minute guns, until I very nearly rose and fell upon him. It is maddening to listen to a person laughing and not to know the joke. 
Jerome's Three Men in a Boat (1889) is another source of allusions. The novel was published in 1889 and was a huge popular success: its first edition sold 200,000 copies (Wild \& Palgrave, 2006). There is no evidence that young Wodehouse was one of its early readers. Yet, episodes from the book are alluded to in his work. Already in 1910, in Psmith in the City (GV.10), Mr Bickersdyle, Psmith's employer, who is standing for Parliament, during a political meeting at Kenningford Town Hall, tells the episode of the plaster-of-Paris trout (in chapter 17 of Jerome's novel) as if it had happened to him. Barely revealing the actual source, the narrator mocks pompous Bickersdyke and his credulous (and, clearly, not so widely read) audience.

"The Government, gentlemen", he said, "achieves nothing worth achieving, and every individual member of the Government takes all the credit for what is done to himself. Their methods remind me, gentlemen, of an amusing experience I had while fishing one summer in the Lake District".

In a volume entitled 'Three Men in a Boat' there is a story of how the author and a friend go into a riverside inn and see a very large trout in a glass case. They make inquiries about it. Five men assure them, one by one, that the trout was caught by themselves. In the end the trout turns out to be made of plaster of Paris. $\mathrm{Mr}$ Bickersdyke told that story as an experience of his own while fishing one summer in the Lake District. It went well. The meeting was amused. Mr Bickersdyke went on to draw a trenchant comparison between the lack of genuine merit in the trout and the lack of genuine merit in the achievements of His Majesty's Government.

The same anecdote is referred to in The Gold Bat (GV.o4) a school-story Wodehouse published in 1904 and, as Green (1983) argues, it is probable that Wodehouse had George's (one of Jerome's characters) recipe for Irish stew (in chapter 14 of Three Men in a Boat) in mind, when he later, in The Man with Two Left Feet, (1917; GV.16, p. 5). defined musical comedy as "the Irish stew of the drama", and glossed: "Anything may be put into it, with the certainty that it will improve the general effect".

As we saw in a previous example, in Wodehouse's works one finds allusions to Conan Doyle's mystery stories and to his celebrated couple, Sherlock Holmes and Dr Watson, as well as to other popular works by contemporary authors (Donaldson, 2014; Green, 1983; Usborne, 1961). A completely different treatment was given to another very popular author of the time, G. K. Chesterton. He is present in 
Wodehouse not with references to his works but as a person, and a stout one at that. One example is this simile, taken from Mr Mulliner Speaking (1929; GV.36, p. 172): "At that moment, however, the drowsy stillness of the summer afternoon was shattered by what sounded to his strained senses like G.K. Chesterton falling on a sheet of tin". The meaning of the simile can be grasped only if one knows that Chesterton was a large man and his physique was the object of many satirical comments and caricatures. His life-long friend (as well as enemy) Bernard Shaw is said, for example, to have once greeted him with the words: "I see there's been a famine in the land" (Furlong, 1967, p. 100), and caricatures of him were drawn by Max Beerbohm in Britain and by James Montgomery Flagg in the USA. Another reference to Chesterton is found in The Clicking of Cuthbert (1922; GV.24, p. 195):

"Flesho!" cried Mrs. Jane Jukes Jopp triumphantly. "I've been trying to remember the name all the afternoon. I saw about it one of the papers. The advertisements speak most highly of it. You take it before breakfast and again before retiring, and they guarantee it to produce firm, healthy flesh on the most sparsely-covered limbs in next to no time. Now, will you remember to get a bottle tonight? It comes in two sizes, the five-shilling (or large size) and the smaller at half-a-crown. G.K. Chesterton writes that he used it regularly for years."

Flesho is one of the numerous names that Wodehouse invented for patent medicines (Hall, 1974), such as Dr. Bennett's Tonic Swamp-Juice (in the same golf story), Mulliner's Buck-U-Uppo, the tonic devised "primarily with the object of providing Indian Rajahs with a specific which would encourage their elephants to face a tiger of the jungle with a jaunty sang-froid" (in Meet Mr Mulliner, 1927; GV.33, p. 110), and Slimmo, described as "the sovereign remedy for obesity" (in Pigs Have Wings, 1952; GV.67, p. 51). Notwithstanding the improbable name for the tonic Mrs Jopp advises her ex-husband to take, the description above is realistic in that it recalls the way such stimulants used to be advertised in newspapers and magazines: a catchy name, a drawing, posology, indications, and sales format. The writing attributed to Chesterton completes the picture in the role of "testimonial". Here, as in the previous example, the allusion is not a kind one and can be understood only with Chesterton's physique

\footnotetext{
${ }^{77}$ For these, Wodehouse's translators had to find suitable renderings; we will see in the section of Chapter 4 devoted to the translation of proper names what solutions his Italian translators found.
} 
in mind. Mario Malatesta, who translated The Clicking of Cuthbert (1922; GV.24) in 1933, probably lacked this knowledge, since he omitted the sentence.

I could not find evidence that Wodehouse knew Chesterton's hugely popular Father Brown stories, but it is known that he had a passion for mystery and detective stories which he retained throughout his long life (Connolly, 1979; Thompson, 1992). In his school days, many such stories were published in instalments in monthly magazines, such as the Boy's Own Paper (which they referred to as BOP, as in Wodehouse's letter to Usborne quoted in Donaldson, 2014, p. 65), The Public School Magazine (for which he was a reviewer and essayist) and The Captain (to which he later also contributed, see Richards, 1988, p. 125). On the first day of every month Wodehouse was anxiously waiting for the bookstall at Dulwich station to open to get the latest Strand Magazine in order to read on about his favourite heroes (Wodehouse \& Townend, 1953). The Strand, a richly illustrated monthly magazine containing factual articles and fictional stories, and of which Arthur Conan Doyle was a regular contributor, had started publication in 1891. During the years in which Wodehouse attended Dulwich, it was extremely popular. Starting from 1905 it also published Wodehouse's stories, some of which were never republished elsewhere (Usborne, 1978). A glance at the archives of the Strand published in those years enables one to grasp the rich suggestions young readers of that age received: articles and stories were illustrated throughout, not only with drawings but with photographs too. General articles covered topics such as geography, inventions, ancient history, artists and the arts, actors and the theatre but also criminals. It is easy to imagine how evocative and inspirational such production was on Wodehouse's young mind and how much it contributed to building the world he created for his characters. I believe that the exposure to visual materials contributes to the creation of an imaginative world from which an author will draw when writing and describing their fictional world. Images retained in an author's mind may form the background of characters' action, a sort of scenic design. One can also assume that this design is shared by other readers and viewers of the original works and images within them. However, this cannot be taken for granted when a work is translated. Therefore, in line with the tenets of my approach, I hold that one of the tasks of a translator is filling the gaps between the author's visual world and that of his or her foreign readers. However, the appreciation of these gaps between visual cultures is highly conjectural. What is certain is that knowing about the author's background, his or her whereabouts, readings, experiences, and style helps translators in making better educated guesses in this respect. The examples taken from Italian translations in the following chapters will help to substantiate these contentions. 
Reading the weekly magazines of his time made Wodehouse familiar with a genre, the school-story, on which he was soon to have an impact. His first five published books, from 1902 to 1905, belong to this popular genre, brought to popular attention by Tom Brown's School Days, a fictionalized autobiography authored by jurist and radical reformer Thomas Hughes. Published in 1858, it was already "enough of a classic for Wodehouse to have been able to laugh at it as such" (Usborne, 1978, p. 77). He was probably also acquainted with others, such as Talbot Baines Reed's The Fifth Form at St Dominic's (serialised in 1881 and published in book form in 1887) and The Willoughby Captains (serialized in 1883-1884), and Frederic William Farrar's Eric, or, Little By Little (1858). All these stories were meant to edify and to mould young boys' minds, but Wodehouse's ones were irreverent and he was already showing his comic talent. He "was an absolute beginner, and already he was laughing at the genre" (Green, 1983, p. 14). In The White Feather (1907; GV.o7, serialized in The Captain in 1905-19o6), he said of the library at Wryklyn, his fictional school: "It had been stocked during the dark ages and was full of stories about the Boy Hero who turns out to be No Coward After All, and thrashes about the Bully [...]" (chapter 2). It is clear that he was well aware that the conventional school stories so popular at that time were stuffed with stereotyped characters. Later, when Psmith meets Mike, just arrived at his new school, he asks him: "Are you the Bully, the Pride of the School, or the Boy who is Led Astray and Takes to Drink in Chapter Sixteen?" (Mike, 1909; GV.o8, chapter 32). The capital letters emphasise that all of them were common character tropes in the genre to which Wodehouse was derisively contributing. In his school stories, Wodehouse did use themes from conventional novels. However, as some examples have already shown, he enhanced his stories by means of literary allusions and quotations. These eventually became one of characteristic features of his later work that I term "knowledge sharing" and that I will treat in greater detail in one of the following sections, devoted to intertextuality.

One of the school stories published while Wodehouse was a child, comic novelist Thomas Anstey Guthrie's Vice Versa (1882), was to have an influence on some of his plots. The story is based on a magical swap between a father and his son, with the result that the father goes through the agonies of being at boarding school while the boy is running the family business. There are echoes of this incongruous situation in Wodehouse's A Prefect's Uncle (1903; GV.o2, serialised in The Public School Magazine in January 1902 and published as a book in 1903) in which the protagonist's uncle is four years younger than him, and also in the much later (1936) Laughing Gas (GV.51), a novel set in Hollywood where the hero (an English gentleman) swaps bodies with a young American movie star under the effect of the anaesthetic two dentists had simultaneously administered to them. Some of Wodehouse's other school stories may 
have used borrowed plot elements too: his last school story, The Head of Kay's (1905; GV.o5, serialised in The Captain in 1904 and published as a book in 1905) "deployed a variation of [The Willoughby Captain's] theme" (Green, 1983, p. 17). The strong influence that this genre had on Wodehouse's production is witnessed by Wodehouse himself: he said that he was prompted to become a writer after admiring the opening sentence of Acton's Feud, a school serial by Frederick Swainson published in The Captain in 19oo, which he later reviewed anonymously in the Public School Magazine, calling it "a classic" (Usborne, 1978, p. 59). He was still remembering it in 196o, when, as Donaldson (2014, p. 87) relates, he wrote to a friend: "It was so different from any other school story I had read, and it made me feel that this was the stuff and that I could do something along those lines myself". And he did, publishing five novels "along those lines" in less than four years and then bringing his characters up to adult life, still retaining something of this kind of juvenilia, a passion for sports, adherence to the schoolboys' moral code, and, possibly, a vision of the opposition between the two worlds of adults and of children, with a clear predilection towards the latter. Priestley (1976, pp. 108-109) observes:

I believe this man, who lived so long, wrote so much, earned several fortunes, was really a schoolboy. He was of course no ordinary schoolboy, but a brilliant superde-luxe schoolboy. This explains what he wrote, why he succeeded, how he behaved. His "eggs, beans and crumpets" give us a schoolboy's notion of Edwardian young men-about-town. His sexless young women, running round breaking off their engagements, and his formidable bullying aunts, all belong to a schoolboy's world. So do his eccentric or quite dotty dukes and earls. His behaviour was mostly that of an elderly schoolboy: [...] there is no sign of a mature man here. Together with his talent for the absurd, this explains his success. Most of us who enjoy him still have a schoolboy somewhere in us, and to reach that schoolboy (aged about fifteen or sixteen), to let him enjoy himself, is a perfect escape from our adult problems and trials.

It is hard not to agree with this judgement, especially if one is acquainted with Wodehouse's later production, since these attitudes of his are echoed in all his comedies and in his novels, as we will see later in this chapter. However, school was just the first environment that was to influence his style. His 
plots, his characters and his language, as we will soon see, were moulded by the various other places and people he frequented.

After leaving Dulwich, Wodehouse was employed for about two years at the Hong Kong and Shanghai Bank in London. Life in the City gave him the semi-autobiographical background for his novels Mike (1909; GV.o8) and Psmith in the City (1910; GV.10). The two protagonists, especially Psmith, are his first grown-up schoolboys, that he had "liberated [...], spilling them out into the streets and clubs and country houses of the outside world" (Green, 1983, p. 31).

Wodehouse's first full time job as a writer was with the Globe, "the leading London evening paper of the day" (McCrum, 2004, p. 30). He was soon appointed editor of the "By the Way" column, a prestigious post previously held by renowned writers. The column appeared every night on the newspaper's front page and had to be ready every morning by twelve: the morning papers were scanned and around half past ten clippings were handed to the editor who was to produce humorous mocking comments, usually in verse, on the main news of the day. In his Over Sixty, Wodehouse wrote that "it was those seven years when I was doing the "By the Way" column on the Globe that gave me the useful knack of being able to work under any conditions" (p. 216). The contributions to "By the Way" were anonymous, but the ingenious and patient work of the experts of the P. G. Wodehouse Globe Reclamation Project has allowed for the collection of 1,378 issues attributable to Wodehouse: poems, jokes, puns, and retellings of the day's news events (Wodehouse \& Dawson, 2015).

It is worthwhile mentioning that Wodehouse impertinently contributed to another genre that was flourishing in his early days as a writer, other than the school stories: the German spy-invasion-scare novels, such as, for example, James Blith's The Swoop of the Vulture. In this novel, published in 19o9, the German invasion of Britain was predicted in 1918. According to Phelps (1992), these books did not help prevent a war with Germany, but rather "soured Britain's relations with Germany” (p. 90). Wodehouse's say on the matter was The Swoop! Or How Clarence Saved England, described as "the only comic contribution to Edwardian invasion literature" (Hynes, 1968, p. 40), published in 1909. It was a satirical short story about England invaded not only by the Germans, but by nine foreign armies simultaneously and tells how the country is saved by a boy scout. It was highly farcical and did not just deride the genre but also targeted politicians, generals, judges, the founder of the scouting movement, Lord Baden Powell, and even the Albert Hall and the London statues. Green (1983) finds also a nod toward Dickens in the sentence: "the German shells had had one excellent result, they had demolished nearly all the London statues", as referring to an anecdote about Dickens. Informed that there was a plan to erect a statue to 
him, he reacted saying that "if people really wished to please him, then instead of erecting another statue, they should knock down one of the old ones" (ibid., p. 49).

In the years in which Wodehouse was taking his first steps in the writing profession, the most fashionable form of entertainment was light comedy and he was a regular theatre-goer (Donaldson, 2014). In his Louder and Funnier, published in 1932, Wodehouse wrote:

Even at the tender age of twelve, the music hall appealed to the artist in me $[\ldots]$ it was my earliest ambition to become a comedian on the halls...It was because a music-hall comedian required vim, pep, espièglerie, a good singing voice, and a sort of indefinable je-ne-sais-quoi - none of which qualities I appeared to possess - that I abandoned my ambition and became a writer (cited in McCrum, 2004, p. 124).

This passage contains at least two elements that characterise Wodehouse's style: an incongruous twist in discourse and the apparently vacuous use of sophisticated-sounding foreign words, which are two of his most frequent stylistic devices. Here, his reasoning seems to start with a self-confident statement, "the artist in me" that ought to be followed by an equally affirmative counterpart. On the contrary, Wodehouse unexpectedly states that all the qualities he lists did not belong to him. There is also incongruence in the choice of the French expressions he uses: "espièglerie" has an exact meaning, while the other term is deliberately vague. Both are the kind of sophisticated terms expected to be used by an idle gentleman-about-town (they in fact belong to Bertie Wooster's vocabulary) and not by a twelve-yearold English boy. Moreover, one would not expect Wodehouse to affirm that becoming an author was a fall-back. The outcome is an instance of what is described as "self-deprecating humour", frequently employed by Bertie Wooster, on which more will be said in Chapter 3 .

William Schwenck Gilbert, playwright, humourist and librettist of the Gilbert \& Sullivan duo, was one of Wodehouse's favourite authors (Donaldson, 2014). The journal he kept, “Money Received for Literary Work", bore an epigraph from Gilbert's Iolanthe (McCrum, 2004, p. 39):

Though never nurtured in the lap

Of luxury, yet I admonish you,

I am an intellectual chap,

And think of things that would astonish you. 
Considering that these words were chosen when Wodehouse was eighteen, living alone in a small room, still divided between his job as a clerk and his free-lance writing (Thompson, 1992), and that he never in his life presented an intellectual image of himself, this could be another instance of self-deprecating humour, rather than the prophetic words of a young writer eagerly wishing to make a name of himself.

Gilbert "fed Wodehouse's thesaurus of words, phrases and names" (Usborne, 1978, p. 21). The first theatre performance he attended was Patience, that "left him absolutely drunk with ecstasy" (McCrum, 2004, p. 30). References to Gilbert \& Sullivan and their Operas and to Gilbert's Bab Ballads are already found in his early works: in his first published contribution to The Public School Magazine, "Work", he wrote: "They'll shrink abashed and swear they have not skill at that, as Gilbert says". This refers to Gilbert's play Rosencrantz and Guildenstern, in an amateur performance of which Wodehouse had played Guilderstern in 1900 (McCrum, 2004, p. 36). Similarly, his first school story, The Pothunters (1902; GV.o1) proves his familiarity with the duo: “[...] Charteris on the banjo was worth hearing. His rendering of extracts from the works of Messrs. Gilbert and Sullivan was an intellectual treat" (Chapter 2). Citations have also been traced in all his school stories (see, for example, Green, 1983, pp.18-19), from the already mentioned The Pothunters, to The Head of Kay's (1905; GV.o5) but Wodehouse's references to Gilbert \& Sullivan can be identified also in his later works, such as, for example, Uncle Dynamite (1948; GV.62) and in The Old Reliable (1951; GV.65), both containing lines referring to the police force, mocked in Gilbert's The Pirates of Penzance (first performed in 1879). Comedy, musical comedy in particular, was the model to which he referred not only for dialogues but for plots and characters (Banfield \& Block, 20o6) and, as Barry Day remarks in his Introduction to P.G. Wodehouse In His Own Words (Wodehouse, Day \& Ring, 2003), his "world owes its distinctive structure to the musical comedy of his early years" (p. xiv).

To sum up, in the early days of the twentieth century, once Wodehouse had settled down at his post as an editor at the Globe, his career, as Norman Murphy and Tony Ring observe, was developing along "three distinct strands of penmanship": in journalism, in fiction and musical comedy (Introduction to Robinson, Wodehouse \& Spiring, 20o9, p. xxi). These all formed the basis for the craftsmanship he showed in his later production. The following sections reveal how these roots developed and what Stylistic Devices Wodehouse employed both at macro and micro level, while in Chapter 4 I show the relevance of this understanding in the perspective opened up by the Epistemic Approach to Translation Studies that I am proposing. 


\section{Comic mood}

Although Wodehouse was exposed to different literary genres and sources in his early days, from fiction to poetry and from the English to the Latin and ancient Greek classics, comedy was definitively the genre that was to influence his production more than others.

In the Western world, comedy traces its origin back to ancient Greek theatre, where it was opposed to tragedy. Tragedy and comedy are easily - and quite superficially - differentiated in terms of the way they end for the protagonist: unhappily in tragedy and happily in comedy. The plots of classical comedy are characterised by "a basic structural pattern which moves from unhappiness to happiness, through the eventual removal of obstacles erected by an intolerant and unjust society" (Mooneyham, 1994, p. 115). Scholars have attempted more sophisticated ways to explain this difference. For example, Langer (1967) bases her distinction on the notion of "feeling" that permeates any form of drama, which is "pure sense of life" in comedy and "knowledge of death" in tragedy, and affirms that "[t]ragedy is the image of Fate, as comedy is of Fortune" (p. 333), whereas Rozik (2011), as we will see shortly, ascribes the differences between tragedy and comedy to the notion of "mood".

Although not specifically dealing with comedy, Aristotle's Poetics initiated the debate, still open today, on whether comedy possesses a specific structure. Tragedy and comedy apparently share the same structure, meaning the way their sections are organized. For example, according to Freytag (1900), the structure of drama consists of five parts: exposition, rising action, climax, falling action and dénouement. This structure indeed characterizes the plots of practically any of Wodehouse's stories and is the one that gave him the advantage of constructing "nearly endless variations on the same theme" (Hall, 1974, p. 47). Aristotle's model of the deep structure of all drama implies the contemporaneous presence of four functions: the ethical nature of a character, the performative nature of the outcome of their actions, the evaluation of such actions on the part of the spectator, and, finally, the ultimate aim of any form of art, $\varkappa \dot{\alpha} \theta \alpha p \sigma \iota \varsigma$ (catharsis), the purgation of emotions. This is a position also supported by the psychoanalytical approach to humour perception, since Freud (1963) states that "our actual enjoyment of an imaginative work proceeds from a liberation of tensions in our mind" (p. 140).

Rozik (2011) basically agrees with the idea that tragedy and comedy share the same structure, and argues that the peculiarities of comedy are to be found "not on the level of structure of action, but on the level of mood" (p. 62). Mood is one of the components of drama, a category Rozik employs to describe 
the tone of a text. It can be serious or light-hearted and "characterizes a fictional world and particularly a character" (p. 22). The comic mood, Rozik states, is "the fundamental specific difference of comedy" (p. 197) and the prism through which the action of a comedy is meant to be perceived by the receiver, both the reader and the spectator. It does not imply the abolition of values, "but the insight that their validity can occasionally be ignored in order to eventually reinstate seriousness" (p. 197). This is a remark that is accounted for in the Epistemic Approach to translation, since it implies a suspension of judgement underpinned by one's KnoW, enlarged to include values shared in one's culture.

In comedy, catharsis is reached by the release of accumulated tension caused by the foolishness or clumsiness of the characters' actions. Therefore, because of the dominance of the comic humorous mood, comedy always ends in expected, archetypal, happy ways, restores a lost balance and implies a new future (Langer, 1967). In Wodehouse, the accumulation of tension is perceived by the reader as anxiety caused by the building up of misunderstandings, impersonations, and tricks. Its release in the dénouement provokes mirth, ascribable to the theory of relief, as we will see in Chapter 3 .

\section{Plots, characters and language}

The comic mood Rozik posits as the basis of comedy was expressed by Wodehouse by means of comic complications, witty dialogues and the whole range of the Stylistic Devices he employed, especially bathos, original and surprising similes, and repetitions of the same phrases and quotations. The following sections will firstly present how Wodehouse's prose achieved his humorous intent by means of plotting and characterization. Secondly, his Stylistic Devices on the linguistic level will be examined, bearing in mind that it was by means of the language he used that Wodehouse could display his plots and describe his characters, and that, as Riffaterre (1959) puts it, "stylistic facts can be apprehended only in language, since that is their vehicle" (p.154, italics in original).

As Stephen Fry rightly observes in his introduction to What Ho! The Best of P.G. Wodehouse (2011, p. xv), "Wodehouse's three great achievements are Plot, Character and Language, and the greatest of these, by far, is Language". Wodehouse's complete mastery over English prose (Hall, 1974, p. 125) was "a gift from God" (Phelps, 1992, p. 43) that, as we have seen, was enhanced by his early experiences. Moreover, his frequent journeys to the USA allowed Wodehouse to take "advantage of the vigorous growth and vivid imagery of American English" (Phelps, 1992, p. 99). The outcome were vivid descriptions, yeasty 
dialogues, outstanding characters, a fast and even pace of narration and plots full of twists and turns (Usborne, 1961).

It would seem obvious that language should be the primary focus of an investigation of his texts translated into another language. However, in analysing the Italian translations I realised that a lot of his Stylistic Devices on sentence, phrase and word level were not given justice, as I show later in this dissertation. Hence, if so much of his style on a strictly linguistic level was mangled or, at best overlooked, by his Italian translators, then plots retain their importance also in translations and therefore deserve close observation. Moreover, one would think that plots are the only aspect of a work that would be safeguarded in translation, but, as already evidenced by the Monicelli/Simenon case, this is not always true: for several reasons, even plots can undergo changes when a work is translated. This fact assumes relevance in the light of the model of text activation, since it takes into account in what way, for example, editorial policies may influence it.

Potty plots

Wodehouse made no secret of the fact that plotting did not come easily to him. As he wrote in How I Write My Books (reproduced in Heineman and Bensen, 1981, p. 3): "It is to the strain of getting plots that I attribute the hideous, lined face and bald head which appear in my photographs".

Wodehouse's plots are complex, and subplots multiply in his stories (Muir, 1990), especially those featuring Bertie Wooster and his valet, Jeeves. Moreover, they "mesh smoothly, and the crises that they cause arise rhythmically and naturally" (Galligan, 1985, p. 612). They are rich in twists, have the rhythm of musical comedies and follow the general pattern, which has much in common with Freytag's model:

\section{Status quo $>$ Trouble $>$ Intervention $>$ Resolution $>$ Re-establishment of status quo ante}

They may seem formulaic but Wodehouse managed to make them extremely lively thanks to his ability to complicate matters, adding mess, tangling things up with misunderstandings and subterfuges on the part of the protagonists and thanks to the comic entanglements he devised for his characters. Eventually, however, an intervention, usually by one of the most cunning characters, puts everything right and everything falls into place. The Jeeves and Bertie stories are an obvious instance of this formula: Bertie is enjoying his idle, quiet life when something (typically, an intervention by one of his aunts) occurs and perturbs it. Trouble follows, Bertie tries to solve it by himself devising one of his "zany" schemes, fails, 
and Jeeves gets into the picture as a deus ex machina and saves the day, thus re-establishing the muchdesired tranquility. The same formula is repeated in other stories, e.g. those told by the Oldest Member or by Mr Mulliner, with slight variations.

Common themes, recurrent situations and expressions are spread throughout Wodehouse's work and I will later argue, in line with Säckel et al. and Thompson (Säckel, Göbel, \& Hamdy, 20o9; Thompson, 1992), that these are aspects of his production that, far from being trite, result in a feature that makes the reader, of both the original and of the translated text, attached to his characters and ultimately to his whole production, so that they will also be one of the reasons for his success. This is the feature of his style that I name "endearment" of which more will be said in the next Chapter.

In several novels, the main plot intertwines with a second one, that follows the classical outline of romantic comedy (Hall, 1974): boys meets girl - boy has difficulties with girl - boy gets girl. As both French (1966) and Hall (1974) have observed, after the mid-192o's, Wodehouse ceased to treat love essentially seriously and farce began to predominate, the most exemplary character being Bertie's friend Bingo Little. He is prone to fall in love with the most diverse girls and does so six times in The Inimitable Jeeves (1923; GV.26) alone, before making his final hit with novelist Rosie Banks and thus moving from the comic juvenile lead role of the young-man-about-time to the other stereotyped one of the henpecked husband in later stories. Bingo is far from being reluctant to let others know about his love affairs. Of him, Bertie asserts: "He always reminds me of the hero of a musical comedy who takes the centre of the stage, gathers the boys round him in a circle, and tells them all about his love at the top of his voice" (The Inimitable Jeeves, p. 437). This citation shows how close to Wodehouse musical comedy was. The same would probably apply to his contemporary readers but not necessarily to the readers of his translated works. This is an issue addressed by the Epistemic Approach to translation, since it takes into account the actual readers' KnoW in text activation.

Wodehouse was extremely flexible and versatile as far as his plots were concerned. "A play became a novel; a novel became a play "(Usborne, 1961, p. 119) and his plots are often repeated. For instance, as Phelps (1992, p. 109) highlights, "Spring Fever (1948; GV.61) and The Old Reliable (1951; GV.65) have the same plot and similar casts". What is changed is just the setting (the former, in England, specifically in a stately home in Sussex, and the latter in California, in a Hollywoodian villa). There is nevertheless a lot of variation in this repetition. For example, as we will see later, the same cliché can be uttered by different characters in different situations or the same difficulty e.g. finding money to be able to get married, can be solved in different ways (winning a jackpot, convincing a reluctant uncle to hand over the money he is 
keeping as a guardian, or even by means of blackmail). And variation in repetition is indeed Wodehouse's most distinguishing feature (Säckel et al., 2009) and how it appealed to his readers is "one of the most intriguing things about Wodehouse" (Thompson, 1992, p. 8). This is how Wodehouse himself explains this characteristic of his in the Introduction to his Summer Lightning (1929; GV.37):

A certain critic - for such men, I regret to say, do exist - made the nasty remark about my last novel that it contained "all the old Wodehouse characters under different names". He has probably by now been eaten by bears, like the children who made mock of the prophet Elisha: but if he still survives he will not be able to make a similar charge against Summer Lightning. With my superior intelligence, I have outgeneralled the man this time by putting in all the old Wodehouse characters under the same names. Pretty silly it will make him feel, I rather fancy.

In addition to his witty remarks, it should be noted that, similarly to Latin classic comedy, originality of plot is not a requirement of comic fiction: "the reader loses no interest in the plot because his knowledge of Wodehouse's previous performances enables him to forecast the present dénouement" (McCracken, 1934, p. 614). Such a remark, which connects to the Humour Device that I term "endearment", fits in both my model of text activation and in the Epistemic Approach.

Wodehouse's seamless plots were the result of various attempts and frequent re-writing, as the annotated manuscripts that have survived demonstrate (Usborne, 1961). He dexterously resorted to plot devices that enabled him to both complicate matters for his characters and help them solve them. These include misunderstandings (see Something Fresh, 1915; GV.15, in which Lord Emsworth pockets a valuable scarab, thinking it a gift, and initiates mayhem), marching orders given by importuning female characters (aunts or girl-friends), unforeseen behaviours due to intoxication (Right Ho, Jeeves, 1934; GV.47 and The Old Reliable, 1951; GV.65), swapped personalities (Laughing Gas, 1936; GV.51) and even crimes (theft, burglary, blackmailing, and other minor misbehaviours, as acutely remarked by Isaac Asimov in his contribution to P. G. Wodehouse A Centenary Celebration, 1981).

Impersonation is a device he often deployed. For example, in The Mating Season (1949; GV.63), Bertie Wooster volunteers to impersonate his friend Augustus Fink-Nottle (Gussie), who has been sentenced to two weeks in prison in London. Unfortunately, both are due at Deverill Hall: Gussie to be presented to his fiancée's godmother and Bertie to star in the village concert. Gussie is later released and gets to the Hall, 
in turn impersonating Bertie. Their valets swap identities too and Jeeves must come to the rescue and extricate the characters. This story is similar to many others and contains the usual array of bossy aunts, formidable girls, unlucky young men, misunderstandings and romantic accidents. It is however more complicated by double impersonations.

False identities and impersonations are also used to deceive bossy chatelaines and prevent them from refusing hospitality to guests who desperately need to be included in the guest list, since they want to reestablish relations with one of the guests, usually a girlfriend. This plot device is, for example, employed in Leave it to Psmith (1923; GV.27) and in Summer Lightning (1929; GV.37).

Lord Ickenham (Uncle Fred) is the master of impersonation: in his first appearance in Uncle Fred Flits By, a short story published in Young Men in Spats (1936; GV.50), he impersonates, in turn, the owner of a house in the suburbs of London (Valley Fields), a vet calling to visit the home pet (a parrot) and, on leaving the premises, another inhabitant of the neighbourhood. Lord Ickenham is so proud of his abilities as an impostor that he boasts he could impersonate "virtually any-one", even the parrot, "except a dwarf, owing to his height, or Gina Lollobrigida, owing to her individual shape" (Cocktail Time 1958; GV.72, p. 165). The exceptions he mentions, instead of being perceived as logical and obvious, sound exaggerated and hence comic. We will see in Chapter 3 that exaggeration is in fact one of the mechanisms deployed to trigger humour. Impersonations sometimes make things more difficult for the protagonist(s), some other times they are the means to solve troubles: in either cases, they are a powerful weapon in Wodehouse's hands to make his plots more intricate and amusing.

\section{Characteristic characters}

In "How I Write My Books" (in Heineman \& Bensen, 1981), Wodehouse explains that when he wanted to write a short story, he sat down comfortably, feet up on another chair, and selected a character. Then, he says, "I keep on sitting till I have discovered what happened to him the time he forgot his wife's birthday or on the afternoon he went to Wembley. [...] In other words, the story grows out of the character" (p. 3). This is an instance of the interplay between the author and his "inner reader", at the basis of the model of text activation that underpins my investigations.

The number of characters Wodehouse created is astonishing: more than two thousand, according to Jasen's Index of Characters (Jasen, 1970). A lot of them are members of categories that belong uniquely to English society, e.g. hereditary peers and their families, surrounded by the predictable entourage of 
butlers, valets, cooks, belonging to what has been dubbed Wodehouse's "world downstairs" (Wodehouse et al., 2003). All this sounds intriguing - and very appealing - to many foreign readers, since it allows them to peek into an exotic lifestyle, although patently fictional. This aspect of Wodehouse's style also deserves close attention in the light of the Epistemic Approach since, as said, not the same degree of familiarity, hence of KnoW, can be assumed of the readers of the original and the translated text. A "balanced" translator takes this concern into consideration when choosing among translation procedures.

To create some of his characters, Wodehouse was inspired by people he or his friends had met in real life. Thus, for example Psmith was based upon Old Etonian Rupert D'Oyly Carte, who "had embraced communism and called everybody 'comrade', was always immaculately dressed, sported a monocle and when asked by a housemaster how he was, replied 'Sir, I grow thinnah and thinnah'” (Muir, 199o, p. 1099). By the same token, eccentric and ill-starred Ukridge was inspired by his friend Herbert Westbrook (Donaldson, 2014), "a self-centred, outrageous but likeable rogue" (McCrum, 2004, p. 63), while George Bevan, the hero of A Damsel in Distress (1919; GV.19), is Guy Reginald Bolton's alter ego (Phelps, 1992). A successful English playwright and a dear friend of Wodehouse's, Bolton had first teamed up with composer Jerome Kern in New York and later with Wodehouse: the trio became famous for the several musicals they authored and went on to dominate Broadway (McCrum, 2004). The friendship between Wodehouse and Bolton was to last more than sixty years.

Wodehouse's characters perform the role that is assigned to each type in comedy. As we saw, the structure of classical comedy followed a formula; moreover, it featured characteristic protagonists that eventually became stock characters, such as those by Latin dramatists Plautus and Terence, to which Wodehouse's comedy has been compared (McCracken, 1934). The story typically develops as such: the hero, a young man (the adulescens), wants to marry a young woman (the virgo) but their wish is opposed by a blocking character (the senex). The action of the comedy revolves around the obstacles, usually parental (Frye, 1957) raised by the blocking character and the resolution is due to a twist in the plot, named $\pi \varepsilon \rho \iota \tau \varepsilon \dot{\tau \varepsilon l \alpha ~(p e r i p e t e i a), ~ m a n i p u l a t e d ~ b y ~ t h e ~ i n g e n i o u s ~ a n d ~ t r i c k y ~ s e r v u s ~(S t o t t, ~ 2005) . ~}$ Traditionally, the clash is one between fathers (authoritative figures epitomizing traditional old views and values) and sons (the new generation), such as those depicted in Menander's Old Cantankerous or in Molière's The Miser. As Usborne (1991) notes, Wodehouse "backed young against old" (p. 197). Frye (1957) underlines the fact that "the movement of comedy is usually a movement from one society to another" 
(p. 163). The society that emerges after the dénouement is a "new" society and one that the audience recognizes as "the proper and desirable state of affairs" (p. 164).

This formula was not exclusive to classical Greek and Latin comedies but was perpetuated in later Western productions, such as those of the Italian commedia dell'arte ${ }^{78}$, the French comedies by Molière (1622-1673) and those written by the reformer of Italian comedy Carlo Goldoni (1707-1793). It was shared by Shakespearean and Elizabethan comedy (Frye, 1957) and was eventually inherited by the American musical that started to develop at the beginning of the 2oth century and to which Wodehouse significantly contributed (McCrum, 2004; Dugan, 2011). In Wodehouse's romantic stories, the action revolves around some young couple, whose aim is marriage, and their attempts to overcome the obstacles posed by blocking characters (usually aunts, uncles, guardians, less often demanding fathers). In this endeavour, the couple are helped by tricky characters (family friends, unconventional uncles and aunts, and the "inimitable" valet, Jeeves). In those stories in which Bertie is the protagonist, the formula is respected, with the only difference being that Bertie's aim is not marriage but, quite the opposite: escaping it.

The prospect of a character's failure produces anxiety, which Rozik believes to be "the vital stuff of drama, including comedy" (2011, p. 82, italics in text). This state is aroused not so much by the obstacles in themselves but rather by the intricate sequence of incidents caused by the - often clumsy - attempts at overcoming them. But when it is the senex (the representative of the "old" society that the audience rejects) who is reduced to frustration, then anxiety, the precondition for catharsis, is released and the "new" society is achieved and celebrated, "by means of some kind of party or festive ritual, which either appears at the end of the play or is assumed to take place immediately after. Weddings are the most common" (Frye, 1957, p. 163). As previously noted, the component of anxiety in comedy is one that deserves close attention since, as I show later in the light of one of the theories of humour, however revised, it is one of the factors that may elicit humour.

The comic mood in comedy is promoted by "various characters" (Rozik, 2011, p. 115). Characterization, i.e. "the configuration of all the permanent traits of a character" (Rozik, 2011, p. 99) is reflected by the actions a character performs. Hall (1974) acutely notes that at least six of Wodehouse's characters assume the leading comic roles typical of the musical comedy of the 1920 and 1930 s that were, "tailored to the

\footnotetext{
${ }^{78}$ Originating during the $16^{\text {th }}$ century, it "had a crucial influence on Western comedy to present day" (Rozik, 2011, p. 148).
} 
special talents of one of the funny men of the time" (p. 29), as in case of each of the Marx Brothers. ${ }^{79}$ These were characteristics with which the audience became familiar and that were expected of actors. According to Hall (1974), Ukridge, Lord Emsworth and Bertie Wooster are the bumblers, whereas Jeeves, Lord Ickenham and Galahad Threepwood (Lord Emsworth's resourceful and often embarrassing younger brother) play the role of the deus ex machina. The bumblers are expected to cause trouble, to complicate matters because of their foolishness, whereas the others, although by means of not always orthodox methods, are meant to bring the story to an end that "gratifies the archetypal expectations of the [...] audience" (Rozik, 2011, p. 93). All six named characters are deeply rooted in the age and society Wodehouse described and are, at the same time, archetypical and functional to the development of the plot. Translations may have had the merit of exposing these roles to the attention of foreign readers, thus enhancing their understanding of the source culture, hence their KnoW.

The element of novelty in Wodehouse's characters is found in the way he described them. Description is a feature in Wodehouse's style that deserves close attention, especially in an investigation on translations. Most of his characters show both positive and negative attitudes, vices and virtues, and Wodehouse is very good at showing human weakness. This is a peculiarity of his humour and a feature I will analyse in Chapter 3. His descriptions are very much "showing" rather than "telling". The description of pompous barrister Sir Raymond Bastable in Cocktail Time (1958; GV.72, p. 5 ) is a typical example:

The door of the Demosthenes [club] had swung open, and there had come down the steps a tall, stout, florid man of middle age who wore his high silk hat like the plumed helmet of Henry of Navarre. He stood on the pavement looking about him for a taxi-cab - with a sort of haughty impatience, as though he had thought that, when he wanted a taxi-cab, ten thousand must have sprung from their ranks to serve him.

As this example shows, Wodehouse does not simply offer the physical attributes of his characters but also suggests their psychological traits. And, as this example also shows, a description very often closes with an unexpected simile or a near-simile ("as though..."). This is how Bertie Wooster's sometime fiancée, Florence Craye, is depicted in Jeeves and the Feudal Spirit (1954; GV.69, p. 22): "[...] tall and

\footnotetext{
${ }^{79}$ Groucho's peculiarity was making faces, Chico's was his mock Italian accent, Harpo's was his remaining mute and playing the harp.
} 
willowy and handsome, with a terrific profile and luxuriant platinum blonde hair, and might, as far as looks are concerned, be the star unit of the harem of one of the better-class Sultans". Lord Elmsworth's neighbour, Alaric, Duke of Dunstable "was an opinionated, arbitrary, autocratic man with an unpleasantly loud voice, bulging eyes and a walrus moustache which he was always blowing at and causing to leap like a rocketing pheasant" (A Pelican at Blandings, 1969; GV.82, p. 19). Such examples could be multiplied. Descriptive passages are in fact those in which Wodehouse produced some of his best similes.

However, it is aunts, a recurrent category of characters in Wodehouse, who are "certainly the most productive of splendid similes" (Muir, 1990, p. 1116). Bertie Wooster feels his aunts haunt him and boss him about. In Much Obliged, Jeeves (1971; GV.84, p. 91) he affirms: "Aunts as a class are like Napoleon: they expect their orders to be carried out without a hitch and don't listen to excuses". In Joy in the Morning (1947; GV.59, p. 271,) he describes his aunt Agatha as "like an elephant - not so much to look at, for in appearance she resembles more a well-bred vulture - but because she never forgets"; he had previously stated that "[s]he has an eye like a man-eating fish" (Extricating Young Gussie, 1915, p. 1). By the same token, of his nicest and gentlest aunt, Dahlia, he says that, when she laughs, she gives "the impression of a hyena which had just heard a good one from another hyena" (Much Obliged, Jeeves, 1971; GV.84, p. 70). Wodehouse's domineering aunts and the - rare - domineering mothers, such as Lady Underhill (Jill the Reckless, 1921; GV.21), play the super-ego figures in his oeuvre. Donaldson (2014) notes that they, too, are stock characters in the tradition of the English equivalent to commedia dell'arte, the so-called stock companies, in a long line of British humour. They can be compared to the conservative female roles predominant in the history of comedy that were also "depicted in the silent slapstick films of the 1920 s and 1930s" (Stott, 2005, p. 97) - such as wealthy and bossy Mrs Teasdale in the 1933 Marx Brothers comedy film Duck Soup. This may therefore be a familiar stock character to the foreign readers who read Wodehouse in translation.

\section{Wodehouse's stylistic devices}

As Usborne (1961) pointed out, Wodehouse's formula for success was "funny people, funny situations, funny words" (p. 193). The aim of this section is to highlight how the words he used allowed him to achieve his humorous intent or, in Rozik's terminology, to attain a "comic mood". Intention is indeed one of the key elements for a linguistic pattern to become a unit of an author's style, i.e. an author's stylistic 
device and key in the process of text activation. Supported by the documents we possess, i.e. autobiographical writings, interviews, and letters, we can state that Wodehouse's intention was to amuse and to entertain. The second element that contributes to the identification of an author's stylistic devices is the information supplied by readers, when they assume the role of informants (Riffaterre, 1959). A stylistic stimulus, as stated by Riffaterre (1959, p. 171) is determined by the reaction of the readers who will provide information as to what has aroused their attention.

The object of the stylistic analysis reported in the following sections of this chapter is, therefore, to identify those aspects of Wodehouse's prose, i.e. his Stylistic Devices, that we can assume he employed to exert his control over the process of text activation in order to achieve his humorous intention (amusement and entertainment), and to do so by means of the reactions supplied by informants (critics, reviewers, biographers, and readers, including myself). In the following sections, I first identify the Stylistic Devices Wodehouse employed at discourse level: imagery, use of allusions and quotations (intertextuality), recurrent phrases (leitmotivs) and stylistic rhythm; secondly, I identify Wodehouse's Stylistic Devices at word level, which I present under three different headings: morphological, lexical, and syntactic. Each device will be identified through the contributions supplied by the various informants, above all Hall (1974). It will also be defined by way of the terminology of literary criticism and stylistics, above all Wales (2001), and exemplified by means of quotations from Wodehouse's works. This methodology allows for the identification of Stylistic Devices that can also be observed quantitatively, a kind of study hitherto never attempted on Wodehouse's works. According to the tenets of the Epistemic Approach, a thorough description of an author's stylistic devices can prove an excellent tool in the hands of translators. In the rest of this chapter, some aspects that might pose some difficulty for translation will be highlighted, although the systematic presentation of all Stylistic Devices in connection to their translation into Italian will be found in Chapter 4.

Stylistic devices on discourse level

\section{Imagery}

Wodehouse's prose has often been praised for the way it employs figures of speech, especially tropes where words are twisted away from their usual meaning (Wales, 2001), such as personification, metaphors and similes (Usborne, 1961; F. Donaldson, 1968; Phelps, 1992; Mooneyham, 1994). This is termed imagery, which in literary criticism is defined as "the sense of a mental picture of an object etc., 
[...] combined with the sense of 'picture' evoked in words" (Wales, 2001, p. 235). An example is Wodehouse's facetious definition of musical comedy as "the Irish stew of the drama" already quoted above. However, imagery may also imply the evocation of other senses rather than just vision, hence seven kinds of imagery have been identified: visual, auditory, olfactory, gustatory, tactile, kinesthetic and organic (Campos \& Gonzalez, 1993). The examples of similes provided in this section will show Wodehouse's mastery in evoking all senses with his imagery. Hall (1974) claims that Wodehouse's imagery is his best known Stylistic Device and Evelyn Waugh, questioned by Frances Donaldson as to why he considered Wodehouse the master of his profession, explained: "One has to regard a man as a Master who can produce on average three uniquely brilliant and entirely original similes to every page" (Donaldson, 2014, p. 5).

\section{Personification}

Personification is the term used to describe a trope in which "an inanimate object, animate non-human, or abstract quality is given human attributes" (Wales, 2001, p. 349). Wodehouse used personification a good deal, with the effect of enlivening his prose and, specifically, his descriptions. He also emphasised the traits of his personifications by explicitly paralleling the object he was describing to human feelings, as in this passage from Something Fresh (1915; GV.15, p. 231).

The hall had that Sunday-morning air of wanting to be left to itself, and disapproving of the entry of anything human until lunch time, which can be felt only by a guest in a large house who remains at home when his fellows have gone to church.

This is an almost lyrical description of a stately home's "mood", paralleled to the one a human being might feel on a lazy summer Sunday morning. It highlights the longing for solitude that is sometimes experienced by humans when they feel overwhelmed and, in Wodehouse's view, by houses as well. However, Wodehouse's best personifications are swift and startling, often enhanced by bathetic effects, such is in these three personifications of "Fate": "What is life but a series of sharp corners, round each of which Fate lies in wait for us with a stuffed eel-skin?" (Uneasy Money, 1917; GV.17, p. 131), "Unseen, in the background, Fate was quietly slipping the lead into the boxing-glove [...]" (Very Good, Jeeves, 1930; GV.38, 
p. 517) and "A lifetime of getting socks on the jaw from the fist of Fate [...]" from Aunts Aren't Gentlemen (1974; GV.87, p. 262).

Wodehouse even goes so far as to have inanimate objects, such as the weather, speak. This figure of speech, technically known as prosopopeia and an extension or variation of personification (Wales, 2001, p. 382), is found in the following quotation from Much Obliged, Jeeves (1971; GV.84, p. 37). "It was one of those heavy, sultry afternoons when Nature seems to be saying to itself 'Now shall I or shall I not scare the pants off these people with a hell of a thunderstorm?'” Overall, it can be stated that, by attributing human feelings and behaviours to objects, but above all to abstract entities, Wodehouse could enrich his array of characters with unusual ones. This kind or originality is ascribable to one of the factors that may explain humour, as the incongruity theories of humour, presented here in Chapter 3, will highlight.

\section{Similes}

Similes, from Latin "similis", meaning "like" (Wales, 2001, p. 421), are instances of imagery that imply a comparison. They are constituted by three elements: the tenor (or topic), i.e. the subject under discussion, the vehicle, meant as what the subject is compared to and the ground, defined as what the author believes the tenor and the vehicle have in common (Richards, 1936). The difference between a simple comparison and a simile is in terms of salience: "a simile uses a vehicle for which a given ground property is especially salient to highlight the property in a topic" while "comparisons [...] merely point out the commonalities between two things, regardless of whether those properties are highly salient in the vehicle" (Veale, 2013, p. 12). The more salient a property of the tenor, the more incongruous, and, hence potentially humorous, the simile is. I also posit that incongruity is ascribable to the "semantic distance" between the tenor and the vehicle. Such distance, as I demonstrate in the next chapter, is computable and, hence, reproducible in translation. Therefore, similes possess a flexibility that allows "an author to yoke a topic to a perspective that is at once both incongruously different and yet appropriately similar" (Veale, 2013, p. 3). Wodehouse took full advantage of this potentiality, bringing together two objects that belong to very dissimilar fields of human experience and thus playing with the element of incongruity that current mainstream research posits as the basis of humour (see Chapter 3 ). In this quotation, from Summer Moonshine (1938; GV.53, p. 27), "[h]e had married young and kept on marrying, springing from blonde to blonde like the chamois of the Alps leaping from crag to crag", the 
salient characteristic of chamois (the vehicle), their jumping over crevasses (the ground), is unexpectedly assigned to an often-married character (the tenor).

The commonest structure of similes in English is the one employing the connectives "like" and "as" but literary descriptions involving the use of verbs such as "resemble" or "suggest" are also comprised (Leech \& Short, 1981). Miller (1979, p. 371) provides a list of words and phrases that can perform this function: together with "like", in its various formulations, such as "is like", "looks like", and "acts like", he lists, for example, "reminds me of" and "is similar to". The particularity found in analysing Wodehouse's similes is "the remarkable array of linguistic means of introducing the comparison statement" (Partington, Duguid, \& Taylor, 2013, p. 178). In a very creative way, he connected his similes also by means of phrases such as "a sort of" or understating expressions such as "it's not unlike". See, for example, this quotation from Jeeves in the Offing, (196o; GV.74, p. 176): "[...] not unlike the last words of a dying duck".

As highlighted by Waugh (quoted in Donaldson, 2014, p. 5), Wodehouse was extremely prolific in producing similes and drew them from various semantic sources, of which the animal world, the world of the theatre and musical comedy and sports (especially golf) are "particularly prominent" (Hall, 1974, p. 109). What follows is my attempt of classifying some of them (a reliable complete inventory could only be compiled with the help of digital tools to process the whole digitalized corpus, that has not yet been collected) according to the semantic sources of the images he used. To my knowledge, this is the first time such a classification has been attempted. Hall (1974) argues that if it were completed, "it would, I believe, be found that Wodehouse jaws [sic] on almost all the phenomena known [...] to a well-educated member of the modern English-speaking world" (p. 108). This range helps to shed light on epistemic factors that translators of Wodehouse must heed, in the light of the approach to translation that I propose.

\begin{tabular}{|l|l|}
\hline Ancient myth & $\begin{array}{l}\text { He groaned slightly and winced like Prometheus watching his vulture dropping } \\
\text { in for lunch. }\end{array}$ \\
\hline Animals & $\begin{array}{l}\text { Jeeves coughed that soft couch of his, the one that sounds like a sheep clearing its } \\
\text { throat on a distant mountainside. }\end{array}$ \\
\hline Celebrities & $\begin{array}{l}\text { You get as much the chance to talk in this house as a parrot living with Tallulah } \\
\text { Bankhead. } \\
\text { She looked more like Marilyn Monroe than anything human }\end{array}$ \\
\hline Fashion & $\begin{array}{l}\text { He was loosely and comfortably dressed in a tweed suit which might have been } \\
\text { built by Omar the Tent Maker. }\end{array}$ \\
\hline Food & Some minds are like soups in a poor restaurant - better left unstirred. \\
\hline
\end{tabular}




\begin{tabular}{|c|c|}
\hline History & $\begin{array}{l}\text { He looked haggard and care-worn, like a Borgia who has suddenly remembered } \\
\text { that he has forgotten to put cyanide in the consommé, and the dinner gong due } \\
\text { any minute. }\end{array}$ \\
\hline Literature & $\begin{array}{l}\text { She looked like something that might have occurred in Ibsen in one of his less } \\
\text { frivolous moments. }\end{array}$ \\
\hline Music & "Mac," said Billie admiringly, "you talk like a Tin Pan Alley song hit" \\
\hline Politics & $\begin{array}{l}\text { He was a man who was musing on the coming Social Revolution. He said } \\
\text { nothing, merely looking at me as if he were measuring me for my lamp-post. }\end{array}$ \\
\hline $\begin{array}{l}\text { Sports and } \\
\text { sportsmen }\end{array}$ & $\begin{array}{l}\text { He was built on large lines and seemed to fill the room to overflowing. In } \\
\text { physique, indeed, he was not unlike what Primo Carnera would have been, if } \\
\text { Carnera had not stunted his growth by smoking cigarettes as a boy. }\end{array}$ \\
\hline The natural world & The Duke's moustache was rising and falling like seaweed on an ebb-tide. \\
\hline The visual arts & {$[\ldots]$ he looked like something thrown off by Epstein. } \\
\hline Theatre and ballet & Smedley leaped like an Ouled Nail dancer who has trotted on a tin-tack. \\
\hline Writers & $\begin{array}{l}\text { Wilfred Allsop was sitting up, his face pale, his eyes glassy, his hair disordered. He } \\
\text { looked like the poet Shelley after a big night out with Lord Byron. }\end{array}$ \\
\hline
\end{tabular}

Table 2.1: Examples of Wodehouse's similes according to semantic sources

This list, however short, is enough to show that the more the semantic source is distant from what is described, the more unusual, surprising, and potentially funny the simile is. This observation fits in with the tenets of one of the mainstream theories of verbal humour. In Chapter 3 I present the "incongruity index", a tool I have devised to empirically calculate this distance that allows translators to reproduce it or compensate for it in translation. The examples above are also an indication of how similes were for Wodehouse a means to enhance his descriptions. What follows is a list of examples of his similes, according to the tenor described.

Aunts: $\quad$ She [Aunt Dahlia] looked like a tomato struggling for expression.

Girlfriends: I once got engaged to his daughter Honoria, a ghastly dynamic exhibit who read Nietzsche and had a laugh like waves breaking on a stern and rockbound coast.

Butlers: $\quad$ Men of Beach's build do not leap from seats. He did, however, rise slowly like a hippopotamus emerging from a river bank.

The clergy: The Rev. looked as disturbed as if he had suddenly detected Pelagianism in a member of his Sunday-School class.

Dogs: It looked like a pen-wiper and something like a piece of hearth-rug. A second and keener inspection revealed it as a Pekinese puppy. 
Similar lists have been published (see, for example, Wodehouse, In His Own Words edited by Barry Day and Tony Ring in 2003); however, no attempt has yet been made to analyse them in the light of any theory of humour. They are one of the sources upon which I draw for my analyses in Chapter 3.

As signalled above, and as the examples already provided have hinted at, Wodehouse's wide range of similes do not just evocate visual imagery, but other senses too; in other words, they are synesthetic images. It is not hard to find an example for each of the other six sensory kinds of imagery.

$\begin{array}{ll}\begin{array}{l}\text { Auditory (sound): } \\ \text { Olfactory (smell): }\end{array} & \begin{array}{l}{[\ldots] \text { she said in a voice like beer trickling out of a jug. }} \\ \text { Joe Beamish was knitting a sock [...] that smelled in equal } \\ \text { proportion of mice, ex-burglars and shag tobacco. }\end{array} \\ \text { Gustatory (taste): } & \begin{array}{l}\text { The medicine had a slightly pungent flavour, rather like } \\ \text { old boot-soles beaten up in sherry. }\end{array} \\ \text { Tactile (feel): } & \begin{array}{l}\text { Mr. Pott said that lending money always made him feel as } \\ \text { if he were rubbing velvet the wrong way. }\end{array} \\ \text { Kinetic (movement): } & \begin{array}{l}\text { Pongo had the illusion that his interior organs were being } \\ \text { scooped out with a spade or trowel. } \\ \text { He felt like a man who, chasing rainbows, has had one of } \\ \text { them suddenly turn and bite him on his leg. }\end{array}\end{array}$

The fact that similes are referred to as "images" implies the assumption that the process of verbal communication relies on the formation of visual constructions in our mind. This assumption dates back in philosophy (such as, for example, in George Berkeley's and David Hume's theories of ideas) as well as in early experimental psychology. It is also at the basis of Allan Paivo's Dual Coding theory (Paivio, 1971) and the more recent theories developed by cognitive psychologist Steven Pinker (Pinker, 2015). It is therefore arguable that all the similes in the list above possess a further element of surprise, since a sense different from vision is involved, that might account for their humorous value.

Sometimes Wodehouse combined a simile with personification, such as in this quotation from Leave It to Psmith (1923; GV.27, p. 278): "A depressing musty scent pervaded the place, as if a cheese had recently died there in painful circumstances". Moreover, his similes are often hyperbolic, such as in this description of the only evil character in his oeuvre, Roderick Spode: "Big chap with a small moustache and the sort of eye that can open an oyster at sixty paces" (Jeeves in the Offing, 196o; GV.74, p. 417) and enriched by one of Wodehouse's most striking linguistic characteristic, a trait of Wodehouse's prose for which I coined the term "hyper-wording". It is the second factor that contributes to the construction of the "incongruity index". It will be shown and defined in Chapter 3, where its connections to incongruity for humorous effect will be highlighted. 
As attested by the many meticulous catalogues compiled by enthusiasts, ${ }^{80}$ Wodehouse's allusions to and quotations from classical texts (such as Shakespeare's or the Bible) and English proverbs, popular texts and songs are recognized features of his comic style (Usborne 1961, Olney 1962, French 1966, Voorhees 1966) and attest his extensive reading begun in his school-days (Hall, 1974). He engaged in a recurring dialogue with certain sources (the pretexts) with comic effects. The rapport between the pretexts and the ones he wrote is in fact an intertextual relationship that, in the light of Broich and Pfister's intermediatory model (Pfister, 2002) can be labelled as "intense" (Säckel, Göbel, \& Hamdy, 20o9): Wodehouse repetitively used and consciously employed intertextuality, defined as "utterance/texts in relation to other utterance/text" (Wales, 2001, p. 259).

There are frequent allusions to figures taken from the Bible, evidence of which is found in the extensive research published on the Biblia Wodehusiana web site (see Appendix 3). For example, hero George Bevan joins a party of aristocrats who are very unlikely to welcome him.

A cloud seemed to have cleared from his brain. He found himself looking on his fellow-diners as individuals rather than as a confused mass. The prophet Daniel, after the initial embarrassment of finding himself in the society of the lions had passed away, must have experienced a somewhat similar sensation (A Damsel in Distress, 1919; GV.19, p. 244).

In The Code of the Woosters (1938; GV.54, p. 195), Bertie whines about his nightmares and says: "I had been dreaming that some bounder was driving spikes through my head - not just ordinary spikes, as used by Jael the wife of Heber, but red-hot ones". The tone of the two quotations is quite different. In the first passage, the reference to a biblical figure is simply unconventional and anachronistic: the elements of incongruity lie in the co-occurrence of an ancient figure and words belonging to modern Western social manners ("embarrassment", "in the society"). In the second one, incongruity lies in the clash between informal language ("some bounder") and the biblical phrasing ("Jael the wife of Heber"). Moreover, Bertie, certain to be able to rely on his readers' familiarity with the biblical episode but unsure as if his

\footnotetext{
${ }^{80}$ See Appendix 3: Wodehouse Studies: key sources.
} 
readers have the right visual image in mind, adds details to better convey his distress: "not just ordinary spikes but...".

Sometimes Wodehouse increases the comic effect by means of a faulty or not so accurate quotation a character uses, as Lord Ickenham in Uncle Dynamite (1948; GV.62, p. 8) does: "Pongo is in terrific form. He bestrides the world like a Colossus. It would not be too much to say that Moab is his washpot and over what's-his-name has he cast his shoe." Here the psalm referred to is 6o.8 in the KJV and the "what's his name" is in fact Edom, one of the nations in Jordan mentioned in the psalm. The citation, although imprecise, is strengthened by the imitation of the structure (verb and subject inverted) that resembles the emphatic language by which the Scriptures are rendered in the English version familiar to Wodehouse's readers. This is a stylistic device used in serious writing "that tend[s] to elevate the level of discourse" (Hall, 1974, p. 79). In Wodehouse, it usually yields a bathetic effect.

Wodehouse draws liberally also from classic Greek and Latin literatures: Homer is flippantly referred to, as in: "You look like Helen of Troy after a good facial" (Uncle Dynamite 1948; GV.62, p. 53). Latin aphorisms and phrases are frequently quoted. The Roman Emperor and stoic philosopher Marcus Aurelius, author of Meditations, is one of Wodehouse's pets and is quoted by Jeeves in The Mating Season (1949; GV.63, p. 206):

“[...] But I wonder if I might call your attention to an observation of the Emperor Marcus Aurelius. He said: 'Does aught befall you? It is good. It is part of the destiny of the universe ordained for you from the beginning. All that befalls you is part of the great web'."

I breathed a bit stertorously.

"He said that, did he?"

"Yes, sir."

"Well, you can tell him from me he's an ass. [...]"

The dialogue has the typical structure of the exchanges between Bertie and Jeeves. Jeeves often quotes wise aphorisms to help Bertie ease his concerns. Bertie's habitual reaction is impatience and, in his irritation, he creates here the impression he considers Marcus Aurelius a contemporary figure and, possibly, one Jeeves knows in person. 
The poet Horace is quoted verbatim twice in The Girl on the Boat (1922; GV.23): "Aequam memento rebus in arduis servare mentem" (Odes) and "Archilochum proprio rabies armavit iambo" (Ars poetica). The following passage exemplifies Wodehouse's stylistic talent for comic intertexuality:

Nothing is more curious than the myriad ways in which reaction from an unfortunate love-affair manifests itself in various men. No two males behave in the same way under the spur of female fickleness. Archilocum, for instance, according to the Roman writer, proprio rabies armavit iambo. It is no good pretending out of politeness that you know what it means, so I will translate. Rabies - his grouch armavit - armed - Archilochum - Archilocus - iambo - with the iambic - proprio his own invention. In other words, when the poet Archilocus was handed his hat by the lady of his affections, he consoled himself by going off and writing satirical verse about her in a new metre which he had thought up immediately after leaving the house. That was the way the thing affected him.

In this passage, the narrator is treating one of the typical mishaps of romantic comedy: the refusal of a lover's proposal. He tells his readers that it is an event so common that we have written evidence since ancient times. The comic elements here are the use of the theatrical expedient of directly addressing the audience, here condescendingly and disparagingly, and the bathetic combination of registers ${ }^{81}$ in the translation he supplies.

English literature is very well represented in Wodehouse's quotations, by the poets Blake, Byron, Gray, Keats, Longfellow, Tennyson, Scott, and, of course, Shakespeare. What follows is the description of Lord Emsworth's first pig-man, craving for a drink.

Although nobody who had met him was likely to get George Cyril Wellbeloved confused with the poet Keats, it was extraordinary on what similar lines the two men's minds worked. 'Oh, for a beaker of the warm South, full of the true, the blushful Hippocrene!' sang Keats, licking his lips, and 'Oh, for a mug of beer, with, if

\footnotetext{
${ }^{81}$ As defined by Halliday, register is characterized by "differences in the type of language selected as appropriate to different types of situation" (Halliday, 1965, p. 87).
} 
possible, a spot of gin in it!' sighed George Cyril Wellbeloved, licking his (Pigs Have Wings, 1952; GV.67, p. 109).

What creates humour here is a clash of registers in the paraphrase, masterfully devised to have each magniloquent expression correspond to a vernacular one, at the same keeping the structure and the rhythm of the invocation. We will see in Chapter 3 why such technique yields humour.

In Wodehouse, the pretext is sometimes veiled; more often, as in the examples above, it is quoted literally, although usually with some additions to justify it in the context and "to make it ridiculously apposite" (Hall, 1974, page 112). It is already worth noting here that literal quotations are more easily dealt with by translators who can refer to an authoritative translated edition of the classic, while those merely suggested may go unnoticed and, therefore, be translated shabbily. In a section of Chapter 5 (Intertextuality in A Damsel in Distress) I compare five different Italian translations of the same fifty instances of intertextuality in Wodehouse and analyse their differences in the light of the Epistemic Approach.

Wodehouse made also use of "frequent repetitions of the same quoted material" (Säcksel et al., 2009), a Stylistic Device that illustrated in the following section, for which I employ the term "endearment". Such is the case, for example, with the phrase "Ships that pass in the night", a literal quotation from Henry W. Longfellow: "Ships that pass in the night and speak each other in passing" (Tales of a Wayside Inn); or with the recurrent (The Mating Season, 1949; GV.63, and others) invocation: "Oh, Woman" taken from Sir Walter Scott's Marmion: “O Woman! In our hours of ease, Uncertain, coy, and hard to please, and variable as the shade by the light of the quivering aspen made; When pain and anguish rack the brow, A ministering angel thou!".

Unless set in an explanatory context, these quotations are not easily recognizable. Luckily, since they are fragments, they present no difficulty when they are to be rendered in translation, even if they do not belong to the translator's repertoire of knowledge. However, given their recurrence, translators more familiar with Wodehouse's works are probably advantaged.

Shakespeare is, predictably, the most frequently quoted author, especially in the Jeeves and Bertie's stories. In these, references, allusions and (mis)quotations are part of the play between the learned servant and the idiotic master. Incidentally, the example that follows also contains a phonological wordplay on "Ma's" and "Mars" whose difficulty in translation is obvious: 
Bertie: "What's that thing of Shakespeare's about something having an eye like Mother's?"

Jeeves: "An eye like Mars, to threaten and command, is possibly the quotation [...], sir."

(The Mating Season, 1949; GV.63, p. 233).

Predictably, wordplay and puns challenge translators. In Chapter 4 I elaborate on the scheme Delabastita (1996, p. 134) devised to identify the techniques that translators have at their disposal to render them and I classify instances of wordplay in Wodehouse's works and their Italian translations.

Bertie sometimes does not acknowledge the source (here: Macbeth and Julius Caesar) and attributes the wise words to Jeeves. See, for example, the following dialogue:

Bertie: “Let's go. If it were - what's the expression of yours?”

Jeeves: "If it were done when 'tis done, then 'twere well it were done quickly, sir."

Bertie: "That's right. No sense in standing humming and hawing."

Jeeves: "No, sir. There is a tide in the affairs of men which, taken at the flood, leads on to fortune."

Bertie: "Exactly,” I said. “I couldn't have put it better myself.” (Jeeves and the Feudal Spirit, 1954; GV.69, p. 90).

We have here two typical features of the exchanges between Bertie and Jeeves: clash of registers and of knowledge. Both possess a humorous property, since, with respect to social expectations, the roles are inverted. This consideration will further be examined in the next chapters in the light of its connections to comedy within the framework of the theories of humour.

Shakespeare is often a source of inspiration for Bertie and, as said, a mine of sagacious words for Jeeves. Just taking one book, The Code of the Woosters (1938; GV.54), as an example, Shakespeare is quoted or referred to eleven times, ranging from "the native hue of resolution" (Hamlet) and "full many a glorious morning" (Sonnet XXXIII) to "taken his pound of flesh" (a reference to The Merchant of Venice). But also, in Bertie's inimitable style: "sleep which does something" groping for the quotation from Macbeth, ${ }^{82}$ or even Macbeth himself referred to as "the cat chap" with a reference to Lady Macbeth's words: "Letting "I

\footnotetext{
82 "Sleep that knits up the ravell'd sleave of care" (Macbeth, Act 2, Scene 2).
} 
dare not" wait upon "I would", Like the poor cat i' the adage?" (Macbeth, Act 1, Scene 7) on page 219. The same allusion is found a few pages later (p. 222):

Halting abruptly, as if he had walked into a lamp-post, he stood goggling like a cat in an adage. Cats in adages, Jeeves tells me, let 'I dare not' wait upon 'I would', and I could see with the naked eye that this was what Stilton was doing.

Not only the classics, though. Wodehouse also drew from legends and popular culture: stories and sagas, such as King Arthur's:

He blinked, like some knight of King Arthur's court, who, galloping to perform a deed of derring-do, has had the misfortune to collide with a tree.

(Uncle Dynamite, 1948; GV.62, p. 9o)

Two authors Wodehouse knew personally, Rudyard Kipling and Sir Arthur Conan Doyle, are frequently quoted. Kipling's poem The Female of the Species (1911) is alluded to in referring to women, as in "The Great Sermon Handicap", a story from The Inimitable Jeeves (1923; GV.26). In Jeeves in the Offing (1974; GV.6o, p. 291) Wodehouse recalls "[t]he big scene in Hound of the Baskervilles"; in Right Ho (1934; GV.47, p. 65) Sherlock Holmes is quoted almost verbatim from The Sign of Four ("You know my methods, Jeeves. Apply them") and A Scandal in Bohemia ${ }^{83}$ is referred to when Jeeves says: "Possibly you may recollect that it was an axiom of the late Sir Arthur Conan Doyle, that the instinct of everyone, upon an alarm of fire, is to save the object dearest to them" (p.185). A Scandal in Bohemia is also quoted literally in The Code of the Woosters (1938; GV.54, p. 216): “[...] you follow me, Watson?”.

Songs and other instances of popular culture did not go unexploited. "[S]itting on the top of the World", in The Mating Season, is drawn from the title of Al Jonson's great hit in 1925, while another recurrent phrase, "more than to be pitied than censured", is a literal quotation from a song composed in the USA by William Benson Gray in 1894 and brought to success by Mae West in her 1938 film She Done Him Wrong.

Intertextuality in Wodehouse is no showing-off or affectation. It is a formidable weapon in the hands of a skilful master of language. It builds up and sustains Wodehouse's world, jokily winks at the reader,

\footnotetext{
83 "When a woman thinks that her house is on fire, her instinct is at once to rush to the thing which she values most. It is a perfectly overpowering impulse, and I have more than once taken advantage of it." (Doyle, A Scandal in Bohemia, 1891, p. 24).
} 
strengthens the relationship between the reader and the writer, and turns classic and light literature upside down. Moreover, seen as an instance of middlebrow culture (Rea, 2015), it shows how Wodehouse had understood its potential to link highbrow intellectualism and popular literature (Valentino in Martìnez Sierra \& Zabalbeascoa Terran, 2017).

\section{Leitmotifs}

As we saw while treating intertextuality, there is a lot of variation in Wodehouse's repetition, but the opposite is also true. Throughout his work, we find recurrent expressions, to which I will refer as leitmotifs, defined as recurrent phrases, often associated with one character or situation, that run from story to story in an author's oeuvre (Wales, 2001). This is a distinctive Stylistic Device of Wodehouse's that has the effect of making the readers feel at their ease in a world that becomes more and more familiar to them as they keep on reading and when they tackle new stories and can be regarded, as Paul Kent, writer, radio producer and Wodehousian enthusiast puts it, as a "knowing wink or nod" ${ }^{84}$ in the direction of his readers. To my knowledge, this is the first time that Wodehouse's leitmotifs have been treated as a distinctive recurrent trait in his production and been systematically analysed as contributing to the effect of "endearment" of his work, that is, the way it is designed to induce readers to become "faithful" to the writer and the world he creates.

Most of his leitmotivs were not original but drew from clichés. His originality lies in the way he handled them. He used and reused clichés and idioms, thus exploiting the nature of automatization they possess, but his phrases have a quality of novelty due to the unexpected twist he added to them. For example, instead of spelling out the cliché, Wodehouse has Bertie saying that he could have been: "knocked [...] down with a f." (Very Good, Jeeves, 1930; GV.38, p. 551). He could cut one cliché into two and play with it, as in this dialogue between Bertie and Jeeves from the short story Indian Summer of an Uncle (from p. 539):

"[...] If Uncle George wants to marry waitresses, let him, say I. I hold that the rank is but the penny stamp -"

"Guinea stamp, sir."

"All right, guinea stamp. Though I don't believe there is such a thing [...]."

\footnotetext{
${ }^{84}$ Personal communication $10^{\text {th }}$ July 2017.
} 
Here, Robert Burn's expression "guinea stamp" that Wodehouse also employed in The Inimitable Jeeves (1923; GV.26), as a cliché to indicate that rank is irrelevant to the assessment of a person's value, is "cut into two", as Kimball (2002) observes, to make a pun playing on the two possible meanings of "stamp", i.e. the mint mark guaranteeing a golden coin's authenticity and the label to be affixed to envelopes or parcels as evidence of the postal charges paid. Bertie, misunderstanding its metaphorical use, doubts that such an expensive postage stamp may exist.

Wodehouse's works show a complex interplay with repetition and clichés and their use as formulaic device is so pervasive in his work as to have become what the Russian Formalists called the "dominant", that is to say the "central structure that organizes the whole work and forces all other devices $[. .$.$] to$ organize themselves around it" (Thompson, 1992, p. 9). This is in fact characteristic of situation comedy, that, if stretched to its limits, may become what Rozik calls "compulsive repetition" whose cumulative effects increase the comic outcome (Rozik, 2011, p. 53). This "is Wodehouse's line of country, and he has stuck to it with relish" (Usborne, 1961, p. 28).

An example is the phrase "a toad under the harrow" that Wodehouse uses to describe somebody who has been through a hard ordeal. It appears, for example, in the golf story The Clicking of Cuthbert (1922; GV.24, p. 104):

\begin{abstract}
The Oldest Member nodded his venerable head. 'You have had a trying time, if I am not mistaken. I feared as much when I saw you go out with Pobsley. How many a young man have I seen go out with Herbert Pobsley exulting in his youth, and crawl back at eventide looking like a toad under the harrow!
\end{abstract}

Wodehouse started to use this phrase in 1917 (The Man With Two Left Feet, 1917; GV.16, p. 88: "If ever there was a toad under the harrow, he was that toad"), then again in The Girl on the Boat (GV.23) in 1922 ("My poor old chap, my only feeling towards you is one of the purest and profoundest pity. He reached out and pressed Sam's hand. "I regard you as a toad beneath the harrow!", p. 116). And once again in The Inimitable Jeeves, (GV.26, p. 267): "You see before you, Jeeves, a toad beneath the harrow" in 1923, then again in 1935 ("Suffice it to say that by a few minutes to five o'clock he had become a mere toad beneath the harrow") in Blandings Castle and Elsewhere (GV.48, p. 203) and later, in 1960, in Jeeves in the Offing (GV.74, p. 241), with additional incongruity ("It may be fun for her", I said with one of my bitter laughs, "but it isn't so diverting for the unfortunate toads beneath the harrow whom she plunges so ruthlessly in 
the soup".) Luckily, this distressing sensation is easily relieved by means of a "stiffish sniffer", as in Pearls, Girls and Monty Bodkin (GV.85), published in 1972: "Where before he had been a mere toad beneath the harrow, under the influence of the generous fluid he had been converted into an up-and-coming toad which seethed with rebellion" (p. 95).

Most leitmotifs found in Wodehouse's books are culturally and historically loaded, consequently their rendering is problematic in translation. Their function as humorous devices, therefore, deserves to be investigated throughout the canon. Such an intriguing task could be easily performed using the tools provided by the digital treatment of texts. At the moment, however, as already said, no complete digitalized corpus of Wodehouse's works exists and research has to be conducted manually. The list that follows supplies some examples and discloses their function in Wodehouse. Some others will be provided in the following chapters where they will be treated as instances of one of Wodehouse's Stylistic Devices that should be handled with care by translators.

"Feudal spirit": in Wodehouse, this phrase is used to indicate the attitude that, according to Bertie, should inform Jeeves's behaviour towards his young master, i.e. absolute loyalty. It is so representative of Wodehouse that it is even found in the title of one book, Jeeves and the Feudal Spirit (1954; GV.69).

"Looking like something the cat had brought in" and "Nothing to write home about": a simile and a phrase with almost the same function, i.e. describing somebody's bad appearance, usually after a trying experience.

"More to be pitied than censured": used to express a tolerant attitude towards somebody's behaviour. Found, for example, in Ring for Jeeves (1953; GV. 68, p. 37): "What asses these French are! Why can't they speak English?" "They are possibly more to be pitied than censured, m'lord. Early upbringing no doubt has a lot to with it."

"Silver lining": a cliché, from the English proverb "There's a silver lining to every cloud", used to highlight the fact that something good can still found even in the worst situation. Wodehouse used it to highlight the optimistic attitudes of some of his characters. 
Spreading "sweetness and light": originally used by Jonathan Swift in his 1697 The Battle of the Books, the phrase "sweetness and light" probably became a cliché after Matthew Arnold had used it in his Culture and Anarchy (published in book form in 1869). In Wodehouse, this is Uncle Fred's favourite activity, although almost never to others' satisfaction: "I always strive, when I can, to spread sweetness and light. There have been several complaints about it" (Service with a Smile, 1962; GV.76, p. $62)$.

"The best of all possible worlds": an expression owed to German philosopher Leibnitz (1646-1716), to claim that the actual world, the one God created, is the best possible one. The phrase was borrowed by Voltaire in his Candide (1759) and Wodehouse used it, almost always ironically, in A Damsel in Distress (1919; GV.19), Sam the Sudden (1925; GV.31), Right Ho, Jeeves (1934; GV.47) and Money in the Bank (1946; GV.58).

"The work of a moment": a phrase Wodehouse very often employed, meaning that somebody acted without hesitation. It is found in A Damsel in Distress (1919; GV.19), Indiscretions of Archie (1921; GV.22), The Inimitable Jeeves (1923; GV.26), Carry On, Jeeves (1925; GV.30), Right Ho, Jeeves (1934; GV.47), Thank You, Jeeves (1934; GV.46) Blandings Castle and Elsewhere (1935; GV.48), and The Code of the Woosters (1938; GV.54).

"Time, the great healer": a cliché whose origin can probably be traced back to Seneca and one of Wodehouse's favourites. It can found in: Love Among the Chickens (19o6; GV.o6), A Damsel in Distress (1919; GV.19), The Clicking of Cuthbert (1922; GV.24), Carry On, Jeeves (1925; GV.30), The Code of the Woosters (1938; GV.54), Right Ho, Jeeves (1934; GV.47), Uncle Fred in the Springtime (1939; GV.55), and Much Obliged, Jeeves (1971; GV.84).

"Wedding bells", a synonym for marriage so often employed throughout the oeuvre that the only authorized imitation of a Wodehouse's novel, penned by Sebastian 
Faulks and published by Arrow Books in 2013 was titled Jeeves and the Wedding Bells.

"Wheels within wheels": Monty Bodkin's recurrent catchphrase [Heavy Weather (1933; GV.45), The Luck of the Bodkins (1935; GV.49), Pearls, Girls and Monty Bodkin (1972; GV.85)], referring darkly to a situation too complex to explain, involving secret malign influences. Essentially, in fact, Monty needs to hold a job for one year in order to comply with blocking character John G. Butterwick's request and demonstrate his worthiness to become his son-in-law. This is a task he fails to fulfil in any of the three novels.

It is noticeable how many of these expressions - even if used ironically - convey optimism: they are "mottos" of a world dominated by the comic mood, where a happy resolution of conflicts is never in doubt.

\section{Stylistic rhythm}

Hall (1974) specifically addresses one of Wodehouse's Stylistic Devices that he names Stylistic Rhythm, equating "the variation in rate of change at which SDs [Stylistic Devices] are introduced" (Hall, 1974, p. 117 ) to the key-change in a musical composition. He states that, in humorous writing in general, Stylistic Rhythm is much more rapid than in serious literature. The rapid rhythmic flux of many of Wodehouse's pages can be paralleled to that of musical comedies, and this is particularly evident in dialogues, sometimes recalling the crosstalk acts typical of vaudeville. French (1966) notes that, especially in later, more mature, novels, Wodehouse's dialogues possess their own dramatic quality and they move "with a strongly-marked dramatic beat" (p. 50). In these dialogues, the role of the stooge is both to feed the lead and to give rest to the lead's lines. Alternation serves the purpose of avoiding a dialogue too rich in gags, since "Wodehouse knows perfectly well that where there is a laugh in every line [...] enjoyment become physically fatiguing and laughter forced" (ibid.).

According to Hall, Wodehouse's efficacy in achieving his humorous intent in dialogues is his ability to alternate stylistic backgrounds in standard English with various Stylistic Devices, such as shifts from standard to non-standard language registers, introductions of semantically incongruous elements, the 
use of over-technical terminology, and his witty treatment of foreign languages. Hall gives a stylistic analysis of the opening passage of Wodehouse's The Luck of the Bodkins (1935; GV.49), here reproduced at the beginning of Chapter 3 below, to demonstrate Wodehouse's "rapid, kaleidoscopically varying stylistic rhythm" (Hall, 1974, pp. 124-125).

Stylistic devices on word level

\section{Morphological devices}

Wodehouse's vocabulary was rich and extremely varied. It mainly drew from "conservative British usage" (Hall, 1974, 71) but also from rustic English speech, from various non-standard varieties of English, from American English to which he was already directly exposed in 1904, and from foreign languages. What is particularly striking and challenging for his translators, though, is the way he managed to combine all these varieties in an extremely creative way and to coin new words.

\section{Inventive word formation}

Affixation, that's to say the process of adding a morpheme to a word (the root) is "a valuable and productive means of word formation in English, for deriving words from other parts of speech" (Wales, 2001, p. 14). Affixes can be added before the root (prefixes) or after the root (suffixes). Each affix has a specific function. So, for example, by adding suffix “-ness" one can form the abstract noun expressing the quality of being what is expressed by the root (usually an adjective), such as in dark/darkness, and by adding prefix "dis-" the meaning of the root is reversed (e.g. continue/discontinue). Wodehouse exploited this characteristic of English especially with hyphenated phrases, such as in this quotation from Much Obliged, Jeeves (1971; GV.84, p. 107): "His manner changed, [...] taking on a welcome all-pals-togetherness". The deletion of prefix "dis-" gave rise to his celebrated back-formation, i.e. "the creation of new words [...] by deletion of the suffixes" (Wales, 2001, p. 45): "He spoke with a certain what-it-is in his voice, and I could see that, if not actually disgruntled, he was far from being gruntled" (The Code of the Woosters, 1938; GV.54, p. 196).

This characteristic is not specific to English. Italian, for example, possesses the same function, so a creative word shaped according to this rule can very likely be also formed in Italian. What distinguishes 
English is, however, the use of the - few - suffixes added to verbs to form tenses (e.g. - ing for present participle that in English is also nominalizing, i.e. used as a noun) and Wodehouse often exploited this potentiality. The Jeeves and Bertie stories are particularly filled with word-formations of this kind, especially with hyphenated phrases. Examples range from suffix -ing for a present continuous verb form, such as in "[...] this telephone call was Aunt Dahlia what-the-helling" (Jeeves in the Offing, 196o; GV.74, p. 412) to prefix -ed for a past simple: "He Good-afternoon-Plank-ed and Plank responded in suitable terms" (Stiff Upper Lip, Jeeves, 1963; GV.77, p. 430). Witty hyphenated phrases and quotations could produce nouns and adjectives, as in: “'Oh, look', she said. She was a confirmed Oh-looker" (Right Ho, Jeeves, 1934; GV.47, p. 81) and in "There's too much of that where-every-prospect-pleases-and-only-man-is-vile stuff buzzing around for my taste" (Jeeves in the Offing, 1960; GV.74, p.181). Since Italian possesses this potentiality to a much lesser extent, more examples will be presented in the next chapters to highlight their difficulties in translation.

\section{Invented words}

Wodehouse was inventive in his usage of the English language and is renowned for having coined new words. McCrum (2004) asserts that the Oxford English Dictionary (OED) lists "more than 1,60o quotations" (p. 417) from Wodehouse. It also contains 22 coinages, such as verb "snooter", meaning "to harass", with three quotations, all taken from Wodehouse's works, or "pottiness", found for the first time in Heavy weather (1933; GV.45) and even the now frequent "cuppa" for "a cup of", traced back into Sam the Sudden (GV.31), published in 1925 (Simpson, 1989). His above-mentioned backformation, "gruntled", is now listed in both the Oxford English and the Meriam-Webster dictionaries, respectively with the meaning of "pleased, satisfied, contented", and "put in a good humour". This is a characteristic of Wodehouse's that cannot be given complete justice in translation, unless it is paired with an equal invention.

Use of synonyms

Wodehouse was also particularly gifted at finding synonyms. Since absolute synonyms, i.e. words which are identical both in their conceptual (denotation) and in their connotative (referring to the associations 
words may evoke), are very rare, a more accurate term for these expression is near-synonyms: "words which are 'similar' in meaning, but which vary in their stylistic values" (Wales, 2001, p. 449).

Wodehouse was aware of this stylistic potentiality and played with it, such as, for example in Jill the Reckless (1921; GV.21, Chapter 1), where he has his hero, Freddie, declaring: "I was possibly a little blotto. Not whiffled, perhaps, but indisputably blotto". Since the humorous potentialities of alcohol abuse underpin some of the incidents in his plots show, he used a number of synonyms for "inebriated", mostly derived from different dialects (e.g. military slang). This aspect is well epitomized by the following quotation from p. 191 of Meet Mr. Mulliner (1927; GV.33, p. 63): "Intoxicated? The word did not express it by a mile. He was oiled, boiled, fried, plastered, whiffled, sozzled, and blotto". Other synonyms for the same condition, especially in the jargon of the members of the Drones club, include: awash, lathered, ossified, pie-eyed, polluted, primed, scrooched, stinko, squiffy, tanked and woozled (Wodehouse \& Kelly, 2016).

Hall (1974) points out that "the use of exaggerated synonyms is pushed even farther [...] by metonymy based on identity of minor semantic features" (p. 94), a technique similar to Old German kenning, a term to describe a metaphorical compound, such as "scaly tribe" for "fish" (Wales, 2001, p. 268). This device can be assimilated to the one used by Wodehouse to produce some of his most effective similes. Bertie, the Drones, and especially Psmith, are particularly given to producing what Hall (1974, p. 95) dubs "recherché synonyms", so that they are caught in referring to a cup of tea as "a cup of the steaming" or "a cup of the Oolong”.

Varieties of language

Except for his dialogues, the diction Wodehouse employed was standard British English, with some incursions into American, more often in morphology and more rarely in syntax (Hall, 1974). The language he employed was the outcome of his education and the correct variety to be used in "catering to the newly literate audience of clerks and office workers, products of the 1870 Education Act" (McCrum, 2004, p. 47). His colloquialisms were mostly British, drawn not only from the Edwardian upper-class standard variety but also from public school slang and from the jargon of suburban clerks, with some phonetic reproductions of non-standard varieties, such as those of the less literate. Some examples are: "guv'nor" for "father" or "boss", "chassis" for "body", and "Q" for "thank you". However, he also borrowed words from foreign languages, especially French sophisticated terminology, as noted by Hall (1974, p. 98): “truite 
bleu [sic]", "preux chevalier", "raissoneur". Latin is recurrent in Jeeves's cultivated remarks, often absorbed into Bertie's less learned language, such as "nolli prosegui", or "rem acu tetigisti".

Pure word loans from other languages are very rare, while there are frequent instances of phrasing in other languages and attempts to reproduce foreign or substandard accents, such as that of a character of Irish origins, in Psmith Journalist (1915; GV.14, e.g. "de" for "the"). Since these two aspects of Wodehouse's treatment of foreign languages pose a challenge to translators, they will be considered in detail in Chapter 4 .

One of the jargons on which Wodehouse most frequently drew, especially in the Jeeves and Bertie stories, but also for his eccentric character Psmith, is the language used by that generation of affluent young-men-about-town residing in the most fashionable boroughs of London in the late Edwardian age, known as the knuts, to which Bertie Wooster belonged too. Idle, educated at Eton and Oxford but "mentally negligible", he epitomised an "image of the British character" that, as Sir Patrick Dean, British ambassador in Washington in 1967, in objecting to a Company of Honour for Wodehouse, said: "we are doing our best to eradicate", as reported in 2002 by articles in The Times (Alan Hamilton, 16th August), The Guardian (John Ezard, 16th August), and The Telegraph (Kevin Myers, 18th August).

The knuts were the typical English sportsmen (never missed a Goodwood Cup), traditional (never missed the Eton vs Harrow cricket match), educated and sophisticated. The lingo they shared was rich in synonyms. For example, a man may be referred to as a "fellow", "chap", "chappie", "bird", "cove", or "Johnnie". They "substituted for the sake of substitution" (Usborne, 1978, p. 92). Some of the characters owe their nicknames to this lingo. The only rich (and mean) member of the Drones Club, Alexander Charles Prosser is known as "Oofy", knuts' slang for "wealthy", and members call each other "old bean" or "old egg" or even "old crumpet", hence the title of Wodehouse's collection of short stories Eggs, Beans and Crumpets (1940; GV.57), published as late as 1940. Wodehouse described the knuts in his preface to Joy in the Morning (1947; GV.59), the novel he wrote during his internment in the Second World War (Sproat, 1981, p. 139) and published in 1947.

The Edwardian knut was never an angry young man. He would get a little cross, perhaps, if his man Meadowes sent him out some morning with odd spats on, but his normal outlook on life was sunny. He was a humble, kindly soul, who knew he was a silly ass but hoped you wouldn't mind. He liked everybody, and most people liked him. Portrayed on the stage by George Grossmith and G. P. Huntley, he was a 
lovable figure, warming the hearts of all. You might disapprove of him not being a world's worker, but you could not help being fond of him [...]. Most knuts were younger sons, and in the reign of good King Edward the position of the younger son in aristocratic families was ... what's the word, Jeeves?, Anomalous? You're sure? Right ho, anomalous. Thank you, Jeeves. Putting it another way, he was a trifle on the superfluous side, his standing about that of the litter of kittens which the household cat deposits in the drawer where you keep your clean shirts.

The character Wodehouse depicts here was familiar to the audiences of the so-called Edwardian musical comedy. English actor and composer George Grossmith and Irish-born comic actor George Patrick Huntley were stars on those stages. The knut was a flippant, frivolous character. He describes himself in a 1914 ballad by Arthur Wimperis and Herman Finck whose refrain goes:

I'm Gilbert the Filbert the Knut with a K

The pride of Piccadilly the blasé roué

Oh Hades, the ladies, who leave their wooden huts

For Gilbert the Filbert the Colonel of the Knuts.

He soon became a comic stereotyped figure and Wodehouse was aware of its comic potentialities. He found a role for him, not only for Bertie with his "[...] spats, and love of flashy clothes, his sketchy education, his schoolboy code" (Thompson, 1992, p. 120) but also for many other characters, such as the various members of the Drones club. Wodehouse went as far as looking at him as a "historical figure", an anachronism. In the same preface, he wrote: "I suppose one thing that makes these drones of mine seem creatures of a dead past is that [...] they are genial and good tempered, friends of all the world. In these days when everybody hates everybody else, anyone who is not snarling at something - or at everything is an anachronism".

Wodehouse's knuts cheerfully address each other with epithets such as: "old gargoyle", "ugly", "old turnip" or just "face". They express their surprise by uttering expressions such as "Good egg!", "Golly", "Great Scott", "By gosh" and their greetings stretch from "Pip Pip!" to "Toodle-oo". Usborne (1961) notes that "in Wodehouse's play Good Morning, Bill, Lord Tidmouth, a Knut, says good-bye in six different ways" (p. 69). 
Another particularity of Bertie's lingo, to which Hall (1974) draws attention, is the use of abbreviations: he breakfasts with b. and e., and a "good old pot of coff." (Thank You, Jeeves, 1934; GV.46, p. 86). When shocked, he asserts that he could have been "knocked [...] down with a f." (Very Good, Jeeves, 1930; GV.38, p. 110), and says: "I could hardly b. my e." (Jeeves in the Offing, 196o; GV.74, p. 274). In most cases the words to which these initials refer are obvious from the context and do not pose any difficulty to the translator, but sometimes they may face a conundrum. This is the case, for example, of "the f. of the s. is d. than the m.", from Right Ho, Jeeves, (1934; GV.47, p. 166) that, not recognized, suffered badly in both Italian translations. The Italian renderings of these examples will be presented and classified in Chapters 4 and 5 .

\section{Characters'names}

Many of the names Wodehouse adopted for his characters, locales, firms and goods are "one of his prime sources of humour" (Hall, 1974, p. 99). Some of the names Wodehouse invented for his characters mock at the double family names frequent in English aristocratic families, as in Cyril Bassington-Bassington and Sir Gregory Parsloe-Parsloe, while others make fun of English phonetics, such as Stanley Featherstonehaugh, whose family name is to be pronounced "Fanshaw". Some characters owe their names to historically memorable events, such as John San Francisco Earthquake Mulliner. Others have names associated with some characteristic of theirs, such as the one chosen for golf-addicted Ferdinand Dibble, alluding to the holes he digs on the golf course. Others easily allow for wordplay, such as Augustus Fink-Nottle who, after having shown his propensity for drinking, is renamed "Spink-Bottle" by an outraged Aunt Dahlia. Another of Bertie's friends bears the improbable name (and nickname) of Claude Cattermole "Catsmeat" Potter-Pright.

Wordplay is the origin of most nicknames assigned to characters. For example, Galahad Threepwood still calls his ex-schoolmates, Lord Tilbury, formerly George Spike, and Sir Roderick Glossop, "Stinker" and "Pimbles" respectively. Especially the latter examples show a characteristic of Wodehouse's that is

very likely to pose difficulties to translators, in the attempt to keep the humorous effect of the original. The treatment of proper names in translation, as we will see in Chapter 4, is in itself an interesting field of investigation, regardless of the possible comic effect they many have on the readers. As with the treatment of synonyms mentioned above, it is worth investigating how much creativity the Italian translators of Wodehouse show in their renderings. This will be done in Chapter 4 . 


\section{Lexical ambiguities}

Ambiguity is potentially a great source of humour and this connection is indeed recognized in the literature (see, for example, Bucaria, 2001). When the ambiguity of an utterance is caused by two words with the same meaning (homonymy) or by a word that has more than one meaning (polysemy) it is named lexical. When lexical ambiguity is used to achieve humour, the result is what is called a "pun", defined by Wales (1989) as a lexical ambiguity that "involves the use of a polysemous word to suggest two or more meanings" (p. 385). Since different languages have different polysemous words, most puns present difficulties in translation, such as the following example from The Luck of the Bodkins (1935; GV.49, p. 187): "He had never acted in his life, and couldn't play the pin in Pinafore", whose Italian translation will be presented and classified in Chapter 4. Another instance is the lexical ambiguity caused by the polysemy of the English word "bank" ("organization offering financial services" or "land alongside a river") that was exploited in the title of Wodehouse's Money in the Bank (1946; GV.58). The pun cannot be reproduced in Italian: the title Quattrini in banca ("money in the bank"), first published in 1949, retains only one meaning (the financial institution). As most of the plot is based on this lexical ambiguity, the title so lazily chosen by the Italian publisher, Elmo, is likely to have puzzled its readers. However, it is interesting to note that it was not changed when it was reissued by Mondadori. Since puns are frequent in Wodehouse's titles (though much less so in his texts), other examples will be illustrated in the section of Chapter 5 entitled "The (re)translations of titles".

\section{Syntactic devices}

\section{Syntactic ambiguities}

Comic effects - and sometimes comic cross-talk (Hall, 1974) - were also produced by Wodehouse by playing with ambiguities aroused by two possible interpretations of the same part of speech, especially prepositions, adverbs and pronouns, as in the following dialogue from Uncle Dynamite (1948; GV.62), which plays on the two possible syntactic functions of the preposition "by": 
"I was assaulted by the duck pond."

"By the duck pond?" Sir Aylmer asked, his eyes widening.

Sir Aylmer is puzzled since the image that takes shape in his mind is that of an elderly gentleman attacked by a pond, failing to grasp the possible alternative meaning: "by", should be understood (in the speaker's intentions) as "beside". Since this specific misunderstanding can only arise in English, translators must choose between losing the comic effect or devising a similar construction in the target language to compensate for it.

\section{Transferred epithets}

Among the syntactic devices that Wodehouse employed, one is particularly frequent in the Bertie and Jeeves cycle, the so-called transferred epithet. This is a figure of speech also named "hyppalage", from Greek, meaning "changing over" (Wales, 2001, p. 464). It consists in the shifting of an adjective (the epithet) qualifying a noun to another one in the same sentence to which it does not logically belong. It is found in the works of several authors, such as, for example, Shakespeare's Othello: "Alas! What ignorant sin have I committed?" (Act IV.2) or Gray's Elegy: “The ploughman homewards plods his weary way".

According to Thompson (1992), Wodehouse may have derived many of his transferred epithets from Conan Doyle. She notes, for example, that A Scandal in Bohemia contains this example: "His eyes sparkled, and he sent up a great triumphant blue cloud from his cigarette" and comments that "the 'triumphant blue cloud' has a faintly absurd quality" (p. 115), a quality that, she tacitly implies, Wodehouse's transferred epithets do not have. I would argue instead that the novelty in usage by which Wodehouse achieves his comic effect is represented by the fact that he projects the character's state of mind onto an inanimate object by means of the juxtaposition of two registers of language, such as in this oft-quoted example, from Jeeves and the Feudal Spirit (1954; GV.69, p. 9): "As I sat in the bathtub, soaping a meditative foot $[. .$.$] ;$ or in virtue of the wide semantic distance between the noun and the adjective that modifies it, as in: "[...] an astonished piece of toast fell from his grasp", from Jeeves in the Offing (1960; GV.74, p. 181). In these instances, the adjective could be interpreted as equivalent to an adverb (Hall, 1973) but this explanation fails to account for the comic effect. Hall (1974) rightly holds that "the basis of this syntactic procedure is essentially semantic, referring emotions or attitudes on the part of some person as expressed by a physical action, expression or characteristic" (p. 87). He maintains that 
the humorous effect is achieved by means of "a slightly incongruous extension of the type of [semantic] reference" (Hall, 1973, p. 94), thus failing to appreciate the much stronger incongruity produced by the clash of registers (soaping/meditative) or semantic distance (astonished/toast).

Moreover, it should be noted that this Stylistic Device may in some instances share features with personification, since it possesses the attributes of synaesthesia, the term already mentioned above to denote "the interconnections between the different senses that can be exploited for literary effect" (Wales, 2001, p. 447). In this example from Jill, the Reckless (1921; GV.21, Chapter 3): "The girl had a quiet, but speaking eye", a human capability is attributed to an inanimate object (personification), while the adjective is shifted from the person to a part of her body (transferred epithet), although 'speaking eye', first employed by Byron, in his poem "Parisina", written in 1816 (Byron, 1852), was an established phrase in Wodehouse's day.

\section{Bathos}

The humorous potentiality of this figure of speech, associated with anti-climax, a deflation from a high tone of the discourse, is clearly outlined by the popular phrase 'from the sublime to the ridiculous' (Wales, 2001). Its efficacy as a comic Stylistic Device lies in its suddenness, apt to surprise the reader, and in incongruity, as in Wodehouse's dedication in The Heart of a Goof (1926; GV.32): "To my daughter Leonora without whose never-failing sympathy and encouragement this book would have been finished in half the time". The final statement rapidly changes the solemn tone expected of a dedication into a much plainer, down-to-earth, ironic or even sarcastic one. Readers are puzzled and must work out an explanation. Once they find it, the tension caused by the cognitive load is released and humour is appreciated. Models that attempt to explain this mechanism are presented in the next Chapter.

In Wodehouse, the comic effect is often produced by a sudden turn of register, such as that between the educated Latinate terms typical of Jeeves's diction and the lingo used by Bertie, and by the movement from an elevated image evoked, for example, by a mythological epical figure to a trivial one, connected to an ordinary activity. An example is found in Big Money (1931; GV.4O, p. 125): "He groaned slightly and winced, like Prometheus watching his vulture dropping in for lunch". The "sublime" can also be embodied by a quotation or a reference to a literary image, as in this utterance by Bingo Little (The Inimitable Jeeves, 1923; GV.26, p. 408): “[...] he can rely on me, even unto half of my kingdom. Well, call it ten quid". 
Wodehouse sometimes uses bathos to mock a character, usually in a benevolent way, much more rarely to convey hostility. When he introduces fascist Roderick Spode, founder of an organization imitating Oswald Mosley's Black Shirts, Bertie's friend Gussie explains that "Roderick Spode is the founder and head of the Saviours of Britain, a Fascist organization better known as the Black Shorts". Bertie objects: "By the way, when you say 'shorts', you mean 'shirts', surely”, but Gussie confirms: “No. By the time Spode formed his association, there were no shirts left. He and his adherents wear black shorts" (The Code of the Woosters, 1938; GV.54, p. 237). Here, the bathetic movement is from the "grandiose" to the "ridiculous", i.e. moving from something that defines itself as extremely serious ("the Saviours of England") to something very easily mocked at (gentlemen in shorts). Bertie finds the eventuality so improbable that he asks: "Footer bags, you mean?". Since Gussie once again confirms, Bertie closes the exchange by glossing: "How perfectly foul." The bathetic movement is therefore perfectly concluded.

\section{Conclusions}

Style is an author's hallmark and must be given justice in translation. In this chapter, I first identified the definition of style that I hold suitable to be applied in a study mainly devoted to the description of the translation process into another language. It is a definition that allows for both quantitative and qualitative research and one that guides the researcher and the translator in the identification of the elements and properties of a text that must be kept in its translation in order not to betray the original author's style.

The subsequent sections of the chapter were devoted to the analysis of such elements and properties in Wodehouse. I identified and presented each of them by means of a systematic analysis of those characteristics that his empirical readers appreciate most, dubbed Stylistic Devices. I showed that his most striking features are: repetition (of plots, characters, types, themes, and leitmotivs), variation (stylistic rhythm and intertextuality) and novelty (imagery and treatment of language varieties). Moreover, this analysis has shown that the most distinctive mark of his style lies in the skilful use of language to create original, creative, and lively images (visual and other sensory) by means of surprising juxtapositions. Ultimately, it can be stated that his humorous intent is achieved by means of what scholars in Humour Studies call "incongruity". As we will see in the next chapter, incongruity is in fact the main tenet of a family of theories that have been developed to explain what makes something funny, 
and of the only theory that has attempted to devise a linguistic framework to explain humour production and its appreciation, the General Theory of Verbal Humour, devised by Attardo and Raskin (1991).

All the formal features of Wodehouse's style, observable qualitatively and quantitatively, as per Herrmann, van Dalen-Oskam and Schöch's definition of style - in other words, his Stylistic Devices illustrated in this chapter are presented again in Chapter 3, with a focus on their function in the light of theories of humour. In Chapter 4 they are examined with a focus on how they were treated by the Italian translators of Wodehouse's works, while some of them are highlighted once again by the comparison of Italian retranslations in Chapter 5 . 


\section{CHAPTER 3}

\section{WODEHOUSE AND HUMOUR}

Into the face of the young man who sat on the terrace of the Hotel Magnifique at Cannes there had crept a look of furtive shame, the shifty, hangdog look which announces that an Englishman is about to talk French. One of the things which Gertrude Butterwick had impressed on Monty Bodkin when he left for his holiday on the Riviera was that he must be sure to practise his French, and Gertrude's word was law. So now, though he knew that it was going to make his nose tickle, he said:

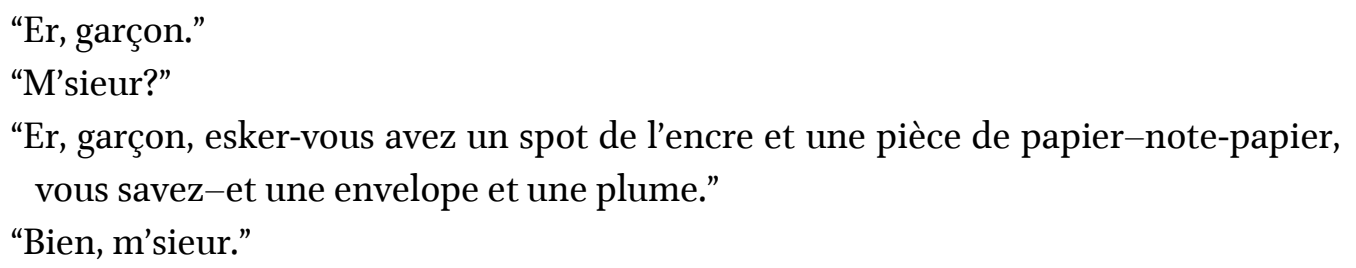

The strain was too great. Monty relapsed into his native tongue.

"I want to write a letter," he said.

And having, like all lovers, rather a tendency to share his romance with the world, he would probably have added "to the sweetest girl on earth", had not the waiter already bounded off like a retriever, to return a few moments later with the fixings.

"V'la sir! Zere you are, sir," said the waiter.

He was engaged to a girl in Paris who had told him that when on the Riviera he must be sure to practise his English.

"Eenk-pin-pipper-envelope-and a liddle bit of bloddib-pipper."

"Oh, merci," said Monty, well pleased at this efficiency.

"Thanks. Right-ho."

"Right-ho, m'sieur," said the waiter.

P.G. Wodehouse's The Luck of the Bodkins, 1935; GV.49, p. 7 .

This passage is one of his most praised openings (Hall, 1974, p. 118) and is perceptibly amusing. It is primarily a lively dialogue that could be transferred to the stage, set on a light comedy background, the terrace of a (fictitious) hotel on a sunny summer day. The situation, a young lover writing a letter to his absent fiancée, also belongs to comedy, a fact underlined by the remark "having, like all lovers, rather a tendency to share his romance with the world", on a par with the already quoted observation by Bertie Wooster from The Inimitable Jeeves (1923; GV.26), when he says of his friend Bingo Little: "He always reminds me of the hero of a musical comedy who takes the centre of the stage, gathers the boys round him in a circle, and tells them all about his love at the top of his voice" (p. 22). The characters are 
Wodehousian "to the core": a young idle English gentleman, an opportunistic waiter, and two bossy girlfriends ("Gertrude's word was law" and "engaged to a girl [...] he must"). The passage incorporates several instances of Wodehouse's Stylistic Devices identified in the previous chapter: treatment of foreign languages (silly accents, phonetic English representation of French, reproduction of French accent in English, colloquial elisions, faulty constructions, wrong words), slang and knuts' lingo ("spot", "Right-ho"), a simile ("like a retriever"), shifts from formal to informal registers ("announces that an Englishman is about to talk French", "return with the fixings").

A closer analysis also shows intertextual repetition, since a joke similar to the one expressed here by the words "a look of furtive shame, the shifty, hangdog look which announces that an Englishman is about to talk French" had been used in The Adventures of Sally (GV.25) in 1922: "He braced himself with a painful air of effort which announces to the world that an Englishman is about to speak a language other than his own" (p. 45). In conclusion, it can be said that this passage bears Wodehouse's mark. However, what makes us recognise it as amusing? Identifying a humourist's Stylistic Devices, as I did for Wodehouse in the previous chapter, is not enough to understand how their texts achieve their humorous intent. A sound theoretical framework and purposely devised tools are needed to highlight which aspects of a text are humorous and why.

In this chapter, that deals with the composite and elusive nature of humour, I present the main theories developed to explain what makes something humorous, traditionally grouped under the headings of superiority, relief, and incongruity. My analyses of the texts that Wodehouse produced allow me to state that, beside comic mood, as defined in Chapter 2, his humour contains all the elements that scholars of mainstream theories in humour research maintain as the bases of humour production. Within this framework, I identify the key concepts necessary to classify the different instances of Wodehouse's humorous messages, namely incongruity, surprise, and exaggeration. In line with the tenets of the Epistemic Approach, to these key concepts, I add two more that pertain to the relationship between Wodehouse and his readers. I name these two additional concepts, "endearment" and "knowledge sharing". By offering numerous examples, I will demonstrate how each of Wodehouse's Stylistic Devices set forth in Chapter 2 can be ascribed to one of these five key concepts. Besides, I will present my view on Wodehouse's humour, supported by the scant scholarly literature and by the evidence supplied by my informants. I will argue that the reference theory that best describes the kind of humour he employed belongs to the family of incongruity theories. I will also show that the best construct to explain his humour is found in Attardo and Raskin's theories of verbal humour, namely 
script opposition. I elaborate on this to propose a new, more inclusive, construct, that I name "scriptclash". It occurs when two expectations of the part of the reader coexist and conflict, for example in a sentence containing utterances in both formal and informal registers, as in the passage quoted above. I show how this construct accounts for all Wodehouse's Stylistic Devices ascribable to incongruity and surprise, such as, for instance, transferred epithets, bathos, his treatment of varieties of languages, his coinages and skilful use of affixation. Moreover, as a result of my analyses on Wodehouse's phrasing, I introduce the term "hyper-wording", that I define as his use of synonyms and collocates to elaborate statements and accounts for Wodehouse's Stylistic Devices ascribable to exaggeration. I also supply a new tool devised to evaluate the level of incongruity in an utterance, based on the construct of semantic distance, meant as a metric in a semantic space to compute how far apart two words in the same language are. The tool I propose, that I term "incongruity index", combines semantic distance and hyperwording to yield a composite value (the "Incongruity Value") to be assigned to any instance of Wodehouse's texts. By testing it on similes, I show its validity to assess the degree of incongruity of humorous utterances, and to guide translators in their task.

To construct my argument, I first illustrate the various perspectives from which humour can be researched and sketch the major theories that have been developed to explain why something causes amusement, with an emphasis on those developed in the remit of linguistics and a focus on those instances of humour more likely to pose difficulties in translation. The second section of the chapter is devoted to an analysis of how Wodehouse produced humour and to the humorous mechanisms incorporated in his stylistic devices illustrated in the previous chapter, seen in the light of the mainstream theory of humour within the remit of linguistics, based on the construct of script. These will, consequently, be renamed Humour Devices (HDs). Building upon existing theories, I analyse his texts to identify the key concepts necessary to understand and classify his humorous instances, namely incongruity, surprise, exaggeration, endearment, and knowledge sharing. I then describe the two constructs of script-clash and hyper-wording that I hold characterise Wodehouse's prose. Lastly, I introduce the measure of semantic distance and present the tool I devised to assess humour in short and long texts, both in the original and the translated versions and offer my formula to define Wodehouse's humour. 


\section{Humour: an overview}

Humour is a universal human characteristic (Martin, 2007) and a product of natural selection (Gervais \& Wilson, 2011). It is not easily defined, being so multifaceted as to be elusive. It is an intrinsically, even if probably not exclusively, human phenomenon (Polimeni and Reiss, 2006). It is pervasive, too: humour is present in almost all communication exchanges (Martin, 2007). It serves many social, emotional, and cognitive functions (Martin, 2007; Chiaro, 2010). Moreover, it may facilitate pair bonding (Weisfeld et al., 2011), attract compatible mates (Watson, Matthews, \& Allman, 2007), elevate one's mood (Weisfeld et al., 2011) and is a form of aesthetic appreciation (Caron 2002; Weisfeld et al., 2011).

Humour can be conveyed verbally and non-verbally. Non-verbal humour can be conveyed by visual art or depend on performance, while verbal humour can play on various levels of a message. It can be produced by playing with phonological aspects, such as mispronunciations or homonyms, or even with letters, as Wodehouse did in a story from Meet Mr Mulliner (1927, GV.33, p. 39):

"Sir Jasper Ffinch-Farrowmere?", said Wilfred.

"ffinch-ffarrowmere", corrected the visitor, his sensitive ear detecting the capital letters.

"Ah yes. You spell it with two small fs".

"Four small fs".

Here, the play is with the so-called "double ff surnames", originated in England in the $15^{\text {th }}$ century (Marshall, 2010), and the butt of the joke is an ostentatious baronet, who pretends to be able to detect the sound capital letters make, as a way of making people aware of the ancient noble origins of his family. On a semantic level, humour is elicited by lexical ambiguities that give rise to misunderstandings; analogously, humour may derive from misunderstandings due to syntactic ambiguities and doublemeanings. Examples from Wodehouse are found in the section devoted to syntactic devices in the previous chapter. On the pragmatic level, humour may occur when conversational rules are not observed, in other words, when an utterance is inappropriate to the context, such as in the following dialogue from "Good Morning, Bill", a musical play derived from the novel Doctor Sally (1922; GV.41), that Wodehouse wrote in 1932: 
Doctor Sally: Now tell me about your sex life.

Bill: $\quad$ Well, naturally, I have had experience, like other men. I admit it. There have been women in my life.

Doctor Sally: (at stethoscope) Say 'Ninety-nine'.

Bill: $\quad$ Not half as many as that!

The conversational rule violated here is the maxim of relation (Grice in Cole \& Morgan, 1975), according to which a speaker must contribute to the conversation by being relevant. While Wodehouse, as the author, is consciously violating the maxim to achieve a humorous effect, on the part of the character, Bill, this is a case of infringement of the maxim. In other words, his contribution to the conversation is not relevant simply because he misunderstands Sally's message. This particular example also raises a cultural issue, since not in every country do doctors auscultating patients ask them to say "ninety-nine". In Italy, for example, patients are asked to say "trentatré", meaning "thirty-three". This is a case in which dynamic equivalence (Nida, 1974), possibly a translator's first choice, would not do justice to the original text and some other solution should be found.

Given the scope of this dissertation, only examples of verbal humour in written texts will be discussed. However, in some cases the nature of instances of embodied humour should be highlighted, since, as already stated in Chapter 2 and, in accordance with others (see, for example, Säckel et al., 2009 and Folgado in Valero-Garces, 2010), I hold that Wodehouse's texts possess the property of conveying vivid images and actions typical of slapstick comedy. This property is exemplified by the following passage from Chapter 11 of Leave it to Psmith (1923; GV.27, p. 249). One night, at Blanding Castle, the "Efficient Baxter", Lord Emsworth's secretary, is on the tracks of a burglar whom he hopes to catch on the act. This is how Wodehouse describes him furtively making his way down the stairs:

With stealthy steps he crept to the head of the stairs and descended. One uses the verb "descend" advisedly, for what is required is some word suggesting instantaneous activity. About Baxter's progress from the second floor to the first floor there was nothing halting or hesitating. He, so to speak, did it now. Planting his foot firmly on a golf-ball which the Hon. Freddie Threepwood, who had been practising putting in the corridor before retiring to bed, had left in his casual fashion just where the steps began, he took the entire staircase in one majestic, 
volplaning sweep. There were eleven stairs in all separating his landing from the landing below, and the only ones he hit were the third and tenth. He came to rest with a squattering thud on the lower landing, and for a moment or two the fever of the chase left him.

The progression of the words here conveys a dynamic description. Wodehouse informs his readers that even the word "descend" is chosen deliberately. The passage, in fact, starts with the description of a silent, measured motion that soon and suddenly becomes frantic. The action does not last long; however, the image that forms in the reader's mind is vivid, also owing to the careful and surprising word choice, e.g. "volplaning" recalling the French phrase vol plané, meaning gliding flight, used to describe downward flight of both birds and airplanes and the curious adjective "squattering" to qualify the noise produced by Baxter. In descriptions of this kind, characters move as if on stage and "make the reader 'picture' a slapstick scene" (Säckel et al., 2009, p. 140). A fast action is an effective way to elicit humour, as acutely advised by Eugene Ionesco (quoted in Bevis, 2013, p. 28): "If you want to turn tragedy into comedy, speed it up". Furthermore, a physical mishap, understood as harmless, is an almost universal occasion for laughter (Warren \& McGraw, 2016).

Since humour is a universal human phenomenon, it can be assumed to exist in every culture (Polimeni \& Reiss, 2006). However, each culture is likely to have distinctive ways to convey it; hence, one could regard humour as untranslatable (Chiaro, 2012; Purdie, 1993). Together with poetry, it is known to challenge translators. One of the tasks of the researcher in this field of Translation Studies is, therefore, to investigate the mechanisms that elicit humour and to assess which of them are universal or at least transferable into another culture. As we have seen, verbal humour relies on the witty use of rhetorical devices, on various levels, from phonological to pragmatic, many of which are culture-specific. Many instances of humour "present the translator with a series of problems which are both practical and theoretical in nature" (Chiaro, 2010, p. 6). Patent examples are puns and wordplay based on idioms. Wodehouse did not deploy them so much, but when he did, he did so with panache. In the example that follows, from Jeeves in the Offing (196o; GV.74, p. 218), he plays with the English idiom "to have kittens", meaning "to be upset or very angry about something" (Cambridge Dictionary of Idioms):

\footnotetext{
"Your uncle will be most upset."

"He'll have the kittens."
} 


\author{
"Kittens?" \\ "That's right." \\ "Why the kittens?" \\ "Why not?"
}

There is a play within the wordplay in this short cross-talk. Bertie uses the idiom, assuming it is familiar to his interlocutor, Sir Roderick Glossop. However, probably because himself shocked, Glossop takes the phrase at face value and does not understand. Instead of making Bertie explain, Wodehouse has him play with the phrase again. This time, the puzzled one is Bertie who, unable to find an explanation for the idiom, replies with a silly question (“Why not?”), perfectly in line with his character. In such cases, translators must be skilled (and lucky) enough to find a similar idiom in the target language in order to reach formal equivalence. Once it is found, then it will not be hard to have the second part of the joke (“Why not?") keep its silly and almost surreal nature. If a translator cannot find a suitable idiom, they must explore other options, such as replacing the joke with another one, or even ignoring it. Chapter 4 presents the whole array of techniques that translators can employ to render or compensate for similar instances.

In Chapter 2 we saw that Wodehouse's language was enriched by slang, such as the so-called knuts' lingo, and that much of his dialogue is based on a clash of language registers, such as, very often, in the exchanges between Bertie Wooster and his valet Jeeves. All these are features that belong to his culture, his time and to his world. They are therefore rendered with difficulty in the language of a different culture and in a different age. Moreover, verbal humour "often consists of the combination of linguistic play with encyclopaedic knowledge" (Chiaro, 2010, p.5), as in Wodehouse's intertextual references. The following dialogues, from Company for Henry (1967; GV.80, p. 169) and from Something Fishy (1915; GV.15, p. 190) respectively, combine a pun with a reference to crime fiction.

"The standard of masculine comeliness must have been very low in those days, because there's a portrait of him in the picture gallery and he looks like Nero Wolfe."

"Stout?"

"Bulging. [...]" 
The play here is between the name of American mystery writer Rex Stout, mostly known for his character Nero Wolfe, and the adjective "stout" meaning "corpulent". In the second example, the play is much more sophisticated:

"You are leaving Shipley Hall, sir?"

"I am. It stinks, and I am ready to depart."

In the second line of this exchange, Wodehouse substituted the word "stinks" for "sinks" in a verse by Walter Savage Landor. The original poem, written in 1879 as his own epitaph, reads:

I strove with none, for none was worth my strife.

Nature I loved, and, next to Nature, Art:

I warm'd both hands before the fire of Life;

It sinks; and I am ready to depart.

The wordplay is almost hidden, very subtle, slightly irreverent, and appreciable only by those familiar with the verses. Its translation poses two levels of challenge: it must be first recognised and then rendered. The following chapter of this dissertation is specifically devoted to the examination of this challenge, for both the researcher and the translator, with many examples from Wodehouse's works translated into Italian, and will also address the role of the translator's knowledge of the world in the process of recognising similar intertextual references.

As we will see in detail in the following section, humour has been investigated from various perspectives: philosophical, psychological, biological, sociological, anthropological, linguistic, and even religious (Roeckelein, 2002). Each perspective focuses on specific aspects of humour, so that different definitions have been suggested: some focus on the cognitive aspect of humour (see, for example, Suls in Goldstein \& McGhee, 1972), others on its affective dimension (Crawford, 1994); others underline its connection to laughter (e.g. Polimeni \& Reiss, 2006), while yet others reject the sufficiency and even the necessity of laughter in humour appreciation (e.g. Langevin and Day in Goldstein \& McGhee, 1972). There is, however, general agreement on the definition of humour as what is perceived as funny or amusing (Attardo, Wagner, \& Urios-Aparisi, 2013, p. 1). The term can be referred to the attributes of a stimulus that prompts mirth or laughter, or to the reaction of individuals to such stimulus. In this 
dissertation, humour is regarded at as a cognitive-perceptual construct, mainly in connection to the translating process.

After an overview of the main contributions to humour research and on the theories developed in their remits, the following sections of the present chapter mainly deal with the production of humour, while the following chapters focus on its understanding, appreciation and rendering in translation. Accordingly, in this chapter I identify how Wodehouse produced humorous effects. The following chapters will examine if and how they were rendered in the Italian versions of his works. They also present and apply a methodology capable of highlighting the strategies employed in the translating process.

\section{Humour research: contributions and perspectives}

Since humour is a widespread phenomenon and a fascinating cognitive function (Polimeni \& Reiss, 2006), it could not be ignored by thinkers and scholars worldwide, although it is often regarded at as a non-serious topic (Martin, 2007). Until the 1970s, when linguistics started to play a role in the debate, humour research in the Western world had for a long time been the realm of philosophers, psychologists and sociologists (Attardo, 20o6). Moreover, since humour is supposed to be common to every culture, it could not be ignored by anthropologists and by sociologists. Other areas of current research include the examinations of gender differences in the appreciation of humour, children's humour, humour in the workplace, and its therapeutic powers.

At least in the Western world, the main contributor to the knowledge of humour, although influenced by philosophy, has been psychology. It looks at humour under various points of view: as a behaviour, as a personality trait, in relation to its role in evolution, human development and health, also looking at its physiological correlates, such as smiling or laughter and at its social and biological functions. Psychology also acknowledges the positive emotion related to humour: mirth, a synonym of happiness, gaiety, and joy. Various cognitive factors are identified in humour production and appreciation. In producing humour, one must process information acquired by direct experience or stored in memory, to play with words and ideas. To understand humour, to "get" it, one must receive the information and process it in order to assess its value as hilarious. A number of other processes are performed in addition to these basic ones. Neurosciences are investigating the involvement of the different regions of the brain in humour processing (see, for example, Wild et al., 2003). It is now acknowledged that humour production 
and humour appreciation involve various and disseminated regions of the brain (Ramachandran, 1998) and depend on a genetically based neurological substrate (Polimeni \& Reiss, 2006).

Humour can also be studied within the evolutionary context, with the advantage of highlighting its adaptive function for both the individual and the group, its role as a facilitator in cooperation, and its function in regulating conflict. It can be argued to have an "evolved basis", i.e. it was selected in the evolution of the species because of its adaptive value. Such evolved behaviour (or trait) can be tested through 5 different strategies, i.e. checking if (i) it is present throughout the species, (ii) it has an early onset, (iii) it requires a specific neural structure, (iv) it occurs in related species and (v) a stereotypy of behaviour can be observed. Weisfeld (1993) applied this procedure to humour and laughter and demonstrated that humour has indeed an evolved basis. Moreover, some scholars maintain that humour is a form of aesthetic appreciation (Caron, 2002) and often enlightens the recipient about social foibles (Weisfeld, 1993).

As for anthropology, it has not only contributed to the exporation of humour cross-culturally, but it has also helped to highlight how humour, like any other aspect of reality, is "socially and culturally constituted" (Driessen in Bremmer \& Roodenburg, 1997, p. 222). There are reasons why anthropologists should be frontline investigators of humour: it is a diffused folk phenomenon and a social process. Joking, playful activities, mocking are common behaviours in every society (Caron, 2002). Moreover, humour is inevitable in fieldwork: anthropologists, regarded by the local population they are studying as weird, surprising, alien, are very often the butt of the joke themselves.

Sociology has not developed its own theory within humour studies (Fine, 1983). However, an interesting view developed by sociology is the historical-comparative approach, an umbrella term to describe most of the research performed by sociologists since the 1990 (Kuipers, 2008, p. 383). In particular, Christie Davies (1990; 1998) conducted comparative studies on jokes, highlighting that the target of humour, i.e. the butt of a joke, differs significantly in cultures, communities and ages. Giselinde Kuipers (2015) added to Davies's findings, showing that also the way people tell jokes varies among cultures and that different social groups regard humour differently.

In the field of Translation Studies, humour is viewed as such an arduous challenge both for the scholar and the translator that Diot (1989, p. 84) was forced to observe: "[w]hen it comes to translating humour, the operation proves to be as desperate as that of translating poetry". Possibly for this reason, academic literature on the translation of humour was scarce when the discipline started to develop in the 1970s and 1980s. However, a significant body of research began to be produced in the mid-199os (Chiaro, 2010). 
A "minimal" definition of humour in terms of its effect was put forth by Vandaele (2002, p. 153) who assured that both translators and translation scholars should not be afraid to accept it, at the same time warning that they should not "take this definition as an excuse to leave instances of humour unanalysed because they consider them either self-evident or unanalysable within any framework" (ibid., p. 155). Although I accept this rather vague definition of humour as "something that elicits amusement", I concentrate my efforts on developing a model for the process of translation, and an approach and tools for analysing humorous instances and their renderings in translation.

\section{Humour research: theories}

The different points of view on humour have been expressed by various theories, the majority of which, as said, were developed in the Western world in the nineteenth and the first half of the twentieth century, mainly in the remit of psychology (Daniel and Keith-Spiegel, 2013). Martin (2007) reports that in his 1928 book, The Psychology of Laughter and Comedy, John Young Thomas Greig was able to list 88 theories altogether, although admitting that "many of them differed from one another in only minor ways" (p. 31). Keith-Spiegel (in Goldstein \& McGhee, 1972) grouped them according to a number of labels: biological, instinct, evolution, superiority, incongruity, surprise, configurational, ambivalence, release and relief, and psychoanalytic theories.

The various theories that have been developed to explain what prompts mirth and laughter can, however, conveniently be grouped according to the basic principles they share. They are traditionally systematized under three main headings: the theories of (1) superiority, of (2) relief and of (3) incongruence. The discreteness of these three theories has been questioned, since scholars have noticed overlaps between them. For example, several humour scholars argue that incongruity theory is not enough to explain amusement and humour must therefore include elements of superiority or relief (Perks, 2012), an opinion I also hold, as I show later in this chapter. As Meyer (2000, p. 310) points out, each of these theories "runs into problems explaining rhetorical applications of humour" and none of them can fully account for any specific instance of humour. However, the traditional classification is still useful in order to guide the researcher. 


\section{Superiority}

For a long time, Western philosophers judged humour and laughter as expressions of irrational feelings and of lack of self-control. ${ }^{85}$ The wise, noble and virtuous man was advised to avoid laughter and wit, since they were connected to scorn, lack of respect and maliciousness. The main mechanism eliciting hilarity was found in derision. Greek philosophers such as Plato and Aristotle devoted some pages to humour, ${ }^{86}$ the study of which was seen as part of the study of aesthetics, asserting that we laugh at those we think are inferior to us, either because they are absurd or stupid in their behaviours or because they are weak, ugly or ill-fated. Superiority theory may account for mockery and for disparaging descriptions, such as the following one, from Wodehouse's The Mating Season (1949; GV.63, p. 264): "Purkiss looked at him fishily, nature having made it impossible for him to look at anyone otherwise, he being a man with a face like a halibut". The insult here is built up slowly, by means of a logical wording in the sentence, making the characteristic of Perkin resembling a fish and his "fishy" attitude almost ineluctable. The outcome is in fact harsh disparagement but one that cannot but be agreed upon.

Superiority has been for a long time the main theory to explain humour, maintaining that amusement "results from a sudden feeling of superiority or triumph one feels from the recognition of the infirmities or misfortunes of others" (Ferguson \& Ford, 2008, p. 288) and that it "emerges from elevated feelings of self-worth after verbal denigration of a target" (Perks, 2012, p. 120). In other words, according to the superiority theory, we laugh at something or somebody that we perceive inferior to us. For example, we can find humour in somebody's naïve, stupid, or illogical behaviour since we would not have behaved in the same way: it is assumed that finding humour is a form of triumph at the expense of others, deemed inferior. There is an obvious connection to comedy here: a consistent part of the amusement an audience gets from comedy is in fact derived from the contemplation of the mishaps the characters suffer. In Wodehouse, where humour is set in the frame of his "comic mood", as pointed out in Chapter 2, this kind of humour is mainly found in the accidents that occur to his characters. In a story from Mulliner Nights (1933; GV.44), for example, hero Sacherwell Mulliner, one of Mr Mulliner's innumerable relatives whose stories are told in the books of the cycle, has been hiding for a while under the bed of one of the hosts, the bishop of Bognor, who has been given the "Blue Suite". Once the bishop is asleep, Sacherwell tries to make his escape but mistakes the door (p. 133).

\footnotetext{
${ }^{85}$ For a comprehensive dissertation on how humour was addressed in the works of ancient Greek and Latin philosophers, see Perks, 2012.

${ }^{86}$ See: Plato's Philebus $5^{\circ} \mathrm{A}$ and Aristotle's Poetics.
} 
The relief which Sacherwell felt as he closed the door behind him would have been less intense, had he realized that through a slight mistake in his bearings he had not, as he supposed, reached the haven of the passage outside but had merely entered the bathroom. This fact was not brought home to him until he had collided with an unexpected chair, upset it, tripped over a bathmat, clutched for support into the darkness and brushed off the glass shelf above the basin a series of bottles, containing - in the order given - Scalpo ('It fertilizes the Follicles'), Soothine - for applying to the face after shaving, and Doctor Wilberforce's Golden Gargle in the large or seven-and-sixpenny size.

Wodehouse carefully plans the incident. Readers already know that the bishop is in fact the Rev. J. G. Smethurst, Sacherwell's former headmaster at Harborough College years before (p.131), one who still scares him to death and that "the Blue Suite was the only one in the house with a bathroom of its own" (p. 124), so the mistake is plausible. They are also aware of the fact that Sacherwell is erroneously convinced that the suite is occupied by his fiancée's former boyfriend (p. 123) and that Sacherwell is jealous. Such careful planning takes, therefore, into account what the readers know and, in the light of the Epistemic Approach, this is a structure that must be respected in translation. Moreover, readers know that Sacherwell is the hero, hence their sympathy goes to him. Nevertheless, they enjoy the mishap and its rich description whose vividness is reached by means of elaborate wording and apparently superfluous details. This is a characteristic of Wodehouse's, for which I coined the term "hyper-wording", which is treated in detail later in this chapter.

The theory of superiority, to which philosopher Thomas Hobbes also adhered (see, for instance Human Nature, 1840), can fully explain what is called disparagement humour, i.e. the type of humour that belittles and often humiliates others, as in sexist or racist jokes. This is not a kind of humour Wodehouse deployed very much. A mild example of racial belittlement is this often-quoted statement, from Blanding Castle and Elsewhere, 1935; GV.48, p. 34: "It is never difficult to distinguish between a Scotsman with a grievance and a ray of sunshine", playing with the stereotype of Scotsmen being badtempered. In a presentation entitled "Let's Take Humour Seriously" that I gave in a symposium organized by my department at Swansea University, I asked the participants to rate five instances of humour. The first one was a remark attributed to Winston Churchill: "I may be drunk, Miss, but in the morning I will be sober and you will still be ugly". One of the participants said that she had felt so offended by this first 
example, that she was unable to judge the other ones, while the other participants did not take offence. Therefore, this theory might partly explain why some people laugh at a joke while others, presented with the identical joke, do not. (La Fave in Goldstein \& McGhee, 1972). However, it does not account for other kinds of humour, such as puns, slapstick, jokes based on wordplay, or what is called affiliative humour, that is to say the benevolent use of humour to create group cohesion.

\section{Relief}

Relief theory originated in the eighteenth century when "the nervous system was represented as a network of tubes inside which the animal spirits sometimes build up pressure, as in emotional excitement" (Morreall, 2004, p. 16): such excitement called for release. The first to propose an excessenergy theory of humour was Herbert Spencer in 186o. In his essay, On the Physiology of Laughter, he argued that humour provokes nervous excitation, which, in turn, causes muscular motion. He maintained that laughter, as a form of physical movement, serves to release the excess energy produced by humour. The theory was later developed by Sigmund Freud and is now generally associated with his name. This version theory should be (and has been) dubbed "psychoanalytical", since it is grounded on the main tenets of psychoanalysis: the acknowledgement of instincts (or drives or motivations) as ultimate cause of human behaviour, of the unconscious and its conflicts with the conscious, and of the protective role of defence mechanisms. Freud distinguishes three different categories of phenomena connected to laughter: jokes or wit (der Witz), the comic, and humour. Wit depends on clever use of cognitive "jokework" techniques (Martin, 2007) and permits the release of the psychic energy that was repressing the negative emotions triggered by some impulse (sexual or hostile). This mechanism works while telling or listening to a joke: the internal censor is avoided, the energy used to repress undesirable emotions becomes redundant, and libido or hostility can be vented. In a nutshell, for a joke to be effective, there are two important requirements: it must involve a clever use of jokework and it must allow for the expression of some repressed sexual or aggressive impulse. Another category that Freud identifies, the comic, does not require a teller (Purdie, 1993). It has no verbal component and is experienced when one watches someone else's actions that are perceived as exaggerated, clumsy, inefficient. Examples are clowns in the circus or slapstick comedy. Freud claims that a great amount of energy is spent while we try to mentally represent actions that we would perform easily and smoothly. Since the action is performed by someone else, the expenditure of energy is inhibited, "it is declared superfluous and is free for use elsewhere or perhaps for discharge by laughter" (Freud, 1974 [1905], p.254). 
Finally, humour, which Freud affirmed to be the best of an individual's mature defence mechanisms and argued that it is not common to everybody (Freud, 1963; Martin, Puhlik-Doris, Larsen, Gray, \& Weir, 2003). It occurs when one can find an amusing aspect in a difficult situation, e.g. threat or aggression: the cause for the negative emotion ceases to exercise its effect, therefore the energy accumulated to face the stressful situation is released. Humour greatly differs from wit, since the latter is aggressive, a proof of repressed hostility, whereas the former is sympathetic, benign. Moreover, humour is rebellious, since it refuses to let the individual suffer and is, consequently, beneficial.

Hypotheses derived from the psychoanalytic theory of humour, mainly on jokes, have been the subject of research that "produced limited and inconsistent supportive evidence" (Martin, 2007, p. 42). However, both Freud's reflections and the research inspired by his theory have the merit of having shed light on various aspects of humour and have "contributed substantially to our knowledge of the psychology of humor" (Martin, 2007, ibid.). Here, in a study mainly dealing with humour production and appreciation, relief theories do not seem to add much to our understanding, since they tend to focus on the role played by humour in everyday life. Nevertheless, it is worth highlighting a possible connection between relief theories and comedy, considering the accumulation of anxiety posited by Rosik (2011) as a condition that elicits humour. It is not here viable to quote a text as an instance of how Wodehouse creates anxiety, since he does so gradually and by disseminating clues throughout the text that build up tension and suspense in his readers, as already partially shown in the previous example of Sackerwell's disastrous nocturnal incursion. However, evidence can be supplied by sketching one of his plots, since, similarly to detective stories, Wodehouse's plots are constructed around a problem-solution structure and they often "contain interwoven problems" (Thompson, 1992,p. 161). In Joy in the Morning (1947; GV.59), as an example, misunderstandings, purloined objects, lies, and secret plans combine to build a plot that may cause anxiety in readers, since the events get more and more intricated and it is hard to foresee a solution for all of them. However, Wodehouse's clues make readers aware that Florence's jealous present fiancé, Stilton Cheeswright, will eventually - and inevitably - find out that Bertie was once engaged to her, a fact Bertie is obviously concealing from him. Readers can also predict the disaster that will arise, for instance, by having Bertie pretending to have rented a cottage for a holiday, while in fact it was meant as a private place for the secret pourparlers between Lord Worplesdon and a rich American entrepreneur. Moreover, once the secret place is no longer secret, Lord Worpleton finally manages to conclude his negotiations at a fancy-dress ball in the village, disguised as Sinbad the sailor. His wife, formidable Aunt Agatha, would be horrified if she knew. Heavily intoxicated, Lord Worpleston 
is accidentally kept locked in the garage, while expected at home. All these anticipations create anxiety that is relieved only when Jeeves manipulates the events and finds a solution to each problem. Anxiety relief is part of the pleasure that Wodehouse's readers get once he skilfully manages to have one of his characters (typically, Jeeves, Psmith, Lord Ickenham and Gally Treepwood) solve all troubles (of which, by the way, they were often the cause in the first place).

\section{Incongruity}

The theory that is now reigning in Humour Studies is incongruity (Warren \& McGraw, 2016) and it is within this framework that the most of research in verbal humour is now concentrated. It appears to account for the reasons that lie behind humour in a more convincing way than the obsolete relief theory, and for forms of humour such as puns, not prompted by feelings of superiority. Incongruity theory, which is cognitive in nature (Perks 2012), maintains that humour is triggered by the detection and the subsequent resolution of something felt to be incongruous, i.e. something unusual and different from what one would expect. Among the early proponents of this theory are Kant and Schopenhauer. Kant (Kant, 179o) posited that laughter is caused by the sudden change of a strained expectation into nothing, while Schopenhauer (Schopenhauer, 1819) argued that it is elicited by a sudden perception of the incongruity between two concepts in a relation. Most definitions of humour based on this approach revolve around the idea of two or more things, understood as facets of the same unit, perceived as inconsistent or unsuitable. The relativity of such a perception is apparent: somebody might perceive incongruity, somebody else might not. Morreall (2004) addressed this issue and posited that humour lies in the enjoyment of the cognitive shift experienced. Some people, however, are puzzled or react with negative emotions. Research must investigate the social, cultural, cognitive and linguistic factors that influence this perception, par later below.

However, incongruity by itself is not enough for something to be perceived as humorous: some incongruities, such as mishaps, incidents, accidents in real life are not funny. In other words, incongruity is a necessary but not sufficient condition for humour. It is in the identification of what is both necessary and sufficient that incongruity theories differ: some maintain that incongruity must occur in a safe, nonthreatening environment (Rothbart, 1977), some others (e.g. Suls, 1972) underline the condition of being sudden for incongruity to be perceived as funny. Wodehouse's texts, since they are meant to be amusing, are safe environments: readers know that even the most disastrous incident will never be harmful to the 
fictional characters. Moreover, as already pointed out, incidents, misunderstandings and potentially dangerous situations are part of the play in comedy. Therefore, given the context, we are allowed to treat Wodehouse's incongruities as instances of deliberate humour (Mitchell, Graesser, \& Louwerse, 2010). We will also later see that the element of surprise is intrinsic in Wodehouse's humour, both in descriptions and in dialogues. Particularly, the reader is likely to be surprised, and maybe puzzled, facing instances of Wodehouse's creative intertextuality:

\footnotetext{
“Do you knit?"

"No."
}

"Sleep does. It knits the ravelled sleave of care."

Here, the first character, a whimsical gentleman whose hobby is knitting, is playing with Shakespeare's Macbeth (Act II, Scene 2) by transferring a metaphor into everyday life. The reader may or may not be aware of the literary reference; however the sudden turn from the prosaic to the sublime and the personification ("Sleep does") is surprising and, possibly, puzzling.

The four ways by which incongruity is conceptualized are: (1) surprise, i.e. something unexpected (2) juxtaposition, i.e. the simultaneous perception of incompatible elements of perception (3) atypicality, i.e. something different from what is normally expected and (4) violation, i.e. something that threatens one's sense of how things should be (Warren \& McGraw, 2016). The following sentences from Wodehouse's works can exemplify each category of incongruity.

1. There is only one cure for grey hair. It was invented by a Frenchman. It is called the guillotine.

2. I hadn't the heart to touch my breakfast. I told Jeeves to drink it himself.

3. It was one of those parties where you cough twice before you speak and then decide not to say it after all.

4. If there is one thing I dislike, it is the man who tries to air his grievances when I wish to air mine.

Each of these statements contains a violation of expectations. I will show later that expectation is a key term employed in the definition of script on which I elaborate to conceptualise my construct of scriptclash, that I posit as the basis of the formula to define Wodehouse's humour. For example, in quotation no 1, taken from The Old Reliable (1951; GV.65, p. 17), we would expect the revelation of the ultimate 
treatment for a problematic phenomenon that affects all of us. What in fact we get is a surprising - and indeed ultimate - solution to it. Overall, these examples show the clash between what we logically expect from the premises and what Wodehouse in fact gives us, always an unexpected, albeit logical, conclusion. Expectations are grounded on rationality, culture and on the schemata and the scripts we bear in mind; therefore, they are grounded on individual and shared KnoW. When expectations are not met, we are surprised, puzzled, compelled to doubt, and forced to find a solution to the clash.

Humour narratives, for example jokes, can be said to follow this path: the perceiver is led towards certain expectations and tension is slowly built; an unexpected twist, already posited by Aristotle as the best way to elicit laughter in an audience (Rhetoric, III, 2), is then added to the narrative that forces the listener to re-interpret the information previously received. Such reinterpretation is unexpected but, at the same time, it accounts for the whole set of information that was expected. Aristotle had put forth this aspect, too. He posited that the surprising twist must be capable of fitting the facts, in other words, the listener must be able to find a logical resolution for the incongruity. That is, one must find a logical proposition in illogical wording.

The Incongruity-Resolution Theory, first and foremost elaborated in the 1970s, maintains that humour "is created by a multi-stage process in which an initial incongruity is created, and then some further information causes that incongruity to be solved" (Ritchie, 1999, p. 78). In the light of this, some (e.g. Ramachandran, 1988) have paralleled this mechanism to Thomas Kuhn's "paradigm shift" in scientific discovery (Kuhn, 1962/1996), stating that "jokes have much in common with scientific creativity" (Ramachandran, 1998, p. 351) and that such a shift is employed as a response to the anomaly of the punch line. Exponents of the Incongruity-Resolution Theory, e.g. Shultz 1974, Minsky 1980 and Paulos 1980, have developed a related model, termed "surprise disambiguation". It assumes two opposite interpretations of a humorous text (typically, as usual, a joke): one more obvious than the other. The less obvious interpretation becomes apparent only once the punch line is reached, conflicting with and evoking the other, more obvious, interpretation.

An example of how this process may work is given by Schultz (1974). In reading or listening to this exchange: "Do you believe in clubs for children?" "Only when kindness fails", the receivers first realizes an incongruity in the wording, grounded on the lexical ambiguity of the term "clubs", that may mean both "associations" or "heavy sticks". Secondly they process the element of incongruity ("Only when kindness fails") and finally they perceive the hidden meaning of the ambiguous expression, thus appreciating the joke (Shultz, 1974). Indeed, as Delabastita (1997, p. 9) points out, "the study of wordplay 
takes one to the heart of the study of communication". A quotation from Wodehouse's Full Moon (1947; GV.6o, p. 26) will further exemplify the process Schultz posits. It is an exchange between Freddie Threepwood and his cousin, Prudence Garland: "It's about those dogs of yours. What do they live on?" "The chairs most of the time". The incongruity here is in the ambiguous syntactic function of the preposition "on". It can be processed either as (function 1) a function word to indicate position in contact with a surface, or (function 2) as particle in a phrasal verb (live on = eat a particular kind of food). Contextual information supplied, that is, the fact that Freddie has just been hired by an American firm dealing in dog food and is constantly trying to sell his goods, especially to his relatives, leads the reader to prefer function 2, whereas Prudence favours function 1. What is interesting to note here is that Wodehouse makes it clear that Prudence's joke is to be perceived as intentional, as Freddie understands it, since the text goes on like this: "Freddie clicked his tongue. One smiles at these verbal pleasantries, but they clog the wheels of commerce". This could be taken as a proof of the fact that Wodehouse did not regard this kind of puns as original enough to be part of his humorous repertoire. However, aware of their potential humorous function, he elaborated on them before including them in his texts.

Mainly tackling verbal jokes and captioned cartoons, Suls (in Goldstein \& McGhee, 1972) proposed a cognitive and structural approach to the understanding of the process we employ when we finish listening to or reading a potentially humorous text. He suggested a two-stage model, dubbed humourappreciation model. In the first stage (recognition) we are surprised to perceive that our expectations about the text are disconfirmed since the end of the text does not follow logically from its premises; we then must retrieve a cognitive rule, defined (p. 82) as "a logical proposition, a definition or a fact of experience", in order to solve the incongruence: this is stage two of the process (resolution), that is similar to a problem solving task (Long \& Graesser, 1988). Suls's model is described in the diagram on the following page. 


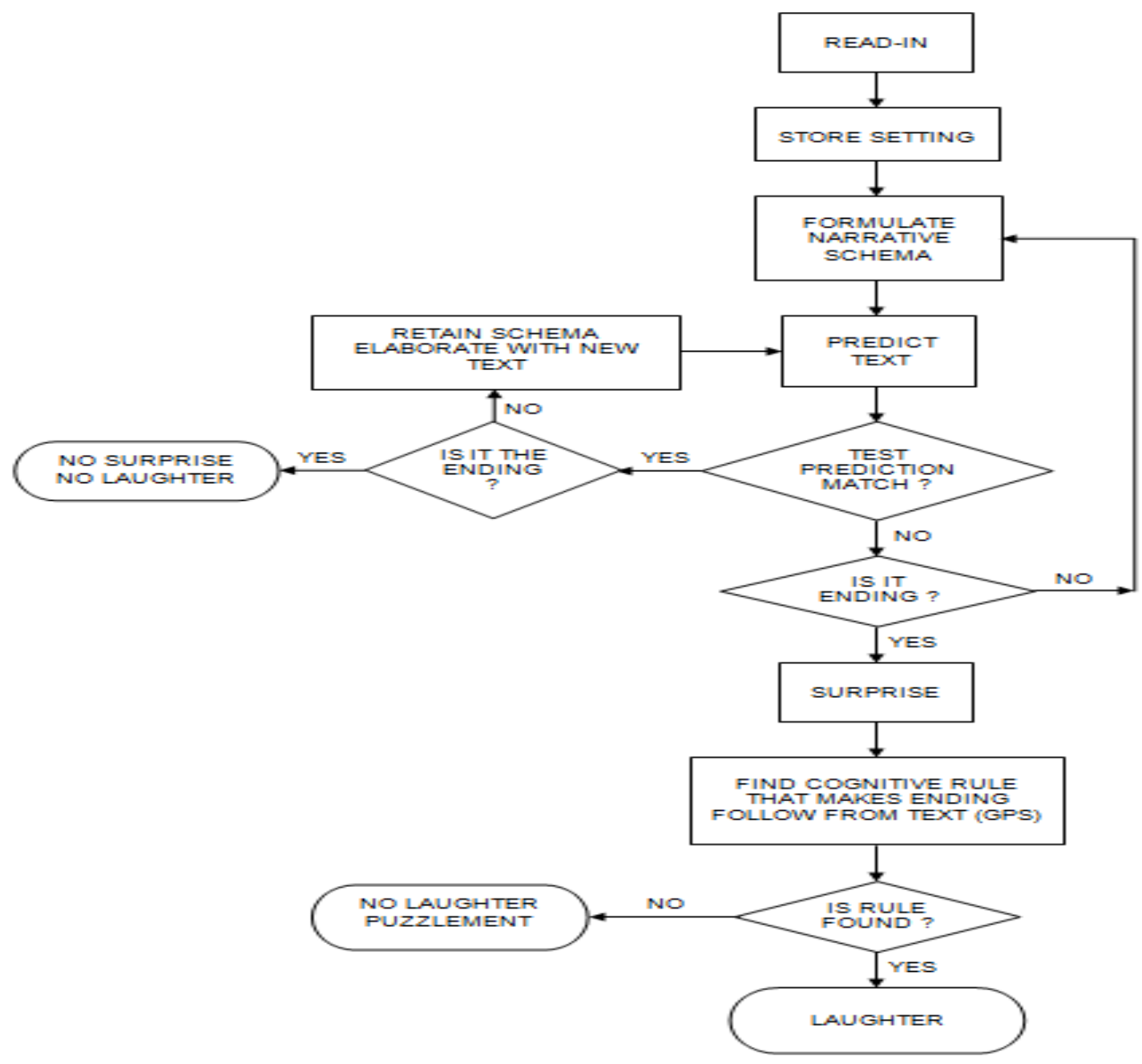

Figure 2: Suls's Humor-appreciation model (1972, p. 85)

Suls argues that the more surprising the incongruity, i.e. the punch line, the greater the appreciation will be, since "the more one should want to overcome the surprise" (in Goldstein \& McGhee, 1972, p. 91). As an example, Suls provides the following joke:

O'Riley was on trial for armed robbery. The jury came out and announced,

"Not guilty".

"Wonderful", said O'Riley, "does that mean that I can keep the money?"

This example "illustrates the properties of humour that have been hypothesized - the ending on the joke is unexpected and incongruous (Stage 1) but it can also be interpreted as to make sense (Stage 2)” (p. 9o). In Stage 1 the joke is read. The reader chooses an appropriate narrative schema (a trial). This choice is 
confirmed (the verdict). O'Riley's first utterance ("Wonderful!") is expected, since it is the plausible reaction of a free man. What is then expected is something like "Does that mean that I can go?". In its place, O'Riley finishes his line with an unexpected question that shows his actual guilt. Since the final line contradicts the expectations suggested by the schema, the reader is engaged in the process of finding a rule capable of reducing the difference between the narrative and the final line (the punch line). Here, the most plausible rule is the one recognizing the difference between legal and actual truth. Once the incongruity is explained, Suls says, "the process should terminate and laughter ensue" (p. 91). This model can be applied to process the following example from Wodehouse's Right Ho, Jeeves (1934; GV.47, p. 33), an exchange between Bertie and his friend Pongo: "You're pulling my leg" "I am not pulling your leg. Nothing would induce me to touch your beastly leg". Readers know that there has been some tension between the two friends and that they were schoolboys together, so informality and the use of idioms is expected in their exchanges. Contextual information would therefore direct the readers, in stage 1, towards the schema evoked by the interpretation of the "pull someone's leg" idiom, meaning "to play a joke on someone" (Gulland \& Hinds-Howell, 2001, p. 102). However, in order to make sense of the final line, that forces them to reconsider their first choice (idiomatic meaning), readers must search for an alternative understanding of the phrase. They will find it in its literal, physical meaning.

The models proposed within the remit of the Incongruity-Resolution Theory are effective in explaining the cognitive paths we follow while processing puns, cartoons and verbal jokes. However, they do not account for the humorous effect reached by more puzzling instances, where a cognitive rule cannot be found, such as quips based on back-formations or on affixes that rely on grammatical humorous potentials in a given language. The humorous efficacy of the following example from Wodehouse (quoted in Attardo, 1994, whose source I could not find): "If it's feasible, let's fease it" can hardly be explained or illustrated by those models. A major role in the process of disambiguation, i.e. in the resolution of incongruity, is, however, always played by inferencing. Inferences are educated guesses grounded on the information possessed and made when one goes beyond available evidence. This process "is based on more or less conventional background knowledge and is dictated by a general principle of relevance" (Houdé, 2004, p. 114). In dealing with instances of humour grounded on grammar rules, for example, affixation, the receivers rely on their knowledge of the Linguistic Code employed and how the grammar rules are generally applied in this language. How this process is performed by translators while interpreting humorous texts and what the implications of their KnoW are on the translating process will be highlighted in Chapter 4. 


\section{Humour research and language}

Humour can be regarded at as "the most complex cognitive function in the animal kingdom" (Polimeni \& Reiss, 2006, p. 362) and could evolve thanks to the morphological (bipedalism) and neurological (high degree of encephalization) changes that occurred in humans, conditions that also helped the development of language. Although studies in neuroscience have demonstrated that laughter developed before and independently of language (Gervais \& Wilson, 2011), there are claims that humour has had a role in its development (Caron, 2002). Although "the full expression of humour in contemporary humans is fundamentally contigent on language" (Polimeni \& Reiss, 2006, p. 359), it was only in the 1970s that linguistics started to play a role in Humour Studies. Quite obviously, the main focus of interest for linguists is verbal humour, i.e. humour produced by language or texts (Raskin, 1985; Norrick, 2004) and its most studied expression is jokes.

Linguist Attardo (Attardo, 1994) adopted a way of classifying theories of humour different from the traditional one. He represented them according to three main labels: Cognitive, Social and Psychoanalytical.

\begin{tabular}{|l|l|l|}
\hline \multicolumn{1}{|c|}{ COGNITIVE } & \multicolumn{1}{|c|}{ SOCIAL } & \multicolumn{1}{c|}{ PSYCHOANALYTICAL } \\
\hline \hline Incongruity & Hostility & Release \\
\hline \hline Contrast & Aggression & Sublimation \\
\hline \hline & Superiority & Liberation \\
\hline \hline & Triumph & Economy \\
\hline \hline & Derision & \\
\hline \hline & Disparagement & \\
\hline
\end{tabular}

Figure 3: The three families of theories of humour (Attardo, 1994 p.47)

Attardo (1994) maintains that theories based on the understanding of humour as a way to despise and mock others, e.g. Superiority and Disparagement theories, are "of interest to the sociolinguistics of humor, but of limited application elsewhere" (p. 50), and holds that Release theories are interesting in linguistics since they account for the de-regulation of language, freeing it from its rules, as in puns and word-play, and for the emphasis on the infractions of the Gricean principles of communication. He points to Incongruity theories as the ancestors of cognitive theories, stating that "they are conceptually 
closer to linguistic theories of structuralist descent since they are essentialist" (p. 49), to the point that linguistic theories of humour have been acritically classified within Incongruity theories. Attardo admits that Incongruity theories and linguistic theories of humour "share some aspects of the general outlook on the phenomena to be explained" (p. 49) but "it would be incorrect to claim that any linguistic theory of humor is necessarily incongruity-based" (ibidem).

\section{Linguistic theories of humour}

In the field of linguistics, the most recent theories were outlined between the mid-1980s and the mid199os and are still open to debate and development. Presented chronologically, the three most important are: Raskin's Script-based Semantic Theory of Humour (1985), Salvatore Attardo's five-level model for the analysis of joke texts (1989), and Attardo and Raskin's General Theory of Verbal Humour (1991). To these, one must add Ruch, Attardo and Raskin's empirical support of the General Theory of Verbal Humour (1993). The foundations of these theories lie in the argument that humour revolves around the opposition of scripts, a term borrowed from cognitive psychology that will be treated in detail later. In 1993, one of Raskin's students proposed a theory that embraces "both the linguistic and the rhetorical aspects of that which occurs in the humorous event" (Carrell, 1993, p.1), the Audience-based Theory of Verbal Humour that posits "that humour resides in the audience" (Carrell in Raskin, 2008, p. 314). Lastly, starting in 1991, Giora has put forth two hypotheses whose claims are compatible with Raskin and colleagues': the marked informativeness requirement and the optimal innovation hypothesis. Giora's work focuses primarily on irony and sarcasm but she sometimes tackles cognitive aspects of jokes (see, for example, Giora, 1991, 2003). The recent involvement of linguistics in humour research has led to the disclosure of paths of investigation that might help researchers to find their way of addressing the issues specifically raised in translation. I draw on these for my considerations on Wodehouse's humour and to devise the tools I will present and employ in my analyses. As already stated, my construct of script-clash elaborates on Raskin's concept of script (1985), as reformulated by Attardo (1997) and I hold that the clash I hypothesise as the basis of Wodehouse's humour is found in the way he employs language to have incongruous elements coexist in his utterances.

The first to openly classify his approach as linguistic was Victor Raskin. In a 1979 paper (Raskin, 1979), he acknowledged the recent developments of pragmatics and semantics, both theoretical and practical, and their contribution to the "study of the linguistic and extra-linguistic context of the utterance" (Raskin, 1979, p. 325) that made it possible to undertake what he stated was his purpose: "the linguistic 
study of verbal humor $[\ldots]$ against the application of those recent developments, as an application of a tentative formal script-oriented semantic theory" (Raskin, 1979, p. 325). He also affirmed that, in order to understand an utterance in context, both semantics (the knowledge of language) and pragmatics (the knowledge of the world) are necessary. He, therefore, introduced into Humour Research key concepts from pragmatics and semantics, such as script (or scheme or frame), presupposition, and implicature. He also highlighted the relevance of what he called cognitive structures, i.e. the knowledge of extra-linguistic facts, grounded on social rules or shared values and learnt from experience, hence in line with my definition of KnoW, in understanding utterances, including those meant to be humorous. His approach was illustrated in more detail in his seminal work, Semantic Mechanisms of Humor (1985), where he formalized his theory, known as the Script-based Semantic Theory of Humor (SSTH), aimed at the semantic analysis mainly of jokes, i.e. humorous narratives often concluding with a punch line.

The main claim of this theory is that verbal humour lies on the surprising overlapping of opposite scripts that are all compatible with the general theme of a joke. A script was defined by Raskin (1985, p. 81) as "a large chunk of semantic information surrounding the word or evoked by it. It is a cognitive structure internalized by the native speaker and it represents the native speaker's knowledge of a small part of the world" (Raskin 1985, p.81). He stated that one of the central issues of his approach was to identify "what exactly it takes for some two scripts to be distinct or opposite enough so that their overlap would produce a humorous effect" (Raskin, 1979, p. 333). His oft-quoted example (Raskin, 1979 p. 332 ) illustrates this point:

\footnotetext{
"Is the doctor at home?" the patient asked in his bronchial whisper.

"No," the doctor's young and pretty wife whispered in reply. "Come on right in."
}

There are two scripts here: the patient's (the "visiting the doctor" script) and the doctor's wife's (the "visiting the lover" script). Each of them is fully consistent in itself; however, when they overlap, they clash and incongruity is perceived, the simultaneity of the two opposing scripts is acknowledged, hence the humorous effect. The linguistic concept relevant here is polysemy, that's to say the association of an utterance (a single word or a phase) to different meanings. Polysemy, as seen above in the examples of humorous texts based on ambiguity, is also a major issue in translation. Here, the concept is stretched to comprise the whole script. In the example above, a way of verbalizing the opposition between the two 
scripts could be: "The patient comes to the doctor's house to see the doctor vs. The patient comes to the doctor's house not to see the doctor" (Raskin, 1985, p.110).

Raskin identifies three basic types of script opposition: the first refers to the situation in which the joke is set (actual vs non-actual, non-existing), the second to the state of affairs (normal/expected vs nonnormal/non-expected) and the third to the situation (possible, plausible situation vs fully or partially impossible or much less plausible situation): a joke describes a "real" situation, at the same time "evoking" another "unreal" one. Raskin's notion of script, later (1997) modified by Attardo, as a "collection[s] of semantic information pertaining to a given subject [...], which can be represented as a set of expectations and/or weighted choices" (p. 402) serves to identify script-opposition, held by the General Theory of Verbal Humour to be the most important knowledge resource to influence funniness, also in texts structured differently from jokes. I will show how my elaboration of these two tenets of Raskin's and Attardo's theorisations (the notions of script, denoted as a set of expectations, and of script opposition, that I rename script-clash) allows me to categorise the kind of humour Wodehouse most frequently employed.

A corollary to Raskin's theory is Ruch's (2001) statement: "A text is funny if and only if the text is compatible (fully or in part) with two distinct scripts, and the two scripts are in some way opposite" (p. 25). Script opposition is found, for example, in this quotation from Wodehouse's The Man Upstairs and Other Stories (1914; GV.13, Chapter 8 "Ruth in Exile"): "To persons of spirit like ourselves the only happy marriage is that which is based on a firm foundation of almost incessant quarrelling", that plays on the opposition between the scripts "happy marriage" and "quarrelsome marriage" and would therefore be classified as a "state of affairs" script opposition. Culture, experience, knowledge of the world, and personality traits influence the receiver's judgement of each "state of affairs" as "normal" or "non-normal". However, the contradiction between the two scripts is obviously perceived as incongruous. Partially in disagreement with Ruch, I posit, as I will demonstrate later, that script opposition is not enough to fully appreciate Wodehouse's texts. His humorous instances contain, at the same time, a clash of scripts and hyper-wording, i.e. an exaggerated number of collocates. In the example above from The Man Upstairs and Other Stories, hyper-wording is found in elaborate wording: "firm foundation of almost incessant quarrelling", instead of merely "quarrelling".

Raskin notes that "many jokes contain an element which triggers the switch from one script evoked by the text and the opposite script" (Raskin 1985, p.114). This element is dubbed "script-switcher" and is identified in the punch line of a joke that makes the receiver realize that the two opposite interpretations 
were in fact possible right from the start. I believe this is the surprising element that elicits humour and I argue that this sudden apprehension is what causes mirth and excitement when one "gets" the joke: the faster the better. By the same token, the linguistic theory proposed by Raskin is compatible with the twostage model of incongruity-solution proposed by Suls (1972).

In their revision of Raskin's Script-based Semantic Theory of Humor, Attardo and Raskin collaborated to formulate a "General Theory of Verbal Humor" (GTVH). According to this theory, a joke is informed by six knowledge resources, or KRs. They are: (1) script opposition, as identified by Raskin (1985), (2) logical mechanism, i.e. figure-ground reversal mechanisms, (3) situation, i.e. the background set-up of the joke, including the audience, (4) target, i.e. the "butt" of the joke, (5) narrative strategy, i.e. the narrative set-up, and (6) language, i.e. the actual realisation and phonetic, morphological and pragmatic structure of the joke. According to Attardo and Raskin, (1991) "each KR is a list or set of lists from which choices need to be made [by the joke teller] for use in the joke" (p. 313). The General Theory of Verbal Humor “incorporates, subsumes, and revises” Raskin's script-based semantic theory (Attardo \& Raskin, 1991, p. 329) and Attardo's five-level model but still concentrates virtually exclusively on the text of the joke. The main achievement of this theory seems to be its capacity to assess the similarity of jokes, in terms of the number of knowledge resources they share. Attardo later expanded this model to describe humour in short stories in Humorous Texts: A Semantic and Pragmatic Analysis (Attardo, 2001). Here, he enriched the model by adding a distinction between "punch line", which occurs in a final position in a joke and "jab line", which he defined as "a type of humorous trigger which occurs in the body of a text" (Attardo, 2001, p. 82). Moreover, he introduced the term "strand" to indicate "a (non-necessarily contiguous) sequence of (punch or jab) lines formally or thematically linked" (p. 83). He addressed register humour (i.e. where two language registers, such as formal and informal, co-exist in the same utterance) and irony, as examples of "diffuse disjunctors", i.e. humorous texts that "do not have a clear cut punch line" (p. viii). His case studies present a text from a TV sitcom (the "Mary Tyler Moore Show"), a poem ("Cinderella" by Anne Sexton), a sample of picaresque (Henry Peachman's A Merry Discourse of Meum and Tuum), an instance of anachronistic intertextuality (the names of some characters in Umberto Eco's Il nome della rosa) and a short story ("Han Rybeck ou le coup de l'étrier" by French humourist Alphonse Allais). He states that he could sometimes "point out a 'wave' pattern in the distribution of the humor" (p. 207) in the texts he analysed, although he admits that "it is very dangerous to generalize from a corpus of one or two texts" (ibid.). 
Another attempt to investigate jokes and irony was made by Giora (1995), whose theory, dubbed the "Graded Salience Hypothesis", is discourse-based. Giora's studies, dealing with irony and polysemy (mainly in jokes) contribute to humour research in linguistics since they discuss them "from a psycholinguistic and discursive point of view" (Nerlich, 2003, p. 17). According to this approach, humour items differ from well-formed texts since the latter must conform to the so-called "relevance requirement" (i.e. the message conveyed must refer to a discourse topic, i.e. to an explicitly stated generalization to appear at the beginning of discourse) and to the "graded informativeness condition" (i.e. sentences progress so that each one is more informative that the previous one) and must overtly show any deviation from preceding requirements by means of connectors such as, for example, "by the way". Jokes and irony are instances of "not well-formed texts", since they conform to the relevance requirement but violate the graded informativeness condition. Jokes introduce an over-informative proposition while irony presents a proposition which is not informative enough. The result is that the receiver of a joke is forced to go beyond the surface interpretation and to find out a second, less salient one, while the receiver of an instance of irony is forced to have the salient, although inappropriate, interpretation coexist with a new one, less salient or not at all salient. There are no jokes in Wodehouse, and very few instances of irony. However, it is possible to attempt an analysis in Giora's terms of the following quotation from Wodehouse's The Girl in Blue (1970; GV.83, p. 213): "You're one of those guys who can make a party just by leaving it. It's a great gift". The ironic element is found in the second sentence. It conforms to the relevance requirement, since it refers to what stated in the first sentence. However, it is a "not well-formed text", as it presents the receiver with a less informative proposition. In order to get the sense of the whole statement, the receiver is compelled to accept two interpretations at the same time: the butt of the ironic statement is said to be a lucky and gifted person and, at the same time, somebody better to avoid.

All in all, linguistic theories of humour have mainly focused on instances of humour, such as jokes, which, as Norrick (2004, p. 1339) remarks, are not about "realistic characters" but "only about caricatures or types". Moreover, these instances stand alone, typically without explicit connections with surrounding conversation or text. They, therefore, differ greatly from the humorous instances contained in personal anecdotes, witty remarks and comic narratives with compound structures that require instruments of investigation and models that have not yet been developed. My research on Wodehouse investigates the stylistic and humorous devices in his novels and short stories, with the purpose of identifying those that 
characterise his humour. Moreover, it is aimed at devising the tools necessary to highlight his specificities that must be maintained in translation.

\section{Wodehouse's Humour}

The analysis of Wodehouse's Stylistic Devices performed in chapter 2 has already pointed out the main tools he employed. The aim of this section is to investigate how they enabled him to achieve a humorous intent and to evaluate their effect on his readers. Mainly by means of examples from his writings, I first identify five key concepts as the headings under which I categorise the Stylistic Devices presented in Chapter 2, seen in the light of mainstream theories of humour. Secondly, I define the two new terms, script-clash and hyper-wording, that I employ to conceptualise my definition of Wodehouse's humour. Third, I supply tools to assess his humor: semantic distance and the incongruity index. Combined with Script-Clash and Hyper-Wording, these tools yield a value assigned to any instance of humour, that I term Incongruity Value.

I believe the best way to open my argument is by exclusion, i.e. stating what Wodehouse's humour is not. It is worth noting that, together with fellow writers such as Lewis Carroll, Walter de la Mare, Beatrix Potter and a few others, Wodehouse "prospected and mined a vein of humour quite different from the literature of wit and satire which [...] prevailed in nineteenth- and twentieth-century England" (Carlson, 1975, p. ix). It is in fact hard to find in Wodehouse instances of what Freud called "der Witz" (i.e. humour triggered by hostility or cynicism, see section on Relief Theories above). Sarcasm is rare, since it is limited to the few types he despised, namely ridiculous characters who are the "product of centuries of privilege" (French, 1966, p. 59), such as the Duke of Dunstable, or representatives of finance and big business, such as American tycoons and exploiters of the poor and "the precocious small boy of the wealthy classes" (French, 1966, p. 51), like those depicted in The Little Nugget (1913; GV.12) and in Laughing Gas (1936; GV.51). See, for example the following quotation from Uncle Fred in the Springtime (1939; GV.55, p. 83): "The Duke of Dunstable had one-way pockets. He would walk ten miles to chisel an orphan out of tuppence". This character is an arrogant overweight elderly nobleman, with a white moustache "like a walrus". His wealth comes from heritage and from a rich marriage. He is "a real old brute [...], vastly rich and vastly mean" (Usborne, 1981, p. 121). The disdain Wodehouse shows towards him is on a par with that he shows towards, for example, J. Preston Peters, the first American millionaire to appear in Wodehouse (Something Fresh, 1915;GV.15) or towards George Pyke, later to become Viscount Tilbury, founder of the Mammoth Publishing Company in London, "rich, short, fat and Napoleonic" (Usborne, 1981, p. 149), who 
is always pursuing money. Sarcasm, mockery and a certain extent of cruelty is shown also towards the amateur dictator, fascist Roderick Spode, as already shown earlier in Chapter 2. But these are rare cases, so that it can safely be affirmed that Wodehouse's can by no means be labelled "disparagement humour".

Jokes, meant as narratives ending with a punch line, such as those examined by Raskin, Attardo and Giora, are conspicuous by their absence. They are sometimes just hinted at, as the one Jeeves suggests that Augustus Fink-Nottle shall tell during the speech he is to deliver at Market Snodsbury Grammar School, in Right Ho, Jeeves (1934; GV.47, p. 135):

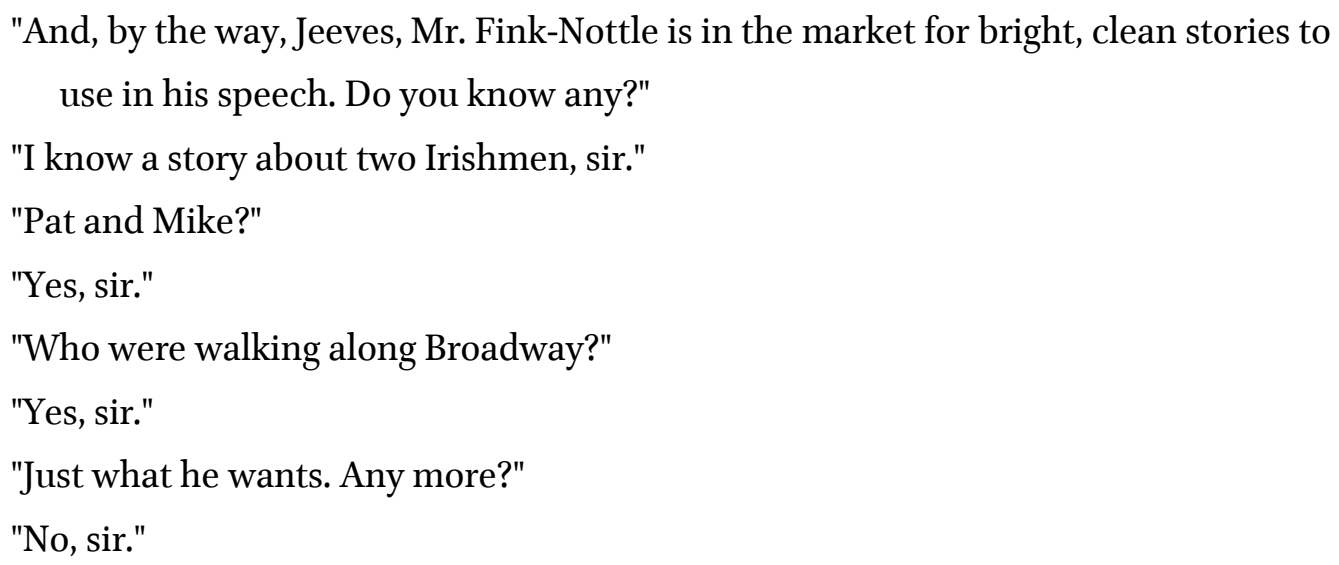

There is no need to tell the joke here. Eventually, given the opportunity, Augustus will tell it. Wodehouse was not trying to tap the repertoire of canned jokes to enrich his fiction. Equally rare are ironic statements and puns, the English form of wit par excellence for a generation or two in the nineteenth century (Leacock, 1935, p. 16). Wodehouse employed them rarely and always in an original way. One of the few examples is this extremely brief exchange in Eggs, Beans and Crumpets (1940/1971; GV.57, p. 15). Bingo Little, married to bilge romantic literature writer Rosie M. Banks, is in trouble, as usual, and worried, as he answers a telephone call from one of his wife's friends:

\footnotetext{
"Hullo," said a female voice. "Is that Rosie?"

"No," said Bingo, and might have added that the future was not either.

"I'm Mr. Little."
}

The pun is played between Bingo's wife's name and the meaning of "rosy" as "bright" or "optimistic". It is not a particularly witty one, but Wodehouse is clever enough not to spell it out. Rather, he leaves it implied in Bingo's unvoiced remark. The pun is both phonological (played on different spelling and same pronunciation) and morphological. It can pose some difficulty to translators if they cannot find an 
adjective bearing the same connotation in the target language, since the character's name cannot be modified, as she is a recurrent character in the Bertie and Jeeves stories. We will see in Chapter 4 what solution the authors of the two extant Italian translations of Eggs, Beans and Crumpets chose to render this pun.

\section{Humorous mechanisms in Wodehouse's stylistic devices}

Instead of being based on the two possible meanings of a word, Wodehouse's wordplay draws on uncommon semantic oppositions, bathetic effects, clash of registers, and creative phrasing, as we saw in the passage from The Luck of the Bodkins (1935; GV.49) opening this chapter. His humour very much has to do with unmet expectations and surprising utterances. The following quotation from The Clicking of Cuthbert (1922; GV.24, Chapter 9) describes an old lady with a harmless but silly hobby: "This aunt made a hobby of collecting dry seaweed, which she pressed and pasted in an album". The narrator's comment is striking in its absurdity: "One sometimes thinks that aunts live entirely for pleasure". In Right Ho, Jeeves (1934; GV.47, p. 174), witnessing his aunt drinking her cocktail, Bertie observes: "For some moments there was nothing to be heard but the sloshing sound of an aunt restoring her tissues". In both cases, the reader is surprised: in the first one, by the remark that clashes with the boring activity, in the second one the startling image clashes with the dignity expected of a lady. In both instances, Wodehouse also employs syntactic structures ("aunts" and "an aunt") to generalize: a feature that adds incongruity to the descriptions and matches with the following simile, from Much Obliged, Jeeves (1971; GV.84, p. 91), also referring to aunts, one of Wodehouse's favourite butts: "Aunts as a class are like Napoleon". Generalisation makes such remarks more incongruous since individuality is lost and substituted by oversimplification, an instance of exaggeration. Similarly, both over- and understatement are instances of exaggeration. Understatement (or meiosis), generally considered a typical mechanism of English humour (Leacock, 1935, p. 31), is occasionally present in Wodehouse, as noted, for example by Folgado (in Valero-Garces, 2010). It can also be recognised in instances of Bertie Wooster's self-deprecating humour, such as the following two quotations, respectively from The Inimitable Jeeves (1923; GV.26, p. 436) and Joy in the Morning (1947; GV.59, p. 337): "We Woosters do not lightly forget. At least, we do - some things appointments, and people's birthdays, and letters to post, and all that - but not an absolutely bally insult like the above" and "It is true of course, that I have a will of iron, but it can be switched off if the circumstances seem to demand it". Even more frequent is overstatement (or hyperbole), as shown by the 
following passage, from Meet Mr Mulliner (1927; GV.33, p. 183) in which overstatements are highlighted in bold:

As he drained his first glass, it seemed to him that a torchlight procession, of whose existence he had hitherto not been aware, had begun to march down his throat and explore the recesses of his stomach. The second glass, though slightly too heavily charged with molten lava, was extremely palatable. It helped the torchlight procession along by adding to it a brass band of singular sweetness of tone. And the third began to touch off fireworks in his head.

The episode refers to the first drink a teetotaller has in his life. The description is vivid, thanks to the highly visual technique employed, paralleling the movement of a drink to that of human beings. However, what is really striking and incongruous is the use of hyperbolic images ("torchlight procession" and "molten lava" to suggest heat and "brass band" to convey the feeling of mental lightness and estrangement intoxication causes). In the passage quoted above, each hyperbolic image is complemented by an exaggerated clause, e.g. "a torchlight procession" is complemented by the carefully crafted clause "of whose existence he had hitherto not been aware". It adds surreal details to the already incongruous image. This, again, is an instance of Wodehouse's hyper-wording, about which more will be said later on in this chapter. Likewise, "Wodehouse also combines the mixing of formal and informal language with deliberately over-intricate grammatical complexity", as Partington (2013, p. 171) shows with the following example, from The Girl on the Boat (1922; GV.23, Chapter 2): "In short, he was one of Nature's rubbernecks, and to dash to the rail and shove a fat man in a tweed cap to one side was with him the work of a moment". Here, the construction "the work of a moment", already presented in Chapter 2 as one of Wodehouse's leitmotifs, is the rhetorical device chosen by Wodehouse to describe his character's actions in an original way. It allows him to underline the impulsivity of his character and, at the same time, to give his mark to the phrasing, by supplying apparently unnecessary adjectives, e.g. "a fat man" and "in a tweed cap", in fact intended to belittle his character's antagonist.

The examples presented are typical, as so it can be stated that Wodehouse's writings show incongruity, surprise, and exaggeration, expressed by means of clashes of expectations and hyperbolic wording. Moreover, as previously highlighted in Chapter 2, several devices Wodehouse employed belong to the world of stage comedy. I therefore maintain that his humour is framed by elements of comedy. As 
said in Chapter 2, already in his school-stories, Wodehouse showed his talent for the comic typical of comedy (French, 1966).

In his essay on humour, Leacock (1935) states that humour "reaches its real ground when it becomes the humour of situation and character" (p. 99). This is definitely achieved by Wodehouse: in analysing his plots and characters the connection to comedy is clear. As already noted in Chapter 2, his plots follow the structure and the formula of comedy. Nonetheless, they possess innovative elements. In comedy, mishaps are necessary to their development. In Wodehouse, these mishaps are in fact set against a background of stable society. There is nothing fantastic in Wodehouse's settings; the background is perfectly plausible, yet, at the same time, patently conjured, since the society Wodehouse portrayed is inhabited by incongruous characters, paradoxically consistent in their incongruity. Lord Emsworth, Lord Ickenham, the Duke of Bastable, Bertie's aunts and friends, Jeeves himself... they all keep on, book after book, showing the consistent peculiarities that make them comic characters. For example, Lord Emsworth is "a fluffy and eccentric peer of an accepted comic tradition" (French, 1966, p. 54) and Jeeves is an instance of the servant abler than his master, a comic device that "may be traced back through Sam Weller to the clever slaves of Latin comedy" (French, 1966, p. 10o). Blocking characters punctuate plots, there are examples of punishment of hubris, and denouements bring the new reality demanded by the younger generation, since: "young people must find their own way in life" (French, 1966, p. 77). Most of the tools Wodehouse employed belong to comedy: misunderstandings, impersonations, tricks, and even a nonchalant, remorseless use of crime, from thefts to blackmail (Asimov in Heineman \& Bensen, 1981). All these features, combined with crisp dialogues, an ability to disseminate plots with clues and to create anxiety, a feature that, according to Rozik (2011) "constitutes the raw material for [...] comic laughter" (p. 27), and what Hall (1974) dubbed "Stylistic Rhythm" combine to create the comic mood that permeates Wodehouse's works.

\section{Key concepts in analysing Wodehouse's humour}

I therefore hold that Wodehouse's humour is framed by comic mood, as described by Rozik (2011). It is found in his plots and sub-plots, in his characters and the way he described them and their (mis)adventures. Within this frame, Wodehouse's Stylistic Devices are ascribable to the following key concepts: incongruity, surprise, exaggeration, endearment and knowledge-sharing. 
The first three key concepts (incongruity, exaggeration, surprise) coincide with those posited as the key ones in the incongruity theories of humour. I hold that they relate to how Wodehouse produced his humorous instances; while the other two, for which I coined the terms "endearment" and "knowledge sharing" refer to the devices that he employed to create a strong relationship with his readers, consistently, book after book. By endearment I mean a constant reference to previous instances of an author's work, such as characters, settings, and phrasing that make readers feel they belong to a group. Wodehouse made his readers feel this sense of belonging by his use of repetitions, such as, for example, what I term his leitmotifs. Moreover, Wodehouse's readers may feel gratified when they share his pleasure for intertextuality: recognising one of his references makes readers enjoy his writings even more. This is the characteristic that I name knowledge-sharing. All these aspects of his production deserve to be analysed separately here, in order to highlight their specificities, since they must be rendered in translation. However, a thorough investigation of Wodehouse's humour must insert them within a correct frame. As I stated above, I identify this frame with comic mood, the prism though which the action of a comedy is meant to be perceived by the receiver (Rozik, 2011). I show how his Stylistic Devices are classified according to the key concepts I identified in the table below, that must be intended as framed by comic mood.

\begin{tabular}{|l|l|}
\hline \multicolumn{1}{|c|}{ KEY CONCEPT } & \multicolumn{1}{c|}{ STYLISTIC DEVICE } \\
\hline \multirow{2}{*}{ INCONGRUITY } & $\begin{array}{l}\text { similes } \\
\text { personifications } \\
\text { register clash } \\
\text { treatment of foreign languages } \\
\text { bathos } \\
\text { transferred epithets }\end{array}$ \\
\hline EXAGGERATION & $\begin{array}{l}\text { hyperbolic descriptions } \\
\text { use of synonyms }\end{array}$ \\
\hline SURPRISE & $\begin{array}{l}\text { linguistic inventiveness: } \\
\text { coinages, affixations, } \\
\text { abbreviations }\end{array}$ \\
\hline ENDEARMENT & leitmotivs \\
\hline KNOWLEDGE SHARING & intertextuality \\
\hline
\end{tabular}

Table 3.1: Wodehouse's Humour Devices according to key-term

In the table above, I ascribed to incongruity imagery (personifications and similes) and various kinds of clash (of register, of varieties of languages, or those created by bathetic effects and transferred epithets). The already highlighted characteristic of hyper-wording relates to exaggeration, while Wodehouse's 
linguistic inventiveness yields a surprising effect on his reader. As said, the other two key concepts, i.e. endearment and knowledge sharing, are not strictly and only related to the production of humour, but may explain the reasons for his success. I identify them, respectively, with his recurrent leitmotifs and intertextuality, as a way of flippantly nodding at his readers and of harmlessly challenging their knowledge. They have the effect of making his readers feeling part of the creative process, as if they were Wodehouse's accomplices.

As we have seen, there is incongruity in plots and subplots, with their misunderstandings, tricks, and impersonations; there is incongruity in characters, in descriptions, in similes, and in transferred epithets. Moreover, incongruity is found in the mixture of formal and informal language. These are typical in the exchanges between Bertie and Jeeves, such as the passage below from The Inimitable Jeeves (1923; GV.26, p. 409), when Bertie asks Jeeves to describe Bingo Little's elderly uncle:

“Tell me about old Mr Little. What sort of a chap is he?'

"A somewhat curious character, sir. Since retiring from business he has become a great recluse, and now devotes himself almost entirely to the pleasures of the table."

"Greedy hog, you mean?"

"I would not, perhaps, take the liberty of describing him in precisely those terms, sir. He is what is usually called a gourmet."

As already pointed out in Chapter 2, there are frequent clashes of registers in the dialogue between Bertie and Jeeves. In Right Ho, Jeeves (1934; GV.47, p. 11), Bertie explains to Jeeves one of his friend's obsessions, keeping and studying newts.

"Well, it's the most extraordinary thing. It must be five years since he was in London. He makes no secret of the fact that the place gives him the pip. Until now, he has always stayed glued to the country, completely surrounded by newts."

"Sir?"

"Newts, Jeeves. Mr. Fink-Nottle has a strong newt complex. You must have heard of newts. Those little sort of lizard things that charge about in ponds."

"Oh, yes, sir. The aquatic members of the family Salamandridae which constitute the genus Molge." 
There is more than just the classical comic effect due to the deployment of a servant character cleverer than his master. What we have here is a deliberate display of erudition, at the same time exaggerated and unexpected, on a par with Jeeves's erudite literary citations and Bertie's "shockingly distorted" quotations (Svensson in Heineman \& Bensen, 1981, p. 6o), such as the following from the same book, Right Ho, Jeeves (1934; GV.47, p. 146): "As Shakespeare says, there are sermons in books, stones in the running brooks, or, rather, the other way about, and there you have it in a nutshell". Here, Wodehouse adds a bathetic effect (from Shakespeare to "in a nutshell") to an already comically jumbled citation.

Wodehouse also employed bathos, as a shift from the romantic to the comical, to deflate sentimentalism. In Money for Nothing (1928; GV.35), for example, when the hero is finally embracing the heroine, a bee makes its way into his trousers. Wodehouse's narrator relates: "He was now positive that it was a bee, and almost as positive that it was merely choosing a suitable spot before stinging him. But he made no move. The moment was too sacred. After all, bee-stings are good for rheumatisms" (p. 307). French (1966, p. 81) argues that the creation of an anti-climax, "the deliberate lowering of the emotional temperature at delicate moments", originated in "a public-school reticence" (ibid.).

Exaggeration is present in Wodehouse's hyperboles, such as when, in The Inimitable Jeeves (1923; GV.26, p. 548), Bertie says: "On the occasions when Aunt is calling Aunt like mastodons bellowing across primeval swamps" and Wodehouse's use of synonyms, such as the sentence "Intoxicated? The word did not express it by a mile. He was oiled, boiled, fried, plastered, whiffled, sozzled, and blotto", from Meet $M r$ Mulliner (1927; GV.33), already quoted in Chapter 2. Exaggeration coincides with hyper-wording in the following example from Ukridge (1924; GV.28, p. 127): "Alf Todd,' said Ukridge, soaring to an impressive burst of imagery, 'has about as much chance as a one-armed blind man in a dark room trying to shove a pound of melted butter into a wild-cat's ear with a red-hot needle'". These instances of exaggeration, which I term hyper-wording, demonstrate Wodehouse's proficiency in employing a vast array of words. This is a characteristic that poses difficulties to translators, as Birgitta Hammar, the Swedish translator of forty-four books by Wodehouse, rightly observed (Svensson in Heineman \& Bensen, 1981, p. 62). Hyperwording, therefore, is given the attention it deserves in Chapter 4, devoted to the analysis of the Italian translations.

Surprising elements are found in Wodehouse's linguistic inventiveness (affixations, coinages) and in his use of abbreviations. Moreover, although necessary elements of comedic developments are often repeated, the mishaps that punctuate his plots are always apt to surprise the reader. Equally surprising are the cunning solutions devised by his characters to get (or, as in Jeeves's case, to get somebody else) 
out of trouble. As we saw in Chapter 2, witty hyphenated phrases and a creative use of affixes is one of Wodehouse's Stylistic Devices. In Joy in the Morning (1947; GV.59), for example, he has Bertie Wooster boasting: "as a dancer I out-Fred the nimblest Astaire" (p. 243). When he is once again offended by a remark by one of his aunts, Bertie says that he "would have what-d'you-call-it-ed" such a slur, had his attention not been drawn elsewhere (Much Obliged, Jeeves, 1971; GV.84, p. 49). In Aunts Aren't Gentlemen (1974; GV.87), Wodehouse really stretches himself to the point of adding suffix -ed for simple past to one of Jeeves's Latin quotations, "Rem acu tetegisti" and has Bertie agree "with him that he had tetigiste-ed the rem acu" (p. 207). Equally surprising are his backformations, such as the oft-quoted "gruntled" from "disgruntled" and these two others, both from "butler": adjective "butlerine" and verb "buttle". In The Code of the Woosters, (1938; GV.54, p. 382) Bertie, fogged, has a feeling of "a vague suggestion of something butlerine"' and in Much Obliged, Jeeves, (1971; GV.84, p. 43) he asks Jeeves, surprised at seeing him in the capacity of a butler at Bertie's Aunt Dahlia's villa: "But what are you doing, buttling?". Besides, as, again, already noted in Chapter 2, abbreviations are a peculiar tract of Bertie Wooster's speech. Examples range from "persp." for "perspiration" to the less obvious "more to be p. than c." standing for "more to be pitied than censured", which is also an instance of intertexuality, as shown in Chapter 2, and one of Wodehouse's leitmotifs, hence a typical example of both "endearment" and "knowledge-sharing".

Insofar, we have seen that Wodehouse's Stylistic Devices mainly refer to the key concepts of incongruity, surprise and exaggeration. In addition, I identified two key concepts that apply to the relationship between him and his readers, namely, endearment and knowledge-sharing. I hold that all the devices by means of which Wodehouse achieved his humorous intent, that I will hereinafter term "humour devices", are classified by these five concepts. In the following paragraphs, I show the combination of which of them depicts Wodehouse's humour and will set forth my definition of it.

Script-clash and hyper-wording

As previously stated, a theoretical framework is necessary to investigate what makes a text humorous. Linguistic theories of humour developed under the umbrella of incongruity theories, such as those proposed by Raskin and Attardo, account for short structured texts ending with a punch line that triggers humour. These theories appear to be appropriate to jokes but are unsuitable for the study of longer humorous texts. The same applies to Giora's achievements in the pragmatic analysis of jokes and irony. 
Still, I hold that incongruity theories offer the best framework for investigating the nature of the humorous texts produced by Wodehouse.

As shown by the examples quoted, Wodehouse's passages often feature the simultaneous presence of two scripts with humour triggered by their clashing. The notion of script I employ here is Attardo's definition, i.e. "a set of expectations and/or weighted choices" (1997, p. 402). I suggest a construct to extend the concept of script opposition between two factors, for which I coined the term "script-clash" (SC). This is found, for example, in instances when formalisms and informalisms are mixed in the same sentence, in other words when a clash of registers occurs closely in the same text (Partington et al., 2013). An example is this quotation from The Inimitable Jeeves (1923; GV.26, p. 439): "Ghastly as the peril was which loomed before me, I was conscious of a rummy sort of exhilaration". Especially in Bertie's narratives, one finds the simultaneous presence in the same sentence of instances from slang (schoolisms, knuts' lingo, idiomatic expressions) and high-flown language. In Much Obliged, Jeeves (1971; GV.84, p. 13), for example, Bertie's narration draws from both registers, with a clashing pair in each clause:

I could appreciate that this put him in quite a spot, the feudal spirit making him wish to do the square thing by the young master, while a natural disinclination to get bunged out of a well-loved club urged him to let the young master boil his head.

The following table shows the contrasting pairs:

\begin{tabular}{|l|l|}
\hline \multicolumn{1}{|c|}{ FORMAL } & \multicolumn{1}{c|}{ INFORMAL } \\
\hline appreciate & put him in quite a spot \\
\hline feudal spirit $^{87}$ & to do the square thing \\
\hline a natural disinclination & bunged out \\
\hline urged him & boil his head \\
\hline
\end{tabular}

Table 3.2: Contrasting pairs (formal vs informal) in Much Obliged, Jeeves (p. 13)

Drawing from Attardo's definition of script, my conceptualization of script-clash includes the notion of unmet expectations. In Wodehouse, incongruity in the sense of unmet expectations is found, for example, in Lady Constance's way of expressing her disappointment in detective Pilbeam's behaviour in

\footnotetext{
${ }^{87}$ see section "Leitmotifs" in Chapter 2.
} 
the following passage from Heavy Weather (1933; GV.45, p. 234): "The fact that [...] he had to all appearances accomplished absolutely nothing seemed to her to argue dilly-dallying of the worst kind, if not actual shilly-shallying". Expectations are not met in this passage, since two colloquial expressions punctuate Lady Constance's thought, mixing with the elevated vocabulary typical of her usual speech. One would expect her grande dame attitude to be reflected also in her thoughts. In addition to the clash between Lady Constance's way of expressing her thought and her usual speech, there is here an internal clash of registers ("accomplished" and "argue" vs "dilly-dallying" and "shilly-shallying"), an instance of what Attardo (1994) calls "register humour", defining it as "humour caused by an incongruity originating in the clash between two registers" (p. 230), as pointed out above. Here, the addition of the reinforcing adjective "actual" to "shilly-shallying" augments incongruity. Another example is from Much Obliged, Jeeves (1971; GV.84, p. 96), when Bertie's aunt Dahlia, "stunned", asks Jeeves: "You mean you slipped him a Mickey Finn?" and he replies. "I believe that is what they are termed in the argot, madam". In the reply, the choice of "argot" instead of the more obvious "slang" further highlights Jeeves's sophisticated diction compared to aunt Dahlia's.

Script-Clash (SC), defined as the simultaneous presence of incongruous and surprising syntactic elements in the same sentence, is therefore one of the main features of Wodehouse's humour. He is not, however, the only humourist whose production constantly shows this feature. An analysis of the works of other humourists would undoubtedly highlight similar constructions. Script-Clash alone cannot, therefore, explain the originality of Wodehouse's humour. In the following paragraphs, I will show the characteristic of his production that, combined with Script-Clash, uniquely typifies his humour.

As shown above, exaggeration, a recognized mechanism of humour, is a key term to describe Wodehouse's humour. It is found in his hyperbolic descriptions and in the number of synonyms Wodehouse's employed. Above all, however, it is found in the striking number of words that enrich his phrasing. He indeed used an exaggerated number of words in descriptions, dialogues, and, as we will see in more detail later in this chapter, in similes. This is a feature, already shown in the passages I quoted above, that I term Hyper-Wording (HW). I define it as the rich, articulated, and detailed phrasing that Wodehouse constantly employs. It can be computed considering the number of words that surround its phrase, i.e. its collocates. The larger the number of collocates $\left(C_{n}\right)$, the more detailed the instance is. Being exaggerated, hyper-wording is humorous since it makes the reader visualise an exaggerated incongruous image, bizarre enough to elicit mirth. In considering the incipit of The Luck of the Bodkins (1935; GV.49), quoted at the beginning of this chapter, for example, the look that "creeps" on Monty's face 
is one "of furtive shame", "shifty" and "hangdog". Or, back to the episode of the "Blue Suite", the "relief which Sacherwell felt" "would have been less intense" if he "had realized that through a slight mistake in his bearings": the same idea could have been conveyed by a simpler, plainer, and less wordy sentence. But it would not have been Wodehousian at all.

Incongruity index and incongruity value

The paragraphs above have discussed the key concepts that characterise Wodehouse's humour and have highlighted some distinctiveness, to describe which I coined two terms, Script-Clash and HyperWording. However, I maintain that a tool is still needed to assess why a text might be more humorous than another one. Such a tool would not only support researchers in their analysis of humorous texts but could also be employed to assist translators in their task, in order to reproduce or compensate for humour.

In the following paragraphs, I present the incongruity index, a tool I devised to analyse Wodehouse's similes and to assign them an incongruity value. I show its use in analysing similes. However, as I will show, it can be extended to longer texts. The incongruity index assigns a value to a humorous instance grounded on the principles of incongruity and script-opposition. It is based on the construct of "semantic distance", employed in computational linguistics to formally quantify the degree of semantic relatedness between words, in research on "word disambiguation, in determining discourse structure $[\ldots]$, and automatic correction of word errors in a text" (Budanitsky \& Hirst, 20o1, p. 1). By the same token, semantic distance or relatedness is key in natural language processing (Kennedy, 2012) and, hence, in machine translation.

For my analysis of similes, I borrow the terminology from Richards (1936), who was the first to supply the technical terms necessary to analyse metaphors and, by extension, similes. In his work, Richards highlights the fact that a metaphor implies a shift of sense from one thing to another (p. 117) and that the author of the metaphor implies that these two things share a property or "some common attitude that we may take up towards them both" (p. 118). In similes, this shift is signalled by "comparison words" (comparators), such as "like" or "resemble". Metaphors and similes, hence, combine two concepts (the tenor and the vehicle, respectively) by identifying the properties that the author assumes is shared by the two (the ground). Tropes like metaphors and similes do not belong to the worlds of poetry and literary texts only. Richards (1936) states that their wide use in ordinary language can be attested by "mere 
observation" (p. 92). As noted by cognitive linguist Lakoff (Lakoff \& Johnson, 1980), metaphors are fundamental mechanisms of our mind, allowing us to learn about experiences, since "our ordinary conceptual system is metaphorical in nature" (p. 4). In their simplest and commonest form, similes relate two concepts belonging to the same semantic field, such as in: "This dress fits me like a glove" or in "He is brave as a lion".

\begin{tabular}{|l|l|l|}
\hline \multicolumn{1}{|c|}{ TENOR } & \multicolumn{1}{c|}{ GROUND \& COMPARATOR } & \multicolumn{1}{c|}{ VEHICLE } \\
\hline This dress & fits me like & a glove \\
\hline He & is as brave as & a lion \\
\hline
\end{tabular}

Table 3.3: Tenor, ground, comparator and vehicle in simple similes

The shift in similes like these is smooth, since the relation between tenor and vehicle is apparent to those sharing a language and the culture that surrounds it, i.e. linguistic code and KnoW. Ordinary similes can in fact very often be idioms and clichés, such as "as busy as a bee" or "as drunk as a lord". Often, therefore, they vary from country to country and from language to language. Their translatability may hence pose a challenge if the source and the target language do not share the same ground. The most effective metaphors and similes are those that connect two different semantic fields. The short poem by Robert Frost (1874-1973), Devotion (1928) is a suitable example of figurative language in poetry, where language is pre-eminently metaphorical, and understood as such.

\footnotetext{
The heart can think of no devotion

Greater than being shore to ocean

Holding the curve of one position

Counting an endless repetition.
}

The analogy Frost adopts makes the whole poem a metaphor, employing the relationship between the shore and the ocean, that can apparently change, but is constant in time, as "an example of the greatest devotion possible" (Tuten \& Zubizarreta, 2001, p. 77). Here, Frost connects two distant semantic fields: devotion, a human affect, to the relationship between two inanimate entities. It can be posited that the more distant the two semantic fields a simile connects, the less common, familiar, obvious, in other words, the more incongruous, hence, effective the simile is. Since incongruity is posited as the basis of 
humour, one would logically conclude that a simile that highlights a connection between two concepts belonging to very distant semantic fields from each other must be humorous. However, as the above example from Frost shows, it is empirically demonstrated that this is not the case. What, then, makes an incongruous simile humorous? The table that follows shows four different instances of Wodehouse's similes.

\begin{tabular}{|c|l|l|l|}
\hline NO & \multicolumn{1}{|c|}{ TENOR } & \multicolumn{1}{|c|}{ GROUND \& COMPARATOR } & \multicolumn{1}{c|}{ VEHICLE } \\
\hline 1a & He & groaned slightly and winced like & $\begin{array}{l}\text { Prometheus watching his vulture } \\
\text { dropping in for lunch }\end{array}$ \\
\hline 1b & Uncle Tom & always looked a bit like & a pterodactyl with a secret sorrow \\
\hline 1c & She & looked like & a tomato struggling for self-expression \\
\hline 1d & Her face & was shining like & a bus driver's trousers \\
\hline
\end{tabular}

Table 3.4: Examples of Wodehouse's similes, according to semantic fields belonging to the four different worlds (the human, the animal, the vegetal, the inanimate)

As already highlighted in Chapter 2, for his similes, Wodehouse drew from different semantic fields belonging to different worlds, for the human to the inanimate. The second simile in the list above (1b), for example, connects an elderly gentleman to an animal; while the fourth one (1d) compares a girl's face to an artefact. It is plausible that the more distant two semantic fields are, the more incongruous the image will be. Comparing, for example, a dyspeptic uncle to an extinct animal is more incongruous than comparing him to a Scotsman, stereotyped as irritable. Four worlds can be identified and hierarchically arranged, from the closest to the furthest to a human tenor: (a) the human, (b) the animal, (c) the vegetal, and (4) the inanimate. One can therefore posit that the distance between two worlds is an index of their incongruity. I hold that the incongruity of any simile equates to the cartesian distance between the tenor and the vehicle. The symbol I use to express this is $\overline{\mathrm{TV}}$.

The distance between two concepts, expressed by two words, is intuitive but can also be objectively computed. Ever since Osgood's (1952) seminal work and the formalization of his "semantic differential", later abandoned by the scholar because he deemed it to rely more on the connotative (i.e. on the emotions evoked by a word) rather than denotative meaning, various methods have been developed to calculate the semantic distance (or better: semantic relatedness, its reverse) between a pair of lexically expressed concepts. A review of 13 of such methods was compiled by Budanitsky (1999) who classified them according to the principal knowledge-source they deploy. He focused on five of them and concluded that, although all of them are reliable, none is particularly superior to another. In should also 
be noted that "human judgements of similarity and relatedness are deemed correct by definition" (Budanitsky \& Hirst, 2001). In order to assess semantic relatedness, therefore, human judgement is still acceptable, but not economical, since it implies large sets of independent judgements.

I started my analysis by submitting pairs of words to WS4J (WordNet Similarity for Java), software that measures semantic similarity/relatedness between English words ${ }^{88}$ and yields eight measures. Each of them is calculated taking into account different parameters. The table below shows four Wodehousian similes, each connecting a different world: (a) the human, (b) the animal, (c) the vegetal, and (d) the inanimate and the pair for which semantic relatedness is given by LESK. The value is given in brackets: the lower the value, the less related, hence distant, the two words are.

\begin{tabular}{|c|l|l|l|l|}
\hline NO & \multicolumn{1}{|c|}{ TENOR } & \multicolumn{1}{|c|}{ GROUND \& COMPARATOR } & \multicolumn{1}{c|}{ VEHICLE } & \multicolumn{1}{c|}{ PAIR } \\
\hline 2a & $\begin{array}{l}\text { Keggs } \\
{[\text { a butler }]}\end{array}$ & looked reproachful, like & $\begin{array}{l}\text { a bishop who has found } \\
\text { his favourite curate } \\
\text { smoking marihuana }\end{array}$ & butler/bishop (30) \\
\hline 2b & Some girls & are like & ants in your pants & girl/ant (48) \\
\hline 2c & The boy's face & closely resembled & $\begin{array}{l}\text { a ripe tomato with a } \\
\text { nose struck on it }\end{array}$ & face/tomato (66) \\
\hline 2d & $\begin{array}{l}\text { A poached } \\
\text { egg? It }\end{array}$ & looks just like & an aunt of mine & $\begin{array}{l}\text { poached } \\
\text { egg/aunt (3) }\end{array}$ \\
\hline
\end{tabular}

Table 3.5: Examples of pairs in Wodehouse's similes belonging to the four different worlds (the human, the animal, the vegetal, the inanimate)

The following four tables show the comparison between each of the similes above to their homologous similes from Table 3.4, i.e. each table compares a couple of similes that connect two different worlds, from the human to the inanimate. Again, the LESK value is given in brackets.

\footnotetext{
${ }^{88}$ Demo version is available on line (http://ws4jdemo.appspot.com/). For practical reasons, I chose to employ here the LESK algorithm supplied by WS4J, based on the overlapping of the two words' dictionary definitions. However, any of the measures that WS 4 J or any other software based on any model may yield could be used in the kind of approach I suggest: what is relevant here to point out is that, whatever the method and, hence, the measure, a value can be assigned to each tenor/vehicle pair, represented by the symbol $\overline{\mathrm{TV}}$, to express their distance. The caveat here is that these algorithms yield measures of semantic similarity/relatedness, therefore readings of semantic distance are counterintuitive.
} 


\begin{tabular}{|c|l|l|l|l|}
\hline NO & \multicolumn{1}{|c|}{ TENOR } & \multicolumn{1}{|c|}{ GROUND \& COMPARATOR } & \multicolumn{1}{c|}{ VEHICLE } & \multicolumn{1}{c|}{ PAIR } \\
\hline 1a & He & $\begin{array}{l}\text { groaned slightly and winced } \\
\text { like }\end{array}$ & $\begin{array}{l}\text { Prometheus watching } \\
\text { his vulture dropping } \\
\text { in for lunch. }\end{array}$ & $\begin{array}{l}\text { young man/ } \\
\text { Prometheus (13) }\end{array}$ \\
\hline 2a & Keggs & looked reproachful, like & $\begin{array}{l}\text { a bishop who has } \\
\text { found his favourite } \\
\text { curate smoking } \\
\text { marihuana }\end{array}$ & butler/bishop (30) \\
\hline
\end{tabular}

Table 3.6: Comparison of similes belonging to the human world

\begin{tabular}{|c|l|l|l|l|}
\hline NO & \multicolumn{1}{|c|}{ TENOR } & \multicolumn{1}{|c|}{ GROUND \& COMPARATOR } & \multicolumn{1}{c|}{ VEHICLE } & \multicolumn{1}{c|}{ PAIR } \\
\hline 1b & Uncle Tom & always looked a bit like & $\begin{array}{l}\text { a pterodactyl with a } \\
\text { secret sorrow }\end{array}$ & $\begin{array}{l}\text { uncle/ } \\
\text { pterodactyl (10) }\end{array}$ \\
\hline 2b & Some girls & are like & ants in your pants & girl/ant (48) \\
\hline
\end{tabular}

Table 3.7: Comparison of similes belonging to the animal world

\begin{tabular}{|c|l|l|l|l|}
\hline NO & \multicolumn{1}{|c|}{ TENOR } & \multicolumn{1}{|c|}{ GROUND \& COMPARATOR } & \multicolumn{1}{c|}{ VEHICLE } & \multicolumn{1}{c|}{ PAIR } \\
\hline 1C & She & looked like & $\begin{array}{l}\text { a tomato struggling } \\
\text { for self-expression }\end{array}$ & lady/tomato (15) \\
\hline 2C & The boy's face & closely resembled & $\begin{array}{l}\text { a ripe tomato with a } \\
\text { nose struck on it }\end{array}$ & face/tomato (179) \\
\hline
\end{tabular}

Table 3.8: Comparison of similes belonging to the vegetal world

\begin{tabular}{|c|l|l|l|l|}
\hline NO & \multicolumn{1}{|c|}{ TENOR } & \multicolumn{1}{|c|}{ GROUND \& COMPARATOR } & \multicolumn{1}{|c|}{ VEHICLE } & \multicolumn{1}{|c|}{ PAIR } \\
\hline 1d & Her face & was shining like & a bus driver's trousers & $\begin{array}{l}\text { face/trousers } \\
(66)\end{array}$ \\
\hline 2d & $\begin{array}{l}\text { A poached } \\
\text { egg? It }\end{array}$ & looks just like & an aunt of mine & $\begin{array}{l}\text { poached } \\
\text { egg/aunt (3) }\end{array}$ \\
\hline
\end{tabular}

Table 3.9: Comparison of similes belonging to the inanimate world

This presentation allows for several considerations. First, the comparison between the pair "young man/Prometheus" and "butler/bishop", although both belonging to the category of similes that connect a human tenor to a vehicle belonging to the human world, shows that they differ in their semantic distances: Prometheus belongs to ancient myth, while a bishop is a real individual. Hence, $\overline{\mathrm{TV}}$ is larger 
in $1 \mathrm{a}$ than in $2 \mathrm{a}$. The same applies to $1 \mathrm{~b}$ and $2 \mathrm{~b}$, connecting humans to the animal world. The distance between a human being and an extinct animal is larger than the one between a human being and a living insect. Besides, if we analyse the couple $1 \mathrm{c}$ and $2 \mathrm{c}$, in which the vehicle is a tomato, we note that $\overline{\mathrm{TV}}$ is larger in 1c, since the connection between a tomato and a lady is less common, hence more incongruous, that the one between a tomato and a face. Moreover, if we compare $2 \mathrm{c}$ and $2 \mathrm{~d}$, we note that the comparison between a face and a tomato is far less incongruous that the one between a face and a pair of trousers.

We can therefore confirm that, in a simile, the semantic distance between its tenor and its vehicle $(\overline{\mathrm{TV}})$ is larger when the vehicle and the tenor belong to different worlds. However, in addition, we note that $\overline{\mathrm{TV}}$ is larger when (1) the tenor and the vehicle belong to the same world, but are conceptually distant and when (2) the comparison is unusual. Consequently, our evaluation of the incongruity of an instance that connects two semantic fields, such as a simile, very much depends on culture and experience, i.e. on both linguistic code and knowledge of the world. Chapter 4 presents examples of the techniques that the Italian translators of Wodehouse employed while dealing with his inventive similes and in Chapter 5 I show my analyses of the same similes rendered by five Italian translators.

The similes shown above are incongruous since they connect ideas from different semantic fields. The use of a measure of semantic distance might enable a value to be assigned to each pair of words, the tenor and the vehicle. Semantic distance is a way to assess the incongruity of two words connected in the same phrase, with reference to their belonging to different semantic fields, since it can also be conceptualized as a script-opposition, in the terms supplied by Raskin's first formulation. However, semantic distance is not enough to assert they are humorous. In other words, as said incongruity is a necessary but not sufficient reason for a text to be humorous. This can easily be demonstrated by comparing the following similes.

\begin{tabular}{|c|l|l|l|}
\hline NO & \multicolumn{1}{|c|}{ TENOR } & \multicolumn{1}{|c|}{ COMPARATOR \& GROUND } & \multicolumn{1}{c|}{ VEHICLE } \\
\hline 3a & The hideous old man & seemed like & some loathsome reptile \\
\hline 3b & Uncle Tom & always looked a bit like & $\begin{array}{l}\text { a pterodactyl with a secret } \\
\text { sorrow }\end{array}$ \\
\hline
\end{tabular}

Table 3.10: Comparison between Dickens's and Wodehouse's similes belonging to the animal world 
The first simile (3a) is taken from Dickens's Oliver Twist, (1837-39), while the second one (3b) is from Wodehouse's Right Ho, Jeeves (1934). Both are unusual, hence incongruous, and both connect a man to a disagreeable animal, so both possess a dehumanizing property. Dickens's one may carry a sarcastic denotation; hence, it is despising but not humorous, nor was it meant as such. On the other hand, the second simile, by Wodehouse, is meant to be humorous and it in fact is. Two other similes, both by Wodehouse and both connecting a man to the same animal (a snail) provide further support to our reasoning.

\begin{tabular}{|c|l|l|l|}
\hline NO & \multicolumn{1}{|c|}{ TENOR } & \multicolumn{1}{c|}{ COMPARATOR \& GROUND } & \multicolumn{1}{c|}{ VEHICLE } \\
\hline 4a & George, & protruding like & a snail [...] \\
\hline 4b & $\mathrm{He}$ & wilted like & a salted snail \\
\hline
\end{tabular}

Table 3.11: Comparison of Wodehouse's similes comparing a man to a snail

The pair (man/snail) are the same, hence they have the same semantic distance. However, $4 \mathrm{~b}$ appears more humorous than 4a. Therefore, what makes one simile more humorous than another one? The analysis of a large number of similes produced by Wodehouse allows me to argue that the difference lies in how the vehicle is described. Not only are Wodehouse's vehicles rich in the visual images they evoke, they are also abundantly detailed, by means of their numerous collocates, i.e. the words that occur in the neighbourhood of the vehicle. This is a device that he also employed in his private writings, as demonstrated by this quotation from a letter written on $1^{\text {st }}$ September 1945 to his friend Guy Bolton: "Things are beginning to stir faintly, like the blood beginning to circulate in a frozen Alpine traveller who has met a St Bernard dog and been given a shot from the brandy flask" (quoted in Wodehouse \& Ratcliffe, 2012, p. 6). This kind of hyper-wording is a characteristic of his similes throughout his career, as the following table shows:

\begin{tabular}{|c|l|l|}
\hline YEAR & \multicolumn{1}{|c|}{ TITLE } & \multicolumn{1}{c|}{ SIMILE } \\
\hline 1906 & $\begin{array}{l}\text { Love Among the } \\
\text { Chickens }\end{array}$ & $\begin{array}{l}\text { Nor was my uneasiness diminished by the spectacle of Ukridge } \\
\text { splashing tactfully in the background like a large seal. }\end{array}$ \\
\hline 1919 & A Damsel in Distress & A kettle bubbled in an undertone, like a whispering pessimist. \\
\hline 1929 & Summer Lightning & $\begin{array}{l}\text { An expression a little like that of a young hindu fakir who } \\
\text { having settled himself on his first bed of spikes is beginning to } \\
\text { wish that he had chosen one of the easier religions. }\end{array}$ \\
\hline
\end{tabular}




\begin{tabular}{|c|l|l|}
\hline 1936 & Laughing Gas & It was a harsh, rasping voice, in its timbre not unlike a sawmill. \\
\hline 1940 & $\begin{array}{l}\text { Eggs, Beans and } \\
\text { Crumpets }\end{array}$ & $\begin{array}{l}\text { He felt like a man who, chasing rainbows, has had one of them } \\
\text { suddenly turn and bite him in the leg. }\end{array}$ \\
\hline 1958 & Cocktail Time & $\begin{array}{l}\text { He uttered a yelp of agony, like a Volga boatman stung by a } \\
\text { wasp. }\end{array}$ \\
\hline 1965 & Galahad at Blandings & $\begin{array}{l}\text { Wilfred Allsop was sitting up, his face pale, his eyes glassy, his } \\
\text { hair disordered. He looked like the poet Shelley after a big night } \\
\text { out with Lord Byron. }\end{array}$ \\
\hline 1970 & The Girl in Blue & $\begin{array}{l}\text { He was a Frenchman, a melancholy-looking man. His aspect } \\
\text { was that of one who has been looking for the leak in a gas pipe } \\
\text { with a lighted candle. }\end{array}$ \\
\hline
\end{tabular}

Table 3.12: Examples of Wodehouse's similes listed according to decades (1906 - 1970)

If the complete corpus of Wodehouse were available in digital format, analyses could be performed on all his works in order to identify a possible trend and verify if this is a constant feature or if Wodehouse developed his technique over time. What is, however, relevant to note is that his similes always imply incongruity between tenor and vehicle (i.e. large $\overline{\mathrm{TV}}$ ) and that vehicles tend to show a larger number of collocates than the tenors. The high number of collocates in Wodehouse's similes matches with the hyper-wording, already highlighted: the great range of synonyms Wodehouse employed and the rich array of adjectives and clauses he added to his descriptions. In the following quotation from Cocktail Time (1958; GV.72, p. 10) Wodehouse enriches a description by combining it to a simile, and is an example of hyper-wording: "(Pongo) uttered a sharp quark of anguish such as might have proceeded from some duck which, sauntering in a reverie beside the duck pond, has inadvertently stubbed its toe on a broken soda-water bottle". Moreover, and interestingly, a close inspection of the collocates shows that most of the similes based on a human tenor compare to an item belonging to another world, e.g. an animal, and invert the direction of the shift, so that the incongruous image is reverted to the human world, by the attribution of human qualities, behaviours or attitude to the vehicle. Examples are found in Stiff Upper Lip, Jeeves (1963; GV.77). The tenor is Bertie's friend Augustus Fink-Nottle, already mentioned above as the "newt enthusiast". Throughout the story, Bertie highlights his resemblance to a halibut, such as when he tells us: “[...] but he was looking so like a halibut that if he hadn't been wearing horn-rimmed spectacles, a thing halibuts seldom do, I might have supposed myself to be gazing on something a.w.o.l. from a fishmonger's slab" (p. 329), so that the reader has already visualized the image. However, the following yields a much more striking one: "He looked like a halibut which has just been asked by 
another halibut to lend it a couple of quid till next Wednesday" (p. 352). Here, the direction of the shift is, first, from human to animal, and then, thanks to Wodehouse's creative hyper-wording "which has just been asked by another halibut to lend it a couple of quid till next Wednesday", back from animal to human. The reverse shift is built up slowly, word after word. The outcome is a comical image that readers can gradually form in their minds. It is a highly incongruous image, that parallels, for example, those of the hippos, elephants, crocodiles, and ostriches in Disney's animated film Fantasia (1940).

My analyses have shown that Wodehouse's similes are characterised by (1) large $\overline{\mathrm{TV}}$ and (2) hyperwording. I therefore propose to measure incongruity in terms of both the cartesian semantic distance between the tenor and vehicle $(\overline{\mathrm{TV}})$ and the number of collocates $\mathrm{C}_{\mathrm{n}}$. The index that I propose assesses the level of incongruity of a humorous instance, here a simile, as a value based on these two arguments. I term the tool Incongruity Index (II), its formula being: $\overline{\mathrm{TV}} * \mathrm{C}_{\mathrm{n}}$, yielding an Incongruity Value (IV) as the composite value assigned to any simile. Besides allowing for the assessment of the incongruity of a simile, the incongruity index is a tool in the hands of translator. I posit that, in order to maintain the incongruity of a simile, a translator must achieve the same Incongruity Value in the target language ${ }^{89}$ In other words, in translating, both $\overline{\mathrm{TV}}$ and $\mathrm{C}_{\mathrm{n}}$ must be maintained. When formal equivalence is not achievable, then this index offers a translator a model to help them compensate safely.

Moreover, being a measure of incongruity, a large semantic distance is also an instance of ScriptClash. The formula I found to identify what makes similes humorous can be enlarged to include any instance containing, at the same time, a Script-Clash and Hyper-Wording. Consequently, it can be applied to identify and assess the humorous potentiality of instances contained in longer texts. In the following passage, from Heavy Weather (1933; GV.45, p. 17), script-clashes are identified in bold and hyper-wording in italics:

I suppose in the case of a chappie of really fine fibre and all that sort of thing, a certain amount of gloom and anguish would have followed this dishing of young Bingo's matrimonial plans. I mean, if mine had been a noble nature, I would have been all broken up. But, what with one thing and another, I can't let it weigh on me

\footnotetext{
${ }^{89}$ Unfortunately, no comparable algorithms are available for English and Italian. Therefore, I could not test the Italian translators' rendering of sematic distance against the LESK values.
} 
very heavily. The fact that less than a week after he had had the bad news I came on young Bingo dancing like an untamed gazelle at Giro's helped me to bear up.

Script-Clashes are represented here by the contemporaneous presence in the same sentence of formal and informal registers (fine fibre/ chappie; gloom and anguish/dishing; noble nature/all broken up) and by the semantic distance between Bingo Little and a gazelle. Hyper-Wording is in the redundancy of phrases, such as "all that sort of things" and "with one thing and another", in the phrase "a certain amount of" added to abstract terms "gloom and anguish", and in the adjective "untamed" to qualify an already incongruous image. Moreover, the passage contains over-worded instances of Bertie's self-derogatory humour and over-intricate syntactic constructions. Similar analyses can be performed on any text by Wodehouse and they would show similar results.

In conclusion, it is apparent that Wodehouse's texts are humorous when they are incongruous, surprising and exaggerated; however, what characterises them is the simultaneous presence of clashing and hyperbolic elements. Therefore, my answer to the question "Why is Wodehouse humorous?" is: Wodehouse's texts are humorous because they contain, at the same time, Script-Clashes and HyperWording.

\section{Conclusions}

As previously noted and notwithstanding their claims, none of the families of theories of humour succeeds in explaining every instance of humour. However, within the remit of psychology, each set of theories seems to be suitable to account for one specific situation, with Superiority Theory able to explain humour when it is intended to criticize or ridicule opponents and, possibly, create cohesion in a group, while Relief Theories can be applied to instances of humour aimed at relaxing tension in controversial situations or to allow the receivers to feel relieved in realizing that the butt of the remark is somebody else, and, lastly, Incongruity Theories present new perspectives and viewpoints, particularly in linguistics (Meyer 2000). Therefore, a single instance of humour can be analysed in the light of each theory, in accordance with one's point of view - one's "theoretical sunglasses", as Meyer (200o p. 315) puts it. So, for example, analysing the following quotation from Wodehouse's The Adventures of Sally (1922; GV.25): "And she's got brains enough for two, which is the exact quantity the girl who marries you will need", supporters of the Superiority Theory would explain that the humorous effect is reached 
because of the implied derision, while supporters of the Relief Theory would claim that humour lies in the relief of not being the butt of the gag and supporters of the Incongruity Theory would argue that humour originates from the surprise and the puzzlement the receiver experiences while reading the line. Meyer (2000 p. 315) presents a similar example and concludes that "any of the three theories of humor origin can ideally explain any instance of humour, and the debate continues". The researcher is therefore authorized to hold a specific position in regard to which theory adhere; in other words, a researcher can decide which "theoretical sunglasses" to wear. Nevertheless, we cannot ignore that the classification into three main families is just a wide, conventional one, and that such multifactorial phenomenon deserves to be addressed in the light of as many perspectives as possible.

My analyses have shown that it is plausible to label Wodehouse's humour as "humour of the incongruous", defined as the kind of humour triggered by the perception of something different from what one would expect. This definition entails the presence of surprise, puzzlement (detection of something felt incongruous), and intellectual challenge (search of the resolution of incongruity). However, I have also shown that Wodehouse's humour may also accommodate factors ascribable to both relief and superiority theories of humour. I claim, all this considered, that Wodehouse produced his humorous instances mainly by means of incongruous elements. I supplied evidence for this and proposed new terminology, namely Script-Clash and Hyper-Wording, and a tool, i.e. the Incongruity Index to analyse and assess them. I add, however, that their appreciation implies factors more logically referable to relief and superiority theories. In other words, I maintain that Wodehouse created his humorous instances by means of incongruity, i.e. script-clashes magistrally crafted by means of hyperwording, while his readers experience pleasure in getting the humour (relief). At the same time, they feel gratified and experience a sense of triumph (superiority), when they find a way to solve the incongruity, having won an intellectual challenge. 


\section{CHAPTER 4}

\section{WODEHOUSE AND TRANSLATION}

Everything was fine. The luck of the Bodkins had held, and the danger was past [...]. As his crusading ancestor, the Sieur Pharamond de Bodkyn [...], had put it, writing home to his wife and telling her how he had been unhorsed at the Battle of Joppa - 'Ytte was suche a dam near squeake as I never wante to have agayne in a month of Sundays. E'en now am I sweating atte every pore, and meseems I hardlie knowe if I stande on ye heat or ye heels.'

The Luck of the Bodkins, 1935; GV.49, pp. 136-137

"...He's got... what is it that Frenchmen have?"

"Beards?"

"No, not beards."

"But you said they had beards."

"Yes, but this is something else. Begins with a journey. Ha!" said Mr Clutterbuck, memory returning to its throne, "Journey say quar."

French Leave, 1956; GV.70, p.202

The two passages above are taken from very popular and widely translated works by Wodehouse..$^{\circ}$ They are examples of two of Wodehouse's Humour Devices, the treatment of varieties of English and of foreign languages, that pose a challenge to his translators. It is also probable that many others, such as his similes, so enriched by hyper-wording, his bathetic movements, his inventiveness in creating names and in employing affixes, for example, would pose a similar challenge. My aim here is to find a way to describe in what way this challenge was tackled by his Italian translators.

This chapter, building on the preceding analyses, discusses (1) issue of the untranslatability of humour, (2) other key issues in Translation Studies, namely equivalence, modernisation, foreignization vs domestication, loss and gain, and visibility, and (3) illustrates how the vast corpus of the Italian translations I could examine allowed me to put forward an approach that may help to shed light on (a)

\footnotetext{
${ }^{90}$ See, for example, the results of queries at Index Translationum http://www.unesco.org/xtrans/bsresult.aspx?a=wodehouse\&stxt=the+luck + of + the+bodkins\&sl=eng\&l=\&c=\&pla= $\&$ pub $=\& \operatorname{tr}=\& \mathrm{e}=\& u d c=\& d=\&$ from $=\&$ to $=\&$ tie $=a$ and http://www.unesco.org/xtrans/bsresult.aspx?a=wodehouse\&stxt=french+leave\&sl=eng\&l=\&c=\&pla=\&pub=\&tr=\& $\mathrm{e}=\&$ udc $=\& \mathrm{~d}=\&$ from $=\&$ to $=\&$ tie $=\mathrm{a}$.
} 
the translation process $(b)$ the role of the translator as an actor (c) the interplay among the various actors (d) the impact the translators choices on the readers' KnoW and, consequently, on the target culture.

By focusing on the choices translators make, the Epistemic Approach enables us to appreciate the phases of the process of text activation through translation and to highlight how the key issues in Translation Studies have been tackled. For example, when humour is based on wordplay, e.g. in puns, its translation never completely meets the requirements of equivalence (Delabastita, 1996, p. 135). Although translators have several procedures to render wordplay, all of them, and paradoxically, the apparently most "faithful", i.e. rendering a pun by another pun in the TL, involve "noticeable textual shifts" (ibid.). This is a significant concern for source-oriented translators and for prescriptive scholars in Translation Studies (see Vandaele in Gambier \& van Doorslaer, 2010, p. 151); much less of a concern for descriptive studies such as this one, mostly, if not rigidly, pursuing the aims suggested by Toury (1995), i.e. "profiling the variable features adopted by functional equivalence" (Assis Rosa in Gambier \& van Doorslaer, 2010, p. 100). However, I hold that tools to investigate and highlight how equivalence is actualised in a text are necessary, even in a study whose aim is description rather than prescription.

In this chapter, I show how I applied the tenets of the Epistemic Approach to identify, classify, and describe the procedures translators have at their disposal and how problematic items have been rendered in translating Wodehouse. Accordingly, I will consider the role played by the mastering of the linguistic codes and of the translators' KnoW in the process of translating. I will then analyse several examples from the Italian editions of Wodehouse's works according to the procedures the translators employed in translating culturally specific terms and Wodehouse's humorous devices. Already in this chapter, I will, when relevant, describe different versions of the same text. However, I will show more examples in Chapter 5 , which focuses on retranslation. Lastly, by presenting some case studies, in the final section of this chapter I will highlight the potential of the Epistemic Approach to translation and of its methodology to investigate general and specific issues concerning translated texts and their impact.

\section{Translating Wodehouse into Italian}

The 87 books of my primary literature have allowed me to analyse a large amount of texts containing a vast array of humour devices expressed in a rich, varied, and inventive language. Here, in order to present the methodology I employed, I show its first two phases applied to the passages presented at the beginning of this chapter. On the basis of my procedural knowledge of the process of translation and on 
declarative knowledge about the two linguistic codes, i.e. the pair English and Italian, and about Wodehouse's style and humour presented in the previous chapters, I will identify the problematic items ${ }^{91}$ and their Italian renderings. ${ }^{92}$ I will show the procedure I employed, namely: (1) identifying the problematic items in a text, (2) understanding the kind of translation challenge posed, and (3) recognising their renderings.

The passage from The Luck of the Bodkins (1935; GV.49) contains an instance of Wodehouse' s skills in playing with language and parody: an utterance attributed to a member of the Bodkin family, who had allegedly lived in the 12th century, whose language is, therefore, alleged Old English. The passage is preceded by an introductory sentence, here reproduced for the sake of contextualisation. The table below shows how it was translated in 1936 by Zoe Lampronti. The most challenging items in the passage are highlighted in bold, along with the words that correspond to them in the Italian translation.

\begin{tabular}{|c|c|}
\hline Wodehouse, 1935 & Lampronti, 1936 \\
\hline The Luck of the Bodkins, pp. 136-137 & La fortuna dei Bodkin, p. 127 \\
\hline $\begin{array}{l}\text { Everything was fine. The luck of the Bodkins had } \\
\text { held, and the danger was past. But it would be some } \\
\text { time before he rounded into mid-season form } \\
\text { again. } \\
\text { As his crusading ancestor, the Sieur Pharamond de } \\
\text { Bodkyn [...], had put it, writing home to his wife } \\
\text { and telling her how he had been unhorsed at the } \\
\text { Battle of Joppa - 'Ytte was suche a dam near } \\
\text { squeake as I never wante to have agayne in a } \\
\text { month of Sundays. E'en now am I sweating atte } \\
\text { every pore, and meseems I hardlie knowe if I } \\
\text { stande on ve heat or ve heels.' }\end{array}$ & $\begin{array}{l}\text { Tutto andava bene! La fortuna dei Bodkin non lo } \\
\text { aveva abbandonato, il pericolo era superato. Ma } \\
\text { ci sarebbe voluto un po' di tempo prima che si } \\
\text { rimettesse completamente. } \\
\text { Avrebbe potuto dire come il suo antenato, il } \\
\text { Crociato Faramondo di Bodkin che scrisse alla } \\
\text { moglie narrandole di essere stato disarcionato } \\
\text { alla battaglia di Soppa: "Me la sono cavata per } \\
\text { miracolo, ma ora sudo da tutti i pori e non } \\
\text { arrivo a capire se sono ritto sulla testa o sulle } \\
\text { gambe". }\end{array}$ \\
\hline
\end{tabular}

The challenge for the translator is to find a formula to render: (1) parody; (2) an (alleged) variety of the language an Italian crusader would have employed; (3) the script-clash contained in the anachronistic crusader's "writing home to his wife"; (4) the script-clash in the register of the message (slang, idioms, bathos). Moreover, two proper nouns must be rendered: the first one is an invented name for the crusading ancestor, Sieur Pharamond de Bodkyn, and the second one a historical name. This second

\footnotetext{
${ }^{91}$ In the light of the Epistemic Approach, it is worth mentioning that, not being a native speaker of English, in order to fully appreciate some instances, I often had to rely on native speakers' remarks and advice, such as the those offered by my inestimable supervisor and those found on Wodehouse's fans websites (see Appendix 3 ).

${ }^{92}$ This first phase corresponds to the first phase of the first of two procedures suggested by Zabelbeascoa (2005, p. 187), namely "mapping" and "prioritizing".
} 
instance poses another problem, since "Joppa" is more commonly spelt "Jaffa", while in Italian it is "Giaffa". Interestingly, the "J" contained in the original English text was probably read as "S" by Lampronti, who rendered "Joppa" as "Soppa". She obviously did not make any connection between "Joppa" ("Jaffa") and the Italian name of the town ("Giaffa"). In the second passage, that contains an instance of what Delabastita (2005, p. 163) calls "bilingual wordplay", ${ }^{93}$ two Britons are talking about another character, a Frenchman.

\begin{tabular}{|c|c|}
\hline Wodehouse, 1956 & Motti, 1956 \\
\hline French Leave, p. 202 & E chis'è visto s'è visto, p. $25^{\circ}$ \\
\hline $\begin{array}{l}\text { “...He's got... what is it that Frenchmen have?” } \\
\text { "Beards?” } \\
\text { "No, not beards.” } \\
\text { "But you said they had beards" } \\
\text { "Yes, but this is something else. } \\
\text { Begins with a journey. Ha!” said Mr Clutterbuck, } \\
\text { memory returning to its throne, "Journey say } \\
\text { quar." }\end{array}$ & $\begin{array}{l}\text { - Quell'uomo ha ... che cos'è che hanno i francesi? } \\
\text { - La barba? } \\
\text { - No, non la barba. } \\
\text { - Lei ha detto che hanno la barba. } \\
\text { - Sì, ma questa è un'altra cosa. Comincia per sge. } \\
\text { Ah! - disse Mr Clutterbuck, mentre la sua } \\
\text { memoria tornava in trono. - Sgenessecuà. Ha del } \\
\text { sgenessecuà. }\end{array}$ \\
\hline
\end{tabular}

The challenge for the translator in this passage consists in finding a way to render or substitute the phonetic similarity between the way an English person would pronounce the French expression "je ne sais quoi" and the English word "journey”.

The samples above illustrate the first phases of the methodology I applied to analyse the problematic textual items in the translation of Wodehouse's works and to describe their renderings in Italian, in the light of the Epistemic Approach to translation. Before illustrating the subsequent phase, i.e. the classification of the problematic items identified, I draw attention to some features of the two linguistic codes, English and Italian, that might pose difficulties in the process of translation. The following section will therefore present some affinities and differences between the two; while, in the sections that will follow, I will focus on the cultural and stylistic aspects of Wodehouse's texts. This will allow me to show how the different problematic items can be classified, a step necessary to complete the description, following the procedure I have illustrated above. I will use the code LC (Linguistic Code) to refer to the strictly linguistic problematic items I identify, CST (Culturally-Specific Term) for those connected to the

\footnotetext{
${ }_{93}$ "I will reserve the term bilingual (or multilingual) wordplay for one specific class of puns, namely for those which throw into contrast two linguistic expressions which belong to different languages (usually two, sometimes more, as in James Joyce's uncontrollably multilingual Finnegans Wake)" (Delabastita, 2005, p. 163).
} 
source culture and HD (Humorous Device) for those defined by their being one of the stylistic devices Wodehouse employed to achieve his humorous intent.

\section{Knowledge of Linguistic Codes: English/Italian contrastive annotations}

Contrastive linguistics is a form of comparative linguistics, i.e. of that branch of linguistics that studies the similarities and differences between languages. Bugarski (1982, p. 77) defined contrastive linguistics as "the systematic synchronic study of similarities and differences in the structure and use of two or more language varieties, carried out for theoretical or practical purposes". Considering the affinities and the difference between a pair of languages is particularly relevant when we deal with the translation of humour based on wordplay, since, as Delabastita (1996) observes, "wordplay based on sound similarity stands a higher chance of being repeatable with minor shifts if the translation occurs between historically related languages" (p. 135). In this section, I will present some remarks regarding the contrast between the English and Italian languages, particularly relevant to the process of the translation of humour, approached both synchronically and diachronically. I will start with a general overview of the structures of the sentence in the two languages. I will then consider similarities and differences on the morphological level and on the syntactic levels. I will focus on those particularly relevant in a study on translations issued over a period spanning almost ninety years.

English and Italian are both SVOC language, i.e. sentence word order is Subject-Verb-ObjectComplement(s). However, in English, the meaning of a clause is largely dependent on the order of words in it. Italian, instead, being more inflected, allows for greater variations in word order and the subject is almost always omitted, unless expressed by a noun. Nevertheless, I have noted that Italian translators publishing in the 1930s and 1940s employed personal pronouns as subjects more than their colleagues working on the same texts years later.

\section{Affixation}

English and Italian differ in the use of affixes, since in English they are more common and allow for novel word formations. We have already seen how creatively Wodehouse took advantage of this feature of the English language that does not always have a perfect correspondence in Italian. A potentially humorous characteristic of the English language is, for example, the possibility of ending a sentence with a 
preposition, demonstrated by the joke on the definition of preposition: "a preposition is a word a sentence should never finish with". Although contested ${ }^{94}$ this structure is common in English. However, since it does not exist in Italian, the humour contained in the question in the table below could not be adequately rendered in the Italian translation.

In The Girl in Blue (1970; GV.83), a character has just reported to the hero, Jerry, another character's intention to give up trying to get hold of a valuable object. This is Jerry's reaction and how it was translated into Italian.

\begin{tabular}{|l|c|c|l|}
\hline \multicolumn{1}{|c|}{ SOURCE } & YEAR & PAGE & \multicolumn{1}{c|}{ TEXT } \\
\hline The Girl in Blue & 1970 & 146 & Is he including himself out? \\
\hline E. Spagnol & 1973 & 135 & Si ritira? \\
\hline
\end{tabular}

Table 4.1: Treatment of "including out" by Elena Spagnol

Wodehouse very probably derived this instance of malapropism from an utterance allegedly attributed to Sam Goldwyn, the Hollywood magnate, who was reported to have said "Gentlemen, you may include me out", when he decided to leave a corporate negotiation (Granger \& Calhoun, 20o8). Wodehouse was very likely to have learnt about this Hollywood legend while he was working there. As previously noted, Italian does not possess a similar syntactic structure. Elena Spagnol did not even attempt to compensate for the loss of the incongruity and plainly rendered it as "Is he withdrawing?".

False friends

Students of any foreign language are aware of the existence of pairs of words that look similar but have a different meaning in two languages. These are commonly known as "false friends" (Steiner, 1998, p. 29). Translators are of course aware of this danger, however sometimes they are snared and fall into the trap, as the following example shows. In his bedroom, Anatole, a highly emotional French chef, feels harassed by Augustus who climbed on the roof to escape a jealous fiancé's fury and has been looking through the skylight, "making faces" to attract his attention. This extract from his long tirade shows how he is complaining to his employer.

\footnotetext{
${ }^{94}$ See http://blog.oxforddictionaries.com/2011/11/grammar-myths-prepositions/.
} 


\begin{tabular}{|l|c|c|l|}
\hline \multicolumn{1}{|c|}{ SOURCE } & YEAR & PAGE & \multicolumn{1}{c|}{ TEXT } \\
\hline Right Ho, Jeeves & 1934 & 171 & $\begin{array}{l}\text { This is a bedroom, what-what, not a house for some } \\
\text { apes? }\end{array}$ \\
\hline Sacchi-Perego & 1935 & 220 & Questa è una camera da letto, non un alveare, no? \\
\hline Buitoni Duca & 1985 & 228 & Questa è una camera da letto, non un alveare, o no? \\
\hline
\end{tabular}

Table 4.2: Treatment of English/Italian false friend "ape" in Right Ho, Jeeves

"Ape" is an English/Italian false friend. English "ape" should be translated "scimmia" into Italian, while Italian "ape" means "bee" in English. Both translators, however, translate "house for some apes" as "alveare", meaning "hive". ${ }^{95}$ They should have recognised the various hints pointing to apes and monkeys and to their behaviours, in Wodehouse's surrounding text. The relevance of this fact is apparent, in the light of the Epistemic Approach. Not only was their LC competence inadequate here, but they also showed that they did not take into account one of Wodehouse's stylistic and humorous devices highlighted in the previous chapters, namely endearment, i.e. the relationship of complicity between Wodehouse and his readers, here actualised through a careful dissemination of clues.

Adjectives and pronouns

In Italian, adjectives may either precede or follow the noun they qualify. This allows for some stylistic liberty, but the difference in usage between the two languages may also deceive translators, as Example 1 shows.

Example 1

In Joy in the Morning (1947), Bertie asks Jeeves: "Who was the chap who was always beefing about losing gazelles?" After Jeeves has reminded him that it was the poet Moore, Bertie compares himself to him.

\begin{tabular}{|l|c|c|l|}
\hline \multicolumn{1}{|c|}{ SOURCE } & YEAR & PAGE & \multicolumn{1}{c|}{ TEXT } \\
\hline Joy in the Morning & 1947 & 279 & I'm a gazelle short. \\
\hline Monicelli & 1948 & 102 & Io sono una gazzella raccorciata. \\
\hline
\end{tabular}

Table 4.3: Treatment of adjective "short" by Monicelli

\footnotetext{
${ }^{95}$ A similar case of wrong translation of the pair ape/bee is reported by Eco (2004) on pages 18-19.
} 
Here, Monicelli interprets "short" as a qualifying adjective and, a victim of linguistic interference, ${ }^{96}$ translates as if the phrase were "I am a short gazelle". However, since "short" ("corta") would have made even less sense in the context, he translates "raccorciata" ("shortened"). According to the Epistemic Approach, his version is faulty for two reasons. Firstly, for lack of linguistic competence and, secondly, for lack of research on the source, because it ignores another of Wodehouse's Stylistic Devices, intertextuality employed for humorous purposes.

Moreover, Italian adjectives, possessive adjectives included, agree in gender with the noun, both when they directly modify the noun and when they are in the predicate of the noun. Italian has two genders, masculine and feminine. As a rule, masculine adjectives end in -o (plural -i), while feminine ones end in -a (plural -e), since they derive from Latin adjectives of the "first class". This applies to possessive adjectives too. So, for example, "my" may be translated "mio", "mia", "miei, or "mie", according to the gender and number of the noun to which it is referred. There also exist several adjectives (derived from those belonging to the Latin "second class" of adjectives) that end in -e (plural -i) for both genders. These latter adjectives allow translators to compensate for the lesser flexibility of English ones, which is strategically exploited by Wodehouse in Example 2 below.

Example 2

In Summer Moonshine (1938), hero Tubby Vanringham overhears a tense conversation between Jane and her father, Sir Buckstone. He gets the impression that Jane's father is “driving his daughter from his door for having erred - an impression which was heightened by the other's words" (p. 9). Talking with the girl later, he learns that Buckstone was in fact directing those words to himself. This is how the text that Tubby overhears was treated by the Italian translator.

\begin{tabular}{|l|c|c|l|}
\hline \multicolumn{1}{|c|}{ SOURCE } & YEAR & PAGE & \multicolumn{1}{c|}{ TEXT } \\
\hline Summer Moonshine & 1938 & 10 & $\begin{array}{l}\text { "Ass!" he was saying, just as any father would to } \\
\text { an erring daughter, [...]. “Fool! Imbecile! } \\
\text { Fathead!" }\end{array}$ \\
\hline Tedeschi & 1939 & 7 & $\begin{array}{l}\text { «Idiota!» egli diceva, come qualunque padre } \\
\text { potrebbe dire a una figlia colpevole. «Imbecille! } \\
\text { Deficiente!» }\end{array}$ \\
\hline
\end{tabular}

Table 4.4: Treatment of insulting words by Tedeschi

\footnotetext{
${ }^{96}$ Interference is the influence of one language upon another's phonology, grammar and vocabulary (see Odlin, 2008).
} 
Here, in order to render the misunderstanding, Tedeschi was faced by the challenge of finding three insulting words that could be applied to both Sir Buckstone and his daughter. The first options to translate "fool" and "fathead" into Italian would be "scemo/a" and "stupido/a", respectively, while "imbecille" corresponds to "imbecile". Tedeschi had to employ adjectives all belonging to the "second class", that, as said above, ending in -e for both genders. Unfortunately, he could only find two. He was, however, clever enough to translate "ass", whose most obvious rendering would be the noun "asino/a", with "idiota", invariable in Italian, both as a noun and as an adjective. On the whole, therefore, Tedeschi managed the problematic item quite well. The device he deployed is on a par with the one used by Jaques Cazotte in The Devil in Love (Le Diable amoureux, 1772) to keep the gender of his devil uncertain throughout the novel, since the French indirect object pronoun "lui" might be referred to both a male or a female and mean, therefore, "him" or "her" in English and, in Italian, "lui" or "lei". This was a valid expedient for Cazotte $^{97}$ but challenged his translators.

Another significant difference is the way of rendering forms of address, since "Italian has a range of pronouns [...] expressing what is expressed in English simply by 'you'" (Maiden \& Robustelli, 2007, p. 452), "tu", "Voi" and "Lei". Moreover, their use has changed over time; also while Wodehouse's works were translated. "Tu" implies reciprocal intimacy between speaker and receiver, while "Voi" and "Lei" imply social distance and respect. In formal written usage (e.g. in letter writing) they are spelled with an initial capital letter. "Voi" is deeply rooted in Italian tradition, especially in Southern Italy, but has gradually become marginalised, while "Lei", introduced in Italian between the sixteenth and the seventeenth centuries, is now the standard form (Serianni \& Castelvecchi, 20o6). "Lei" and "tu" are also employed unidirectionally, i.e. in exchanges between a person and somebody over whom the speaker has power or authority, for example, an adult uses "tu" in addressing a child, while "Lei" is expected on the part of the child to address the adult. In the light of the Epistemic Approach applied to the Italian translations of the Bertie and Jeeves stories, this issue is relevant. Before choosing the correct form of address and its direction, translators must consider all they know about the English society of the time to infer, for example, about the relationship between Bertie and his "personal gentleman's gentleman", and also take into account their attitude towards modernisation in translation. The practical implications of this issue will be treated in detail in Chapter 5 , in a discussion of the differences in translations issued in Italy at different times.

\footnotetext{
${ }^{97}$ For a discussion of textual ambiguities in Cazotte's Diable Amoreoux see Andriano, 1993, p. 9.
} 
As said, today the most common way of formally addressing a person in Italy is "Lei". It is identical to the third person feminine pronoun and verbs are conjugated accordingly. During fascism, and more precisely in 1938 (Germino, 2009, p. 26), the use of "Lei" was prohibited by law. ${ }^{98}$ Italians were to address each other by "Voi", a form deemed "native" and not a heritage of the Spanish domination in Italy. Intellectuals faced a dilemma regarding this issue (Salvatorelli, 1962). This is also reflected in the Italian translations of Wodehouse's books. Some translators employed "Voi", possibly in accordance with the party's regulations, while some others kept on using "Lei", as Table 4.5 below shows. The use of "Voi" in standard Italian has now disappeared. Texts employing "Voi", therefore, sound distant and antiquated to the contemporary reader. However, this fact can be fruitfully employed when a translator wishes to convey an aura of chronological distance. In the light of the model of text activation, it is worth investigating how this issue was treated by the sixty-three ${ }^{99}$ translators that have worked on Wodehouse's texts.

\begin{tabular}{|c|c|c|}
\hline TRANSLATOR & ACTIVITY & FORM OF ADDRESS \\
\hline Spaventa, Filippi Silvio & $1928-1929$ & Lei \\
\hline Traverso, Aldo & 1930 & Voi \\
\hline Tedeschi, Alberto & $1930-1940$ & Voi \\
\hline Martone, Maria & 1931 & Lei \\
\hline Mozzati, Ariberto & 1931 & Voi \\
\hline Malatesta, Mario & $1931-1937$ & Voi \\
\hline Palumbo, Francesco & $1931-1937$ & Voi \\
\hline Lori, Ida & $1931-1932$ & Lei \\
\hline Pitta, Alfredo & $193^{1-193^{2}}$ & Voi \\
\hline Baraldi, Lina & 1932 & Voi \\
\hline Benzi(g), Mario & $193^{2}$ & Lei \\
\hline Bernardini, L. & 1932 & Voi \\
\hline Carlesimo, Maria & $193^{2}$ & Lei \\
\hline Casale Rossi, Teresita & $193^{2}$ & Voi \\
\hline Fratta, Lepido & $193^{2}$ & Voi \\
\hline Pisano, G. V. & $193^{2}$ & Voi \\
\hline Rafanelli, Metello Brunone & $1932-1933$ & Voi \\
\hline Zanini, A. & $193^{2-1933}$ & Lei \\
\hline Gilli, Mario & 1933 & Voi \\
\hline Roberti, Roberto & 1933 & Voi \\
\hline Shepley, F. Leon & 1933 & Lei \\
\hline Lampronti, Zoe & $1933-1936$ & Lei \\
\hline
\end{tabular}

\footnotetext{
${ }^{98}$ Decreto 5 dicembre 1938, n. 2172.

${ }^{99}$ In analysing the treatment of "you" in Italian translations, I included a sixty-third translator who worked on a US edition, Vincenzo Latronico, since he, in fact, retranslated in 2007 seven short stories originally included in various UK editions.
} 


\begin{tabular}{|c|c|c|}
\hline Brugiotti, Giulia & 1934-1940 & Lei \\
\hline Bianchini, Alfredo & 1935 & Voi \\
\hline Sacchi-Perego, Cina & 1935 & Lei \\
\hline Carter, Dienne & 1938 & Voi \\
\hline Dauli, Gian & 1939-1940 & Voi \\
\hline Monicelli, Giorgio & 1948 & Voi \\
\hline Agnati, Sirio/Sario & 1949-1966 & Lei \\
\hline Motti, Adriana & 1949-1977 & Lei/Voi \\
\hline Lattanzi, Luciano & 1952 & Lei \\
\hline Comucci, Vittoria & 1954 & Voi \\
\hline Buckwell Gilson, Mary & $1955^{-1997}$ & Voi \\
\hline Previtali, Oriana & 1961 & Lei \\
\hline Ferri, Corrado & 1966 & Voi \\
\hline Brioschi, Luigi & $1966-2001$ & Lei \\
\hline Longanesi, Caterina & 1970 & Voi \\
\hline Spagnol, Elena & $1972-1976$ & Lei/Voi \\
\hline Janin, Pia & 1984 & Lei \\
\hline Brera, Carlo & 1989 & Lei \\
\hline Buitoni Duca, Maria & 1985 & Lei \\
\hline Serragli, Nadia & 1989 & Voi \\
\hline Zuffada Locuratolo, Angela & 1990 & Lei \\
\hline Campagna Ponzetto, Sandra & 1990-1992 & Voi \\
\hline Castelli, Giulia & $1990-1992$ & Lei/Voi \\
\hline Spagnol, Luigi & 1990-1993 & Lei \\
\hline Trimarchi, Anna Chiara & 1990-1993 & Voi \\
\hline Bodoman, Mario & 1990-2011 & Voi \\
\hline Bertola, Stefania & 1990-1991 & Lei \\
\hline Salvatorelli, Franco & 1991 & Lei \\
\hline del Tanaro, Teobaldo & 1991-1992 & Voi \\
\hline Morzenti, Monica & $1992-1997$ & Lei/Voi \\
\hline Palazzi, Rosetta & 1992-1997 & Lei/Voi \\
\hline Melani, Sandro & 1993 & Lei \\
\hline Salmaggi, Cesare & 1995 & Lei \\
\hline Mainardi, Riccardo & 1997 & Lei \\
\hline Bernardinis, Fulvio & 1998 & Lei \\
\hline Mazzarelli, Paola & 2005 & Lei \\
\hline Lord, Tracy/Calise, Leslie & $2005^{-2017}$ & Lei \\
\hline Latronico, Vincenzo & 2007 & Voi \\
\hline Musso, Dolores & 2007 & Lei \\
\hline Pieraccini, Silvia & $2010-2013$ & Lei \\
\hline
\end{tabular}

Table 4.5: Translation of "you" by Wodehouse's Italian translators ordered according to years of activity

The table shows that "Voi" was already the commonest form employed by translators before the 1938 regulations issued by the fascist regime. It is, however, relevant to note that Sacchi-Perego, translator of the first edition of Right Ho, Jeeves (originally 1934; GV.47) used "Lei". It might be interesting to note that 
two translators who employed "Voi" in the Fascist period, Dienne Carter (pseudonym of the Americanborn Edith Carpenter) and Gian Dàuli (one of the numerous pseudonyms of Giuseppe Ugo Nalato), both active in the years between 1938 and 1940, were wife and husband. In the aftermath of the Second World War "Voi" was gradually abandoned and after 1997 all translators used "Lei", confirming to the current standard usage, established in standard Italian in the 196os (Serianni \& Castelvecchi, 2006), except Latronico. This means that none of them has taken advantage of the potentiality of "Voi" to evoke the feeling of yesteryear, except for Latronico, who recently retranslated stories originally published between 1910 and 1921. My database (see Appendix 5) shows that only five new titles were issued between 1938 and the fall of the fascist government, i.e. 1943. Of these, four were translated by Tedeschi, who used "Voi" and one by Brugiotti ("Lei”), in 1940. As for the forty-two reprints, of which eighteen employed "Lei", it is worth noting that none of the three publishers, namely Bietti, Monanni and S.A.C.S.E., bothered to change their versions to conform to the government's regulations. Furthermore, cross-analyses show that the use of "Lei" and "Voi" by some translators from 1949 to the 199 os is independent of the cycle the books belonged to (e.g. The Blanding "saga" or the Jeeves and Bertie stories).

Many more similarities and differences between English and Italian than the ones treated here could be shown to highlight other linguistic, social and political aspects of the translators' work. However, the issues discussed already demonstrate the value of contrastive studies in Translation Studies, not only because they are "based on the general assumption that difference equals difficulty" (Granger \& Calhoun, 2008, p. 18) but also as a tool to investigate and describe the stance taken by translators, as well as, not to be forgotten, by publishers, regarding, for example, modernisation, or even to imply the sociological aspect of their choices, and, hence, their impact on the perception of the source culture in the target one. This brings us to the topic of what I term "KnoW" - Knowledge of the World - as relevant to the translation task.

\section{Knowledge about the author's culture and style}

Under the perspective of the Epistemic Approach to translation, detailed knowledge of the culture that surrounds an author's work is essential especially when a translator must deal with Culturally Specific Terms (CSTs), also termed "realia" (Vlakhov and Florin, 2004, in Osimo, 2011), i.e. proper names, words which indicate institutions, everyday objects, habits, idioms and so forth. By the same token, great attention must be devoted to the author's Stylistic Devices. In the case of the translation of humour, 
these are more accurately described as "Humorous Devices" (HDs). Therefore, the following two sections will be devoted to the classification of CSTs and HDs in Wodehouse and to the description of how they have been rendered by his Italian translators. For each category, I will supply a way to classify them and examples of the way the methodology I illustrated above can be applied, separately and in combination, to identify, classify and analyse the problematic textual items ascribable to the two categories and their translations.

Culturally-Specific Terms in Wodehouse and their translation

Realia include geographical names or words related to climate, or flora and fauna, an English example being "the Lake District". Others refer to food and common objects, such as "cheese cake". Some others are related to how a society is organized; they include political terms, for instance, "Tory" or "MP", and literary references, from the scholarly to folklore, such as, for example, a reference to a proverb. Moreover, since cultures vary in their habits and behaviours, realia include also the ways people use to greet each other or express their feelings, for example, surprise. Wodehouse offers plenty of instances, ranging from "Coo!" to "Lord love a duck!". As Nida (1964, p. 130) states, "differences between cultures may cause more severe complications for the translator than do differences in language structure". A translator is compelled to choose among various options, that range from keeping the term as such to creating a neologism.

Newmark's definition of culture as "the way of life and its manifestations that are peculiar to a community that uses a particular language as its means of expression" (Newmark 1988: 94) carries two implications in Translation Studies, i.e., that each language expresses specific cultural features and that translators must render them. Given the relevance of this aspect in Translation Studies, researchers have proposed several ways to classify realia. Vlakhov and Florin (in Osimo, 2011, p. 63), who were the first to employ the term realia, suggested three categories to classify them: 1) Geography 2) Ethnography and 3) Politics and Society. Newmark (Newmark, 1988, p. 95) proposed to classify them as instances of (1) Material Culture, (2) Social Culture, (3) Organisations/Social Organisations and (4) Gestures and Habits, whereas Katan (2015) suggested: (1) Ecology (2) Material Culture, (3) Social Culture, (4) Organisations, customs, activities, procedure or concepts, and (5) Gestures. The issue has also been addressed by other scholars, such Newmark (1988), Baker (2011) and Nord (1994). 
My proposal is the classification of realia (for which I will use the label Culturally Specific Terms and its acronym, CST) in four categories. The following lists contains a definition of each of the four categories I identified, while Table 4.6 shows a few examples of realia from Wodehouse's works, classified according to the four categories.

1. Environmental, to include geographical proper names (here abbreviated as PNs), terms used for the natural world and so forth

2. Ethnographic, i.e. terms relating to institutions, jobs, food, everyday objects and activities, etc.

3. Behavioural, which include phrases used for interpersonal communication and relations, such as greetings and expressions of surprise.

4. Linguistic, a category that embraces phenomena such as intertextuality ${ }^{100}$ and idioms.

\begin{tabular}{|c|l|l|}
\hline 1. & Environmental & The Leigh, bloodhound, peke, aspen, chamois, newts \\
\hline 2. & Ethnographic & $\begin{array}{l}\text { Somerset House, stately home, gentleman's gentleman, } \\
\text { cow-creamer, cricket }\end{array}$ \\
\hline 3. & Behavioural & Right-ho, Pip-pip, Egad!, Lord love a duck! \\
\hline 4. & Linguistic & $\begin{array}{l}\text { To be in the soup, to slip something raw, ewe lamb, } \\
\text { Kipling's soldier }\end{array}$ \\
\hline
\end{tabular}

Table 4.6: Examples of Culturally-Specific Terms (realia) in Wodehouse classified in four categories

In Wodehouse, most realia belong to the English-speaking world and refer to quintessential English traditions and stereotypes, for example, haunted houses (e.g. in Heavy Weather, 1933; GV.45). However, he also alludes to other cultures, for example, in this quotation from The Girl in Blue (1970; GV.83, p. 110): "She was my guest and bursting with my salt", which alludes to the sacred bond between hosts and their guests, in the Bedouin culture of Saudi Arabia (Haykel, Hegghammer, \& Lacroix, 2015, p. 248). Moreover, since his literary allusions, as already seen in the previous chapters, draw from his wide readings, references to foreign authors and works are not infrequent. In addition to this, one cannot forget that Wodehouse was extremely inventive in his language and created a world of his own for his characters. His translators' difficulties are therefore often doubled: they must, for example, find a solution to render

\footnotetext{
${ }^{100}$ As here defined, after Wales, 2001, p. 259, in Chapter 2.
} 
the name of Lord Tilbury's "Mammoth Publishing Company", depicted in Bill the Conqueror (1924; GV.39), Summer Lightning (1929; GV.37), Heary Weather (1933; GV.45) and Frozen Assets (1964; GV.78).

Moreover, the long span of Wodehouse's career implies that the Culturally-Specific Terms he employed belong not only to different societies, but also to different historical periods. In his early works, for example, he referred to "picture-palaces" (A Damsel in Distress, 1919; GV.19) but by 1935 (The Luck of the Bodkins GV.49) he was referring to "cinemas". His characters exchange letters, telegrams ("wires"), radio telegrams ("wireless") but also use the telephone and watch television. Britons in the USA receive "cablegrams" from relatives and friends in the UK. Means of transport mentioned include "landaulettes", "steamers" and "liners", "Rolls Royces", "cabs" and "taxis", while in Aunts Aren't Gentlemen (1974; GV.87), Bertie Wooster still drives his "two-seater", referred to as "the old sport model" ${ }^{101}$ Besides, as we have seen in the previous chapter, much of Wodehouse's language draws from slang, especially the so-called 'knuts' lingo". The analysis of the translation of these terms and references, therefore, does not just address the obvious issues of foreignisation and domestication (Venuti, 1998), but also tackles modernisation (Eco, 2004). In other words, by investigating how Wodehouse was translated, we can highlight the various procedures translators employ to solve conundra and translate obsolete terms for their contemporary readerships. In addition, by being able to compare translations of the same work issued at different times, we can investigate how the issues of foreignization, domestication, and modernisation have been tackled and have changed in time. It is worth recalling here that my collection of Italian translations spans from 1928 to 2017, since the publisher Polillo is still today commissioning new translations to be published in the "I Jeeves" series. In the following paragraphs, I show how Translation Studies scholars have investigated the strategies that translators may employ to render CSTs and I will set forth my proposal.

Newmark (1988) distinguishes between translation methods, referring to whole texts, and translation procedures, referring to single items (p. 81). The translation methods he mentions (1988, p. 45-47) are (1) word-for-word (word order is kept as in the original and words are translated singly), (2) literal (words are translated singly, whereas syntactic constructions are converted to their nearest equivalents), (3) faithful (attempts to reproduce the contextual meaning), (4) semantic (takes the aesthetic value of the text more into account than faithful translation), (5) adaptation (a method mainly employed in the translation of poetry and plays), (6) free (ignores the style of the original text and sometimes even

\footnotetext{
${ }^{101}$ The producers of the ITV series based on the Bertie and Jeeves stories, broadcast in the 1990s, chose a pre-war Aston Martin $1 / 2$ litre Mark 2 to depict it.
} 
produces a different content), (7) idiomatic (simply reproduces the "message" of the original text but prefers colloquialisms), and (8) communicative (attempts to render the exact contextual meaning of the original in such a way that both content and language are readily acceptable and comprehensible to the readership). As for translation procedures, Newmark compiled a detailed list of fifteen procedures, ranging from "transference", i.e. reproducing the original term, to "componential analysis", defined as "comparing an SL word with a TL word which has a similar meaning but is not an obvious one-to-one equivalent, by demonstrating first their common and then their differing sense components" (Newmark, 1988, p. 114). He differentiates among cultural, functional, and descriptive equivalents. The first, which he considers "not accurate" (p. 83), consists of replacing a cultural term in the source language with another one in the target language; functional equivalents require cultural-neutral words (p. 83), whereas we have a descriptive equivalent when the term is "explained in several words" (p.83) without employing footnotes.

More simply, Graedler (2000, p. 3) enumerates only four procedures: (1) making a new word, (2) explaining the term instead of translating it, (3) keeping the same term and (4) "opting for a word in the TL which seems similar to or has the same 'relevance' as the SL term". By the same token, Harvey (200o, p. 2-6) lists four procedures: (1) functional equivalence, i.e. the use of a term in the target culture whose function is similar to that of the source language (p. 2), (2) formal or linguistic equivalence, which equals word-for-word translation (p. 3), borrowing, or transcription, i.e. reproducing or, where necessary, transliterating the original term (p. 4) and (4) descriptive or self-explanatory translation that uses "generic rather than culture-bound terms to convey the meaning" (p. 6).

I took into account the considerations above and my observations of the Italian translations of Wodehouse's works to construct my own proposal to describe the translation procedures (TPs) employed in dealing with CSTs, presented in the table below.

\begin{tabular}{|c|l|l|}
\hline I & TRANFERENCE & The CST is kept as in the original, yielding a borrowing or a calque. ${ }^{102}$ \\
\hline II & $\begin{array}{l}\text { FORMAL } \\
\text { EQUIVALENCE }\end{array}$ & The CST is translated word-for-word. \\
\hline III & $\begin{array}{l}\text { FUNCTIONAL } \\
\text { EQUIVALENCE }\end{array}$ & $\begin{array}{l}\text { The CTS is rendered by a cultural equivalent, i.e. a similar word } \\
\text { conveying the same meaning. }\end{array}$ \\
\hline IV & DESCRIPTION & The CST is reworded, i.e. a CST is rendered by a non-CST. \\
\hline
\end{tabular}

\footnotetext{
${ }^{102}$ As defined by Vinay \& Darbelnet, 1977, p. $3^{2}$.
} 


\begin{tabular}{|c|l|l|}
\hline V & INTERVENTION & The text surrounding the CST is modified and/or new text is added. \\
\hline VI & EXPLANATION & The CST is explained, e.g. by a footnote. \\
\hline VII & NEOLOGISM & A new word is created for the CST. \\
\hline VIII & OMISSION & The CST is simply omitted. \\
\hline O & KnoLC & $\begin{array}{l}\text { The translation is faulty due to lack of knowledge of the Linguistic } \\
\text { Code(s). }\end{array}$ \\
\hline
\end{tabular}

Table 4.7: Proposed Translation Procedures for Culturally Specific Terms

By choosing among the procedures that keep the original concept and those that substitute it, a translator takes a stance in relation to the controversial issue in Translation Studies, already discussed in the Introduction: the opposition between "foreignization" and "domestication", in Venuti's terms (1998). Procedures I, II, V, and VI allow for foreignization, since they introduce terms from the source culture into the target language. By contrast, Procedures III, IV, VII and, to some extent, VIII are domesticating or, in Schleiermacher's wording, they allow the translator to leave "the reader in peace" and move the "author towards him" (Schleiermacher in Venuti, 2012, p. 74). For example, in Cocktail Time (1958; GV.72), Wodehouse makes frequent references to a poem by Henry Newbolt (1862-1938) "Drake's Drum". Set to music, it premiered in 1904 and was later popularized by Australian-born bass-bariton Peter Smith Dawson (1882-1961). Thus, this CST belongs to the folklore of the English-speaking community and is therefore classified as belonging to the category I labelled "ethnographic" (ETH). The two Italian translators chose different procedures to render it. Motti (1960) translated it literally "il Tamburo di Drake", thus employing procedure II, while Bernardinis (1998) left it as in the original (Procedure I). This example is systematically presented in the table below.

\begin{tabular}{|l|l|l|l|c|}
\hline \multicolumn{1}{|c|}{ SOURCE } & \multicolumn{1}{c|}{ YEAR } & \multicolumn{1}{c|}{ PAGE } & \multicolumn{1}{c|}{ TEXT } & CST/TP \\
\hline Cocktail Time & 1958 & 208 & Drake's Drum & ETH \\
\hline Motti & 1960 & 248 & il Tamburo di Drake & II \\
\hline Bernardinis & 1998 & 183 & Drake's Drum & I \\
\hline
\end{tabular}

Table 4.8: Classification of the treatment of "Drake's Drum" by Motti and Bernardinis 
The use of capital letter "T" in Motti's version is a clue for the reader that she is not referring to the musical instrument, but rather to some kind of artistic work. However, readers could infer it being a painting, a poem, or even a book, since the convention of using italics for book title is rarely observed in fiction books in Italy. Moreover, readers might understand "Drake" as the name of the artist or the author. By keeping the original CST, Bernardinis is more likely to force the reader not familiar with the poem or the song to look for the source. Procedure I is, at least in this case, more "foreignising" than Procedure II and potentially adds more information to the reader's KnoW.

The following example, from the same book, is an instance of what Leppihalme (1997, p. 10) terms "allusion proper", i.e. an allusion containing a proper name. While Bernardinis, as he did above, chose to keep the original name of Brigham Young, the American Mormon leader who had fifty-five wives (Procedure I, foreignizing), Motti substituted it with the Italian translation for Henry VIII. This is a particular case (as we will soon see, a recurrent one in Motti's work) of functional equivalence (Procedure III, domesticating), in which a term is substituted by another one, also belonging to the source culture, but considered by the translator to be more familiar to the readers of the translated text. The following table shows how I classify the two solutions.

\begin{tabular}{|l|c|c|l|c|}
\hline \multicolumn{1}{|c|}{ SOURCE } & YEAR & PAGE & \multicolumn{1}{|c|}{ TEXT } & CST/TP \\
\hline Cocktail Time & $195^{8}$ & 210 & $\begin{array}{l}\text { There's nothing like getting married. It's the only } \\
\text { life, as Brigham Young [...] would tell you [...]. }\end{array}$ & ETH \\
\hline Motti & 1960 & 251 & $\begin{array}{l}\text { Essere sposati è l'ideale. L'unica vita possibile, } \\
\text { come ti direbbe[ro] Enrico Ottavo [...] }\end{array}$ & III \\
\hline Bernardinis & 1998 & 185 & $\begin{array}{l}\text { Non c'è niente di meglio al mondo del } \\
\text { matrimonio. È la vita vita, come Brigham Young } \\
{[\ldots] \text { potrebbe[ro] dirti [...]. }}\end{array}$ & I \\
\hline
\end{tabular}

Table 4.9: Classification of the treatment of "Brigham Young" by Motti and Bernardinis

Brigham Young is quoted again in The Girl in Blue (1970; GV.83). It is very probable that he was not known even by educated Italian readers; however, Elena Spagnol, the translator of the only Italian version, kept his name as in the original (La ragazza in blu, 1973; GV.83), as Bernardinis did in 1990. The procedure they chose (in my terminology, I, Transference) is the one that "stands at the far end of SLoriented strategies" (Harvey, 200o, p. 4) and is therefore one that potentially enhances the reader's KnoW. As said above, not being familiar with the concept (or, as it may be the case, with the person) readers may feel the need to look it up. On the other hand, Motti's solution is domesticating. It would 
have been praised by Newmark, since he affirms that this procedure is to be employed "when the character's name is not yet current amongst an educated TL readership" (Newmark, 1988, p. 215). The implications of both Newmark's opinion and Motti's solution are apparent: allusions to CulturallySpecific Terms, in this case, a proper name, are lost, as is the opportunity for the foreign readership to acquire new facts about the source culture. In analysing Motti's renderings (she translated fourteen books by Wodehouse) and her renowned Italian translation of Salinger's The Catcher in the Rye (1951), ${ }^{103}$ compared to the more recent one, by Matteo Colombo (2014), I realised that "functional equivalence" is a constant in her work and her notion of it is quite wide. Just like authors, translators possess a style of their own, i.e. "a consistent use of specific strategies" (Baker, 2001).

The example quoted above also allows for a consideration relative to the reader's cognitive processes. It is worth noting that understanding a new Culturally-Specific Term in Wodehouse implies a process of inferencing, given a characteristic of his style already mentioned in the previous chapters, i.e. his habit of disseminating hints and allusions throughout a text, an instance of what I call "endearment". In both the cases presented above, for example, Wodehouse links Brigham Young to King Solomon (who, as the Bible says, had seven hundred wives). The complete quotations read: "It's the only life, as Brigham Young and King Solomon would tell you, if they were still with us" (Cocktail Time, 1958; GV.72, pp. 210-211) and "[...] there was only one girl in the world he could possibly marry, and [he could not avoid] marrying another. An impasse, if ever there was one. King Solomon and Brigham Young would have taken it in their stride, [...]" (The Girl in Blue, 1970; GV.83, p. 71). Any reader, translators included, familiar with the biblical character would infer that Brigham Young had several or many wives (simultaneously). The question of inferencing in translation is also implicitly tackled by Eco (2004) when he affirms that it is sometimes impossible to translate a sentence without contextual information (p. 20) and states that "a translation is also the result of a conjecture" (p. 23).

The employment of Procedure VI (Explanation), namely the use of footnotes, is advocated by Nida (1964, pp. 237-239), both to adjust linguistic and cultural discrepancies, for example by giving equivalents of measures and to supply additional information to help the reader understand the historical and cultural background of the text. However, their employment in a translated literary text is controversial. Some scholars, for example Munday (2012), advocate their use, since they allow the reader to benefit from the text as if were reading the original. Indeed, to Munday (2001), "gloss translation", i.e. a translation complemented by scholarly footnotes, is the most typical form of formal equivalence. Notes

\footnotetext{
${ }^{103}$ Motti's version was published in Italy by Einaudi with the title of Il giovane Holden, in 1961.
} 
allow the reader to peruse a text without interventions by the translator (Procedure V, Intervention), that might distort meaning and betray the author. To this should be added the property that footnotes have in helping readers to enrich their KnoW. In the light of the Epistemic Approach, I hold that decisions to employ them should be made taking into account: (a) the readers' KnoW and their reasons for reading a text, e.g. being informed, or entertained, and (b) whether the text fragment for which an explanation is deemed necessary cannot be rendered without such obvious interventions as footnotes. We will see later in the chapter, for example, the various procedures that a translator can employ to render puns. In the case of a text that contains a large number of CSTs, an option sometimes employed is a glossary at the end of the book. It allows the reader to decide whether the flow of the text they are reading should be interrupted or not. However, I share Carol Meier's opinion and hold that by far the best option is an explanatory paratext compiled by the translator. In addition, as Meier remarks "[t]ranslators' prefaces and annotations often provide insightful observation about translation practice" (Meier in Baker \& Saldanha, 2009, p. 237). Translators can inform their readership about the major issues they had to face and how they tackled them, highlight the author's stylistic devices they have rendered, and show details of the translating process. Such paratext has the advantages of (a) reducing disruptions in reading, (b) enhancing the readers' KnoW and their knowledge of both LCs and (c) making readers aware of aspects of both the author's style and of the process of translation, hence augmenting the translator's visibility.

An obvious case for which explanations may be required are acronyms, very frequent in English and likely to be puzzling for foreign readers. This is how one of these was handled by Brioschi, Italian translator of four of Wodehouse's books.

\begin{tabular}{|l|c|c|l|c|}
\hline \multicolumn{1}{|c|}{ SOURCE } & YEAR & PAGE & \multicolumn{1}{c|}{ TEXT } & HD/TP \\
\hline Mulliner Nights & 1933 & 10 & "How about O.B.E.s?" & ETH \\
\hline Brioschi & 1985 & 14 & "E degli O. B. E. * che ne dite?" & VI \\
\hline
\end{tabular}

Table 4.10: Classification of the treatment of "O.B.E.s" by Brioschi

This is the first instance of this acronym that is employed three times in this book. Brioschi added a footnote reading, simply, "Order of the British Empire". It is an example of "minimal" explanation: foreignising in nature, it simply helps the reader to infer the meaning of the acronym, without truly explaining or translating it. 
As said, the behavioural category of CSTs includes words and phrases employed to express feelings and emotions and those relative to personal relationships: expressions of surprise, greetings, insults, and praise. Wodehouse employed many uncommon greetings. "Pip-pip", is for example, an informal greeting that, as the OED states, originated with an imitation of the sound of a car or bicycle horn. It was employed by Kipling in 'Traffic \& Discovery' in 1904: “Children sat on the damp doorsteps to shout 'pippip' at the stranger" (Kipling \& Arscott, 2007, p. 41) and in Shaw's "Major Barbara” in 1907 (Act 3): "Sarah (touching Lady Britomart's ribs with her finger tips and imitating a bicycle horn) Pip! pip!". Wodehouse used it quite often. It occurs, for example, in the following example, from the Bertie and Jeeves novel, Joy in the Morning (1947; GV.59) of which three Italian translations were published, in 1948, 1990 and 2006.

\begin{tabular}{|l|c|c|l|c|}
\hline \multicolumn{1}{|c|}{ SOURCE } & YEAR & PAGE & \multicolumn{1}{c|}{ TEXT } & CTS/TP \\
\hline Joy in the Morning & 1947 & 315 & "Pip-pip, Boko." & BEH \\
\hline Monicelli & 1948 & 159 & - Bai-bai, Boko. & VII \\
\hline Campagna Ponzetto & 1990 & 143 & - Salve, Boko. & IV \\
\hline Lord & 2006 & 155 & "Salve, Boko». & IV \\
\hline
\end{tabular}

Table 4.11: Classification of the treatment of "pip-pip" by Monicelli, Campagna Ponzetto and Lord

By employing a misspelt reproduction of the English greeting "bye bye" in an Italian orthographic rendering, Monicelli tried to reproduce the informality of the greeting, as a childish version of "good bye" and created, in fact, a neologism (TP VII); whereas, the other two versions employ a rather formal greeting.

I label "linguistic" those CSTs that are linguistically expressed in the source culture and whose origins are deeply rooted in it, such as instances of non-standard varieties, i.e. slang, in addition to proverbs and idioms. The table below shows the different treatment of an English idiom by two Italian translators.

\begin{tabular}{|l|c|c|l|c|}
\hline \multicolumn{1}{|c|}{ SOURCE } & YEAR & PAGE & \multicolumn{1}{c|}{ TEXT } & CST/TP \\
\hline Frozen Assets & 1964 & 112 & It's in the bag. & LIN/idiom \\
\hline Agnati & 1953 & 121 & Il gatto è nel sacco & III \\
\hline Morzenti & 1997 & 94 & Cosa fatta capo ha. & III \\
\hline
\end{tabular}

Table 4.12: Classification of the treatment of "It's in the bag" by Agnati and Morzenti 
I classified both translations as TP III, since both translators rendered the idiom by a corresponding one in Italian. Both, in fact, draw from proverbs and express something uttered by someone who is certain to achieve something, such as the English phrase. However, Italian translators could not always find a suitable expression in Italian. This is particularly true with slang, as in the example shown below.

\begin{tabular}{|l|c|c|l|c|}
\hline \multicolumn{1}{|c|}{ SOURCE } & YEAR & PAGE & \multicolumn{1}{c|}{ TEXT } & CST/TP \\
\hline Laughing Gas & 1936 & 10 & $\begin{array}{l}\text { If Eggy wanted to get spliced, let him, was the } \\
\text { way I looked at it. Marriage might improve him. }\end{array}$ & LIN/slang \\
\hline Tedeschi & 1938 & 8 & Omitted & VIII \\
\hline
\end{tabular}

Table 4.13: Classification of the treatment of "To get spliced" by Tedeschi

Here Tedeschi employed TP VIII, Omission. Unfortunately, when the use of a particular linguistic CST is also one of the author's HD, the outcome is a loss on both cultural and stylistic levels. In analysing the Italian translations, I found that, as a rule, idioms and proverbs are kept (TP III), sometimes they are reworded (TP IV); whereas slang expression are often omitted (TP VIII, as in the example above). The linguistic category can also include other forms of formulaic language, i.e. the so-called "pause-fillers", such as "Well,", "Er" or "Um". Although these are an interesting field of investigation in Translation Studies and in Applied Linguistics (see, for example, Ellis, Simpson-Vlach, \& Maynard, 2009), I deemed it unnecessary to treat them here, as they are not frequent in Wodehouse's dialogue and they are always rendered in his Italian translators by TP III (Functional Equivalence) since Italian has corresponding words.

In a study of translations issued over a wide period of time, the treatment of proper names is particularly relevant since the choice made by a translator reflects his/her attitude towards the issue that in Translation Studies is traditionally referred to as foreignization vs domestication. Proper names are defined as "names of a particular person, place of thing" that are "spelled with a capital letter" (Richards \& Schmidt, 2010, p. 68). In translation, basically, a proper name can be (1) simply transferred, thus preserving its nationality, e.g. Barack Obama, (2) translated, such as, conventionally, the names of the popes, and (3) naturalized, e.g. the name of the Latin poet Horatius, naturalised in English as Horace (Newmark, 1988). Italian translators active before and immediately after the Second World War tended to naturalise proper names, in line both with the fascist regulations and with the trend of italianising proper names in vogue in Italy until the end of the first half of the twentieth century (Manini in Delabastita, 1996, p. 171). Hervey and Higgins (1992, p. 29) state that "either the name can be taken over 
unchanged from the ST to the TT, or it can be adopted to conform to the phonic/graphic conventions of the TL". In Hervey and Higgins's terms, the first method is named "transliteration", while the second is "exoticism" (ibid.). The issue and its possible solutions are not so clear-cut, though. Sometimes translators feel the need to modify the original name, either to adapt it to the conventions of the target language or to shed light on the CST that the proper name identifies. Indeed, Hervey and Higgins (1992) suggest another alternative that they term "cultural transplantation", meant as a translation technique by means of which proper names in the original text are replaced by indigenous proper names in the target language that "are not their literal equivalents, but have similar cultural connotations" (ibid.). In my classification, the techniques identified by Hervey and Higgins respectively correspond to "Tranference" (Procedure I), "Formal Equivalence” (Procedure II), and “Functional Equivalence” (Procedure III).

The methodology adopted to analyse CSTs also allows for considerations about the issue of modernisation and compensation. Characters' first names were usually rendered with Italian names in early translations of Wodehouse's works. The usage was kept throughout the 1940s after which names were transferred, i.e. rendered as in the original. This is an instance of modernisation, in that the usage of translating first names had traditional, historical, and even political reasons.

By the same token, in their renderings of behavioural CSTs, such as slang insults, translators quite often compensated for the loss in rendering them by adding some other similar instance in the surrounding text. For example, in Stiff Upper Lip, Jeeves (1963; GV.77, p. 143), Lord (2007) had to translate "fishfaced blighter". Instead of rendering the whole expression, she chose a general word "essere", depreciatively meaning "guy," to which she added a functional translation of "fishfaced", i.e. "con la faccia di torta" (p. 171). This is a slightly less insulting phrase, meaning "cakefaced". The result is a slightly less offensive description.

The analyses I performed on Culturally-Specific Terms reveal that Wodehouse's Italian translators have generally tended to favour domesticating translation Procedures (III, IV, VII and VIII, in my classification) when dealing with all CSTs belonging to the behavioural category (namely, greetings and expressions of surprise), thus highlighting a tendency to appreciate the pragmatics of the communicative message. Similarly, they tended to choose a domesticating procedure while treating linguistic phenomena such as idioms. These findings are in line with Attardo's considerations (Attardo in Vandaele, 2002, pp. 174-175) on the relevance of the "pragmatic force" of a text in his definition of 
translation. ${ }^{104}$ On the other hand, Italian translators favour foreignizing translation procedures (I, II V, or VI, in my classification) when dealing with CSTs belonging to the environmental and ethnographic categories. As already pointed out, foreignizing procedures are the ones that offer the reader information about the source culture, enhance their knowledge and make them appreciate "das Fremde". They are, therefore, the most significant in the light of the Epistemic Approach. Employed by Italian translators, they might be one of the reasons that explain Wodehouse's success in Italy.

Humour Devices in Wodehouse and their translation

This section of the chapter treats the Italian renderings of the Humour Devices (HDs) Wodehouse employed, according to the five key terms I identified to describe them, namely incongruity, surprise, exaggeration, endearment, and knowledge sharing. I will label the procedures they employed by means of a classification I elaborated starting from the scheme proposed by Delabastita (1996, p. 134) to identify the procedures among which translators may choose to render wordplay in translation. I apply the Epistemic Approach to highlight which traits of Wodehouse's humour have been rendered by his Italian translators and in which way and to show the consequences on their readerships of the techniques they chose. I also address the issue of modernisation in translation, by underlining, when relevant, the differences and the similarities that the Italian renderings reveal in editions published at different times, from 1928 to 2017 .

In dealing with the translatability of wordplay, specifically puns, Delabastita (1996) lists eight procedures at a translator's disposal (p. 134). Elaborating on his scheme, I propose here the following one, referring to the more comprehensive concept of Humour Device. My list is meant both as a way to present the Humour Device Translation Procedures (HDTPs) among which translators of humorous texts can choose and also as a tool to classify the examples from Italian translations that I will cite in this chapter. This classification is similar to the one employed to examine CSTs and complements it, since the two classifications can be employed together in combined analyses of texts containing both CSTs and HDs. An example of combined analysis is offered here in Table 4.15.

\footnotetext{
${ }^{104}$ In this contribution, Attardo supplies his working definition of translation as: "a correspondence between two texts $T_{1}$ and $T_{2}$, such that the meaning $(M)$ of $T_{1}$ and the meaning of $T_{2}$ are similar (approximate) and /or the pragmatic force $(\mathrm{F})$ of $\mathrm{T}_{1}$ and the pragmatic force of $\mathrm{T}_{2}$ are similar/approximate".
} 


\begin{tabular}{|c|c|c|}
\hline 1 & $\mathrm{HD}>\mathrm{HD}$ & $\begin{array}{l}\text { The HD is translated in the TL maintaining its formal structure and } \\
\text { features (e.g. Script-Clash or Hyper-Wording). }\end{array}$ \\
\hline 2 & $\mathrm{HD}>\mathrm{WW}$ & The HD is translated word-for-word. \\
\hline 3 & $\mathrm{HD}>\mathrm{FE}$ & The HD is rendered by a functionally equivalent utterance. \\
\hline 4 & $\mathrm{HD}>\mathrm{SM}$ & The HD is simplified, e.g. rendered by a phrase containing less words. \\
\hline 5 & $\mathrm{HD}>\mathrm{AD}$ & New material is added to the HD, including compensation and footnotes. \\
\hline 6 & $\mathrm{HD}>\mathrm{GN}$ & $\begin{array}{l}\text { The HD is generalised, i.e. rendered by means of a word or an utterance } \\
\text { belonging to a hyper-category, e.g. a hypernym or standard language } \\
\text { instead of slang. }\end{array}$ \\
\hline 7 & $\mathrm{HD}>\mathrm{AM}$ & $\begin{array}{l}\text { The HD is amended, i.e. the text is modified and the meaning and } \\
\text { function of the HD is subverted. }\end{array}$ \\
\hline 8 & HD $>$ ZERO & The portion of the text containing the HD is simply omitted. \\
\hline $\mathrm{O}$ & HD $>$ KnoLC & $\begin{array}{l}\text { The translation is faulty due to lack of knowledge of the Linguistic } \\
\text { Code(s). }\end{array}$ \\
\hline
\end{tabular}

Table 4.14: Proposed Translation Procedures for Humour Devices

With the exception of the first example (table 4.15), in this section I will only apply the classification above, since here the purpose is to identify the procedures employed and their outcome on the humorous effect intended in Wodehouse's texts. In the examples shown, the humorous device contained in a text will sometimes be highlighted in bold for the sake of presentation. A number (from 1 to 8 ) is assigned to each procedure. In addition, a rendering can be classified "O" if it shows lack of knowledge of the Linguistic Code, either English or Italian. As Delabastita (1996) notes, the procedures can be combined, so, for example, a footnote may be chosen to explain why an HD was left out. The only procedure that allows for the HD to be fully rendered in translation is procedure no 1 . By employing the other ones, translators lose some of the features of the original text. Two procedures, namely nos 3 and 5 allow for compensation, while the consequences of procedure 2 on the HD must be evaluated for each instance; however, as a rule, word-for-word translations of HDs do not do them justice. Procedure nos 6, 7, 8 and $\mathrm{O}$ yield sub- or mis-renderings.

Sometimes two or more procedures are employed in the same passage. This is a strategy advocated for example, by Eco (2004, p. 192) who affirms that, in translating a text, the best solution should be chosen ("negotiated", in his terminology) for every line. For example, the Italian translators chose to sometimes keep and sometimes modify the creative names Wodehouse devised for his characters, an instance of the HD showing his linguistic inventiveness. The following example, in which the classification of the translation procedures to render HDs is combined with the one employed in the previous section on 
CSTs, will further illustrate this case and show how my methodology can be employed to describe the choices translators make.

In Pearls, Girls and Monty Bodkin (1972; GV.85), following the device already used in the Mulliner's stories (1927, 1929 and 1933), where characters are identified by the drinks they are having, Wodehouse has five characters on stage in the opening scene of chapter 2. The scene is set in the smoking room of the Drones club and Wodehouse uses it as a ploy to summarise the events of previous books featuring Monty Bodkin: having succeeded in keeping a job for one year, he is back in London, entitled to marry Gertrude Butterwick. In the (only) Italian translation, entitled I "gioielli" di Monty Bodkin (1974), Elena Spagnol sometimes transfers the names of the members of the Drones club and sometimes she changes them. These are instances of ethnographic CSTs. In the table below Elena Spagnol's renderings are classified according to the codes I have assigned to each translation procedure for both HD (HDTP) and CSTs (CSTTP).

\begin{tabular}{|l|c|l|c|c|c|}
\hline \multicolumn{1}{|c|}{$\begin{array}{c}\text { WODEHOUSE'S } \\
\text { CHARACTER }\end{array}$} & PAGE & $\begin{array}{c}\text { ELENA SPAGNOL'S } \\
\text { CHARACTER }\end{array}$ & PAGE & HDTP & CSTTP \\
\hline 1. A Whisky Sour & 14 & 1. Un Whisky Sour & 22 & 2 & II \\
\hline $\begin{array}{c}\text { 2.A Martini-with-small- } \\
\text { onion-not-an-olive }\end{array}$ & 14 & $\begin{array}{l}\text { 2. Un Martini-con-cipollina- } \\
\text { no-niente-oliva }\end{array}$ & 22 & 1 & II \\
\hline $\begin{array}{l}\text { 3. A Screwdriver (with dark } \\
\text { circles under his eyes) }\end{array}$ & 15 & $\begin{array}{l}\text { 3. Un Daiquiri (con cerchi neri } \\
\text { sotto gli occhi) }\end{array}$ & 23 & 3 & III \\
\hline $\begin{array}{l}\text { 4. A (well-informed) } \\
\text { Manhattan }\end{array}$ & 15 & $\begin{array}{l}\text { 4. Un Manhattan (ben } \\
\text { informato) }\end{array}$ & 23 & 1 & II \\
\hline 5. A (puzzled) Gimlet & 15 & 5. (perplesso) un Bloody Mary & 23 & 3 & III \\
\hline
\end{tabular}

Table 4.15: Classification of the treatment of "loaded names" by Elena Spagnol

Wodehouse's names are extreme instances of "loaded" names, in the terms used by Hermans (in King, Wintle, \& Vincent, 1988, p. 13). Hermans distinguishes between "conventional" and "loaded" names for fictional characters, with loaded names not simply identifying and denoting but also characterising and connoting them. Elena Spagnol employed different procedures to render them in Italian. For characters 1 and 4, she kept the same name as in the original (HDTP 2, "word-for-word"), while she changed the names of characters 3 and 5 . She probably deemed the corresponding cocktails to be unknown to her Italian readers, so she substituted with others, familiar to them (and, of course, to her). This is a case of cultural adaptation in translation, corresponding to Procedure III (Functional Equivalence), in my classification of renderings of CSTs. She also kept the "head" of character 2 (HDTP 1 ), surely known to her 
readers, since it owes its name to its main ingredient, an Italian vermouth. Moreover, she translated the immediately surrounding hyper-wording. The combination of these two procedures enabled her to retain the humour of this sobriquet. In conclusion, one can assert that the HDTPs Spagnol employed allowed her to render the humorous effect, since she employed procedures that either maintained the features of the HD or allowed her to compensate for the loss. Moreover, she flexibly used CSTPTs II and III, depending on her judgement of her readers' KnoW.

Before analysing Wodehouse's most characteristic Humour Devices, e.g. similes and hyper-wording, I will show the methodology to analyse the renderings of some of his simpler wordplays, i.e. puns, the "lowest form of wit" (Chiaro, 2012, p. 3). These, according to Newmark (1991, p. 57) epitomise the "slipperiness of meaning". As already shown in Chapter 3, Wodehouse was never predictable when he deployed them in his texts, although he sometimes reused them. Such is, for example, the case of the pun shown below, together with its Italian translation.

\begin{tabular}{|l|c|c|l|c|}
\hline \multicolumn{1}{|c|}{ SOURCE } & YEAR & PAGE & \multicolumn{1}{|c|}{ TEXT } & HD/HDTP \\
\hline $\begin{array}{l}\text { The Luck of the } \\
\text { Bodkins }\end{array}$ & 1935 & 187 & $\begin{array}{l}\text { "Monty Bodkin [...] has never acted in his } \\
\text { life, and couldn't play the pin in Pinafore. } \\
{[\ldots] \text { " }}\end{array}$ & pun \\
\hline Lampronti & 1936 & 171 & $\begin{array}{l}\text { «[..] non ha mai recitato in vita sua e non } \\
\text { saprebbe neanche fare la parte di un servo } \\
\text { muto [...].» }\end{array}$ & 1 \\
\hline
\end{tabular}

Table 4.16: Classification of the treatment of pun played on "Pinafore" by Lampronti

The backtranslation of Lampronti's version is: "He never acted in his life and couldn't play a dumb servant". Here, she maintained the formal structure of the HD and used Functional Equivalence to render the pun. The pun is rendered by a substitution that, though less witty than Wodehouse's, conveys the intended meaning, but with no wordplay. The English pun used by Wodehouse is, possibly, a variant of the traditional joke directed by theatre critics to actors "putting the ham in Hamlet". He had previously employed the pun played on "Pinafore" in The Coming of Bill (1920; GV.20). The table below shows that both Italian translators omitted to translate it (HDTP 8).

\begin{tabular}{|l|c|c|l|c|}
\hline \multicolumn{1}{|c|}{ SOURCE } & YEAR & PAGE & \multicolumn{1}{|c|}{ TEXT } & HD/HDTP \\
\hline $\begin{array}{l}\text { The Coming of } \\
\text { Bill }\end{array}$ & 1920 & Ch 4 & $\begin{array}{l}\text { "Percy," continued Miss Reece, "shake hands } \\
\text { with my friend Mr Bannister. I been telling } \\
\text { him about how you made such a hit as the pin } \\
\text { in 'Pinafore'!" }\end{array}$ & pun \\
\hline
\end{tabular}




\begin{tabular}{|l|c|c|l|c|}
\hline Pitta & $193^{2}$ & 65 & $\begin{array}{l}\text { - Percy, - continuò Freda - il mio amico signor } \\
\text { Bannister. Gli stavo dicendo appunto il } \\
\text { successo che aveste in quella commedia... }\end{array}$ & 8 \\
\hline Casale-Rossi & $193^{2}$ & 47 & $\begin{array}{l}\text { - Percy - continuò Freda - stringi la mano al } \\
\text { mio amico signor Bannister. Gli ho raccontato } \\
\text { del successo che avete avuto... }\end{array}$ & 8 \\
\hline
\end{tabular}

Table 4.17: Classification of the treatment of pun on "Pinafore" by Pitta and Casale-Rossi

In both versions, the TP in number 8 (HD > ZERO): the pun is foregone and substituted by an ellipsis “...". The translators probably intend to suggest that other details are about to be added by the speaker. Readers perceive that Miss Reece's utterance has been interrupted by Percy, while the original text does not imply this. These examples illustrate the fact that in rendering HDs, translators can not only "negotiate" options with respect to items in the source text, but may try to compensate for inevitable losses by introducing HDs in the target text. In doing so they marshall their knowledge of Wodehouse's literary intentions and devices as well as their knowledge or assumptions about readers' knowledge. In the following pages, I present analyses of translations of Wodehouse's characteristic Humour Devices, applying the same methodology to instances of Script-Clash and Hyper-Wording in similes, which I previously argued to be crucial to his humour. This combination of features is well represented in the following simile, connecting Tubby, a young friend of Bertie's, to a bulldog.

\begin{tabular}{|l|c|c|l|c|}
\hline \multicolumn{1}{|c|}{ SOURCE } & YEAR & PAGE & \multicolumn{1}{|c|}{ TEXT } & HD/TP \\
\hline $\begin{array}{l}\text { Right ho, } \\
\text { Jeeves }\end{array}$ & 1934 & $79 / 8$ & $\begin{array}{l}\text { In build and appearance, Tuppy somewhat resembles } \\
\text { a bulldog, and his aspect now was that of one of these } \\
\text { fine animals who has just been refused a slice of cake. }\end{array}$ & simile \\
\hline $\begin{array}{l}\text { Sacchi- } \\
\text { Perego }\end{array}$ & 1935 & 71 & $\begin{array}{l}\text { Nell'insieme Tuppy assomiglia un poco ad un bulldog, } \\
\text { ed in questo momento sembrava un proprio uno di } \\
\text { quei begli animali cui sia stata rifiutata una fetta di } \\
\text { dolce. }\end{array}$ & 1 \\
\hline $\begin{array}{l}\text { Buitoni } \\
\text { Duca }\end{array}$ & 1985 & 82 & $\begin{array}{l}\text { Nell'insieme, Tuppy assomiglia a un bulldog, e adesso } \\
\text { pareva proprio uno di questi splendidi animali che } \\
\text { avesse appena rifiutato un pezzo di dolce. }\end{array}$ & $1+\mathrm{O}$ \\
\hline
\end{tabular}

Table 4.18: Classification of the treatment of a simile with large semantic distance and hyper-wording by Sacchi-Perego and Buitoni Duca

The semantic distance (young man - dog) is kept by both translators. However, Buitoni Duca's version does not convey the same image (a disappointed bulldog), since she translates the passive voice as an 
active one (backtranslation: "one of those splendid animals who had just refused a slice of cake"). This error results in confusion for the reader, as dogs are not known to refuse treats. Sacchi-Perego, in contrast, renders both correct semantic distance and hyper-wording, thus conveying the same humorous effect of the original.

The following example is an instance of hyper-wording in description, i.e. an exaggerated number of words and details, which also includes script-clash. It is the passage from Mulliner Nights (1933: GV.44) already presented in Chapter 3 as an instance of a vivid description, enriched by hyper-wording in the form of apparently superfluous details. It is presented here with its translation by Brioschi (1985).

\begin{tabular}{|c|c|c|c|c|}
\hline SOURCE & YEAR & PAGE & TEXT & HD/TP \\
\hline $\begin{array}{l}\text { Mulliner } \\
\text { Nights }\end{array}$ & 1933 & 133 & $\begin{array}{l}\text { The relief which Sacherwell felt as he closed the door } \\
\text { behind him would have been less intense, had he } \\
\text { realized that through a slight mistake in his bearings } \\
\text { he had not, as he supposed, reached the haven of the } \\
\text { passage outside but had merely entered the bathroom. } \\
\text { This fact was not brought home to him until he had } \\
\text { collided with an unexpected chair, upset it, tripped } \\
\text { over a bathmat, clutched for support into the darkness } \\
\text { and brushed off the glass shelf above the basin a series } \\
\text { of bottles, containing - in the order given - Scalpo ('It } \\
\text { fertilizes the Follicles'), Soothine - for applying to the } \\
\text { face after shaving, and Doctor Wilberforce's Golden } \\
\text { Gargle in the large or seven-and-sixpenny size. }\end{array}$ & $\begin{array}{c}\text { Hyper- } \\
\text { wording }\end{array}$ \\
\hline Brioschi & 1985 & 133 & $\begin{array}{l}\text { Il sollievo che Sacherwell provò nel chiudersi la porta } \\
\text { alle spalle sarebbe stato meno intenso se si fosse reso } \\
\text { conto che, a causa di un piccolo errore di direzione, } \\
\text { non era giunto, come credeva, al rifugio del corridoio, } \\
\text { ma era semplicemente entrato in bagno. Ciò non gli fu } \\
\text { chiaro se non nel momento in cui cozzò contro una } \\
\text { sedia del tutto inaspettata, col risultato che la fece } \\
\text { cadere, inciampò in un tappetino, e brancolando nel } \\
\text { buoi alla ricerca di una appiglio spazzò via dalla } \\
\text { mensola di vetro sopra il lavandino una serie di flaconi } \\
\text { contenenti - nell'ordine - Scalpo (« fertilizza i follicoli } \\
\text { », Soothine (da applicare al viso dopo la rasatura), e il } \\
\text { liquido per gargarismi del dottor Wilberforce nella } \\
\text { misura grande ovvero da sette scellini e sei pence. }\end{array}$ & 1 \\
\hline
\end{tabular}

Table 4.19: Classification of the treatment of hyper-wording in description by Brioschi

Brioschi's is an almost word-for-word translation and a neat, pleasant version that maintains Wodehouse's syntactic complexity and all the details he adds to his description. Brioschi's translation is 
so literal, that I was tempted to have it machine-backtranslated. His version, Google Translate's version of his, and Wodehouse's original test are compared in the table below.

\begin{tabular}{|c|c|c|}
\hline BRIOSCHI & $\begin{array}{c}\text { GOOGLE TRANSLATE, } \\
14^{\mathrm{TH}} \mathrm{JULY} 2017\end{array}$ & WODEHOUSE \\
\hline $\begin{array}{l}\text { Il sollievo che Sacherwell provò } \\
\text { nel chiudersi la porta alle spalle } \\
\text { sarebbe stato meno intenso se } \\
\text { si fosse reso conto che, a causa } \\
\text { di un piccolo errore di } \\
\text { direzione, non era giunto, come } \\
\text { credeva, al rifugio del corridoio, } \\
\text { ma era semplicemente entrato } \\
\text { in bagno. } \\
\text { Ciò non gli fu chiaro se non nel } \\
\text { momento in cui cozzò contro } \\
\text { una sedia del tutto inaspettata, } \\
\text { col risultato che la fece cadere, } \\
\text { inciampò in un tappetino, e } \\
\text { brancolando nel buio alla } \\
\text { ricerca di una appiglio } \\
\text { spazzò via dalla mensola } \\
\text { di vetro sopra il lavandino } \\
\text { una serie di flaconi contenenti } \\
\text { - nell'ordine - Scalpo } \\
\text { (« fertilizza i follicoli », } \\
\text { Soothine (da applicare al viso } \\
\text { dopo la rasatura), e il liquido } \\
\text { per gargarismi del dottor } \\
\text { Wilberforce nella misura } \\
\text { grande ovvero da sette scellini } \\
\text { e sei pence. }\end{array}$ & $\begin{array}{l}\text { The relief Sacherwell tried to } \\
\text { close the door behind him } \\
\text { would have been less intense } \\
\text { if he realized that because of } \\
\text { a small error in direction he } \\
\text { had not come to the shelter } \\
\text { of the corridor as he thought, } \\
\text { but he simply entered the } \\
\text { bathroom. } \\
\text { It was unclear to him, except } \\
\text { at the moment when he } \\
\text { cradled himself against an } \\
\text { unexpected chair, with the } \\
\text { result that he dropped it, } \\
\text { stumbled into a mat, and } \\
\text { scurrying in the dark in } \\
\text { search of a suit swept away } \\
\text { from the glass shelf over the } \\
\text { sink one Series of vials } \\
\text { containing - in the order - } \\
\text { Scalpo ("fertilizes the } \\
\text { follicles", Soothine (to apply } \\
\text { to the face after shaving), and } \\
\text { the fluid for gobblings of Dr. } \\
\text { Wilberforce in large measure, } \\
\text { or seven shillings and six } \\
\text { pence. }\end{array}$ & $\begin{array}{l}\text { The relief which Sacherwell felt } \\
\text { as he closed the door behind him } \\
\text { would have been less intense, } \\
\text { had he realized that through a } \\
\text { slight mistake in his bearings he } \\
\text { had not, as he supposed, reached } \\
\text { the haven of the passage outside } \\
\text { but had merely entered the } \\
\text { bathroom. } \\
\text { This fact was not brought home } \\
\text { to him until he had } \\
\text { collided with an unexpected } \\
\text { chair, upset it, } \\
\text { tripped over a bathmat, } \\
\text { clutched for support } \\
\text { into the darkness } \\
\text { and brushed off the glass } \\
\text { shelf above the basin a } \\
\text { series of bottles, } \\
\text { containing - in the order given - } \\
\text { Scalpo ('It fertilizes the } \\
\text { Follicles'), Soothine - for } \\
\text { applying to the face after } \\
\text { shaving, and Doctor } \\
\text { Wilberforce's Golden Gargle in } \\
\text { the large or seven-and-sixpenny } \\
\text { size. }\end{array}$ \\
\hline
\end{tabular}

Table 4.20: Comparison of the backtranslation (GoogleTranslate) of Brioschi's rendering of hyper-worded description to Wodehouse's original text

Except for a few words, notably "provò" backtranslated "tried", due to the fact that Italian verb "provare" can mean either "feel" or "try", the backtranslation yields Wodehouse's text almost literally. This was a useful experiment to assess whether a machine translation may help to identify differences between the original and its translation. In this case, it confirmed the result of my description of Brioschi's choices as HDTP 1 . This shows that Google Translate may fruitfully be used to confirm and complement the analysis of a translation; however, it is simply confirmative, rather than informative. 
In translating Wodehouse's Humour Devices, Italian translators successfully render some of them (HDTP 1 ), but in most cases they choose translation procedures that convey the meaning of the message and, usually, safeguard the plot, although they do not maintain the features of the HD. More specifically, the least successfully rendered HDs are affixation and the script-clashes that Wodehouse achieved through the opposition of standard and non-standard varieties of English and between English and a foreign language (Latin included). Rendering slang is difficult, unless the translator is creative enough to draw from a consistent source of sub-standard Italian, such as, for example, young people's. However, this choice cannot stand the test of time, so the translations by Pisano and Pitta are no longer readable. On the whole, register clash is generally rendered poorly or not rendered at all. Interestingly, the exception to this rule is the exchanges between Bertie and Jeeves, and Bertie's narratives containing register clashes, where the clash originates from the employment of Latinate words together with common language. Here, translators do not need to find a faithful rendering of Bertie's knuts' lingo to keep the clash, but simply to contrast high and low registers. Bathos and transferred epithets are rendered effectively, since both are rhetorical devices in Italian too. Intertextuality often goes unnoticed; however, when recognised, renderings are often fruitfully complemented by footnotes (HDTP 5 ). In the light of the Epistemic Approach, this is a remarkable achievement, since these renderings add to the readers' KnoW. On the other hand, the fact that so many different translators have worked on Wodehouse's texts accounts for the inconsistent renderings of his leitmotifs. the same leitmotif is often translated differently; thereby, the connotation of "endearing" HD that I ascribed to leitmotifs is lost.

Overall, the combination of HDs that I posit as the basis of Wodehouse's humour, i.e. Script-Clash achieved by semantic distance, and Hyper-wording, both in similes and in descriptions, have been maintained by his Italian translators in many cases. It is possible to hypothesise that this contributed to Wodehouse's success in Italy.

\section{Case studies}

This section presents the outcome of applying the Epistemic Approach, employing its methodology to some particularly interesting Italian editions of Wodehouse. These case studies show how the Epistemic Approach applied to translation can shed light on key issues in Translation Studies and supply evidence for interdisciplinary investigations. 


\section{The first book translated into Italian}

In 1928 the Casa Editrice Monanni published the first Italian translation of a book by Wodehouse, Carry On, Jeeves (1925; GV.30), under the title of Avanti Jeeves! It is a collection of ten short stories, featuring Bertie Wooster, Jeeves, his valet and a number of Bertie's friends. This was the first time that a book written in Italian had to render the colloquialisms employed by Bertie when he cannot recall the correct word, such as "what's-its-name" and "thingummy" (p. 426) and his childish use of abbreviations, as in "Mix me a b-and-s" (p. 504). The task was performed by Silvio Spaventa Filippi (1871-1931), a journalist and a writer, defined in the preface of the first edition as "a fine man of letters" (Avanti, Jeeves!, 1928, p. 5). He had already worked on English literature, both as a translator and as a literary critic. ${ }^{105}$ In the same preface, his translation is defined as "diretta e fedele", "straight and faithful" (ibid.).

The analysis of his translation in the light of the Epistemic Approach shows that these adjectives are too bland to describe it. He tackled Wodehouse's Humorous Devices skilfully, so that he could maintain their features. In fact, most of his choices fall into the category I label "HD1", i.e. "the HD is translated in the TL so as to maintain its formal structure and features". For example, he retained the light tone of Bertie's utterances containing some French, by keeping the French words in the Italian text, as the table below shows.

\begin{tabular}{|l|c|c|l|c|}
\hline \multicolumn{1}{|c|}{ SOURCE } & YEAR & PAGE & \multicolumn{1}{c|}{ TEXT } & CST/TP \\
\hline $\begin{array}{l}\text { Carry On, } \\
\text { Jeeves }\end{array}$ & 1925 & 514 & $\begin{array}{l}\text { There's something about Paris that always } \\
\text { makes me feel fairly full of espièglerie and joie } \\
\text { de vivre. }\end{array}$ & foreign \\
\hline $\begin{array}{l}\text { Spaventa- } \\
\text { Filippi }\end{array}$ & 1928 & 135 & $\begin{array}{l}\text { Vi è non so che nell'aria parigina che mi fa } \\
\text { sentire bellamente colmo e vibrante di } \\
\text { «espièglerie»e «joie de vivre». }\end{array}$ & I \\
\hline
\end{tabular}

Table 4.21: Classification of the treatment of foreign languages (French) by Spaventa-Filippi

Moreover, Spaventa-Filippi recognised the various instances of intertextuality he encountered, both from the Scriptures and from English literature, and rendered them adequately. As for the treatment of CSTs, except for the translation of first names (TP II, formal equivalence), in line with the conventions of

\footnotetext{
${ }^{105}$ see Enciclopedia Italiana, 1938, I Appendice, Roma: Istituto dell'Enciclopedia Italiana.
} 
his time, his version is foreignising. He kept as in the original (TP I, Transcription) places and monuments, e.g. Albert Memorial, Madison Square Garden, Long Island, just sometimes adding a word to supply an extra clue for the reader, such as in the case of "Grant's Tomb" (p. 481) to which he added the word corresponding to "General" (TP V). He also partially modified his rendering of "the Mint" (p. 582). The Italian mint is usually referred to as "la zecca di stato" ("the state mint"), because "zecca" as a common noun means "tick" (the insect). Spaventa-Filippi cleverly translated "the Mint" as "la Banca d'Inghilterra" (p. 231), an instance of Functional Equivalence combined with intervention (TP III and TP V). These adjustments are valuable according to the Epistemic Approach, since they help the reader to interact more easily with the translated text, without reducing its potential to enrich the reader's knowledge of the source culture. Moreover, I hold that they are also instances of ethical behaviour on the part of the translator. By means of wise slight interventions, translators avoid giving incorrect, if not fake, information to their readers. Referring to the instance above, for example, by employing a modified formal equivalence, Spaventa-Filippi did not induce his reader to think that something like a "State Mint" exists in England. Spaventa-Filippi's Italian is elegant, rich. It is the prose of a learned and witty man of his age. Today, it sounds old-fashioned but still comprehensible and enjoyable.

\section{The worst translation}

An apparent case of inadequate knowledge of the linguistic codes producing a very bad translation can be found in G. V. Pisano's version of a collection of thirteen short stories, The Man with Two Left Feet (1917; GV.16), literally translated as L'uomo con due piedi sinistri (1932). Little is known about Pisano, not even what the initials stand for, hence even gender is unknown. L'uomo con due piedi sinistri is the only translated book recorded in the Italian OPAC under this name. ${ }^{106}$ This translation contains a significant array of mistakes, both on semantic and syntactic levels. For example, Pisano translates "fan" in phrases such "baseball fan" by "volante", possibly meaning "ventola", since one of its meanings is "fan". There even is a cat "as saturated as a dynamo" ("saturo come una dinamo", p. 19o) instead of "purring like a dynamo". Moreover, Pisano could not decode stock metaphors, so that the Thames referred to as a "watery grave" becomes "a water hole" ("una pozza d'acqua", p. 25). Unsurprisingly, Wodehouse's hyper-wording and intertextuality were ill-treated. However, the most striking blunder is a girl dancer mistaken for a man. It originates in the fact that English adjectives are invariable for gender. When Pisano meets the opening

\footnotetext{
${ }^{106} \mathrm{http}: / /$ opac.sbn.it/opacsbn/opac/iccu/free.jsp.
} 
sentence of the seventh story: "I was feeling blue and restless, tired of New York", s/he translates: "Ero malinconico e irrequieto, stanco di New York" (p. 120). All the Italian adjectives are coded masculine (see Section Adjectives and pronouns in this Chapter). Instead of suspending judgement, Pisano decides that the narrator is a man and does not change her/his mind even after meeting the following utterance further down the page, clearly addressed to the narrator: "Why, Miss Roxborough!". Pisano ignores the clue, translates "Miss" with "signor" and, instead of going back and amending the mistake, keeps on telling the story of this transgendered dancer for twenty pages. The consequences for the plot are disastrous, and Wodehouse's clever denouement makes no sense. This is an extraordinary example of semantic mis-decoding. For the purposes of this dissertation, Pisano's translation is interesting for two reasons. Firstly, it shows the effects of inadequate knowledge of the LCs (Linguistic Codes) on plot and text actualisation. Secondly, this example of careless translation and editing also had negative consequences on Wodehouse's reputation in Italy. Evidence found still today on blogs shows that readers judge this one of Wodehouse's worst books. ${ }^{107}$ Since Bietti shamelessly republished this translation seven times, it was the only one available to Italian readers until Mursia published Teobaldo del Tànaro's translation in 1991. Bietti's editions are now out of print; however, they can still be borrowed from libraries.

\section{The most anomalous editions}

In general, Wodehouse's works were published in Italian as parts in a series of humorous books. For example, they were a substantial part of Bietti's series "Il Picchio" (see Chapter 1 footnote 40), together with books by Mark Twain, J. K. Jerome and Oscar Wilde. However, there are also atypical editions published for other commercial reasons. For example, one of the stories originally contained in The Man with Two Left Feet (1917; GV.16), "The Mixer" was published by Mursia as a stand-alone story about a dog, under the title Il bastardo (1995) in their series "arCANI \& C" devoted to dogs, since "cani" means "dogs" in Italian.

One of the most curious editions is the one issued by Casa Editrice E.I.A. in 1940, entitled Il fermaglio di zia Giulia, by G. P. [sic] Wodehouse. It is a slender booklet (48 pages) that I found by chance and

\footnotetext{
${ }^{107}$ See, for example, https://abrightshininglie.wordpress.com/2011/o7/29/recensione-106-luomo-con-due-piedisinistri/.
} 
bought from an antiquarian bookstore. Given its peculiarities, I photographed some of its pages and the cover is reproduced in Appendix 8. The cover is in colour and the book contains some line drawings, an unusual feature in Wodehouse's Italian editions. Wodehouse is named G. P. Wodehouse instead of P.G. and the original title is printed on the title page as "THE LEVEL BUSINES HEAD"). This is a Ukridge story from Lord Emsworth and Others (1937; GV.52), in its earliest known Italian translation. Unfortunately, the translator is not named and I could not unequivocally identify him or her.

A recent, edited selection of stories by Wodehouse, Death at the Excelsior (2004), was only published in English in the USA, and was published in an Italian translation in 2007. I restricted my own corpus of source texts to UK editions, but the 'Excelsior' selection is of interest because the Italian edition entitled Delitto all'Excelsior e altri racconti (2007) was commissioned and published because it recalled the name of the Milan-based publishing company, Excelsior 1881, which has otherwise shown no interest in publishing Wodehouse. As all the stories in the book are in the public domain in the USA, Italian rights must not have been expensive.

There also exists a very interesting Bietti edition of a collection of abridged stories especially designed as school reading, dated 1973. Among them is the first episode in Avanti, Jeeves, in the old translation by Spaventa Filippi, firstly published in 1928. The editor, Corrado Ferri, who translated Jill, the Reckless (GV.21) for Bietti in 1966, made use of didactic notes, even to explain some of Wodehouse's recurrent citations from the Bible or the Classics. Examples are his explanations for Shopshire ("a British county"), Nietzsche ("an important German philosopher"), Washington Square ("a road [sic] in New York"), Manhattan ("name of a theatre on Manhattan Island, the most important area in New York"), Long Island ("an island close to New York"). Moreover, Ferri gives the young readers footnotes on some words found in the Italian text, in italics: caffe' concerto ("music-hall"), originale ("the manuscript"), panoplia ("suit of armour"), teosofo ("theosophist") and explanations about boy scouts and British habits and clothes. Ferri also authors the brief introduction, where he states that Wodehouse was a social humorist. To my knowledge, this is the only edition of Wodehouse in which the didactic intent is so obvious. However, as said above with regard to Motti, some translators used footnotes. They were mostly frequently employed, among the translators I have examined, by Campagna-Ponzetto and by Palazzi, whose treatment of instances of intertexuality is compared to four other translations of A Damsel in Distress (1919; GV.19) in Chapter 5 . 


\section{The most modified books}

As we have just seen, editorial policies influence a book's destiny. Among Wodehouse's Italian translations, Poi, tutto si accomoda (1939) and Luna Piena (1954) are instances of the way a whole book can be altered. Both were drastically modified to fit the series in which they were to be published: the "pink" series of Mondadori's Biblioteca Economica. Particularly striking is the treatment of Poi, tutto si accomoda, the translation by Tedeschi of Summer Moonshine (GV.53). Wodehouse is hardly recognisable as a result of the numerous cuts in the text. By multiplying the number of typographical characters per page by the number of pages of both the original and of Poi, tutto si accomoda, I estimate that only $6 \circ \%$ of the text is maintained. The number of chapters (25) is the same; however, there are significant differences in the number of paragraphs in each chapter. A chapter randomly chosen, Chapter 14, contains 45 paragraphs in the English version and only 20 in Italian. A closer analysis reveals that most paragraphs were summarised, with the consequence of omitting most of Wodehouse's humour. The overall outcome is that only the romantic plot is safeguarded; readers miss most of the second plot, the misadventures of an English peer struggling to get rid of the "blasted rural doss-house" he has inherited by selling it. For example, in Chapter 2, the six paragraphs describing him and his attitude toward his ancestral home are omitted. What is lost, in the light of the Epistemic Approach, is not only Wodehouse's linguistic skill, but also information about British society and culture. Similarly, cuts have a consequence on the renderings of Wodehouse's intertextuality and hyper-wording, as this example shows.

\begin{tabular}{|l|c|c|l|c|}
\hline \multicolumn{1}{|c|}{ SOURCE } & YEAR & PAGE & \multicolumn{1}{c|}{ TEXT } & HD/TP \\
\hline $\begin{array}{l}\text { Summer } \\
\text { Moonshine }\end{array}$ & 1938 & 253 & $\begin{array}{l}\text { The comatose peace of the High Street, empty } \\
\text { now except for a Rolls-Royce standing outside } \\
\text { the Blue Boar, a child trundling a tin can along } \\
\text { the pavement with a stick, and a dog making a } \\
\text { light snack off something it had found in the } \\
\text { gutter, filled her with fixed feelings. }\end{array}$ & $\begin{array}{c}\text { Hyper- } \\
\text { wording }\end{array}$ \\
\hline Tedeschi & 1939 & 139 & $\begin{array}{l}\text { La pace comatosa della strada principale ormai } \\
\text { sgombra sconcertò un poco la ragazza. }\end{array}$ & 4 \\
\hline
\end{tabular}

Table 4.22: Classification of the treatment of hyper-wording by Tedeschi

What is obviously lost here is Wodehouse's Hyper-Worded description, since the complex sentence is extremely simplified (HDTP 4); in the light of the model of text activation, however, what is lost is also a 
relevant cue to the plot, since the luxury belongs to one of the characters that will play a major role in the story. Most intertextual references cannot be found in Poi, tutto si accomoda, not even the Dantean quotation "Abandon all hope" (p. 41), lazily and ignorantly rendered "Abbandonate ogni speranza" (p. 22), instead of quoting the original "Lasciate ogni speranza" (Inferno, Canto III, v. 9). Tedeschi also simplified the Italian text, for example, when he translated names of places. For example, "The Goose and Gander" pub is rendered "l'Anitra" ("the duck"). Moreover, highly connotative words, such as "blighter" and "capital chap" (both from p. 321) are rendered by means of HDTP 6 ("Generalisation"), i.e., respectively, "buono a nulla" ("good-for-nothing") (p. 184) and "bravo ragazzo" ("nice guy") (p. 185). Tedeschi's treatment of CSTs confirm his penchant towards domestication (mainly TP III), that I found in other books translated by him (see Appendix 6). The outcome in this instance is that most of the differences that Wodehouse highlights between the British and the American cultures of the time are lost, as is the potential enhancement of Italian readers' knowledge in this respect.

\section{The most prolific translator}

The methodology I apply can be used to investigate a translator's style, especially if we can analyse a substantial number of works. This is the case of Adriana Motti, who translated into Italian fourteen books by Wodehouse (see Appendix 5), as well as works by many other authors. She was the protagonist of a literary sensation in Italy in the 196os with her translation of Salinger's The Catcher in the Rye (1951). Moreover, hers is an interesting case because, by her own admission, when she started her career as a translator she did not know English at all. ${ }^{108}$ Wodehouse's Uncle Dynamite (1948; GV.62) was the first book she translated (Lo zio dinamite, 1949). Already in it, Motti shows her talent in rendering Wodehouse's intertextualities, leitmotifs, and register clashes. Her Italian is rich and versatile. She is particularly gifted in rendering slang with slang, drawing from non-standard Italian. Some examples from Servizio Espresso, (Quick Service, 1940; GV.56), published by Elmo in 1951, are: "pinch" > "grattare" and "snoozed" > "ciucco". In Grullo nel paese delle meraviglie (1953), the only Italian translation of Barmy in Wonderland (1952; GV.66), she employs vernacular words such as "cucuzze" and "patacche" for "money" and "grand". All the above are instances classifiable as HDTP 1. She also uses light-hearted slang to convey, for example, the carefree and dynamic character of Wilhelmina "Bill" Shannon, in The Old

\footnotetext{
${ }^{108}$ La donna che tradusse II Giovane Holden Interview in Wittgenstein, $1^{\text {st }}$ September, 1999; http://www.wittgenstein.it/1999/og/o1/la-donna-che-tradusse-il-giovane-holden/.
} 
Reliable (1951; GV.65). Moreover, she supplied her readers with explanations through unobtrusive footnotes (HDTP 5). For example, in Cocktail Time (1958; GV.72), a Mr Saxby, asks another character, Cosmo Wisdom: "How's your wife?" Cosmo answers that he is a bachelor. Mr Saxby responds: "Then Wordsworth was wrong. He said you were married to immortal verse" (p. 113). Motti translates literally, adding to her readers' knowledge about the source culture, and adds a note, explaining that to get the joke, one must consider the meaning of "wisdom" (Mister I. ci sa fare, 196o, p. 134). In analysing her style, I noticed that she frequently changed her renderings of the same phrase. This is the case, for example, with "dash it". In Qualcosa di losco (1958), her translation of Something Fishy (1957; GV.71), it is translated with "accidenti!", "per tutti i fulmini", "diamine", "corpo di..." and "corbezzoli!" All these are expressions of surprise, drawn from the vast Italian repertoire of utterances. This variety, as a feature of her style, is also remarked by critics of her translation of the Catcher in the Rye (Il giovane Holden, 1961). She rendered Salinger's recurrent expression "and all" by varied expressions, such as "eccetera eccetera", "tutto quanto", "e via discorrendo", "e quel che segue”. Her translations of Wodehouse's books (from 1949 to 1977) reveal that this was a constant characteristic of her style.

\section{Conclusions}

In this chapter, I have shown how the Epistemic Approach is applied to investigate, analyse, and describe items problematic in translation and their renderings. This approach is valuable both as a descriptive and predictive approach to translation, since it allows us to:

1. highlight, analyse and classify which translation procedure each translator has employed to render specific aspects of a text and of an author's style;

2. hypothesise the reasons that made translators opt for one procedure, on the basis of what we know about them and about the target culture of their time.

Moreover, the application of the Epistemic Approach and of its methodology can help researchers in Translation Studies to investigate:

3. in what way the key issues of foreignization, domestication, modernisation, and compensation have been handled by translators. Therefore, it permits us to formulate hypotheses regarding the impact of their choices on the target readership;

4. how an author's style has been reproduced in another language; 
5. the consequences that inadequate knowledge of the Linguistic Codes has on the activation of the text through translation, on its reception, and, ultimately, on the author's reputation;

6. the influence that external factors, such as censorship or editorial policies, may have on the translation of a text in a given historical period;

7. the visibility of the translators' work, based on the paratexts published in a book, e.g. footnotes and translator's notes.

When used to analyse the translations of humorous texts, the method helps researchers to assess:

8. the perception and the production of humour in different cultures;

9. how the perception of humour influences its reproduction in another language;

10. in what way translators tackle problematic linguistic items, such as those posed by sociodialects;

11. what procedures translators employ to compensate for the instances of humour that do not find a straightforward rendering in the target language.

Moreover, when applied to the translated works of an author whose career stretches over many years, as in the case of Wodehouse translated into Italian, the Epistemic Approach may shed light on:

12. the style of a translator or of a number of translators grouped, for example, according to their years of activity or their belonging to the team of a given publisher;

13. in what way various typographic aspects, e.g. italics and footnotes, were dealt with over time;

14. how book titles are translated and why.

In addition, and besides being a tool in the hands of translators, the Epistemic Approach to translation may have a value in Applied Linguistics, for example in foreign language learning and teaching. Its findings may also attract scholars from disciplines engaged in studying human communication, such as psychologists and sociologists. 


\section{CHAPTER 5}

\section{WODEHOUSE AND RETRANSLATION}

As the collection of the 176 Italian translations contained in my database (Appendix 4) shows, Wodehouse was frequently retranslated into Italian. Therefore, the Italian corpus is a valuable source of information for a study on (re)translation. A text can be retranslated in various ways: it can be translated again from the original text in the same target language, or translated from a translation into another language, the so-called relay translations and even back-translated into the source language, a process sometimes called "retro-translation" (Baker \& Saldanha, 20o9, p. 233). In this study, retranslation is meant as "a second or later translation of a single source text into the same target language" (Koskinen \& Paloposki in Gambier \& van Doorslaer, 2010, p. 294). I will, therefore, employ the terms "retranslation" and "retranslating" to refer, respectively, to the product and to the process of translating a text that has already been translated into the same target language; while, following the convention employed by Sharon Deane-Cox (2014), I will use "(re)translation" and "(re)translate" to refer to both initial, i.e. first translations and retranslations proper.

\section{Retranslation and Translation Studies}

Interest in retranslations has been growing since Translation Studies established itself as a new discipline in the 1970s. The first edition of the Routledge Encyclopedia of Translation Studies published in 1998 did not have an entry for "retranslation"; however, the second edition (2009) rectified this through a contribution by Şehnaz Tahir Gürçağlar (in Baker \& Saldanha, 20o9), where she underlines the fact that the most retranslated texts still are sacred, dramatic and literary canonical texts; however, she adds, other kinds of texts, such as retranslations issued by EU institutions, are now given attention (ibid. p. 233).

The current academic debate around retranslation officially started in 1990, with a special issue of Palimpsestes on "Retraduire" edited by Paul Bensimon and Antoine Berman. Their stance, particularly Bensimon's (Bensimon, 1990), was later operationalised by Andrew Chesterman (in Olohan, 20oo, pp. 1527) as the "Retranslation Hypothesis" $(\mathrm{RH})$ and as such referred to hereafter. According to the Retranslation Hypothesis, says Chesterman, "[l]ater translations tend to be closer to the original than the 
earlier ones" (ibid. p. 23). A more articulate rephrasing of the Retranslation Hypothesis that takes into account both Bensimon's and Berman's considerations would read: first translations tend to deviate from the source text more than the subsequent ones since they are more assimilating. Therefore, they show more concern towards issues such as readability and acceptability in the target culture (Gambier, 1994, p. 414). Although it is not formulated as a falsifiable hypothesis, several studies have been designed to test the Retranslation Hypothesis. However, no conclusive results have been reached. For example, Paloposki and Koskinen (2010) maintain that "the strong version of the retranslation hypothesis [...] is not sufficient alone to cover the field of retranslations" (p. 33). The same opinion had already been expressed by Isabelle Desmidt (2009) who states that the Retranslation Hypothesis "clearly does not have a general value" (p. 669).

Several scholars have recently contributed to the debate on the phenomenon of retranslation from different perspectives. Issues connected to retranslation are dealt with in general studies of translation, such as Toury's (1995) and Venuti's (1995). More recent publications prove the growing interest in retranslation. For example, the Handbook of Translation Studies (Gambier \& van Doorslaer, 2010) contains the chapter on retranslation by Koskinen \& Paloposki from which I quoted above; in 2015, Alvstad and Assis Rosa edited a special issue of Target titled "Voice in Retranslation". Moreover, a monograph by Sharon Deane-Cox on selected French literary retranslations that draws from narratology and stylistics and is based on Halliday's (2004) Systemic Functional Grammar, was published in 2014 (Deane-Cox, 2014). Here, I contribute by showing how the Epistemic Approach, underpinned by the model of text activation, may help to shed light on the reasons that motivate retranslations.

\section{Motives for retranslation}

As Susam-Sarajeva (2003) underlines, "retranslations are usually associated with the 'ageing' of translated texts" (p. 2). However, this obvious reason requires a more articulated argumentation. Among the reasons for the retranslation of a text, Şehnaz Tahir Gürçağlar (in Baker \& Saldanha, 2009, pp. 233-236) lists the evolution of translation norms, language changes, the need to modernise or revise a text, or to introduce a new interpretation or a re-orientation, lack of coordination among publishers, and lack of awareness of the existence of a previous translation, as pointed out by Venuti (Venuti, 2004, p. 25). Moreover, in his doctoral dissertation, "Towards a Sociology of Drama Translation: A Bourdieusian Perspective on Translations of Shakespeare's Great Tragedies in Egypt" (2006), Sameh Hanna, drawing 
from Bourdieu's sociology, introduces competition among translators as one of the reasons for retranslation. To those motives, my examination of Wodehouse's Italian translations allows for the addition of competition among publishers. In Italy, this was particular evident in the 1930s when Bietti was competing with Monanni. For example, they both issued a translation of Indiscretions of Archie (1921, GV. 22) in 1931 in the same translation by Pitta. Bietti's version was titled Arcibaldo conquista l'America, meaning "Archibald conquers America", while Monanni's title was the literal translation Indiscrezioni di Arcibaldo. Similarly, The Prince and Betty (1912; GV.10), The Little Nugget (1913; GV.12), and A Damsel in Distress (1919, GV.19) saw simultaneous (re)translations in 1931, again by Monanni and Bietti, a few months apart.

Notwithstanding the richness of the corpus of Italian (re)translations of Wodehouse's works, this chapter is only partially intended as a contribution to the theoretical debate on retranslation; rather, its main purpose is showing the application of my methodology to translations of the same work issued at different times, with the aim of describing the translators' choices and their consequences for the activation of the text, in the light of the Epistemic Approach. The variety revealed by the corpus I collected supports a multi-causal model for retranslation, as does the model of text activation I propose. In agreement with Gürçağlar (in Baker \& Saldanha, 2009), I hold that "retranslations [...] cannot be studied outside their historical context" (p. 236). Therefore, I suggest the application of my model against the various Italian historical, social, and economic backgrounds highlighted in Chapter 1, with a focus on how the choices the translators and the publishers made may have influenced their readerships' KnoW. This allows for a more comprehensive understanding of the phenomenon of retranslation than the one derived from a mere social-causational model, such as those developed in the 199os that Antony Pym described as "generally of the 'toolbox' kind" (Pym, Shlesinger, \& Jettmarová, 2006, p. 1), and that, although sometimes focused on translators, would not take into account all the human factors involved. Moreover, the Epistemic Approach I propose offers ways of appreciating factors relative to the work of different translators, hence the highlighting of the cognitive and creative aspects of translation advocated, for example, by Brisset (2004), who stated: "L'analyse comparative [...] ferait émerger l'acte cognitive, l'acte de créativité du traducteur" (p. 64, emphasis in original) 


\section{Wodehouse retranslated into Italian}

Most of the 87 books by Wodehouse considered in this study were translated more than once $(\mathrm{N}=57$; $66 \%)$. Of these, $5 \%(\mathrm{~N}=3)$ were translated five times, $7 \%(\mathrm{~N}=4)$ were translated four times, $26 \%(\mathrm{~N}=15)$ were translated three times, and $62 \%$ were translated twice. The table below lists the codes of the books and their English titles, grouped according to the number of their (re)translations.

\begin{tabular}{|c|c|c|}
\hline $\begin{array}{l}\text { NUMBER OF } \\
\text { (RE)TRANSLATIONS }\end{array}$ & $\begin{array}{l}\text { NUMBER OF } \\
\text { TITLES }\end{array}$ & CODES (ENGLISH TITLE) \\
\hline 5 & 3 & $\begin{array}{l}\text { GV.o6 (Love Among the Chickens), GV.18 (Piccadilly Jim), GV.19 (A } \\
\text { Damsel in Distress). }\end{array}$ \\
\hline 4 & 4 & $\begin{array}{l}\text { GV.o9 (A Gentleman of Leisure), GV.12 (The Little Nugget), GV.14 } \\
\text { (Psmith Journalist), GV.21 (Jill, the Reckless). }\end{array}$ \\
\hline 3 & 15 & $\begin{array}{l}\text { GV.11 (The Prince and Betty), GV.13 (The Man Upstairs and Other } \\
\text { Stories ), GV.15 (Something Fresh), GV.17 (Uneasy Money), GV.22 } \\
\text { (Indiscretions of Archie ), GV.3o(Carry On, Jeeves), GV.38 (Very } \\
\text { Good, Jeeves), GV.46 (Thank You, Jeeves), GV.54 (The Code of the } \\
\text { Woosters), GV.59 (Joy in the Morning), GV.63 (The Mating } \\
\text { Season), GV.68 (Ring for Jeeves), GV.74 (Jeeves in the Offing), } \\
\text { GV. } 77 \text { (StiffUpper Lip, Jeeves), GV.84 (Much Obliged, Jeeves). }\end{array}$ \\
\hline 2 & 35 & $\begin{array}{l}\text { GV.o5 (The Head of Kay's), GV.o8 (Mike), GV.10 (Psmith in the } \\
\text { City), GV.16 (The Man With Two Left Feet), GV.20 (The Coming of } \\
\text { Bill), GV.24 (The Clicking of Cuthbert), GV.25 (The Adventures of } \\
\text { Sally), GV.26 (The Inimitable Jeeves), GV.29 (Bill the Conqueror), } \\
\text { GV.32 (The Heart of a Goof), GV.33 (Meet Mr Mulliner), GV.34 } \\
\text { (The Small Bachelor), GV.35 (Money for Nothing), GV.36 (Mr } \\
\text { Mulliner Speaking), GV.37 (Summer Lightning), GV.4O (Big } \\
\text { Money), GV.41 (Doctor Sally), GV.42 (Hot Water), GV.44 (Mulliner } \\
\text { Nights), GV.45 (Heavy weather), GV.47 (Right Ho, Jeeves), GV.48 } \\
\text { (Blandings Castle and Elsewhere), GV.50 (Young Men in Spats), } \\
\text { GV.52 (Lord Emsworth and Others), GV.56 (Quick Service), GV.57 } \\
\text { (Eggs, Beans and Crumpets), GV.6o (Full Moon), GV.61 (Spring } \\
\text { Fever), GV.72 (Cocktail Time), GV.73 (A Few Quick Ones), GV.76 } \\
\text { (Service with a Smile), GV.78 (Frozen Assets), GV.79 (Galahad at } \\
\text { Blandings), GV.81 (Do Butlers Burgle Banks?), GV.87 (Aunts Aren't } \\
\text { Gentlemen). }\end{array}$ \\
\hline
\end{tabular}

Table 5.1: Original titles and their codes, grouped according to the number of (re)translations 
Some (re)translations were issued almost at the same time, for example the two editions of GV.o5 (The Head of Kay's, 1905), published by Bietti in $193^{109}$ and in 1933 by Monanni, ${ }^{110}$ These are instances of what Pym (1998, p. 82) terms "active" retranslation, i.e. issued at the same time and in the same place. There are also several examples of "passive” retranslations, in Pym's terminology (ibid.), i.e. retranslations that are chronologically distant. Examples in my corpus are the two Italian translations of Heavy Weather (1933; GV. 45): the first translation was issued by Bietti twice in 1933; ${ }^{111}$ the second one was published by Guanda in $1990 .{ }^{112}$ The chronologically most distant pair in the Italian corpus is the (re)translation of The Inimitable Jeeves (1923, GV.26), whose first version was published by Monanni and by Bietti in the same year (1930) in the same translation by Traverso. More than eighty years elapsed before Polillo published a new translation, by Tracy Lord, in 2010. Since, according to Pym, passive translations "challenge the validity of previous translations" (Pym, 1998, p. 82), their comparison may highlight how their specific realisations of the linguistic norms of their respective times met the readers' expectations and influenced their KnoW about the source culture.

As shown in the table above, three of Wodehouse's titles were translated five times. Multiple (re)translations, again, allow for investigations about modernising and historicising translations (J. S. Holmes, 1988). In addition, they bring evidence of various motives for retranslation, such as competition, readability, and shifts in ideological and political aspects. For this study, the most interesting case is the (re)translation of GV.19 (A Damsel in Distress, 1919) because we also have a manuscript, enabling us to study what the publisher (or the editor) changed.

Given the main aim of this study, I describe and classify here the choices made by the Italian translators of two works, The Inimitable Jeeves (1926, GV.26) and A Damsel in Distress (1919, GV.19). As mentioned above, for the former, we have two editions, published 8o years apart, in 1930 by Monanni ${ }^{113}$ and in 2010 by Polillo. ${ }^{114}$ The latter was translated into Italian five times: two translations issued in 1931, by Monanni ${ }^{15}$ and by Bietti ${ }^{116}$ and authored by Palumbo (Trans A) and Mozzati (Trans B) respectively;

\footnotetext{
${ }^{109}$ Il capo della Kay: romanzo, translated by Palumbo.

${ }^{110}$ Il capo del Kay: romanzo sportivo inglese, translated by Shepley.

${ }^{11}$ Translated by Lampronti. The first edition was printed with a wrong title, e.g. "Acqua pesante" ("Heavy water"): it was not withdrawn; copies are still available in Italian libraries today. The frontespicies of the two editions are reproduced in Appendix 8.

${ }^{112}$ Aria di tempesta, translated by Luigi Spagnol.

${ }^{{ }^{13}}$ L'inimitabile Jeeves, translated by Traverso; later republished by Bietti with the same title in 1933, 1937, 1942, 1949, 1951, 1956, 1960, 1962, 1964, and 1966.

${ }^{114}$ L'inimitabile Jeeves, translated by Lord Tracy; reprinted in 2013, 2014, and 2016.

${ }^{115}$ Una donzella in imbarazzo: romanzo umoristico inglese, 1931; reprinted in 1932.
} 
two published in 1935 by S.A.C.S.E. ${ }^{117}$ and by Lucchi, ${ }^{118}$ authored by Bianchini (Trans C) and by Dàuli (Trans D) respectively and finally one published by Mursia in $1994,{ }^{119}$ authored by Palazzi (Trans E).

One of the short stories contained in The Inimitable Jeeves, i.e. Chapter 13, "The Great Sermon Handicap", was chosen by the American publisher Heinemann for the multi-lingual edition issued in six volumes in $1989 .{ }^{120}$ This means that three Italian translations of this story are available for investigation. I can therefore show how the same instances of Culturally-Specific Terms were rendered in 1930, 1989 and 2010. As for A Damsel in Distress, the 1935 manuscript of one Gian Dàuli's work (Trans D MS) was found in the materials of a printing company kept by Apice ${ }^{121}$ (Archivi della parola e dell'immagine), an institution of the University of Milan. Given the rules of this institution, I could not take pictures of the material. However, I could inspect it on site and take notes of the editor's annotations in it. In line with the tenets of the Epistemic Approach, this allows me to highlight the consequences of editorial interventions on text activation through translation.

In the first section of the chapter, I chiefly focus on how Culturally-Specific Terms were treated in the Italian translations of The Inimitable Jeeves, given the chronological distance between the extant translations, thus mainly addressing the issues of domestication, foreignization and modernisation. I show examples of Italian renderings and classify the translation procedures employed, by means of the list presented in Chapter 4 (Table 4.14). I recall here that Translation Procedures (TP) nos I, II, and V yield more foreignizing translations, while TPs nos III, IV, VI, VII and VIII yield more domesticating ones. ${ }^{122}$ In the second section of the chapter, I exploit the potential of the five Italian translators of $A$ Damsel in Distress to describe the renderings of Wodehouse's Humour Devices, namely (a) instances of intertextuality and (b) similes, thus addressing the issues of compensation and of the untranslatability of humour, and highlighting the relevance of my formula to define Wodehouse's humour from the perspective of the Epistemic Approach. The last section of the chapter shows how the titles of Wodehouse's works were (re)translated into Italian. This survey highlights some aspects of the sales policies of the Italian publishers of Wodehouse from 1928 to the present day.

\footnotetext{
${ }^{116}$ Una signorina in imbarazzo: romanzo umoristico inglese, 1931; reprinted in 1932, 1950,196o,1963,1965, and 1966.

${ }^{117}$ Un capriccio e poi..., 1935; reprinted in the same year under the title of Un matrimonio complicato: romanzo.

${ }^{118}$ Una magnifica avventura: romanzo umoristico, 1939.

${ }^{119}$ Una damigella in pericolo, 1994; later republished with the same title by Guanda (2004) and by TEA (2006).

${ }^{120}$ The cover of the first volume, that includes the Italian version, is reproduced in Appendix Five.

${ }^{121} \mathrm{http}: / /$ www.apice.unimi.it/.

${ }^{122}$ In order to compare a wider range of translators' choices, I will sometimes show renderings of the same item, i.e. a term or a device, from translations of other books by other translators.
} 
Two translations 8o years apart: The Inimitable Jeeves

The Inimitable Jeeves $(1923, \mathrm{GV} .26)$ is a collection of 18 short stories belonging to the Bertie and Jeeves cycle. All the stories had already been published in magazines (The Strand, The Saturday Evening Post and Cosmopolitan) between 1918 and 1922. The stories, slightly altered, although retaining their titles, were collected and published in book form in 1923, both in the UK and in the USA. The book is shaped as a semi-novel, whose theme is Jeeves helping both Bertie and his friend Bingo with their love affairs. Bingo falls in love with seven different girls in succession, while Bertie risks getting engaged to girls chosen for him by his terrifying Aunt Agatha.

The first translation, by Aldo Traverso was first published in 1930 by Monanni, who republished it in 1932; while Bietti published it in the same translation first in 1930 and then again in 1933, 1937, 1942, 1949, 1951, 1956, 196o, 1962, 1964, and 1966 (see footnote 113). In 2010 a second translation appeared, by Tracy Lord, and was published by Polillo, who reprinted it in 2013, 2014 and 2016. The last reprint bears the translator's real name, Leslie Calise.

Both translations are based on the original UK first edition published by Herbert Jenkins, with the titles of the stories listed at the beginning of the book. All Bietti's editions display a table of contents, but Polillo treats the book as a semi-novel, with no ToC. The table below shows how the chapter titles were translated in the two editions.

\begin{tabular}{|c|l|l|l|}
\hline CH. & \multicolumn{1}{|c|}{ ORIGINAL UK TITLE } & \multicolumn{1}{|c|}{ TRAVERSO, 1930 } & \multicolumn{1}{c|}{ LORD, 2O10 } \\
\hline 1 & $\begin{array}{l}\text { Jeeves Exerts the Old } \\
\text { Cerebellum }\end{array}$ & Il cerebro di Jeeves lavora & Jeeves fa lavorare il cervello \\
\hline 2 & No Wedding Bells for Bingo & $\begin{array}{l}\text { Le campane nunziali non } \\
\text { vogliono sonare }\end{array}$ & $\begin{array}{l}\text { Niente campane a nozze per } \\
\text { Bingo }\end{array}$ \\
\hline 3 & Aunt Agatha Speaks her Mind & Zia Agatha comanda & Zia Agatha parla chiaro \\
\hline 4 & Pearls Mean Tears & Perle che portano lacrime & Le perle portano lacrime \\
\hline 5 & $\begin{array}{l}\text { The Pride of the Woosters is } \\
\text { Wounded }\end{array}$ & L'orgoglio dei Woosters ferito & $\begin{array}{l}\text { L'orgoglio dei Wooster viene } \\
\text { ferito }\end{array}$ \\
\hline 7 & Introducing Claude and Eustace & $\begin{array}{l}\text { Presentazione di Claude ed } \\
\text { Eustace }\end{array}$ & $\begin{array}{l}\text { Vi presento Claude ed } \\
\text { Eustace }\end{array}$ \\
\hline
\end{tabular}




\begin{tabular}{|c|l|l|l|}
\hline 8 & Sir Roderick Comes to Lunch & Sir Roderick a colazione & A pranzo con Sir Roderick \\
\hline 9 & A letter of Introduction & Una lettera di presentazione & Una lettera di presentazione \\
\hline 10 & $\begin{array}{l}\text { Startling Dressiness of a Lift } \\
\text { Attendant }\end{array}$ & $\begin{array}{l}\text { Le scarpe rosse fanno un cuore } \\
\text { felice }\end{array}$ & $\begin{array}{l}\text { La sorprendente eleganza di } \\
\text { un ascensorista }\end{array}$ \\
\hline 11 & Comrade Bingo & Il «Collega» Bingo & Il compagno Bingo \\
\hline 12 & Bingo has a Bad Goodwood & Le finanze di Bingo vanno male & La sfortuna di Bingo \\
\hline 13 & The Great Sermon Handicap & L' «handicap» delle prediche & $\begin{array}{l}\text { La gara handicap del } \\
\text { sermone }\end{array}$ \\
\hline 14 & The Purity of the Turf & L'ingenuità agreste & Il mondo puro delle corse \\
\hline 15 & The Metropolitan Touch & Il gusto cittadino & Il gusto metropolitano \\
\hline 16 & $\begin{array}{l}\text { The Delayed Exit of Claude and } \\
\text { Eustace }\end{array}$ & $\begin{array}{l}\text { La partenza di Claude e } \\
\text { d'Eustace }\end{array}$ & $\begin{array}{l}\text { La partenza ritardata di } \\
\text { Claude ed Eustace }\end{array}$ \\
\hline 17 & Bingo and The Little Woman & Bingo e la donnina & Bingo e la donnina \\
\hline 18 & All's Well & Tutto finisce bene & Tutto finisce bene \\
\hline
\end{tabular}

Table 5.2: Italian translations of the chapters of The Inimitable Jeeves (GV.26) by Traverso and Lord

Four titles are identical. Some are very similar, and the utterances are not significant for tone or style. But both slight and considerable differences are found in others. For example, while Traverso's translation of the title of chapter 1 retains the scientific register of the original text ("cerebellum" > "cerebro"), Lord's "cervello" just translates "brain". It is worth noting that neither translator attempts a rendering for "old" connected to a part of the body, a characteristic of Bertie's idiolect about which more will be said later. The two translations of the title of Chapter 14 differ greatly. Lord's translation, whose backtranslation reads: "The pure world of racing" (TP III) keeps the reference to sports, implied in one of the possible meanings of the English word "turf", i.e. a race held on a track covered in sports grass, whereas Traverso focused to another meaning of "turf", i.e. "grass" or "lawn" and translated the title as "Rural naivety". Since the story is set against the events at a village fair on which the protagonists take bets, I classified Traverso's choice as TP V and not O (lack of KnoLC) since it somehow manages to suggest the contents of the plot. Some discrepancies between the renderings of titles are ascribable to differences in usage in Italian, such as "colazione" and "pranzo" respectively employed by Traverso and by Lord to translate 
"lunch" in the title of chapter 8: "colazione" should be employed to translate "breakfast", ${ }^{123}$ however in Italy "colazione" is also sometimes affectedly used to refer to the midday meal, instead of the more appropriate "pranzo" (Nesi, 2013). Moreover, Bietti's edition employs guillemets to signal that a word is either foreign ("handicap") or employed in an unusual way. The word "comrade" in chapter 11 posed a problem for Traverso, who was working during the fascist era. He could have chosen between "camerata", close to "comrade" and "compagno", functionally equivalent to "comrade", since it referred to members of the communist party. Both terms were therefore taboo for Traverso. He was forced to resort to the more general form of "collega", which translates as "colleague", and may be considered a synonym of "compagno"124 but without carrying any political connotation. After fascism, the term "compagno" was freed again and it was employed in this sense by Giovanni Guareschi in his Don Camillo stories. ${ }^{125}$ Another interesting difference is found in the title, as well as in the text, of chapter 10. Here, and in the previous chapter, the sub-plot revolves around Bertie's favouring a pair of purple socks that do not have Jeeves's approval. Throughout the text, Traverso refers to them as a pair of red shoes instead. For no apparent reason, they are also mentioned in Bietti's title, whose backtranslation reads: "Red shoes make a heart happy", while Lord's is a word-for-word translation. In Traverso's times even an indirect reference to feet was still considered an instance of bad taste and had to be removed at any cost. The cost here was the alteration of the plot and the puzzling of the readers when they learn that Jeeves "lugged them out of the drawer as if he were a vegetarian fishing a caterpillar out of the salad" (p. 465), literally translated by Traverso as "le tirò fuori dal cassetto, come se fosse stato un vegetariano che stesse togliendo un bruco dal suo piatto di insalata" (p. 118).

These last two examples are particularly interesting in the light of the model of text activation, since they show how political and social pressure on translation may force a translator to alter a text and possibly jeopardise its author's reputation. Moreover, they also demonstrate Bietti's indifference towards his readers. As said, he reprinted the same text ten times between 1934 and 1966. Even after the end of the regime and when the public sensibility had changed, he did not amend the text. While I was inspecting his editions, I noticed the same printing defects, such as stains, and I realised that he kept on using the same plates. Moreover, Traverso's polished wording, his use of "Voi" also when characters are

\footnotetext{
${ }^{123}$ See: http://dizionari.corriere.it/dizionario-si-dice/C/colazione-pranzo.shtml.

${ }^{124}$ See: http://www.treccani.it/vocabolario/collega/.

${ }^{125}$ See, for example, Mondo Piccolo: Il Compagno Don Camillo, Rizzoli, 1963. First published in UK by Victor Gollancz, in 1964 in Frances Frenaye's translation, as Comrade Don Camillo.
} 
addressing children, his erudite phrasing in rendering everybody's speech and even Bertie's informal slang certainly made his version out of date already in the 1950s.

Since all the stories in The Inimitable Jeeves are told in the first person by Bertie, they exhibit many instances of his idiosyncratic use of abbreviations, of his burlesque upper-class slang and of his typical parlance, including the use of definite article "the" referring to parts of the body, in contrast with the standard usage of employing possessive adjectives. Examples are: the already mentioned "metrop." for London; "give [...] the pip", Edwardian slang for "irritate", and "the old lemon", Bertie's self-deprecating way of referring to his not very brilliant brain. Bertie's slang deserves attention in a study on translation, since it carries several interesting connotations. It reveals Bertie's being mundane and narrow minded. Moreover, it challenges translators as it is drawn from an Edwardian society that, if it ever existed, did so in a timeless pre-Depression-era England very distant from Italy both in the 193os and even more in the twenty-first century. Another characteristic of the language employed in the Jeeves and Bertie cycle is shown in the exchanges between the eternally idle Bertie and his trustworthy knowledgeable valet. In the following sections, after showing how Culturally-Specific Terms were translated into Italian 8o years apart, I will also focus on some of Wodehouse's Humour Devices contained in The Inimitable Jeeves, namely register clash in the exchanges between Bertie and Jeeves, the use of abbreviations for one of Wodehouse's leitmotifs as an instance of "endearment", and Wodehouse's inventiveness in creating new words.

Culturally-Specific Terms in The Inimitable Jeeves

"The Great Sermon Handicap", is the thirteenth story in the book. Probably because of its masterfully crafted plot and its originality, in addition to the role of deus ex machina of a Jeeves in mid-season form, it was described by Usborne (1981, p. 37) as "one for the anthologies". Like all the others, it is told by Bertie in the first person. This time, Bertie tells us in the opening paragraphs of the story (pp. 489-499), since London, i.e. "the metrop.", in Bertie's words, gives him "the pip" in August, he and Jeeves "shift-ho" to a place in the country, Twing Hall. The place belongs to Lord Wickhammersley, a "great pal" of Bertie's "guv'nor's" when he was alive and Bertie has "a standing invitation to pop down there" when he likes. Bertie's friend's Bingo, broken again after "a bad Goodwood", is spending the summer at the hall, tutoring Lord Wickhammersley's young son, while Bertie's twin cousins, twice defined by Jeeves as "very highspirited young gentlemen" (p. 499 and 550) and "undeniable blisters" by Bertie (p. 550), are there, too, 
being tutored by the vicar. Since they are bored and resent "sweating up the Classics when it's a hundred in the shade" (p. 505), they set a book to bet on which of the many parsons of the neighbourhood will preach the longest sermon "tomorrow week - Sunday the twenty-third" (ibid.). They easily convince Bertie to finance the betting syndicate, since neither of them has "a bean" (p. 506). As usual, Bertie gets engaged in complicate manoeuvres to influence the race. Needless to say, Jeeves places the only winning bet in the handicap.

The story contains a great number of Culturally-Specific Terms, mainly derived from the world of betting and horseracing, very likely to challenge translators. For example, the preachers are referred to as the "starters", and the favourite is the bookies' "nominee". When one of the "starters" catches a cold, he is said to have been "coughing in his stable all last night": he will soon be "officially scratched out" by his doctor, i.e. he will have to withdraw. Another one is observed making a "fine trial gallop" at a mothers' meeting a few days before the handicap. There are even official "stewards"126 observing the handicap. Bertie rides ten miles on a bicycle to attend the syndicate's "nominee" and must admit that he is "a stayer" ${ }^{127}$ All the characters are at ease with the lexicon typical of betting. Examples are: ante-post betting, and, since he has got "inside information", Jeeves's inevitable "SP job: ${ }^{128}$ "I believe that is the technical term, sir". Being able to render the clash between dignified preaching and horse racing entails the ability to handle the jargon.

The Heinemann's 1989 edition contains this story translated into 57 different languages and phonetic English. The Italian version, by Olga Ragusa, ${ }^{129}$ is found in Volume 1. Hence, we can compare the renderings of the sporting jargon by three Italian translators, as shown in the table below.

\footnotetext{
${ }^{126}$ Officials in overall charge of a race meeting.

${ }^{127}$ A horse that specialises in racing over long distances.

${ }^{128} \mathrm{SP}$ is abbreviation for "Starting price", a bet placed at the odds current when the race starts, with the advantage of never losing one's money in case the horse is withdrawn. A technical explanation is found at: http://www.betting-explained.com/starting-price-bet-explained/.

${ }^{129}$ Olga Ragusa, now Da Ponte Professor Emeritus at Columbia University, New York, moved to the USA with her family in 1931. She pursued an academic career and in 1963 became a member of the Italian department at Columbia. She also was the editor-in-chief of the journal Italica from 1968 to 1984.The daughter of a German mother and an Italian father, she wrote about her father's activity as a bookseller and publisher both in Italy and in the USA. Together with her sister, she took over his bookshop after his death. The historical bookshop has recently hosted the Centro Primo Levi in New York. See: http://primolevicenter.org/printed-matter/conversation-witholga-ragusa/.
} 


\begin{tabular}{|c|c|c|c|c|c|c|c|c|c|c|}
\hline GV 26 & PAGE & $\begin{array}{c}\text { TRAVERSO } \\
1930\end{array}$ & PAGE & $\mathrm{TP}$ & $\begin{array}{c}\text { RAGUSA } \\
1989\end{array}$ & PAGE & $\mathrm{TP}$ & $\begin{array}{l}\text { LORD } \\
2010\end{array}$ & PAGE & $\mathrm{TP}$ \\
\hline scratch & 500 & $\begin{array}{l}\text { senza } \\
\text { handicap }\end{array}$ & 178 & III & eliminato & 91 & $\mathrm{O}$ & $\begin{array}{l}\text { nessun } \\
\text { handicap }\end{array}$ & 148 & III \\
\hline punters & 507 & puntatori & 191 & III & giocatori & 98 & III & scommettitori & $15^{8}$ & III \\
\hline starter & 507 & starter & 192 & I & corridore & 98 & II & concorrente & 159 & III \\
\hline $\begin{array}{l}\text { dark } \\
\text { horse }\end{array}$ & $5 \circ 7$ & [omitted] & $192^{*}$ & VIII & acqua cheta & 98 & V & outsider & 159 & VII \\
\hline nominee & 508 & favorito & 193 & III & candidato & 99 & II & favorito & 159 & III \\
\hline $\begin{array}{l}\text { ante-post } \\
\text { betting }\end{array}$ & $5 \circ 9$ & $\begin{array}{l}\text { scommesse } \\
\text { troppo } \\
\text { anticipate } \\
\end{array}$ & 194 & V & $\begin{array}{l}\text { scommesse } \\
\text { anticipate }\end{array}$ & 100 & II & $\begin{array}{l}\text { scommesse } \\
\text { troppo } \\
\text { anticipate }\end{array}$ & 161 & $\mathrm{~V}$ \\
\hline SP & $5 \circ 9$ & [paraphrase] & $195^{*}$ & V & $\begin{array}{l}\text { scommesse } \\
\text { alla partenza }\end{array}$ & 100 & III & $\begin{array}{l}\text { al momento } \\
\text { della partenza } \\
\text { della corsa }\end{array}$ & 161 & IV \\
\hline $\begin{array}{l}\text { the odds } \\
\text { shortened }\end{array}$ & 510 & $\begin{array}{l}\text { il vantaggio è } \\
\text { stato } \\
\text { diminuito }\end{array}$ & 196 & III & $\begin{array}{l}\text { le quotazioni } \\
\text { si sono } \\
\text { contratte }\end{array}$ & 100 & II & la quota è scesa & 162 & II \\
\hline $\begin{array}{l}\text { scratched } \\
\text { by the } \\
\text { doctor }\end{array}$ & 510 & $\begin{array}{l}\text { cancellato } \\
\text { dalla lista }\end{array}$ & 196 & IV & $\begin{array}{l}\text { ufficialmente } \\
\text { eliminato }\end{array}$ & 101 & III & $\begin{array}{l}\text { cancellato dalla } \\
\text { lista }\end{array}$ & 162 & IV \\
\hline $\begin{array}{l}\text { trial } \\
\text { gallop }\end{array}$ & 510 & $\begin{array}{l}\text { galoppo } \\
\text { finale }\end{array}$ & 196 & $\mathrm{O}$ & $\begin{array}{l}\text { galoppata di } \\
\text { collaudo }\end{array}$ & 101 & II & $\begin{array}{l}\text { insolitamente } \\
\text { in forma }\end{array}$ & 163 & $\mathrm{~V}$ \\
\hline stayer & 510 & bontà & 196 & IV & $\begin{array}{l}\text { tenacia } \\
\text { nell'ultimo } \\
\text { tratto }\end{array}$ & 102 & III & resistenza & 164 & III \\
\hline $\begin{array}{l}\text { home } \\
\text { stretch }\end{array}$ & $5^{11}$ & partenza & 196 & $\mathrm{O}$ & ultimo tratto & 102 & IV & $\begin{array}{l}\text { dirittura } \\
\text { d'arrivo }\end{array}$ & 164 & III \\
\hline $\begin{array}{l}\text { romps } \\
\text { home }\end{array}$ & $5^{11}$ & va benissimo & 197 & IV & $\begin{array}{l}\text { vince senza } \\
\text { difficoltà }\end{array}$ & 102 & III & $\begin{array}{l}\text { vince } \\
\text { facilmente }\end{array}$ & 164 & III \\
\hline tenner & $5^{11}$ & decino & 198 & III & dieci sterline & 102 & IV & dieci sterline & 164 & IV \\
\hline
\end{tabular}

Table 5.3: Italian renderings of Culturally-Specific Terms from the worlds of betting and horse-racing by Traverso, Ragusa and Lord

The comparison of some of the renderings of the CSTs shows that:

1. notwithstanding the difficulty in rendering some of the terms, e.g. "SP" or "stayer" no translators employed TP VI, i.e. explanation, for example by means of a footnote; the onus of appreciating the parallelism between vicars preaching long sermons and the world of horse-racing is entirely left to the readership. Seen in this light, Italian renderings are foreignizing, since Italian readers were treated like those of the original text; 
2. Traverso's translation is more assimilating. Evidence is found in the fact that, although he sometimes kept the English term, this was printed in italics, a convention used in Italy to indicate that the foreign word is not in current use;

3. Ragusa and Lord correctly, however differently, rendered "home stretch", while Traverso, misreading the episode in which the term was employed, interpreted "home" as "starting post" and rendered it accordingly; this is evidence of how inaccurate inferences drawn from the context, by influencing translating choices, yield inaccurate translations.

Apart from being drawn from horse racing and betting, the Culturally-Specific Terms in the story also belong to the environmental, ethnographic, behavioural, and linguistic categories.

An example of environmental CSTs are the reference to "Goodwood" right at the beginning of the story: "After Goodwood's over" (p. 488). By "Goodwood" Bertie means the Goodwood Cup, the horse race established in 1808 at Goodwood, near the city of Chichester in West Sussex, still held every year between the end of July and the beginning of August. ${ }^{130}$ As usual, Bertie's reference is casual, obviously addressed to a knowledgeable model reader. There is no need for him to specify further, for example adding "racecourse" or "Cup" to be understood by his readers. Things may be different with foreigners, probably not familiar with British horseracing. Therefore, Italian translators should have helped their readers' inferencing process by rendering the CST in a way suggesting its wider meaning. Traverso (1930, p. 175) rendered it "finite le corse di Goodwood" (TP V, Intervention), meaning "once the Goodwood races are over", Ragusa (1989) translated word-for-word, i.e. "passato Goodwood" (p. 89, TP I, Transcription), whereas Lord (2010) rendered it by "Goodwood Cup", thus employing TPs I and V combined, i.e. Transcription and Intervention. It must be added that both Traverso and Lord and their readers benefited from having already read the previous story, "Bingo has a Bad Goodwood" in which "comrade" Bingo had been demasked at the Goodwood races. Possibly, Ragusa was not familiar with this story and with the CST itself. This lack of knowledge influenced her rendering and left her Italian readers in the dark about what "Goodwood" exactly is.

\footnotetext{
${ }^{130}$ See: https://www.goodwood.com/sports/horseracing/.
} 
Another instance of environmental CTS is "a hundred in the shade" (p. 505) where the reference is Fahrenheit scale commonly used in the UK until the $1960 .{ }^{131}$ Italy uses the Celsius scale, therefore Ragusa's rendering "quaranta gradi all'ombra", meaning "forty degrees in the shade" is an instance of TP III (Functional Equivalence), since $100^{\circ} \mathrm{F}$ corresponds roughly to $38^{\circ} \mathrm{C}$, a considerably high temperature also according to Italian standards. On the contrary, Traverso and Lord employed TP II (Formal Equivalence) keeping "one hundred" in their translations ("cento gradi"). The result of their choice is a hyperbolic phrase suggesting unbearable heat. Readers aware of the employment of the Fahrenheit scale in England in the 1930s might recognize, however, an instance of what James S. Holmes (1988, p. 48) terms "historicising translation". I prefer the term "preserving" to highlight the nature of this choice of maintaining a CST as close as possible to the original to evoke the original ambiance and the patina of its age, sometimes favoured in (re)translations issued several years after the source text was written. In my classification, I label this choice as an instance of TP II (Formal Equivalence) whose consequence is foreignization, hence potentially enhancing the readers' KnoW about the source culture. This is a choice that Lord sometimes followed, while Traverso favoured TP III (Functional Equivalence), as other renderings shown in the following pages confirm.

The Inimitable Jeeves contains many CSTs belong to the ethnographic category. The two tables below show the treatments of two proper nouns.

\begin{tabular}{|l|c|c|l|c|}
\hline \multicolumn{1}{|c|}{ SOURCE } & YEAR & PAGE & \multicolumn{1}{|c|}{ TEXT } & CST/TP \\
\hline The Inimitable Jeeves & 1923 & 499 & He got $m e$ through Smalls & ETH \\
\hline Traverso & 1930 & 177 & Mi ha fatto promuovere agli esami & IV \\
\hline Ragusa & 1989 & 90 & È riuscito a fare superare gli esami di Smalls a $m e$ & O \\
\hline Lord & 2010 & 146 & Ha fatto superare gli esami persino a $m e$ & IV \\
\hline
\end{tabular}

Table 5.4: Italian renderings of "Smalls" by Traverso, Ragusa and Lord

Here, Bertie uses the student term for "Responsions", the first of the university exams in Greek, Latin, Logic, and Geometry that Oxford undergraduates had to pass to qualify for a Bachelor Degree (Brockliss, 2016, p. 367). Traverso and Lord chose to eliminate the ethnographic reference and to "generalise" (TP IV), i.e. they employed a more general term to refer to any exam, rather that the Oxford ones. On the

\footnotetext{
${ }^{131}$ https://en.wikipedia.org/wiki/Fahrenheit.
} 
contrary, Ragusa kept the proper noun and translated as if "Smalls" were a person. Her choice does not add anything to her readers' KnoW, rather, since no clues are offered, readers are likely to be puzzled.

\begin{tabular}{|l|c|c|l|c|}
\hline \multicolumn{1}{|c|}{ SOURCE } & YEAR & PAGE & \multicolumn{1}{|c|}{ TEXT } & CST/TP \\
\hline The Inimitable Jeeves & 1923 & 506 & Smile's SelfHelp & ETH \\
\hline Traverso & 1930 & 190 & Chi s'aiuta Dio l'aiuta dello Smiles & III \\
\hline Ragusa & 1989 & 97 & Manuale di «far da sé» & IV \\
\hline Lord & 2010 & 157 & Manuale Smile di Self-Help & II \\
\hline
\end{tabular}

Table 5.5: Italian renderings of "Smile's Self Help" by Traverso, Ragusa and Lord

Here, the CST refers to a published book, Self-Help by Samuel Smile. An Italian version had been published in Italy in 1865 , translated by Gustavo Stafforello. ${ }^{132} \mathrm{~A}$ new translation by Cesare Donati appeared in 1871. Both editions were extremely successful and were reprinted several times. The book, whose Italian title means "God helps those who help themselves", was quoted in speeches and writings by the Italian scholar and senator Michele Lessona (1823-1894) and is still available today in public libraries. Apparently, only Traverso was aware of the Italian version since he cites its title correctly in his version. On the contrary, Lord translated the title of the work literally, without checking if such a book really exists in Italy; while Ragusa chose to use a hypernym, "a self-help manual". Her choice is however misleading, since "far da sé" usually means “D.I.Y." in Italian.

Another example of ethnographic CST is found in chapter 9 of The Inimitable Jeeves, "A Letter of Introduction" for which we only have two translations.

\begin{tabular}{|l|c|c|l|c|}
\hline \multicolumn{1}{|c|}{ SOURCE } & YEAR & PAGE & \multicolumn{1}{|c|}{ TEXT } & CST/TP \\
\hline The Inimitable Jeeves & 1923 & 472 & $\begin{array}{l}\text { I had a kind of feeling that I was about as } \\
\text { popular with him as a cold Welsh rarebit }\end{array}$ & ETH \\
\hline Traverso & 1930 & 129 & $\begin{array}{l}\text { Sentivo, in certo modo, che per lui non valevo } \\
\text { molto di più d'un coniglio gallese }\end{array}$ & O \\
\hline Lord & 2010 & 108 & $\begin{array}{l}\text { Avevo la vaga sensazione di piacergli quanto un } \\
\text { pezzo di pane raffermo }\end{array}$ & IV \\
\hline
\end{tabular}

Table 5.6: Italian renderings of "Welsh rarebit" by Traverso and Lord

\footnotetext{
${ }^{132}$ Samuel Smiles, Chi si aiuta Dio l'aiuta, ovvero Storia degli uomini che dal nulla seppero innalzarsi ai più alti gradi in tutti i rami della umana attività, traduzione dall'originale inglese da S. Strafforello con note, Milano, Editori della biblioteca utile, 1865 . Reprinted in 1870, 1872, 1874 and 1878. Donati's retranslation was first published by Treves Editore in 1871 and reprinted 73 times in 50 years (Turi \& Palazzolo, 1997, p. 130).
} 
A Welsh rarebit is a traditional dish from Wales, a hot cheese sauce spread on toast. Neither translator knows how to offer an Italian name for this recipe. Ragusa translates "rarebit" as "rabbit" ("coniglio") and ignores the adjective "cold"; hence, the meaning of the sentence is altered and she leaves her readers to try to infer it. On the other hand, Lord's version makes apparent that she had inferred the reference to a food and generalised, i.e. she translated, functionally, as "a piece of stale bread" that renders the metaphor employed by Wodehouse, without actually adding anything about the source culture.

The co-protagonist of The Inimitable Jeeves is Bertie's friend Bingo Little who has a romantic nature and often resorts to Jeeves's help. When the two friends meet, Bertie addresses Bingo in his usual way. The tale below describes how the three Italian translators treated his greeting.

\begin{tabular}{|l|c|c|l|c|}
\hline \multicolumn{1}{|c|}{ SOURCE } & YEAR & PAGE & \multicolumn{1}{|c|}{ TEXT } & CST/TP \\
\hline The Inimitable Jeeves & 1923 & 502 & "Hallo, old scream" & BEH \\
\hline Traverso & 1930 & 183 & - Ehi, vecchio mio! & IV \\
\hline Ragusa & 1989 & 93 & «Ciao, buffone» & III \\
\hline Lord & 2010 & 151 & «Ehilà, vecchia sagoma!» & III \\
\hline
\end{tabular}

Table 5.7: Italian renderings of "Hallo, old scream" by Traverso, Ragusa and Lord

Ragusa and Lord render the slightly offensive connotation of Bertie's informal greeting, whose backtranslations read, respectively: "Hallo, clown" and "Hey there, old scream!"; while Traverso just employs an informal greeting between friends, meaning "Hey, old man".

Elsewhere in The Inimitable Jeeves, two other Wodehousian greetings appear: "Pip-pip" and "What ho".

\begin{tabular}{|l|c|c|l|c|}
\hline \multicolumn{1}{|c|}{ SOURCE } & YEAR & PAGE & \multicolumn{1}{|c|}{ TEXT } & CST/TP \\
\hline The Inimitable Jeeves & 1923 & 468 & Well, pip-pip! & BEH \\
\hline Traverso & 1930 & 125 & Ebbene, addio. & IV \\
\hline Lord & 2010 & 104 & Be', alla prossima! & IV \\
\hline
\end{tabular}

Table 5.8: Italian renderings of "Pip-pip" by Traverso and Lord

As reported in Chapter 4, the informal greeting "pip-pip", meaning "good bye", originated with an imitation of the sound of a car or a bicycle horn. There is no corresponding expression in Italian; therefore, translators must choose among the various greetings Italian offers. Both versions simply render the correspondence to "good bye" implied in "Pip-pip", without suggesting any informal nor vernacular connotation. 
“What ho!", roughly equivalent to "Hi, there!", is one of Wodehouse's most renowned greetings. The Oxford English Dictionary classifies it as (1) an exclamation used to call the attention of a person and (b) an expression of excitement or exultation. Obsolete nowadays, in Wodehouse it is mainly employed by the Drones, and by Bertie in particular, but is also found in stories belonging to other cycles, such as Piccadily Jim (one occurrence), Mike (two occurrences) and A Gentleman of Leisure (three occurrences). ${ }^{133}$ In Carry On, Jeeves (GV.30; 1925, p. 464) one can read this whimsical dialogue, containing seven occurrences of "What ho!".

'What ho!' I said.

'What ho!' said Motty.

'What ho! What ho!'

'What ho! What ho! What ho!'

After that it seemed rather difficult to go on with the conversation.

The table below shows how this greeting was rendered by Spaventa Filippi, Italian translator who authored the first Italian translation.

\begin{tabular}{|l|c|l|c|}
\hline \multicolumn{1}{|c|}{ CARRY ON, JEEVES } & PAGE & \multicolumn{1}{c|}{ SPAVENTA FILIPPI } & PAGE \\
\hline What ho! Without there? & 459 & Ehi, che c’è fuori? & 58 \\
\hline What ho! (7 times) & 464 & Ehi! (7 times) & 66 \\
\hline Tra-la! What ho! & 465 & Tralla-là [OMITTED] & 67 \\
\hline “What Ho!" said Bicky. "All right, then." & 490 & $\begin{array}{l}\text { D'accordo allora, - disse Bicchio - } \\
\text { Benissimo. }\end{array}$ & 102 \\
\hline What ho? & 595 & Che fare? & 595 \\
\hline
\end{tabular}

Table 5.9: Italian renderings of "What-ho" by Spaventa Filippi

Judging from the use that Wodehouse makes of it, "What ho" seems to be something more than just an informal greeting. For example, as Mark Hodson remarks, ${ }^{134}$ the interjection "What ho! Without there" was a cliché of historical fiction. Hodson reports that there are examples of it in Scott's Kenilworth (1821), Gilbert and Sullivan's "Utopia Limited" (1893), and Edgar Rice Burroughs The Outlaw of Torn (1927) and that he even found it in a play dating back to 1731, "The London Merchand" by George Lillo (1693-1739). I

\footnotetext{
${ }^{133}$ It is so naturally linked to Wodehouse that What Ho! is the title given to a collection of stories published in 2011 by Random House. It is subtitled "The best of Wodehouse" and contains a long introduction by Stephen Fry, the actor who played Jeeves in the ITV series "Jeeves and Bertie", aired from 1990 to 1993.

${ }^{134}$ See: http://www.madameulalie.org/annots/pgwbooks/pgwcojı.html.
} 
also found an example in another play by the same author in the same year: "What ho! Without there? Who waits?" (Lillo, 1731, p. 196). In the other cases, "What ho" is either used as a greeting or to express agreement. The last occurrence in table 5.9 is in fact a question, employed to express puzzlement, adequately rendered by Spaventa Filippi, as "What shall we do?". Spaventa Filippi's translations prove that he appreciated the function the phrase had in each occurrence. Only once he omits to translate it. In all other cases, his renderings are instances of Functional Equivalence (Technique III).

In The Inimitable Jeeves, "What ho!" is found in chapter 12 "Bingo has a Bad Goodwood".

\begin{tabular}{|l|c|c|l|c|}
\hline \multicolumn{1}{|c|}{ SOURCE } & YEAR & PAGE & \multicolumn{1}{c|}{ TEXT } & CST/TP \\
\hline The Inimitable Jeeves & 1923 & 491 & What ho! & BEH \\
\hline Traverso & 1930 & 162 & Oh! & I \\
\hline Lord & 2010 & 135 & Ehilà! & III \\
\hline
\end{tabular}

Table 5.10: Italian renderings of "What ho!" by Traverso and Lord

Traverso and Lord attempt to render the exclamatory connotation of the greeting employed here; however, Lord uses the same phrase, meaning "Hey there!" she employed to translate "Hallo", elsewhere in the Jeeves canon (see, for example, Table 5.7, p. 214).

As said, Bertie and his young, easy-going friends, the Drones, employ phrases and idioms in use during the Edwardian age. The two tables below show the renderings of two idiomatic expressions, with roughly the same meaning. Today, both expressions have obscene connotations; in Bertie's times, the first one meant "'to hiss someone like a goose"; while the other one was used to express disapproval. However, in the first example here, by "you gave me the bird", Bertie means "you told me to get lost".

\begin{tabular}{|l|c|c|l|c|}
\hline \multicolumn{1}{|c|}{ SOURCE } & YEAR & PAGE & \multicolumn{1}{c|}{ TEXT } & CST/TP \\
\hline The Inimitable Jeeves & 1923 & 502 & “[...] you gave me the bird.” & LIN \\
\hline Traverso & 1930 & 182 & $-[\ldots]$ mi avete piantato. & III \\
\hline Ragusa & 1989 & 93 & «[...] mi hai piantato.» & III \\
\hline Lord & 2010 & 151 & «[...] mi mandasti al diavolo & III \\
\hline
\end{tabular}

Table 5.11: Italian renderings of "give the bird" by Traverso, Ragusa and Lord 


\begin{tabular}{|l|c|c|l|c|}
\hline \multicolumn{1}{|c|}{ SOURCE } & YEAR & PAGE & \multicolumn{1}{c|}{ TEXT } & CST/TP \\
\hline The Inimitable Jeeves & 1923 & 503 & {$[\ldots]$ she had given him the raspberry. } & LIN \\
\hline Traverso & 1930 & 184 & {$[\ldots]$ era stato piantato. } & III \\
\hline Ragusa & 1989 & 94 & E l'aveva piantato. & III \\
\hline Lord & 2010 & $15^{2}$ & Lei gli aveva dato il benservito & IV \\
\hline
\end{tabular}

Table 5.12: Italian renderings of "give the raspberry" by Traverso, Ragusa and Lord

Almost always, Italian translators appreciated the informal connotation of both expressions and rendered them adequately. Traverso and Ragusa employed the same verb "piantare", meaning "to plant" that is a common slang expression, meaning "to dumpen somebody". The expression Lord chose in her first rendering means "you told me to go to the devil". However, in her rendering of 'raspberry', she generalised by employing an expression not specifically employed for a love affair, that means in English "to give somebody the sack".

Adding "old" to almost any word is common in the parlance of Wodehouse's world, usually used affectionately. "Old boy" and "old chap" are quite well-known monikers for friends. Then there are the lesser known "old horse" and "old bean". "Old bean" is different from the others, however, as it has another meaning beyond the one referring to a person. Bertie Wooster often refers to his own brain as "the old bean", and similar expressions, such as "the old lemon", in a very self-deprecating manner.

\begin{tabular}{|c|c|c|c|c|c|c|c|}
\hline PHRASE & PAGE & TRAVERSO, 1930 & PAGE & TP & LORD, 2010 & PAGE & $\mathrm{TP}$ \\
\hline the old lemon & 407 & $\begin{array}{l}\text { egli s'annuvolava } \\
\text { tutto }\end{array}$ & 17 & $\mathrm{O}$ & $\begin{array}{l}\text { il fesso si era un po' } \\
\text { rannuvolato }\end{array}$ & 13 & $\mathrm{O}$ \\
\hline off his onion & 451 & squilibrato & 94 & IV & fuori di testa & 78 & III \\
\hline $\begin{array}{l}\text { to clear the old } \\
\text { lemon }\end{array}$ & $45^{2}$ & ingozzare la pillola & 96 & $\mathrm{O}$ & snebbiare il cervello & 80 & IV \\
\hline off his rocker & 454 & manca un venerdì & 100 & III & manca una rotella & 84 & III \\
\hline $\begin{array}{l}\text { the best efforts } \\
\text { of the old bean }\end{array}$ & 468 & grandi sforzi mentali & 123 & IV & $\begin{array}{l}\text { tutte le mie energie } \\
\text { mentali }\end{array}$ & 103 & IV \\
\hline $\begin{array}{l}\text { exercising the } \\
\text { old bean }\end{array}$ & 470 & $\begin{array}{l}\text { pascere il vostro } \\
\text { cervello }\end{array}$ & 126 & IV & $\begin{array}{l}\text { esercitarlo, il tuo } \\
\text { cervello }\end{array}$ & 106 & III \\
\hline $\begin{array}{l}\text { impression } \\
\text { rooted in the } \\
\text { old bean }\end{array}$ & 475 & $\begin{array}{l}\text { m'ero formato } \\
\text { l'opinione }\end{array}$ & 134 & IV & mi ero ficcato in testa & 112 & III \\
\hline $\begin{array}{l}\text { exercising the } \\
\text { old bean }\end{array}$ & 479 & tormentarmi & 142 & $\mathrm{O}$ & $\begin{array}{l}\text { spremermi le } \\
\text { meningi }\end{array}$ & 118 & III \\
\hline off my chump & 580 & pazzo & 315 & IV & fuori di testa & 265 & III \\
\hline
\end{tabular}

Table 5.13: Italian renderings of "old" by Traverso and Lord 
In general, Bertie's expressions are rendered by equally informal Italian ones. Only once, Traverso and Lord inferred badly: in translating the phase "the old lemon", both translators infer that Bertie is referring to his friend Bingo, engaged in a conversation with him. They interpret the phrase as an insult and translate as if Bingo was the subject of the sentence.

\section{Humour Devices in The Inimitable Jeeves}

The Inimitable Jeeves is one of the eleven novels featuring the famous couple, Bertie and Jeeves, who are also the protagonists of thirty-five short stories. Their relationship dates to 1915 when Jeeves first appeared in a short story, entitled "Extricating Young Gussie", originally published in The Man with Two Left Feet (1917), where he only had two lines: "Mrs Gregson to see you, sir" and "Very well, sir, which suit will you wear?" (GV.16, Ch. 2). Two short lines, indeed, but already revealing something of the relation that was to last for fifty-nine years, since Jeeves also appears in Wodehouse's last novel, Aunts Aren't Gentlemen (1974). "Mrs Gregson” is Bertie's Aunt Agatha who will harass Bertie in practically every story of the cycle, devising plans to have Bertie "engaged to be married" to several girls of her (but not Bertie's) choice, such as Honoria Glossop or Aline Hemmingway in The Inimitable Jeeves only. Her plans are doomed to failure thanks to Jeeves's brilliant manipulation of events. The second line, Jeeves's imperturbable reaction to Bertie's announcement "Jeeves, we start for America on Saturday", anticipates in a soft tone another of Jeeves's characteristics, i.e. his aplomb and his role as a faithful, reliable valet. Eventually, as the relation strengthens, Jeeves becomes Bertie's invaluable ally. He can cure Bertie's hangovers, and disentangle him and his friends from the most intricate incidents. Moreover, he is widely read and knowledgeable about both practical and academic matters, from betting to ornithology. He fluently quotes Shakespeare, Keats and Burns, and is at ease with French and Latin phrases. In chapter 7 of The Inimitable Jeeves ("Introducing Claude and Eustace"), due to Honoria Glossop's diktat: "When we are married, you must get rid of Jeeves" (p. 449) the relation risks being broken. It is true that this relation is sometimes tense: the couple disagree over clothes, such as a white dinner jacket, an "alpine" hat or a pair of purple socks. Bertie sometimes shows his impatience and he once defines Jeeves as "a domestic Mussolini" (Thank You, Jeeves, GV.46, p. 12). However, as Brian Holcomb remarks in his contribution to Middlebrow Wodehouse (Rea, 2015), entitled "The Queer Domesticity of Bertie and Jeeves", Bertie "acknowledges that in love and fashion (and ostensibly all other matters) Jeeves knows best" (p. 220). 
Given Bertie's propensity towards upper-class metropolitan slang and Jeeves' erudite diction, their exchanges are often characterised by a clash of register, one of Wodehouse's Humour Devices highlighted in the previous chapters.

\begin{tabular}{|l|c|c|l|c|}
\hline \multicolumn{1}{|c|}{ SOURCE } & YEAR & PAGE & \multicolumn{1}{c|}{ TEXT } & HD/TP \\
\hline The Inimitable Jeeves & 1923 & 509 & $\begin{array}{l}\text { "Has he got the wind up?" } \\
\text { “Somewhat vertically, sir, to judge from his voice." }\end{array}$ & $\begin{array}{c}\text { Script- } \\
\text { clash }\end{array}$ \\
\hline Traverso & 1930 & 195 & $\begin{array}{l}\text { - Era eccitato? } \\
\text { - Eccitatissimo, a giudicare dalla voce. }\end{array}$ & 6 \\
\hline Ragusa & 1989 & 100 & $\begin{array}{l}\text { «Ha paura?» } \\
\text { «Direi, signore, almeno a giudicare dalla voce.» }\end{array}$ & 7 \\
\hline Lord & 2010 & 161 & $\begin{array}{l}\text { «Era agitato?» } \\
\text { «Agitatissimo, a giudicare dalla voce». }\end{array}$ \\
\hline
\end{tabular}

Table 5.14: Italian renderings of script-clash between "wind up" and "somehow vertically" by Traverso, Ragusa and Lord

Since the play in the original text is between an idiomatic form "to have got the wind up", meaning "to be anxious or scared" and Jeeves's witty Latinate phrasing, i.e. "vertically", Italian translators should have found a way to render this juxtaposition. Unfortunately, none of them succeeded. The outcome is a predictable exchange that has nothing to do with Wodehouse's script-clash. Moreover, since both Traverso and Lord employed a superlative adjective ("eccitatissimo" and "agitatissimo" mean respectively "very excited" and "very upset") their choices betray the aplomb - typified by understatemant, as in "somewhat" - that characterises Jeeves. Ragusa chose to translate as "Is he scared?" "I would say so, sir". All of them literally, hence not idiomatically, translate the second part of Jeeves's line "to judge from his voice".

The same issue presents itself in the following exchange, between Jeeves and a surprised and greatly disappointed Bingo, that shows a clash between Jeeves's phlegmatic and formal diction and the slang normally employed by Bertie and his friends. Therefore, its structure shows script-clash and is on a par with the exchange from Much Obliged, Jeeves (1971) between Aunt Dahlia and Jeeves quoted in Chapter 3, when she asks Jeeves: "You mean you slipped him a Mickey Finn?" and he replies: "I believe that is what they are termed in the argot, madam". 


\begin{tabular}{|l|c|c|l|c|}
\hline \multicolumn{1}{|c|}{ SOURCE } & YEAR & PAGE & \multicolumn{1}{|c|}{ TEXT } & HD/TP \\
\hline The Inimitable Jeeves & 1923 & 513 & $\begin{array}{l}\text { "Great Scott!" he whispered hoarsely. "An SP job!" } \\
\text { "I believe that is the technical term, sir," said } \\
\text { Jeeves. }\end{array}$ & $\begin{array}{c}\text { Script- } \\
\text { clash }\end{array}$ \\
\hline Traverso & 1930 & 200 & $\begin{array}{l}\text { - Gran Dio! - disse con voce rauca. - Voi avevate } \\
\text { avuto informazioni segrete, accidenti! } \\
\text { OMITTED }\end{array}$ & 8 \\
\hline Ragusa & 1989 & 104 & $\begin{array}{l}\text { «Incredibile!» sussurrò con voce rauca. «È un caso } \\
\text { di scommesse alla partenza. Avete fatto un bel } \\
\text { lavoro!» } \\
\text { «Penso che quello sia il termine tecnico, signore» } \\
\text { disse Jeeves. }\end{array}$ & $7+5$ \\
\hline Lord & 2010 & 166 & $\begin{array}{l}\text { «Accidenti!», disse con voce rauca. «Hai ricevuto } \\
\text { una dritta!» } \\
\text { «Penso che quello sia il termine tecnico, signore» } \\
\text { rispose Jeeves. }\end{array}$ & 1 \\
\hline
\end{tabular}

Table 5.15: Italian renderings of script-clash between "SP job" and "technical term" by Traverso, Ragusa and Lord

As noted above, in betting, "SP" refers to a bet placed at the odds current when the race starts; this is what Jeeves does, unbeknownst to the others, since he is the only punter to know that the longest sermon will be preached by a "black horse" who has borrowed the text of the sermon from the preacher "scratched out" by his doctor. As usual in the exchanges between Jeeves and Bertie or Bertie's friends, the script-clash is register-clash. In order to render the HD, translators must find a way to render the informal terminology and Jeeves's phlegmatic reply in formal register, rather than faithfully translate the two utterances. Here, Lord's is the only successful rendering, since she employs a vernacular expression, meaning "You were given some pointers", while Traverso renders by a formal utterance, meaning "You had secret information". Ragusa translates literally the CST, since "scommesse" means "betting" but modifies the HD and renders by a, probably sarcastic, added phrase "You did a good job!" (HDTP 5, ADDITION).

In analysing the treatments of various script-clashes in The Inimitable Jeeves by its Italian translators, I noticed that, in line with what I found in other translated texts, they are not always adequately rendered, due to the difficulty of finding an Italian lingo suitable to replace Bertie's. In particular, Traverso tends to employ a formal, monotonous phrasing and to favour domesticating translation procedures. By making an effort to find informal phrases to render Bertie's utterances, Ragusa and Lord often succeeded in rendering the script-clash to some extent. 
Wodehouse showed his inventiveness not only in creating plots and characters, but also words. An example of his coinages is "snooter" that the OED defines as "to harass, to bedevil, to snub", crediting its invention to Wodehouse. It is found in The Indiscretions of Archie (1921, GV.22) and in The Code of the Woosters (1938, GV.54), as well as The Inimitable Jeeves.

\begin{tabular}{|l|c|c|l|c|}
\hline \multicolumn{1}{|c|}{ SOURCE } & YEAR & PAGE & \multicolumn{1}{|c|}{ TEXT } & HD/TP \\
\hline $\begin{array}{l}\text { The Inimitable } \\
\text { Jeeves }\end{array}$ & 1923 & 419 & $\begin{array}{l}{[\ldots] \text { my Aunt Agatha had gone to France and }} \\
\text { wouldn't be on hand to snooter me for at } \\
\text { least another six weeks. }\end{array}$ & Inventiveness \\
\hline Traverso & 1930 & 38 & $\begin{array}{l}{[\ldots] \text { mia zia Agatha era partita per la Francia e }} \\
\text { non sarebbe ritornata a tormentarmi per } \\
\text { almeno sei settimane. }\end{array}$ & 6 \\
\hline Lord & 2010 & 29 & $\begin{array}{l}{[\ldots] \text { zia Agatha era partita per la Francia e }} \\
\text { non avrebbe potuto fustigarmi per almeno } \\
\text { sei settimane. }\end{array}$ & 6 \\
\hline
\end{tabular}

Table 5.16: Italian renderings of "to snooter" by Traverso and Lord

In such cases, translators must rely on contextual information around the problematic textual item to infer the meaning of the invented word. Alternatively, inferences can be drawn from their knowledge about the characters and their relationship. By the same token, in order to understand the reasons for the translators' choices, the researcher may rely on what is known about their work on the same author. The Inimitable Jeeves was the only book by Wodehouse Traverso ever translated, while Lord had already translated eight books of the cycle before this one, all of them featuring dreadful Aunt Agatha. Since both translators render the coinage appropriately (both "tormentare" and "fustigare" convey the same meaning as Wodehouse's coinage), it can be deduced that the contextual information was sufficient to point them in the right direction. It is also worth noting that, as usual with Wodehouse's translators, neither translator ventured to create an Italian neologism for "snooter".

As already shown in the opening paragraphs of The Inimitable Jeeves, one of Bertie's affectations is the use of abbreviations in place of words. Thompson (1992, p. 324) suggests that Wodehouse may have drawn this device from Dickens's Great Expectations (1861), in which the character Wemmick refers to his father as the "Aged P.", abbreviation for "aged parent" and notes that "Bertie occasionally uses 'aged relative' when referring to or addressing Aunt Dahlia" (ibid.). My investigation of the renderings of Bertie's abbreviations in The Inimitable Jeeves shows that no Italian translator ever attempted to render 
them as such. They all contented themselves to being able to recognise the word it was replacing and to translate it.

There are, however, interesting cases in other stories of the Jeeves and Bertie cycle, when Wodehouse combined one of his leitmotivs with Bertie's abbreviations. This is the case, for example, of "more to be p. than c." ("more to be pitied than censored", a quotation from a song brought to success by Mae West in 1938 that Wodehouse's characters employ to express a tolerant attitude towards somebody's behaviour) that was to puzzle the two Italian translators of Right Ho, Jeeves (GV 47, 1939), "the f. of the s. being more d. than the m." (p. 229), a witty reference to Kipling's poem The Female of the Species (1911), ${ }^{135}$ also one of Wodehouse's leitmotifs. The complete quotation from Right Ho, Jeeves and its renderings in Italian are shown in the table below.

\begin{tabular}{|l|l|l|l|c|}
\hline SOURCE & YEAR & PAGE & \multicolumn{1}{|c|}{ TEXT } & HD/TP \\
\hline Right Ho, Jeeves & 1934 & 229 & $\begin{array}{l}\text { I've said it before, and I'll say it gain - girls are } \\
\text { rummy. Old Pop Kipling never said a truer word } \\
\text { than when he made that crack about the f. of } \\
\text { the s. being more d. than the m. }\end{array}$ & $\begin{array}{c}\text { Inter- } \\
\text { textuality } \\
\text { /abbr }\end{array}$ \\
\hline Sacchi-Perego & 1935 & 213 & $\begin{array}{l}\text { L'ho già detto, e lo ripeto, le ragazze sono molto } \\
\text { bizzarre. [OMITTED] }\end{array}$ & 8 \\
\hline Buitoni Duca & 1985 & 221 & $\begin{array}{l}\text { L'ho già detto e non mi stancherò di ripeterlo: le } \\
\text { ragazze sono bizzarre. Il Vecchio Papi Kipling } \\
\text { non disse mai niente di più vero, come quando } \\
\text { pronunciò quella battuta sulla f. dello s. che è } \\
\text { più d. del m. }\end{array}$ & O \\
\hline
\end{tabular}

Table 5.17: Italian renderings of "the f. of the s. being more d. than the m." by Sacchi-Perego and Buitoni Duca

Sacchi-Perego's choice is easily classified: she simply ignored the reference altogether. On the contrary, Buitoni Duca employed a mixed procedure that I could not find in any other rendering in the works I examined: she translated the structure of the phrase word-for-word, e.g. "about the" = "sulla" and "more" = "più" into Italian, keeping the initial letters of the English words. The outcome is an incomprehensible

\footnotetext{
${ }^{135}$ "When the Himalayan peasant meets the he-bear in his pride,/He shouts to scare the monster, who will often turn aside./But the she-bear thus accosted rends the peasant tooth and nail,/For the female of the species is more deadly than the male [...] (Kipling \& Arscott, 2007).
} 
utterance. I therefore classified the procedure she employed as "O", since it demonstrates lack of knowledge of English culture. Moreover, both translators' choices display their laziness, since the opening of the sentence "Old Pop Kipling" was enough to point them in the right direction and, consequently, to the right quotation and correct rendering, that should have been "la f. della s. che è più m. del m."(la femmina della specie che è più mortale del maschio). A comparison between this version and Buitoni Duca's reveals a difference of just one letter. Enough, nevertheless, to spoil an instance of intertextuality. As for the further consequences on text activation and on the readers' KnoW, such misrendering prevented the early creation in Italy of one of Wodehouse's leitmotivs.

On the whole, the investigation of Wodehouse's works (re)translated into Italian reveals that the initial translation tended to favour a domesticating translation procedure and did not tend to render Wodehouse's script-clashes, especially when represented by the contrast of the language registers employed by Bertie and Jeeves. These translations, mainly issued in the 1930s, chose to safeguard the romantic plots, often at the expense of Wodehouse's efforts to offer witty phrasings and exchanges between his characters. These features are more evident when a comparison with more recent translations can be made. Indeed, more recent translations tend to be more conscientious, and seek to reflect Wodehouse's original ambience, his plots, his characterisation, and his language choices. More recent translations do reveal more foreignizing and, sometimes, preserving translation procedures to render CSTs, with the consequence of offering a more intriguing portrait of Wodehouse's world to Italian readers and of enhancing their KnoW more than more chronologically distant translations.

As for Humour Devices, Italian readers of any time could generally get enjoyment from Wodehouse's incongruous and hyper-worded descriptions, but wordplay and surprising juxtapositions are rendered more successfully by more recent translations than by those published in the 193os. However, some other Wodehousian Humour Devices in the Jeeves and Bertie cycle have not yet been adequately rendered by any of his Italian translators. This is particularly true for Wodehouse's inventiveness in word formation by means of affixation and coinages, and for the script-clash he achieved by juxtaposing's Jeeves erudite diction and Bertie's carefree slang and affectations. This inability on the part of Wodehouse's Italian translators affects, therefore, not so much the plots or the depiction of Wodehouse's Edwardian England but rather his characterisation and, consequently, some of his humour.

The next section of the chapter will shed more light on this issue, by investigating other Humour Devices employed by Wodehouse, namely intertextuality and similes. 
Five (re)translations and a manuscript: A Damsel in Distress

A Damsel in Distress (GV.19), one of Wodehouse's early stand-alone novels, was serialised in The Saturday Evening Post in 1919. It was published in book form in both the US and the UK in the same year, and made into a silent film that same year too. Although humorous, it is mainly a romance novel. The hero, an American writer of musical comedies, George Bevan, is shaped after Wodehouse's life-long friend Guy Bolton (Phelps, 1992, p. 125); however, his profile matches George Gershwin's (Green, 1983, p. 176) . Bevan is in England to supervise the production of one of his musicals in London. The action soon moves to Belpher Castle, owned by Lord Marshmoreton, who is bossed about by his sister and just wishes to be left alone in his much-beloved garden. He is the precursor of one of Wodehouse's most long-lived characters, Lord Emsworth. The damsel in distress is Maude, Lord Marshmoreton's daughter, confined to the castle since she has fallen in love with an unknown American youth. She meets George during an escapade to London: unfortunately, her brother Percy is also in town and it is to escape from him that she seeks refuge in George's taxi. The plot is intricate but not at all original: there are intrigues, unexpected turns, and love lost and regained. However, the book already contains the comic dialogue, the rich hyperworded descriptions, the witty intertextual references of the more mature books by Wodehouse.

\section{Intertextuality in A Damsel in Distress}

Given the relevance of intertextual references in Wodehouse, as one of his Humour Devices that I ascribe to the key concept of "knowledge sharing", the five extant Italian translations of A Damsel in Distress offer a valuable source of investigation. As noted in the previous chapters, Wodehouse's wide reading and his experience in the world of journalism and theatre allowed him to add intertextual references that range from folklore to the classics, from mystery stories to the Scriptures. As remarked by Ann-Marie Einhaus (in Rea, 2015, page 16), intertextuality is evidence of Wodehouse's belonging to the so-called middlebrow literature. His constant and conscious resorting to it, skilfully mixing erudite, highbrow material with popular literature and songs, demonstrates that he had understood its formula and this also helps to explain his success with large audiences in the English-speaking world. Research on his works in translation can address the question whether this middlebrow formula was reproduced in other languages and to hypothesise a similar outcome with his foreign audiences too. Moreover, by comparing 
(re)translations of the same work containing instances of intertextuality, we can investigate renderings issued at different times and hypothesise the outcome for audiences of difference ages.

This section presents the classification of 50 selected instances of intertextuality in the novel $A$ Damsel in Distress in the five extant translations. ${ }^{136}$ The five extant translations will be coded:
A) Monanni, 1931, translated by Palumbo
B) Bietti, 1931, translated by Mozzati
C) S.A.C.S.E., 1935, translated by Bianchini
D) Lucchi, 1935, translated by Dàuli
E) Mursia, 1994, translated by Palazzi

The fifty instances and page references, both for the original text and the five Italian translations are listed in Appendix 7. Table 5.18 below shows the classification of Italian rendering of the fifty instances, listed according to the category to which each belongs (Folklore, Literature, Music, Myths, and Scriptures). For each instance, a reference number is given as to where it is found in Appendix 6. Each rendering has been assessed by means of my classification of the Translation Procedures for HDs (see Table 4/14). In two cases, Translator E's renderings of instances 19 and 22, two TPs were combined, since the translator added a footnote. Table 5.19 shows stastics for HDTPs per translator.

\begin{tabular}{|c|c|c|c|c|c|c|c|}
\hline NO & CATEGORY & REFERENCE & TRANS A & TRANS B & TRANS C & TRANS D & TRANS E \\
\hline 3 & Folklore & nursery rhyme & 1 & $\mathrm{O}$ & 8 & $\mathrm{O}$ & 1 \\
\hline 18 & Folklore & proverb & 1 & 1 & 1 & 1 & 1 \\
\hline 24 & Folklore & Western film & 2 & 6 & 8 & 6 & 2 \\
\hline 25 & Folklore & legend & 2 & 6 & 7 & 2 & 3 \\
\hline 42 & Folklore & traditional song & 8 & $\mathrm{O}$ & 8 & $\mathrm{O}$ & 2 \\
\hline 45 & Folklore & proverb & 5 & 8 & 5 & 5 & 1 \\
\hline 1 & Literature & Scott, Dickens & 1 & 1 & 4 & 1 & 1 \\
\hline 2 & Literature & Tennyson & 4 & 1 & $\mathrm{o}$ & o & 1 \\
\hline 4 & Literature & Ade, Bawer & 4 & 4 & 4 & 4 & 1 \\
\hline 5 & Literature & Beecher Stowe & 6 & 6 & 6 & 6 & 1 \\
\hline 7 & Literature & Shakespeare & 1 & 1 & 1 & 1 & 1 \\
\hline 9 & Literature & Tennyson & 1 & 6 & 8 & 6 & 1 \\
\hline 10 & Literature & Shakespeare & 7 & 6 & 8 & 6 & 4 \\
\hline 12 & Literature & Dickens, Shaw & 4 & 4 & 4 & 3 & 6 \\
\hline 13 & Literature & Hood & 1 & 1 & 1 & 1 & 1 \\
\hline 14 & Literature & Hunt & 4 & 7 & 4 & 6 & 1 \\
\hline 15 & Literature & Shakespeare & 4 & 7 & 4 & 7 & 7 \\
\hline
\end{tabular}

\footnotetext{
${ }^{136}$ An earlier version of this study has been published, in Italian: Valentino, 2017.
} 


\begin{tabular}{|c|c|c|c|c|c|c|c|}
\hline 16 & Literature & Shakespeare & 4 & 7 & 4 & 6 & 1 \\
\hline 17 & Literature & Lovelace & 1 & 1 & 1 & 1 & 1 \\
\hline 23 & Literature & Lewis Carroll & 1 & 8 & 1 & 5 & 6 \\
\hline 26 & Literature & Tennyson & 4 & 4 & 4 & $\mathrm{O}$ & 2 \\
\hline 27 & Literature & Dickens & 6 & 6 & 6 & 1 & 8 \\
\hline 28 & Literature & Longfellow & 8 & $\mathrm{O}$ & 8 & 2 & 1 \\
\hline 30 & Literature & Byron & 4 & 1 & 4 & 1 & 2 \\
\hline 31 & Literature & Shakespeare & 6 & 2 & 6 & 2 & 1 \\
\hline 33 & Literature & Hemans & 8 & 2 & 8 & 8 & 6 \\
\hline 35 & Literature & Longfellow & 6 & $\mathrm{O}$ & 6 & 2 & 1 \\
\hline 37 & Literature & Voltaire & 6 & 6 & 6 & 6 & 1 \\
\hline 38 & Literature & Shakespeare & 4 & 1 & 2 & 6 & 1 \\
\hline 39 & Literature & Browning & 2 & 8 & 8 & 2 & 1 \\
\hline 40 & Literature & Shakespeare & 8 & 7 & 8 & 7 & 3 \\
\hline 41 & Literature & Wallace & 8 & 7 & 8 & 2 & 2 \\
\hline 43 & Literature & Tennyson & 3 & 2 & 8 & 1 & 1 \\
\hline 48 & Literature & Longfellow & 2 & 2 & 2 & 2 & 2 \\
\hline 6 & Music & Mendelssohn & 7 & 6 & 7 & $\mathrm{O}$ & 1 \\
\hline 20 & Music & song & 8 & 6 & 8 & 1 & 1 \\
\hline 21 & Music & song & 8 & 8 & 8 & 7 & 1 \\
\hline 11 & Myth & Holy Grail & 7 & 3 & 7 & 7 & 1 \\
\hline 36 & Myth & Plutarch & 6 & 6 & 8 & 6 & 1 \\
\hline 8 & Scriptures & Apostles & 1 & 4 & 8 & 8 & 6 \\
\hline 19 & Scriptures & Samuel & 4 & 7 & 8 & 4 & $1+5(\mathrm{fn})$ \\
\hline 22 & Scriptures & Deuteronomy & 4 & 8 & 4 & 8 & $1+5(\mathrm{fn})$ \\
\hline 29 & Scriptures & Matthew & 7 & 7 & 4 & $\mathrm{O}$ & 1 \\
\hline 32 & Scriptures & Bk of Revel. & 7 & 3 & 7 & 1 & 1 \\
\hline 34 & Scriptures & Exodus & 1 & 4 & 1 & 4 & 3 \\
\hline 44 & Scriptures & Genesis & 7 & 6 & 7 & 1 & 1 \\
\hline 46 & Scriptures & Daniel & 1 & 1 & 8 & 1 & 1 \\
\hline 47 & Scriptures & Daniel & 8 & 7 & 8 & 7 & 1 \\
\hline 49 & Scriptures & Jeremy & 2 & 2 & 8 & 2 & 1 \\
\hline 50 & Scriptures & Apostles & 8 & 2 & 8 & 2 & 4 \\
\hline
\end{tabular}

Table 5.18: Italian renderings of 50 instances of intertextuality from A Damsel in Distress (1919, GV.19) by Palumbo (1931), Mozzati (1931), Bianchini (1935), Dàuli (1935) and Palazzi (1994)

\begin{tabular}{|l|c|c|c|c|c|c|}
\hline $\begin{array}{c}\text { RENDERINGS CLASSIFIED ACCORDING } \\
\text { TO TRANSLATION PROCEDURE } \\
\text { (SEE TABLE 4. XX) }\end{array}$ & $\begin{array}{c}\text { TRANS } \\
\text { A }\end{array}$ & $\begin{array}{c}\text { TRANS } \\
\text { B }\end{array}$ & $\begin{array}{c}\text { TRANS } \\
\text { C }\end{array}$ & $\begin{array}{c}\text { TRANS } \\
\text { D }\end{array}$ & $\begin{array}{c}\text { TRANS } \\
\text { E }\end{array}$ & $\begin{array}{c}\text { TOTALS } \\
\text { AND \% }\end{array}$ \\
\hline $\begin{array}{l}\text { 1 = HD }>\text { HD: The formal structure and the } \\
\text { features of the HD are maintained }\end{array}$ & 11 & 9 & 6 & 12 & 33 & $71 ; 28 \%$ \\
\hline $\begin{array}{l}2=\text { WW: the HD is translated word-by- } \\
\text { word }\end{array}$ & 5 & 6 & 2 & 9 & 6 & $28 ; 11 \%$ \\
\hline $\begin{array}{l}3=\text { HD }>\text { SB: the HD is substituted (formal } \\
\text { equivalence) }\end{array}$ & 1 & 2 & - & 1 & 3 & $7 ; 3 \%$ \\
\hline $\begin{array}{l}\text { 4 = HD > SM: the TT employs less words } \\
\text { than the ST }\end{array}$ & 11 & 5 & 10 & 3 & 2 & $31: 12 \%$ \\
\hline
\end{tabular}




\begin{tabular}{|l|c|c|c|c|c|c|}
\hline $\begin{array}{l}5=\mathrm{HD}>\mathrm{AD}: \text { the TT employs more words } \\
\text { than the ST, including footnotes (ft) }\end{array}$ & 1 & - & 1 & 2 & 2 (fn) & $6 ; 2 \%$ \\
\hline $\begin{array}{l}6=\mathrm{HD}>\mathrm{GN} \text { : the TT employs a general } \\
\text { term }\end{array}$ & 6 & 11 & 5 & 9 & 4 & $3514 \%$ \\
\hline $\begin{array}{l}7 \text { = HD > AM: the TT is modified and the } \\
\text { meaning of the HD is subverted }\end{array}$ & 6 & 8 & 5 & 5 & 1 & $2510 \%$ \\
\hline $8=\mathrm{HD}>\mathrm{ZERO}$ : the HD is omitted & 9 & 5 & 20 & 3 & 1 & $38 ; 15 \%$ \\
\hline $\begin{array}{l}\text { O = HD }>\text { *LC: the HD is mis-rendered due } \\
\text { to lack of knowledge of the Linguistic Code }\end{array}$ & - & 4 & 1 & 6 & - & $11 ; 5 \%$ \\
\hline TOTALS & 50 & 50 & 50 & 50 & $\begin{array}{c}50 \\
(+2 \mathrm{fn})\end{array}$ & $\begin{array}{c}25 \% \\
10 \% \%\end{array}$ \\
\hline
\end{tabular}

Table 5.19: Number and percentages of Translation Procedures employed the five Italian translators

The Epistemic Approach focuses on the role that all the actors' KnoW plays in text activation, so from this perspective, the most interesting renderings are those which alter the structure of the HD. The researcher, taking into account what is known about the translation norms of the time, the social, political and economic factors and all that is known about each translator's activity, will infer the reasons for the choices. Moreover, the research will try to hypothesise the consequences of the translator's choices on the target readership, and the author's reception and reputation in the target culture.

The first thing to be noted is the fact that in about $15 \%$ of cases the intertextual references were ignored in the Italian translation (TP 8). This is particularly true for Trans C, Bianchini, who ignored twenty instances out of fifty. The outcome for the text is the loss of the incongruity devised by Wodehouse, and consequently of the script-clash that I posit as one of the constituent elements of Wodehouse's humour. The table also shows lack of knowledge of the linguistic codes (classified as TP O), particularly on the part of Trans D, Dàuli and Trans B, Mozzati. A striking example of mis-rendering due to lack of knowledge of English and indeed of European musical culture) is Trans D's rendering of "Mendelssohn's March Daughters" (instance 6), that was translated as if "March" was the month ("marzo") instead of a piece of music. Popular cultural references, e.g. those in instances 20 and 21, were often ignored by early translators, while Trans E, Palazzi, probably favoured by being the daughter of the curator of one of Italy's most renowned dictionaries, ${ }^{137}$ could draw from reliable first-hand information.

\footnotetext{
${ }^{137}$ Novissimo dizionario della lingua italiana etimologico, fraseologico, grammaticale, ideologico, nomenclatore e dei sinonimi, first published in 1939 by the publishing company Cheschina and later republished first by Fabbri (1974) and by Loescher (1994) as Dizionario della lingua italiana by Ferdinando Palazzi and Gianfranco Folena.
} 
As for the English classics, it is worth noting that, although no translator employed an authoritative translation as source for their renderings, three of them (B, D and E) succeeded in rendering the tone and the rhythms of the poem by Tennyson that the young Albert reads aloud (instance 26). The other two simply summarise the scene. The quotation from Shakespeare's Macbeth ("Nothing in his life became him [...]", instance 15) is never rendered literally. Some translators did not recognize it, translated freely and consequently did not reproduce the script-clash present in the original text.

The two cases in which Wodehouse based a script-clash on anachronisms, instances 32 and 34, were not adequately rendered. Only two translators (D and E) render the "Egyptian obscurity" (instance 34) surrounding Lord Belpher, locked up in the parish cellar, and two others (A and C) reproduce the tone of the Scriptures in "the coming of the Millennium" (instance 32). It would be interesting to analyse more Italian renderings of these anachronisms, in the light of Attardo's (2001, p. 148) findings, since he underlines how Umberto Eco achieved humour by means of anachronistic reference in his Il nome della rosa. Two cases are not sufficient to attempt a comparison, particularly because, as in many other cases, the renderings of Trans $\mathrm{C}$ were exactly the same as Trans A, hence legitimately raising a suspicion of plagiarism, although Trans C excels in HDTP 8, OMISSION, far more than Trans A.

As for hyper-wording, the second factor to which I ascribe Wodehouse's humour, as a rule, it was adequately rendered. However, instance 36 , "Centuries before we were born or thought of there was a widely press-agented boy in Sparta who even went so far as to let a fox gnaw his tender young stomach without permitting the discomfort inseparable from such a proceeding to interfere with either his facial expression or his flow of small talk", was translated literally only by Trans E; three others (A, B, and C) employed TP 6 (Generalisation) and ignored the rich wording in Wodehouse's phrasing; finally, Trans D omitted the quotation. As $\mathrm{E}$ is the most recent, this confirms the observation that more recent translation show greater accuracy.

Critical investigations of Wodehouse's historical and linguistic contexts have shown how the use of intertextuality is one of the SDs used by the author to achieve incongruity with a consequent humorous effect: the analysis of the renderings of the intertextual references has shown whether the original function has been maintained. Likewise, in recognizing the function of intertextuality in Wodehouse as an instance of middlebrow culture, by comparing different translations it is possible to hypothesize the impact of each translation on the Italian reader of the time in which it was published. The general evaluation is that the translations issued in the 1930s yielded less insights into both Wodehouse's world 
and humour that the one published in 1994, at least as far as intertextuality is concerned. Further investigation on other Humour Devices, such as similes, will show if this insight is correct.

\section{Similes in A Damsel in Distress}

Similes are probably the most renowned and praised among Wodehouse's Humour Devices and one in which hyper-wording plays a relevant role, as already noted. In the following paragraphs I compare the five Italian renderings of the most interesting similes found in A Damsel in Distress, selected since they show Wodehouse's different ways of employing them. As seen in Chapter 3, the two elements that I consider while investigating Wodehouse's similes are 1) the semantic distance between the tenor and the vehicle $(\overline{T V})$ and 2) the number of words used, i.e. its collocates $\left(C_{n}\right)$. Together they yield a value that I term "incongruity index". The wider the semantic distance and the larger the number of collocates, the more incongruous and, hence, humorous, the simile is likely to be. I examined and classified the renderings of five similes rendered by the five Italian translators, who are, again, coded as: Trans A (Palumbo for Monanni, 1931), Trans B (Mozzati for Bietti, 1931), Trans C (Bianchini for S.A.C.S.E., 1935), Trans D (Dàuli for Lucchi, 1939), and Trans E (Palazzi for Mursia). No differences in treatment were found between Dàuli's manuscript (Trans D MS) and the published version; therefore, the manuscript will not be taken into consideration here. However, some considerations will be drawn from the comparison between the manuscript and the published version later in this chapter.

The tenor and the vehicle of each simile are highlighted in bold. I coded both semantic distance and the number of collocates by the signs " =", ">" and " $<$ ", respectively meaning that the values are equivalent, superior, or inferior to the ones conceived by Wodehouse. However, and interestingly, no instance of superior value is found in the sample examined here. When the simile is omitted or rendered by a paraphrase I code it "O" (zero). The original five similes considered for the comparison are listed in tables 5.20 and 5.25 .

\begin{tabular}{|c|c|l|}
\hline SIMILE & CH/PAGE & \multicolumn{1}{|c|}{ ENGLISH TEXT } \\
\hline 1 & $1 / 8$ & Keggs looks far too much like a particularly saintly bishop \\
\hline 2 & $3 / 37$ & $\begin{array}{l}\text { His spirits, so low but a few moments back, soared like a good niblick shot out of } \\
\text { the bunker of Gloom }\end{array}$ \\
\hline
\end{tabular}




\begin{tabular}{|c|c|l|}
\hline 3 & $15 / 153$ & $\begin{array}{l}\text { An X-ray photograph of your liver would show something that looked like a } \\
\text { crumpled oak-leaf studded with hob-nails. }\end{array}$ \\
\hline 4 & $25 / 265$ & said Lord Marshmoreton, and disappeared like a diving duck. \\
\hline 5 & $26 / 267$ & A kettle bubbled in an undertone, like a whispering pessimist. \\
\hline
\end{tabular}

Table 5.20: Selected similes in A Damsel in Distress (GV.19)

\begin{tabular}{|c|c|l|c|c|}
\hline SIMILE & PAGE & \multicolumn{1}{|c|}{ ITALIAN TEXT } & $\overline{T V}$ & $\mathrm{C}_{\mathrm{n}}$ \\
\hline 1 & 10 & Keggs ha l'aria di un vescovo devoto $[\ldots]$ & $=$ & $<$ \\
\hline 2 & 48 & $\begin{array}{l}\text { Le sue idee tanto scoraggiate un momento prima, erano } \\
\text { lanciate e librate in aria fuori dai penetrali della malinconia. }\end{array}$ & $\mathrm{O}$ & $=$ \\
\hline 3 & 187 & $\begin{array}{l}\text { Se ti radiografassero il fegato, si vedrebbe qualcosa che } \\
\text { somiglia a una foglia di quercia spiegazzata. }\end{array}$ & $=$ & $<$ \\
\hline 4 & 312 & $\begin{array}{l}\text { Disse Lord Marshmoreton, e scomparve come un'anitra } \\
\text { acquatica. }\end{array}$ & $=$ & $<$ \\
\hline 5 & $314^{*}$ & [Omitted] & $\mathrm{O}$ & $\mathrm{O}$ \\
\hline
\end{tabular}

Table 5.21: Translator A: Francesco Palumbo, 1931

\begin{tabular}{|c|c|l|c|c|}
\hline SIMILE & PAGE & \multicolumn{1}{|c|}{ ITALIAN TEXT } & $\overline{T V}$ & $\mathrm{C}_{\mathrm{n}}$ \\
\hline 1 & 10 & Keggs ha troppo l'aria di un sant'uomo & $<$ & $<$ \\
\hline 2 & 34 & $\begin{array}{l}\text { Il suo spirito poco prima così depresso si levava ora sopra la } \\
\text { nuvolaglia della noia e della tristezza. }\end{array}$ & 0 & $=$ \\
\hline 3 & 109 & $\begin{array}{l}\text { Una radioscopia del tuo stomaco avrebbe mostrato qualche } \\
\text { cosa simile a una foglia di quercia tempestata di chiodi. }\end{array}$ & $=$ & $=$ \\
\hline 4 & 238 & $\begin{array}{l}\text { disse Lord Marshmoreton e sparve come una nave che si } \\
\text { immerga nel mare. }\end{array}$ & $<$ & $=$ \\
\hline 5 & 240 & $\begin{array}{l}\text { un bricco borbottava sottovoce e pareva un sussurro di cattivo } \\
\text { augurio. }\end{array}$ & $<$ & $=$ \\
\hline
\end{tabular}

Table 5.22: Translator B: Ariberto Mozzati, 1931

\begin{tabular}{|c|c|l|c|c|}
\hline SIMILE & PAGE & \multicolumn{1}{|c|}{ ITALIAN TEXT } & $\overline{T V}$ & $\mathrm{C}_{\mathrm{n}}$ \\
\hline 1 & 8 & Keggs ha l'aspetto di un vescovo & $=$ & $<$ \\
\hline 2 & 36 & $\begin{array}{l}\text { Le sue idee tanto scoraggiate un momento prima, erano } \\
\text { lanciate fuori dai penetrali della malinconia. }\end{array}$ & $\mathrm{O}$ & $=$ \\
\hline
\end{tabular}




\begin{tabular}{|c|c|l|c|c|}
\hline 3 & 140 & $\begin{array}{l}\text { Se ti radiografassero il fegato, si vedrebbe qualche cosa che } \\
\text { somiglia a una foglia di quercia spiegazzata. }\end{array}$ & $=$ & $<$ \\
\hline 4 & 236 & $\begin{array}{l}\text { [Whole chapter omitted] } \\
\text { [Whole paragraph omitted. Bianchini compensates by adding } \\
\text { "in preda a un certo sospirante pessimismo", referring to Maud } \\
\text { instead of to the kettle, to the following paragraph.] }\end{array}$ & $\mathrm{O}$ & $\mathrm{O}$ \\
\hline 5 & $267^{*}$ & \begin{tabular}{l} 
O \\
\hline
\end{tabular}
\end{tabular}

Table 5.23: Translator C: Alfredo Bianchini, 1935

\begin{tabular}{|c|c|l|c|c|}
\hline SIMILE & PAGE & \multicolumn{1}{|c|}{ ITALIAN TEXT } & $\overline{T V}$ & $\mathrm{C}_{\mathrm{n}}$ \\
\hline 1 & 6 & Keggs ha troppo l'aria di un sant'uomo & $<$ & $<$ \\
\hline 2 & 33 & $\begin{array}{l}\text { Il suo spirito, prima così depresso, si levava ora sereno sopra la } \\
\text { nuvolaglia della noia e della tristezza. }\end{array}$ & $\mathrm{O}$ & $=$ \\
\hline 3 & 137 & $\begin{array}{l}\text { Una radioscopia del tuo fegato mostrerebbe qualcosa simile a } \\
\text { una foglia di quercia tempestata di chiodi. }\end{array}$ & $=$ & $=$ \\
\hline 4 & 235 & $\begin{array}{l}\text { disse Lord Marshmoreton, e sparve come un'anitra che si tuffi } \\
\text { nell'acqua, }\end{array}$ & $=$ & $=$ \\
\hline 5 & $237^{*}$ & Un calderino borbottava sottovoce. & $\mathrm{O}$ & $\mathrm{O}$ \\
\hline
\end{tabular}

Table 5.24: Translator D: Gian Dàuli, 1939

\begin{tabular}{|c|c|l|c|c|}
\hline SIMILE & PAGE & \multicolumn{1}{|c|}{ ITALIAN TEXT } & $\overline{T V}$ & $\mathrm{C}_{\mathrm{n}}$ \\
\hline 1 & 12 & Keggs somiglia troppo a un vescovo particolarmente pio & $=$ & $=$ \\
\hline 2 & 39 & $\begin{array}{l}\text { Il suo umore, così a terra solo pochi istanti prima, si sollevò } \\
\text { come un buon tiro realizzato da un niblick fuori dal bunker } \\
\text { della Malinconia. }\end{array}$ & $=$ & $=$ \\
\hline 3 & 145 & $\begin{array}{l}\text { Una radiografia del fegato mostrerebbe un'immagine simile a } \\
\text { una foglia di quercia accartocciata, costellata di bulloni. }\end{array}$ & $=$ & $=$ \\
\hline 4 & 246 & $\begin{array}{l}\text { affermò lord Marshmoreton e scomparve come un'anatra in } \\
\text { immersione. }\end{array}$ & $=$ & $=$ \\
\hline 5 & 247 & $\begin{array}{l}\text { Un bricco bolliva, in tono sommesso, e sembrava il sussurro di } \\
\text { un pessimista. }\end{array}$ & $<$ & $=$ \\
\hline
\end{tabular}

Table 5.25: Translator E: Rosetta Palazzi, 1994

As with renderings of any Humour Device, the focus of the researcher is on the ones that do not maintain its structure. It is worth noticing that only the most recent translation, i.e. Palazzi's, manages to consistently render both the constituent factors of Wodehouse's translation. This could be explained by the greater awareness of his mechanisms on the part of a translator already aware of his work. Another 
explanation may be found in Gambier's (1994) remarks about the reasons for retranslation, seen as a process of improvement. In other words, a more accurate rendering of an author's style may also be due to increased knowledge of the source language in the translating culture, i.e. better resources for translators, as well as higher quality standards and expectations among publishers and audiences.

The analysis of the less successful renderings shows that:

1. A simile is paraphrased, hence omitted, when it contains a problematic CST, as a reference to golf in simile no 2 and, for Trans A and C, also in simile no 5, where the reference is to a "kettle", an uncommon item in Italian kitchens. In this respect, it is worth noting that Trans $\mathrm{C}$, Bianchini, compensates the loss by adding to the following paragraph the phrase "in preda a un certo sospirante pessimismo", meaning "fallen prey to a certain sighing pessimism", referring to Maud instead of to the kettle;

2. English affixation, here represented by the adjective "diving" in instance 4 is rendered with difficulty. This observation is in line with the outcome of my analysis of other instances of affixation throughout the corpus, presented in Chapter 4;

3. When faced with problematic items, earlier translators tend to reproduce previous versions. Comparisons show that translator $\mathrm{C}$ certainly worked using translation $\mathrm{A}$ as a reference and that he abundantly copied from it. The two versions are very often identical, although, in the presence of a crux, translator C, possibly overwhelmed by doubts, completely omitted to translate the problematic item. By the same token, Trans D copied Trans A's rendering of the most problematic item, i.e. simile no 2 .

A general overview of the Italian translations of these examples reveals that, of the two elements of Wodehouse's humorous similes, i.e. semantic distance and hyper-wording, represented by the number of collactes $\left(C_{n}\right)$, the one that is better reproduced is the latter, while semantic distance was generally inferior. By comparing the solutions found by the translators, we can see how the KnoW of each of them influenced the translation process and, consequently, their renderings. The translators of the 193os could certainly rely on fewer resources (dictionaries, other printed works of reference, and internet resources) than the translator of the 199 os.

Moreover, it is worth noting that the comparison between Trans D published version and the manuscript I examined (Trans D MS) reveals that the editor, who amended the text by hand, did not 
intervene on any of the instances of intertextuality and of similes examined in this study, nor on other renderings. Rather, the editorial intervention covered typographic conventions, such as the use of italics for emphasis and for foreign words.

Editorial interventions probably also played a role in modifying Trans C's original version, since a whole chapter is missing and several paragraphs omitted. This could be a choice made to save on paper, given the costs involved in publishing in the mid-193os in Italy and taking into account that Lucchi was a small company, compared to Bietti. According to Gambier (1994, p. 414), cuts are frequently featured in first translations, since they are due to concerns regarding readability. However, the fact that this was in fact a third (re)translation and the lack of translation of many problematic passages, some crucial to the plot, suggest an opportunistic choice. From this observation and the ones already presented in the case studies in Chapter 4, it is apparent that editorial policies may influence an author's work and reception. Therefore, the following section will treat another aspect of publishing, the translation of titles and its relevance in a study on (re)translation.

\section{The (re)translation of titles}

As already highlighted in Chapter 1, the same work by Wodehouse was published in Italian under different titles. Generally speaking, the Italian titles of Wodehouse's books are literal translations. This is the case, for example, of Il Principe e Betty (GV.11; The Prince and Betty, 1912), a title that was kept for all translations, i.e. those by Francesco Palumbo for Bietti in 1932, by Martone for Monanni in the same year, and by Castelli in 1992 for Mursia, and in all reprints (by Bietti in 1942, 1948, 1962, 1964 and 1966 and by Mursia in 1991 and 1993). A similar case is The Inimitable Jeeves (GV.26; 1923), whose literally translated title, L'inimitabile Jeeves, was kept by its three publishers, Monanni, Bietti and Polillo, with two translations and fifteen editions from 1930 to 2016. Six books were translated literally also when they were reprinted or republished by another company, namely La venuta di Bill (GV.20; The Coming of Bill, 1920), with two translations and eight editions between 1932 and 1966, Lampi d'estate (GV.37; Summer Lightning, 1929) with two translations and nine editions between 1933 and 2006, Gas esilarante (GV.51; Laughing Gas, 1936, one translation and six editions), Zio Fred in primavera (GV.55; Uncle Fred in the Springtime, 1939, one translation and eight editions), and Luna Piena (GV.6o; Full Moon, 1947, two translations and three editions). 
There are some notable exceptions to the rule of translating titles literally. For example, Psmith in the City (GV.10; 1910) was always translated as Psmith in banca, meaning "Psmith in bank", starting from Bietti's first edition in 1932, probably because Italians would have hardly identified the "City" as the financial centre of London in the 193os and a literal translation, i.e. "la Città", would not have made sense in Italian. However, the title was kept also when a new translation was commissioned by Mursia in 1990. Moreover, it is curious to note that If I Were You (GV.39; 1931), first translated in 1933 and republished in 1936, was always titled Se fossi Voi that keeps the "Voi", the form of address that had long disappeared from Italian usage when the book was republished in the 1950s and 196os, when "Se fossi Lei" would have been current. This may be an instance of a "preserving" title, meant to suggest that Wodehouse was a writer of a "past age". However, it must be noted that, due to the equivalence between the formal address form "Lei" and the third person feminine pronoun, such a title would have been misleading, since an alternative meaning would have been "If I were her". ${ }^{13}$

When a new edition was issued, some slight variation sometimes showed. For example, The Little Nugget (GV.12; 1913) was published by Monanni in 1932 as La pepita d'oro, meaning "the golden nugget" and literally as La piccola pepita by Bietti in the same year. Similarly, Uneasy Money (GV.17; 1917) was first titled Denaro difficile (hard money) by Monanni in 1932. In the same year, Bietti published a different translation under the title Danaro incomodo, which translates the original title more literally, however employing a less etymologically correct assimilation of "denaro", "danaro", ${ }^{139}$ and an adjective unfrequently employed in association with money, "incomodo", meaning "uncomfortable". From 1932 to 1966, Bietti (and S.A.C.S.E. in 1935) maintained the same translation by Palumbo and the same title, although the adjective "incomodo" must have already sounded outdated in the 196os, since it was now only - and rarely - employed as a noun, meaning "inconvenience". Probably for this reason, in 1992, Mursia revived the first title in a new translation commissioned from Del Tanaro.

As noted in Chapter 3, dealing with the pun contained in Money in the Bank (GV.58; 1946), the titles of Wodehouse's books and stories very often hide a pun or a reference of some kind, from historical characters to literary clichés. Not always do the Italian titles keep the reference, as the following cases show. For example, there is an obvious historical reference in Bill the Conqueror (GV.29; 1924). The book

\footnotetext{
${ }^{138}$ This is, in fact, the Italian translation of the title of the 2005 US film "In Her Shoes" by Curtis Hanson.

${ }^{139}$ The word "denaro" is derived from Latin "denarius" which contains the root "de" of the distributive number "deni", meaning "ten times". "Danaro" is therefore a variation, defined as "assimilation", i.e. the process by which "a speech sound changes and becomes more like another sound which follows or precedes it" (Richards, Platt, \& Weber, 1985, p. 19).
} 
was translated twice in Italy, by Rafanelli and by Brioschi. The title under which it was first published in Italy, by Bietti in 1933 and reprinted several times, is Bill il conquistatore (which retains the witty reference to William, that is not, however, easily identifiable by foreign readers,). The new translation was first published by Mursia in 1993. Brioschi's translation, republished by Guanda and by TEA, in 2006 and 2008, respectively, was titled La conquista di Londra, simply meaning "the conquest of London", thus losing any explicit reference to the Norman conquest. Another case, in which the reference is to the visual arts, is the title of a later novel by Wodehouse, published in 1970, The Girl in Blue (GV.83). It revolves around a fictitious miniature by Gainsborough, who painted the "Blue Boy", translated into Italian as il "Ragazzo Azzurro" (the "blue boy"). The two Italian editions by Arnoldo Mondadori (1970) and by Mursia (1990) have the same title, La ragazza in blu. This translates literally, but loses both the emotional implication of "blue" and the reference to Gainsborough's painting.

The fourth story contained in Very Good, Jeeves (GV.30; 1930) is titled "Jeeves and the Song of Songs", with a reference to the Song of Solomon from the Old Testament. In the Italian translation by Alberto Tedeschi, Benissimo, Jeeves, published by Monanni in the same year, the reference is ignored, and the title reads "Jeeves e gli amori di Tuppy": "Jeeves and Tuppy’s love affairs". On the contrary, the allusion to Psalm XXX, "Weeping may endure for a night, but joy cometh in the morning", in the Bertie and Jeeves 1947 novel, Joy in the Morning (GV.59), is kept in La gioia è col mattino ("joy is with the morning"), published by Elmo. However, it is lost in Un mattino di gioia ("a joyful morning"), published by Mursia and by Polillo, with the same title but in two different translations.

Some titles are puns played on works of literature. One example is "The Aunt and the Sluggard", a story contained in Carry On, Jeeves (GV.30; 1925), whose title plays on the English title of one of Aesop's fables, The Ant and the Grasshopper. In Spaventa Filippi's translation, the title of the story is "La zia e il poltrone", which translates the original title literally and does not render the pun. Lewis Carroll's poem "The Walrus and the Carpenter" from Through the Looking-Glass and What Alice Found There (1872) is referred to in the title of a Blandings novel, Pigs Have Wings (GV.67; 1952). It was published in Italy under the literal and catchy title I porci hanno le ali by Elmo in 1953. Since Lewis Carroll's book had been translated twice (in 1949 and, in a more popular edition, in 1952) in Italy before Wodehouse's novel appeared, it is possible that some readers might have recognised the allusion. Robert Browning's poem "Love Among the Ruins" is paraphrased in the title of the book that launched Wodehouse as a novelist, Love Among the Chickens (GV.o6; 1906), translated literally into Italian either as L'amore tra i polli or as Amore tra i polli (five translations altogether between 1929 and 1994). The allusion is not essential to the 
humour in this instance and little is lost in the translations. Another literary reference is in the title of a story in Lord Emsworth and Others (GV.52; 1937), "Farewell to Legs", clearly a pun on Hemingway's Farewell to Arms (1929). In Italian, the title of the story is "Sorte di un bellimbusto", meaning "the fate of a fop", in which every reference is lost, but the title is nonetheless apt in using a humorous bathetic clash between "sorte" and "bellimbusto". Another, opposite, example is "Birth of a Salesman", a story featuring Lord Emsworth and contained in Nothing Serious (GV.64; 1950). The title evokes Arthur Miller's Death of a Salesman (1949). In the Italian version by Sario Agnati (1965), it was literally translated "Nascita di un commesso viaggiatore", alluding to "Morte di un commesso viaggiatore" the Italian title of Miller's play, published in Italy in $1952^{140}$

Some of Wodehouse's titles play on clichés, such as "Buried Treasures", a pirate story cliché, or $A$ Damsel in Distress, a romance one. "Buried Treasures" is the title of a story in Lord Emsworth and Others (GV.52; 1937): it was translated literally in Italian, as "Tesori sepolti". As we saw, the novel A Damsel in Distress (GV.19; 1919) was published in Italy in five translations. However, since Bianchini's version was reprinted by S.A.C.S.E. under two titles, there are altogether six different titles., of which only two play with the same cliché: Una donzella in imbarazzo (Monanni) and Una damigella in pericolo (Mursia, later reprinted by Guanda and TEA). Both "donzella" and "damigella" are archaic literary terms for "girl", so the play is partly kept. However, "imbarazzo" does not translate "distress", meaning (today) "embarrassment", while "in pericolo", meaning "in danger", keeps the cliché slightly better.

Some other allusions are less obvious. For example, Frozen Assets (GV.78; 1964) refers to stock exchange jargon. When it was published by Elmo in 1965, it was translated into Italian as Eredità sotto chiave, meaning "locked up legacy", an intriguing title with a more explicit hint to the plot. However, a second translation was published by Mursia in 1997 under the literal, less telling, title Beni congelati.

Due to space constraints, given that 176 (re)translations were produced from the 87 works considered in this study, this review is far from exhaustive; however, I think it is sufficient to shed light on how Wodehouse's Italian readers were generally exposed to attractive titles that, on the whole, succeeded in capturing the effect of the original title.

\footnotetext{
${ }^{140}$ Morte di un commesso viaggiatore. Dramma in due atti e un requiem, 1952, translated by Gerardo Guerrieri, Collana Amena n.102, Milano, Aldo Garzanti Editore.
} 


\section{Conclusions}

This chapter has demonstrated that the methodology underpinned by the model of text activation and by the Epistemic Approach is suitable to investigate retranslations. More specifically, I have shown how it is applied to compare different renderings of the same translated texts, with a focus on CulturallySpecific Terms and on some of Wodehouse's Humour Devices. This was a choice made out of necessity, due to space constraints and the overall scope of this dissertation. The corpus I collected would in fact allow for many more investigations on many more aspects of retranslation, since $66 \%$ of the 87 books by Wodehouse were retranslated. (Re)translations are indeed valuable material to shed light on the translation process. Moreover, since it takes into account what is known about a translated text, the Epistemic Approach is a suitable framework also to investigate motives for retranslation.

The socio-historical survey I conducted and the analyses I performed on the texts reveal that:

1. many retranslations were issued as a result of competition among publishers on the book market, i.e. between Monanni and Bietti in the years 1930 to 1934 and between Bietti and Elmo in the 196os;

2. none of Wodehouse's Italian retranslations can be attributed to one of the motives suggested by Venuti (2004), i.e. lack of awareness of the existence of a previous editions, given the geographical contiguity of the Italian companies and to the fact that a number of translators worked for more than one of them;

3. no evidence can be found for retranslations issued as a result of competition among translators, as suggested by Hanna (2006);

4. some renderings, especially those by Traverso in the 1930s, confirm that social and political pressure can influence a translator's choices; however, there is no evidence of any attempt to offer a new interpretation or a re-orientation of Wodehouse's work in Italy;

5. Italian renderings of Wodehouse's instances of intertextuality, unfortunately, did not help to build his reputation in Italy as an exponent of middle-brow culture. Rather, earlier translations, given their polished phrasing and diction, proposed his books as sophisticated reading, however light in tenor;

6. the most retranslated books by Wodehouse belong to the Jeeves and Bertie cycle and the Blandings Saga. This is very likely to be the outcome of the deal between 
Mursia and Guanda, in 1989, later to include TEA, posited by Pensato (2015). Thanks to the commitment of these publishers, and to Polillo Editore, these two cycles are the most popular in Italy, as they are in the UK. It is worth mentioning that no TV series has ever been broadcast in Italy, therefore no influence on sales can be ascribed to this mediatic exposure;

7. the number of retranslations commissioned after several years support Pym's (1998) claim that passive translations challenge the validity of previous ones, at least since the translation norms which later Italian retranslations followed allowed Wodehouse to reach to a wider readership than the ones issued in the 1930 . Evidence is found in the fact that Polillo Editore have commissioned retranslations for almost all titles in their "I Jeeves" series; however, they are still reissuing the translation of Right Ho, Jeeves, originally authored in 1985 by Buitoni-Duca;

8. the relevance of the (re)translation of book titles to capitalise on the marketability of a translation.

Discussion of the extant versions of The Inimitable Jeeves has shown the relevance of my approach to key issues in Translation Studies, such as modernisation vs preservation and domestication vs foreignization; while the comparison of five (re)translations of $A$ Damsel in Distress shed light on the (un)translatability of humour and on the incommensurability of language structures. Moreover, there is evidence of the Italian publishers' concern toward readability, since they have invested in new translations. As for the features that the Retranslation Hypothesis posits as typical of first translations, my analyses have shown that Italian first translations were indeed more assimilating than retranslations. For example, the comparison of Traverso's (1930) renderings of Culturally-Specific Terms to those by Lord (2010) show that the first translator was aligned to the translation norms of the fascist era which called for polished, conventional and "Italianised" versions, especially in terms of the translation of proper names and foreign terms. The most obvious reason for retranslation, ageing, is confirmed by my data, particularly by the comparisons of renderings of instances of intertextuality and of the usage of footnotes, that also show the impact of accessibility to resources such as better education, updated encyclopaedias and dictionaries and, possibly, the internet on the translators' work.

Given the scope of this study, only a minimal part of the material collected has been examined here. However, its richness and the time span that characterise Wodehouse's career and his publishing history in Italy allows for many more investigations, as I will highlight in the conclusions. 


\section{CONCLUSIONS}

This thesis has investigated problems shared in both Translation and Humour Studies, given the acknowledged difficulty in transposing humour from one culture to another (Chiaro, 2010b; Purdie, 1993) and the interdisciplinary nature of the field. The investigation has drawn on contributions from cognitive stylistics, linguistics, philosophy, pragmatics, psychology, and sociology.

Wodehouse's vast corpus of Italian (re)translations, specifically 176 translations of 87 books originally published between 1902 and 1974, and on which 62 translators have worked, has allowed for analyses of numerous renderings published over a long period of time, from 1928 to 2017. I have shown here in what way the Epistemic Approach may help to describe these renderings and, hence, the translating process.

Wodehouse's humour is complex, his production rich and his publishing history in Italy intricate. I firstly established the value of his work as a corpus to be analysed in Translation and Humour Studies. By collecting and inspecting Italian books and recording their metadata, a database containing records of 579 Italian editions, is now available for further interdisciplinary research. Secondly, I identified Wodehouse's Humour Devices and five key concepts to which they are ascribable: incongruity, exaggeration, surprise, endearment, and knowledge sharing. Mainly drawing from the construct of script at the basis of Attardo and Raskin's General Theory of Verbal Humor (1991) and from traditional theories in Humour Studies, I coined two terms to describe Wodehouse's most remarkable Humour Devices, namely (1) Script-Clash and (2) Hyper-Wording, defined, respectively, as (1) the contemporaneous presence of incongruous and surprising syntactic elements in the same sentence and (2) the rich, articulated, and detailed phrasing that Wodehouse constantly employs. On this basis, I have put forth an original formula to describe Wodehouse's humour, as humour of incongruity that embraces elements of surprise and exaggeration and expresses itself by means of utterances containing Script-Clashes and Hyper-Wording.

Since,as Chiaro states (2010, p. 1 ) "[t]he combination of linguistic and culture specific features [...] creates one of the most arduous challenges [...] for professional translators of comic literature". The thesis proposes two new, complementary classifications to describe the translation procedures employed by translators to render Culturally-Specific Terms and Humour Devices. I classify instances of translations published in Italy from 1928 to the present. Finally, the chapter on retranslations discusses how these classifications are employed in analysing different versions of the same work in the same 
language issued years apart, with a focus on some of Wodehouse's most praised Humour Devices, namely register clashes, intertextuality and similes.

\section{The model, the approach and the tools}

Since, in line with much of the literature (see Risku, 2012, for a review), I regard translation both as cognitive process implying choices (Wills, 1996) and a culturally and socially embedded phenomenon (Wolf in Gambier \& van Doorslaer, 2010), the model of text activation that underpins the Epistemic Approach I propose has the merit of highlighting the connection between the cognitive dimension and the social-cultural factors implied in the process of translation. In this light, it may find a place within the framework of the Polysystem Theory in Translation Studies (Even-Zohar, 1979).

The Epistemic Approach draws attention to what is known, that is to say the outcome of experiences transmuted into more abstract sorts of knowledge. It therefore encompasses various forms of learning, both formal and informal, in addition to cultural and social learning, in other words knowledge that is culturally constructed and achieved through social interaction. It therefore has a place in the approaches to Translation Studies that regard translation as a cognitive and socially situated interaction (Gambier \& van Doorslaer, 2010; see Risku, 2012 for a review). Moreover, its methodology and the tools I have employed may allow for the shift from description to explanation advocated by Chesterman (2004) and $\operatorname{Pym}(2010)$.

\section{A synthesis of findings and further developments}

Given the vast primary literature I have examined, the presentation of the findings has unavoidably been limited in this work. However, it has shown that the model of text activation and the Epistemic Approach can be applied to identify and describe a writer's style and its renderings in translation. Taking into account Wodehouse's life, career and experiences in the source culture, this approach allows for the appreciation of the kind of humour he employed and to highlight the most problematic items to be rendered in translation.

Specifically as for Wodehouse's contribution to the diffusion of the source culture, his style and humour, more research remains to be done in aspects other than the ones I could show in this study, for example, on the way he depicted the "world downstairs". He started to depict it in Something Fresh in 1915 and continued to describe his butlers, valets and the staff of the stately homes in the background of 
many of his stories set in England until his last book in 1975. It could be of great interest to investigate how Wodehouse's depictions changed while his society was changing, and how this transformation was received in the target culture through translations.

The analytical methods I propose are suitable to tackle aspects relative to the pragmatics of humour: to test Wodehouse's style against Grices's maxims (1975), and explore how Wodehouse engages the reader through the narrative point of view and how he sometimes addresses the "narratee", i.e. the audience of the narrator, as in the case of the stories of the Jeeves and Bertie cycle (Olson, 1996). The notion of Wodehouse as a "benign humourist" (Carlson, 1975), versus Pirandello's description of humour as "the sentiment of the opposite" (Pirandello, 1974; see: Eco, 1994, p. 167 for a translation of the phrase) would be of interest. So would a comparison of his life and works with those by the Italian humourist Giovannino Guareschi, since, as noted above, they share some significant traits. These are among further avenues for cross-cultural research on Wodehouse.

As for translation more widely, the tools I propose allow for the appreciation and the description of the treatment of specific items, such as varieties of foreign languages and of English, e.g. slang, at different times in the target culture, classified according to the translation procedures employed. My classifications facilitate comparisons between the renderings of the same items by different translators and also potentially the identification of translators' styles, by comparing their renderings with those in other books they translated, as in the case of Adriana Motti's translation of The Catcher in the Rye, discussed above. Investigation on a translator' s style, as advocated by Baker (2006), is one possible application of the Epistemic Approach that I propose.

The methodology I developed to classify renderings can also support investigations on misrenderings. Unlike approaches that mainly regard translation errors as offences against the function of the translation (see, Wills, 1996, p. 201), and approaches for which "the notion of translation error must be defined in terms of the translation process or product" (Nord, 1997, p. 73) and "should thus be related to that of the functional text unit" (ibid. p. 75), my approach focuses on the consequences of translation errors for text activation and, hence, on the readers' KnoW and on the writer's reputation in the target culture, thus additionally addressing the issue of the "alief in equivalence" posited in the Introduction (p. 1). My classifications allow for the assessment of mis-renderings in terms of lack of KnoW and of knowledge of the linguistic code(s). By relying on studies in Contrastive Linguistics, they permit the abstription of each of them to a specific morphological or syntactic area. Furthermore, by identifying the translation procedures employed, the classifications that I propose highlight the translators' choices in 
terms, for example, of the employment of hypernyms (Generalisation) and the consequences for their renderings (see, e.g. Tables 4.14 and 5.18).

Reflections on the shift to crowdsourcing and open translation projects in Web 2.0 and on its potentially subversive bi-directionality (Cronin in Venuti, 2012, p. 478), may add to the model of text activation and make it expand to incorporate a new notion of translation, i.e. translation as consumeroriented, rather than production-oriented. In this light, the Epistemic Approach to translation would offer insights as how the current notion of literacy in the post-print era and on reading practices, witnessing a shift from linear progression to fast browsing, may re-define the translator's agency. Moreover, the model I propose might be extended to include the actors that Buzelin (2005) calls "nonhuman hands" (p. 211), i.e. translation software, Personal Digital Assistants, Translation Memory Systems (Williams \& Chesterman, 2002, p. 15).

The tools I have proposed may be employed to investigate further instances of translations of verbally expressed humour in written texts by any authors to compare renderings of Humour Devices to renderings in any other language pairs. As a contribution to Thematic Studies, it would be stimulating to investigate how translators at different times rendered Wodehouse's "politically incorrect" language, i.e. phrases such as "one of the whitest men I know" that he sometimes employed, for example in A Damsel in Distress (1919; GV.19, chapter 21), to render which Italian translators employed "bravo" (Trans A and C), "retto" (Trans C), "honest" (Trans D) and "corretto" (trans E), respectively meaning "good", "honorable", "honest", and "decent" and in Joy in the Morning (1947; GV.59, p. 332) or "nigger" (in my corpus, only found in a reference to the "minstrel chaps" in Thank You, Jeeves, 1934; GV.46). ${ }^{141}$ A focus on the gender of the translator could be of interest, by comparing translations of the same text authored by female and male translators, specifically for renderings of Wodehouse's "sexist" remarks about aunts, girls and, generally, about "females of the species". I plan a paper on this topic to be submitted to the journal Humor for its special issue on gender differences in humour, planned in 2019.

Further studies on the corpus of Italian retranslations of Wodehouse's works in the light of the model of text activation may confirm the claim that publishing policies are based, especially in the case of big companies, on commercial interests and that "the textual profiles of translations are not determined simply by their chronological order of appearance but to respond to a number of different reasons and settings" (Koskinen \& Paloposki, 2003, p. 19) that are worth investigating. Furthermore, the many (re)translations in the Italian corpus can also be employed in translator training, by supplying students

\footnotetext{
${ }_{141}$ "[...] and most of these nigger minstrel chaps can pick the strings like nobody's business (p. 25)".
} 
with multiple translations in order to develop their understanding by means of practice, reflection and description, since as Evans (2014, p. 207) states, retranslation "encourages a critical practice of translation that is informed by a critical reading of other translations and theoretical approaches".

If a digitalised corpus of all 87 original books considered in this study were available, it would also be possible to:

1. perform computational explorations and diachronic analyses of similes (in line with Veale, 2013) according to (a) semantic fields (b) semantic distance between tenor and vehicle, (c) Wodehouse's use of Hyper-Wording and (d) periods and cycles of his production, as advocated by Hall (1974, p. 108);

2. investigate similes as instances of embodied humour (Risku, 2012, p. 6), with reference to all sensory modalities employed by Wodehouse;

3. conduct a systematic survey of Wodehouse's leitmotifs and co-occurrences throughout his oeuvre, such as the one, necessarily partial, conducted by Partington (2013, pp. 165-186) on a relatively small corpus of Wodehouse's early works from the 1910s and 1920s;

4. perform systematic analyses of Shakespearian intertextuality in both Wodehouse's original texts and on his Italian translators' renderings, with the aim of identifying trends both in his production and in the translating procedures employed in the different periods of his publishing history in Italy. Similar analyses could be performed on instances of the biblical images to which Wodehouse referred and on intertextual references to other writers and poets (Olney, 1962);

5. examine the Humour Devices I identified in the diachronic corpus to measure Wodehouse's vocabulary size and stylistic changes with age, given his high level of productivity into old age. This would complement Cotter's et al.'s findings (Cotter, Wilkinson, Canavan, \& O'Keeffe, 2011) that Wodehouse's vocabulary size and syntax did not show any decline with age, similarly to Bernard Shaw's and differently from Agatha Christie's (Lancashire \& Hirst, 2009).

Furthermore, by collaborating with other researchers, I could employ my tools to further investigate the potential of Heinemann's multi-lingual edition of "The Great Sermon Handicap", by comparing the analyses I performed on the Italian translations with some of the other $5^{8}$ languages in this edition. By 
the same token, collaboration might bring revealing results in contrastive studies, for example on the use of forms of address to render English "you" in French, Spanish and German and on their directionality, by examining how they were employed in the exchanges between Jeeves and Bertie. Besides, it would be intriguing to analyse and translate into Italian the text of what is almost certainly the first Wodehouse ever translated, "An Afternoon Dip", a short story published in a Dutch magazine in October 1904, within a month of its first appearance in Pearson's Magazine for September 1904. This is a recent (2017) discovery by Peter Nieuwenhuizen, President of the P. G. Wodehouse Dutch Society, ${ }^{142}$ that I have not yet seen but that I wish I could compare with an Italian version.

The findings of these further investigations would be made public on the blog on the translation of Wodehouse that I will soon start. In addition, in the 2017 Annual General Meeting of the P. G. Wodehouse Society U.K. - of which I am a member - held on September $25^{\text {th }} 2017$, I learnt that the newly founded P.G. Wodehouse International Society, an umbrella body of Wodehouse societies outside the $\mathrm{UK}$, is planning to develop the use of social media across the members of all existing societies and Wodehouse's fans all over the world. My blog devoted to translations, aiming at the collection of contributions of European scholars and experts on Wodehouse's works and their translations, will be part of this project.

To further investigate the material, I had six selected chapters of A Damsel in Distress machine translated once a month for ten months between March 2016 and January 2017. I have not included in this study the results of my analyses on the rendering of the instances of intertextuality and of the five similes I have presented here since they have not yielded relevant results. However, I will exploit this material to investigate if and in what respect the versions change over a longer stretch of time.

I also intend to apply the Epistemic Approach to identify the problematic textual items and eventually translate Wodehouse's first and last published works, never translated into Italian, namely the two short stories entitled "Some Aspects of Game-Captaincy" (for which Wodehouse won a prize) and "Work" published in The Public School Magazine in February and December 19oo, respectively, and Sunset at Blandings, the book on the manuscript of which Wodehouse was working in hospital (Usborne in Wodehouse, 1990, p. 104) when he died, on $14^{\text {th }}$ February 1974. The two early short stories already contain aspects of Wodehouse's stylistic and humour devices that I highlighted in this study. In "Some Aspects of Game-Captaincy", for example, one finds instances of Wodehouse's creative employment of affixation to form adjectives and adjectival phrases, such as "He is wearing a cap. [...] he is ordered to

\footnotetext{
${ }^{142}$ Tony Ring, personal communication $1^{\text {st }}$ July 2017.
} 
assume a capless state" and "These excuses are of the 'had-to-go-and-see-a-man-about-a-dog' type"; while in "Work" he already employed Hyper-Wording in dialogues, and exaggeration and incongruity in describing fellow students. ${ }^{143}$ Interestingly, "Work”, which depicts school life, also contains Wodehouse's first fictional dramatic dialogue. It already possesses the comic mood and the stylistic rhythm so praised by Hall (1974, p. 117) and some reflections on the joys of translation:

[...] never again have I felt the excitement that used to wander athwart my moral backbone when I was put on to translate a passage containing a notorious crux and seventeen doubtful readings, with only that innate genius, which is the wonder of the civilized world, to pull me through. And what a glow of pride one feels when it is all over; when one has made a glorious, golden guess at the $c r u x$, and trampled the doubtful readings under foot with inspired ease. It is like a day at the seaside.

Sunset at Blandings is an unfinished book, published posthumously by Chatto \& Windus with numerous notes and voluminous appendixes by Richard Usborne in 1977. A new edition, revised and amended by the editors and with a foreword by Douglas Adams, was released in 2000 by Penguin Books. I will investigate how Usborne epistemically approached the unfinished text, by particularly employing what he knew about Wodehouse's previous works, life experiences, writing methods and style, and the onehundred and eighty-three handwritten pages Wodehouse left, together with the ninety pages already typed on Wodehouse's favourite old 1927 Royal (Wodehouse, 1977, p. 104), to construct the missing parts of the manuscript and to hypothesise the evolution of the plot. Very much in line with my text activation model, Usborne also included Wodehouse's manuscript notes with a transcription to allow readers to develop their own hypotheses and ideas. I will then compare Usborne's annotations with those offered in the 2000 revised edition to highlight the way in which the editors, Wodehousian experts N. T. P. Murphy and Tony Ring, applied their knowledge to revise and update Usborne's footnotes to the original text, that they have "shortened and depersonalised" (P.G. Wodehouse, 200o, p. ii).

Lastly, I intend to conduct a personal research on the so-called "Berlin broadcast", the five radio talks Wodehouse gave in Berlin in 1940, soon after having been released from internment in Nazi camps and translate them into Italian for the first time. In 2011 newly declassified MI5 documents revealed the

\footnotetext{
${ }^{143}$ "J. Essop of the first eleven, who can it a ball over two ponds, a wood and seven villages" and "Mill-Stuart who [...] can speak Sanscrit like a native of Sancritia".
} 
persistent attempts on the part of his friends to enable Wodehouse to return to Great Britain after the Second World War without fear of being persecuted for alleged treachery. The British Library has recently acquired Wodehouse's personal archive containing the camp diary Wodehouse kept during imprisonment. I will therefore be able to research this period of Wodehouse's life in its personal, social and political context, in other words, highlighting Wodehouse's and Great Britain's "Sitz im Leben" when the five talks were broadcast. I will do this as an act of homage to a writer and a country to whom I owe so much. Wodehouse's reputation is still stained in Italy since the complete events surrounding the Berlin Broadcast and the so-called War Controversy has never been told in full in Italian yet. But this will be another story. 


\begin{tabular}{|c|c|c|}
\hline CODE & ORIGINAL TITLE UK & CYCLE \\
\hline GV.o1 & The Pothunters & SS \\
\hline GV.02 & A Prefect's Uncle & SS \\
\hline GV.o3 & Tales of St Austin's & SS \\
\hline GV.04 & The Gold Bat & SS \\
\hline GV.05 & The Head of Kay's & SS \\
\hline GV.o6 & Love Among the Chickens & UK \\
\hline GV.o7 & The White Feather & SS \\
\hline GV.o8 & Mike & PS \\
\hline GV.o9 & A Gentleman of Leisure & SA \\
\hline GV.10 & Psmith in the City & PS \\
\hline GV.11 & The Prince and Betty & SA \\
\hline GV.12 & The Little Nugget & SS \\
\hline GV.13 & The Man Upstairs and Other Stories & SA \\
\hline GV.14 & Psmith, Journalist & PS \\
\hline GV.15 & Something Fresh & $\mathrm{BC}$ \\
\hline GV.16 & The Man With Two Left Feet & SA \\
\hline GV.17 & Uneasy Money & SA \\
\hline GV.18 & Piccadilly Jim & SA \\
\hline GV.19 & A Damsel in Distress & SA \\
\hline GV.2O & The Coming of Bill & SA \\
\hline GV.21 & Jill, the Reckless & SA \\
\hline GV.22 & Indiscretions of Archie & SA \\
\hline GV.23 & The Girl on the Boat & SA \\
\hline GV.24 & The Clicking of Cuthbert & GS \\
\hline GV.25 & The Adventures of Sally & SA \\
\hline GV.26 & The Inimitable Jeeves & $\mathrm{JB}$ \\
\hline GV.27 & Leave it to Psmith & PS \\
\hline GV.28 & Ukridge & UK \\
\hline GV.29 & Bill the Conqueror & SA \\
\hline
\end{tabular}




\begin{tabular}{|c|c|c|}
\hline CODE & ORIGINAL TITLE UK & CYCLE \\
\hline GV.3o & Carry on, Jeeves & JB \\
\hline GV.31 & Sam the Sudden & SA \\
\hline GV.32 & The Heart of a Goof & GS \\
\hline GV.33 & Meet Mr Mulliner & MM \\
\hline GV.34 & The Small Bachelor & SA \\
\hline GV.35 & Money for Nothing & SA \\
\hline GV.36 & Mr Mulliner Speaking & MM \\
\hline GV.37 & Summer Lightning & $\mathrm{BC}$ \\
\hline $\mathrm{GV} \cdot 38$ & Very Good, Jeeves & JB \\
\hline GV.39 & If I Were You & SA \\
\hline GV.4O & Big Money & SA \\
\hline GV.41 & Doctor Sally & SA \\
\hline GV.42 & Hot Water & SA \\
\hline GV.43 & Louder and Funnier & SA \\
\hline GV.44 & Mulliner Nights & $\mathrm{MM}$ \\
\hline GV.45 & Heavy weather & $\mathrm{BC}$ \\
\hline GV.46 & Thank You, Jeeves & JB \\
\hline GV.47 & Right Ho, Jeeves & JB \\
\hline GV.48 & Blandings Castle and Elsewhere & $\mathrm{BC}$ \\
\hline GV.49 & The Luck of the Bodkins & $\mathrm{DC}$ \\
\hline GV.5O & Young Men in Spats & DC \\
\hline GV.51 & Laughing Gas & SA \\
\hline GV.52 & Lord Emsworth and Others & $\mathrm{BC}$ \\
\hline GV.53 & Summer Moonshine & SA \\
\hline GV.54 & The Code of the Woosters & JB \\
\hline GV.55 & Uncle Fred in the Springtime & UF \\
\hline GV.56 & Quick Service & SA \\
\hline GV.57 & Eggs, Beans and Crumpets & $\mathrm{DC}$ \\
\hline GV.58 & Money in the Bank & SA \\
\hline GV.59 & Joy in the Morning & $\mathrm{JB}$ \\
\hline GV.6o & Full Moon & $\mathrm{BC}$ \\
\hline GV.61 & Spring Fever & SA \\
\hline
\end{tabular}




\begin{tabular}{|c|c|c|}
\hline CODE & ORIGINAL TITLE UK & CYCLE \\
\hline GV.62 & Uncle Dynamite & UF \\
\hline GV.63 & The Mating Season & JB \\
\hline GV.64 & Nothing Serious & $\mathrm{BC}$ \\
\hline GV.65 & The Old Reliable & SA \\
\hline GV.66 & Barmy in Wonderland & SA \\
\hline GV.67 & Pigs Have Wings & $\mathrm{BC}$ \\
\hline GV.68 & Ring for Jeeves & JB \\
\hline GV.69 & Jeeves and the Feudal Spirit & JB \\
\hline GV.7O & French Leave & SA \\
\hline GV.71 & Something Fishy & SA \\
\hline GV.72 & Cocktail Time & UF \\
\hline GV.73 & A Few Quick Ones & JB \\
\hline GV.74 & Jeeves in the Offing & JB \\
\hline GV.75 & Ice in the Bedroom & SA \\
\hline GV.76 & Service with a Smile & $\mathrm{BC}$ \\
\hline GV.77 & Stiff Upper Lip, Jeeves & JB \\
\hline GV.78 & Frozen Assets & SA \\
\hline GV.79 & Galahad at Blandings & $\mathrm{BC}$ \\
\hline GV.8o & Company for Henry & SA \\
\hline GV.81 & Do Butlers Burgle Banks? & SA \\
\hline GV.82 & A Pelican at Blandings & $\mathrm{BC}$ \\
\hline GV.83 & The Girl in Blue & SA \\
\hline GV.84 & Much Obliged, Jeeves & JB \\
\hline GV.85 & Pearls, Girls and Monty Bodkin & SA \\
\hline GV.86 & Bachelors Anonymous & SA \\
\hline GV.87 & Aunts Aren't Gentlemen & JB \\
\hline
\end{tabular}




\section{Appendix $2 \quad$ P.G. Wodehouse: works and cycles}

This section presents Wodehouse's books, whose translations have been examined in this study, according to ten "cycles", that's to say, to their recurrent locations and characters. Works belonging to each cycle are identified by the "GV codes" used in compiling the list designed for the purposes of this research. Not all books belong to a cycle (in the following paragraphs they will be labelled "stand-alone stories"; while others feature characters that belong to more than one cycle and are,hence, listed twice.

\begin{tabular}{|c|c|c|}
\hline Blandings Castle & $\mathrm{BC}$ & $\begin{array}{l}\text { This cycle, referred to by Wodehouse himself }{ }^{144} \text { as the "Blandings Saga" } \\
\text { is a series of stories and novels set in the idyllic location of an early } \\
\text { Tudor stately home and its gardens, the very embodiment of } \\
\text { Wodehouse's "Never-never Land". The castle can be at times inhabited } \\
\text { by lots of denizens (aunts, nieces, nephews, cousins, and occasional } \\
\text { guests or impostors). The large domestic staff includes Sebastian } \\
\text { Beach, Wodehouse's first and archetypal butler (McCrum, 2004). The } \\
\text { head of the family, Lord Emsworth, good-natured, absent-minded, } \\
\text { longing for solitude and rural peace, is the character said to be the one } \\
\text { "with whom Wodehouse identified most readily" (McCrum, 2oo4, p. } \\
\text { 172). He is said to be so constituted that "no man or thing really had the } \\
\text { power to trouble him deeply".145 The first book of the cycle, Something } \\
\text { Fresh (GV.15), appeared in 1915 and was published in the USA under } \\
\text { the title of Something New in the same year. According to McCrum } \\
\text { (20o4), Something Fresh is pervaded by a honeymoon atmosphere and } \\
\text { is a celebration of Wodehouse's own marriage. }{ }^{146} \text { There are several } \\
\text { other titles in the series: Summer Lightning (1929; GV.37), Heavy } \\
\text { Weather (1933; GV.45), Blanding Castle and Elsewhere (1935; GV.48), } \\
\text { Lord Emsworth and Others (1937; GV.52), Uncle Fred in the Springtime } \\
\text { (1939; GV.55), Full Moon (1947; GV.6o), Nothing serious (1950; GV.64), } \\
\text { Pigs Have Wings (1952; GV.67), Service with a Smile (1962; GV.76), } \\
\text { Galahad at Blandings (1964; GV.79), A Pelican at Blandings (1969; } \\
\text { GV.82), and Sunset at Blandings (unfinished, published posthumously } \\
\text { in 1977). Wodehouse loved his Saga. In a letter to his grand-daughter in } \\
\text { 1948, after telling her how exhausted he was in those days, having "two } \\
\text { shows in rehearsal", 147 he told her that in his free time he was reading } \\
\text { Blanding Castle and "was lost in admiration for the brilliance of the } \\
\text { author" (Wodehouse \& Ratcliffe, 2012, p. } 414 \text { ). }\end{array}$ \\
\hline
\end{tabular}

\footnotetext{
${ }^{144}$ Something Fresh, Introduction to 1969 edition.

${ }^{145}$ Something Fresh, 1915, p. 12.

${ }^{146}$ Wodehouse met Ethel Rowley, a widow, in New York in 1914 and they got married the following year.

${ }^{147}$ They were "The Play's the Thing" and "Sally", already represented respectively in 1921 and 1926 in New York.
} 


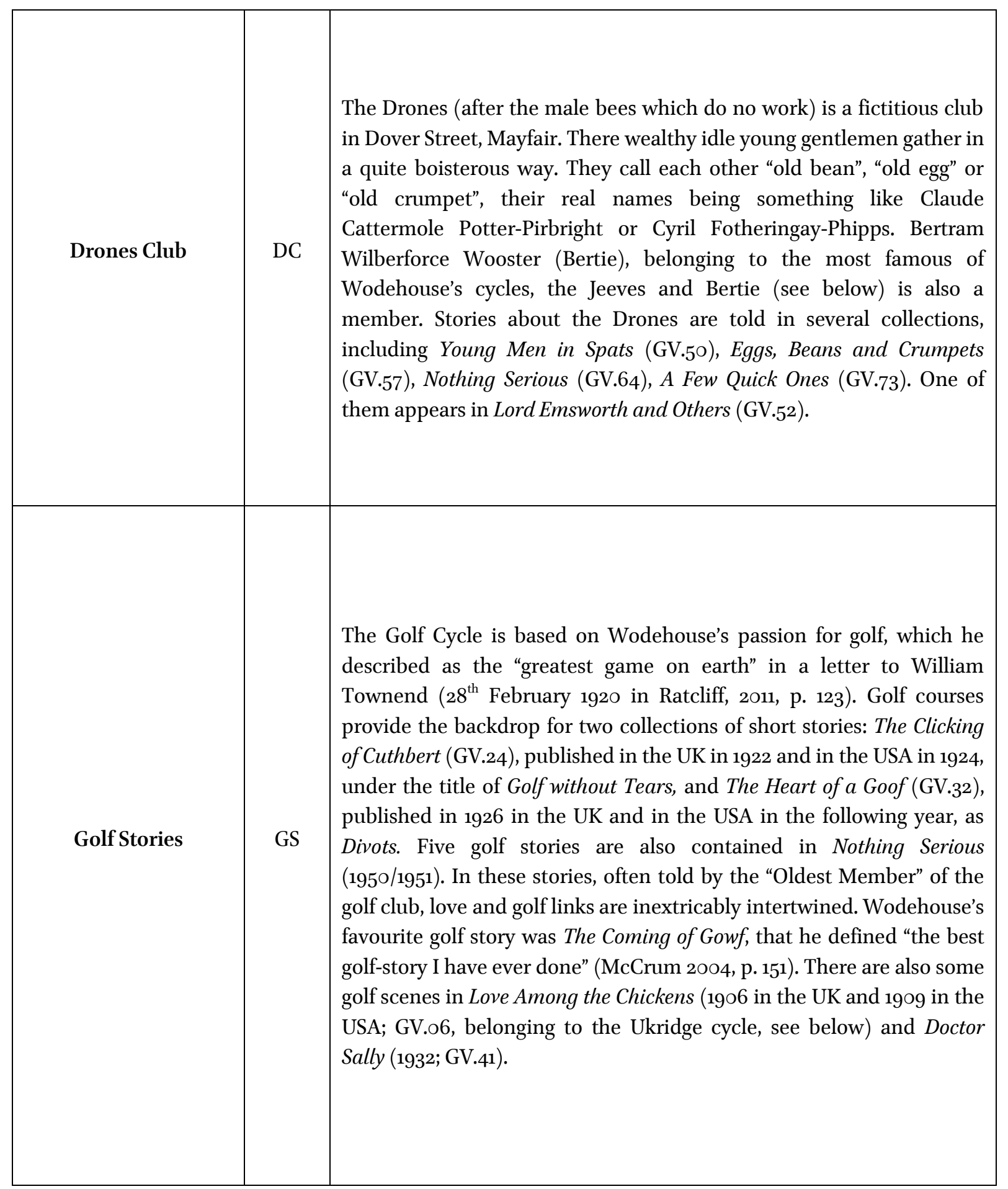




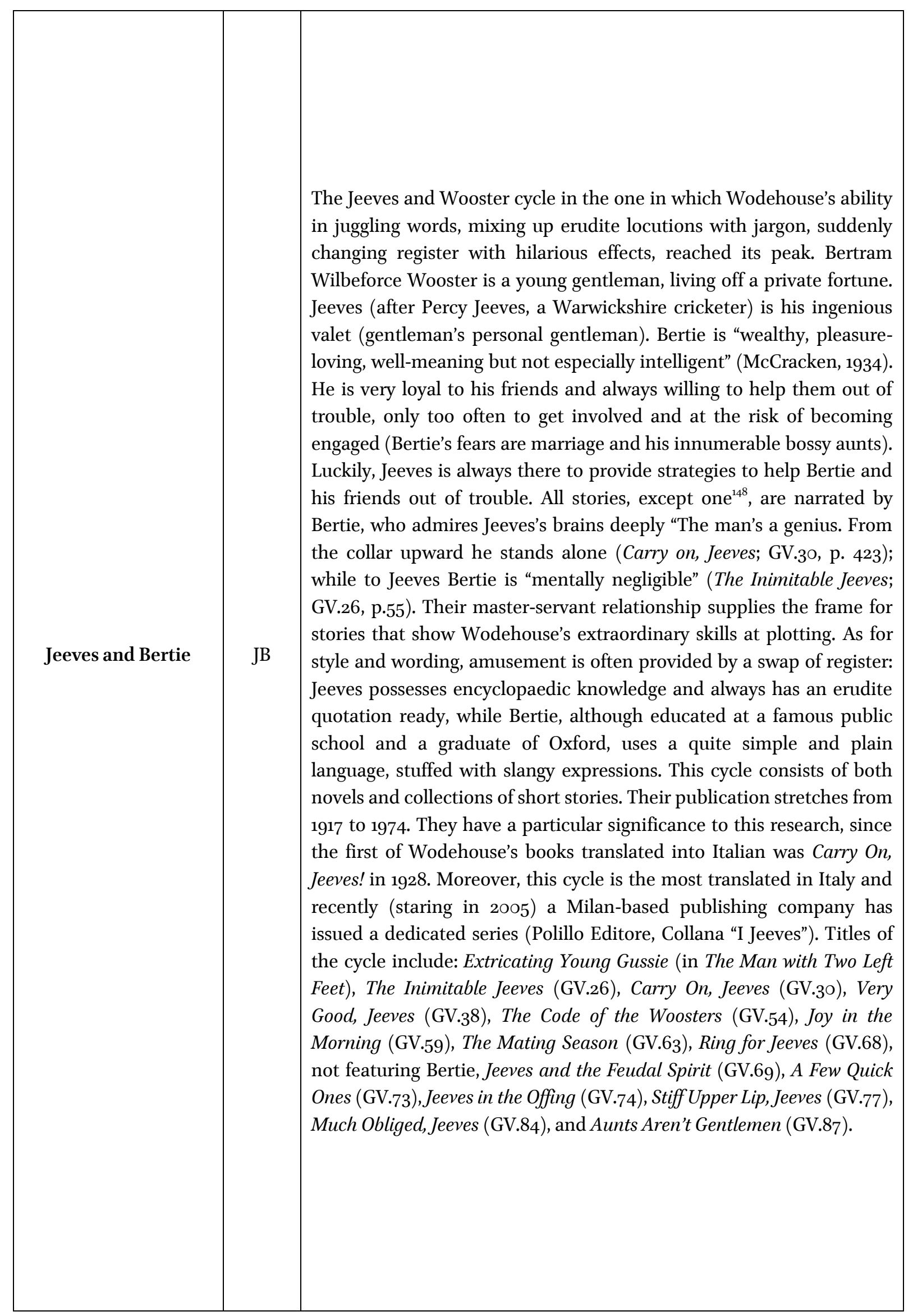

${ }^{148}$ Bertie Changes His Mind (1922), told by Jeeves. 


\begin{tabular}{|c|c|c|}
\hline Mr Mulliner & MM & $\begin{array}{l}\text { Mr Mulliner is a born story-teller, his characteristic being that of } \\
\text { always finding a way to get inspiration from any event he witnesses at } \\
\text { the Angler's Rest pub to tell an improbable story involving one of his } \\
\text { many relatives. The collections of stories in this cycle include Meet Mr } \\
\text { Mulliner (GV.33), Mr Mulliner Speaking (GV.36) and Mulliner Night } \\
\text { (GV.44). Mr Mulliner's companions are identified by the drinks they } \\
\text { are having at the pub, such as a "Scotch and Lemon" or a "Stout-and- } \\
\text { Mild". }\end{array}$ \\
\hline Psmith & PS & $\begin{array}{l}\text { The Psmith cycle (with a silent P added to distinguish himself from the } \\
\text { "too many Smiths", as he admits on page } 166 \text { of the } 2008 \text { edition of } \\
\text { Mike, originally written in 1909, the first title of the series) revolves } \\
\text { around one of the most inspired of Wodehouse's characters } \\
\text { (Donaldson, 2014). Ingenious, original, imperturbable, stylish in his } \\
\text { immaculate clothes and monocle, trustworthy, and, although } \\
\text { somehow reckless, gifted with the noblest aristocratic virtues, with an } \\
\text { inclination toward socialism. He is the central character in four novels: } \\
\text { Mike (GV.o8), Psmith in the City (GV.10), Psmith, Journalist (GV.14) and } \\
\text { Leave it to Psmith (GV.27), a story set at Blandings Castle, so that this } \\
\text { cycle overlaps with a the second one, the Blanding's Castle Saga. }\end{array}$ \\
\hline Stand-Alone & SA & $\begin{array}{l}\text { The Stand-Alone stories include books which appeared over quite a } \\
\text { long time. From } 1918 \text { (Piccadilly Jim; GV.18) to } 1940 \text { (Quick service; } \\
\text { GV.56) and even to 1961, if we are to take into account the fact that } \\
\text { Sam the Sudden (1925; GV31) was later (1961) re-worked as Ice in the } \\
\text { Bedroom (McCrum, 2004) }{ }^{149} \text {. Locations embrace the idealized suburbs } \\
\text { of Valley Fields, one of Wodehouse's favourite places (identifiable with } \\
\text { the grounds where his alma mater, Dulwich College, was located), a } \\
\text { huge estate in Hollywood, California, owned by a movie mogul, and a } \\
\text { country house in Sussex populated by both British and American } \\
\text { denizens. Not all are exclusive characters; some minor ones also } \\
\text { appear in other books, belonging to one of the other cycles. }\end{array}$ \\
\hline
\end{tabular}

${ }^{149}$ Previously serialized in the Saturday Evening Post as Sam in the Suburbs, it was one of Wodehouse's own favourite books (McCrum 2004, pp. 24 and 405). 


\begin{tabular}{|c|c|c|}
\hline School Stories & SS & $\begin{array}{l}\text { A lot of autobiographical reference can be found throughout } \\
\text { Wodehouse's works }{ }^{150} \text {, but they are at their most evident in the School } \\
\text { Stories cycle, written between } 1902 \text { and 1907. Sports and the hardships } \\
\text { of studying are the recurrent themes in these novels. The Pothunters } \\
\text { (GV.o1), Wodehouse's first novel, and the collection of the Tales of St. } \\
\text { Austin (GV.o3) are set at St. Austin's public school. A Prefect's Uncle } \\
\text { (GV.o2) is set at Beckford College, while the background for The Gold } \\
\text { Bat (GV.o4) and The While Feather (GV.o7), the last book of the cycle, } \\
\text { is Wrykin public school. The first two are cricket stories, whereas the } \\
\text { sport protagonist of the last one is boxing. From } 1894 \text { to 19oo } \\
\text { Wodehouse was in fact a boarder at Dulwich College, London } \\
\text { (founded in 1619), together with his two older brothers while their } \\
\text { parents were living in Hong Kong. He remained so attached to his old } \\
\text { school that every time he was in London he found time to visit it and } \\
\text { to attend school cricket matches (F. L. Donaldson, 2014). There are } \\
\text { frequent references to the "old school days" in both Wodehouse's } \\
\text { books and letters. Besides, he maintained long-life relationships with } \\
\text { some of his former school mates, especially William Townend who } \\
\text { edited Performing Flea, published in 1953, a collection of the letters } \\
\text { Wodehouse had sent to him. School provided Wodehouse with a } \\
\text { classical education but he was equally talented in writing "school slang } \\
\text { (oil; archbish; barge; biff; corking)" which would eventually morph into } \\
\text { the lingo of his 194O story collection Eggs, Beans and Crumpets, } \\
\text { belonging to the Drones Club cycle (see above). }\end{array}$ \\
\hline Uncle Fred & UF & $\begin{array}{l}\text { The Uncle Fred features Reginald (Pongo) Twistleton's (one of the } \\
\text { Drones) uncle. Frederick Altamont Conwallis Twistleton, who has } \\
\text { unexpectedly inherited the title of Earl of Ickenham as a result of a } \\
\text { series of deaths in his family, has a home in Hampshire but visits } \\
\text { Blanding Castle twice. Consequently, two of these novels overlap with } \\
\text { the Blandings Cycle (see above). In the } 189 \text { os, Uncle Fred used to be a } \\
\text { member of the Pelican club, just like the On. Galahad Treepwood } \\
\text { (Gally), Lord Emsworth's younger brother. Both are distinguish- } \\
\text { looking gentlemen depicted in their late fifties, who travelled widely in } \\
\text { their youth and got acquainted with lots of people belonging to both } \\
\text { the high and low classes of Victorian and Edwardian London. When } \\
\text { Uncle Fred manages to get rid of his wife's surveillance, he flees to } \\
\text { London where he inevitably involves scared-to-death Pongo in his } \\
\text { crazy adventures and often compels him to impersonate people. Uncle } \\
\text { Fred made his first appearance in a 1935 short story (Uncle Fred Flits } \\
\text { By) included in Young Men in Spats (GV.5O). He was then the main } \\
\text { character in Uncle Dynamite (GV.62) and Cocktail Time (GV.72). Two } \\
\text { other novels of this cycle, Uncle Fred in the Spring Time (GV.55) and } \\
\text { Service with a Smile (GV.76), are set at Blandings. }\end{array}$ \\
\hline
\end{tabular}

\footnotetext{
${ }^{150}$ Many names that Wodehouse devised for characters were inspired by places where he used to live. Examples are: Emsworth is the coastal town in Hampshire where he rented Threepwood Cottage at the beginning of the 190os, while Beach, the butler featuring in the Blandings cycle, was named after Beach Road which runs down to the seashore at Emsworth (McCrum, 2004, p.6o).

${ }^{151}$ McCrum at http://public.oed.com/aspects-of-english/shapers-of-english/pg-wodehouse-in-the-oed/ (accessed $28^{\text {th }}$ May 2015).
} 


\begin{tabular}{|l|l|l|}
\hline Ukridge & $\begin{array}{l}\text { Strictly speaking, the Ukridge cycle it consists of only two books. The } \\
\text { protagonist, Stanley Featherstonehaugh Ukridge, appears for the first } \\
\text { time in the } 1906 \text { novel Love Among the Chickens (GV.o6) but is the } \\
\text { longest runner of Wodehouse's characters, appearing from time to } \\
\text { time in several stories spanning over 6o years. }{ }^{25} \text { Ukridge's main } \\
\text { characteristics are his chaotic schemes conceived to make easy money } \\
\text { and his "equally chaotic wardrobe" (Wodehouse \& Ratcliffe, 2012, p. } \\
\text { 6o). A collection of ten stories (Ukridge; GV.28) published in the UK in } \\
1924 \text { is entirely devoted to his adventures, told by an old school friend } \\
\text { of his, writer James "Corky" Corcoran. The character of Ukridge owned } \\
\text { much to one of Wodehouse's long-life friends, William Townsend, and } \\
\text { to one of Wodehouse's early collaborators, Herbert Westbrook, }{ }^{153} \\
\text { known to his friends as the "King of Slackers" (ibid. p. 53). He also } \\
\text { appears in collections of short stories, including Lord Emsworth and } \\
\text { Others (GV.52), Nothing Serious (GV.64),A Few Quick Ones (GV.73). }\end{array}$ \\
\hline
\end{tabular}

\footnotetext{
${ }^{152}$ In a letter wrote to Frances Donaldson, on June, $2{ }^{\text {nd }} 1945$, Wodehouse wrote: "It looks to me as if the only one of my characters who will be able to carry on is Ukridge" (Wodehouse \& Ratcliffe, 2012, p. 365).

${ }^{153}$ In 1907, Westbrook co-authored with Wodehouse Not George Washington, a semi-autobiographical novel telling about Wodehouse's early career as a journalist in London.
} 


\section{Appendix $3 \quad$ Wodehouse studies: key sources}

\section{Books:}

Cazalet-Keir, Thelma, (Ed), 1973. Homage to P.G. Wodehouse: A Critical and Historical Essay. London: Barrie \& Jenkins Ltd.

Connolly, Joseph, 1979. P. G. Wodehouse: An Illustrated Biography. London: Orbis.

Donaldson, Frances, 1982. P. G. Wodehouse: The Authorized Biography. London: Weidenfeld \& Nicholson.

Easdale, Roderick, 2004, The Novel Life of P. G. Wodehouse. Newtown: Cyhoeddwyr y Superscript Ltd. French, R.B.D, 1966, P. G. Wodehouse. Edinburgh and London: Oliver and Boyd Ltd.

Green, Benny, 1981. P. G. Wodehouse: A Literary Biography. London: Pavilion Books.

Hall, Robert A, Jr, 1974. The Comic Style of P. G. Wodehouse. Hamden, Connecticut. Archon Books.

McCrum, Robert, Wodehouse: A Life. Viking, London, 2004

Morris, J. H. C., 1981. Thank You, Wodehouse. London: Weidenfeld and Nicolson Ltd.

Phelps, Barry, 1992. P. G. Wodehouse: Man and Myth. London: Constable and Co Ltd.

Sproat, Iain, 1981. Wodehouse at War. London: Milner and Co Ltd.

Rea, A. (Ed.), 2015. Middlebrow Wodehouse: P.G. Wodehouse's Work in Context. Abington: Routledge.

Thompson, Kristin, 1992. Wooster Proposes, Jeeves Disposes. New York: James H. Heineman, Inc.

Usborne, Richard, 1961. Wodehouse at Work. London: Herbert Jenkins.

Usborne, Richard, 1978. Wodehouse at Work to the End. London: Penguin.

Usborne, Richard, 1981. A Wodehouse Companion. London: Elm Tree Books.

Usborne, Richard, 1991. After Hours with P. G. Wodehouse. London: Hutchinson.

\section{Websites:}

P.G. Wodehouse Society U.K. : http://www.pgwodehousesociety.org.uk/

Madame Eulalie's rare Plums. Devoted to the early works of P.G. Wodehouse: http://www.madameulalie.org/

Biblia Wodehousiana: http://terry-mordue.co.uk/biblia-wodehousiana/

The Globe Reclamation Project: http://www.madameulalie.org/grp/GRPMenu.html Plumtopia: https://honoriaplum.wordpress.com/ 


\section{Appendix $4 \quad$ First editions of Italian translations with translators}

\begin{tabular}{|c|c|c|c|c|c|c|}
\hline$C O D E$ & ORIGINAL TITLE UK & $\begin{array}{c}U K \\
Y E A R\end{array}$ & ITALIAN TITLE & TRANSLATOR & $\begin{array}{c}I T \\
Y E A R\end{array}$ & PUBLISHER \\
\hline GV.o1 & The Pothunters & 1902 & I conquistatori di coppe: romanzo & Benzi Mario & $193^{2}$ & Bietti \\
\hline GV.o2 & A Prefect's Uncle & $19 \circ 3$ & Lo zio del prefetto: romanzo & Palumbo Francesco & $193^{2}$ & Bietti \\
\hline GV.o3 & Tales of St Austin's & 1903 & Racconti di sant'Agostino & Lori Ida & 1932 & Bietti \\
\hline GV.o4 & The Gold Bat & 1904 & Battaglie sportive & Baraldi Lina & $193^{2}$ & Bietti \\
\hline GV.o5 & The Head of Kay's & $19 \circ 5$ & Il capo della Kay: romanzo & Palumbo Francesco & 1932 & Bietti \\
\hline GV.o5 & The Head of Kay's & 1905 & Il capo del Kay: romanzo sportivo inglese & Shepley F. Leon & 1933 & Monanni \\
\hline GV.o6 & Love Among the Chickens & $19 \circ 6$ & L'amore tra i polli & Spaventa Filippi Silvio & 1929 & Monanni \\
\hline GV.o6 & Love Among the Chickens & $19 \circ 6$ & Amore tra i polli: romanzo & Palumbo Francesco & 1932 & Bietti \\
\hline GV.o6 & Love Among the Chickens & $19 \circ 6$ & L'amore tra i polli & Carter Dienne & 1938 & Aurora \\
\hline GV.o6 & Love Among the Chickens & $19 \circ 6$ & Amore fra i polli & Previtali Oriana & 1961 & Rizzoli \\
\hline GV.o6 & Love Among the Chickens & $19 \circ 6$ & L'amore fra i polli & Bodoman Mario & 1990 & Mursia \\
\hline GV.o7 & The White Feather & 1907 & Una penna di coda: romanzo & Benzi Mario & $193^{2}$ & Bietti \\
\hline GV.o8 & Mike & $19 \circ 9$ & Mike: storia di un collegio: romanzo & Benzi Mario & $193^{2}$ & Bietti \\
\hline GV.o8 & Mike & $19 \circ 9$ & Mike & Castelli Giulia & 1992 & Mursia \\
\hline GV.o9 & A Gentleman of Leisure & 1910 & Un gentiluomo in ozio: romanzo umoristico inglese & Lori Ida & 1931 & Bietti \\
\hline GV.o9 & A Gentleman of Leisure & 1910 & Un gentiluomo in ozio: romanzo umoristico inglese & Rafanelli Metello Brunone & 1932 & Monanni \\
\hline GV.o9 & A Gentleman of Leisure & 1910 & Jimmy all'opra & Bianchini Alfredo & 1935 & S.A.C.S.E. \\
\hline GV.o9 & A Gentleman of Leisure & 1910 & Il gentiluomo spensierato: un giallo umoristico & Dàuli Gian & 1939 & Lucchi \\
\hline GV.o9 & A Gentleman of Leisure & 1910 & Un gentiluomo in ozio: romanzo umoristico inglese & Trimarchi Anna Chiara & 1993 & Mursia \\
\hline GV.10 & Psmith in the City & 1910 & Psmith in banca: romanzo & Pitta Alfredo & $193^{2}$ & Bietti \\
\hline GV.10 & Psmith in the City & 1910 & Psmith in banca & Trimarchi Anna Chiara & 1990 & Mursia \\
\hline GV.11 & The Prince and Betty & 1912 & Il principe e Betty: romanzo & Palumbo Francesco & $193^{2}$ & Bietti \\
\hline GV.11 & The Prince and Betty & 1912 & Il principe e Betty: romanzo umoristico inglese & Martone Maria & 1932 & Monanni \\
\hline GV.11 & The Prince and Betty & 1912 & Il principe e Betty & Castelli Giulia & 1990 & Mursia \\
\hline GV.12 & The Little Nugget & 1913 & Pepita d'oro: romanzo umoristico inglese & Malatesta Mario & $193^{2}$ & Monanni \\
\hline GV.12 & The Little Nugget & 1913 & La piccola pepita: romanzo & Pitta Alfredo & 1932 & Bietti \\
\hline GV.12 & The Little Nugget & 1913 & Il filone d'oro: romanzo umoristico & Dàuli Gian & 1940 & Lucchi \\
\hline GV.12 & The Little Nugget & 1913 & La piccola pepita & Castelli Giulia & 2012 & Mursia \\
\hline GV.13 & The Man Upstairs and Other Stories & 1914 & L'uomo del piano di sopra & Palumbo Francesco & $193^{2}$ & Bietti \\
\hline GV.13 & The Man Upstairs and Other Stories & 1914 & L'uomo del piano di sopra: racconti umoristici inglesi & Martone Maria & 1933 & Monanni \\
\hline GV.13 & The Man Upstairs and Other Stories & 1914 & L'uomo del piano di sopra e altri racconti & del Tanaro Teobaldo & 1992 & Mursia \\
\hline GV.14 & Psmith, Journalist & 1915 & Psmith giornalista: romanzo & Pitta Alfredo & 1932 & Bietti \\
\hline GV.14 & Psmith, Journalist & 1915 & Psmith giornalista: romanzo umoristico & Dàuli Gian & 1940 & Lucchi \\
\hline GV.14 & Psmith Journalist & 1915 & Le gesta di Psmith & Bertola Stefania & 1990 & Guanda \\
\hline GV.14 & Psmith, Journalist & 1915 & Psmith giornalista & Trimarchi Anna Chiara & 1991 & Mursia \\
\hline GV.15 & Something Fresh & 1915 & Qualche cosa di nuovo: romanzo umoristico & Fratta L. & $193^{2}$ & Bietti \\
\hline GV.15 & Something Fresh & 1915 & Qualche cosa di nuovo: romanzo umoristico inglese & Bernardini Lepido & 1932 & Monanni \\
\hline GV.15 & Something Fresh & 1915 & Qualcosa di nuovo & Bodoman Mario & 2011 & Guanda \\
\hline GV.16 & The Man With Two Left Feet & 1917 & L'uomo con due piedi sinistri & Pisano G. V. & $193^{2}$ & Bietti \\
\hline GV.16 & The Man With Two Left Feet & 1917 & L'uomo con due piedi sinistri & del Tanaro Teobaldo & 1991 & Mursia \\
\hline GV.17 & Uneasy Money & 1917 & Denaro difficile: romanzo umoristico inglese & Carlesimo Maria & $193^{2}$ & Monanni \\
\hline
\end{tabular}




\begin{tabular}{|c|c|c|c|c|c|c|}
\hline GV.17 & Uneasy Money & 1917 & Danaro incomodo: romanzo & Palumbo Francesco & 1938 & Bietti \\
\hline GV.17 & Uneasy Money & 1917 & Denaro difficile & del Tanaro Teobaldo & 1992 & Mursia \\
\hline GV.18 & Piccadilly Jim & 1918 & Jim di Piccadilly: romanzo umoristico & Lori Ida & 1931 & Bietti \\
\hline GV.18 & Piccadilly Jim & 1918 & Jim di Piccadilly: romanzo umoristico inglese & Malatesta Mario & 1931 & Monanni \\
\hline GV.18 & Piccadilly Jim & 1918 & Jim di Piccadilly: romanzo umoristico & Serragli Nadia & 1989 & Lucarini \\
\hline GV.18 & Piccadilly Jim & 1918 & Piccadilly Jim & Salvatorelli Franco & 1991 & Mursia \\
\hline GV.18 & Piccadilly Jim & 1918 & Piccadilly Jim & Mazzarelli Paola & 2005 & Guanda \\
\hline GV.19 & A Damsel in Distress & 1919 & Una donzella in imbarazzo: romanzo umoristico inglese & Palumbo Francesco & 1931 & Monanni \\
\hline GV.19 & A Damsel in Distress & 1919 & Una signorina in imbarazzo: romanzo umoristico inglese & Mozzati Ariberto & 1931 & Bietti \\
\hline GV.19 & A Damsel in Distress & 1919 & Un capriccio e poi... & Bianchini Alfredo & 1935 & S.A.C.S.E. \\
\hline GV.19 & A Damsel in Distress & 1919 & Una magnifica avventura: romanzo umoristico & Dàuli Gian & 1939 & Lucchi \\
\hline GV.19 & A Damsel in Distress & 1919 & Una damigella in pericolo & Palazzi Rosetta & 1994 & Mursia \\
\hline GV.2O & The Coming of Bill & 1920 & La venuta di Bill: romanzo umoristico inglese & Pitta Alfredo & $193^{2}$ & Monanni \\
\hline GV.2O & The Coming of Bill & 1920 & La venuta di Bill: romanzo umoristico & Casale-Rossi Teresa & $193^{2}$ & Bietti \\
\hline GV.21 & Jill, the Reckless & 1921 & Jill ragazza bizzarra & Pitta Alfredo & 1931 & Bietti \\
\hline GV.21 & Jill, the Reckless & 1921 & Giulia la bizzarra: romanzo umoristico inglese & Rafanelli Metello Brunone & $193^{2}$ & Monanni \\
\hline GV.21 & Jill, the Reckless & 1921 & Jill ragazza bizzarra & Ferri Corrado & 1966 & Bietti \\
\hline GV.21 & Jill, the Reckless & 1921 & Jill ragazza bizzarra & Bodoman Mario & 1991 & Mursia \\
\hline GV.22 & Indiscretions of Archie & 1921 & Indiscrezioni di Arcibaldo & Palumbo Francesco & 1931 & Monanni \\
\hline GV.22 & Indiscretions of Archie & 1921 & Arcibaldo conquista l'America & Pitta Alfredo & 1931 & Bietti \\
\hline GV.22 & Indiscretions of Archie & 1921 & Le imprudenze di Archie & Melani Sandro & 1993 & Mursia \\
\hline GV.23 & The Girl on the Boat & 1922 & La ragazza del transatlantico: romanzo umoristico inglese & Pitta Alfredo & $193^{2}$ & Monanni \\
\hline GV.24 & The Clicking of Cuthbert & 1922 & Il colpo di Cuthbert: romanzo umoristico inglese & Malatesta Mario & 1933 & Bietti \\
\hline GV.24 & The Clicking of Cuthbert & 1922 & Il colpo di Cuthbert e altri racconti & Buckwell Gilson Mary & 1990 & Mursia \\
\hline GV.25 & The Adventures of Sally & 1922 & Le avventure di Sally: romanzo umoristico inglese & Martone Maria & 1931 & Monanni \\
\hline GV.25 & The Adventures of Sally & 1922 & Le avventure di Sally: romanzo umoristico inglese & Palazzi Rosetta & 1995 & Mursia \\
\hline GV.26 & The Inimitable Jeeves & 1923 & L'inimitabile Jeeves & Traverso Aldo & 1930 & Monanni \\
\hline GV.26 & The Inimitable Jeeves & 1923 & L'inimitabile Jeeves & Lord Tracy & 2010 & Polillo \\
\hline GV.27 & Leave it to Psmith & 1923 & Lasciate fare a Psmith: romanzo umoristico inglese & Gilli Mario & 1933 & Monanni \\
\hline GV.28 & Ukridge & 1924 & Ukridge Romanzo umoristico inglese & Martone Maria & 1931 & Monanni \\
\hline GV.29 & Bill the Conqueror & 1924 & Bill il conquistatore: romanzo umoristico inglese & Rafanelli Metello Brunone & 1933 & Bietti \\
\hline GV.29 & Bill the Conqueror & 1924 & Bill il conquistatore & Brioschi Luigi & 1993 & Mursia \\
\hline GV.3o & Carry On, Jeeves & 1925 & Avanti, Jeeves! : romanzo umoristico inglese & Spaventa Filippi Silvio & 1928 & Monanni \\
\hline GV.30 & Carry On, Jeeves & 1925 & Avanti, Jeeves & Salvatorelli Franco & 1991 & Mursia \\
\hline GV.3o & Carry On, Jeeves & 1925 & Avanti, Jeeves & Lord Tracy & 2011 & Polillo \\
\hline GV.31 & Sam the Sudden & 1925 & Sam il dinamico: romanzo umoristico inglese & Rafanelli Metello Brunone & 1933 & Bietti \\
\hline GV.32 & The Heart of a Goof & 1926 & Il cuore di un coniglio & Malatesta Mario & 1931 & Monanni \\
\hline GV.32 & The Heart of a Goof & 1926 & Il cuore di un paranoico & Palazzi Rosetta & 1992 & Mursia \\
\hline GV.33 & Meet Mr Mulliner & 1927 & Mr Mulliner: romanzo umoristico inglese & Tedeschi Alberto & 1931 & Monanni \\
\hline GV.33 & Meet Mr Mulliner & 1927 & Il signor Mulliner racconta & Buckwell Gilson Mary & 1995 & Mursia \\
\hline GV.34 & The Small Bachelor & 1927 & Il piccolo scapolo: romanzo umoristico inglese & Zanini A. & $193^{2}$ & Monanni \\
\hline GV.34 & The Small Bachelor & 1927 & Il piccolo scapolo: romanzo umoristico inglese & Morzenti Monica & 1996 & Mursia \\
\hline GV.35 & Money for Nothing & 1928 & Denaro trovato: romanzo umoristico inglese & Benzi Mario & $193^{2}$ & Monanni \\
\hline GV.35 & Money for Nothing & 1928 & E' tutto denaro sprecato & Palazzi Rosetta & 1997 & Mursia \\
\hline GV.36 & Mr Mulliner Speaking & 1929 & Parla Mr Mulliner: romanzo umoristico inglese & Tedeschi Alberto & 1931 & Monanni \\
\hline GV.36 & Mr Mulliner Speaking & 1929 & L'uomo che smise di fumare & Pieraccini Silvia & 2010 & Guanda \\
\hline GV.37 & Summer Lightning & 1929 & Lampi d'estate: : romanzo umoristico inglese & Rafanelli Metello Brunone & 1933 & Monanni \\
\hline
\end{tabular}




\begin{tabular}{|c|c|c|c|c|c|c|}
\hline GV.37 & Summer Lightning & 1929 & Lampi d'estate & Brera Carlo & 1989 & U. Guanda \\
\hline GV.38 & Very Good, Jeeves & $193^{\circ}$ & Benissimo, Jeeves & Tedeschi Alberto & 1930 & Monanni \\
\hline GV.38 & Very Good, Jeeves & 1930 & Benissimo, Jeeves & Zuffada Locuratolo Angela & 1990 & Mursia \\
\hline GV.38 & Very Good, Jeeves & 1930 & Molto bene, Jeeves & Lord Tracy & 2012 & Polillo \\
\hline GV.39 & If I Were You & 1931 & Se io fossi voi: romanzo umoristico inglese & Zanini A. & 1933 & Bietti \\
\hline GV.40 & Big Money & 1931 & Quattrini a palate: romanzo umoristico inglese & Benzi Mario & $193^{2}$ & Monanni \\
\hline GV.4O & Big Money & 1931 & Quattrini a palate & Buckwell Gilson Mary & 1997 & Mursia \\
\hline GV.41 & Doctor Sally & $193^{2}$ & Dottor Sally: romanzo umoristico inglese & Roberti Roberto & 1933 & Monanni \\
\hline GV.41 & Doctor Sally & 1932 & La dottoressa Sally & Bodoman Mario & 1990 & Mursia \\
\hline GV.42 & Hot Water & $193^{2}$ & Acqua bollente: romanzo umoristico inglese & Rafanelli Metello Brunone & 1933 & Bietti \\
\hline GV.43 & Louder and Funnier & $193^{2}$ & Più forte e più allegro: saggi umoristici & Lampronti Zoe & 1934 & Bietti \\
\hline GV.44 & Mulliner Nights & 1933 & Le serate di mulliner: romanzo umoristico inglese & Tedeschi Alberto & 1933 & Bietti \\
\hline GV.44 & Mulliner Nights & 1933 & Le sere di Mulliner & Brioschi Luigi & 1985 & Rizzoli \\
\hline GV.45 & Heavy weather & 1933 & Acqua pesante: romanzo umoristico inglese & Lampronti Zoe & 1933 & Bietti \\
\hline GV.45 & Heavy weather & 1933 & Tempo pesante: romanzo umoristico inglese & Lampronti Zoe & 1933 & Bietti \\
\hline GV.45 & Heavy Weather & 1933 & Aria di tempesta & Spagnol Luigi & 1990 & Guanda \\
\hline GV.46 & Thank You, Jeeves & 1934 & Grazie, Jeeves: romanzo umoristico inglese & Brugiotti Giulia & 1934 & Bietti \\
\hline GV.46 & Thank You, Jeeves & 1934 & Grazie, Jeeves & Janin Pia & 1984 & Rizzoli \\
\hline GV.46 & Thank You, Jeeves & 1934 & Grazie, Jeeves & Lord Tracy & 2005 & Polillo \\
\hline GV.47 & Right Ho, Jeeves & 1934 & Alla buonora, Jeeves: romanzo umoristico inglese & Sacchi-Perego Cina & 1935 & Bietti \\
\hline GV.47 & Right Ho, Jeeves & 1934 & Perfetto, Jeeves & Buitoni Duca Maria & 1985 & Rizzoli \\
\hline GV.48 & Blandings Castle and Elsewhere & 1935 & Il castello di Blandings & Brugiotti Giulia & 1936 & Bietti \\
\hline GV.48 & Blandings Castle and Elsewhere & 1935 & Il castello di Blandings & Brioschi Luigi & 1966 & Bietti \\
\hline GV.49 & The Luck of the Bodkins & 1935 & La fortuna dei Bodkin: romanzo umoristico inglese & Lampronti Zoe & 1936 & Bietti \\
\hline GV.5O & Young Men in Spats & 1936 & Giovanotti con le ghette: romanzo umoristico inglese & Lampronti Zoe & 1936 & Bietti \\
\hline GV.5० & Young Men in Spats & 1936 & Il mistero dei cappelli & Pieraccini Silvia & 2013 & Guanda \\
\hline GV.51 & Laughing Gas & 1936 & Gas esilarante & Tedeschi Alberto & 1938 & Mondadori \\
\hline GV.52 & Lord Emsworth and Others & 1937 & Lord Emsworth ed altri personaggi & Brugiotti Giulia & 1940 & Bietti \\
\hline GV.52 & Lord Emsworth and Others & 1937 & Ondata di crimini a Blandings & Spagnol Luigi & 1993 & Guanda \\
\hline GV.53 & Summer Moonshine & 1938 & Poi tutto s'accomoda: romanzo & Tedeschi Alberto & 1939 & Mondadori \\
\hline GV.54 & The Code of the Woosters & 1938 & Jeeves non si smentisce: romanzo & Tedeschi Alberto & 1939 & Mondadori \\
\hline GV.54 & The Code of the Woosters & 1938 & Il codice dei Wooster & Buckwell Gilson Mary & 1989 & Mursia \\
\hline GV.54 & The Code of the Woosters & 1938 & Il codice dei Wooster & Vigano' Giovanni & 2005 & Polillo \\
\hline GV.55 & Uncle Fred in the Springtime & 1939 & Zio Fred in primavera & Tedeschi Alberto & 1940 & Mondadori \\
\hline GV.56 & Quick Service & 1940 & Servizio espresso & Motti Adriana & 1951 & Elmo \\
\hline GV.56 & Quick Service & 1940 & Presto e bene & Morzenti Monica & 1992 & Mursia \\
\hline GV.57 & Eggs, Beans and Crumpets & 1940 & Il club dei nati stanchi & Agnati Sario & 1962 & Elmo \\
\hline GV.57 & Eggs, Beans and Crumpets & 1940 & Tizio, Caio e Sempronio & Melani Sandro & 1993 & Mursia \\
\hline $\mathrm{GV} \cdot 5^{8}$ & Money in the Bank & 1946 & Quattrini in banca: romanzo & Agnati Sirio & 1949 & Elmo \\
\hline GV.59 & Joy in the Morning & 1947 & La gioia e' col mattino & Monicelli Giorgio & 1948 & Elmo \\
\hline GV.59 & Joy in the Morning & 1947 & Un mattino di gioia & Campagna Ponzetto Sandra & 1990 & Mursia \\
\hline GV.59 & Joy in the Morning & 1947 & Un mattino di gioia & Lord Tracy & 2006 & Polillo \\
\hline GV.6o & Full Moon & 1947 & Luna piena & Comucci Vittoria & 1954 & Mondadori \\
\hline GV.6o & Full Moon & 1947 & Luna piena & Bertola Stefania & 1991 & Guanda \\
\hline GV.61 & Spring Fever & 1948 & Febbre di primavera & Lattanzi Luciano & $195^{2}$ & Elmo \\
\hline GV.61 & Spring Fever & 1948 & Febbre di primavera & Salvatorelli Franco & 1994 & Mursia \\
\hline GV.62 & Uncle Dynamite & 1948 & Lo zio dinamite & Motti Adriana & 1949 & Elmo \\
\hline
\end{tabular}




\begin{tabular}{|c|c|c|c|c|c|c|}
\hline GV.63 & The Mating Season & 1949 & Sotto le fresche frasche & Motti Adriana & $195^{\circ}$ & Elmo \\
\hline GV.63 & The Mating Season & 1949 & La stagione degli amori & Campagna Ponzetto Sandra & 1990 & Mursia \\
\hline GV.63 & The Mating Season & 1949 & La stagione degli amori & Lord Tracy & 2006 & Polillo \\
\hline GV.64 & Nothing Serious & $195^{\circ}$ & Non c'è da preoccuparsi & Agnati Sario & 1965 & Elmo \\
\hline GV.65 & The Old Reliable & 1951 & Diario segreto & Motti Adriana & $195^{2}$ & Elmo \\
\hline GV.66 & Barmy in Wonderland & $195^{2}$ & Grullo nel paese delle meraviglie & Motti Adriana & 1953 & Elmo \\
\hline GV.67 & Pigs Have Wings & $195^{2}$ & I porci hanno le ali & Motti Adriana & 1953 & Elmo \\
\hline GV.68 & Ring for Jeeves & 1953 & Chiamate Jeeves: romanzo & Motti Adriana & 1954 & Elmo \\
\hline GV.68 & Ring for Jeeves & 1953 & Chiamate Jeeves & Palazzi Rosetta & 1988 & Mursia \\
\hline GV.68 & Ring for Jeeves & 1953 & Tanto di cappello a Jeeves & Lord Tracy & 2006 & Polillo \\
\hline GV.69 & Jeeves and the Feudal Spirit & 1954 & Jeeves e la cavalleria & Buckwell Gislon Mary & 1988 & Mursia \\
\hline GV.70 & French Leave & 1956 & E chi s'è visto s'è visto & Motti Adriana & 1956 & Elmo \\
\hline GV.71 & Something Fishy & 1957 & Qualcosa di losco & Motti Adriana & $195^{8}$ & Elmo \\
\hline GV.72 & Cocktail Time & 1958 & Mister I ci sa fare & Motti Adriana & 1960 & Elmo \\
\hline GV.72 & Cocktail Time & $195^{8}$ & Cocktail time & Bernardinis Fulvio & 1998 & Mursia \\
\hline GV.73 & A Few Quick Ones & 1959 & Storie spicciole & Agnati Sario & 1961 & Elmo \\
\hline GV.73 & A Few Quick Ones & 1959 & Un grosso affare & Musso Dolores & 2007 & Guanda \\
\hline GV.74 & Jeeves in the Offing & 1960 & Jeeves taglia la corda & Motti Adriana & 1962 & Elmo \\
\hline GV.74 & Jeeves in the Offing & 1960 & Jeeves sta alla larga & Palazzi Rosetta & 1989 & Mursia \\
\hline GV.74 & Jeeves in the Offing & 1960 & Jeeves taglia la corda & Lord Tracy & 2007 & Polillo \\
\hline GV.75 & Ice in the Bedroom & 1961 & Ghiaccio in una stanza da letto & Agnati Sario & 1962 & Elmo \\
\hline GV.76 & Service with a Smile & 1962 & I signori sono serviti & Motti Adriano (sic) & 1970 & Elmo \\
\hline GV.76 & Service with a Smile & 1962 & Il ratto dell'imperatrice & Salmaggi Cesare & 1995 & Guanda \\
\hline GV.77 & Stiff Upper Lip, Jeeves & 1963 & Lei e' unico, Jeeves & Agnati Sario & 1964 & Elmo \\
\hline GV.77 & Stiff Upper Lip, Jeeves & 1963 & Teniamo duro, Jeeves & Palazzi Rosetta & 1990 & Mursia \\
\hline GV.77 & Stiff Upper Lip, Jeeves & 1963 & Teniamo duro, Jeeves & Lord Tracy & 2007 & Polillo \\
\hline GV.78 & Frozen Assets & 1964 & L'eredita' sotto chiave & Agnati Sario & 1965 & Elmo \\
\hline GV.78 & Frozen Assets & 1964 & Beni congelati & Morzenti Monica & 1997 & Mursia \\
\hline GV.79 & Galahad at Blandings & 1965 & Genero al verde & Agnati Sario & 1966 & Elmo \\
\hline GV.79 & Galahad at Blandings & 1965 & Un intrigo a Blandings & Mainardi Riccardo & 1997 & Guanda \\
\hline GV.8o & Company for Henry & 1967 & In compagnia di Henry & Motti Adriana & 1977 & Mondadori \\
\hline GV.81 & Do Butlers Burgle Banks? & 1968 & I maggiordomi rapinano le banche? & Motti Adriana & 1977 & Mondadori \\
\hline GV.81 & Do Butlers Burgle Banks? & 1968 & I maggiordomi svaligiano le banche? & Campagna Ponzetto Sandra & 1992 & Mursia \\
\hline GV.82 & A Pelican at Blandings & 1969 & Il pellicano a Blandings & Longanesi Caterina & 1970 & Mondadori \\
\hline GV.83 & The Girl in Blue & 1970 & La ragazza in blu & Spagnol Elena & 1973 & Mondadori \\
\hline GV.84 & Much Obliged, Jeeves & 1971 & Molto obbligato, Jeeves & Spagnol Elena & 1972 & Mondadori \\
\hline GV.84 & Much Obliged, Jeeves & 1971 & Molto obbligato, Jeeves & Buckwell Gilson Mary & 1989 & Mursia \\
\hline GV.84 & Much Obliged, Jeeves & 1971 & Molto obbligato, Jeeves & Lord Tracy & 2008 & Polillo \\
\hline GV.85 & Pearls, Girls and Monty Bodkin & 1972 & I "gioiellI" di Monty Bodkin & Spagnol Elena & 1974 & Mondadori \\
\hline GV.86 & Bachelors Anonymous & 1973 & Anonima scapoli & Spagnol Elena & 1975 & Mondadori \\
\hline GV.87 & Aunts Aren't Gentlemen & 1974 & Le zie non sono gentiluomini & Spagnol Elena & 1976 & Mondadori \\
\hline GV.87 & Aunts Aren't Gentlemen & 1974 & Le zie non sono gentiluomini & Lord Tracy & 2009 & Polillo \\
\hline
\end{tabular}




\section{Appendix $5 \quad$ Database of all Italian editions}

\begin{tabular}{|c|c|c|c|c|c|}
\hline$C O D E$ & ORIGINAL TITLE UK & $\begin{array}{c}U K \\
Y E A R\end{array}$ & ITALIAN TITLE & $\begin{array}{c}I T \\
Y E A R\end{array}$ & PUBLISHER \\
\hline GV.o1 & The Pothunters & 1902 & I conquistatori di coppe: romanzo & 1932 & Bietti \\
\hline GV.o2 & A Prefect's Uncle & $19 \circ 3$ & Lo zio del prefetto: romanzo & $193^{2}$ & Bietti \\
\hline GV.o3 & Tales of St Austin's & $19 \circ 3$ & Racconti di sant'Agostino & $193^{2}$ & Bietti \\
\hline GV.o4 & The Gold Bat & 1904 & Battaglie sportive & 1932 & Bietti \\
\hline GV.o5 & The Head of Kay's & $19 \circ 5$ & Il capo della Kay: romanzo & 1932 & Bietti \\
\hline GV.o5 & The Head of Kay's & 1905 & Il capo del Kay: romanzo sportivo inglese & 1933 & Monanni \\
\hline GV.o6 & Love Among the Chickens & $19 \circ 6$ & L'amore tra i polli & 1929 & Monanni \\
\hline GV.o6 & Love Among the Chickens & $19 \circ 6$ & L'amore tra i polli & 1931 & Monanni \\
\hline GV.o6 & Love Among the Chickens & 1906 & Amore tra i polli: romanzo & 1932 & Bietti \\
\hline GV.o6 & Love Among the Chickens & $19 \circ 6$ & L'amore tra i polli: romanzo umoristico inglese & 1933 & Bietti \\
\hline GV.o6 & Love Among the Chickens & 1906 & L'amore tra i polli: romanzo umoristico inglese & 1935 & Bietti \\
\hline GV.o6 & Love Among the Chickens & 1906 & L'amore tra i polli & 1937 & Bietti \\
\hline GV.o6 & Love Among the Chickens & $19 \circ 6$ & L'amore tra i polli & 1938 & Aurora \\
\hline GV.o6 & Love Among the Chickens & $19 \circ 6$ & L'amore fra i polli: romanzo umoristico inglese & 1943 & Bietti \\
\hline GV.o6 & Love Among the Chickens & $19 \circ 6$ & L'amore fra i polli & 1946 & Bietti \\
\hline GV.o6 & Love Among the Chickens & 1906 & L'amore fra i polli & 1952 & Bietti \\
\hline GV.o6 & Love Among the Chickens & 1906 & L'amore fra i polli & 1960 & Bietti \\
\hline GV.o6 & Love Among the Chickens & $19 \circ 6$ & Amore fra i polli & 1961 & Rizzoli \\
\hline GV.o6 & Love Among the Chickens & $19 \circ 6$ & L'amore fra i polli & 1964 & Bietti \\
\hline GV.o6 & Love Among the Chickens & 1906 & L'amore tra i polli & 1966 & Bietti \\
\hline GV.o6 & Love Among the Chickens & $19 \circ 6$ & L'amore fra i polli & 1980 & Rizzoli \\
\hline GV.o6 & Love Among the Chickens & 1906 & L'amore fra i polli & 1990 & Mursia \\
\hline GV.o6 & Love Among the Chickens & $19 \circ 6$ & Amore fra i polli & 1993 & Rizzoli \\
\hline GV.o6 & Love Among the Chickens & 1906 & Amore fra i polli & 1994 & Cuore \\
\hline GV.o6 & Love Among the Chickens & $19 \circ 6$ & Amore fra i polli & 1994 & Fabbri \\
\hline GV.o6 & Love Among the Chickens & $19 \circ 6$ & Amore fra i polli & 1994 & Rizzoli \\
\hline GV.o6 & Love Among the Chickens & $19 \circ 6$ & L'amore fra i polli & 2006 & Mursia \\
\hline GV.o6 & Love Among the Chickens & 1907 & L'amore fra i polli & 2015 & Mursia \\
\hline GV.o7 & The White Feather & 1907 & Una penna di coda: romanzo & $193^{2}$ & Bietti \\
\hline GV.o8 & Mike & $19 \circ 9$ & Mike: storia di un collegio: romanzo & $193^{2}$ & Bietti \\
\hline GV.o8 & Mike & $19 \circ 9$ & Mike: storia di un collegio: romanzo & 1933 & Bietti \\
\hline GV.o8 & Mike & $19 \circ 9$ & Mike: storia di un collegio: romanzo & 1936 & Bietti \\
\hline GV.o8 & Mike & 1909 & Mike: storie di un collegio: romanzo & 1938 & Bietti \\
\hline GV.o8 & Mike & $19 \circ 9$ & Mike & 1992 & Mursia \\
\hline GV.o9 & A Gentleman of Leisure & 1910 & Un gentiluomo in ozio: romanzo umoristico inglese & 1931 & Bietti \\
\hline GV.o9 & A Gentleman of Leisure & 1910 & Un gentiluomo in ozio: romanzo umoristico inglese & 1932 & Monanni \\
\hline GV.o9 & A Gentleman of Leisure & 1910 & Un gentiluomo in ozio: romanzo umoristico inglese & 1932 & Bietti \\
\hline GV.o9 & A Gentleman of Leisure & 1910 & Jimmy all'opra & 1935 & S.A.C.S.E. \\
\hline GV.o9 & A Gentleman of Leisure & 1910 & Un gentiluomo in ozio: romanzo umoristico inglese & 1935 & Bietti \\
\hline GV.o9 & A Gentleman of Leisure & 1910 & Un gentiluomo in ozio: romanzo umoristico inglese & 1938 & Bietti \\
\hline GV.o9 & A Gentleman of Leisure & 1910 & Il gentiluomo spensierato: un giallo umoristico & 1939 & Lucchi \\
\hline GV.o9 & A Gentleman of Leisure & 1910 & Un gentiluomo in ozio: romanzo umoristico inglese & 1940 & Bietti \\
\hline GV.o9 & A Gentleman of Leisure & 1910 & Un gentiluomo in ozio: romanzo umoristico inglese & 1949 & Bietti \\
\hline
\end{tabular}




\begin{tabular}{|c|c|c|c|c|c|}
\hline GV.o9 & A Gentleman of Leisure & 1910 & Un gentiluomo in ozio & 1960 & Bietti \\
\hline GV.o9 & A Gentleman of Leisure & 1910 & Un gentiluomo in ozio & 1962 & Bietti \\
\hline GV.o9 & A Gentleman of Leisure & 1910 & Un gentiluomo in ozio & 1964 & Bietti \\
\hline GV.o9 & A Gentleman of Leisure & 1910 & Un gentiluomo in ozio & 1966 & Bietti \\
\hline GV.o9 & A Gentleman of Leisure & 1910 & Un gentiluomo in ozio: romanzo umoristico inglese & 1993 & Mursia \\
\hline GV.10 & Psmith in the City & 1910 & Psmith in banca: romanzo & 1932 & Bietti \\
\hline GV.10 & Psmith in the City & 1910 & Psmith in banca & 1934 & Bietti \\
\hline GV.10 & Psmith in the City & 1910 & Psmith in banca & 1954 & Bietti \\
\hline GV.10 & Psmith in the City & 1910 & Psmith in banca & 1962 & Bietti \\
\hline GV.10 & Psmith in the City & 1910 & Psmith in banca & 1966 & Bietti \\
\hline GV.10 & Psmith in the City & 1910 & Psmith in banca & 1990 & Mursia \\
\hline GV.10 & Psmith in the City & 1910 & Psmith in banca & 2007 & Mursia \\
\hline GV.11 & The Prince and Betty & 1912 & Il principe e Betty: romanzo & $193^{2}$ & Bietti \\
\hline GV.11 & The Prince and Betty & 1912 & Il principe e Betty: romanzo umoristico inglese & 1932 & Monanni \\
\hline GV.11 & The Prince and Betty & 1912 & Il principe e Betty & 1942 & Bietti \\
\hline GV.11 & The Prince and Betty & 1912 & Il principe e Betty: romanzo & 1948 & Bietti \\
\hline GV.11 & The Prince and Betty & 1912 & Il principe e Betty & 1962 & Bietti \\
\hline GV.11 & The Prince and Betty & 1912 & Il principe e Betty & 1964 & Bietti \\
\hline GV.11 & The Prince and Betty & 1912 & Il principe e Betty & 1966 & Bietti \\
\hline GV.11 & The Prince and Betty & 1912 & Il principe e Betty & 1990 & Mursia \\
\hline GV.11 & The Prince and Betty & 1912 & Il principe e Betty & 1991 & Mursia \\
\hline GV.11 & The Prince and Betty & 1912 & Il principe e Betty & 1993 & Mursia \\
\hline GV.12 & The Little Nugget & 1913 & Pepita d'oro: romanzo umoristico inglese & 1932 & Monanni \\
\hline GV.12 & The Little Nugget & 1913 & La piccola pepita: romanzo & 1932 & Bietti \\
\hline GV.12 & The Little Nugget & 1913 & Il filone d'oro: romanzo umoristico & 1940 & Lucchi \\
\hline GV.12 & The Little Nugget & 1913 & La piccola pepita: romanzo & 1940 & Bietti \\
\hline GV.12 & The Little Nugget & 1913 & La piccola pepita: romanzo & 1950 & Bietti \\
\hline GV.12 & The Little Nugget & 1913 & La piccola pepita & 1960 & Bietti \\
\hline GV.12 & The Little Nugget & 1913 & La piccola pepita & 1963 & Bietti \\
\hline GV.12 & The Little Nugget & 1913 & La piccola pepita: romanzo & 1964 & Bietti \\
\hline GV.12 & The Little Nugget & 1913 & La piccola pepita & 1966 & Bietti \\
\hline GV.12 & The Little Nugget & 1913 & La piccola pepita & 1991 & Mursia \\
\hline GV.12 & The Little Nugget & 1913 & La piccola pepita & 2012 & Mursia \\
\hline GV.13 & The Man Upstairs and Other Stories & 1914 & L'uomo del piano di sopra & 1932 & Bietti \\
\hline GV.13 & The Man Upstairs and Other Stories & 1914 & L'uomo del piano di sopra: racconti umoristici inglesi & 1933 & Monanni \\
\hline GV.13 & The Man Upstairs and Other Stories & 1914 & L'uomo del piano di sopra & 1935 & Bietti \\
\hline GV.13 & The Man Upstairs and Other Stories & 1914 & L'uomo del piano di sopra & 1938 & Bietti \\
\hline GV.13 & The Man Upstairs and Other Stories & 1914 & L'uomo del piano di sopra & 1942 & Bietti \\
\hline GV.13 & The Man Upstairs and Other Stories & 1914 & L'uomo del piano di sopra & 1948 & Bietti \\
\hline GV.13 & The Man Upstairs and Other Stories & 1914 & L'uomo del piano di sopra & 1949 & Bietti \\
\hline GV.13 & The Man Upstairs and Other Stories & 1914 & L'uomo del piano di sopra & 1962 & Bietti \\
\hline GV.13 & The Man Upstairs and Other Stories & 1914 & L'uomo del piano di sopra & 1966 & Bietti \\
\hline GV.13 & The Man Upstairs and Other Stories & 1914 & L'uomo del piano di sopra e altri racconti & 1992 & Mursia \\
\hline GV.13 & The Man Upstairs and Other Stories & 1914 & L'uomo del piano di sopra & 2012 & Guanda \\
\hline GV.14 & Psmith, Journalist & 1915 & Psmith giornalista: romanzo & 1932 & Bietti \\
\hline GV.14 & Psmith, Journalist & 1915 & Psmith giornalista: romanzo & 1933 & Bietti \\
\hline GV.14 & Psmith, Journalist & 1915 & Psmith giornalista: romanzo & 1935 & Bietti \\
\hline GV.14 & Psmith, Journalist & 1915 & Psmith giornalista: romanzo umoristico & 1940 & Lucchi \\
\hline GV.14 & Psmith, Journalist & 1915 & Psmith giornalista: romanzo & 1950 & Bietti \\
\hline
\end{tabular}




\begin{tabular}{|c|c|c|c|c|c|}
\hline GV.14 & Psmith, Journalist & 1915 & Psmith giornalista & 1966 & Bietti \\
\hline GV.14 & Psmith, Journalist & 1915 & Le gesta di Psmith & 1990 & Guanda \\
\hline GV.14 & Psmith, Journalist & 1915 & Psmith giornalista & 1991 & Mursia \\
\hline GV.14 & Psmith, Journalist & 1915 & Le gesta di Psmith & 2002 & TEA \\
\hline GV.15 & Something Fresh & 1915 & Qualche cosa di nuovo: romanzo umoristico & $193^{2}$ & Bietti \\
\hline GV.15 & Something Fresh & 1915 & Qualche cosa di nuovo: romanzo umoristico inglese & 1932 & Monanni \\
\hline GV.15 & Something Fresh & 1915 & Qualcosa di nuovo: romanzo umoristico & 1938 & Bietti \\
\hline GV.15 & Something Fresh & 1915 & Qualcosa di nuovo: romanzo umoristico & 1942 & Bietti \\
\hline GV.15 & Something Fresh & 1915 & Qualcosa di nuovo & $195^{\circ}$ & Bietti \\
\hline GV.15 & Something Fresh & 1915 & Qualcosa di nuovo & 1963 & Bietti \\
\hline GV.15 & Something Fresh & 1915 & Qualcosa di nuovo & 1964 & Bietti \\
\hline GV.15 & Something Fresh & 1915 & Qualcosa di nuovo & 1966 & Bietti \\
\hline GV.15 & Something Fresh & 1915 & Qualcosa di nuovo & 1991 & Mursia \\
\hline GV.15 & Something Fresh & 1915 & Qualcosa di nuovo & 2011 & Guanda \\
\hline GV.15 & Something Fresh & 1915 & Qualcosa di nuovo & 2015 & Il sole 24 ore \\
\hline GV.16 & The Man With Two Left Feet & 1917 & L'uomo con due piedi sinistri & 1932 & Bietti \\
\hline GV.16 & The Man With Two Left Feet & 1917 & L'uomo con due piedi sinistri & 1936 & Bietti \\
\hline GV.16 & The Man With Two Left Feet & 1917 & L'uomo con due piedi sinistri & 1938 & Bietti \\
\hline GV.16 & The Man With Two Left Feet & 1917 & L'uomo con due piedi sinistri & 1948 & Bietti \\
\hline GV.16 & The Man With Two Left Feet & 1917 & L'uomo con due piedi sinistri & 1961 & Bietti \\
\hline GV.16 & The Man With Two Left Feet & 1917 & L'uomo con due piedi sinistri & 1962 & Bietti \\
\hline GV.16 & The Man With Two Left Feet & 1917 & L'uomo con due piedi sinistri & 1965 & Bietti \\
\hline GV.16 & The Man With Two Left Feet & 1917 & L'uomo con due piedi sinistri & 1966 & Bietti \\
\hline GV.16 & The Man With Two Left Feet & 1917 & L'uomo con due piedi sinistri & 1991 & Mursia \\
\hline GV.16 & The Man With Two Left Feet & 1917 & L'uomo con due piedi sinistri & 2007 & Mursia \\
\hline GV.17 & Uneasy Money & 1917 & Denaro difficile: romanzo umoristico inglese & 1932 & Monanni \\
\hline GV.17 & Uneasy Money & 1917 & Danaro incomodo: romanzo & 1932 & Bietti \\
\hline GV.17 & Uneasy Money & 1917 & Danaro incomodo: romanzo & 1935 & S.A.C.S.E. \\
\hline GV.17 & Uneasy Money & 1917 & Danaro incomodo: romanzo & 1938 & Bietti \\
\hline GV.17 & Uneasy Money & 1917 & Danaro incomodo & 1940 & Bietti \\
\hline GV.17 & Uneasy Money & 1917 & Danaro incomodo: romanzo & 1948 & Bietti \\
\hline GV.17 & Uneasy Money & 1917 & Danaro incomodo & 1964 & Bietti \\
\hline GV.17 & Uneasy Money & 1917 & Danaro incomodo & 1966 & Bietti \\
\hline GV.17 & Uneasy Money & 1917 & Denaro difficile & 1992 & Mursia \\
\hline GV.18 & Piccadilly Jim & 1918 & Jim di Piccadilly: romanzo umoristico & 1931 & Bietti \\
\hline GV.18 & Piccadilly Jim & 1918 & Jim di Piccadilly: romanzo umoristico inglese & 1931 & Monanni \\
\hline GV.18 & Piccadilly Jim & 1918 & Jim di Piccadilly: romanzo umoristico inglese & 1932 & Monanni \\
\hline GV.18 & Piccadilly Jim & 1918 & Jim di Piccadilly: romanzo umoristico & 1937 & Aurora \\
\hline GV.18 & Piccadilly Jim & 1918 & Jim di Piccadilly & 1938 & Bietti \\
\hline GV.18 & Piccadilly Jim & 1918 & Jim di Piccadilly & $195^{8}$ & Bietti \\
\hline GV.18 & Piccadilly Jim & 1918 & Jim di Piccadilly: romanzo umoristico & 1963 & Bietti \\
\hline GV.18 & Piccadilly Jim & 1918 & Jim di Piccadilly: romanzo umoristico & 1964 & Bietti \\
\hline GV.18 & Piccadilly Jim & 1918 & Jim di Piccadilly & 1966 & Bietti \\
\hline GV.18 & Piccadilly Jim & 1918 & Jim di Piccadilly: romanzo umoristico & 1989 & Lucarini \\
\hline GV.18 & Piccadilly Jim & 1918 & Piccadilly Jim & 1991 & Mursia \\
\hline GV.18 & Piccadilly Jim & 1918 & Piccadilly Jim & 2005 & Guanda \\
\hline GV.18 & Piccadilly Jim & 1918 & Piccadilly Jim: romanzo & 2007 & TEA \\
\hline GV.19 & A Damsel in Distress & 1919 & Una donzella in imbarazzo: romanzo umoristico inglese & 1931 & Monanni \\
\hline GV.19 & A Damsel in Distress & 1919 & Una signorina in imbarazzo: romanzo umoristico inglese & 1931 & Bietti \\
\hline
\end{tabular}




\begin{tabular}{|c|c|c|c|c|c|}
\hline GV.19 & A Damsel in Distress & 1919 & Una signorina in imbarazzo: romanzo umoristico inglese & $193^{2}$ & Bietti \\
\hline GV.19 & A Damsel in Distress & 1919 & Una donzella in imbarazzo: romanzo umoristico inglese & 1932 & Monanni \\
\hline GV.19 & A Damsel in Distress & 1919 & Un capriccio e poi... & 1935 & S.A.C.S.E. \\
\hline GV.19 & A Damsel in Distress & 1919 & Un matrimonio complicato: romanzo & 1935 & S.A.C.S.E. \\
\hline GV.19 & A Damsel in Distress & 1919 & Una magnifica avventura: romanzo umoristico & 1939 & Lucchi \\
\hline GV.19 & A Damsel in Distress & 1919 & Una signorina in imbarazzo: romanzo umoristico inglese & $195^{\circ}$ & Bietti \\
\hline GV.19 & A Damsel in Distress & 1919 & Una signorina in imbarazzo: romanzo umoristico inglese & 1960 & Bietti \\
\hline GV.19 & A Damsel in Distress & 1918 & Una signorina in imbarazzo: romanzo umoristico inglese & 1963 & Bietti \\
\hline GV.19 & A Damsel in Distress & 1919 & Una signorina in imbarazzo & 1965 & Bietti \\
\hline GV.19 & A Damsel in Distress & 1919 & Una signorina in imbarazzo & 1966 & Bietti \\
\hline GV.19 & A Damsel in Distress & 1919 & Una damigella in pericolo & 1994 & Mursia \\
\hline GV.19 & A Damsel in Distress & 1919 & Una damigella in pericolo & 2004 & Guanda \\
\hline GV.19 & A Damsel in Distress & 1919 & Una damigella in pericolo & 2006 & TEA \\
\hline GV.20 & The Coming of Bill & 1920 & La venuta di Bill: romanzo umoristico inglese & $193^{2}$ & Monanni \\
\hline GV.2O & The Coming of Bill & 1920 & La venuta di Bill: romanzo umoristico & 1932 & Bietti \\
\hline GV.2O & The Coming of Bill & 1920 & La venuta di Bill: romanzo umoristico & 1937 & Bietti \\
\hline GV.2O & The Coming of Bill & 1920 & La venuta di Bill: romanzo umoristico & 1938 & Bietti \\
\hline GV.2O & The Coming of Bill & 1920 & La venuta di Bill: romanzo umoristico & 1948 & Bietti \\
\hline GV.20 & The Coming of Bill & 1920 & La venuta di Bill: romanzo umoristico & 1959 & Bietti \\
\hline GV.2O & The Coming of Bill & 1920 & La venuta di Bill: romanzo umoristico & 1963 & Bietti \\
\hline GV.2O & The Coming of Bill & 1920 & La venuta di Bill: romanzo umoristico & 1966 & Bietti \\
\hline GV.21 & Jill, the Reckless & 1921 & Jill ragazza bizzarra & 1931 & Bietti \\
\hline GV.21 & Jill, the Reckless & 1921 & Giulia la bizzarra: romanzo umoristico inglese & 1932 & Monanni \\
\hline GV.21 & Jill, the Reckless & 1921 & Jill ragazza bizzarra: romanzo umoristico inglese & 1933 & Bietti \\
\hline GV.21 & Jill, the Reckless & 1921 & Jill, ragazza bizzarra: romanzo umoristico inglese & 1936 & Bietti \\
\hline GV.21 & Jill, the Reckless & 1921 & Jill, ragazza bizzarra: romanzo umoristico inglese & 1938 & Bietti \\
\hline GV.21 & Jill, the Reckless & 1921 & Jill, ragazza bizzarra: romanzo umoristico inglese & 1951 & Bietti \\
\hline GV.21 & Jill, the Reckless & 1921 & Jill, ragazza bizzarra & 1960 & Bietti \\
\hline GV.21 & Jill, the Reckless & 1921 & Jill ragazza bizzarra & 1966 & Bietti \\
\hline GV.21 & Jill, the Reckless & 1921 & Jill ragazza bizzarra & 1991 & Mursia \\
\hline GV.22 & Indiscretions of Archie & 1921 & Indiscrezioni di Arcibaldo & 1931 & Monanni \\
\hline GV.22 & Indiscretions of Archie & 1921 & Arcibaldo conquista l'America & 1931 & Bietti \\
\hline GV.22 & Indiscretions of Archie & 1921 & Indiscrezioni di Arcibaldo & 1931 & Bietti \\
\hline GV.22 & Indiscretions of Archie & 1921 & Arcibaldo conquista l'America & 1931 & Novissima \\
\hline GV.22 & Indiscretions of Archie & 1921 & Indiscrezioni di Arcibaldo: romanzo umoristico & $193^{2}$ & Bietti \\
\hline GV.22 & Indiscretions of Archie & 1921 & Indiscrezioni di Arcibaldo: romanzo umoristico & 1934 & Bietti \\
\hline GV.22 & Indiscretions of Archie & 1921 & Indiscrezioni di Arcibaldo: romanzo umoristico & 1937 & Bietti \\
\hline GV.22 & Indiscretions of Archie & 1921 & Indiscrezioni di Arcibaldo: romanzo umoritico & 1941 & Bietti \\
\hline GV.22 & Indiscretions of Archie & 1921 & Indiscrezioni di Arcibaldo & 1962 & Bietti \\
\hline GV.22 & Indiscretions of Archie & 1921 & Indiscrezioni di Arcibaldo & 1964 & Bietti \\
\hline GV.22 & Indiscretions of Archie & 1921 & Indiscrezioni di Arcibaldo & 1966 & Bietti \\
\hline GV.22 & Indiscretions of Archie & 1921 & Le imprudenze di Archie & 1993 & Mursia \\
\hline GV.23 & The Girl on the Boat & 1922 & La ragazza del transatlantico: romanzo umoristico inglese & $193^{2}$ & Monanni \\
\hline GV.23 & The Girl on the Boat & 1922 & La ragazza del transatlantico: romanzo umoristico inglese & 1933 & Monanni \\
\hline GV.23 & The Girl on the Boat & 1922 & La ragazza del transatlantico: romanzo umoristico inglese & 1936 & Bietti \\
\hline GV.23 & The Girl on the Boat & 1922 & La ragazza del transatlantico: romanzo umoristico inglese & 1943 & Bietti \\
\hline GV.23 & The Girl on the Boat & 1922 & La ragazza del transatlantico: romanzo umoristico inglese & 1945 & Bietti \\
\hline GV.23 & The Girl on the Boat & 1922 & La ragazza del transatlantico: romanzo umoristico inglese & 1949 & Bietti \\
\hline GV.23 & The Girl on the Boat & 1922 & La ragazza del transatlantico: romanzo umoristico inglese & 1957 & Bietti \\
\hline
\end{tabular}




\begin{tabular}{|c|c|c|c|c|c|}
\hline GV.23 & The Girl on the Boat & 1922 & La ragazza del transatlantico: romanzo umoristico inglese & 1964 & Bietti \\
\hline GV.23 & The Girl on the Boat & 1922 & La ragazza del transatlantico: romanzo umoristico inglese & 1966 & Bietti \\
\hline GV.24 & The Clicking of Cuthbert & 1922 & Il colpo di Cuthbert: romanzo umoristico inglese & 1933 & Bietti \\
\hline GV.24 & The Clicking of Cuthbert & 1922 & Il colpo di Cuthbert: romanzo umoristico inglese & 1937 & Bietti \\
\hline GV.24 & The Clicking of Cuthbert & 1922 & Il colpo di Cuthbert & 1938 & Bietti \\
\hline GV.24 & The Clicking of Cuthbert & 1922 & Il colpo di Cuthbert & 1973 & Bietti \\
\hline GV.24 & The Clicking of Cuthbert & 1922 & Il colpo di Cuthbert e altri racconti & 1990 & Mursia \\
\hline GV.25 & The Adventures of Sally & 1922 & Le avventure di Sally: romanzo umoristico inglese & 1931 & Monanni \\
\hline GV.25 & The Adventures of Sally & 1922 & Le avventure di Sally: romanzo umoristico inglese & $193^{2}$ & Monanni \\
\hline GV.25 & The Adventures of Sally & 1922 & Le avventure di Sally: romanzo umoristico inglese & 1933 & Monanni \\
\hline GV.25 & The Adventures of Sally & 1922 & Le avventure di Sally: romanzo umoristico inglese & 1938 & Bietti \\
\hline GV.25 & The Adventures of Sally & 1922 & Le avventure di Sally: romanzo umoristico inglese & 1957 & Bietti \\
\hline GV.25 & The Adventures of Sally & 1922 & Le avventure di Sally: romanzo umoristico inglese & 1962 & Bietti \\
\hline GV.25 & The Adventures of Sally & 1922 & Le avventure di Sally & 1964 & Bietti \\
\hline GV.25 & The Adventures of Sally & 1922 & Le avventure di Sally & 1966 & Bietti \\
\hline GV.25 & The Adventures of Sally & 1922 & Le avventure di Sally: romanzo umoristico inglese & 1995 & Mursia \\
\hline GV.26 & The Inimitable Jeeves & 1923 & L'inimitabile Jeeves & 1930 & Monanni \\
\hline GV.26 & The Inimitable Jeeves & 1923 & L'inimitabile Jeeves & 1930 & Bietti \\
\hline GV.26 & The Inimitable Jeeves & 1923 & L'inimitabile Jeeves: romanzo umoristico inglese & $193^{2}$ & Monanni \\
\hline GV.26 & The Inimitable Jeeves & 1923 & L'inimitabile Jeeves: romanzo umoristico inglese & 1933 & Bietti \\
\hline GV.26 & The Inimitable Jeeves & 1923 & L'inimitabile Jeeves: romanzo umoristico inglese & 1937 & Bietti \\
\hline GV.26 & The Inimitable Jeeves & 1923 & L'inimitabile Jeeves: romanzo umoristico inglese & 1942 & Bietti \\
\hline GV.26 & The Inimitable Jeeves & 1923 & L'inimitabile Jeeves: romanzo umoristico inglese & 1949 & Bietti \\
\hline GV.26 & The Inimitable Jeeves & 1923 & L'inimitabile Jeeves: romanzo umoristico inglese & 1951 & Bietti \\
\hline GV.26 & The Inimitable Jeeves & 1923 & L'inimitabile Jeeves: romanzo umoristico inglese & 1956 & Bietti \\
\hline GV.26 & The Inimitable Jeeves & 1923 & L'inimitabile Jeeves: romanzo umoristico inglese & 1960 & Bietti \\
\hline GV.26 & The Inimitable Jeeves & 1923 & L'inimitabile Jeeves & 1962 & Bietti \\
\hline GV.26 & The Inimitable Jeeves & 1923 & L'inimitabile Jeeves & 1964 & Bietti \\
\hline GV.26 & The Inimitable Jeeves & 1923 & L'inimitabile Jeeves & 1966 & Bietti \\
\hline GV.26 & The Inimitable Jeeves & 1923 & L'inimitabile Jeeves & 2010 & Polillo \\
\hline GV.26 & The Inimitable Jeeves & 1924 & L'inimitabile Jeeves & 2013 & Polillo \\
\hline GV.26 & The Inimitable Jeeves & 1925 & L'inimitabile Jeeves & 2014 & Polillo \\
\hline GV.26 & The Inimitable Jeeves & 1926 & L'inimitabile Jeeves & 2016 & Polillo \\
\hline GV.27 & Leave it to Psmith & 1923 & Lasciate fare a Psmith: romanzo umoristico inglese & 1933 & Monanni \\
\hline GV.27 & Leave it to Psmith & 1923 & Lasciate fare a Psmith: romanzo umoristico inglese & 1933 & Bietti \\
\hline GV.27 & Leave it to Psmith & 1923 & Lasciate fare a Psmith: romanzo umoristico inglese & 1936 & Bietti \\
\hline GV.27 & Leave it to Psmith & 1923 & Lasciate fare a Psmith: romanzo umoristico inglese & 1949 & Bietti \\
\hline GV.27 & Leave it to Psmith & 1923 & Lasciate fare a Psmith: romanzo umoristico inglese & 1952 & Bietti \\
\hline GV.27 & Leave it to Psmith & 1923 & Lasciate fare a Psmith & 1960 & Bietti \\
\hline GV.27 & Leave it to Psmith & 1923 & Lasciate fare a Psmith & 1966 & Bietti \\
\hline GV.28 & Ukridge & 1924 & Ukridge Romanzo umoristico inglese & 1931 & Monanni \\
\hline GV.28 & Ukridge & 1924 & Ukridge: romanzo umoristico inglese & 1933 & Monanni \\
\hline GV.28 & Ukridge & 1924 & Ukridge: romanzo umoristico inglese & 1936 & Bietti \\
\hline GV.28 & Ukridge & 1924 & Ukridge: romanzo umoristico inglese & 1937 & Bietti \\
\hline GV.28 & Ukridge & 1924 & Ukridge: romanzo umoristico inglese & 1942 & Bietti \\
\hline GV.28 & Ukridge & 1924 & Ukridge: romanzo umoristico inglese & 1946 & Bietti \\
\hline GV.28 & Ukridge & 1924 & Ukridge: romanzo umoristico inglese & 1948 & Bietti \\
\hline GV.28 & Ukridge & 1924 & Ukridge: romanzo umoristico inglese & 1950 & Bietti \\
\hline GV.28 & Ukridge & 1924 & Ukridge: romanzo umoristico inglese & 1959 & Bietti \\
\hline
\end{tabular}




\begin{tabular}{|c|c|c|c|c|c|}
\hline GV.28 & Ukridge & 1924 & Ukridge: romanzo umoristico inglese & 1962 & Bietti \\
\hline GV.28 & Ukridge & 1924 & Ukridge & 1963 & Bietti \\
\hline GV.28 & Ukridge & 1924 & Ukridge & 1966 & Bietti \\
\hline GV.29 & Bill the Conqueror & 1924 & Bill il conquistatore: romanzo umoristico inglese & 1933 & Bietti \\
\hline GV.29 & Bill the Conqueror & 1924 & Bill il conquistatore: romanzo umoristico inglese & 1936 & Bietti \\
\hline GV.29 & Bill the Conqueror & 1924 & Bill il conquistatore: romanzo umoristico inglese & 1948 & Bietti \\
\hline GV.29 & Bill the Conqueror & 1924 & Bill il conquistatore: romanzo umoristico inglese & 1959 & Bietti \\
\hline GV.29 & Bill the Conqueror & 1924 & Bill il conquistatore & 1964 & Bietti \\
\hline GV.29 & Bill the Conqueror & 1924 & Bill il conquistatore & 1966 & Bietti \\
\hline GV.29 & Bill the Conqueror & 1924 & Bill il conquistatore & 1993 & Mursia \\
\hline GV.29 & Bill the Conqueror & 1924 & La conquista di Londra & 2006 & Guanda \\
\hline GV.29 & Bill the Conqueror & 1924 & La conquista di Londra: romanzo & 2008 & TEA \\
\hline GV.3o & Carry On, Jeeves & 1925 & Avanti, Jeeves! : romanzo umoristico inglese & 1928 & Monanni \\
\hline GV.3o & Carry On, Jeeves & 1925 & Avanti, Jeeves! : romanzo umoristico inglese & 1930 & Monanni \\
\hline GV.3o & Carry On, Jeeves & 1925 & Avanti, Jeeves! : romanzo umoristico inglese & 1931 & Monanni \\
\hline GV.3o & Carry On, Jeeves & 1925 & Avanti, Jeeves! : romanzo umoristico inglese & 1932 & Monanni \\
\hline GV.30 & Carry On, Jeeves & 1925 & Avanti, Jeeves! : romanzo umoristico inglese & 1933 & Bietti \\
\hline GV.3o & Carry On, Jeeves & 1925 & Avanti, Jeeves! : romanzo umoristico inglese & 1934 & Bietti \\
\hline GV.3O & Carry On, Jeeves & 1925 & Avanti, Jeeves! : romanzo umoristico inglese & 1935 & Bietti \\
\hline GV.3o & Carry On, Jeeves & 1925 & Avanti, Jeeves! : romanzo umoristico inglese & 1936 & Bietti \\
\hline GV.3o & Carry On, Jeeves & 1925 & Avanti, Jeeves! : romanzo umoristico inglese & 1938 & Bietti \\
\hline GV.30 & Carry On, Jeeves & 1925 & Avanti, Jeeves! : romanzo umoristico inglese & 1938 & S.A.C.S.E. \\
\hline GV.3o & Carry On, Jeeves & 1925 & Avanti, Jeeves! : romanzo umoristico inglese & 1943 & Bietti \\
\hline GV.3O & Carry On, Jeeves & 1925 & Avanti, Jeeves! : romanzo umoristico inglese & 1948 & Bietti \\
\hline GV.30 & Carry On, Jeeves & 1925 & Avanti, Jeeves! : romanzo umoristico inglese & $195^{8}$ & Bietti \\
\hline GV.30 & Carry On, Jeeves & 1925 & Avanti, Jeeves! : romanzo umoristico inglese & 1960 & Bietti \\
\hline GV.3o & Carry On, Jeeves & 1925 & Avanti, Jeeves & 1962 & Bietti \\
\hline GV.3o & Carry On, Jeeves & 1925 & Avanti, Jeeves & 1964 & Bietti \\
\hline GV.3o & Carry On, Jeeves & 1925 & Avanti, Jeeves & 1966 & Bietti \\
\hline GV.30 & Carry On, Jeeves & 1925 & Avanti, Jeeves & 1973 & Bietti \\
\hline GV.30 & Carry On, Jeeves & 1925 & Avanti, Jeeves & 1991 & Mursia \\
\hline GV.3o & Carry On, Jeeves & 1925 & Avanti, Jeeves & 2000 & Mursia \\
\hline GV.30 & Carry On, Jeeves & 1925 & Avanti, Jeeves & 2011 & Polillo \\
\hline GV.31 & Sam the Sudden & 1925 & Sam il dinamico: romanzo umoristico inglese & 1933 & Bietti \\
\hline GV.31 & Sam the Sudden & 1925 & Sam il dinamico: romanzo umoristico inglese & 1934 & Bietti \\
\hline GV.31 & Sam the Sudden & 1925 & Sam il dinamico: romanzo umoristico inglese & 1935 & Bietti \\
\hline GV.31 & Sam the Sudden & 1925 & Sam il dinamico: romanzo umoristico inglese & 1936 & Bietti \\
\hline GV.31 & Sam the Sudden & 1925 & Sam il dinamico: romanzo umoristico inglese & 1948 & Bietti \\
\hline GV.31 & Sam the Sudden & 1925 & Sam il dinamico: romanzo umoristico inglese & 1960 & Bietti \\
\hline GV.31 & Sam the Sudden & 1925 & Sam il dinamico & 1963 & Bietti \\
\hline GV.31 & Sam the Sudden & 1925 & Sam il dinamico & 1966 & Bietti \\
\hline GV.32 & The Heart of a Goof & 1926 & Il cuore di un coniglio & 1931 & Monanni \\
\hline GV.32 & The Heart of a Goof & 1926 & Il cuore di un coniglio: romanzo umoristico inglese & 1933 & Bietti \\
\hline GV.32 & The Heart of a Goof & 1926 & Il cuore di un coniglio & 1973 & Bietti \\
\hline GV.32 & The Heart of a Goof & 1926 & Il cuore di un paranoico & 1992 & Mursia \\
\hline GV.33 & Meet Mr Mulliner & 1927 & Mr Mulliner: romanzo umoristico inglese & 1931 & Monanni \\
\hline GV.33 & Meet Mr Mulliner & 1927 & Mister Mulliner: romanzo umoristico inglese & 1932 & Monanni \\
\hline GV.33 & Meet Mr Mulliner & 1927 & Mr Mulliner: romanzo umoristico inglese & 1933 & Bietti \\
\hline GV.33 & Meet Mr Mulliner & 1927 & Mister Mulliner: romanzo umoristico inglese & 1942 & Bietti \\
\hline
\end{tabular}




\begin{tabular}{|c|c|c|c|c|c|}
\hline GV.33 & Meet Mr Mulliner & 1927 & Mister Mulliner: romanzo umoristico inglese & 1945 & Bietti \\
\hline GV.33 & Meet Mr Mulliner & 1927 & Mister Mulliner: romanzo umoristico inglese & 1946 & Bietti \\
\hline GV.33 & Meet Mr Mulliner & 1927 & Mister Mulliner: romanzo umoristico inglese & 1963 & Bietti \\
\hline GV.33 & Meet Mr Mulliner & 1927 & Mister Mulliner: romanzo umoristico inglese & 1964 & Bietti \\
\hline GV.33 & Meet Mr Mulliner & 1927 & Mister Mulliner: romanzo umoristico inglese & 1966 & Bietti \\
\hline GV.33 & Meet Mr Mulliner & 1927 & Il signor Mulliner racconta & 1995 & Mursia \\
\hline GV.33 & Meet Mr Mulliner & 1927 & La mossa del vescovo & 2009 & Guanda \\
\hline GV.34 & The Small Bachelor & 1927 & Il piccolo scapolo: romanzo umoristico inglese & 1932 & Monanni \\
\hline GV.34 & The Small Bachelor & 1927 & Il piccolo scapolo: romanzo umoristico inglese & 1933 & Bietti \\
\hline GV.34 & The Small Bachelor & 1927 & Il piccolo scapolo: romanzo umoristico inglese & 1937 & Bietti \\
\hline GV.34 & The Small Bachelor & 1927 & Il piccolo scapolo & 1938 & Bietti \\
\hline GV.34 & The Small Bachelor & 1927 & Il piccolo scapolo: romanzo umoristico inglese & $195^{8}$ & Bietti \\
\hline GV.34 & The Small Bachelor & 1927 & Il piccolo scapolo: romanzo umoristico inglese & 1961 & Bietti \\
\hline GV.34 & The Small Bachelor & 1927 & Il piccolo scapolo & 1962 & Bietti \\
\hline GV.34 & The Small Bachelor & 1927 & Il piccolo scapolo: romanzo umoristico inglese & 1964 & Bietti \\
\hline GV.34 & The Small Bachelor & 1927 & Il piccolo scapolo & 1966 & Bietti \\
\hline GV.34 & The Small Bachelor & 1927 & Il piccolo scapolo: romanzo umoristico inglese & 1996 & Mursia \\
\hline GV.35 & Money for Nothing & 1928 & Denaro trovato: romanzo umoristico inglese & 1932 & Monanni \\
\hline GV.35 & Money for Nothing & 1928 & Denaro trovato: romanzo umoristico inglese & 1933 & Bietti \\
\hline GV.35 & Money for Nothing & 1928 & Danaro trovato & 1949 & Bietti \\
\hline GV.35 & Money for Nothing & 1928 & Danaro trovato & 1966 & Bietti \\
\hline GV.35 & Money for Nothing & 1928 & E' tutto denaro sprecato & 1997 & Mursia \\
\hline GV.36 & Mr Mulliner Speaking & 1929 & Parla Mr Mulliner: romanzo umoristico inglese & 1931 & Monanni \\
\hline GV.36 & Mr Mulliner Speaking & 1929 & Parla Mister Mulliner: romanzo umoristico inglese & 1933 & Bietti \\
\hline GV.36 & Mr Mulliner Speaking & 1929 & Parla Mister Mulliner: romanzo umoristico inglese & 1936 & Bietti \\
\hline GV.36 & Mr Mulliner Speaking & 1929 & Parla Mr Mulliner: romanzo umoristico inglese & 1949 & Bietti \\
\hline GV.36 & Mr Mulliner Speaking & 1929 & Parla Mister Mulliner: romanzo umoristico inglese & 1963 & Bietti \\
\hline GV.36 & Mr Mulliner Speaking & 1929 & Parla Mr Mulliner: romanzo umoristico inglese & 1964 & Bietti \\
\hline GV.36 & Mr Mulliner Speaking & 1929 & Parla Mister Mulliner: romanzo umoristico inglese & 1966 & Bietti \\
\hline GV.36 & Mr Mulliner Speaking & 1929 & L'uomo che smise di fumare & 2010 & Guanda \\
\hline GV.37 & Summer Lightning & 1929 & Lampi d'estate: : romanzo umoristico inglese & 1933 & Monanni \\
\hline GV.37 & Summer Lightning & 1929 & Lampi d'estate & 1938 & Bietti \\
\hline GV.37 & Summer Lightning & 1929 & Lampi d'estate: romanzo umoristico inglese & 1948 & Bietti \\
\hline GV.37 & Summer Lightning & 1929 & Lampi d'estate & 1960 & Bietti \\
\hline GV.37 & Summer Lightning & 1929 & Lampi d'estate & 1964 & Bietti \\
\hline GV.37 & Summer Lightning & 1929 & Lampi d'estate & 1966 & Bietti \\
\hline GV.37 & Summer Lightning & 1929 & Lampi d'estate & 1989 & Guanda \\
\hline GV.37 & Summer Lightning & 1929 & Lampi d'estate & 1993 & TEA \\
\hline GV.37 & Summer Lightning & 1929 & Lampi d'estate & 2006 & TEA \\
\hline GV.38 & Very Good, Jeeves & 1930 & Benissimo, Jeeves & 1930 & Monanni \\
\hline GV.38 & Very Good, Jeeves & 1930 & Benissimo, Jeeves & 1931 & Monanni \\
\hline GV.38 & Very Good, Jeeves & 1930 & Benissimo, Jeeves!: romanzo umoristico inglese & 1933 & Bietti \\
\hline GV.38 & Very Good, Jeeves & 1930 & Benissimo, Jeeves!: romanzo umoristico inglese & 1936 & Bietti \\
\hline GV.38 & Very Good, Jeeves & 1930 & Benissimo, Jeeves: romanzo umoristico inglese & 1938 & Bietti \\
\hline GV.38 & Very Good, Jeeves & 1930 & Benissimo, Jeeves: romanzo umoristico inglese & 1946 & Bietti \\
\hline GV.38 & Very Good, Jeeves & 1930 & Benissimo, Jeeves: romanzo umoristico inglese & 1950 & Bietti \\
\hline GV.38 & Very Good, Jeeves & 1930 & Benissimo, Jeeves: romanzo umoristico inglese & 1959 & Bietti \\
\hline GV.38 & Very Good, Jeeves & 1930 & Benissimo, Jeeves & 1964 & Bietti \\
\hline GV.38 & Very Good, Jeeves & 1930 & Benissimo, Jeeves! & 1966 & Bietti \\
\hline
\end{tabular}




\begin{tabular}{|c|c|c|c|c|c|}
\hline GV.38 & Very Good, Jeeves & 1930 & Benissimo, Jeeves & 1977 & Bietti \\
\hline GV.38 & Very Good, Jeeves & 1930 & Benissimo, Jeeves & 1990 & Mursia \\
\hline GV.38 & Very Good, Jeeves & 1930 & Molto bene, Jeeves & 2012 & Polillo \\
\hline GV.38 & Very Good, Jeeves & 1930 & La vita e' strana, Jeeves (selezione) & 2013 & Polillo \\
\hline GV.38 & Very Good, Jeeves & 1930 & La vita e' strana, Jeeves (selezione) & 2014 & Polillo \\
\hline GV.38 & Very Good, Jeeves & 1930 & La vita e' strana, Jeeves (selezione) & 2016 & Polillo \\
\hline GV.39 & If I Were You & 1931 & Se io fossi voi: romanzo umoristico inglese & 1933 & Bietti \\
\hline GV.39 & If I Were You & 1931 & Se io fossi voi & 1936 & Bietti \\
\hline GV.39 & If I Were You & 1931 & Se io fossi voi & 1951 & Bietti \\
\hline GV.39 & If I Were You & 1931 & Se io fossi voi: romanzo umoristico inglese & 1962 & Bietti \\
\hline GV.39 & If I Were You & 1931 & Se io fossi voi & 1964 & Bietti \\
\hline GV.39 & If I Were You & 1931 & Se io fossi voi & 1966 & Bietti \\
\hline GV.40 & Big Money & 1931 & Quattrini a palate: romanzo umoristico inglese & $193^{2}$ & Monanni \\
\hline GV.40 & Big Money & 1931 & Quattrini a palate: romanzo umoristico inglese & 1936 & Bietti \\
\hline GV.40 & Big Money & 1931 & Quattrini a palate: romanzo umoristico inglese & 1938 & Bietti \\
\hline GV.40 & Big Money & 1931 & Quattrini a palate: romanzo umoristico inglese & 1942 & Bietti \\
\hline GV.40 & Big Money & 1931 & Quattrini a palate: romanzo umoristico inglese & 1948 & Bietti \\
\hline GV.4O & Big Money & 1931 & Quattrini a palate: romanzo umoristico inglese & 1949 & Bietti \\
\hline GV.4O & Big Money & 1931 & Quattrini a palate & 1962 & Bietti \\
\hline GV.40 & Big Money & 1931 & Quattrini a palate & 1966 & Bietti \\
\hline GV.40 & Big Money & 1931 & Quattrini a palate & 1997 & Mursia \\
\hline GV.41 & Doctor Sally & $193^{2}$ & Dottor Sally: romanzo umoristico inglese & 1933 & Monanni \\
\hline GV.41 & Doctor Sally & 1932 & Doctor Sally: romanzo umoristico inglese & 1934 & Bietti \\
\hline GV.41 & Doctor Sally & 1932 & Doctor Sally: romanzo umoristico inglese & 1938 & Bietti \\
\hline GV.41 & Doctor Sally & 1932 & Dottor Sally & 1950 & Bietti \\
\hline GV.41 & Doctor Sally & 1932 & Dottor Sally & 1962 & Bietti \\
\hline GV.41 & Doctor Sally & 1932 & Doctor Sally & 1964 & Bietti \\
\hline GV.41 & Doctor Sally & 1932 & Dottor Sally & 1966 & Bietti \\
\hline GV.41 & Doctor Sally & $193^{2}$ & La dottoressa Sally & 1990 & Mursia \\
\hline GV.42 & Hot Water & 1932 & Acqua bollente: romanzo umoristico inglese & 1933 & Bietti \\
\hline GV.42 & Hot Water & $193^{2}$ & Acqua bollente: romanzo umoristico inglese & 1937 & Bietti \\
\hline GV.42 & Hot Water & 1932 & Acqua bollente: romanzo umoristico inglese & 1948 & Bietti \\
\hline GV.42 & Hot Water & 1932 & Acqua bollente & 1964 & Bietti \\
\hline GV.42 & Hot Water & $193^{2}$ & Acqua bollente & 1966 & Bietti \\
\hline GV.43 & Louder and Funnier & $193^{2}$ & Più forte e più allegro: saggi umoristici & 1934 & Bietti \\
\hline GV.43 & Louder and Funnier & 1932 & Più forte e più allegro: saggi umoristici & 1949 & Bietti \\
\hline GV.43 & Louder and Funnier & 1932 & Più forte e più allegro & 1959 & Bietti \\
\hline GV.43 & Louder and Funnier & 1932 & Più forte e più allegro & 1962 & Bietti \\
\hline GV.43 & Louder and Funnier & $193^{2}$ & Piu' forte e piu' allegro & 1964 & Bietti \\
\hline GV.43 & Louder and Funnier & 1932 & Più forte e più allegro & 1966 & Bietti \\
\hline GV.44 & Mulliner Nights & 1933 & Le serate di mulliner: romanzo umoristico inglese & 1933 & Bietti \\
\hline GV.44 & Mulliner Nights & 1933 & Le serate di Mulliner: romanzo umoristico inglese & 1936 & Bietti \\
\hline GV.44 & Mulliner Nights & 1933 & Le serate di Mulliner & 1958 & Bietti \\
\hline GV.44 & Mulliner Nights & 1933 & Le serate di Mulliner & 1963 & Bietti \\
\hline GV.44 & Mulliner Nights & 1933 & Le serate di Mulliner: romanzo umoristico inglese & 1964 & Bietti \\
\hline GV.44 & Mulliner Nights & 1933 & Le serate di Mulliner & 1966 & Bietti \\
\hline GV.44 & Mulliner Nights & 1933 & Le sere di Mulliner & 1985 & Rizzoli \\
\hline GV.44 & Mulliner Nights & 1933 & Le sere di Mulliner & 1993 & Mursia \\
\hline GV.44 & Mulliner Nights & 1933 & I gatti non sono cani & 2001 & Guanda \\
\hline
\end{tabular}




\begin{tabular}{|c|c|c|c|c|c|}
\hline GV.44 & Mulliner Nights & 1933 & I gatti non sono cani & 2004 & TEA \\
\hline GV.45 & Heavy weather & 1933 & Acqua pesante: romanzo umoristico inglese & 1933 & Bietti \\
\hline GV.45 & Heavy weather & 1933 & Tempo pesante: romanzo umoristico inglese & 1933 & Bietti \\
\hline GV.45 & Heavy weather & 1933 & Tempo pesante: romanzo umoristico inglese & 1936 & Bietti \\
\hline GV.45 & Heavy weather & 1933 & Tempo pesante: romanzo umoristico inglese & 1948 & Bietti \\
\hline GV.45 & Heavy weather & 1933 & Tempo pesante & 1962 & Bietti \\
\hline GV.45 & Heavy weather & 1933 & Tempo pesante & 1966 & Bietti \\
\hline GV.45 & Heavy weather & 1933 & Aria di tempesta & 1990 & Guanda \\
\hline GV.45 & Heavy weather & 1933 & Aria di tempesta & 1994 & TEA \\
\hline GV.45 & Heavy weather & 1933 & Aria di tempesta & 2004 & TEA \\
\hline GV.46 & Thank You, Jeeves & 1934 & Grazie, Jeeves: romanzo umoristico inglese & 1934 & Bietti \\
\hline GV.46 & Thank You, Jeeves & 1934 & Grazie, Jeeves: romanzo umoristico inglese & 1935 & Bietti \\
\hline GV.46 & Thank You, Jeeves & 1934 & Grazie, Jeeves: romanzo umoristico inglese & 1937 & Bietti \\
\hline GV.46 & Thank You, Jeeves & 1934 & Grazie, Jeeves: romanzo umoristico inglese & 1938 & Bietti \\
\hline GV.46 & Thank You, Jeeves & 1934 & Grazie, Jeeves: romanzo umoristico inglese & 1951 & Bietti \\
\hline GV.46 & Thank You, Jeeves & 1934 & Grazie, Jeeves: romanzo umoristico inglese & 1954 & Bietti \\
\hline GV.46 & Thank You, Jeeves & 1934 & Grazie, Jeeves: romanzo umoristico inglese & 1962 & Bietti \\
\hline GV.46 & Thank You, Jeeves & 1934 & Grazie, Jeeves & 1964 & Bietti \\
\hline GV.46 & Thank You, Jeeves & 1934 & Grazie, Jeeves & 1966 & Bietti \\
\hline GV.46 & Thank You, Jeeves & 1934 & Grazie, Jeeves & 1984 & Rizzoli \\
\hline GV.46 & Thank You, Jeeves & 1934 & Grazie, Jeeves & 1993 & Mursia \\
\hline GV.46 & Thank You, Jeeves & 1934 & Grazie, Jeeves & 2000 & Mursia \\
\hline GV.46 & Thank You, Jeeves & 1934 & Grazie, Jeeves & 2005 & Polillo \\
\hline GV.46 & Thank You, Jeeves & 1934 & Grazie, Jeeves & 2013 & Polillo \\
\hline GV.46 & Thank You, Jeeves & 1934 & Grazie, Jeeves & 2014 & Polillo \\
\hline GV.46 & Thank You, Jeeves & 1934 & Grazie, Jeeves & 2016 & Polillo \\
\hline GV.47 & Right Ho, Jeeves & 1934 & Alla buonora, Jeeves: romanzo umoristico inglese & 1935 & Bietti \\
\hline GV.47 & Right Ho, Jeeves & 1934 & Alla buon'ora, Jeeves!: romanzo umoristico inglese & 1938 & Bietti \\
\hline GV.47 & Right Ho, Jeeves & 1934 & Alla buonora, Jeeves: romanzo umoristico inglese & 1942 & Bietti \\
\hline GV.47 & Right Ho, Jeeves & 1934 & Alla buonora, Jeeves: romanzo umoristico inglese & 1950 & Bietti \\
\hline GV.47 & Right Ho, Jeeves & 1934 & Alla buonora, Jeeves: romanzo umoristico inglese & 1957 & Bietti \\
\hline GV.47 & Right Ho, Jeeves & 1934 & Alla buon'ora Jeeves & 1962 & Bietti \\
\hline GV.47 & Right Ho, Jeeves & 1934 & Alla buon'ora Jeeves & 1964 & Bietti \\
\hline GV.47 & Right Ho, Jeeves & 1934 & Alla buon'ora Jeeves & 1966 & Bietti \\
\hline GV.47 & Right Ho, Jeeves & 1934 & Alla buon'ora, Jeeves! & 1976 & Bietti \\
\hline GV.47 & Right Ho, Jeeves & 1934 & Perfetto, Jeeves & 1985 & Rizzoli \\
\hline GV.47 & Right Ho, Jeeves & 1934 & Perfetto, Jeeves & 1985 & Rizzoli \\
\hline GV.47 & Right Ho, Jeeves & 1934 & Perfetto, Jeeves & 1993 & Mursia \\
\hline GV.47 & Right Ho, Jeeves & 1934 & Perfetto, Jeeves & 2005 & Polillo \\
\hline GV.48 & Blandings Castle and Elsewhere & 1935 & Il castello di Blandings & 1936 & Bietti \\
\hline GV.48 & Blandings Castle and Elsewhere & 1935 & il castello di Blandings: romanzo umoristico inglese & 1937 & Bietti \\
\hline GV.48 & Blandings Castle and Elsewhere & 1935 & Il castello di Blandings & 1966 & Bietti \\
\hline GV.48 & Blandings Castle and Elsewhere & 1935 & Il castello di Blandings & 1984 & Rizzoli \\
\hline GV.48 & Blandings Castle and Elsewhere & 1935 & Il castello di Blandings & 1992 & Guanda \\
\hline GV.48 & Blandings Castle and Elsewhere & 1935 & Il castello di Blandings & 1995 & TEA \\
\hline GV.48 & Blandings Castle and Elsewhere & 1935 & Il castello di Blandings & 2003 & TEA \\
\hline GV.49 & The Luck of the Bodkins & 1935 & La fortuna dei Bodkin: romanzo umoristico inglese & 1936 & Bietti \\
\hline GV.49 & The Luck of the Bodkins & 1935 & La fortuna dei Bodkin: romanzo umoristico inglese & 1937 & Bietti \\
\hline GV.49 & The Luck of the Bodkins & 1935 & La fortuna dei Bodkin: romanzo umoristico inglese & 1938 & Bietti \\
\hline
\end{tabular}




\begin{tabular}{|c|c|c|c|c|c|}
\hline GV.49 & The Luck of the Bodkins & 1935 & La fortuna dei Bodkin & 1973 & Bietti \\
\hline GV.5o & Young Men in Spats & 1936 & Giovanotti con le ghette: romanzo umoristico inglese & 1936 & Bietti \\
\hline GV.5० & Young Men in Spats & 1936 & Giovanotti con le ghette: romanzo umoristico inglese & 1937 & Bietti \\
\hline GV.50 & Young Men in Spats & 1936 & Giovanotti con le ghette & 1962 & Bietti \\
\hline GV.5O & Young Men in Spats & 1936 & Giovanotti con le ghette & 1964 & Bietti \\
\hline GV.5o & Young Men in Spats & 1936 & Giovanotti con le ghette & 1966 & Bietti \\
\hline GV.5० & Young Men in Spats & 1936 & Il mistero dei cappelli & 2013 & Guanda \\
\hline GV.51 & Laughing Gas & 1936 & Gas esilarante & 1938 & Mondadori \\
\hline GV.51 & Laughing Gas & 1936 & Gas esilarante & 1955 & Mondadori \\
\hline GV.51 & Laughing Gas & 1936 & Gas esilarante & 1971 & Mondadori \\
\hline GV.51 & Laughing Gas & 1936 & Gas esilarante & 1979 & Mondadori \\
\hline GV.51 & Laughing Gas & 1936 & Gas esilarante & 2000 & Guanda \\
\hline GV.51 & Laughing Gas & 1936 & Gas esilarante & 2003 & TEA \\
\hline GV.52 & Lord Emsworth and Others & 1937 & Lord Emsworth ed altri personaggi & 1940 & Bietti \\
\hline GV.52 & Lord Emsworth and Others & 1937 & Un eroe da romanzo & 1973 & Bietti \\
\hline GV.52 & Lord Emsworth and Others & 1937 & Lord Emsworth e altri racconti & 1973 & Bietti \\
\hline GV.52 & Lord Emsworth and Others & 1937 & Ondata di crimini a Blandings & 1993 & Guanda \\
\hline GV.52 & Lord Emsworth and Others & 1937 & Ondata di crimini a Blandings & 1997 & TEA \\
\hline GV.52 & Lord Emsworth and Others & 1937 & Ondata di crimini a Blandings & 2002 & TEA \\
\hline GV.53 & Summer Moonshine & 1938 & Poi tutto s'accomoda: romanzo & 1939 & Mondadori \\
\hline GV.53 & Summer Moonshine & 1938 & Poi, tutto s'accomoda & 1955 & Mondadori \\
\hline GV.54 & The Code of the Woosters & 1938 & Jeeves non si smentisce: romanzo & 1939 & Mondadori \\
\hline GV.54 & The Code of the Woosters & 1938 & Jeeves non si smentisce & 1956 & Mondadori \\
\hline GV.54 & The Code of the Woosters & 1938 & Jeeves non si smentisce & 1962 & Mondadori \\
\hline GV.54 & The Code of the Woosters & 1938 & Jeeves non si smentisce mai: romanzo & 1973 & Mondadori \\
\hline GV.54 & The Code of the Woosters & 1938 & Jeeves non si smentisce & 1976 & Mondadori \\
\hline GV.54 & The Code of the Woosters & 1938 & Il codice dei Wooster & 1989 & Mursia \\
\hline GV.54 & The Code of the Woosters & 1938 & Il codice dei Wooster & 2001 & Mursia \\
\hline GV.54 & The Code of the Woosters & 1938 & Il codice dei Wooster & 2005 & Polillo \\
\hline GV.55 & Uncle Fred in the Springtime & 1939 & Zio Fred in primavera & 1940 & Mondadori \\
\hline GV.55 & Uncle Fred in the Springtime & 1939 & Zio Fred in primavera & 1964 & Mondadori \\
\hline GV.55 & Uncle Fred in the Springtime & 1939 & Zio Fred in primavera & 1972 & Mondadori \\
\hline GV.55 & Uncle Fred in the Springtime & 1939 & Zio Fred in primavera & 1991 & Guanda \\
\hline GV.55 & Uncle Fred in the Springtime & 1939 & Zio Fred in primavera & 1994 & TEA \\
\hline GV.55 & Uncle Fred in the Springtime & 1939 & Zio Fred in primavera & 1997 & TEA \\
\hline GV.55 & Uncle Fred in the Springtime & 1939 & Zio Fred in primavera & 2003 & Euromeeting \\
\hline GV.55 & Uncle Fred in the Springtime & 1939 & Zio Fred in primavera & 2006 & TEA \\
\hline GV.56 & Quick Service & 1940 & Servizio espresso & 1951 & Elmo \\
\hline GV.56 & Quick Service & 1940 & Servizio espresso & 1962 & Elmo \\
\hline GV.56 & Quick Service & 1940 & Presto e bene & 1992 & Mursia \\
\hline GV.57 & Eggs, Beans and Crumpets & 1940 & Il club dei nati stanchi & 1962 & Elmo \\
\hline GV.57 & Eggs, Beans and Crumpets & 1940 & Tizio, Caio e Sempronio & 1993 & Mursia \\
\hline GV.57 & Eggs, Beans and Crumpets & 1940 & Colpo di fulmine alle terme & 2008 & Guanda \\
\hline GV.57 & Eggs, Beans and Crumpets & 1940 & Colpo di fulmine alle terme & 2016 & Guanda \\
\hline GV.58 & Money in the Bank & 1946 & Quattrini in banca: romanzo & 1949 & Elmo \\
\hline GV.58 & Money in the Bank & 1946 & Quattrini in banca & $195^{8}$ & Mondadori \\
\hline GV.58 & Money in the Bank & 1946 & Quattrini in banca & 1964 & Mondadori \\
\hline GV.58 & Money in the Bank & 1946 & Quattrini in banca & 1974 & Mondadori \\
\hline GV.59 & Joy in the Morning & 1947 & La gioia e' col mattino & 1948 & Elmo \\
\hline
\end{tabular}




\begin{tabular}{|c|c|c|c|c|c|}
\hline GV.59 & Joy in the Morning & 1947 & La gioia e' col mattino & 1949 & Elmo \\
\hline GV.59 & Joy in the Morning & 1947 & La gioia e' col mattino & 1961 & Elmo \\
\hline GV.59 & Joy in the Morning & 1947 & Un mattino di gioia & 1990 & Mursia \\
\hline GV.59 & Joy in the Morning & 1947 & Un mattino di gioia & 2006 & Polillo \\
\hline GV.59 & Joy in the Morning & 1947 & Un mattino di gioia & 2013 & Polillo \\
\hline GV.59 & Joy in the Morning & 1947 & Un mattino di gioia & 2017 & Polillo \\
\hline GV.6o & Full Moon & 1947 & Luna piena & 1954 & Mondadori \\
\hline GV.6o & Full Moon & 1947 & Luna piena & 1991 & Guanda \\
\hline GV.6o & Full Moon & 1947 & Luna piena & 1996 & TEA \\
\hline GV.61 & Spring Fever & 1948 & Febbre di primavera & $195^{2}$ & Elmo \\
\hline GV.61 & Spring Fever & 1948 & Febbre di primavera & 1965 & Elmo \\
\hline GV.61 & Spring Fever & 1948 & Febbre di primavera & 1994 & Mursia \\
\hline GV.62 & Uncle Dynamite & 1948 & Lo zio dinamite & 1949 & Elmo \\
\hline GV.62 & Uncle Dynamite & 1948 & Lo zio dinamite & 1955 & Elmo \\
\hline GV.62 & Uncle Dynamite & 1948 & Lo zio dinamite & 1962 & Elmo \\
\hline GV.62 & Uncle Dynamite & 1948 & Zio dinamite & 1998 & Guanda \\
\hline GV.62 & Uncle Dynamite & 1948 & Zio dinamite: Romanzo & 2002 & TEA \\
\hline GV.62 & Uncle Dynamite & 1948 & Zio dinamite: Romanzo & 2006 & TEA \\
\hline GV.63 & The Mating Season & 1949 & Sotto le fresche frasche & $195^{\circ}$ & Elmo \\
\hline GV.63 & The Mating Season & 1949 & La stagione degli amori & 1990 & Mursia \\
\hline GV.63 & The Mating Season & 1949 & La stagione degli amori & 2006 & Polillo \\
\hline GV.63 & The Mating Season & 1949 & La stagione degli amori & 2016 & Polillo \\
\hline GV.64 & Nothing Serious & $195^{\circ}$ & Non c'è da preoccuparsi & 1965 & Elmo \\
\hline GV.64 & Nothing Serious & 1950 & Niente di serio & 2014 & Guanda \\
\hline GV.65 & The Old Reliable & 1951 & Diario segreto & $195^{2}$ & Elmo \\
\hline GV.66 & Barmy in Wonderland & $195^{2}$ & Grullo nel paese delle meraviglie & 1953 & Elmo \\
\hline GV.66 & Barmy in Wonderland & $195^{2}$ & Grullo nel paese delle meraviglie & 1963 & Elmo \\
\hline GV.67 & Pigs Have Wings & $195^{2}$ & I porci hanno le ali & 1953 & Elmo \\
\hline GV.67 & Pigs Have Wings & $195^{2}$ & I porci hanno le ali: romanzo & 1962 & Elmo \\
\hline GV.67 & Pigs Have Wings & $195^{2}$ & I porci hanno le ali: romanzo & 1994 & Guanda \\
\hline GV.67 & Pigs Have Wings & $195^{2}$ & I porci hanno le ali: romanzo & 2001 & TEA \\
\hline GV.68 & Ring for Jeeves & 1953 & Chiamate Jeeves: romanzo & 1954 & Elmo \\
\hline GV.68 & Ring for Jeeves & 1953 & Tanto di cappello a Jeeves & 1955 & Elmo \\
\hline GV.68 & Ring for Jeeves & 1953 & Tanto di cappello a Jeeves & 1979 & Mondadori \\
\hline GV.68 & Ring for Jeeves & 1953 & Chiamate Jeeves & 1988 & Mursia \\
\hline GV.68 & Ring for Jeeves & 1953 & Chiamate Jeeves & 2007 & Polillo \\
\hline GV.69 & Jeeves and the Feudal Spirit & 1954 & Jeeves e la cavalleria & 1988 & Mursia \\
\hline GV.69 & Jeeves and the Feudal Spirit & 1954 & Jeeves e la cavalleria & 1989 & Mursia \\
\hline GV.69 & Jeeves and the Feudal Spirit & 1954 & Jeeves e la cavalleria & 2003 & Mursia \\
\hline GV.69 & Jeeves and the Feudal Spirit & 1954 & Jeeves e la cavalleria & 2006 & Mursia \\
\hline GV.69 & Jeeves and the Feudal Spirit & 1954 & Tanto di cappello a Jeeves & 2006 & Polillo \\
\hline GV.70 & French Leave & $195^{6}$ & E chi s'è visto s'è visto & 1956 & Elmo \\
\hline GV.70 & French Leave & 1956 & E chi s'è visto s'è visto & 1966 & Elmo \\
\hline GV.71 & Something Fishy & 1957 & Qualcosa di losco & $195^{8}$ & Elmo \\
\hline GV.72 & Cocktail Time & $195^{8}$ & Mister I ci sa fare & 196 o & Elmo \\
\hline GV.72 & Cocktail Time & $195^{8}$ & Mister I ci sa fare & 1961 & Elmo \\
\hline GV.72 & Cocktail Time & $195^{8}$ & Mister I ci sa fare & 1964 & Elmo \\
\hline GV.72 & Cocktail Time & $195^{8}$ & Cocktail time & 1998 & Mursia \\
\hline GV.72 & Cocktail Time & $195^{8}$ & Cocktail time & 2008 & Guanda \\
\hline
\end{tabular}




\begin{tabular}{|c|c|c|c|c|c|}
\hline GV.72 & Cocktail Time & $195^{8}$ & Cocktail time & 2016 & Guanda \\
\hline GV.73 & A Few Quick Ones & 1959 & Storie spicciole & 1961 & Elmo \\
\hline GV.73 & A Few Quick Ones & 1959 & Un grosso affare & 2007 & Guanda \\
\hline GV.74 & Jeeves in the Offing & 1960 & Jeeves taglia la corda & 1962 & Elmo \\
\hline GV.74 & Jeeves in the Offing & 1960 & Jeeves taglia la corda & 1979 & Mondadori \\
\hline GV.74 & Jeeves in the Offing & 1960 & Jeeves sta alla larga & 1989 & Mursia \\
\hline GV.74 & Jeeves in the Offing & 1960 & Jeeves taglia la corda & 2007 & Polillo \\
\hline GV.74 & Jeeves in the Offing & 1960 & Jeeves taglia la corda & 2014 & Polillo \\
\hline GV.74 & Jeeves in the Offing & 1960 & Jeeves taglia la corda & 2017 & Polillo \\
\hline GV.75 & Ice in the Bedroom & 1961 & Ghiaccio in una stanza da letto & 1962 & Elmo \\
\hline GV.76 & Service with a Smile & 1962 & I signori sono serviti & 1970 & Elmo \\
\hline GV.76 & Service with a Smile & 1962 & Il ratto dell'imperatrice & 1995 & Guanda \\
\hline GV.76 & Service with a Smile & 1962 & Il ratto dell'imperatrice & 2002 & TEA \\
\hline GV.77 & Stiff Upper Lip, Jeeves & 1963 & Lei e' unico, Jeeves & 1964 & Elmo \\
\hline GV.77 & Stiff Upper Lip, Jeeves & 1963 & Teniamo duro, Jeeves & 1990 & Mursia \\
\hline GV.77 & Stiff Upper Lip, Jeeves & 1963 & Teniamo duro, Jeeves & 2007 & Polillo \\
\hline GV.77 & Stiff Upper Lip, Jeeves & 1963 & Teniamo duro, Jeeves & 2013 & Polillo \\
\hline GV.77 & Stiff Upper Lip, Jeeves & 1963 & Teniamo duro, Jeeves & 2016 & Polillo \\
\hline GV.78 & Frozen Assets & 1964 & L'eredita' sotto chiave & 1965 & Elmo \\
\hline GV.78 & Frozen Assets & 1964 & Beni congelati & 1997 & Mursia \\
\hline GV.79 & Galahad at Blandings & 1965 & Genero al verde & 1966 & Elmo \\
\hline GV.79 & Galahad at Blandings & 1965 & Un intrigo a Blandings & 1997 & Guanda \\
\hline GV.79 & Galahad at Blandings & 1965 & Un intrigo a Blandings & 1999 & TEA \\
\hline GV.8o & Company for Henry & 1967 & In compagnia di Henry & 1977 & Mondadori \\
\hline GV.81 & Do Butlers Burgle Banks? & 1968 & I maggiordomi rapinano le banche? & 1977 & Mondadori \\
\hline GV.81 & Do Butlers Burgle Banks? & 1968 & I maggiordomi svaligiano le banche? & 1992 & Mursia \\
\hline GV.82 & A Pelican at Blandings & 1969 & Il pellicano a Blandings & 1970 & Mondadori \\
\hline GV.82 & A Pelican at Blandings & 1969 & Il pellicano a Blandings & 1976 & Mondadori \\
\hline GV.82 & A Pelican at Blandings & 1969 & Un pellicano a Blandings & 1996 & Guanda \\
\hline GV.82 & A Pelican at Blandings & 1969 & Un pellicano a Blandings & 2000 & TEA \\
\hline GV.83 & The Girl in Blue & 1970 & La ragazza in blu & 1973 & Mondadori \\
\hline GV.83 & The Girl in Blue & 1970 & La ragazza in blu & 1990 & Mursia \\
\hline GV.84 & Much Obliged, Jeeves & 1971 & Molto obbligato, Jeeves & 1972 & Mondadori \\
\hline GV.84 & Much Obliged, Jeeves & 1971 & Molto obbligato, Jeeves & 1973 & Mondadori \\
\hline GV.84 & Much Obliged, Jeeves & 1971 & Molto obbligato, Jeeves & 1976 & Mondadori \\
\hline GV.84 & Much Obliged, Jeeves & 1971 & Molto obbligato, Jeeves & 1989 & Mursia \\
\hline GV.84 & Much Obliged, Jeeves & 1971 & Molto obbligato, Jeeves & 2008 & Polillo \\
\hline GV.85 & Pearls, Girls and Monty Bodkin & 1972 & I $<<$ gioielli $>>$ di Monty Bodkin & 1974 & Mondadori \\
\hline GV.85 & Pearls, Girls and Monty Bodkin & 1972 & I gioielli di Monty Bodkin & 1990 & Mursia \\
\hline GV.86 & Bachelors Anonymous & 1973 & Anonima scapoli & 1975 & Mondadori \\
\hline GV.86 & Bachelors Anonymous & 1973 & Anonima scapoli & 1990 & Mursia \\
\hline GV.87 & Aunts Aren't Gentlemen & 1974 & Le zie non sono gentiluomini & 1976 & Mondadori \\
\hline GV.87 & Aunts Aren't Gentlemen & 1974 & Le zie non sono gentiluomini & 1989 & Mursia \\
\hline GV.87 & Aunts Aren't Gentlemen & 1974 & Le zie non sono gentiluomini & 2009 & Polillo \\
\hline GV.87 & Aunts Aren't Gentlemen & 1974 & Le zie non sono gentiluomini & 2013 & Polillo \\
\hline GV.87 & Aunts Aren't Gentlemen & 1974 & Le zie non sono gentiluomini & 2016 & Polillo \\
\hline
\end{tabular}


Appendix $6 \quad$ Italian translators and titles translated

Agnati, Sario

\begin{tabular}{|l|l|c|l|c|c|}
\hline GV.57 & Eggs, Beans and Crumpets & 1940 & Il club dei nati stanchi & 1962 & Elmo \\
\hline GV.58 & Money in the Bank & 1946 & Quattrini in banca: romanzo & 1949 & Elmo \\
\hline GV.64 & Nothing Serious & 1950 & Non c'è da preoccuparsi & 1965 & Elmo \\
\hline GV.73 & A Few Quick Ones & 1959 & Storie spicciole & 1961 & Elmo \\
\hline GV.75 & Ice in the Bedroom & 1961 & Ghiaccio in una stanza da letto & 1962 & Elmo \\
\hline GV.77 & Stiff Upper Lip, Jeeves & 1963 & Lei e' unico, Jeeves & 1964 & Elmo \\
\hline GV.78 & Frozen Assets & 1964 & L'eredita' sotto chiave & 1965 & Elmo \\
\hline GV.79 & Galahad at Blandings & 1965 & Genero al verde & 1966 & Elmo \\
\hline
\end{tabular}

Baraldi, Lina

\begin{tabular}{|l|l|c|l|c|c|}
\hline GV.o4 & The Gold Bath & 1904 & Battaglie sportive & 1932 & Bietti \\
\hline
\end{tabular}

\section{Benzi, Mario}

\begin{tabular}{|c|l|c|l|c|c|}
\hline GV.o1 & The Pothunters & 1902 & $\begin{array}{l}\text { I conquistatori di coppe: } \\
\text { romanzo }\end{array}$ & $193^{2}$ & Bietti \\
\hline GV.o7 & The White Feather & 1907 & Una penna di coda: romanzo & $193^{2}$ & Bietti \\
\hline GV.o8 & Mike & 1909 & $\begin{array}{l}\text { Mike: storia di un collegio: } \\
\text { romanzo }\end{array}$ & $193^{2}$ & Bietti \\
\hline GV.35 & Money for Nothing & 1928 & $\begin{array}{l}\text { Denaro trovato: romanzo } \\
\text { umoristico inglese }\end{array}$ & $193^{2}$ & Monanni \\
\hline GV.40 & Big Money & 1931 & $\begin{array}{l}\text { Quattrini a palate: } \text { romanzo } \\
\text { umoristico inglese }\end{array}$ & $193^{2}$ & Monanni \\
\hline
\end{tabular}

Bernardini, Lepido

\begin{tabular}{|c|l|c|l|c|c|}
\hline GV.15 & Something Fresh & 1915 & $\begin{array}{l}\text { Qualche cosa di nuovo: romanzo } \\
\text { umoristico inglese }\end{array}$ & $193^{2}$ & Monanni \\
\hline
\end{tabular}

Bernardinis, Fulvio

\begin{tabular}{|l|l|c|l|c|c|}
\hline GV.72 & Cocktail Time & 1958 & Cocktail time & 1998 & Mursia \\
\hline
\end{tabular}

Bertola, Stefania

\begin{tabular}{|c|l|c|l|c|c|}
\hline GV.14 & Psmith Journalist & 1915 & Le gesta di Psmith & 1990 & Guanda \\
\hline GV.6o & Full Moon & 1947 & Luna piena & 1991 & Guanda \\
\hline
\end{tabular}

Bianchini Alfredo

\begin{tabular}{|l|l|c|l|c|c|}
\hline GV.o9 & A Gentleman of Leisure & 1910 & Jimmy all'opra & 1935 & S.A.C.S.E. \\
\hline GV.19 & A Damsel in Distress & 1919 & Un capriccio e poi... & 1935 & S.A.C.S.E. \\
\hline
\end{tabular}

Bodoman, Mario

\begin{tabular}{|c|l|c|l|c|c|}
\hline GV.o6 & Love Among the Chickens & 1906 & L'amore fra i polli & 1990 & Mursia \\
\hline GV.15 & Something Fresh & 1915 & Qualcosa di nuovo & 2 2011 & Guanda \\
\hline
\end{tabular}




\begin{tabular}{|l|l|c|l|c|c|}
\hline GV.21 & Jill, the Reckless & 1921 & Jill ragazza bizzarra & 1991 & Mursia \\
\hline GV.41 & Doctor Sally & $193^{2}$ & La dottoressa Sally & 1990 & Mursia \\
\hline
\end{tabular}

Brera, Carlo

\begin{tabular}{|l|l|c|l|c|c|}
\hline GV.37 & Summer Lightning & 1929 & Lampi d'estate & 1989 & Guanda \\
\hline
\end{tabular}

Brioschi, Luigi

\begin{tabular}{|l|l|c|l|c|c|}
\hline GV.29 & Bill the Conqueror & 1924 & Bill il conquistatore & 1993 & Mursia \\
\hline GV.44 & Mulliner Nights & 1933 & Le sere di Mulliner & 1985 & Rizzoli \\
\hline GV.48 & Blandings Castle and Elsewhere & 1935 & Il castello di Blandings & 1966 & Bietti \\
\hline
\end{tabular}

Brugiotti, Giulia

\begin{tabular}{|c|l|c|l|c|c|}
\hline GV.46 & Thank You, Jeeves & 1934 & $\begin{array}{l}\text { Grazie, Jeeves: romanzo } \\
\text { umoristico inglese }\end{array}$ & $\mathbf{1 9 3 4}$ & Bietti \\
\hline GV.48 & Blandings Castle and Elsewhere & 1935 & Il castello di Blandings & 1936 & Bietti \\
\hline GV.52 & Lord Emsworth and Others & 1937 & $\begin{array}{l}\text { Lord Emsworth ed altri } \\
\text { personaggi }\end{array}$ & 1940 & Bietti \\
\hline
\end{tabular}

Buckwell Gilson, Mary

\begin{tabular}{|c|l|c|l|c|c|}
\hline GV.24 & The Clicking of Cuthbert & 1922 & $\begin{array}{l}\text { Il colpo di Cuthbert e altri } \\
\text { racconti }\end{array}$ & 1990 & Mursia \\
\hline GV.33 & Meet Mr Mulliner & 1927 & Il signor Mulliner racconta & 1955 & Mursia \\
\hline GV.4O & Big Money & 1931 & Quattrini a palate & 1997 & Mursia \\
\hline GV.54 & The Code of the Woosters & 1938 & Il codice dei Wooster & 1989 & Mursia \\
\hline GV.69 & Jeeves and the Feudal Spirit & 1954 & Jeeves e la cavalleria & 1988 & Mursia \\
\hline GV.84 & Much Obliged, Jeeves & 1971 & Molto obbligato, Jeeves & 1989 & Mursia \\
\hline
\end{tabular}

Buitoni Duca, Maria

\begin{tabular}{|l|l|c|l|c|c|}
\hline GV.47 & Right Ho, Jeeves & 1934 & Perfetto, Jeeves & 1985 & Rizzoli \\
\hline
\end{tabular}

Campagna Ponzetto, Sandra

\begin{tabular}{|c|l|c|l|c|c|}
\hline GV.59 & Joy in the Morning & 1947 & Un mattino di gioia & 1990 & Mursia \\
\hline GV.63 & The Mating Season & 1949 & La stagione degli amori & 1990 & Mursia \\
\hline GV.81 & Do Butlers Burgle Banks? & 1968 & $\begin{array}{l}\text { I maggiordomi svaligiano le } \\
\text { banche? }\end{array}$ & 1992 & Mursia \\
\hline
\end{tabular}

\section{Carlesimo, Maria}

\begin{tabular}{|l|l|c|l|c|c|}
\hline GV.17 & Uneasy Money & 1917 & $\begin{array}{l}\text { Denaro difficile: romanzo } \\
\text { umoristico inglese }\end{array}$ & $\mathbf{1 9 3 2}^{2}$ & Monanni \\
\hline
\end{tabular}

Carter, Dienne

\begin{tabular}{|l|l|c|l|c|c|}
\hline GV.o6 & Love Among the Chickens & 1906 & L'amore tra i polli & 1938 & Aurora \\
\hline GV.20 & The Coming of Bill & 1920 & $\begin{array}{l}\text { La venuta di Bill: romanzo } \\
\text { umoristico }\end{array}$ & 1932 & Bietti \\
\hline
\end{tabular}




\begin{tabular}{|c|l|c|l|c|c|}
\hline GV.o8 & Mike & 1909 & Mike & 1992 & Mursia \\
\hline GV.11 & The Prince and Betty & 1912 & Il principe e Betty & 1990 & Mursia \\
\hline GV.12 & The Little Nugget & 1913 & La piccola pepita & 2012 & Mursia \\
\hline
\end{tabular}

\section{Comucci, Vittoria}

\begin{tabular}{|c|c|c|l|c|c|}
\hline GV.6o & Full Moon & 1947 & Luna piena & 1954 & Mondadori \\
\hline \multicolumn{7}{|c|}{ Dàuli, Gian } \\
GV.o9 & A Gentleman of Leisure & 1910 & $\begin{array}{l}\text { Il gentiluomo spensierato: un } \\
\text { giallo umoristico }\end{array}$ & 1939 & Lucchi \\
\hline GV.12 & The Little Nugget & 1913 & $\begin{array}{l}\text { Il filone d'oro: romanzo } \\
\text { umoristico }\end{array}$ & 1940 & Lucchi \\
\hline GV.14 & Psmith, Journalist & 1915 & $\begin{array}{l}\text { Psmith giornalista: romanzo } \\
\text { umoristico }\end{array}$ & 1940 & Lucchi \\
\hline GV.19 & A Damsel in Distress & 1919 & $\begin{array}{l}\text { Una magnifica avventura: } \\
\text { romanzo umoristico }\end{array}$ & 1939 & Lucchi \\
\hline
\end{tabular}

\begin{tabular}{|c|l|c|l|c|c|}
\hline GV.13 & $\begin{array}{l}\text { The Man Upstairs and Other } \\
\text { Stories }\end{array}$ & 1914 & $\begin{array}{l}\text { L'uomo del piano di sopra e altri } \\
\text { racconti }\end{array}$ & 1992 & Mursia \\
\hline GV.16 & The Man With Two Left Feet & 1917 & L'uomo con due piedi sinistri & 1991 & Mursia \\
\hline GV.17 & Uneasy Money & 1917 & Denaro difficile & 1992 & Mursia \\
\hline
\end{tabular}

\section{Ferri, Corrado}

\begin{tabular}{|l|l|c|l|c|c|}
\hline GV.21 & Jill, the Reckless & 1921 & Jill ragazza bizzarra & 1966 & Bietti \\
\hline
\end{tabular}

Fratta, L.

\begin{tabular}{|c|l|c|l|c|c|}
\hline GV.15 & Something Fresh & 1915 & $\begin{array}{l}\text { Qualche cosa di nuovo: } \\
\text { romanzo umoristico }\end{array}$ & $193^{2}$ & Bietti \\
\hline
\end{tabular}

Gilli, Mario

\begin{tabular}{|c|c|c|c|c|c|}
\hline GV.27 & Leave it to Psmith & 1923 & Lasciate fare a Psmith & 1933 & Monanni \\
\hline \multicolumn{6}{|c|}{ Janin, Pia } \\
\hline GV.46 & Thank You, Jeeves & 1934 & Grazie, Jeeves & 1984 & Rizzoli \\
\hline
\end{tabular}

Lampronti, Zoe

\begin{tabular}{|c|l|c|l|c|c|}
\hline GV.43 & Louder and Funnier & 1932 & $\begin{array}{l}\text { Più forte e più allegro: saggi } \\
\text { umoristici }\end{array}$ & 1934 & Bietti \\
\hline GV.45 & Heavy weather & 1933 & $\begin{array}{l}\text { Acqua pesante: romanzo } \\
\text { umoristico inglese }\end{array}$ & 1933 & Bietti \\
\hline GV.45 & Heavy weather & 1933 & $\begin{array}{l}\text { Tempo pesante: romanzo } \\
\text { umoristico inglese }\end{array}$ & 1933 & Bietti \\
\hline GV.49 & The Luck of the Bodkins & 1935 & $\begin{array}{l}\text { La fortuna dei Bodkin: romanzo } \\
\text { umoristico inglese }\end{array}$ & $\mathbf{1 9 3 6}$ & Bietti \\
\hline GV.50 & Young Men in Spats & 1936 & $\begin{array}{l}\text { Giovanotti con le ghette: } \\
\text { romanzo umoristico inglese }\end{array}$ & 1936 & Bietti \\
\hline
\end{tabular}


Lattanzi, Luciano

\begin{tabular}{|c|c|c|c|c|c|}
\hline GV.61 & Spring Fever & 1948 & Febbre di primavera & $195^{2}$ & Elmo \\
\hline \multicolumn{6}{|c|}{ Longanesi, Caterina } \\
\hline GV.82 & A Pelican at Blandings & 1969 & Il pellicano a Blandings & 1970 & Mondadori \\
\hline \multicolumn{6}{|c|}{ Lord, Tracy } \\
\hline GV.26 & The Inimitable Jeeves & 1923 & L'inimitabile Jeeves & 2010 & Polillo \\
\hline GV.30 & Carry On, Jeeves & 1925 & Avanti, Jeeves & 2011 & Polillo \\
\hline GV.38 & Very Good, Jeeves & 1930 & Molto bene, Jeeves & 2012 & Polillo \\
\hline GV.46 & Thank You, Jeeves & 1934 & Grazie, Jeeves & 2005 & Polillo \\
\hline GV.59 & Joy in the Morning & 1947 & Un mattino di gioia & 2006 & Polillo \\
\hline GV.63 & The Mating Season & 1949 & La stagione degli amori & 2006 & Polillo \\
\hline GV.68 & Ring for Jeeves & 1953 & Tanto di cappello a Jeeves & 2006 & Polillo \\
\hline $\mathrm{GV} \cdot 74$ & Jeeves in the Offing & 1960 & Jeeves taglia la corda & 2007 & Polillo \\
\hline GV.77 & Stiff Upper Lip, Jeeves & 1963 & Teniamo duro, Jeeves & 2007 & Polillo \\
\hline GV.84 & Much Obliged, Jeeves & 1971 & Molto obbligato, Jeeves & 2008 & Polillo \\
\hline GV.87 & Aunts Aren't Gentlemen & 1974 & Le zie non sono gentiluomini & 2009 & Polillo \\
\hline
\end{tabular}

Lori, Ida

\begin{tabular}{|c|l|c|l|c|c|}
\hline GV.o3 & Tales of St Austin's & 1903 & Racconti di sant'Agostino & $193^{2}$ & Bietti \\
\hline GV.o9 & A Gentleman of Leisure & 1910 & $\begin{array}{l}\text { Un gentiluomo in ozio: } \\
\text { romanzo umoristico inglese }\end{array}$ & 1931 & Bietti \\
\hline GV.18 & Piccadilly Jim & 1918 & $\begin{array}{l}\text { Jim di Piccadilly:romanzo } \\
\text { umoristico }\end{array}$ & 1931 & Bietti \\
\hline
\end{tabular}

Mainardi, Riccardo

\begin{tabular}{|l|l|c|l|c|c|}
\hline GV.79 & Galahad at Blandings & 1965 & Un intrigo a Blandings & 1997 & Guanda \\
\hline
\end{tabular}

Malatesta, Mario

\begin{tabular}{|c|l|c|l|c|c|}
\hline GV.12 & The Little Nugget & 1913 & $\begin{array}{l}\text { Pepita d'oro: romanzo } \\
\text { umoristico inglese }\end{array}$ & 1932 & Monanni \\
\hline GV.18 & Piccadilly Jim & 1918 & Jim di Piccadilly & 1931 & Monanni \\
\hline GV.24 & The Clicking of Cuthbert & 1922 & $\begin{array}{l}\text { Il colpo di Cuthbert: romanzo } \\
\text { umoristico inglese }\end{array}$ & 1933 & Bietti \\
\hline GV.32 & The Heart of a Goof & 1926 & Il cuore di un coniglio & 1931 & Monanni \\
\hline
\end{tabular}

Martone, Maria

\begin{tabular}{|c|l|c|l|c|c|}
\hline GV.11 & The Prince and Betty & 1912 & $\begin{array}{l}\text { Il principe e Betty: romanzo } \\
\text { umoristico inglese }\end{array}$ & 1932 & Monanni \\
\hline GV.13 & $\begin{array}{l}\text { The Man Upstairs and Other } \\
\text { Stories }\end{array}$ & 1914 & $\begin{array}{l}\text { L'uomo del piano di sopra: } \\
\text { racconti umoristici inglesi }\end{array}$ & 1933 & Monanni \\
\hline GV.25 & The Adventures of Sally & 1922 & $\begin{array}{l}\text { Le avventure di Sally:romanzo } \\
\text { umoristico inglese }\end{array}$ & $\mathbf{1 9 3 1}$ & Monanni \\
\hline GV.28 & Ukridge & 1924 & $\begin{array}{l}\text { Ukridge: romanzo umoristico } \\
\text { inglese }\end{array}$ & $\mathbf{1 9 3 1}$ & Monanni \\
\hline
\end{tabular}


Mazzarelli, Paola

\begin{tabular}{|l|l|c|l|c|c|}
\hline GV.18 & Piccadilly Jim & 1918 & Piccadilly Jim & 2005 & Guanda \\
\hline
\end{tabular}

Melani, Sandro

\begin{tabular}{|c|l|c|l|c|c|}
\hline GV.22 & Indiscretions of Archie & 1921 & Le imprudenze di Archie & 1993 & Mursia \\
\hline GV.57 & Eggs, Beans and Crumpets & 1940 & Tizio, Caio e Sempronio & 1993 & Mursia \\
\hline
\end{tabular}

Monicelli, Giorgio

\begin{tabular}{|l|l|c|l|c|c|}
\hline GV.59 & Joy in the Morning & 1947 & La gioia e' col mattino & 1948 & Elmo \\
\hline
\end{tabular}

\section{Morzenti, Monica}

\begin{tabular}{|c|l|c|l|c|c|}
\hline GV.34 & The Small Bachelor & 1927 & $\begin{array}{l}\text { Il piccolo scapolo: romanzo } \\
\text { umoristico inglese }\end{array}$ & 1996 & Mursia \\
\hline GV.56 & Quick Service & 1940 & Presto e bene & 1992 & Mursia \\
\hline GV.78 & Frozen Assets & 1964 & Beni congelati & 1997 & Mursia \\
\hline
\end{tabular}

Motti, Adriana

\begin{tabular}{|l|l|c|l|c|c|}
\hline GV.56 & Quick Service & 1940 & Servizio espresso & 1951 & Elmo \\
\hline GV.62 & Uncle Dynamite & 1948 & Lo zio dinamite & 1949 & Elmo \\
\hline GV.63 & The Mating Season & 1949 & Sotto le fresche frasche & 1950 & Elmo \\
\hline GV.65 & The Old Reliable & 1951 & Diario segreto & 1952 & Elmo \\
\hline GV.66 & Barmy in Wonderland & 1952 & $\begin{array}{l}\text { Grullo nel paese delle } \\
\text { meraviglie }\end{array}$ & 1953 & Elmo \\
\hline GV.67 & Pigs Have Wings & 1952 & I porci hanno le ali & 1953 & Elmo \\
\hline GV.68 & Ring for Jeeves & 1953 & Chiamate Jeeves: romanzo & 1954 & Elmo \\
\hline GV.70 & French Leave & 1956 & E chi s'è visto s'è visto & 1956 & Elmo \\
\hline GV.71 & Something Fishy & 1957 & Qualcosa di losco & 1958 & Elmo \\
\hline GV.72 & Cocktail Time & 1958 & Mister I ci sa fare & 1960 & Elmo \\
\hline GV.74 & Jeeves in the Offing & 1960 & Jeeves taglia la corda & 1962 & Elmo \\
\hline GV.76 & Service with a Smile & 1962 & I signori sono serviti & 1970 & Elmo \\
\hline GV.8o & Company for Henry & 1967 & In compagnia di Henry & 1977 & Mondadori \\
\hline GV.81 & Do Butlers Burgle Banks? & 1968 & $\begin{array}{l}\text { I maggiordomi rapinano le } \\
\text { banche? }\end{array}$ & 1977 & Mondadori \\
\hline
\end{tabular}

Mozzati, Ariberto

\begin{tabular}{|c|l|c|l|c|c|}
\hline GV.19 & A Damsel in Distress & 1919 & $\begin{array}{l}\text { Una signorina in imbarazzo: } \\
\text { romanzo umoristico inglese }\end{array}$ & 1931 & Bietti \\
\hline
\end{tabular}

Musso, Dolores

\begin{tabular}{|l|l|c|l|c|c|}
\hline GV.73 & A Few Quick Ones & 1959 & Un grosso affare & 2007 & Guanda \\
\hline
\end{tabular}

Palazzi, Rosetta

\begin{tabular}{|c|l|c|l|c|c|}
\hline GV.19 & A Damsel in Distress & 1919 & Una damigella in pericolo & 1994 & Mursia \\
\hline GV.25 & The Adventures of Sally & 1922 & $\begin{array}{l}\text { Le avventure di Sally: romanzo } \\
\text { umoristico inglese }\end{array}$ & 1995 & Mursia \\
\hline
\end{tabular}




\begin{tabular}{|l|l|c|l|c|c|}
\hline GV.32 & The Heart of a Goof & 1926 & Il cuore di un paranoico & 1992 & Mursia \\
\hline GV.35 & Money for Nothing & 1928 & E' tutto denaro sprecato & 1997 & Mursia \\
\hline GV.68 & Ring for Jeeves & 1953 & Chiamate Jeeves & 1988 & Mursia \\
\hline GV.74 & Jeeves in the Offing & 1960 & Jeeves sta alla larga & 1989 & Mursia \\
\hline GV.77 & Stiff Upper Lip, Jeeves & 1963 & Teniamo duro, Jeeves & 1990 & Mursia \\
\hline
\end{tabular}

Palumbo, Francesco

\begin{tabular}{|c|l|c|l|c|c|}
\hline GV.o2 & A Prefect's Uncle & 1903 & Lo zio del prefetto: romanzo & $\mathbf{1 9 3 2}$ & Bietti \\
\hline GV.o5 & The Head of Kay's & 1905 & Il capo della Kay: romanzo & $\mathbf{1 9 3 2}$ & Bietti \\
\hline GV.o6 & Love Among the Chickens & 1906 & Amore tra i polli: romanzo & $193^{2}$ & Bietti \\
\hline GV.11 & The Prince and Betty & 1912 & Il principe e Betty: romanzo & $\mathbf{1 9 3 2}$ & Bietti \\
\hline GV.13 & $\begin{array}{l}\text { The Man Upstairs and Other } \\
\text { Stories }\end{array}$ & 1914 & L'uomo del piano di sopra & $\mathbf{1 9 3 2}$ & Bietti \\
\hline GV.17 & Uneasy Money & 1917 & Danaro incomodo: romanzo & $193^{8}$ & Bietti \\
\hline GV.19 & A Damsel in Distress & 1919 & $\begin{array}{l}\text { Una donzella in imbarazzo: } \\
\text { romanzo umoristico inglese }\end{array}$ & $\mathbf{1 9 3 1}$ & Monanni \\
\hline GV.22 & Indiscretions of Archie & 1921 & Indiscrezioni di Arcibaldo & $\mathbf{1 9 3 1}$ & Monanni \\
\hline
\end{tabular}

Pieraccini, Silvia

\begin{tabular}{|l|l|c|l|c|c|}
\hline GV.36 & Mr Mulliner Speaking & 1929 & L'uomo che smise di fumare & 2010 & Guanda \\
\hline GV.50 & Young Men in Spats & 1936 & Il mistero dei cappelli & 2013 & Guanda \\
\hline
\end{tabular}

Pisano, G.V.

\begin{tabular}{|l|l|c|l|c|c|} 
GV.16 & The Man With Two Left Feet & 1917 & L'uomo con due piedi sinistri & $\mathbf{1 9 3 2}^{2}$ & Bietti \\
\hline
\end{tabular}

Pitta, Alfredo

\begin{tabular}{|c|l|c|l|c|c|}
\hline GV.10 & Psmith in the City & 1910 & Psmith in banca: romanzo & $193^{2}$ & Bietti \\
\hline GV.12 & The Little Nugget & 1913 & La piccola pepita: romanzo & $193^{2}$ & Bietti \\
\hline GV.14 & Psmith, Journalist & 1915 & Psmith giornalista: romanzo & $193^{2}$ & Bietti \\
\hline GV.20 & The Coming of Bill & 1920 & La venuta di Bill & $\mathbf{1 9 3 2}$ & Monanni \\
\hline GV.21 & Jill, the Reckless & 1921 & Jill ragazza bizzarra & $\mathbf{1 9 3 1}$ & Bietti \\
\hline GV.22 & Indiscretions of Archie & 1921 & Arcibaldo conquista l'America & 1931 & Bietti \\
\hline GV.23 & The Girl on the Boat & 1922 & $\begin{array}{l}\text { La ragazza del transatlantico: } \\
\text { romanzo umoristico inglese }\end{array}$ & $\mathbf{1 9 3 2}$ & Monanni \\
\hline
\end{tabular}

\section{Previtali, Oriana}

\begin{tabular}{|l|l|l|l|l|c|}
\hline GV.o6 & Love Among the Chickens & 1906 & Amore fra i polli & 1961 & Rizzoli \\
\hline
\end{tabular}

Rafanelli, Metello Brunone

\begin{tabular}{|l|l|c|l|c|c|}
\hline GV.o9 & A Gentleman of Leisure & 1910 & $\begin{array}{l}\text { Un gentiluomo in ozio: romanzo } \\
\text { umoristico inglese }\end{array}$ & 1932 & Monanni \\
\hline GV.21 & Jill, the Reckless & 1921 & $\begin{array}{l}\text { Giulia la bizzarra: romanzo } \\
\text { umoristico inglese }\end{array}$ & 1932 & Monanni \\
\hline GV.29 & Bill the Conqueror & 1924 & $\begin{array}{l}\text { Bill il conquistatore: romanzo } \\
\text { umoristico inglese }\end{array}$ & 1933 & Bietti \\
\hline
\end{tabular}




\begin{tabular}{|c|l|c|l|c|c|}
\hline GV.31 & Sam the Sudden & 1925 & $\begin{array}{l}\text { Sam il dinamico: romanzo } \\
\text { umoristico inglese }\end{array}$ & 1933 & Bietti \\
\hline GV.37 & Summer Lightning & 1929 & $\begin{array}{l}\text { Lampi d'estate: : romanzo } \\
\text { umoristico inglese }\end{array}$ & 1933 & Monanni \\
\hline GV.42 & Hot Water & 1932 & $\begin{array}{l}\text { Acqua bollente: romanzo } \\
\text { umoristico inglese }\end{array}$ & 1933 & Bietti \\
\hline
\end{tabular}

Roberti, Roberto

\begin{tabular}{|l|l|c|l|c|c|}
\hline GV.41 & Doctor Sally & $193^{2}$ & $\begin{array}{l}\text { Dottor Sally: romanzo } \\
\text { umoristico inglese }\end{array}$ & 1933 & Monanni \\
\hline
\end{tabular}

Sacchi,-Perego Cina

\begin{tabular}{|c|l|c|l|c|c|}
\hline GV.47 & Right Ho, Jeeves & 1934 & $\begin{array}{l}\text { Alla buonora, Jeeves: romanzo } \\
\text { umoristico inglese }\end{array}$ & 1935 & Bietti \\
\hline
\end{tabular}

Salmaggi, Cesare

\begin{tabular}{|l|l|c|l|c|c|}
\hline GV.76 & Service with a Smile & 1962 & Il ratto dell'imperatrice & 1995 & Guanda \\
\hline
\end{tabular}

Salvatorelli, Franco

\begin{tabular}{|l|l|c|l|c|c|}
\hline GV.18 & Piccadilly Jim & 1918 & Piccadilly Jim & 1991 & Mursia \\
\hline GV.30 & Carry On, Jeeves & 1925 & Avanti, Jeeves & 1991 & Mursia \\
\hline GV.61 & Spring Fever & 1948 & Febbre di primavera & 1994 & Mursia \\
\hline
\end{tabular}

Serragli, Nadia

\begin{tabular}{|l|l|c|c|c|c|}
\hline GV.18 & Piccadilly Jim & 1918 & $\begin{array}{l}\text { Jim di Piccadilly:romanzo } \\
\text { umoristico }\end{array}$ & 1989 & Lucarini \\
\hline GV.o5 & The Head of Kay's & 1905 & $\begin{array}{l}\text { Shepley, F. Leon } \\
\text { inglese }\end{array}$ & 1933 & Monanni \\
\hline
\end{tabular}

\begin{tabular}{|l|l|c|l|c|l|}
\hline GV.83 & The Girl in Blue & 1970 & La ragazza in blu & $\mathbf{1 9 7 3}$ & Mondadori \\
\hline GV.84 & Much Obliged, Jeeves & 1971 & Molto obbligato, Jeeves & $\mathbf{1 9 7 2}$ & Mondadori \\
\hline GV.85 & Pearls, Girls and Monty Bodkin & 1972 & I "gioiellI" di Monty Bodkin & $\mathbf{1 9 7 4}$ & Mondadori \\
\hline GV.86 & Bachelors Anonymous & 1973 & Anonima scapoli & $\mathbf{1 9 7 5}$ & Mondadori \\
\hline GV.87 & Aunts Aren't Gentlemen & 1974 & Le zie non sono gentiluomini & $\mathbf{1 9 7 6}$ & Mondadori \\
\hline
\end{tabular}

Spagnol, Luigi

\begin{tabular}{|l|l|c|l|c|c|}
\hline GV.45 & Heavy Weather & 1933 & Aria di tempesta & 1990 & Guanda \\
\hline GV.52 & Lord Emsworth and Others & 1937 & Ondata di crimini a Blandings & 1993 & Guanda \\
\hline
\end{tabular}

Spaventa Filippi, Silvio

\begin{tabular}{|l|l|c|l|c|c|}
\hline GV.o6 & Love Among the Chickens & 1906 & L'amore tra i polli & $\mathbf{1 9 2 9}$ & Monanni \\
\hline GV.30 & Carry On, Jeeves & 1925 & $\begin{array}{l}\text { Avanti, Jeeves! : romanzo } \\
\text { umoristico inglese }\end{array}$ & $\mathbf{1 9 2 8}$ & Monanni \\
\hline
\end{tabular}


Tedeschi, Alberto

\begin{tabular}{|c|l|c|l|c|c|}
\hline GV.33 & Meet Mr Mulliner & 1927 & $\begin{array}{l}\text { Mr Mulliner: romanzo } \\
\text { umoristico inglese }\end{array}$ & 1931 & Monanni \\
\hline GV.36 & Mr Mulliner Speaking & 1929 & $\begin{array}{l}\text { Parla Mr Mulliner: romanzo } \\
\text { umoristico inglese }\end{array}$ & 1931 & Monanni \\
\hline GV.38 & Very Good, Jeeves & 1930 & Benissimo, Jeeves & 193 o & Monanni \\
\hline GV.44 & Mulliner Nights & 1933 & $\begin{array}{l}\text { Le serate di mulliner: romanzo } \\
\text { umoristico inglese }\end{array}$ & 1933 & Bietti \\
\hline GV.51 & Laughing Gas & 1936 & Gas esilarante & 1938 & Mondadori \\
\hline GV.53 & Summer Moonshine & 1938 & Poi tutto s'accomoda: romanzo & 1939 & Mondadori \\
\hline GV.54 & The Code of the Woosters & 1938 & $\begin{array}{l}\text { Jeeves non si smentisce: } \\
\text { romanzo }\end{array}$ & 1939 & Mondadori \\
\hline GV.55 & Uncle Fred in the Springtime & 1939 & Zio Fred in primavera & 1940 & Mondadori \\
\hline
\end{tabular}

Traverso, Aldo

\begin{tabular}{|l|l|c|l|c|c|}
\hline GV.26 & The Inimitable Jeeves & 1923 & L'inimitabile Jeeves & 193 o & Monanni \\
\hline
\end{tabular}

Trimarchi, Anna Chiara

\begin{tabular}{|c|l|c|l|c|c|}
\hline GV.o9 & A Gentleman of Leisure & 1910 & $\begin{array}{l}\text { Un gentiluomo in ozio: romanzo } \\
\text { umoristico inglese }\end{array}$ & 1993 & Mursia \\
\hline GV.10 & Psmith in the City & 1910 & Psmith in banca & 1990 & Mursia \\
\hline GV.14 & Psmith, Journalist & 1915 & Psmith giornalista & 1991 & Mursia \\
\hline
\end{tabular}

Vigano', Giovanni

\begin{tabular}{|l|l|c|l|c|c|}
\hline GV.54 & The Code of the Woosters & 1938 & Il codice dei Wooster & 2005 & Polillo \\
\hline
\end{tabular}

Zanini, A.

\begin{tabular}{|c|l|c|l|c|c|}
\hline GV.34 & The Small Bachelor & 1927 & $\begin{array}{l}\text { Il piccolo scapolo: romanzo } \\
\text { umoristico inglese }\end{array}$ & $193^{2}$ & Monanni \\
\hline GV.39 & If I Were You & 1931 & $\begin{array}{l}\text { Se io fossi voi: romanzo } \\
\text { umoristico inglese }\end{array}$ & 1933 & Bietti \\
\hline
\end{tabular}

Zuffada Locuratolo, Angela

\begin{tabular}{|l|l|c|l|c|c|}
\hline GV.38 & Very Good, Jeeves & 1930 & Benissimo, Jeeves & 1990 & Mursia \\
\hline
\end{tabular}


Appendix $7 \quad$ Selected instances of intertextuality in A Damsel in Distress

\begin{tabular}{|c|c|c|c|c|c|c|c|}
\hline REF & ORIGINAL TEXT & $\begin{array}{l}\text { ORIG. } \\
\text { PAGE }\end{array}$ & $\begin{array}{l}\text { TRAD A } \\
\text { PAGE }\end{array}$ & $\begin{array}{l}\text { TRAD B } \\
\text { PAGE }\end{array}$ & $\begin{array}{l}\text { TRAD C } \\
\text { PAGE }\end{array}$ & $\begin{array}{l}\text { TRAD D } \\
\text { PAGE }\end{array}$ & $\begin{array}{l}\text { TRAD E } \\
\text { PAGE }\end{array}$ \\
\hline 1 & But the voice of calumny is never silent. & 8 & 10 & 6 & 8 & 6 & 12 \\
\hline 2 & Reggie's was a troubled spirit these days. & 15 & 20 & 13 & 15 & 13 & 19 \\
\hline 3 & $\begin{array}{l}\text { And everywhere the uncle went, the chappie } \\
\text { was sure to go! }\end{array}$ & 21 & 27 & 18 & 21 & 18 & 24 \\
\hline 4 & $\begin{array}{l}\text { On the morning after an opening your } \\
\text { sensitive artist is always apt to feel as if he had } \\
\text { been dried over a barrel. }\end{array}$ & 25 & 33 & 22 & 25 & 22 & 28 \\
\hline 5 & $\begin{array}{l}\text { You were up as late as I was, and you look like } \\
\text { Little Eva after a night of sweet, childish } \\
\text { slumber. }\end{array}$ & 27 & 35 & 24 & 27 & 24 & 30 \\
\hline 6 & $\begin{array}{l}\text { If I could find the right man, }[. . .] \text { I'd become } \\
\text { one of the Mendelssohn's March Daughters. }\end{array}$ & 31 & 40 & 28 & 31 & 28 & 34 \\
\hline 7 & We shall meet at Filippi. & 31 & 40 & 28 & 31 & 28 & 34 \\
\hline 8 & $\begin{array}{l}\text { He gazed upon Piccadilly with eyes from the } \\
\text { scales had fallen. }\end{array}$ & 37 & 48 & 33 & 36 & 32 & 39 \\
\hline 9 & $\begin{array}{l}\text { No Vere de Vere could have exhibited greater } \\
\text { response of manner. }\end{array}$ & 38 & $5^{\circ}$ & 35 & 37 & 34 & 41 \\
\hline 10 & $\begin{array}{l}\text { The stout young man, whose peculiar } \\
\text { behaviour had drawn all this flattering } \\
\text { attention from the many-headed }[. . .]\end{array}$ & 41 & 53 & 38 & 40 & 37 & 43 \\
\hline 11 & $\begin{array}{l}\text { A rich, deep, soft, soothing voice slid into the } \\
\text { heated scene like the Holy Grail sliding } \\
\text { athwart a sunbeam. }\end{array}$ & 53 & 68 & 48 & $5^{\circ}$ & 47 & 54 \\
\hline 12 & $\begin{array}{l}\text { Common prudence and the lessons of a } \\
\text { carefully-taught youth fell from him like a } \\
\text { garment. }\end{array}$ & 54 & 69 & 49 & $5^{2}$ & 48 & 55 \\
\hline 13 & $\begin{array}{l}{[\ldots] \text { and poor old Percy walked between with }} \\
\text { gyves upon his wrists. }\end{array}$ & 67 & 85 & 60 & 63 & 59 & 67 \\
\hline 14 & [...] Ben Adhem's name led all the rest. & 69 & 87 & 63 & 66 & 62 & 69 \\
\hline 15 & $\begin{array}{l}{[\ldots] \text { he held the opinion that nothing in }} \\
\text { Percy's life so became him as this assault on } \\
\text { the Force. }\end{array}$ & 71 & 89 & 64 & 68 & 63 & 71 \\
\hline 16 & $\begin{array}{l}\text { From childhood up she had held the } \\
\text { customary feminine views upon the Lie } \\
\text { Direct. }\end{array}$ & 75 & 94 & 68 & 72 & 67 & 74 \\
\hline 17 & $\begin{array}{l}\text { Stone walls do not a prison make nor iron bars } \\
\text { a cage. }\end{array}$ & 78 & 98 & 70 & 75 & 70 & 77 \\
\hline 18 & Love laughs at locksmiths. & 79 & 100 & 71 & 77 & 71 & 78 \\
\hline
\end{tabular}




\begin{tabular}{|c|c|c|c|c|c|c|c|}
\hline 19 & $\begin{array}{l}\text { The glory of Belpher is dead; and over its gates } \\
\text { Ichabod is written. }\end{array}$ & 82 & 103 & 75 & 79 & 74 & 81 \\
\hline 20 & $\begin{array}{l}{[\ldots] \text { till you have finished the Bedouin's Love }} \\
\text { Song. }\end{array}$ & 83 & 105 & 76 & 80 & 75 & 82 \\
\hline 21 & $\begin{array}{l}{[\ldots] \text { and are annoying the local birds, roosting }} \\
\text { the trees, with Poor Butterfly. }\end{array}$ & 83 & 105 & 76 & 80 & 75 & 82 \\
\hline 22 & $\begin{array}{l}\text { On other days of the week all he could do was } \\
\text { to stand like Moses on Pisgah. }\end{array}$ & 84 & 106 & 77 & 81 & 76 & 83 \\
\hline 23 & $\begin{array}{l}\text { His smiling face vanished under the car like } \\
\text { the Cheshire cat. }\end{array}$ & 89 & 113 & 82 & 86 & 81 & 88 \\
\hline 24 & You may fire when ready, Gridley. & 93 & 117 & 85 & 89 & 84 & 91 \\
\hline 25 & $\begin{array}{l}\text { [she] had read about in the Ingloldsby } \\
\text { Legends. }\end{array}$ & 100 & 127 & 92 & 97 & 91 & 98 \\
\hline 26 & $\begin{array}{l}\text { "Wiv' blekest morss the flower-ports/Was-I } \\
\text { mean were-crusted one and orl;/Ther rusted } \\
\text { niles fell from the knorts/That 'eld the pear to } \\
\text { the garden-worll./Ther broken sheds looked } \\
\text { sed and stringe;/Unlifted was the clinking } \\
\text { latch;/Weeded and worn their ancient } \\
\text { thatch/Er-pon ther lownely moated } \\
\text { gringe,/She only said 'Me life is dreary,/'E } \\
\text { cometh not,' she said." Wiv bleckest morss ..." }\end{array}$ & 102 & 129 & 93 & 98 & 92 & 99 \\
\hline 27 & $\begin{array}{l}\text { George found himself unequal to the } \\
\text { intellectual pressure of the conversation. }\end{array}$ & 112 & 140 & 103 & 107 & 101 & 108 \\
\hline 28 & The thoughts of Youth are long, long thought. & 119 & 149 & 109 & 115 & 107 & 115 \\
\hline 29 & $\begin{array}{l}\text { What George was thinking was that the late } \\
\text { King Herod had been unjustly blamed for a } \\
\text { policy which had been both statesmanlike and } \\
\text { in the interests of the public. }\end{array}$ & 119 & 149 & 109 & 112 & 107 & 115 \\
\hline 30 & $\begin{array}{l}{[\ldots] \text { "a galaxy of fair women and brave men" }} \\
{[\ldots]}\end{array}$ & 126 & 156 & 115 & 118 & 113 & 121 \\
\hline 31 & $\begin{array}{l}\text { Alice Faraday was one of those girls whose } \\
\text { dream it is to be a ministering angel to some } \\
\text { chosen man. }\end{array}$ & 130 & 160 & 118 & 122 & 117 & 124 \\
\hline $3^{2}$ & $\begin{array}{l}\text { It is the presence on the globe of these } \\
\text { Plummers that delays the coming of the } \\
\text { Millenium. }\end{array}$ & 135 & 166 & 122 & 125 & 121 & 128 \\
\hline 33 & $\begin{array}{l}\text { He was in the position of captains who must } \\
\text { be last to leave their ships, and of boys who } \\
\text { stand on burning decks whence all but they } \\
\text { had fled. }\end{array}$ & 142 & 174 & 129 & 130 & 127 & 135 \\
\hline 34 & $\begin{array}{l}\text { He was trapped. Groping in Egyptian } \\
\text { darkness, his hands met a coat. }\end{array}$ & 165 & 200 & 149 & $15^{\circ}$ & 147 & $15^{6}$ \\
\hline 35 & $\begin{array}{l}\text { Confronting him was a vast man whose } \\
\text { muscles, like those of that other and more } \\
\text { celebrated village blacksmith, were plainly as } \\
\text { strong as iron bands. }\end{array}$ & 166 & 201 & $15^{\circ}$ & 151 & 148 & 157 \\
\hline
\end{tabular}




\begin{tabular}{|c|c|c|c|c|c|c|c|}
\hline 36 & $\begin{array}{l}\text { Centuries before we were born or thought of } \\
\text { there was a widely press-agented boy in Sparta } \\
\text { who even went so far as to let a fox gnaw his } \\
\text { tender young stomach without permitting the } \\
\text { discomfort inseparable from such a } \\
\text { proceeding to interfere with either his facial } \\
\text { expression or his flow of small talk. }\end{array}$ & 183 & 221 & 165 & 167 & 163 & 172 \\
\hline 37 & $\begin{array}{l}\text { Here, undeniably, we have a man without a } \\
\text { secret sorrow, a man at peace with this best of } \\
\text { all possible worlds. }\end{array}$ & 187 & 225 & 169 & 168 & 167 & 176 \\
\hline 38 & $\begin{array}{l}\text { I seem to be in the position of the tinker in the } \\
\text { play whom everybody conspired to delude } \\
\text { into the believe that he was a king. }\end{array}$ & 199 & 238 & 178 & 178 & 176 & 186 \\
\hline 39 & God this morning was in His heaven. & 207 & 248 & 186 & 185 & 183 & 193 \\
\hline 40 & $\begin{array}{l}{[\ldots] \text { it was he who had been in a Fool's }} \\
\text { Paradise. }\end{array}$ & 207 & 249 & 186 & 185 & 183 & 193 \\
\hline 41 & $\begin{array}{l}\text { Reggie: "...You see in front of you old Colonel } \\
\text { Romeo, the Man who Knows! }\end{array}$ & 211 & $25^{2}$ & 190 & 188 & 187 & 197 \\
\hline 42 & È...] the Yeoman's Wedding Song. & 215 & 255 & 193 & 190 & 190 & 200 \\
\hline 43 & $\begin{array}{l}{[\ldots] \text { the maddest, merriest day of all the glad }} \\
\text { New year and so forth. }\end{array}$ & 217 & 257 & 195 & 192 & 192 & 202 \\
\hline 44 & $\begin{array}{l}{[\ldots] \text { as if you were Noah telling the boys down }} \\
\text { at the corner store about the good times they } \\
\text { all had before the Flood. }\end{array}$ & 228 & 270 & 222 & 203 & 203 & 213 \\
\hline 45 & Boys will be boys. & 231 & 274 & 207 & 206 & 206 & 215 \\
\hline 46 & $\begin{array}{l}\text { The prophet Daniel, after the initial } \\
\text { embarrassment of finding himself in the } \\
\text { society of the lions had passed away, must } \\
\text { have experienced a somewhat similar } \\
\text { sensation. }\end{array}$ & 244 & 289 & 219 & 218 & 217 & 227 \\
\hline 47 & $\begin{array}{l}\text { Shadrach, Meschach and Abednego combined } \\
\text { had never felt a tithe of the warmth that } \\
\text { consumed him. }\end{array}$ & $25^{\circ}$ & 295 & 224 & 224 & 222 & 232 \\
\hline 48 & Plummer $[\ldots]$ was chanting Tosti's "Good-bye". & 255 & 300 & 228 & 229 & 226 & 237 \\
\hline 49 & $\begin{array}{l}\text { The very furniture of Lord Marshmoreton's } \\
\text { study seemed to shrink, seared by the flame of } \\
\text { her wrath ...seared by the flame of [lady } \\
\text { Caroline's] wrath. }\end{array}$ & 262 & 308 & 235 & 236 & 232 & 243 \\
\hline $5^{\circ}$ & All flesh is as grass. & 278 & 325 & 249 & 248 & 247 & 258 \\
\hline
\end{tabular}




\section{Appendix $8 \quad$ Covers}

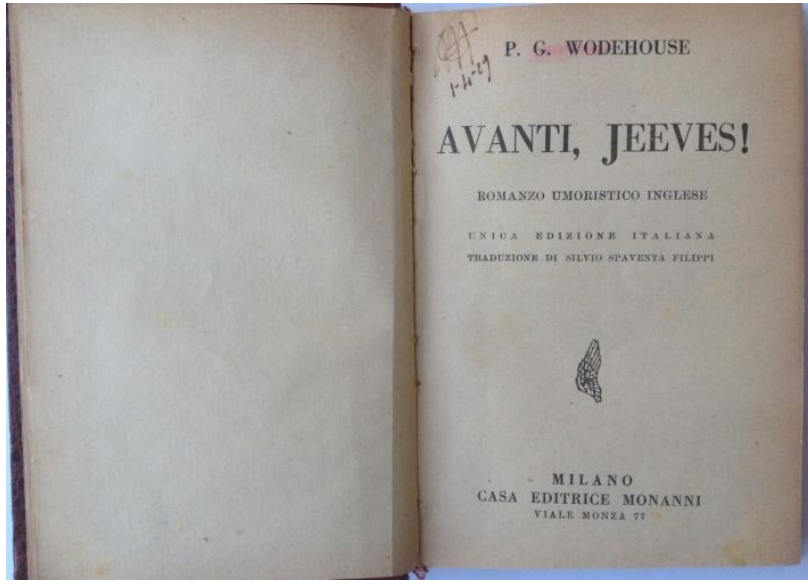

The first Italian translation

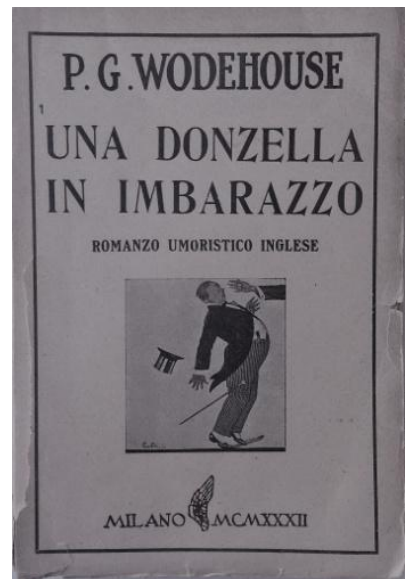

Monanni's first edition of $A$ Damsel in Distress
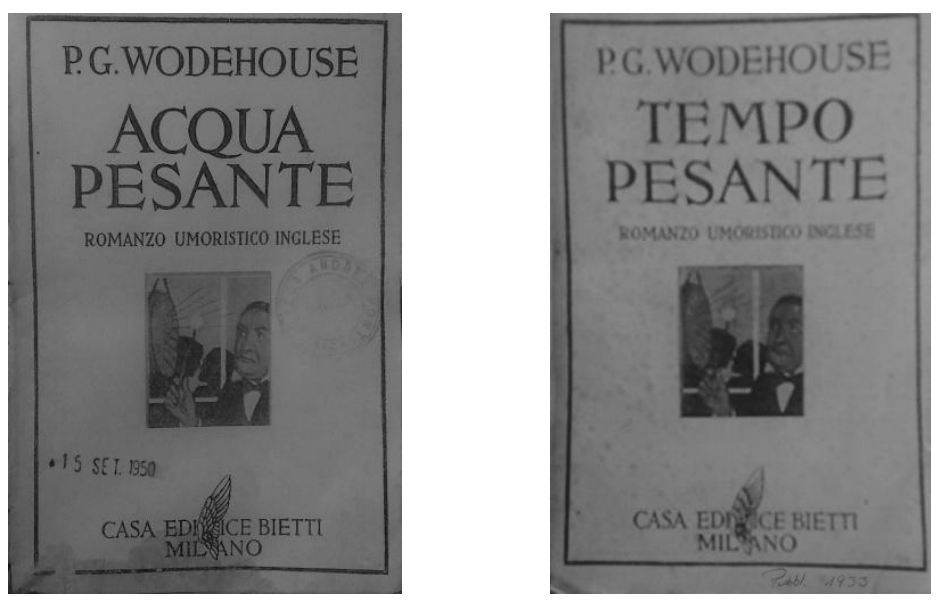

Bietti's two 1933 editions of Heavy Weather
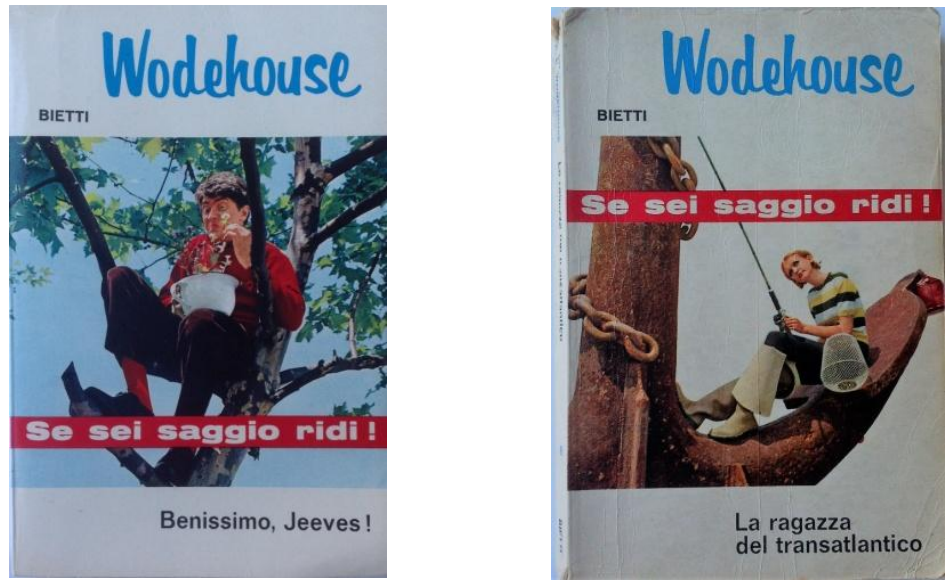

Two of Bietti's titles in the "Il picchio" series

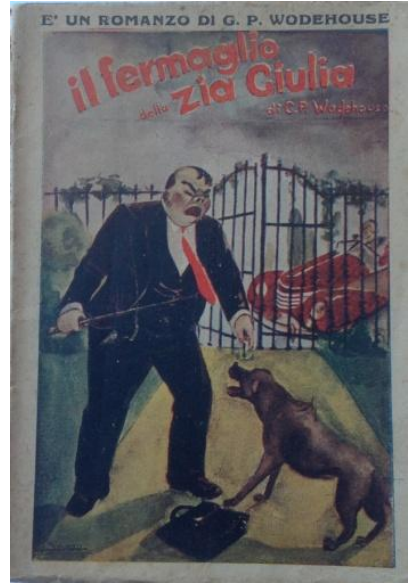

Wodehouse's name mispelt

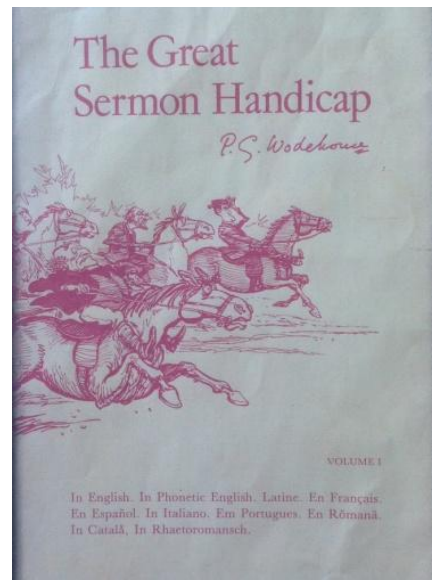

Cover of the first volume of Heineman's 1989 multi-lingual edition of "The Great Sermon Handicap" 


\section{BIBLIOGRAPHY}

\section{Primary literature: source texts}

Wodehouse, P.G. (2008). A Damsel in Distress. London: Arrow Books

Wodehouse, P.G. (2009). A Few Quick Ones. London: Everyman's Library

Wodehouse, P.G. (1991). A Gentleman of Leisure. London: Penguin Books

Wodehouse, P.G. (2008). A Pelican at Blandings. London: Arrow Books

Wodehouse, P.G. (1903). A Prefect's Uncle. https://www.gutenberg.org/ebooks/6985

Wodehouse, P.G. (1993). Aunts Aren't Gentlemen. In The Jeeves Omnibus 5 (pp. 157-288). London: Hutchinson

Wodehouse, P.G. (2012). Bachelors Anonymous. London: Everyman's Library

Wodehouse, P.G. (1968). Barmy in Wonderland. London: Pan Books

Wodehouse, P.G. (2008). Big Money. London: Arrow Books

Wodehouse, P.G. (2008). Bill the Conqueror. London: Everyman's Library

Wodehouse, P.G. (2008). Blandings Castle and Elsewhere. London: Arrow Books

Wodehouse, P.G. (1990). Carry On, Jeeves. In The Jeeves Omnibus 2 (pp. 421-6o7). London: Hutchinson

Wodehouse, P.G. (2008). Cocktail Time. London: Arrow Books

Wodehouse, P.G. (1980). Company for Henry. Harmondsworth: Penguin Books

Wodehouse, P.G. (1979). Do Butlers Burgle Banks? Harmondsworth: Penguin Books

Wodehouse, P.G. (2008). Doctor Sally. London: Arrow Books

Wodehouse, P.G. (1999). Eggs, Beans and Crumpets. London: Penguin Books

Wodehouse, P.G. (1992). French Leave. London: Penguin Books

Wodehouse, P.G. (1993). Frozen Assets. London: Vintage

Wodehouse, P.G. (2008). Full Moon, London: Arrow Books

Wodehouse, P.G. (1973). Galahad at Blandings. London: Penguin Books

Wodehouse, P.G. (2001), Heavy Weather, London: Everyman's Library

Wodehouse, P.G. (2008). Hot Water. London: Arrow Books

Wodehouse, P.G. (2011). Ice in the Bedroom. London: Arrow Books

Wodehouse, P.G. (1991). If I Were You. London: Penguin Books

Wodehouse, P.G. (1921). Indiscretions of Archie. https://www.gutenberg.org/ebooks/3756 
Wodehouse, P.G. (1992). Jeeves and the Feudal Spirit. In The Jeeves Omnibus 4 (pp. 7-171). London: Hutchinson

Wodehouse, P.G. (1992). Jeeves in the Offing. In The Jeeves Omnibus 4 (pp. 171-310). London: Hutchinson Wodehouse, P.G. (1921).Jill, the Reckless. https://www.gutenberg.org/ebooks/20533

Wodehouse, P.G. (1990). Joy in the Morning. In The Jeeves Omnibus 2. (pp. 211-420). London: Hutchinson Wodehouse, P.G. (1987). Laughing Gas. London: Penguin Books

Wodehouse, P.G. (2008). Leave it to Psmith. London: Arrow Books

Wodehouse, P.G. (1966). Lord Emsworth and Others. London: Penguin Books

Wodehouse, P.G. (2008). Louder and Funnier. London: Arrow Books

Wodehouse, P.G. (1906). Love Among the Chickens. https://www.gutenberg.org/ebooks/3829

Wodehouse, P.G. (2008). Meet Mr Mulliner. London: Arrow Books

Wodehouse, P.G. (1909). Mike. https://www.gutenberg.org/ebooks/7423

Wodehouse, P.G. (2008). Money for Nothing. London: Arrow Books

Wodehouse, P.G. (1964). Money in the Bank. London: Penguin Books

Wodehouse, P.G. (2008). Mr Mulliner Speaking. London: Arrow Books

Wodehouse, P.G. (1993). Much Obliged, Jeeves. In The Jeeves Omnibus 5 (pp. 7-156). London: Hutchinson

Wodehouse, P.G. (2008). Mulliner Nights. London: Arrow Books

Wodehouse, P.G. (2008). Nothing Serious. London: Everyman's Library

Wodehouse, P.G. (1974). Pearls, Girls and Monty Bodkin. Harmondsworth: Penguin Books

Wodehouse, P.G. (1918). Piccadilly Jim. https://www.gutenberg.org/ebooks/2005

Wodehouse, P.G. (2008). Pigs Have Wings. London: Arrow Books

Wodehouse, P.G. (1910). Psmith in the City. https://www.gutenberg.org/ebooks/23899

Wodehouse, P.G. (1915). Psmith, Journalist. https://www.gutenberg.org/ebooks/26o7

Wodehouse, P.G. (1987). Quick Service. Harmondsworth: Penguin Books

Wodehouse, P.G. (2008). Right Ho, Jeeves. London: Arrow Books

Wodehouse, P.G. (1991). Ring for Jeeves. In The Jeeves Omnibus 3 (pp. 7-174). London: Hutchinson

Wodehouse, P.G. (1982). Sam the Sudden. Harmondsworth: Penguin Books

Wodehouse, P.G. (2008). Service with a Smile. London: Arrow Books

Wodehouse, P.G. (2008). Something Fishy. London: Everyman's Library

Wodehouse, P.G. (2008). Something Fresh. London: Arrow Books

Wodehouse, P.G. (1969). Spring Fever. Harmondsworth: Penguin Books

Wodehouse, P.G. (1992). Stiff Upper Lip, Jeeves. In The Jeeves Omnibus 4 (pp. 311-459). London: Hutchinson 
Wodehouse, P.G. (2008). Summer Lightning. London: Arrow Books

Wodehouse, P.G. (2003). Summer Moonshine. London: Everyman's Library

Wodehouse, P.G. (1903). Tales of St Austin's. https://www.gutenberg.org/ebooks/6980

Wodehouse, P.G. (1989). Thank You, Jeeves. In The Jeeves Omnibus 1 (pp. 1-192). London: Hutchinson

Wodehouse, P.G. (1922). The Adventures of Sally. https://www.gutenberg.org/ebooks/7464

Wodehouse, P.G. (2008). The Clicking of Cuthbert. London: Arrow Books

Wodehouse, P.G. (1989). The Code of the Woosters. In The Jeeves Omnibus 1 (pp. 193-40o). London:

Hutchinson

Wodehouse, P.G. (1920). The Coming of Bill. https://www.gutenberg.org/ebooks/688o

Wodehouse, P.G. (2008). The Girl in Blue. London: Arrow Books

Wodehouse, P.G. (1922). The Girl on the Boat. https://www.gutenberg.org/ebooks/20717

Wodehouse, P.G. (1904). The Gold Bat. https://www.gutenberg.org/ebooks/6879

Wodehouse, P.G. (1905). The Head of Kay's. https://www.gutenberg.org/ebooks/6877

Wodehouse, P.G. (2008). The Heart of a Goof. London: Arrow Books

Wodehouse, P.G. (1989). The Inimitable Jeeves. In The Jeeves Omnibus 1 (pp. 401-581). London:

Hutchinson

Wodehouse, P.G. (1913). The Little Nugget. https://www.gutenberg.org/ebooks/6683

Wodehouse, P.G. (2008). The Luck of the Bodkins. London: Arrow Books

Wodehouse, P.G. (1914). The Man Upstairs and Other Stories. https://www.gutenberg.org/ebooks/7471

Wodehouse, P.G. (1917). The Man With Two Left Feet. https://www.gutenberg.org/ebooks/7471

Wodehouse, P.G. (1991). The Mating Season. In The Jeeves Omnibus 3 (pp. 175-368). London: Hutchinson

Wodehouse, P.G. (2011). The Old Reliable. London: Everyman's Library

Wodehouse, P.G. (1902). The Pothunters. https://www.gutenberg.org/ebooks/6984

Wodehouse, P.G. (1912). The Prince and Betty. https://www.gutenberg.org/ebooks/6955

Wodehouse, P.G. (2008). The Small Bachelor. London: Arrow Books

Wodehouse, P.G. (1907). The White Feather. https://www.gutenberg.org/ebooks/6927

Wodehouse, P.G. (2008). Ukridge. London: Arrow Books

Wodehouse, P.G. (2006). Uncle Dynamite. London: Everyman's Library

Wodehouse, P.G. (2008). Uncle Fred in the Springtime. London: Arrow Books

Wodehouse, P.G. (1917). Uneasy Money. https://www.gutenberg.org/ebooks/6684

Wodehouse, P.G. (1991). Very Good, Jeeves. In The Jeeves Omnibus 3 (pp. 369-574). London: Hutchinson

Wodehouse, P.G. (2009). Young Men in Spats. London: Arrow Books 


\section{Primary literature: target texts}

Wodehouse, P.G. (1933). Acqua bollente: romanzo umoristico inglese. Tr. Metello Brunone Rafanelli. Milano: Bietti.

Wodehouse, P.G. (1933). Acqua pesante: romanzo umoristico inglese. Tr. Zoe Lampronti. Milano: Bietti. Wodehouse, P.G. (1966). Alla buon'ora, Jeeves: romanzo umoristico inglese. Tr. Cina Sacchi-Perego. Milano: Bietti.

Wodehouse, P.G. (1961). Amore fra i polli. Tr. Oriana Previtali. Milano: Rizzoli

Wodehouse, P.G. (1932). Amore tra i polli: romanzo. Tr. Francesco Palumbo. Milano: Bietti.

Wodehouse, P.G. (1975). Anonima scapoli. Tr. Elena Spagnol. Milano: Mondadori.

Wodehouse, P.G. (1931). Arcibaldo conquista l'America. Tr. Alfredo Pitta. Milano: Novissima.

Wodehouse, P.G. (1990). Aria di tempesta. Tr. Luigi Spagnol. Milano: Guanda.

Wodehouse, P.G. (1991). Avanti, Jeeves. Tr. Franco Salvatorelli. Milano: Mursia.

Wodehouse, P.G. (2011). Avanti, Jeeves. Tr. Tracy Lord. Milano: Polillo.

Wodehouse, P.G. (1928). Avanti, Jeeves! : romanzo umoristico inglese. Tr. Silvio Spaventa Filippi. Milano: Monanni.

Wodehouse, P.G. (1932). Battaglie sportive. Tr. Lina Baraldi. Milano: Bietti.

Wodehouse, P.G. (1997). Beni congelati. Tr. Monica Morzenti. Milano: Mursia.

Wodehouse, P.G. (1964). Benissimo, Jeeves. Tr. Alberto Tedeschi. Milano: Bietti.

Wodehouse, P.G. (1990). Benissimo, Jeeves. Tr. Angela Zuffada Locuratolo. Milano: Mursia.

Wodehouse, P.G. (1993). Bill il conquistatore. Tr. Luigi Brioschi. Milano: Mursia.

Wodehouse, P.G. (1933). Bill il conquistatore: romanzo umoristico inglese. Tr. Metello Brunone Rafanelli. Milano: Bietti.

Wodehouse, P.G. (1988). Chiamate Jeeves. Tr. Rosetta Palazzi. Milano: Mursia.

Wodehouse, P.G. (1954). Chiamate Jeeves: romanzo. Tr. Adriana Motti. Milano: Elmo.

Wodehouse, P.G. (1998). Cocktail time. Tr. Fulvio Bernardinis. Milano: Mursia.

Wodehouse, P.G. (1966). Danaro incomodo: romanzo. Tr. Francesco Palumbo. Milano: Bietti.

Wodehouse, P.G. (1992). Denaro difficile. Tr. Teobaldo del Tanaro. Milano: Mursia.

Wodehouse, P.G. (1932). Denaro difficile: romanzo umoristico inglese. Tr. Maria Carlesimo. Milano:

Monanni.

Wodehouse, P.G. (1966). Danaro trovato: romanzo umoristico inglese. Tr. Mario Benzi. Milano: Bietti.

Wodehouse, P.G. (1952). Diario segreto. Tr. Adriana Motti. Milano: Elmo.

Wodehouse, P.G. (1933). Dottor Sally: romanzo umoristico inglese. Tr. Roberto Roberti. Milano: Monanni. Wodehouse, P.G. (1956). E chi s'è visto s'è visto. Tr. Adriana Motti. Milano: Elmo.

Wodehouse, P.G. (1997). E' tutto denaro sprecato. Tr. Rosetta Palazzi. Milano: Mursia. 
Wodehouse, P.G. (1952). Febbre di primavera. Tr. Luciano Lattanzi. Milano: Elmo.

Wodehouse, P.G. (1994). Febbre di primavera. Tr. Franco Salvatorelli. Milano: Mursia.

Wodehouse, P.G. (1955). Gas esilarante. Tr. Alberto Tedeschi. Milano: Mondadori.

Wodehouse, P.G. (1966). Genero alverde. Tr. Sario Agnati. Milano: Elmo.

Wodehouse, P.G. (1962). Ghiaccio in una stanza da letto. Tr. Sario Agnati. Milano: Elmo.

Wodehouse, P.G. (1936). Giovanotti con le ghette: romanzo umoristico inglese. Tr. Zoe Lampronti. Milano: Bietti.

Wodehouse, P.G. (1932). Giulia la bizzarra: romanzo umoristico inglese. Tr. Metello Brunone Rafanelli. Milano: Monanni.

Wodehouse, P.G. (1984). Grazie, Jeeves. Tr. Pia Janin. Milano: Rizzoli

Wodehouse, P.G. (2005). Grazie, Jeeves. Tr. Tracy Lord. Milano: Polillo.

Wodehouse, P.G. (1934). Grazie, Jeeves: romanzo umoristico inglese. Tr. Giulia Brugiotti. Milano: Bietti.

Wodehouse, P.G. (1953). Grullo nel paese delle meraviglie. Tr. Adriana Motti. Milano: Elmo.

Wodehouse, P.G. (1974). I "gioielli" di Monty Bodkin. Tr. Elena Spagnol. Milano: Mondadori.

Wodehouse, P.G. (1932). I conquistatori di coppe: romanzo. Tr. Mario Benzi. Milano: Bietti.

Wodehouse, P.G. (1977). Imaggiordomi rapinano le banche? Tr. Adriana Motti. Milano: Mondadori.

Wodehouse, P.G. (1992). Imaggiordomi svaligiano le banche? Tr. Sandra Campagna Ponzetto. Milano: Mursia.

Wodehouse, P.G. (1953). I porci hanno le ali. Tr. Adriana Motti. Milano: Elmo.

Wodehouse, P.G. (1970). I signori sono serviti. Tr. Adriano Motti (sic) Milano: Elmo.

Wodehouse, P.G. (1933). Il capo del Kay: romanzo sportivo inglese. Tr. Leon F. Shepley. Milano: Monanni.

Wodehouse, P.G. (1932). Il capo della Kay: romanzo. Tr. Francesco Palumbo. Milano: Bietti.

Wodehouse, P.G. (1936). Il castello di Blandings. Tr. Giulia Brugiotti. Milano: Bietti.

Wodehouse, P.G. (1966). Il castello di Blandings. Tr. Luigi Brioschi. Milano: Bietti.

Wodehouse, P.G. (1962). Il club dei nati stanchi. Tr. Sario Agnati. Milano: Elmo.

Wodehouse, P.G. (1989). Il codice dei Wooster. Tr. Mary Buckwell Gilson. Milano: Mursia.

Wodehouse, P.G. (2005). Il codice dei Wooster. Tr. Giovanni Viganò. Milano: Polillo.

Wodehouse, P.G. (1990). Il colpo di Cuthbert e altri racconti. Tr. Mary Buckwell Gilson. Milano: Mursia.

Wodehouse, P.G. (1973). Il colpo di Cuthbert: romanzo umoristico inglese. Tr. Mario Malatesta.

Milano: Bietti.

Wodehouse, P.G. (1931). Il cuore di un coniglio. Tr. Mario Malatesta. Milano: Monanni.

Wodehouse, P.G. (1992). Il cuore di un paranoico. Tr. Rosetta Palazzi. Milano: Mursia.

Wodehouse, P.G. (1940). Il filone d'oro: romanzo umoristico. Tr. Gian Dàuli. Milano: Lucchi.

Wodehouse, P.G. (1939). Il gentiluomo spensierato: un giallo umoristico. Tr. Gian Dàuli. Milano: Lucchi.

Wodehouse, P.G. (2013). Il mistero dei cappelli. Tr. Silvia Pieraccini. Milano: Guanda. 
Wodehouse, P.G. (1970). Il pellicano a Blandings. Tr. Caterina Longanesi. Milano: Mondadori.

Wodehouse, P.G. (1932). Il piccolo scapolo: romanzo umoristico inglese. Tr. A. Zanini. Milano: Monanni.

Wodehouse, P.G. (1996). Il piccolo scapolo: romanzo umoristico inglese. Tr. Monica Morzenti. Milano: Mursia.

Wodehouse, P.G. (1990). Il principe e Betty. Tr. Giulia Castelli. Milano: Mursia.

Wodehouse, P.G. (1932). Il principe e Betty: romanzo. Tr. Francesco Palumbo. Milano: Bietti.

Wodehouse, P.G. (1932). Il principe e Betty: romanzo umoristico inglese. Tr. Maria Martone. Milano:

Monanni.

Wodehouse, P.G. (1995). Il ratto dell'imperatrice. Tr. Cesare Salmaggi. Milano: Guanda.

Wodehouse, P.G. (1955). Il signor Mulliner racconta. Tr. Mary Buckwell Gilson. Milano: Mursia.

Wodehouse, P.G. (1977). In compagnia di Henry. Tr. Adriana Motti. Milano: Mondadori.

Wodehouse, P.G. (1966). Indiscrezioni di Arcibaldo. Tr. Francesco Palumbo. Milano: Bietti.

Wodehouse, P.G. (1988). Jeeves e la cavalleria. Tr. Mary Buckwell Gislon. Milano: Mursia.

Wodehouse, P.G. (1939).Jeeves non si smentisce: romanzo. Tr. Alberto Tedeschi. Milano: Mondadori.

Wodehouse, P.G. (1989).Jeeves sta alla larga. Tr. Rosetta Palazzi. Milano: Mursia.

Wodehouse, P.G. (1962). Jeeves taglia la corda. Tr. Adriana Motti. Milano: Elmo.

Wodehouse, P.G. (2007).Jeeves taglia la corda. Tr. Tracy Lord. Milano: Polillo.

Wodehouse, P.G. (1931).Jill ragazza bizzarra. Tr. Alfredo Pitta. Milano: Bietti.

Wodehouse, P.G. (1966).Jill ragazza bizzarra. Tr. Corrado Ferri. Milano: Bietti.

Wodehouse, P.G. (1991). Jill ragazza bizzarra. Tr. Mario Bodoman. Milano: Mursia.

Wodehouse, P.G. (1931).Jim di Piccadilly:romanzo umoristico. Tr. Ida Lori. Milano: Bietti.

Wodehouse, P.G. (1989). Jim di Piccadilly:romanzo umoristico. Tr. Nadia Serragli. Milano: Lucarini.

Wodehouse, P.G. (1931).Jim di Piccadilly: romanzo umoristico inglese. Tr. Mario Malatesta.

Milano: Monanni.

Wodehouse, P.G. (1935).Jimmy all'opra. Tr. Alfredo Bianchini. Milano: S.A.C.S.E.

Wodehouse, P.G. (1990). La dottoressa Sally. Tr. Mario Bodoman. Milano: Mursia.

Wodehouse, P.G. (1973). La fortuna dei Bodkin: romanzo umoristico inglese. Tr. Zoe Lampronti.

Milano: Bietti.

Wodehouse, P.G. (1948). La gioia e' col mattino. Tr. Giorgio Monicelli. Milano: Elmo.

Wodehouse, P.G. (2012). La piccola pepita. Tr. Giulia Castelli. Milano: Mursia.

Wodehouse, P.G. (1932). La piccola pepita: romanzo. Tr. Alfredo Pitta. Milano: Bietti.

Wodehouse, P.G. (1964). La ragazza del transatlantico: romanzo umoristico inglese. Tr. Alfredo Pitta. Milano: Bietti.

Wodehouse, P.G. (1973). La ragazza in blu. Tr. Elena Spagnol. Milano: Mondadori.

Wodehouse, P.G. (1990). La stagione degli amori. Tr. Sandra Campagna Ponzetto. Milano: Mursia. 
Wodehouse, P.G. (2006). La stagione degli amori. Tr. Tracy Lord. Milano: Polillo.

Wodehouse, P.G. (1966). La venuta di Bill: romanzo umoristico. Tr. Teresa Casale-Rossi. Milano: Bietti.

Wodehouse, P.G. (1932). La venuta di Bill: romanzo umoristico inglese. Tr. Alfredo Pitta. Milano: Monanni.

Wodehouse, P.G. (1990). L'amore fra i polli. Tr. Mario Bodoman. Milano: Mursia.

Wodehouse, P.G. (1929). L'amore tra i polli. Tr. Silvio Spaventa Filippi. Milano: Monanni.

Wodehouse, P.G. (1938). L'amore tra i polli. Tr. Dienne Carter. Milano: Aurora

Wodehouse, P.G. (1989). Lampi d'estate. Tr. Carlo Brera. Milano: Guanda.

Wodehouse, P.G. (1933). Lampi d'estate: : romanzo umoristico inglese. Tr. Metello Brunone Rafanelli. Milano: Monanni.

Wodehouse, P.G. (1933). Lasciate fare a Psmith: romanzo umoristico inglese. Tr. Mario Gilli. Milano: Monanni.

Wodehouse, P.G. (1995). Le avventure di Sally: romanzo umoristico inglese. Tr. Rosetta Palazzi. Milano: Mursia.

Wodehouse, P.G. (1931). Le avventure di Sally:romanzo umoristico inglese. Tr. Maria Martone. Milano: Monanni.

Wodehouse, P.G. (1990). Le gesta di Psmith. Tr. Stefania Bertola. Milano: Guanda.

Wodehouse, P.G. (1993). Le imprudenze di Archie. Tr. Sandro Melani. Milano: Mursia.

Wodehouse, P.G. (1933). Le serate di mulliner: romanzo umoristico inglese. Tr. Alberto Tedeschi. Milano: Bietti.

Wodehouse, P.G. (1985). Le sere di Mulliner. Tr. Luigi Brioschi. Milano: Rizzoli

Wodehouse, P.G. (1976). Le zie non sono gentiluomini. Tr. Elena Spagnol. Milano: Mondadori.

Wodehouse, P.G. (2009). Le zie non sono gentiluomini. Tr. Tracy Lord. Milano: Polillo.

Wodehouse, P.G. (1964). Lei e' unico, Jeeves. Tr. Sario Agnati. Milano: Elmo.

Wodehouse, P.G. (1965). L'eredita' sotto chiave. Tr. Sario Agnati. Milano: Elmo.

Wodehouse, P.G. (1960). L'inimitabile Jeeves. Tr. Aldo Traverso. Milano: Bietti.

Wodehouse, P.G. (2016). L'inimitabile Jeeves. Tr. Leslie Calise. Milano: Polillo.

Wodehouse, P.G. (1932). Lo zio del prefetto: romanzo Tr. Francesco Palumbo. Milano: Bietti.

Wodehouse, P.G. (1949). Lo zio dinamite. Tr. Adriana Motti. Milano: Elmo.

Wodehouse, P.G. (1940). Lord Emsworth ed altri personaggi. Tr. Giulia Brugiotti. Milano: Bietti.

Wodehouse, P.G. (1954). Luna piena. Tr. Vittoria Comucci. Milano: Mondadori.

Wodehouse, P.G. (1991). Luna piena. Tr. Stefania Bertola. Milano: Guanda.

Wodehouse, P.G. (2010). L'uomo che smise difumare. Tr. Silvia Pieraccini. Milano: Guanda.

Wodehouse, P.G. (1958). L'uomo con due piedi sinistri. Tr. G. V. Pisano. Milano: Bietti.

Wodehouse, P.G. (1991). L'uomo con due piedi sinistri. Tr. Teobaldo del Tanaro. Milano: Mursia. 
Wodehouse, P.G. (1932). L'uomo del piano di sopra. Tr. Francesco Palumbo. Milano: Bietti.

Wodehouse, P.G. (1992). L'uomo del piano di sopra e altri racconti. Tr. Teobaldo del Tanaro. Milano: Mursia.

Wodehouse, P.G. (1933). L'uomo del piano di sopra: racconti umoristici inglesi. Tr. Maria Martone. Milano: Monanni.

Wodehouse, P.G. (1992). Mike. Tr. Giulia Castelli. Milano: Mursia.

Wodehouse, P.G. (1932). Mike: storia di un collegio: romanzo. Tr. Mario Benzi. Milano: Bietti.

Wodehouse, P.G. (1960). Mister I ci sa fare. Tr. Adriana Motti. Milano: Elmo.

Wodehouse, P.G. (2012). Molto bene, Jeeves. Tr. Tracy Lord. Milano: Polillo.

Wodehouse, P.G. (1972). Molto obbligato, Jeeves. Tr. Elena Spagnol. Milano: Mondadori.

Wodehouse, P.G. (1989). Molto obbligato, Jeeves. Tr. Mary Buckwell Gilson. Milano: Mursia.

Wodehouse, P.G. (2008). Molto obbligato, Jeeves. Tr. Tracy Lord. Milano: Polillo.

Wodehouse, P.G. (1931). Mr Mulliner: romanzo umoristico inglese. Tr. Alberto Tedeschi. Milano:

Monanni.

Wodehouse, P.G. (1965). Non c'è da preoccuparsi. Tr. Sario Agnati. Milano: Elmo.

Wodehouse, P.G. (1993). Ondata di crimini a Blandings. Tr. Luigi Spagnol. Milano: Guanda.

Wodehouse, P.G. (1966). Parla Mr Mulliner: romanzo umoristico inglese. Tr. Alberto Tedeschi.

Milano: Bietti.

Wodehouse, P.G. (1985). Perfetto, Jeeves. Tr. Maria Buitoni Duca. Milano: Rizzoli.

Wodehouse, P.G. (1991). Piccadilly Jim. Tr. Franco Salvatorelli. Milano: Mursia.

Wodehouse, P.G. (2005). Piccadilly Jim. Tr. Paola Mazzarelli. Milano: Guanda.

Wodehouse, P.G. (1932). Pipita d'oro: romanzo umoristico inglese. Tr. Mario Malatesta. Milano: Monanni.

Wodehouse, P.G. (1934). Più forte e più allegro: saggi umoristici. Tr. Zoe Lampronti. Milano: Bietti.

Wodehouse, P.G. (1955). Poi tutto s'accomoda: romanzo. Tr. Alberto Tedeschi. Milano: Mondadori.

Wodehouse, P.G. (1992). Presto e bene. Tr. Monica Morzenti. Milano: Mursia.

Wodehouse, P.G. (1991). Psmith giornalista. Tr. Anna Chiara Trimarchi. Milano: Mursia.

Wodehouse, P.G. (1932). Psmith giornalista: romanzo. Tr. Alfredo Pitta. Milano: Bietti.

Wodehouse, P.G. (1940). Psmith giornalista: romanzo umoristico. Tr. Gian Dàuli. Milano: Lucchi.

Wodehouse, P.G. (1990). Psmith in banca. Tr. Anna Chiara Trimarchi. Milano: Mursia.

Wodehouse, P.G. (1934). Psmith in banca: romanzo umoristico inglese. Tr. Alfredo Pitta. Milano: Bietti.

Wodehouse, P.G. (1932). Qualche cosa di nuovo: romanzo umoristico. Tr. L. Fratta. Milano: Bietti.

Wodehouse, P.G. (1932). Qualche cosa di nuovo: romanzo umoristico inglese. Tr. Lepido Bernardini.

Milano: Monanni.

Wodehouse, P.G. (1958). Qualcosa di losco. Tr. Adriana Motti. Milano: Elmo.

Wodehouse, P.G. (1966). Qualcosa di nuovo. Tr. Unknown. Milano: Bietti. 
Wodehouse, P.G. (1997). Quattrini a palate. Tr. Mary Buckwell Gilson. Milano: Mursia.

Wodehouse, P.G. (1962). Quattrini a palate: romanzo umoristico inglese. Tr. Mario Benzi. Milano: Bietti.

Wodehouse, P.G. (1964). Quattrini in banca: romanzo. Tr. Sirio Agnati. Milano: Mondadori.

Wodehouse, P.G. (1932). Racconti di sant'Agostino. Tr. Ida Lori. Milano: Bietti.

Wodehouse, P.G. (1933). Sam il dinamico: romanzo umoristico inglese. Tr. Metello Brunone Rafanelli. Milano: Bietti.

Wodehouse, P.G. (1964). Se io fossivoi: romanzo umoristico inglese. Tr. A. Zanini. Milano: Bietti.

Wodehouse, P.G. (1951). Servizio espresso. Tr. Adriana Motti. Milano: Elmo.

Wodehouse, P.G. (1950). Sotto le fresche frasche. Tr. Adriana Motti. Milano: Elmo.

Wodehouse, P.G. (1961). Storie spicciole. Tr. Sario Agnati. Milano: Elmo.

Wodehouse, P.G. (2006). Tanto di cappello a Jeeves. Tr. Tracy Lord. Milano: Polillo.

Wodehouse, P.G. (1948). Tempo pesante: romanzo umoristico inglese. Tr. Zoe Lampronti. Milano: Bietti.

Wodehouse, P.G. (1990). Teniamo duro, Jeeves. Tr. Rosetta Palazzi. Milano: Mursia.

Wodehouse, P.G. (2007). Teniamo duro, Jeeves. Tr. Tracy Lord. Milano: Polillo.

Wodehouse, P.G. (1993). Tizio, Caio e Sempronio. Tr. Sandro Melani. Milano: Mursia.

Wodehouse, P.G. (1931). Ukridge Romanzo umoristico inglese. Tr. Maria Martone. Milano: Monanni.

Wodehouse, P.G. (1935). Un capriccio e poi... Tr. Alfredo Bianchini. Milano: S.A.C.S.E.

Wodehouse, P.G. (1931). Un gentiluomo in ozio: romanzo umoristico inglese. Tr. Ida Lori. Milano: Bietti.

Wodehouse, P.G. (1932). Un gentiluomo in ozio: romanzo umoristico inglese. Tr. Metello Brunone Rafanelli. Milano: Monanni.

Wodehouse, P.G. (1993). Un gentiluomo in ozio: romanzo umoristico inglese. Tr. Anna Chiara Trimarchi. Milano: Mursia.

Wodehouse, P.G. (2007). Un grosso affare. Tr. Dolores Musso. Milano: Guanda.

Wodehouse, P.G. (1997). Un intrigo a Blandings. Tr. Riccardo Mainardi. Milano: Guanda.

Wodehouse, P.G. (1990). Un mattino di gioia. Tr. Sandra Campagna Ponzetto. Milano: Mursia.

Wodehouse, P.G. (2006). Un mattino di gioia. Tr. Tracy Lord. Milano: Polillo.

Wodehouse, P.G. (1994). Una damigella in pericolo. Tr. Rosetta Palazzi. Milano: Mursia.

Wodehouse, P.G. (1931). Una donzella in imbarazzo:romanzo umoristico inglese. Tr. Francesco Palumbo. Milano: Monanni.

Wodehouse, P.G. (1939). Una magnifica avventura: romanzo umoristico. Tr. Gian Dàuli. Milano: Lucchi. Wodehouse, P.G. (1932). Una penna di coda: romanzo. Tr. Mario Benzi. Milano: Bietti.

Wodehouse, P.G. (1931). Una signorina in imbarazzo: romanzo umoristico inglese. Tr. Ariberto Mozzati. Milano: Bietti.

Wodehouse, P.G. (1964). Zio Fred in primavera. Tr. Alberto Tedeschi. Milano: Mondadori. 


\section{Secondary sources}

Almansi, G. (1986). La ragion comica. Milano: Feltrinelli.

Anderson R. \& Pearson P. (1984). A schemata theoretic view of basic processes on reading comprehension. In P. Pearson (Ed.) Handbook of Reading Research. London: Longman.

Andriano, J. (1993). Our ladies of darkness : Feminine daemonology in male gothic fiction. Pennsylvania, PA: Pennsylvania State University Press.

Apte, M. L. (1985). Humor and laughter: An anthropological approach. Ithaca, NY: Cornel University Press.

Argentieri, M- (2003). CENSURA Enciclopedia del Cinema (2003) di Mino Argentieri, Giuliana Muscio. Retrieved from http://www.treccani.it/enciclopedia/censura_(Enciclopedia-del-Cinema)/

Arnold, M. (1869/2015). Culture and anarchy. Munich: BookRix.

Asimov, I. (1981). In J. Heineman \& D. Bensen (Eds.), P.G. Wodehouse, a centenary celebration, 1881-1981. New York, NY: Pierpont Morgan Library.

Assis Rosa A. (2010). In Y. Gambier \& L. van Doorslaer (Eds.), Handbook of translation studies (Vol. 2). Amsterdam: John Benjamins Publishing Company.

Attardo, S. (1994). Linguistic theories of humor. The Hague: Mouton de Gruyter.

Attardo, S. (1997). The semantic foundations of cognitive theories of humor. Humor: International Journal of Humor Research, 10 (4), 395-420.

Attardo, S. (2001). Humorous texts : a semantic and pragmatic analysis. Humor Research, (6), xiv, 238.

Attardo S. (2002). In J.Vandaele (Ed.). Translating humour. [Special Issue]. The Translator: Studies in Intercultural Communication, $8(2)$.

Attardo, S. (2006). Cognitive linguistics and humor. Humor: International Journal of Humor Research, 19 (3), $341-362$.

Attardo, S., \& Raskin V. (1991). Script theory revis(it)ed: joke similarity and joke representation model. Humor: International Journal of Humor Research, 4(3-4).

Attardo, S., Wagner, M., \& Urios-Aparisi, E. (Eds.). (2013). Prosody and humor, Amsterdam: John Benjamins Publishing Company.

Baker, M. (1993). Corpus linguistics in translation studies: Implications and application. In M. Baker, G. Francis, E.Tognini-Bonelli, \& J. Sinclair, (Eds.). Text and technology: In honour ofJohn Sinclair. Philadelphia, PA: John Benjamins Publishing Company.

Baker, M. (2005). Narratives in and of translation. SKASE Journal of Translation and Interpretation, 1(1), $73-89$.

Baker, M. (2006). Towards a methodology for investigating the style of a literary translator. Target, $12(2), 241-266$.

Baker, M. (2011). In other words: a coursebook on translation $\left(2^{\text {nd }}\right.$ edit.). London; New York: Routledge. 
Baker, M., \& Saldanha, G. (2009). Routledge encyclopedia of translation studies. ( $2^{\text {nd }}$ edit.). London: Routledge.

Banfield, S., \& Block, G. H. (2006). Jerome Kern. New Haven: Yale University Press.

Bassnett, S. (2013). Translation studies. Hoboken: Taylor and Francis.

Beaugrande R. A. \& Dressler W. U. (1981). Introduction to text linguistics. London: Longman.

Bensimon, P. (1990). Présentation. Palimpsestes, XIII(4), ix-xiii.

Benzing, G. M. (2008). Una vita per la traduzione: Mario Benzing. Milan: Acme.

Bergson, H. (2010/1900). Le rire: Essai sur la signification du comique (1900.) Paris: Quadrige/PUF.

Berman A. (1990). La retraduction comme espace de la traduction, Palimpsestes, XIII(4), 1-7.

Berman A. (1995). Pour une critique des traductions:John Donne. Paris. Gallimard.

Bermann, S. \& Porter C. (Eds.) (2014). A companion to translation studies. Oxford: Oxford University Press.

Berni, S. (2005). A caccia di libri proibiti. Macerata: Edizioni Simply.

Bevis, M. (2013). Comedy: a very short introduction. Oxford: Oxford University Press.

Bloch, M. (2004). La guerra e le false notizie. Milan: Donizelli.

Bloom, P. (2010). How pleasure works: the new science of why we like what we like. London: Vintage.

Boase-Beier, J. (2006). Stylistic approaches to translation. Manchester: St Jerome.

Boase-Beier, J. (2011). A critical introduction to translation studies. London: Continuum.

Bonsaver, G. (2007). Censorship and literature in fascist Italy. Toronto: University of Toronto Press.

Bonsaver, G. (2013). Mussolini censore: Storie di letteratura, dissenso e ipocrisia. Bari: Laterza.

Booth, W. C. (1983). The Rhetoric of Fiction. Chicago, IL: University of Chicago Press.

Bourdieu, P., \& Thompson, J. B. (Ed. and Trans.) (1970). Language and symbolic power. Cambridge;

Malden, MA: Polity Press.

Bourdieu, P., \& Wacquant, L. J. D. (1992). An Invitation to Reflexive Sociology. Chicago, IL: University of Chicago Press.

Bowker L., Kenny, D. \& Pearson, J. (Eds). (1998). Bibliography of translation studies. Amsterdam: John Benjamins.

Bremmer, J. N., \& Roodenburg, H. (1997). A cultural history of humour : From antiquity to the present day. Cambridge; Malden, MA: Polity Press.

Brisset, A., \& Annie. (2004). Retraduire ou le corps changeant de la connaissance : Sur l'historicité de la traduction. Palimpsestes, (15), 39-67.

Brockliss, L. W. B. (2016). The University of Oxford: a history (1 $1^{\text {st }}$ edition.). Oxford: Oxford University Press.

Bucaria, C. (2004). Lexical and syntactic ambiguity as a source of humor: The case of newspaper headlines. Humor: International Journal of Humor Research 17(3), 279-309. 
Budanitsky, A. (1999 August). Lexical semantic relatedness and its application in natural language processing. Retrieved from //ftp.cs.toronto.edu/pub/gh/Budanitsky-99.pdf

Budanitsky, A., \& Hirst, G. (2001). Semantic distance in WordNet: An experimental, application-oriented evaluation of five measures. Workshop on WordNet and other lexical resources, Second Meeting of the North American Chapter of the Association for Computational Linguistics, 2(12), 29-34.

Bugarski, R. (1982). Contrastive analysis of terminology and the terminology of contrastive analysis. Languages in Contact and Contrast, 1(3), 13-18.

Buzelin, H. (2005). Unexpected allies. The Translator, 11(2), 193-218.

Byron, G. (1852). The complete works of Lord Byron: in one volume. Frankfort: J. Baer.

Caccia, P. (2013). Editori a Milano (1900-1945). Repertorio. Milan: Franco Angeli.

Cadioli, A., \& Vigini, G. (2012). Storia dell'editoria italiana dall'unità ad oggi: un profilo introduttivo. Milan: Editrice Bibliografica.

Campos, A., \& Gonzalez, A. (1993). Vividness of imagery and creativity. Perceptual and Motor Skills, 77, 923-928.

Cannistraro, P. V. (1975). La fabbrica del consenso: Fascismo e mass media. Bari: Laterza.

Carlson, R. S. (1975). The benign humorists. Hamden, CT: Archon Books.

Caron, J. E. (2002). From ethology to aesthetics: Evolution as a theoretical paradigm for research on laughter, humor, and other comic phenomena. Humor. International Journal of Humor Research, $15(3), 245^{-281 .}$

Carrell, A. (2008). In V. Raskin (Ed.). The primer of humor research. Berlin: Mouton de Gruyter.

Carrell, A. T. (1993). Audience/community, situation, and language: A linguistic/rhetorical theory of verbal humor. Unpublished Dissertation. Purdue University. Retrieved from http://docs.lib.purdue.edu/dissertations/AAI9403662

Carrell, P. L. (1987). Content and formal schemata in ESL reading. Tesol Quarterly, 21(3), 461-481.

Carroll R. \& Prickett, S. (2008). (Eds.) The Bible: Authorised King James version with apocrypha, Oxford: Oxford University Press.

Catford, J. C. (1965). A linguistic theory of translation: An essay in applied linguistics. Oxford: Oxford University Press.

Cazalet-Keir, Thelma, (Ed.). (1973). Homage to PG Wodehouse: A critical and historical essay. London: Barrie \& Jenkins Ltd.

Cesari, M. (1978). La censura nel periodo fascista. Naples: Liguori Editore.

Chabod, F. (1974). A history of Italian fascism. Bath: Cedric Chivers.

Chabod, F., \& Grindrod M. (Eds.) (1975). A history of Italian fascism. New York: H. Fertig.

Charnitzky, Jurgen. Fascismo e scuola: La politica scolastica del regime (1922-1943). Florence: La Nuova Italia, 1996.

Chesterman A. (200o). In M. Olohan (Ed.). A causal model for translation studies. Manchester: St Jerome. 
Chesterman, A. (2004). Hypotheses about translation universals. In G. Hansen, K. Malmkjaer, \& D Gile (Eds.). Claims, changes and challenges in translation studies. Amsterdam: Benjamins.

Chiaro, D. (1992). The language of jokes: Analyzing verbal play. London: Routlegde.

Chiaro, D. (2010). Translation, humour and literature. London; New York: Continuum.

Chiaro, D. (Ed.). (2012). Translation, humour and literature. Volume 1: translation and humour. London: Continuum.

Chiesa, A. (1972). Don Basilio giornale satirico contro le parrocchie di ogni colore. Rome: Napoleone Editore.

Coaloa R. (2006). Giornalismo, propaganda e censura nella prima guerra mondiale in G. La Rosa (a cura di) L'inizio della fine, Milan: European Press Academic Publishing.

Cole, P. \& Morgan, J. L. (1975). Speech acts. New York, NY: Academic Press.

Colina, S. (2015). Fundamentals of translation. Cambridge: Cambridge University Press.

Conan Doyle, A. (1891/2005). A scandal in Bohemia. Chelmsford, England: Goode Press.

Connolly, J. (1979). P.G. Wodehouse: An illustrated biography: with complete bibliography and collector's guide. London: Orbis Pub.

Coppa, F. J. (1985). Dictionary of modern Italian history. Westport, CT: Greenwood Press.

Cotter, P., Wilkinson, C., Canavan, M., \& O'Keeffe, S. (2011). Language change with ageing in Pelham Grenville Wodehouse and George Bernard Shaw.Journal of the American Geriatrics Society, 59(8), $1567-1568$.

Cozzi, L. (20o6). L'era di Giorgio Monicelli. Roma: Profondo Rosso.

Craighead, W., \& Nemeroff, C. (2004). The Concise Corsini Encyclopedia of Psychology and Behavioral Science. Hoboken, NJ:John Wiley \& Sons.

Crawford, C.B. (1994). Theory and implications regarding the utilization of strategic humour by leaders. The Journal of Leadership Studies, 1(4), 53-67.

Crawford, M. (2003). Gender and humour in social context. Journal of Pragmatics, 35, 1413-1430.

Critchley, S. (2002). On humour. London: Routledge.

Cronin J. (2012). In L.Venuti, The translation studies reader. ( $3^{\text {rd }}$ ed.). London: Routledge.

Daniel, E., \& Keith-Spiegel, P. (2013). The psychology of humor: Theoretical perspectives and empirical issues. The Psychology of Humor: Theoretical Perspectives and Empirical Issues, 26(8), 560-565.

Davies, C. (1990). Ethnic humor around the world: a comparative analysis. Bloomington, IN: Indiana University Press.

Davies, C. (1998).Jokes and their relation to society. Berlin: Mouton de Gruyter.

Davis, T. \& Womack, K. (2002). Formalist criticism and reader-response theory. Basingstoke: Palgrave.

De Beaugrande, R., \& Dressler, W. (1981). Introduction to text linguistics. London: Longman.

De Donato, G. \& Gazzola Stacchini V. (1991). I bestseller del ventennio. Il regime e il libro di massa. Roma: Editori Riuniti.

De Fort, E. La scuola elementare dall'Unità alla caduta del fascismo. Bologna: il Mulino, 1996. 
De Koning, E. D. and Weiss, R. L. (2002). The relational humour inventory: Functions of humour in close relationships. American Journal of Family Therapy, 30 (1), 1-18.

Deane-Cox, S. (2014). Retranslation: Translation, literature and reinterpretation. London: Bloomsbury Academic.

Delabastita D. (1993). There's a double tongue: An investigation into the translation of Shakespeare's wordplay with special reference to Hamlet. Amsterdam; Atlanta, GA: Rodopi.

Delabastita, D. (1994). Focus on the pun. Target, 6(2), 223-243.

Delabastita D. (Ed.) (1996). Wordplay \& translation. [Special Issue]. The Translator: Studies in Intercultural Communication, 2(2).

Delabastita D. (Ed.) (1997). Traductio: Essays on punning and translation. Manchester: St Jerome; Namur: Presses Universitaires de Namur.

Delabastita, D. (2005). Cross-language comedy in Shakespeare. Humor: International Journal of Humor Research. 18(2), 161-184.

Desmidt, I. (2009). (Re)translation revisited. Meta:Journal Des Traducteurs / Meta: Translators'Journal, $54(4), 669-683$.

Di Porto, V. (2000). Le leggi della vergogna: Norme contro gli ebrei in Italia e Germania. Florence: Le Monnier.

Diot, R. (1989). Humor for intellectuals: Can it be exported and translated? Meta:Journal Des Traducteurs/Meta: Translators'Journal, 34(1), 84.

Domenico, R. P., \& Hanley, M. Y. (2006). Encyclopedia of Modern Christian Politics. Westport, CT: Greenwood Press.

Donaldson, F. L. (1968). Evelyn Waugh: portrait of a country neighbour. Philadelphia, PA: Chilton.

Donaldson, F. L. (2014). P. G. Wodehouse: A biography. London: Andre Deutsch..

Dondi, G. (1968). BIETTI, Antonio. Dizionario biografico degli Italiani, Vol. 10, http://www.treccani.it/enciclopedia/antonio-bietti_\%28Dizionario-Biografico\%29/

Donovan, T. R., \& McClelland, B. W. (1980). Eight approaches to teaching composition. Urbana, IL: National Council of Teachers of English.

Dossena, G. (1991). Fai da te : saggi di letteratura, turismo e bricolage. Milan: Rizzoli.

Dowst, K. (1980). In T. Donovan, \& B. McClelland, Eight approaches to teaching composition. Urbana, IL: National Council of Teachers of English.

Dugan, L. (2011). Worcestershirewards: Wodehouse and the Baroque. Connotations, 20(2-3), 228-247.

Easdale, Roderick, (2004). The novel life of P. G. Wodehouse. Newtown (Wales?): Cyhoeddwyr y Superscript Ltd.

Eatwell, R. (1995). Fascism: A history. London: Chatto \& Windus.

Eco, U. (1994). The limits of interpretation. Bloomington, IN: Indiana University Press.

Eco, U. (1994). The role of the reader: explorations in the semiotics of texts. Bloomington, IN: Indiana University Press. 
Eco U. (1995). In S. Nergaard, \& R. Jakobson (Eds.). Teorie contemporanee della traduzione. Milan: Bompiani.

Eco, U. (2004). Mouse or rat?: translation as negotiation. London: Phoenix.

Einhaus A. M. (2015). In Rea, A. (Ed.). Middlebrow Wodehouse: P.G. Wodehouse's work in context. Abington: Routledge.

Ellis, N. C., Simpson-Vlach, R., \& Maynard, C. (2009). Formulaic language in native and second language speakers. Psycholinguistics, Corpus Linguistics, and TESOL. Pawley \& Syder, 42(3).

Emmot C. (2014). In M. Hühn, D. Gruyter, \& D. Gruyter (Eds.). Handbook. Schemata, (October), 756 764 .

Emmott, B. (2012). Good Italy, bad Italy: Why Italy must conquer its demons to face the future. New Haven, CT: Yale University Press.

Evans, J. (2014). Translation as a critical practice: Using retranslation when teaching translation. Quaderns: Revista de Traduccio, 21, 199-209.

Even-Zohar, I. (1979). Polysystem theory. Poetics Today, 1(1-2), 287-310.

Fantl, J. (2008). Knowing-how and knowing-that. Philosophy Compass, 3(3), 451-470.

Faulkes S. (2013). Jeeves and the wedding bells. London: Random House

Fawcett, P. (1997). Translation and language. Linguistic theories explained. Manchester: St Jerome.

Ferguson, M. A., \& Ford, T. E. (2008). Disparagement humor: A theoretical and empirical review of psychoanalytic, superiority, and social identity theories. Humor: International Journal of Humor Research, 21(3), 283-312.

Ferretti, G., (2004). Storia dell'editoria letteraria in Italia: 1945-2003, Turin: Einaudi.

Fine, G. A. (1983). Sociological approaches to the study of humor. In Handbook of humor research. New York: Springer New York.

Fiske, S. T., \& Taylor, S. E. (1991). Social cognition: From brains to culture. London: Sage.

Fitzpatrick, E. (2007). Corpus linguistics beyond the word. Amsterdam: Rodopi.

Flamini, G. (2007). L'Italia dei colpi di Stato: storie di burattini e di burattinai, di ricatti politici e di micce spente all'ultimo minuto: nomi, cognomi e amicizie segrete degli uomini che hanno attentato alla democrazia. Rome: Newton Compton.

Flores D'Arcais, P. (2006). Ilventennio populista: da Craxi a Berlusconi (passando per D'Alema?). Rome: Fazi.

Folgado, V. L. (2010). In C. Valero-Garces (Ed). Dimensions of humor explorations in linguistics, literature, cultural studies and translation. Valencia: Universidad de Valencia.

Fontana G., (2013, April).“Mussolini censore”: la stretta del fascismo sull'editoria italiana, in: Domenica24.

Fortini, F. (2011). Lezioni sulla traduzione. Macerata, Italy: Quodlibet.

Franzinelli, M. (2013). Il Duce e le donne: avventure e passioni extraconiugali di Mussolini. Milan: Mondolibri 
Frei, M. (1996). Italy: The unfinished revolution. London: Arrow.

French, R. B. D. (1966). P.G. Wodehouse. London: Oliver\& Boyd.

Freud, S. (1963). Jokes and their relation to the unconscious. New York: Norton.

Freud, S. (1927). Humor. International Journal of Psychoanalysis 9: 1-6.

Freytag, G. (1900). Technique of the drama: an exposition of dramatic composition and art. An authorized translation from the 6th German ed. by Elias J. MacEwan. Chicago, IL: Scott, Foresman and Company.

Fruttero, C., Lucentini, F. (1993). <La cassa sbagliata >, gioiello dell'umorismo, La Stampa, 8-05-1993.

Fry, S. (2011) Preface. In Wodehouse, P. G., What ho! The best of P. G. Wodehouse (pp. xiii-xxvii). London: Arrow.

Frye, N. (1957). Anatomy of criticism. Princeton, NJ: Princeton University Press.

Furlong, W. B. (1967). Shaw and Chesterton: the link was "Magic". The Shaw Review, 10(3), 100-107.

Galfré, M. (2005). Il regime degli editori: Libri, scuola e fascismo. Bari: Laterza

Galligan, E. L. (1985). P.G.Wodehouse master of farce. The Sewanee Review, 93(4), 6o9-617.

Gambier, Y. (1994). La retraduction, retour et détour. Meta:Journal Des Traducteusr/Meta: Translators' Journal, 39, 413.

Gambier, Y., \& van Doorslaer, L. (Eds.). (2010). Handbook of translation studies (Vol. 2). Amsterdam: John Benjamins Publishing Company.

Gandini, G. (2011). Storie sparse: racconti, fumetti, illustrazioni, incontri e topi. Milano: Il saggiatore.

Gee, J. P. (2001). Reading as situated language: A sociocognitive perspective. Journal of Adolescent \& Adult Literacy, 44(8), 714-725.

Geeraerts, D. (2006). Cognitive linguistics: basic readings. The Hague: Mouton de Gruyter.

Gendler, T. S. (2007). Journal of Philosophy. Annals of Neurology, (April), 1-28.

Gendler, T. S. (2008). Alief in action (and reaction). Mind and Language, 23(5), 552-585.

Genette, G. (1987). Seuils. Paris: Edition du Seuil.

Genovesi, P. (2009). Il manuale di storia in Italia: Dal fascismo alla repubblica. Milan: Franco Angeli, 2009 .

Gentile G. (1920). La riforma dell'educazione. Bari, Laterza.

Germino, D. (2009). The Italian fascist party in power: a study in totalitarian rule. Minneapolis, MN: Univ. of Minneapolis Press.

Gernsbacher, M. A., \& Givón, T. (Eds.). (1995). Coherence in spontaneous text (31). Amsterdam: John Benjamins Publishing Company.

Gervais, M., \& Wilson, D. S. (2011). The evolution and functions of laughter and humor: a synthetic approach. Quarterly Review of Biology, 81(4), 327-347.

Gianni E., (2001). L'inventore del nome dei Gialli. Tradurre, 1.

Ginsborg, P. (2001). Italy and its discontents: family, civil society, state, 1980-2001. Allen Lane: Penguin Press. 
Giora, R. (1991). On the cognitive aspects of the joke. Journal of Pragmatics, 16(5), 465-485.

Giora, R. (1995). On irony and negation. Discourse Processes, 19(2), 239-264.

Giora, R. (2003). On our mind: Salience, context, and figurative language. Oxford University Press.

Goldstein, J. H., \& McGhee, P. E. (1972). The psychology of humor: Theoretical perspectives and empirical issues. New York: Academic Press.

Gomez, P., \& Travaglio, M. (2005). Inciucio. Milan: Rizzoli.

Gracia, J. J. E. (1996). Texts: ontological status, identity, author, audience. New York, NY: SUNY Press.

Graedler, A. L. (200o). Cultural shock. Oslo: University of Oslo.

Granger, F., \& Calhoun, R. (2008). Include me out: my life from Goldwyn to Broadway. New York, NY: St. Martin's Griffin.

Gray, B. (1969). Style: the problem and its solution. The Hague: Mouton.

Greco, L. (1983). Censura e scrittura. Vittorini, lo pseudo-Malaparte, Gadda. Milan: Il Saggiatore.

Green, B. (1983). P.G. Wodehouse: A literary biography. Oxford: Oxford University Press.

Green, B. (1981). P. G. Wodehouse: A literary biography. London: Pavilion Books.

Greig, J. (1923). The psychology of laughter and comedy. New York, NY: Dodd Mead.

Grice H. P. (1975). Logic and conversation. In P. Cole \& J. Morgan (Eds.). Syntax and Semantics, 3. New York, NY: Academic Press.

Gulland, D. M., \& Hinds-Howell, D. (2001). The Penguin dictionary of English idioms. London: Penguin.

Gutt, E. A. (2000). Translation and relevance. Manchester: St. Jerome.

Hall, R. A. Jr. (1973). The transferred epithet in P. G. Wodehouse. Linguistic Inquiry, 4(1), 92-94.

Hall, R. A. Jr. (1974). The comic style of P.G. Wodehouse. London: Archon Books.

Halliday, M. A. K. (1965). The linguistic sciences and language teaching. Bloomington, IN: Indiana University Press.

Halliday, M. A. K. (2004). An Introduction to functional grammar (3rd edit.). London: Arnold.

Halliday, M. A. K. \& Hasan R. (1976). Cohesion in English. London: Longman.

Harvey, M. (2000). A beginner's course in legal translation: The case of culture-bound terms. $L a$ Traduction Juridique Histoire Théories et Pratique, 1-9.

Hatim, B. \& Mason I. (1990). Discourse and the translator. Harlow, NY: Pearson Education Limited.

Hatim, B. (2001). Teaching and researching translation. Harlow; NY: Longman.

Haykel, B., Hegghammer, T., \& Lacroix, S. (2015). Saudi Arabia in transition: insights on social, political, economic and religious change. New York, NY: Cambridge University Press.

Heineman, J. H., \& Bensen, D. R. (1981). P.G. Wodehouse, a centenary celebration, 1881-1981. New York, NY: Pierpont Morgan Library.

Hermans T. (1988). In P. King, M. Wintle, M. \& P. Vincent (Eds.). Modern Dutch studies: essays in honour of Peter King, professor of modern Dutch studies at the University of Hull on the occasion of his retirement. London: Athlone Press. 
Hermans, T. (2014). Translation in systems: Descriptive and system-oriented approaches explained. Abington, NY: Routledge.

Herrmann, J. B., van Dalen-Oskam, K., \& Schöch, C. (2015). Revisiting style: a key concept in literary studies. Journal of Literary Theory, 9(1), 25-52.

Hervey, S. G. J., \& Higgins, I. (1992). Thinking Translation: A course in translation method, French-English. Abington; New York, NY: Routledge.

Hitchens, C., (2004). 'The honorable schoolboy', Book review of Wodehouse: A life, by Robert McCrum, The Atlantic, November 2004, retrieved from http://www.theatlantic.com/magazine/archive/2004/11/the-honorable-schoolboy/303563/

Hobbes, Th. (1840). Human nature. London: John Bohn

Holland, S. (1992). The state as entrepreneur: New dimensions for public enterprise: The IRI State Shareholding Formula, London, Weidenfeld \& Nicolson.

Holmes, J. S. (1988). Translated!: Papers on literary translation and translation studies. Amsterdam: Rodopi.

Holmes, D. I. (1998). The evolution of stylometry in humanities scholarship. Literary and Linguistic Computing, 13(3), 111-117.

Holmes, J. and Marra, M. (2002). 'Having a laugh at work: How humour contributes to workplace culture.' Journal of Pragmatics, 34 (12), 1683-1710.

Hood, J. (2012). Jack London's 'The iron heel': An enduring classic. World Socialist Web Site

Hood, J. (2016). Waking up from the American dream. San Francisco, CA: Counter-Current Publishing.

Hoover, D. L. (2007). Corpus stylistics, stylometry, and the styles of Henry James. Style, 41 (2).

Houdé, O. (2004). Dictionary of cognitive science: Neuroscience, psychology, artificial intelligence, linguistics, and philosophy. London: Psychology Press.

Hühn, M. S. I. (2014). Gruyter, D. \& Gruyter, D. (Eds.). Handbook. Schemata, (October), 756-764.

Hynes, S. (1968). The Edwardian turn of mind. Princeton, NJ: Princeton University Press.

Inghilleri M. (2009). Baker, M., \& Saldanha, G. Routledge encyclopedia of translation studies. ( ${ }^{\text {nd }}$ Edit.). London: Routledge.

Iser, W. (1974). The implied reader: patterns of communication in prose fiction from Bunyan to Beckett. Baltimore, ML: Johns Hopkins University Press.

Iser, W. (1978). The act of reading: A theory of aesthetic response. Abington, UK: Routledge and Kegan Paul.

Iser, W., Suleiman, S., \& Crosman, I. (1980). The reader and the text: Essay on audience and interpretation. Princeton, NJ: Princeton University Press.

Jakobson R. (1959/2012). In Venuti, L. The translation studies reader. ( $3^{\text {rd }}$ edit.). London: Routledge.

Jasen, D. A. (1970). A bibliography and reader's guide to the first editions of P.G. Wodehouse. Hamden, CT: Archon Books.

Kant, I. (1790). Kritik der Urteilskraft. Berlin: Lagarde. 
Katan, D. (2015). Translating cultures: an introduction for translators, interpreters and mediators. Abington: Taylor \& Francis.

Katz, B. (1993). A neural resolution of the incongruity and incongruity-resolution theories of humour. Connection Science, 5, 59-75.

Keith-Spiegel, P. (1972). Early conception of humor: Varieties and issues. In J. Goldstein \& P. McGhee, The psychology of humor: Theoretical perspectives and empirical issues. New York, NY: Academic Press.

Kennedy, A. (2012). Measuring semantic relatedness across languages. Retrieved from https://km.aifb.kit.edu/ws/xlite/xLiTe-Paper-AlistairKennedy.pdfKi

Kenny D. (2009). In M. Baker \& G. Saldanha, Routledge encyclopedia of translation studies. ( $2^{\text {nd }}$ Edit.). London: Routledge.

Kimball, R. (2000, October). 'The genius of Wodehouse', The New Criterion 19, 1-10, retrieved from http://www.newcriterion.com/articles.cfm/The-genius-of-Wodehouse--2327

King, P., Wintle, M. J., \& Vincent, P. F. (1988). Modern Dutch studies: essays in honour of Peter King, professor of modern Dutch studies at the University of Hull on the occasion of his retirement. London: Athlone Press.

Kipling, R., \& Arscott, D. (2007). A Sussex Kipling: an anthology of poetry and prose. Lewes, Sussex: Pomegranate Press.

Koff, S. Z., \& Koff, S. P. (2000). Italy, from the first to the second republic. Abington, Routledge.

Koskinen, K. (2010). In Y. Gambier, \& van L. Doorslaer (Eds.). Handbook of translation studies (Vol. 1). Amsterdam: John Benjamins Publishing Company.

Koskinen, K., \& Paloposki, O. (2003). Retranslations in the age of digital reproduction. Cadernos de Tradução, 11, 19-38.

Kruglanski, A. W. (1981). The epistemic approach in cognitive therapy. International Journal of Psychology, 16(4), 275.

Kuhn, T. S. (1996). The structure of scientific revolutions. Chicago, IL: University of Chicago Press.

Kuipers, G. (2008). The sociology of humor. In V. Raskin (Ed.). The primer of humor research. Berlin; Mouton de Gruyter.

Kuipers, G., \& Simms, K. (2015). Good humor, bad taste: A sociology of the joke. Berlin : Mouton de Gruyter.

La Fave L. (1972). In J. Goldstein \& P. McGhee, (Eds.) The psychology of humor: Theoretical perspectives and empirical Issues. New York, NY: Academic Press.

Lakoff, G., \& Johnson, M. (1980). Metaphors we live by. Chicago, IL: University of Chicago Press.

Lamantia B. \& Cucca G. (2007). Libri proibiti. Quattro secoli di censura cattolica. Viterbo: Nuovi Equilibri.

Lanaro, S. (1994). Storia dell'Italia repubblicana: dalla fine della guerra agli anni novanta. Venice: Marsilio.

Lancashire, I., \& Hirst, G. (2009). Vocabulary changes in Agatha Christie's mysteries as an indication of dementia: A Case Study. Presented at the 19th Annual Rotman Research Institute Conference, Cognitive Aging: Research and Practice, 8-10 March, 1-5. 
Langer, S. (1967). Feeling and form: A theory of art developed from philosophy in a new key (4 ${ }^{\text {th }}$ edit.). London: Routledge \& Kegan Paul.

Latour, B. (1987). Science in action: How to follow scientists and engineers through society. Cambridge, MA: Harvard University Press.

Latour, B. (2005). Reassembling the social: An introduction to actor-network-theory. (Vol. 1) Oxford: Oxford University Press.

Latour, B., \& Woolgar, S. (1986). Laboratory life: The construction of scientific facts. Princeton, NJ: Princeton University Press.

Laviosa, S. (2002). Corpus-based translation studies: Theory, findings, applications. Amsterdam: Rodopi.

Laviosa, S., Pagano, A., Kemppanen, H., \& Ji, M. (2016). Textual and contextual analysis in empirical translation studies. New York, NY: Springer Verlag.

Leacock, S. (1935). Humour: its theory \& technique, with examples and samples : a book of discovery. London: John Lane the Bodley Head.

Leech, G. N., \& Short, M. (1981). Style in fiction: a linguistic introduction to English fictional prose. London: Longman.

Lefevere, A. (1977). Translating literature: the German tradition from Luther to Rosenzweig. Assen:Van Gorcum.

Lefevere, A. (1992). Translation, rewriting, and the manipulation of literary fame. Abington: Routledge.

Leppihalme, R. (1997). Culture bumps: an empirical approach to the translation of allusions. Bristol: Multilingual Matters.

Lillo, G. (1731). Sylvia or the country burial: An opera as it is performed at the Theatre Royal in Lincoln'sInn-Fields. London: J. Watts.

Lindblom, J. (2015). Embodied social cognition. Cham: Springer International Publishing.

Lomartire, C. M. (2008). Il qualunquista: Guglielmo Giannini e l'antipolitica. Milano: Mondadori.

London, J. (1908). The iron heel. New York, NY: Macmillan

London, J. (1928). Il tallone diferro (G. Dàuli, Trans.). Milan: Monanni.

Long, D., \& Graesser, A. (1988/2013). Wit and humor in discourse processing. Discourse Processes, 11, 3560.

Lowry, M. (1947). Under the volcano. New York, NY: Reynal \& Hitchcock.

Lowry, M. (1961). Sotto il vulcano (G. Monicelli, Trans.). Milan: Feltrinelli

Mack Smith, D., \& Mack Smith, D. (1997). Modern Italy: A political history. New Haven, CN: Yale University Press.

Maiden, M., \& Robustelli, C. (2007). A reference grammar of modern Italian. Abington: Routledge.

Maier, C. (2009). In M. Baker, \& G. Saldanha (Eds.) Routledge encyclopedia of translation studies. $\left(2^{\text {nd }}\right.$ Edit.). London: Routledge.

Maier, N. R. F. (1932). A Gestalt theory of humour. British Journal of Psychology, 23, 69-74.

Mammone, A., \& Veltri, G. A. (2010). Italy Today: the sick man of Europe. Abington: Routledge. 
Mancini, M. E. (2006). L'Archivio Laterza e la storia dell'editoria negli anni del fascismo. Bari: Laterza.

Mandich, A.M. (2007). L'editoria per la lingua francese in epoca fascista, in: Quaderni del CIRSIL - Vol.6

Manini L. (1996). In D. Delabastita (Ed.). Wordplay \& translation. [Special Issue]. The Translator: Studies in Intercultural Communication, 2 (2).

Marshall, H. (2010). Palaeography for family and local historians. Andover: Phillimore \& Co. Ltd.

Martin, R. A. (2007). The psychology of humor: an Integrative Approach. Burlington, MA: Elsevier Academic Press.

Martin, R. A., Puhlik-Doris, P., Larsen, G., Gray, J., \& Weir, K. (2003). Individual differences in uses of humor and their relation to psychological well-being: Development of the Humor Styles Questionnaire. Journal of Research in Personality, 37(1), 48-75.

McCracken, G. (1934). Wodehouse and Latin comedy. The Classical Journal, 29(8), 612-614.

McCrum, R. (2004). Wodehouse: A life. London: Viking.

McGann, J. J. (1991). The textual condition. Princeton, NJ: Princeton University Press.

McGhee, P. E. \& Goldstein G. (Eds.) (1983). Handbook of humour research. New York, NY: Springer Verlag.

McGhee, P. E. (Ed.) (1979). Humor: Its origin and development. San Francisco, CA: Freeman.

Meade, R. C. (1990). Red Brigades : the story of Italian terrorism. London: Macmillan.

Mellinger, C. D. \& Hanson, T. A. (2017). Quantitative research methods in translation and interpreting Studies. London: Routledge.

Meyer, J. C. (2000). Humor as a double-edged sword: Four functions of humor in communication. Communication Theory, 10(3), 310-331.

Miller, G. (1979). Images and models, similes and metaphors. In A. Ortony (Ed.) Metaphor and thought. Cambridge: Cambridge University Press.

Mitchell, H. H., Graesser, A. C., \& Louwerse, M. M. (2010). The effect of context on humor: A constraintbased model of comprehending verbal jokes. Discourse Processes, 47, 104-129.

Mooneyham, L. (1994). Comedy among the modernists: P. G. Wodehouse and the anachronism of Comic Form. Twentieth Century Literature, 4O(1), 114.

Morgan, P., (2003). Fascism in Europe, 1919-1945. London: Routledge.

Morreal, J. (2009). Comic relief a comprehensive philosophy of humor. Hoboken, NJ: Wiley-Blackwell.

Morreal, J. (Ed.) (1987). The philosophy of laughter and humor. Albany, NY: SUNY Press.

Morris, J. H. C., (1981). Thankyou, Wodehouse. London: Weidenfeld and Nicolson Ltd.

Muir, F. (1990). The Oxford book of humorous prose: from William Caxton to P.G. Wodehouse: a conducted tour. Oxford: Oxford University Press.

Munday, J. (2001). Introducing translation studies: theories and applications. Abington: Routledge.

Munday, J. (2012). Evaluation in translation: Critical points of translator decision-making. Abington: Routledge.

Munday, J. (Ed.). (2009). The Routledge companion to translation studies. Abington: Routledge. 
Nash, W. (1985). The language of humor (English Language Series 16). London: Longman.

Nepomuceno-Fernandez, A., Soler-Toscano, F., \& Velazquez-Quesada, F. R. (2013). An epistemic and dynamic approach to abductive reasoning: selecting the best explanation. Logic Journal of IGPL, 21(6), 943-961.

Nergaard, S., \& Jakobson, R. (Eds.) (1995). Teorie contemporanee della traduzione. Milan: Bompiani.

Nerlich, B. (2003). Polysemy: flexible patterns of meaning in mind and language. The Hague: Mouton de Gruyter.

Nesi, A. (2013). Fare pranzo o mangiare pranzo? Consigli di lingua, non di dieta. Crusca per Voi, 47, 11-13. Retrieved from http://www.accademiadellacrusca.it/it/pubblicazioni/crusca-per-voi/indice-deinumeri/ii-2013-o

Newmark, P. (1981). Approaches to translation. Oxford: Pergamon Press.

Newmark, P. (1988). A textbook of translation. Englewood Cliffs, NJ: Prentice-Hall International.

Newmark, P. (1991). About translation. Bristol: Multilingual Matters.

Nida, E. (1974). The theory and practice of translation. Leiden: E.J. Brill for the United Bible Societies.

Nida, E. A. (1964/2003). Toward a science of translating. ( $2^{\text {nd }}$ Impr.). Leiden: Brill.

Noorman, L. \& Vonk W. (1992). In: J. Oakhil \& A. Gernham (Eds.). Discourse representation and text processing. Hover: Laurence Erlbaum Associates.

Nord, C. (1994). It's tea-time in wonderland: Culture-makers in fictional texts. Intercultural Communication, $523-537$.

Nord, C. (1997). Translating as a purposeful activity: Functionalist approaches explained. Manchester: St. Jerome.

Norrick, N. R. (2004). Non-verbal humor and joke performance. Humor: International Journal of Humor Research, 17(4), 401-409.

Oakes, M. P., \& Ji, M. (2012). Quantitative methods in corpus-based translation studies: a practical guide to descriptive translation research. Amsterdam: John Benjamins Pub. Co.

Odlin, T. (2008). Cross-linguistic influence. In C. Doughty \& M. Long (Eds.) Handbook of second language acquisition. Oxford: Blackwell.

Olney, C. (1962). Wodehouse and the poets. The Georgia Review, XVI(4), 392-399.

Olohan, M. (Ed.). (2000). A causal model for translation studies. In Intercultural Faultlines (pp. 15-27). Manchester: St. Jerome.

Olohan, M. (2004). Introducing corpora in translation studies. Abington: Routledge.

Olson, K. (1996). Bertie and Jeeves at the end of history: P. G. Wodehouse as political scientist. Humor: International Journal of Humor Research, 9(1), 73-88.

Osgood, C. E. (1952). The nature and measurement of meaning. Psychological Bulletin, 49(3).

Osimo, B. (2011). Manuale del traduttore: guida pratica con glossario. Milano: Hoepli.

Paivio, A. (1971). Imagery and verbal processes. New York: Holt, Rinehart and Winston. 
Paloposki, O., \& Koskinen, K. (2010). Reprocessing texts. The fine line between retranslating and revising. Across Languages and Cultures, 11(1), 29-49.

Panetta, M. (2012). Panorama storico-critico dell'editoria italiana nel Novecento. Torino: Bibliomanie.

Partington, A., Duguid, A., \& Taylor, C. (2013). Patterns and meanings in discourse: Theory and practice in corpus-assisted discourse studies (CADS) (Studies in corpus linguistics). Amsterdam: John Benjamins Publishing Company.

Pavese, C. (1990). Letteratura americana e altri saggi. Torino: Einaudi.

Pensato, R. (2015). Ben detto, Jeeves: P. G. Wodehouse, gli aforismi e i motti di spirito, la fortuna editoriale in Italia (1928-2015). Macerata: Biblohaus.

Perks, L. G. (2012). The ancient roots of humor theory. Humor: International Journal of Humor Research, 25(1), 119-132.

Perry, A. R., \& Gibson Library Connections. (2010). The Don Camillo stories of Giovannino Guareschi : a humorist portrays the sacred. Toronto: University of Toronto Press.

Petrillo, G. (2014). L'altro Monicelli. Tradurre, 6.

Phelps, B. (1992). P.G. Wodehouse: man and myth. London: Constable.

Pinker, S. (2014). The sense of style: the thinking person's guide to writing in the 21st century! London: Penguin Books

Pinker, S. (2015). How the mind works. London: Penguin Books

Pirandello, L. (1974). On humour. (A. Illiano and D. P. Testa, Trans.). Chapel Hill, NC: The University of North Carolina Press.

Pivato, S., \& Tonelli, A. (2004). Italia vagabonda: il tempo libero degli italiani. Rome: Carocci.

Polimeni, J., \& Reiss, J. P. (2006). The first joke: Exploring the evolutionary origins of humor. Evolutionary Psychology, 4, 347-366.

Popper, K. (1963/2002). Conjectures and refutations: The growth of scientific knowledge. London; New York: Routledge.

Popper, K. R. (1972). Objective knowledge: an evolutionary approach. Wotton under Edge: Clarendon Press.

Priestley, J. (1976). English humour. New York, NY: Stein and Day.

Purdie, S. (1993). Comedy: the mastery of discourse. Toronto: University of Toronto Press.

Pym, A. (1998). Method in translation history. Manchester: St Jerome.

Pym, A. (2010). Exploring translation theories. Abington: Routledge.

Pym, A., Shlesinger, M., \& Jettmarová, Z. (Eds.). (2006). Sociocultural aspects of translating and interpreting, 67. Amsterdam: John Benjamins Publishing Company.

Pym, B. (1978). Una relazione sconveniente (N. Carano, Trans.). Rome: La tartaruga.

Rafanelli, L. (1946). Una donna e Mussolini. Milan: Rizzoli.

Ragone, G. (1999). Un secolo di libri: storia dell'editoria in Italia dall'Unità al post-moderno. Turin: Einaudi. 
Ramachandran, V.S. (1998). The neurology and evolution of humor, laughter, and smiling: the false alarm theory. Medical Hypotheses, 51(4), 351-354.

Raskin, V. (1979). Semantic mechanisms of humor. Journal of Pragmatics, 10, 269-273.

Raskin, V. (1985). Semantic mechanisms of humor. Dordrecht, Germany: D. Reidel.

Raskin, V. (2008) (Ed.). The primer of humor research. Berlin: Mouton de Gruyter.

Rea, A. (2015). Middlebrow Wodehouse: P.G. Wodehouse's work in context. Abington: Routledge.

Richards, I. (1936). The philosophy of rhetoric. London: Oxford University Press.

Richards, J. (1988). Happiest days: the public schools in English fiction. Manchester: Manchester University Press.

Richards, J. C., \& Schmidt, R. W. (2010). Longman dictionary of language teaching and applied linguistics. Harlow, England: Longman.

Richards, J. C., Platt, J. T., \& Weber, H. (1985). Longman dictionary of applied linguistics. Harlow, England: Longman.

Ricœur, P. (1971). The model of the text: Meaningful action considered as a text. Social Research, 38(3), 529-562.

Ricœur, P. (2006). On translation. (E. Brennan, trans.). London: Routledge.

Ricœur, P., \& Thompson, J. B. (1970/1981). Hermeneutics and the human sciences: essays on language, action, and interpretation. Cambridge: Cambridge University Press.

Riffaterre, M. (1959). Criteria for style analysis. Word, 15(1), 154-174.

Riffaterre, M. (1992). In R. Schulte \& J. Biguenet (Eds.). Theories of translation. Chicago, IL: University of Chicago Press.

Risku, H. (2012). Cognitive approaches to translation. In The encyclopedia of applied linguistics. Oxford: Blackwell Publishing Ltd.

Ritchie, G. (1999). Developing the incongruity-resolution theory. Institute for Communicating and Collaborative Systems. Retrieved from http://www.informatics.ed.ac.uk/

Ritchie, G. (2004). The linguistic analysis of jokes. London: Routledge.

Roberts, D. (1979). The syndacalist tradition and Italian fascism. Chapel Hill, NC: University of North Carolina Press.

Robinson, B., Wodehouse, P. G. \& Spiring, P. R. (2009). Bobbles \& Plum :four satirical playlets. London: MX Pub.

Roeckelein, J. E. (2002). The psychology of humor: A reference guide and annotated bibliography. Westport, CT: Greenwood Press.

Romero, E. J. \& Cruthirds. K. W. (2006). The use of humour in the workplace. Management Perspectives, $20(2), 58-69$.

Rossi, A (1938). The rise of Italian fascism, 1918-1922. London: Methuen. 
Rothbart, M. K \& Plen D. (1977). "Elephants and marshmallows: A theoretical synthesis of incongruity resolution and arousal theories of humour." In A. Chapman \& H. Foot, It's a funny thing, humour. New York, NY: Pergamon.

Rozik, E. (2011). Comedy: A critical introduction. Eastbourne: Sussex Academic Press.

Ruch, W. (2001). The perception of humor. In A.W. Kaszniak (Ed.), Emotion, qualia, and consciousness. Tokyo: Word Scientific Publisher.

Ruch, W., Attardo S., \& Raskin V. (1993). Toward an empirical verification of the general theory of verbal humor. Humor: International Journal of Humor Research, 6 (2), 123-136.

Rundle, C. (1999). Publishing translations in Mussolini's Italy: a case study of Arnoldo Mondadori. Textus, 12(2), 427-442.

Rundle, C. (200o). The censorship of translation in fascist Italy. The Translator, 6(1), 67-76.

Rundle, C. (2004). Il ruolo /la (in)visibilità del traduttore e dell'interprete nella storia, Il Traduttore Nuovo, LX.

Rundle, C. (2010). Publishing translations in fascist Italy. Oxford: Peter Lang.

Rundle, C. (2013) La recensione /6 - La narrativa popolare nel ventennio e la censura mancata, Tradurre, (4).

Ryle, G. (1971). Collected papers. London: Hutchinson.

Säckel, S., Göbel, W., \& Hamdy, N. (2009). Semiotic encounters: Text, image and translation. Amsterdam: Rodopi.

Saldanha, G. \& O' Brien S. (2013). Research methodologies in translation studies. Manchester: St Jerome.

Salinger, J. D. (1951). The catcher in the rye. Boston, MA: Little, Brown and Company.

Salinger, J. D. (1961). Il Giovane Holden (A. Motti, Trans.). Turin: Einaudi.

Salinger, J. D. (2014). Il Giovane Holden (M.Colombo, Trans.). Turin: Einaudi.

Salvatorelli, L. (1962). Storia d'Italia nel periodo fascista (4. ed.). Turin: Einaudi.

Santarelli, E. (1996). Storia critica della Repubblica : l'Italia dal 1945 al 1994. Milan: Feltrinelli.

Schirone, F. (1994). La Casa Editrice Sociale: Appunti sull'attività dell'editore anarchico Giuseppe Monanni, Rivista storica dell'anarchismo I(2), 96-116

Schopenhauer, A. (1819). Die Welt als Wille und Vorstellung. Leipzig: Brockhaus.

Segre, C. (1999). Avviamento all'analisi del testo letterario. Turin: Einaudi.

Serianni, L., \& Castelvecchi, A. (2006). Grammatica italiana: italiano comune e lingua letteraria. Turin: UTET.

Sfondrini, F. (1997). Autori e libri inglesi tradotti in Italia nel ventennio 1920-1940. Bologna: Università di Bologna.

Shultz, T. R. (1974). Order of cognitive processing in humour appreciation. Canadian Journal of Psychology, 28, 409-420.

Silj, A. (1994). Malpaese: criminalità, corruzione e politica nell'Italia della prima Repubblica, 1943-1994. Donzelli editore. 
Simpson, J. (1989). The Oxford English dictionary. ( $2^{\text {nd }}$ edit.). Oxford: Oxford University Press.

Singer, M., Graesser, A. C., \& Trabasso, T. (1994). Minimal or global inference during reading. Journal of Memory and Language, 33(4), 421-441.

Spaventa Filippi, S. (1932). L'umorismo e gli umoristi ed altri saggi. Milan: Monanni.

Spencer, H. (1860). On the physiology of laughter. London: Macmillan

Sperber G. \& Wilson, D. (1995). Relevance: Communication \& cognition. Oxford: Blackwell.

Sproat, I. (1981). Wodehouse at war. London: Milner and Co.

Spurio, F. (2001), Censura e veleni fascisti. Le traduzioni di Agatha Christie degli Anni Trenta, in Tradurre, Numero o.

Stanovich, K. E. (2009). What intelligence tests miss: the psychology of rational thought. New Haven: Yale University Press.

Steiner, G. (1998). After Babel: aspects of language and translation. London: Oxford University Press.

Stephenson, W. (1978). The Wodehouse world of Hollywood. Literature/Film Quarterly, 6(3), 190-203.

Stott, A. M. (2005). Comedy. New York: Routledge.

Suls, J. M. (1972). A two-stage model for the appreciation of jokes and cartoons. In J. Goldstein, \& P. McGhee, The psychology of humor: Theoretical perspectives and empirical issues. New York, NY: Academic Press.

Suls, J. M. (1983). Cognitive processes in humor appreciation, In J. Goldstein, \& P. McGhee, (Eds.) Handbook of humour research: Vol. 1: Basic issues. New York, NY: Springer Verlag.

Susam-Sarajeva, S. (2003). Multiple-entry visa to travelling theory: Retranslations of literary and cultural theories. Target, $15(1), 1-36$.

Svensson, K. (1981) In: Heineman, J. H., \& Bensen, D. R., P.G. Wodehouse, a centenary celebration, 18811981. New York, NY: Pierpont Morgan Library.

Swift, J. (1697/2010). The battle of the books. The Floating Press.

Talbot, G. (Ed.) .(2007) Censorship in fascist Italy, 1922-43. Basingstoke, England: Palgrave Macmillan, 2007.

Thompson, K. (1992). Wooster proposes, Jeeves disposes : or, le mot juste. New York: James H. Heineman.

Thurlow, R. Fascism. (1999). Cambridge: Cambridge University Press.

Tobergte, D. R., \& Curtis, S. (2013). Heuristics and biases. Journal of Chemical Information and Modeling, 53(9), 1689-1699.

Toury, G. (1995). Descriptive translation studies and beyond. Amsterdam: John Benjamins Publishers

Toury, G. (2012). Descriptive translation studies - and beyond (100). Amsterdam: John Benjamins Pub. Co.

Tranfaglia, N., \& Vittoria, A. (2007). Storia degli editori italiani: dall'unità alla fine degli anni sessanta. Bari: Laterza.

Turi, G., \& Palazzolo, M. I. (1997). Storia dell'editoria nell'Italia contemporanea. Florencw: Giunti.

Tuten, N. L., \& Zubizarreta, J. (2001). The Robert Frost encyclopedia. Westport, CT: Greenwood Press. 
Uitti K. (1969). Linguistics and literary theory. Englewood Cliffs, NJ: Prentice-Hall.

Usborne, R. (1961). Wodehouse at work. A study of the books and characters of P. G. Wodehouse across nearly sixty years. London: Herbert Jenkins.

Usborne, R. (1978). Wodehouse at work to the end (Rev. ed.). Harmondsworth: Penguin.

Usborne, R. (1981). A Wodehouse companion. London: Elm Tree Books.

Usborne, R. (1991). After hours with P.G. Wodehouse. London: James H. Heineman.

Valentino G. (2017). Analisi del trattamento dell'intertestualità nelle traduzioni italiane delle opere di P.G. Wodehouse. In J. Martìnez Sierra, \& P. Zabalbeascoa Terran, (Eds.). MonTi 9: The Translation of Humour, 9, 101-124.

Valentino, G. (2010). Intelligere: manuale per comprendere articoli scientifici in inglese. Turin: E.A.E.

Valero-Garces, C. (2010). Dimensions of humor explorations in linguistics, literature, cultural studies and translation. Alcala: Universidad de Alcala.

Vandaele, J. (2010). In Y. Gambier, \& L. van Doorslaer (Eds.). Handbook of translation studies (Vol. 2). Amsterdam: John Benjamins Publishing Company.

Vandaele, J. (Ed.) (2002). Translating humour. [Special Issue]. The Translator: Studies in Intercultural Communication, 8 (2), 149-172.

Veale, T. (2004). Incongruity in humour: Root cause or epiphenomenon? Humor: International Journal of Humor Research, 17 (4), 419-428.

Veale, T. (2013). Humorous similes. Humor: International Journal of Humor Research, 26(1), 3-22.

Venuti, L. (Ed.). (1992). Rethinking translation: Discourse, subjectivity, ideology. London: Routledge.

Venuti, L. (1995). The Translator's invisibility: A history of translation. Abington: Routledge.

Venuti, L. (1998). The scandals of translation: Towards an ethics of difference. Abington: Routledge.

Venuti, L. (2004). Retranslations: The creation of value, Bucknell Review, 47(1).

Venuti, L. (2012). The translation studies reader. ( $3^{\text {rd }}$ ed.). London: Routledge.

Venuti, L. (2013). Translation changes everything: Theory and practice. Abington: Routledge.

Vinay, J.-P., \& Darbelnet, J. (1977). Stylistique comparée du français et de l'anglais : méthode de traduction. Didier. Retrieved from https://catalog.hathitrust.org/Record/oo6954551

Vlakhov S. \& Florin S. (2011). In B. Osimo, Manuale del traduttore: guida pratica con glossario. Milan: Hoepli.

Voos, J , Vesonder G. \& Spilich G. (1980). Text generation and recall by high-knowledge subjects. Journal of Verbal Learning and Verbal Behavior. 19, 651-667.

Wales, K. (2001). A Dictionary of Stylistics. London: Longman.

Wallace E. (1918). The man who knew. New York: A. L. Burt Company

Wallace E. (1930). L'uomo che sapeva (A. R. Ferrarin, Trans.). Milan: Alberto Tedeschi Editore.

Warren, C., \& McGraw, A. P. (2016). Differentiating what is humorous from what is not. Journal of Personality and Social Psychology, 110(3), 407-430. 
Watson, K. K., Matthews, B. J., \& Allman, J. M. (2007). Brain activation during sight gags and languagedependent humor. Cerebral Cortex, 17(2), 314-324.

Weisfeld, G. E. (1993). The adaptive value of humor and laughter, Ethology and Sociobiology, 14, 141-169.

Weisfeld, G. E., Nowak, N. T., Lucas, T., Weisfeld, C. C., Olcay, E., Lu, I., Parkhill, M. R. (2011). Do women seek humorousness in men because it signals intelligence? A cross-cultural test, Humor: International Journal of Humor Research, 24(4), 435-462.

Whittam, J. (1995). Fascist Italy. Manchester: Manchester University Press.

Wild, J. (2006). The rise of the office clerk in literary culture, 1880-1939. Basingstoke: Palgrave Macmillan.

Williams, J., \& Chesterman, A. (2002). The map: A beginner's guide to doing research in translation studies. Manchester: St Jerome.

Wills, W. (1996). Knowledge and skills in translator behaviour. Amsterdam: John Benjamins.

Wodehouse, P. G. (1904). William Tell told again. London: Adam and Charles Black.

Wodehouse, P. G. (1909). The swoop! London: Alston Rivers.

Wodehouse, P. G. (1957/2014). Over seventy. London: Everyman.

Wodehouse, P. G. (1977). Sunset at Blandings. London: Chatto \& Windus.

Wodehouse, P. G. (1989). The great sermon handicap. New York, NY: Heineman

Wodehouse, P. G. (2000). Sunset at Blandings. (N. T. P. Murphy \& T. Ring, Eds.). London: Penguin

Wodehouse, P. G. (2007). Death at the Excelsior and other stories. Rockville, MD: Wildside Press.

Wodehouse, P. G. (2007). Delitto all'Excelsior e altri racconti (V. Latronico, Trans.). Milan: Excelsior 1881.

Wodehouse, P. G. (2011). What ho! The best of P. G. Wodehouse. London: Arrow.

Wodehouse, P. G. (2012). Weekend Wodehouse. Arrow Books.

Wodehouse, P. G. \& Ratcliffe, S. (2012). P.G. Wodehouse: a life in letters. London: Arrow.

Wodehouse, P. G. \& Townend, W. (1953). Performing flea: a self-portrait in letters. London: Everyman.

Wodehouse, P. G. \& Westbrook, H. (1985). The Globe By the Way book. New York, NY: Heineman.

Wodehouse, P. G., \& Dawson J. (Ed.). (2015). P.G. Wodehouse in the Globe Newspaper - Sunnyvale, CA: GRP Publication.

Wodehouse, P. G., \& Kelly, R. T. (2016). Highballs for breakfast. London: Hutchinson.

Wodehouse, P. G., \& Ring T. (Ed.). (2015). By the Way: 200 verses. Sunnyvale, CA: GRP Publication.

Wodehouse, P. G., Day, B., \& Ring, T. (2003). P.G. Wodehouse, in his own words. Woodstock, NY: Overlook Press.

Wolf, M. (2010). In Y. Gambier, \& L. van Doorslaer, (Eds.). Handbook of translation studies, 1 Amsterdam: John Benjamins Publishing Company.

Zabalbeascoa, P. (2005). Humor and translation: An interdiscipline. Humor: International Journal of Humor Research, 18(2), 185-207. 